Prepared in cooperation with the City of Sioux Falls

\title{
Occurrence of Organic Wastewater Compounds in Drinking Water, Wastewater Effluent, and the Big Sioux River in or near Sioux Falls, South Dakota, 2001-2004
}

Scientific Investigations Report 2006-5118 



\section{Occurrence of Organic Wastewater Compounds in Drinking Water, Wastewater Effluent, and the Big Sioux River in or near Sioux Falls, South Dakota, 2001-2004}

By Steven K. Sando, Edward T. Furlong, James L. Gray, and Michael T. Meyer

Prepared in cooperaton with the City of Sioux Falls

Scientific Investigations Report 2006-5118 


\title{
U.S. Department of the Interior DIRK KEMPTHORNE, Secretary
}

\author{
U.S. Geological Survey \\ P. Patrick Leahy, Acting Director
}

\section{U.S. Geological Survey, Reston, Virginia: 2006}

\author{
For sale by U.S. Geological Survey, Information Services \\ Box 25286, Denver Federal Center \\ Denver, CO 80225 \\ For more information about the USGS and its products: \\ Telephone: 1-888-ASK-USGS \\ World Wide Web: http://www.usgs.gov/
}

Any use of trade, product, or firm names in this publication is for descriptive purposes only and does not imply endorsement by the U.S. Government.

Although this report is in the public domain, permission must be secured from the individual copyright owners to reproduce any copyrighted materials contained within this report.

Suggested citation:

Sando, S.K., Furlong, E.T., Gray, J.L., and Meyer, M.T., 2006, Occurrence of organic wastewater compounds in drinking water, wastewater effluent, and the Big Sioux River in or near Sioux Falls, South Dakota, 2001-2004: U.S. Geological Survey Scientific Investigations Report 2006-5118, 168 p. 


\section{Contents}

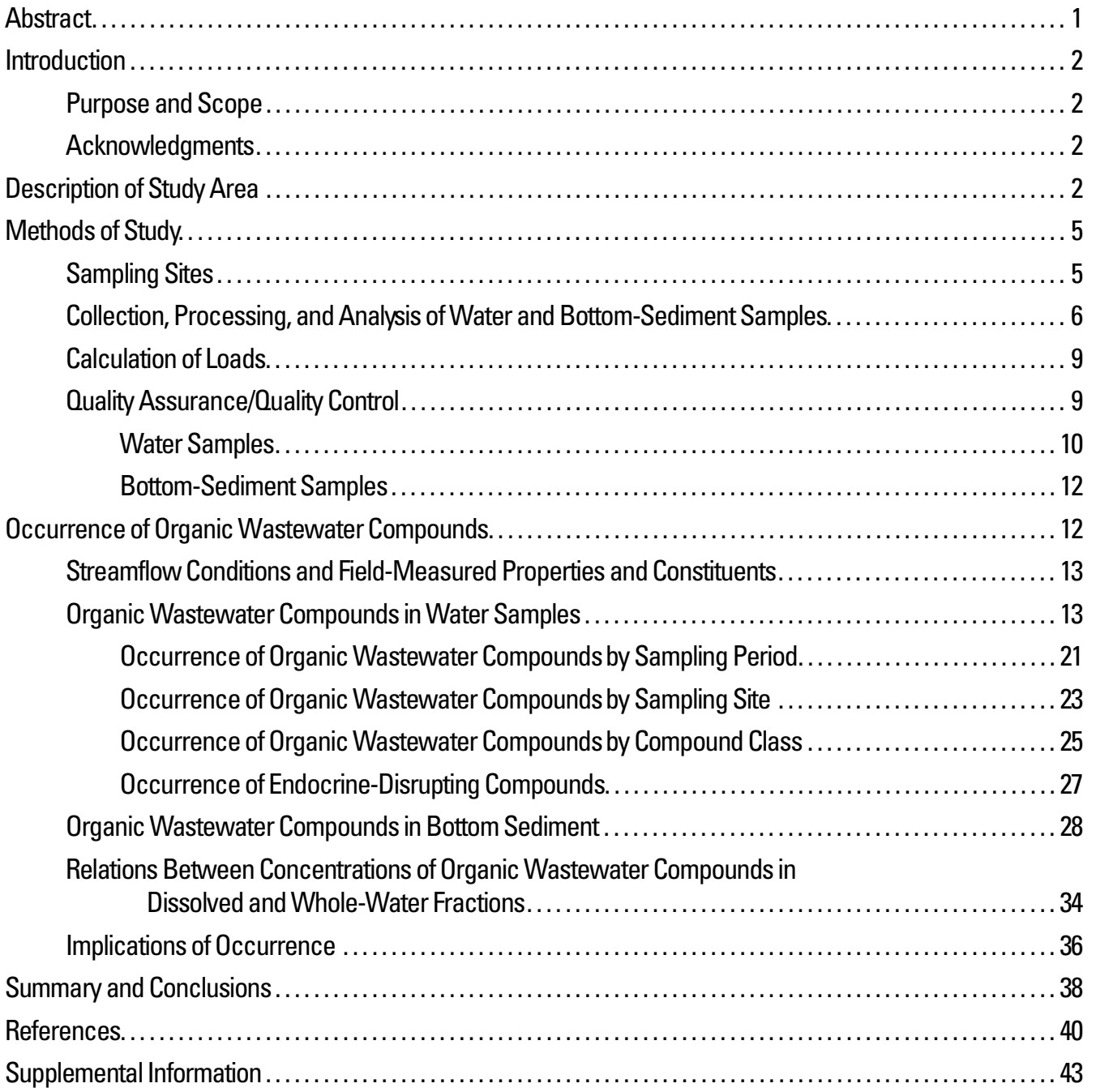

\section{Figures}

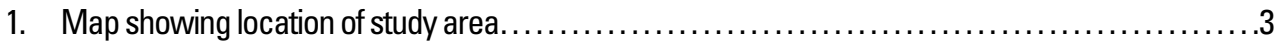

2-6. Graphs showing:

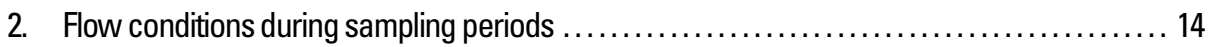

3. Results for field-measured properties and constituents ......................... 15

4. Results for organic wastewater compounds in water samples...................... 18

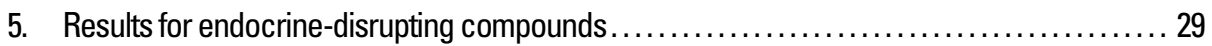

6. Results for organic wastewater compounds and suspected endocrine-disrupting compounds in bottom-sediment samples for the September 2002 sampling period.......... 32 


\section{Tables}

1. Selected characteristics of the Sioux Falls wastewater treatment plant.......................

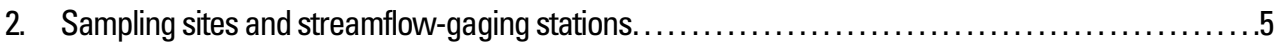

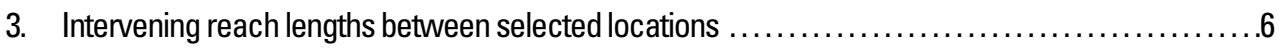

4. Statistical summaries of data related to occurrence of whole-water 3-beta-coprostanol in water samples collected from wastewater effluents and the Big Sioux River ............... 28

5. Statistical summaries of analytical results for organic wastewater compounds

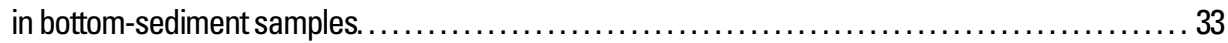

6. Organic wastewater compounds detected in bottom-sediment samples. .................... 35

7. Field-measured properties and constituents and analytical constituents .................. 44

8. Statistical summaries of analytical results for detected compounds in

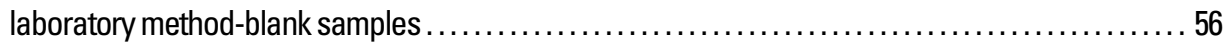

9. Statistical summaries of analytical results for laboratory reagent-spike samples ...............6 60

10. Statistical summaries of analytical results for laboratory surrogate-spike samples .............6 65

11. Statistical summaries of analytical results for detected compounds in field

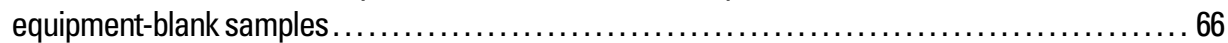

12. Statistical summaries for field replicate samples for organic wastewater compounds (OWCs) detected in any sample for any primary/replicate sample pair . .................... 67

13. Statistical summaries for environmental matrix-spike samples........................... 70

14. Results for field-measured properties and constituents in water samples ................... 75

15. Analytical results for human pharmaceutical compounds (HPCs) in

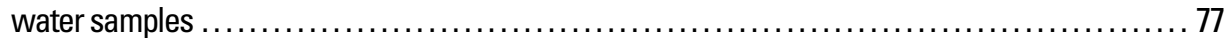

16. Analytical results for human and veterinary antibiotic compounds (HVACs) in

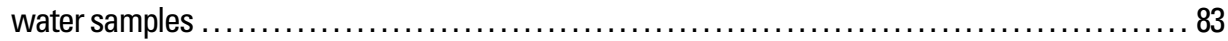

17. Analytical results for major agricultural herbicides (MAHs) in water and

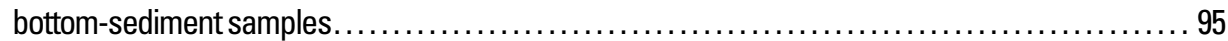

18. Analytical results for household, industrial, and minor agricultural use compounds (HIACs) in water and bottom-sediment samples. .......................... 98

19. Analytical results for polyaromatic hydrocarbons (PAHs) in water and bottom-sediment samples.

20. Analytical results for sterol compounds (SCs) in water and bottom-sediment samples.

21. Statistical summaries of analytical results and load results for organic wastewater compounds in water samples

22. Organic wastewater compounds detected at concentrations greater than study reporting levels in water samples 


\section{Conversion Factors}

\begin{tabular}{lcl}
\hline Multiply & By & To obtain \\
\hline cubic foot per second $\left(\mathrm{ft}^{3} / \mathrm{s}\right)$ & 0.02832 & cubic meter per second $\left(\mathrm{m}^{3} / \mathrm{s}\right)$ \\
foot (ft) & 0.3048 & meter $(\mathrm{m})$ \\
inch (in.) & 2.54 & centimeter $(\mathrm{cm})$ \\
inch (in.) & 25.4 & millimeter $(\mathrm{mm})$ \\
mile (mi) & 1.609 & kilometer $(\mathrm{km})$ \\
million gallons per day $(\mathrm{Mgal} / \mathrm{d})$ & 0.04381 & cubic meter per second $\left(\mathrm{m}^{3} / \mathrm{s}\right)$ \\
pounds per day $(\mathrm{lb} / \mathrm{d})$ & 0.4536 & kilograms per day $(\mathrm{kg} / \mathrm{d})$ \\
square mile $\left(\mathrm{mi}^{2}\right)$ & 259.0 & hectare $($ ha) \\
square mile $\left(\mathrm{mi}^{2}\right)$ & 2.590 & square kilometer $\left(\mathrm{km}^{2}\right)$ \\
\hline
\end{tabular}

Temperature in degrees Celsius $\left({ }^{\circ} \mathrm{C}\right)$ may be converted to degrees Fahrenheit $\left({ }^{\circ} \mathrm{F}\right)$ as follows:

$$
{ }^{\circ} \mathrm{F}=\left(1.8 \mathrm{x}^{\circ} \mathrm{C}\right)+32
$$

Horizontal coordinate information is referenced to the North American Datum of 1927 (NAD 27).

Specific conductance is given in microsiemens per centimeter at 25 degrees Celsius $(\mu \mathrm{S} / \mathrm{cm})$.

Concentrations of chemical constituents in water are given either in milligrams per liter (mg/L) or micrograms per liter $(\mu \mathrm{g} / \mathrm{L})$.

Loads of organic wastewater compounds were estimated by multiplying discharges at the times of sampling by constituent concentrations and by a conversion factor $(0.0053919)$ to convert cubic feet per second and micrograms per liter to pounds per day. 


\section{Definition of Acronyms}

$\begin{array}{ll}\text { AHTN } & \text { 7-Acetyl-1,1,3,4,4,6-hexamethyl tetrahydronaphthalene } \\ \text { AP } & \text { Alkylphenol } \\ \text { ASE } & \text { Accelerated solvent extraction } \\ \text { EDCs } & \text { Suspected endocrine-disrupting compounds } \\ \text { FDW } & \text { Finished drinking water } \\ \text { HHCB } & \text { 1,3,4,6,7,8-hexahydro-4,6,6,7,8,8-hexamethyl cyclopenta-g-2-benzopyran } \\ \text { HIACs } & \text { Household, industrial, and minor agricultural use compounds } \\ \text { HLB } & \text { Hydrophilic-lipophilic-balance } \\ \text { HPCs } & \text { Human pharmaceutical compounds } \\ \text { HPLC/ESI-MS } & \text { High-performance liquid chromatography/electrospray ionization mass } \\ & \text { spectrometry } \\ \text { HVACs } & \text { Human and veterinary antibiotic compounds } \\ \text { LRL } & \text { Laboratory reporting level } \\ \text { MAHs } & \text { Major agricultural herbicides } \\ \text { NP } & \text { para-Nonylphenol } \\ \text { NP1EO } & \text { Nonylphenol monoethoxylate } \\ \text { NP2EO } & \text { Nonylphenol diethoxylate } \\ \text { NWOL } & \text { National Water Quality Laboratory } \\ \text { OGRL } & \text { Organic Geochemistry Research Laboratory } \\ \text { OP1EO } & \text { Octylphenol monoethoxylate } \\ \text { OP2EO } & \text { Octylphenol diethoxylate } \\ \text { OWCs } & \text { Organic wastewater compounds } \\ \text { PAHs } & \text { Polyaromatic hydrocarbons } \\ \text { OA/OC } & \text { Quality assurance/quality control } \\ \text { RPD } & \text { Relative percent difference } \\ \text { RSD } & \text { Relative standard deviation } \\ \text { SCs } & \text { Sterol compounds } \\ \text { SIM } & \text { Selected ion monitoring } \\ \text { SPE } & \text { Solid-phase extraction } \\ \text { SRL } & \text { Study reporting level } \\ \text { USGS } & \text { U.S. Geological Survey } \\ \text { WWE } & \text { Wastewater treatment plant effluent } \\ \text { WWTP } & \text { Wastewater treatment plant } \\ & \end{array}$




\title{
Occurrence of Organic Wastewater Compounds in Drinking Water, Wastewater Effluent, and the Big Sioux River in or near Sioux Falls, South Dakota, 2001-2004
}

\author{
By Steven K. Sando, Edward T. Furlong, James L. Gray, and Michael T. Meyer
}

\section{Abstract}

The U.S. Geological Survey (USGS) in cooperation with the city of Sioux Falls conducted several rounds of sampling to determine the occurrence of organic wastewater compounds (OWCs) in the city of Sioux Falls drinking water and wastewater effluent, and the Big Sioux River in or near Sioux Falls during August 2001 through May 2004. Water samples were collected during both base-flow and storm-runoff conditions. Water samples were collected at 8 sites, which included 4 sites upstream from the wastewater treatment plant (WWTP) discharge, 2 sites downstream from the WWTP discharge, 1 finished drinking-water site, and 1 WWTP effluent (WWE) site.

A total of 125 different OWCs were analyzed for in this study using five different analytical methods. Analyses for OWCs were performed at USGS laboratories that are developing and/or refining small-concentration (less than 1 microgram per liter $(\mu \mathrm{g} / \mathrm{L}))$ analytical methods. The OWCs were classified into six compound classes: human pharmaceutical compounds (HPCs); human and veterinary antibiotic compounds (HVACs); major agricultural herbicides (MAHs); household, industrial, and minor agricultural compounds (HIACs); polyaromatic hydrocarbons (PAHs); and sterol compounds (SCs). Some of the compounds in the HPC, MAH, HIAC, and PAH classes are suspected of being endocrine-disrupting compounds (EDCs). Of the 125 different OWCs analyzed for in this study, 81 OWCs had one or more detections in environmental samples reported by the laboratories, and of those 81 OWCs, 63 had acceptable analytical method performance, were detected at concentrations greater than the study reporting levels, and were included in analyses and discussion related to occurrence of OWCs in drinking water, wastewater effluent, and the Big Sioux River.

OWCs in all compound classes were detected in water samples from sampling sites in the Sioux Falls area. For the five sampling periods when samples were collected from the Sioux Falls finished drinking water, only one OWC was detected at a concentration greater than the study reporting level (metolachlor; $0.0040 \mu \mathrm{g} / \mathrm{L})$.

During base-flow conditions, Big Sioux River sites upstream from the WWTP discharge had OWC contributions that primarily were from nonpoint animal or crop agriculture sources or had OWC concentrations that were minimal. The influence of the WWTP discharge on OWCs at downstream river sites during base-flow conditions ranged from minimal influence to substantial influence depending on the sampling period. During runoff conditions, OWCs at sites upstream from the WWTP discharge probably were primarily contributed by nonpoint animal and/or crop agriculture sources and possibly by stormwater runoff from nearby roads. OWCs at sites downstream from the WWTP discharge probably were contributed by sources other than the WWTP effluent discharge, such as stormwater runoff from urban and/or agriculture areas and/or resuspension of OWCs adsorbed to sediment deposited in the Big Sioux River. OWC loads generally were substantially smaller for upstream sites than downstream sites during both base-flow and runoff conditions.

In general, HPCs and HVACs accounted for relatively small portions of the total OWC concentrations in water samples collected from all sampling sites. MAHs generally accounted for a relatively small part of the total OWC concentrations during base-flow conditions for all sites, and for a substantial part at the river sites during some but not all stormrunoff sampling periods. HIACs generally accounted for a substantial part of the total OWC concentrations in samples collected from the WWE site during all sampling periods. In samples collected from downstream sites, HIACs generally accounted for a substantial part of the total OWC concentration during base-flow conditions and during some but not all of the storm-runoff sampling periods. PAHs only were detected at Big Sioux River sites that might be substantially affected by stormrunoff from roads. PAHs were not detected during any baseflow sampling period and were detected during some but not all storm-runoff periods. SCs generally comprised a substantial part of the total detected OWC concentrations for WWE and Big Sioux River sites during both base-flow and storm-runoff conditions. Results indicate that the WWTP discharge substantially contributed to the occurrence of OWCs in the Big Sioux River during below-normal base-flow conditions.

There were no human-health concerns apparent in the results of this study. Occurrence of EDCs in aquatic systems is a very complex and sensitive issue. A complete assessment of potential effects of EDCs in the Big Sioux River in or near 


\section{Organic Wastewater Compounds in Drinking Water, Wastewater Effluent, and the Big Sioux River, 2001-2004}

Sioux Falls based on the results of this study is not possible. However, EDC concentrations in the Big Sioux River generally were less than concentrations reported to have substantial endocrine-disrupting effects on aquatic organisms. The relatively large frequency of detection for atrazine might indicate a cause for concern with respect to endocrine-disruption effects for aquatic organisms.

\section{Introduction}

Many organic compounds used in or produced by household, industrial, and agricultural activities are soluble and resistant to wastewater treatment processes, and have been shown to occur in wastewater discharges to natural streams (Richardson and Bowron, 1985; Halling-Sorensen and others, 1998). Additionally, some of these organic wastewater compounds (OWCs) can persist in natural water systems (Barnes and others, 2002; Kolpin and others, 2002; Stackelberg and others, 2004) and potentially have long-term effects on stream biota; human exposure also might occur when those systems are used as water supplies. Some OWCs are hormonally active and have been shown to disrupt the endocrine systems of animals in laboratory studies (Jobling and others, 1996; Thorpe and others, 2001). Evidence also indicates that endocrine systems of some fish and other vertebrate animals in natural systems have been affected by OWCs (Sumpter and Johnson, 2005), although after a decade of intensive research in the laboratory and field, the mechanisms of endocrine modulation and the long-term, sublethal effects of low-level exposure to OWCs remain poorly understood. Thus, data documenting the concentrations and composition of OWC mixtures in the environment contribute to the understanding of the potential effect these chemicals might have in the environment.

Within the Big Sioux River drainage basin in eastern South Dakota (fig. 1), considerable agricultural activities occur; both crops and livestock are raised, and numerous concentrated animal feeding operations exist. Potential exists for OWCs associated with agricultural activities, including pesticides, antibiotics, and feed supplements from feeding operations, to be introduced into both surface and ground water in the basin. Additionally, wastewater discharges from some of the larger cities in South Dakota (including Watertown, Brookings, and Sioux Falls) and from several smaller cities are released directly into the Big Sioux River. These wastewater discharges also might contain OWCs.

The U.S. Geological Survey (USGS) in cooperation with the city of Sioux Falls conducted several rounds of sampling to determine the occurrence of OWCs in the city of Sioux Falls drinking water and wastewater effluent, and the Big Sioux River in or near Sioux Falls during August 2001 through May 2004. Water samples were collected from eight sites during both base-flow and runoff conditions. Bottom-sediment samples also were collected from three sites in September 2002.
The OWCs analyzed for in this study (table 7 in the Supplemental Information section at the back of this report) are classified into six compound classes: human pharmaceutical compounds (HPCs), which are commonly used prescription and non-prescription pharmaceutical drugs; human and veterinary antibiotic compounds (HVACs), which are prescription drugs used in the treatment of infectious diseases; major agricultural herbicides (MAHs), which include atrazine, metolachlor, and prometon; household, industrial, and minor agricultural compounds (HIACs), which are various generally synthetic organic compounds used for a variety of purposes including detergents, fire retardants, plasticizers, fragrances, solvents, preservatives, and disinfectants; polyaromatic hydrocarbons (PAHs), which are compounds often occurring in fossil fuels or produced by the combustion of fossil fuels; and sterol compounds (SCs), which are predominantly unsaturated solid alcohols of the steroid group naturally occurring in fatty tissues of plants and animals and present in animal fecal material. Some of the compounds in the HPC, MAH, HIAC, and PAH classes are suspected of being endocrine-disrupting compounds (EDCs).

\section{Purpose and Scope}

The purpose of this report is to describe the occurrence of OWCs in drinking water, wastewater effluent, and the Big Sioux River in or near Sioux Falls during 2001-2004. Specifically, this report describes the data-collection and analytical methods used in the study and the analytical results documenting the presence, concentrations, loads, and distributions of OWCs in this watershed.

\section{Acknowledgments}

The authors would like to recognize the valuable contributions to this study made by Lyle Johnson, Tim Stefanich, Kevin Smith, and Trent Lubbers of the city of Sioux Falls. Also, the authors thank the individuals involved in the field data collection for this study, including Dave Hernandez, Nate Stevens, Bryan Schaap, Mike Burr, Mark Freese, and Roy Bartholomay.

\section{Description of Study Area}

The Big Sioux River originates in northeastern South Dakota and flows to the south along the eastern edge of the State (fig. 1). The Big Sioux River drains an extended highland or plateau, the Coteau des Prairie, which is the largest single topographic feature in eastern South Dakota (Lawrence and Sando, 1989). The coteau is a 200-mi-long constructional remnant from glacial ice sheets that moved south along the eastern edge of South Dakota (Flint, 1971; Leap, 1988). The study area comprises about 5,120 $\mathrm{mi}^{2}$ from a location near Brandon, South Dakota, upstream to the headwaters of the Big Sioux River 

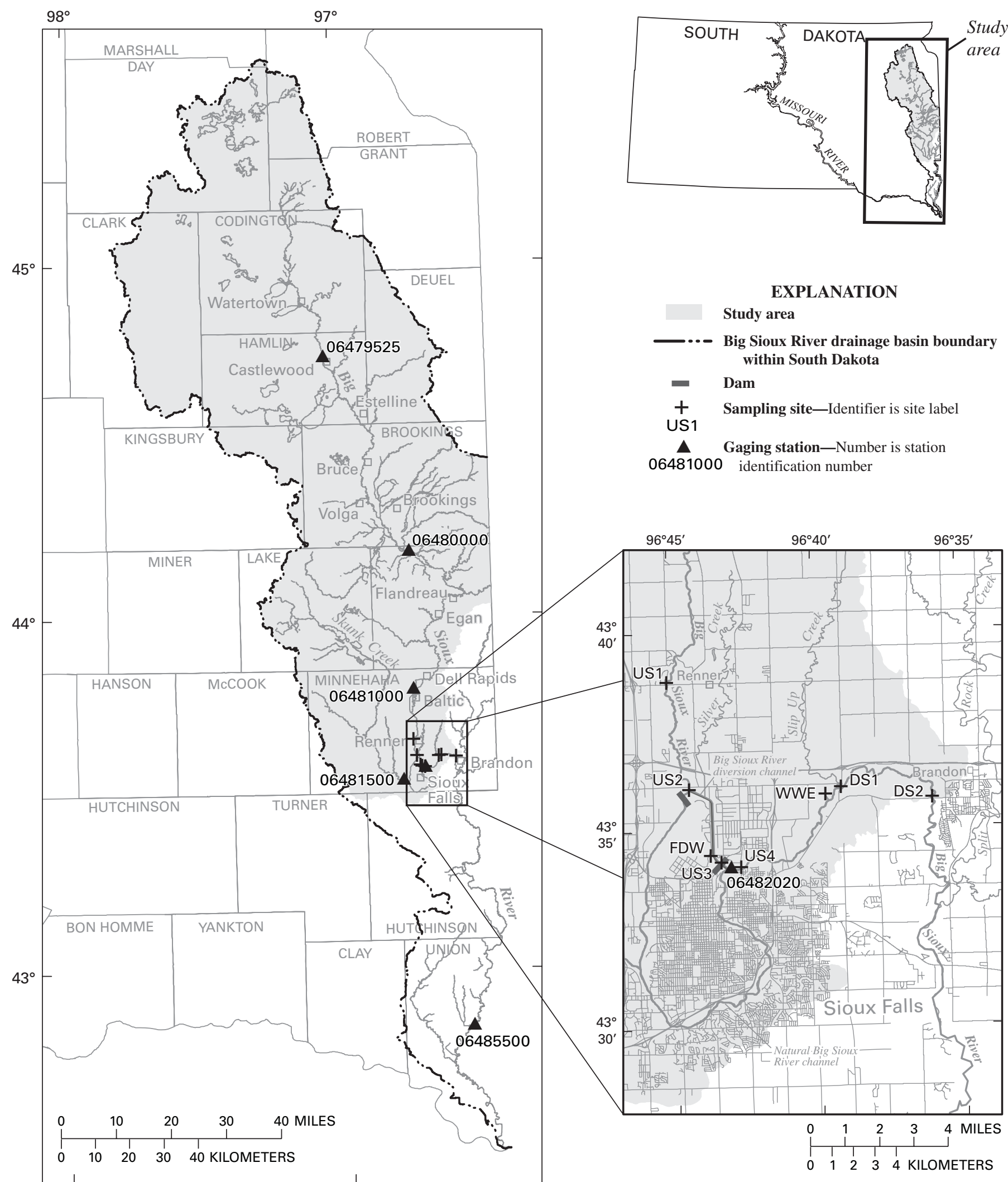

\section{EXPLANATION}

Study area

_..- Big Sioux River drainage basin boundary within South Dakota

- Dam

$+\quad$ Sampling site-Identifier is site label

US1

Gaging station-Number is station 06481000 identification number

$96^{\circ} 45^{\prime}$

$96^{\circ} 40^{\prime}$

$96^{\circ} 35^{\prime}$

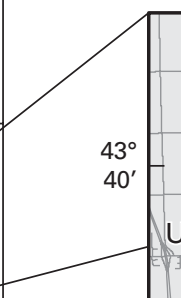

5.
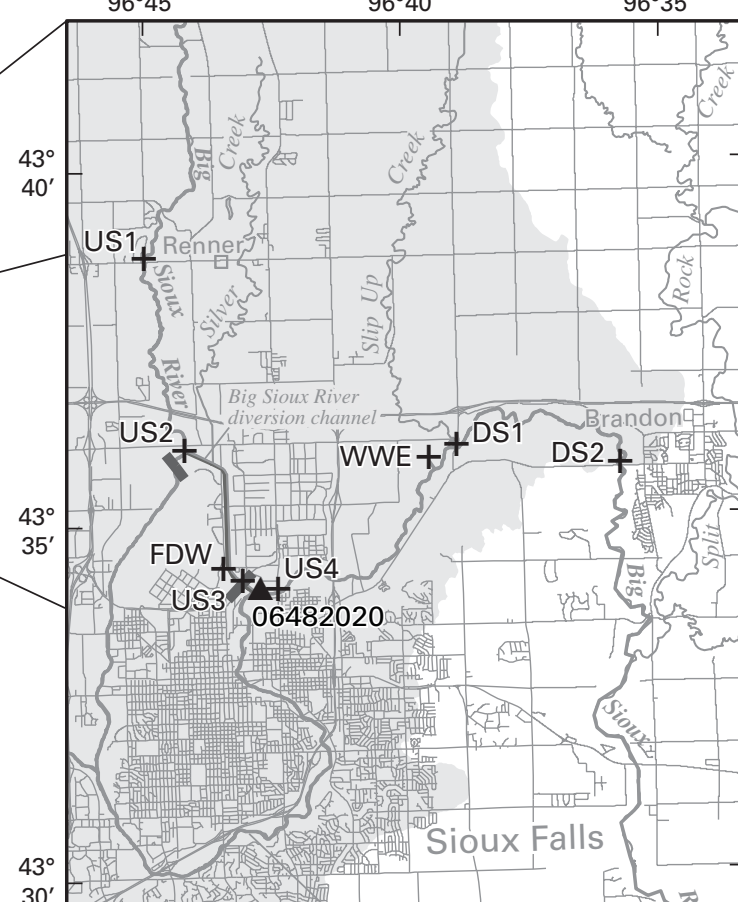

S17
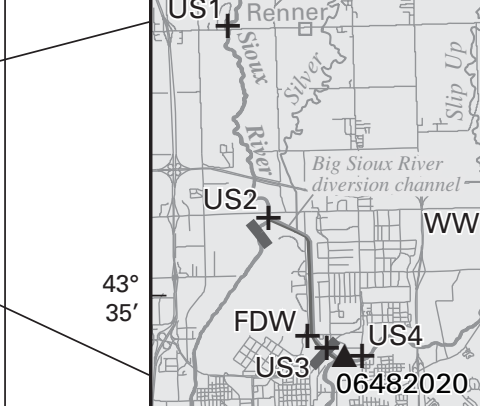

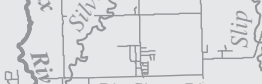
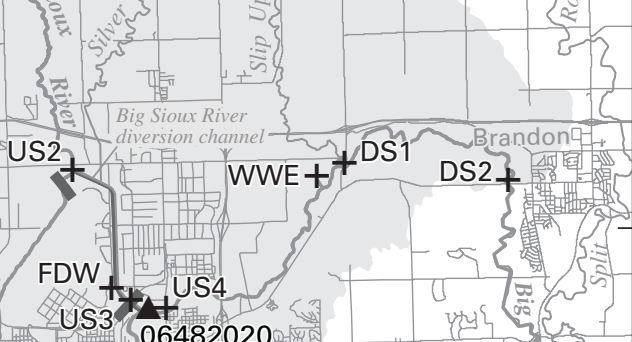

Base from U.S. Geological Survey digital data, 1:100,000, 1985

Universal Traverse Mercator projection, zone 14

Figure 1. Location of study area. 


\section{Organic Wastewater Compounds in Drinking Water, Wastewater Effluent, and the Big Sioux River, 2001-2004}

(fig. 1). Sampling sites were focused in or near Sioux Falls, South Dakota.

The climate in the study area is continental and is characterized by large seasonal and daily variations in temperature. The normal (1971-2000) mean daily July temperature at Sioux Falls is about $22.8^{\circ} \mathrm{C}$, and the normal mean daily January temperature is about $-10.0^{\circ} \mathrm{C}$. Normal annual precipitation is about 25 in. (South Dakota State University, 2005). On average, about 81 percent of annual precipitation occurs as rainfall during the months of April through October.

Land use in the study area primarily is agricultural with corn, wheat, soybeans, miscellaneous small grains, and alfalfa as the major crops (Lawrence and Sando, 1989). Livestock raised in the basin primarily include dairy cattle, beef cattle, and hogs. The cities of Watertown, Brookings, and Sioux Falls are the major urban areas in the study area. Smaller cities in the study area that are close to the Big Sioux River channel include Castlewood, Estelline, Bruce, Volga, Flandreau, Egan, Dell Rapids, Baltic, and Renner (fig.1).

Outwash deposits along the Big Sioux River and its tributaries underlie much of the Big Sioux River Basin (Lawrence and Sando, 1989). These outwash deposits include the various units of the Big Sioux aquifer, which is one of the more extensively developed aquifers in South Dakota. The outwash deposits consist of cross-bedded gravel, sand, and silt that range in thickness from a few feet to about $200 \mathrm{ft}$, and range in depth below land surface from about 1 to $100 \mathrm{ft}$ (Lawrence and Sando, 1989). Many of the outwash deposits have areas where they are hydraulically connected with the Big Sioux River.

The Big Sioux River is a major tributary to the Missouri River in eastern South Dakota. The mean annual streamflow of the Big Sioux River for water years 1977-2004 is about $99 \mathrm{ft}^{3} / \mathrm{s}$ for USGS gaging station 06479525 (located about 15 river miles downstream from the city of Watertown; contributing drainage area is about $780 \mathrm{mi}^{2}$ ), about $434 \mathrm{ft}^{3} / \mathrm{s}$ for USGS gaging station 06480000 (located about 20 river miles downstream from the city of Brookings; contributing drainage area is about $2,665 \mathrm{mi}^{2}$ ), about $577 \mathrm{ft}^{3} / \mathrm{s}$ for USGS gaging station 06481000 (located about 23 river miles upstream from the Sioux Falls city limits; contributing drainage area is about $3,250 \mathrm{mi}^{2}$ ), about $732 \mathrm{ft}^{3} / \mathrm{s}$ for USGS gaging station 06482020 (located in the city of Sioux Falls (shown as site US4 in fig.1); contributing drainage area about $3,975 \mathrm{mi}^{2}$ ), and about $1,935 \mathrm{ft}^{3} / \mathrm{s}$ for USGS gaging station 06485500 (located about 55 river miles upstream from the confluence with the Missouri River near Sioux City, Iowa; contributing drainage area is about 7,345 $\mathrm{mi}^{2}$ ).

The Big Sioux River channel in the Sioux Falls area has been substantially modified from its natural condition primarily for flood control and water-level management. In 1961, the U.S. Army Corps of Engineers completed construction of a channelization, levee, and diversion dam project to reduce effects from flooding of the Big Sioux River and Skunk Creek on Sioux Falls. One of the major aspects of this project was the construction of a diversion dam and channel near the northern edge of Sioux Falls that allows the flow of the Big Sioux River to be routed either through the natural Big Sioux River channel (which flows along the western and southern edges and through the center of Sioux Falls; fig.1) or through the diversion channel (which bypasses most of Sioux Falls). A second low-head diversion dam is located on the diversion channel and functions to maintain the water level in the diversion channel to facilitate pump withdrawals from the Big Sioux River for the Sioux Falls drinking-water supply. Prior to 1990, the city of Sioux Falls relied entirely on ground water for its water supply. In late 1990 , the city completed construction of an intake structure to withdraw and treat surface water from the Big Sioux River to provide drinking water. Since that time, the city has maintained a goal of obtaining at least 50 percent of its annual drinkingwater supply directly from the Big Sioux River (Kevin Smith, Sioux Falls Public Works Department, written commun., May 2005).

During precipitation events, a substantial amount of the stormwater drainage from Sioux Falls flows into the natural Big Sioux River channel. Also, Skunk Creek, with a contributing drainage area of about $610 \mathrm{mi}^{2}$, enters the natural Big Sioux River channel in the southwest part of Sioux Falls.

Sioux Falls is the largest city in South Dakota with a population of about 124,000 (U.S. Census Bureau, 2005) and a land area of about $63 \mathrm{mi}^{2}$ (Kevin Smith, Sioux Falls Public Works Department, written commun., March 2005). Characteristics of the wastewater treatment plant (WWTP) for Sioux Falls are presented in table1. The Sioux Falls WWTP discharges

Table 1. Selected characteristics of the Sioux Falls wastewater treatment plant.

\begin{tabular}{|c|c|}
\hline Population served & 123,975 \\
\hline $\begin{array}{l}\text { Population density (people per } \\
\text { square mile) }\end{array}$ & $1,967.9$ \\
\hline $\begin{array}{l}\text { Design capacity (million gallons } \\
\text { per day) }\end{array}$ & 13.43 \\
\hline Number of permitted industries & 20 \\
\hline $\begin{array}{l}\text { General description of permitted } \\
\text { industries }\end{array}$ & $\begin{array}{l}\text { Farm, fire, and industrial } \\
\text { equipment manufacturers, } \\
\text { hospitals, electronics } \\
\text { equipment manufacturer, metal } \\
\text { fabricator, livestock sales, } \\
\text { meat packing, fluid dairy and } \\
\text { juices, bakery, prison, airport, } \\
\text { cardboard box manufacturer, } \\
\text { concrete products, truck wash }\end{array}$ \\
\hline Preliminary treatment & Screening and grit removal \\
\hline Primary treatment & Settling basin clarification \\
\hline Secondary treatment & $\begin{array}{l}\text { Trickling filtration, secondary } \\
\text { clarification }\end{array}$ \\
\hline Tertiary treatment & $\begin{array}{l}\text { Aerated activated-sludge } \\
\text { processing, sand gravity } \\
\text { filtration, chlorine disinfection, } \\
\text { sulfur dioxide to neutralize } \\
\text { chlorine, post-treatment } \\
\text { aeration }\end{array}$ \\
\hline Primary sludge treatment & Anaerobic digestion \\
\hline
\end{tabular}


continuously to the Big Sioux River. During low-flow periods, the Sioux Falls WWTP effluent discharges can account for more than 50 percent of the Big Sioux River streamflow downstream from the effluent discharges. Wastewater effluent leaves the Sioux Falls WWTP in a concrete pipe about $0.2 \mathrm{mi}$ in length that discharges directly to the Big Sioux River.

\section{Methods of Study}

Water samples were collected at eight sites to investigate the occurrence of OWCs in drinking water, wastewater effluent, and the Big Sioux River (fig.1; table 2) in or near Sioux Falls. The primary sampling objectives evolved during the course of sampling activities. Initially, a single round of sampling was conducted during August 2001 at three sites to determine whether detectable concentrations of OWCs were present in (1) raw water withdrawn from the Big Sioux River for treatment to supply drinking water, (2) finished drinking water in the drinking-water distribution system, and (3) the Big Sioux River downstream from the Sioux Falls urban area and the Sioux Falls wastewater effluent discharge.

After detectable concentrations of OWCs were found in the August 2001 Big Sioux River samples, four rounds of sampling were conducted during September 2002 through June 2003 (two during base-flow conditions and two during stormrunoff conditions) primarily to investigate the relative contribution of the Sioux Falls wastewater effluent discharge to the occurrence of OWCs in the Big Sioux River downstream from Sioux Falls. The results of these four rounds of sampling gener- ally indicated that during below-normal base-flow periods, the primary source of OWCs in the Big Sioux River downstream from Sioux Falls probably was the Sioux Falls WWTP discharge. However, during storm-runoff conditions, loads of OWCs in the Big Sioux River downstream from Sioux Falls were substantially larger than what could only be accounted for by the Sioux Falls WWTP discharge. The network of sampling sites for the September 2002 through June 2003 sampling rounds was not adequate to confidently identify the possible sources of OWCs other than the Sioux Falls wastewater effluent discharge.

To better understand possible sources of OWCs in the Big Sioux River during storm-runoff conditions, two rounds of sampling were conducted during May 2004. Additional sampling sites were included in these sampling rounds.

\section{Sampling Sites}

A labeling scheme is used for the sampling sites consisting of a three-character identifier of the sample medium and the relation between the sampling site and the wastewater effluent (tables 2 and 3). The three-character identifiers are defined as follows:

- $\quad$ US1 = Big Sioux River near Renner; Big Sioux River sampling site farthest upstream from the Sioux Falls WWTP discharge; substantially upstream from any influences from the city of Sioux Falls and isolated from substantial road traffic;

Table 2. Sampling sites and streamflow-gaging stations.

[mi ${ }^{2}$, square miles; e, estimated; --, not applicable]

\begin{tabular}{|c|c|c|c|c|c|c|}
\hline $\begin{array}{l}\text { Site } \\
\text { label }\end{array}$ & $\begin{array}{c}\text { Station } \\
\text { identification }\end{array}$ & Station name & $\begin{array}{c}\text { Drainage } \\
\text { area } \\
\left(\mathrm{mi}^{2}\right)\end{array}$ & $\begin{array}{c}\text { Contributing } \\
\text { drainage } \\
\text { area } \\
\left(\mathrm{mi}^{2}\right)\end{array}$ & $\begin{array}{l}\text { Latitude } \\
\text { (degrees, } \\
\text { minutes, } \\
\text { seconds) }\end{array}$ & $\begin{array}{l}\text { Longitude } \\
\text { (degrees, } \\
\text { minutes, } \\
\text { seconds) }\end{array}$ \\
\hline-- & 06481000 & Big Sioux River near Dell Rapids, SD & $\mathrm{e} 4,330$ & $\mathrm{e} 3,250$ & $43^{\circ} 47^{\prime} 25^{\prime \prime}$ & $096^{\circ} 44^{\prime} 42^{\prime \prime}$ \\
\hline US1 & 433843096450500 & Big Sioux River near Renner, SD & e4,365 & $\mathrm{e} 3,285$ & $43^{\circ} 38^{\prime} 43^{\prime \prime}$ & $096^{\circ} 45^{\prime} 05^{\prime \prime}$ \\
\hline US2 & 433600096442400 & $\begin{array}{c}\text { Sioux Falls pump station intake from } \\
\text { Big Sioux River at Sioux Falls, SD }\end{array}$ & e 4,400 & e3,320 & $43^{\circ} 36^{\prime} 00^{\prime \prime}$ & $096^{\circ} 44^{\prime} 24^{\prime \prime}$ \\
\hline FDW & 433419096434200 & $\begin{array}{l}\text { Sioux Falls water treatment plant } \\
\text { finished water at Sioux Falls, SD }\end{array}$ & -- & -- & -- & -- \\
\hline US3 & 433408096432000 & $\begin{array}{l}\text { Big Sioux River diversion channel at } \\
\text { North Drive at Sioux Falls, SD }\end{array}$ & e4,405 & $\mathrm{e} 3,325$ & $43^{\circ} 34^{\prime} 08^{\prime \prime}$ & $096^{\circ} 43^{\prime} 20^{\prime \prime}$ \\
\hline US4 & 06482020 & $\begin{array}{l}\text { Big Sioux River at North Cliff Ave- } \\
\text { nue, at Sioux Falls, SD }\end{array}$ & e5,065 & e3,975 & $43^{\circ} 34^{\prime} 01^{\prime \prime}$ & $096^{\circ} 42^{\prime} 39^{\prime \prime}$ \\
\hline WWE & 433531096394200 & $\begin{array}{l}\text { Sioux Falls wastewater treatment plant } \\
\text { effluent }\end{array}$ & -- & -- & -- & -- \\
\hline DS1 & 433559096390700 & $\begin{array}{l}\text { Big Sioux River downstream from } \\
\text { Sioux Falls wastewater discharge }\end{array}$ & e5,110 & e4,020 & $43^{\circ} 35^{\prime} 59^{\prime \prime}$ & $096^{\circ} 39^{\prime} 07^{\prime \prime}$ \\
\hline DS2 & 433541096355800 & Big Sioux River at Brandon, SD & $\mathrm{e} 5,120$ & e4,030 & $43^{\circ} 35^{\prime} 41^{\prime \prime}$ & $096^{\circ} 35^{\prime} 58^{\prime \prime}$ \\
\hline-- & 06485500 & Big Sioux River at Akron, IA & $\mathrm{e} 8,425$ & $\mathrm{e} 7,345$ & $43^{\circ} 47^{\prime} 25^{\prime \prime}$ & $096^{\circ} 44^{\prime} 42^{\prime \prime}$ \\
\hline
\end{tabular}


Table 3. Intervening reach lengths between selected locations.

\begin{tabular}{|c|c|c|}
\hline Starting location & Ending location & $\begin{array}{l}\text { Intervening reach length } \\
\text { (river miles) }\end{array}$ \\
\hline USGS gaging station 06481000 & Study sampling site US1 & 16.4 \\
\hline Study sampling site US1 & Study sampling site US2 & 4.0 \\
\hline Study sampling site US2 & Study sampling site US3 & 2.6 \\
\hline Study sampling site US3 & Study sampling site US4 (USGS gaging station 06482020) & .6 \\
\hline Study sampling site US2 & $\begin{array}{l}\text { Study sampling site US4 (USGS gaging station 06482020) } \\
\text { (through the natural Big Sioux River channel) }\end{array}$ & 16.4 \\
\hline USGS gaging station 06481500 & $\begin{array}{l}\text { Study sampling site US4 (USGS gaging station 06482020) } \\
\text { (through the natural Big Sioux River channel) }\end{array}$ & 11.8 \\
\hline $\begin{array}{l}\text { Study sampling site US4 } \\
\text { (USGS gaging station 06482020) }\end{array}$ & $\begin{array}{l}\text { Confluence of Sioux Falls wastewater treatment plant } \\
\text { effluent and Big Sioux River }\end{array}$ & 4.2 \\
\hline $\begin{array}{l}\text { Confluence of Sioux Falls wastewater treatment } \\
\text { plant effluent and Big Sioux River }\end{array}$ & Study sampling site DS1 & 6 \\
\hline Study sampling site DS1 & Study sampling site DS2 & 4.3 \\
\hline
\end{tabular}

- $\mathrm{US} 2=$ Sioux Falls pump station intake from Big Sioux River at Sioux Falls; Big Sioux River sampling site second most upstream from the Sioux Falls WWTP discharge; intake for Sioux Falls drinking water where two low-head dams create a backwater pool on the Big Sioux River; located just downstream from where the Big Sioux River enters the Sioux Falls urban area; in an area of moderate-volume road traffic and downstream from a small amount of stormwater runoff from the Sioux Falls urban area;

- $\mathrm{FDW}=$ Sioux Falls water treatment plant finished water at Sioux Falls; city of Sioux Falls finished drinking water;

- US3 = Big Sioux River diversion channel at North Drive at Sioux Falls; Big Sioux River sampling site third most upstream from the Sioux Falls WWTP discharge; Big Sioux River diversion channel just upstream from confluence with natural Big Sioux River channel; in an area of moderate-volume road traffic and can be influenced to a small degree by stormwater runoff from the Sioux Falls urban area;

- US4 = Big Sioux River at North Cliff Avenue, at Sioux Falls; Big Sioux River sampling site closest upstream from the Sioux Falls WWTP discharge; just downstream from confluence of natural Big Sioux River channel and diversion channel; in an area of high volume road traffic and downstream from nearly all stormwater runoff from the Sioux Falls urban area; a short distance upstream from US4 is a meat packing plant that discharges an average of about $4 \mathrm{ft}^{3} / \mathrm{s}$ of effluent to the Big Sioux River;

- $\mathrm{WWE}=$ Sioux Falls WWTP effluent;

- DS1 = Big Sioux River downstream from Sioux Falls WWTP discharge; Big Sioux River sampling site closest downstream from the Sioux Falls WWTP discharge; and

- DS2 = Big Sioux River near Brandon; Big Sioux River sampling site farthest downstream from the Sioux Falls WWTP discharge.

\section{Collection, Processing, and Analysis of Water and Bottom-Sediment Samples}

Water samples were collected at sites in or near Sioux Falls during seven sampling periods: August 15-16, 2001, September 9-11, 2002, January 22-24, 2003, March 19-21, 2003, June 25-27, 2003, May 17-18, 2004, and May 30-31, 2004. Because the primary sampling objectives changed during the course of sampling activities, not all sampling sites were sampled during every sampling round. During all sampling periods, the Sioux Falls WWTP was continuously discharging to the Big Sioux River.

Variability in the flow of the Big Sioux River during the sampling periods (especially for the runoff sampling periods) complicates the ability to directly compare OWC loads and concentrations between sites for a given sampling period. Available resources did not allow conducting a Lagrangian scheme that samples a given pulse of water as it moves downstream. However, during a given sampling period, the timing of sample collection at each site was designed to generally provide reasonable representation of the streamflow conditions that were occurring in the Sioux Falls area during the sampling periods.

At Big Sioux River sampling sites (except US2 where Big Sioux River water is pumped from a backwater pool into the intake pipe of the Sioux Falls drinking-water treatment system), streamflow was measured using standard USGS procedures (Rantz and others, 1982a; Rantz and others 1982b). WWTP discharges at the time of sampling were determined from monitoring records provided by the city of Sioux Falls (Trent Lubbers, 
Sioux Falls WWTP operator, written commun., 2005). For site US2, streamflow was estimated by analyzing the Big Sioux River flow at upstream and downstream sites. Other fieldmeasured properties and constituents were determined using standard USGS procedures (U.S. Geological Survey, 19972004) (table 7).

Water-quality samples for analysis of OWCs were collected and processed using standard USGS techniques (U.S. Geological Survey, 1997-2004). Containers and sampling equipment contacting the sample water were constructed of fluorocarbon polymer, glass, aluminum, or stainless steel and were rigorously cleaned using standard USGS procedures. Ultra-clean two-person sampling procedures were used and sampling teams wore powderless nitrile gloves. Special requirements for collection of wastewater, pharmaceutical, and antibiotic compounds also were adhered to (U.S. Geological Survey, 1997-2004), including avoiding use of insect repellents, sunscreen, tobacco, caffeine, and pharmaceutical drugs by the sampling team.

Wastewater effluent samples were collected using a depthintegrated grab from the centroid of the effluent channel downstream from all treatment activities. Water samples for Big Sioux River sites (except US2) were collected using standard USGS width- and depth-integrating procedures, generally at 5 to 10 verticals across the sampling transect. For site US2, water samples were collected directly from a tap on the intake pipe of the Sioux Falls drinking-water treatment system. Following collection, samples were composited into a glass or fluorocarbon polymer compositing container that was immediately chilled and transported to a laboratory processing area. Samples were processed at the laboratory processing area within a few hours of sample collection. The composite samples were split, filtered (if required), decanted into final sample bottles, packaged with ice, and sent by 1-day shipping to the analytical laboratories. Where appropriate, filtration was performed by passing sample water through a pre-conditioned 0.7 -micrometer $(\mu \mathrm{m})$, nominal-pore-size, baked glass-fiber filter. In this report, constituents in filtered water samples are referred to as "dissolved," which is operationally defined as that part of a water sample that passes through a $0.7-\mu \mathrm{m}$, nominalpore-size, baked glass-fiber filter. Constituents in unfiltered water samples are referred to as "whole water."

Bottom-sediment samples were collected from three sampling sites (US2, DS1, and DS2) during the September 2002 sampling period. Samples were collected following procedures described by Shelton and Capel (1994). All sampling equipment and containers contacting the bottom-sediment samples were constructed of stainless steel or glass, and were rigorously cleaned using standard USGS procedures. Ultra-clean twoperson sampling procedures were used, and sampling teams wore powderless nitrile gloves. At each sampling site, 10 subsamples of fine-grained material were collected from the upper few centimeters of the stream bottom in depositional zones within about $300 \mathrm{ft}$ of the water-sampling cross section. The subsamples were sieved through a 2-mm stainless-steel sieve into a compositing container and thoroughly homogenized. A sample of the composited homogenate was placed into a glass sample container, placed on ice, and sent in for analysis.

A total of 125 different OWCs were analyzed for in this study using five different analytical methods. Analyses for OWCs were performed at USGS laboratories that are developing and/or refining small-concentration (less than 1 microgram per liter $(\mu \mathrm{g} / \mathrm{L}))$ analytical methods. The following five analytical methods were used:

Analytical method 1 (performed at USGS National Water Quality Laboratory (NWQL) in Lakewood, Colorado) determined 20 prescription and nonprescription HPCs and selected metabolites and 4 HVACs in filtered water samples (table 7; Cahill and others, 2004) by using hydrophilic-lipophilicbalance (HLB) solid-phase extraction (SPE) cartridges. Pharmaceuticals concentrated in sample extracts were separated, identified, and quantified by reversed-phase, high-performance liquid chromatography/electrospray ionization mass spectrometry (HPLC/ESI-MS) using selected ion monitoring (SIM) and operated in the positive ionization mode.

Analytical method 2 (performed at the USGS Organic Geochemistry Research Laboratory (OGRL) in Lawrence, Kansas) determined 43 human and veterinary antibiotic compounds in filtered water samples (table 7). Water samples were analyzed for compounds primarily in the beta-lactam, macrolide, quinoline, sulfonamide, and tetracycline classes of antibiotics. The beta-lactams, macrolides, quinolones, sulfonamides, and tetracyclines were analyzed separately using online SPE methods and HPLC/ESI-MS in positive-ion mode. Samples were extracted for the beta-lactams, macrolides, quinolones, and sulfonamides using Prospekt cartridges (Waters) and for the tetracyclines using a proprietary Glyphosate Prospekt cartridge (Spark-Holland). The antibiotics for each class were eluted and separated using liquid chromatography gradient. Individual antibiotic compounds were analyzed using SIM and were identified using retention times and the ratio(s) of a quantifying ion to one or two confirming ions. The antibiotic compounds were quantified using the ratio of the area of the basepeak ion of the analyte to the area of the base-peak ion of the internal standard. Prior to December 2003, samples were analyzed at OGRL using a single quadrapole HPLC mass spectrometer. After December 2003, samples were analyzed at OGRL using a triple quadrapole HPLC mass spectrometer that reduced the laboratory reporting levels (LRL) by a factor of about 10 .

Analytical method 3 (performed at NWQL) determined 2 nonprescription HPCs, 3 MAHs, 50 HIACs, 10 PAHs, and 4 SCs in whole-water samples (table 7). Target compounds were extracted from water samples using continuous liquidliquid extraction with methylene chloride at $\mathrm{pH} 2.0$ (Lee and others, 2004). Extracts were separated and measured by gas chromatography/mass spectrometry using electron impact ionization and operated in the full-scan mode.

Analytical method 4 (performed at NWQL) determined 2 nonprescription HPCs, 2 MAHs, 43 HIACs, 10 PAHs, and 4 SCs in filtered samples (table 7). Target compounds were extracted from water samples by vacuum through disposable 


\section{Organic Wastewater Compounds in Drinking Water, Wastewater Effluent, and the Big Sioux River, 2001-2004}

SPE cartridges that contain polystyrene-divinylbenzene resin. Sorbed compounds were eluted with dichloromethane-diethylether. Compounds were measured by capillary-column gas chromatography/mass spectrometry. Other procedures of analytical method 4 were similar to method 3 but were performed on filtered samples (Zaugg and others, 2002).

Analytical method 5 (performed at NWQL) determined 3 MAHs, 44 HIACs, 10 PAHs, and 4 SCs in bottom sediment (table 7) using procedures described by Burkhardt and others (2005). Compound concentrations in solids samples were measured by placing a wet sediment sample in a stainless-steel cell and extracting it using an accelerated solvent extraction (ASE) system (Dionex ASE 200) with isopropyl alcohol/water. The compounds were then isolated from the ASE extracts using SPE cartridges (Waters, OASIS HLB polystyrenedivinylbenzene phase). The SPE cartridges were then dried, and a Florisil SPE cartridge was attached at the base to provide additional extract cleanup during elution with dichloromethane/diethyl ether. The volume of the extract was reduced under a gentle stream of nitrogen, and the methods compounds were analyzed by gas chromatography/mass spectrometry.

The determination of compounds of interest was a twostep process. First the compound was qualitatively identified followed by a quantitative determination of concentration. Strict criteria were used to assess both steps prior to reporting a compound and its concentration (Barnes and others, 2002; Kolpin and others, 2002; Lee and others, 2004). The first step of qualitative identification was the presence of the compound of interest within an expected chromatographic retention time. If present within the chromatographic window, compound mass spectrum and diagnostic ion abundance ratios were required to match that of the reference compound standard. After qualitative identification criteria were attained, analyte concentrations were calculated using a 5- to 8-point calibration curve (concentrations generally from 0.01 to $10.0 \mu \mathrm{g} / \mathrm{L}$ ) using internal standard quantitation. The most abundant ion typically was used for quantitation, and, if possible, as many as two diagnostic fragment qualifier ions were used for ion abundance ratio confirmation. For method 2, calibration standards were processed throughout the extraction procedure, which generally corrects concentrations for methodological losses during extraction but not for matrix effects. Methods 1, 3, 4, and 5 did not extract calibration standards; thus, the reported compound concentrations determined using these methods were not corrected for method losses.

LRLs were determined for each analyte by a previously published procedure (U.S. Environmental Protection Agency, 1992) for methods 1, 3, 4, and 5. Selected analyte concentrations were flagged with an "e" to indicate estimated values. Several of the reasons that the concentration of a qualitatively identified compound was reported as an estimate include concentrations that fell outside the calibration range, concentrations for analytes with average recoveries less than 60 percent, analytes routinely detected in laboratory blanks, and constituents with reference standards prepared from technical mixtures (Barnes and others, 2002; Kolpin and others, 2002; and Lee and others, 2004). Quality-assurance/quality-control (QA/QC) data were analyzed in detail, and for compounds that were determined to have acceptable QA/QC results, estimated values flagged with an "e" were considered to be reasonable estimates of actual concentrations and were included in analyses and discussions related to occurrence of OWCs.

In addition to the OWCs in table 7, samples also were analyzed for bromoform and four human hormone compounds (17-beta-estradiol, equilenin, estrone, and ethynyl estradiol). Bromoform is a volatile organic compound that typically occurs as a disinfection by-product and requires special sampling procedures (that were not used in this study) for accurate quantitation. Thus, analytical results for bromoform are not included in this report. NWQL has determined that the performance of the analytical methods for the four human hormone compounds have not yet been adequately verified to report the analytical results, given the particularly sensitive nature of the occurrence of these compounds in aquatic systems. Thus, analytical results for the four human hormone compounds are not included in this report.

Five OWCs - two HPCs (caffeine and cotinine) and three HVACs (erythromycin, sulfamethoxazole, and trimethoprim) - were determined by more than one analytical method. For each of these compounds, QA/QC results and LRLs were investigated, and the analytical method judged to provide the best performance was selected. Only the results for the selected method were included in analyses and discussion related to occurrence of OWCs in wastewater effluents and the Big Sioux River.

For the two May 2004 sampling periods, 2 HPCs, 2 MAHs, 43 HIACs, 10 PAHs, and 4 SCs were determined by analytical methods 3 and 4, on whole-water and filtered samples, respectively. QA/QC results and LRLs were investigated to assess performances of the two methods for each constituent. Analytical results also were investigated to determine whether whole-water concentrations were substantially larger than dissolved concentrations (that is, whether a substantial amount of the constituent was in the particulate phase), which could provide information concerning possible sources of OWCs. Only the results from one of the methods were included in summary analyses and discussion related to occurrence of OWCs in wastewater effluents and the Big Sioux River. Generally, selection of analytical method 3 results for inclusion in summary analyses and discussion was deemed preferable because it provides greater consistency than method 4 for comparison of the results of the May 2004 sampling periods with previous sampling periods. However, for several constituents, percent recoveries for laboratory reagent spikes and/or environmental matrix spikes were noticeably better (that is, closer to 100 percent) for analytical method 4 than for analytical method 3 , and the analytical method 4 results were judged to provide the best method performance and were included in summary analyses and discussion. This might slightly affect the comparability of OWC concentrations between the May 2004 sampling periods and the previous sampling periods. Information on which constituents 
were included in summary analyses and discussion for each sampling period is presented in table 7 .

\section{Calculation of Loads}

Loads of OWCs were estimated to provide coarse information on sources and fate of OWCs in the Big Sioux River. Because non-Lagrangian sampling was conducted, no attempt was made to sample a specific pulse of water as it moved downstream. Thus, exact correspondence between water samples collected at different sampling sites would not be expected. A primary effect on comparison of loads between sites could be diurnal variability in the magnitude of WWTP effluent discharges and concentrations of OWCs in the wastewater effluent. The largest effect of this variability would occur when comparing concentrations and loads of OWCs for the WWTP effluent discharge with those for Big Sioux River sampling sites downstream from the WWTP effluent discharge for a given sampling period. Diurnal variability of the WWTP effluent discharge generally was about $10 \mathrm{ft}^{3} / \mathrm{s}$ for most sampling periods. Typical daily operations of the Sioux Falls WWTP result in smaller and more variable discharges from about 2:00 a.m. to about 9:00 a.m., and larger and mostly stable discharges from about 9:00 a.m. to about 2:00 a.m. For sampling periods when the WWTP effluent discharge was sampled, sample collection at downstream Big Sioux River sampling sites generally was conducted such that the part of the sampled Big Sioux River discharge that was contributed by the WWTP effluent discharge was very similar to the WWTP effluent discharge at the time that the WWTP effluent discharge was sampled. However, no data were collected to evaluate diurnal variability in concentrations of OWCs in the WWTP effluent; the effect of this variability on comparison between concentrations and loads of OWCs for downstream Big Sioux River sampling sites and the WWTP effluent discharge is unknown.

Loads of OWCs were estimated by multiplying discharges at the times of sampling by constituent concentrations and by a conversion factor (0.0053919) to convert cubic feet per second and micrograms per liter to pounds per day. For constituents reported as less than the study reporting level (SRL) (defined in the Quality Assurance/Quality Control section), the concentrations were assumed to be zero in the load calculations. Load values are reported to two significant figures.

The load estimates presented in this report should be used with caution. Possible effects of non-Lagrangian sampling have been described. Also, most of the OWC concentrations were very small (often near the lower limits of analytical quantitation) and reported by the laboratories as estimated values. The multiplication of the concentrations by discharge, which can vary substantially from site to site and for some sampling periods was very large, might result in substantially increasing the effect of analytical error in the reported load estimates. However, although the error in the absolute values of the load estimates may be substantial, the load estimates probably provide reasonably accurate estimates for relative comparison between sites and between sampling periods.

\section{Quality Assurance/Quality Control}

Analytical results for OWCs presented in this report require additional interpretive effort not typically necessary for other water-quality constituents that usually occur at larger concentrations. Many OWCs were analyzed for in this study and substantial differences exist in the capability to quantify lowlevel (part-per-billion and lower) concentrations of individual compounds. For the five analytical methods used in this study, method performance can vary substantially between methods, and between compounds within a given method because of the range of chemical classes and properties of the compounds included in any one method. Also, because several of these OWCs (including the plasticizers, surfactants, and caffeine) are widely used in common consumer and industrial products, the risk of sample contamination in either the laboratory or the field varies between compounds and may be an important issue in low-level analysis of some trace OWCs. These factors result in variable precision/accuracy among compounds and complicate presentation of OWC analytical results.

The long-term performance for a given compound in any of the analytical methods used in this study spans a continuum. Establishing specific QA/QC criteria to define an "acceptable performance" range within this continuum typically is done in analytical chemistry practice. However, such criteria are inherently arbitrary and can exclude detections that violate the specified criteria but for which qualitative identification are reliable. This can be the case for some compounds determined by the analytical methods used in this study, which rely on mass spectrometry. Thus, when a concentration is qualified by the laboratories as "estimated," it serves as a categorical warning to pay particular attention to potential use of the numerical concentration, but not as a distinct boundary between "good" and "poor" data.

Given these complications, possible approaches for presentation of OWC analytical results that address the inherent complications include:

- Approach 1: reporting OWC analytical results in a manner that lessens the effect of precision/accuracy variability by focusing on presence/absence instead of quantification (for example, reporting frequency of detection instead of concentrations);

- Approach 2: selecting rigorous QA/QC criteria for screening analytical results and only presenting or discussing analytical results that are tightly controlled and have a very high probability of accurately representing "true" concentrations;

- Approach 3: selecting broader QA/QC criteria for screening analytical results, excluding from discussion compounds and concentration ranges that clearly are not accurately quantified, but presenting and discussing semiquantitative results for a larger set (than 
Approach 2) of compounds and concentration ranges for which analytical results are determined to reasonably accurately represent "true" concentrations.

Selection of an appropriate approach for presenting OWC analytical results is subjective and dependent upon study objectives. Approaches 1 and 2 probably represent a more conservative presentation of OWC analytical results than Approach 3. However, these approaches truncate the data set, and potentially valuable information relevant to study objectives might be excluded from discussion. Approach 1 limits data presentation to simple qualitative categories of "presence/absence;" potentially useful semiquantitative information contained in the relative magnitudes of concentrations is excluded. Approach 2 might result in presentation of tightly controlled data for few compounds meeting rigorous QA/QC criteria, but useful semiquantitative information for many other compounds might be excluded. Approach 3 requires greater effort to define and report the selected QA/QC screening criteria but could provide additional valuable semiquantitative information on the occurrence of OWCs.

Approach 3 was selected for use in this report. Detailed information concerning QA/QC screening criteria is presented in this report to allow evaluation of levels of uncertainty associated with reported concentrations. Because some of the analytical methods for OWCs are relatively new or still in development, the QA/QC screening criteria used in this study were less amenable to stringent quantitative limits than those for well-established analytical methods; thus, screening criteria used in this study probably are broader than those for many water-quality studies. In general, individual concentrations presented in this report should be considered semiquantitative estimates (even though QA/QC results for many of the compounds would satisfy even very strict precision/accuracy criteria). Qualifying the data as semiquantitative does not undermine the suitability of the data for meeting important objectives of this study, which included investigation of the "relative" variability in OWC occurrence between different sites and between different sampling periods. Analytical results for OWCs that passed QA/QC screening criteria were determined to be appropriate for this purpose. Within this report, if a specific concentration for a specific compound is of particular interest to the reader, the QA/QC data presented in the report need to be reviewed in detail to better evaluate the uncertainty associated with the specific reported concentration.

\section{Water Samples}

QA/QC samples were collected to assess precision and accuracy of analytical results for water samples. For the watersample results, QA/QC data were used to determine which compounds had acceptable method performance and to establish SRLs for individual OWCs. QA/QC included both laboratory and field activities.

Laboratory QA/QC procedures included processing and analyzing method-blank and reagent-spike samples, and adding surrogate compounds to all laboratory QA/QC samples, field QA/QC samples, and environmental samples. Method-blank samples consist of analyte-free water that is processed and analyzed in the laboratory identically to environmental samples. Method-blank samples are used to evaluate possible introduction of method compounds or interferences in the laboratory setting. For compounds that were detected in laboratory method-blank samples, a screening level of five times the detected concentration was applied by the laboratories to reported detected concentrations in environmental samples associated with the method-blank samples with detections (that is, concentrations in environmental samples detected by the laboratories that were less than five times the detected concentration in the laboratory method-blank samples were reported as less than the LRL). Reagent-spike samples consist of a reagent water sample that is fortified with known concentrations of the method analytes. Reagent-spike samples are used to monitor the performance of a given analytical method (in the absence of environmental matrix influences) at the time the environmental samples were analyzed, and in aggregate to assess the long-term performance of the method over the course of the study. Surrogate compounds are similar in physical and chemical properties to one or more of the method analytes, and are added in known quantities to all QA/QC and environmental water samples prior to analysis. Surrogate compounds are used to assess the effects of specific environmental matrixes on the performance of a given analytical method and in some cases to assess the potential for errors during the processing of a specific environmental sample. At least one method-blank and reagent-spike sample typically are analyzed with each set of 10 to 15 environmental samples.

Field QA/QC samples included field equipment blanks, replicates, and matrix spikes. For this study, 4 to 6 field equipment-blank samples (depending on analytical method), 4 to 10 replicate samples, and 3 to 10 environmental matrix spikes were collected and analyzed for laboratory analytical constituents (table 7). This level of field QA/QC sampling represents about 50 percent of the environmental samples collected.

Field equipment-blank samples were collected at field sampling sites by passing analyte-free water through the collection and processing equipment used for environmental samples using procedures identical to those used to collect and process the environmental samples. A field equipment-blank sample with constituent concentrations equal to or less than the SRL for a given constituent indicates that the overall process of sample collection, processing, and laboratory analysis is free of significant contamination. Sporadic, infrequent detections at concentrations near the SRL probably represent random contamination or instrument calibration error that is not persistent in the process and that is not likely to cause significant positive bias in study results. Consistent detections in the field equipmentblank samples at concentrations that are substantially less than concentrations in environmental samples probably indicate routine contamination but do not substantially affect evaluation of the environmental data. None of the OWCs analyzed for in this study had consistent detections in field equipment-blank 
samples. For OWCs that were sporadically detected in field equipment-blank samples, reported detected concentrations in environmental samples collected during the same sampling period as field equipment-blank samples with detections were at least five times greater than the field equipment-blank concentrations.

Field replicate samples were used to identify the level of precision (reproducibility) of analytical results at environmentally relevant concentrations. Field replicate samples were collected and processed immediately after each associated primary environmental sample was collected and processed, and procedures used for replicate samples were identical to those used for primary environmental samples. Field replicate samples are considered essentially identical in composition to the associated primary environmental samples. Precision of analytical results for field replicate samples is affected by numerous sources of variability potentially introduced by both field and laboratory processes, including sample collection, sample processing and handling, and laboratory preparation and analysis. Analyses of field replicate samples, therefore, can indicate the reproducibility of environmental data and provide information on the adequacy of procedures to produce consistent results.

Precision of analytical results for field replicate samples was determined by calculating the relative percent difference (RPD) for each primary/replicate sample pair as indicated in the following equation:

$$
R P D=(d / \bar{x}) * 100,
$$

where

$d=$ difference in concentration between the primary environmental sample and the field replicate sample for a given primary/replicate sample pair, and

$\bar{x}=$ mean concentration of the primary environmental sample and the field replicate sample for a given primary/replicate sample pair.

RPDs only were calculated for primary/replicate sample pairs in which a given compound was detected in both samples. Because many environmental OWC detections occur near the limit at which a compound can be qualitatively identified and quantified, a compound might be detected in a primary sample, but not the replicate, and vice versa. Thus, the number of primary/replicate sample pairs in which a given compound was detected in only one of the samples (but not both) was noted and also used to assess data quality and establish SRLs.

Generally, an RPD of 20 percent or less represents an acceptable level of precision, although for very small concentrations near the limit of analytical detectability, the percent differences can be substantially larger and still be considered reasonable due to the limits of resolution (Taylor, 1987). Most of the detected concentrations reported in this study are very small and near the limit of analytical detectability. Thus, a median RPD of 40 percent generally was used in this study to determine acceptability of results for field replicate samples. Three compounds (dissolved OP1EO, dissolved phenol, and whole-water pyrene) did not meet this criterion but were not excluded from analyses and discussion. These compounds had only one primary/replicate sample pair in which the compound was detected, and the compound was detected in both the primary and replicate samples, but the RPDs exceeded 40 percent. All other QA/QC results for these compounds were examined in detail and judged to be acceptable. Because a single primary/ replicate sample pair presents limited opportunity to evaluate analytical precision, and because the other QA/QC analyses for these compounds indicated acceptable analytical performance, it was determined that these compounds should not be excluded from analyses and discussion. RPDs for these three compounds ranged from 46 to 68 percent.

Environmental matrix spikes consist of replicate samples collected and processed identically to the primary environmental sample that were shipped to the laboratories where they were fortified with known concentrations of the method analytes. Concentrations of the method analytes in primary environmental samples and the environmental matrix spikes are determined, then the ambient concentrations in the primary sample are subtracted from the matrix-spike concentrations, and the resulting concentrations compared to the expected concentrations to calculate percent recoveries of analytes. Environmental matrix-spike samples are used to monitor the performance of a given analytical method for a specific environmental matrix.

Performance of the analytical methods for individual compounds was evaluated by calculating the relative standard deviation (RSD; expressed in percent) of the percent recoveries separately for laboratory reagent spikes, laboratory surrogates, and environmental matrix spikes. In the percent recovery calculations for the various spiked samples, any censored values reported as less than the LRL (for either the unspiked primary samples or the spiked samples) were arbitrarily assigned a value of zero. RSDs were computed from the standard deviations and the mean concentrations of percent recoveries for the spiked samples for a given compound. Expressing precision relative to a mean concentration standardizes comparison of precision among individual constituents. The RSD, in percent, is calculated using the following equation:

$$
R S D=(S / \bar{X}) * 100,
$$

where

$$
\begin{aligned}
S= & \begin{array}{l}
\text { standard deviation of percent recoveries of spiked } \\
\text { samples, and }
\end{array}
\end{aligned}
$$

$\bar{X}=$ mean of percent recoveries of spiked samples.

Analytical results for laboratory method blanks, laboratory reagent spikes, laboratory surrogates, field equipment blanks, field replicates, and environmental matrix spikes are summarized in tables 8-13, respectively, in the Supplemental Information section. QA/QC results were analyzed in a two-phase process that determined acceptability of analytical method performance for a given compound and then determined an SRL that represents the lower level of quantitation at which the compound could be consistently identified and reasonably accurately quantified. Acceptability of analytical method 
performance for a given compound was determined by analysis of percent recoveries for laboratory reagent spikes (table 9), laboratory surrogates (table 10), and environmental matrix spikes (table 13). Analytical method performance was considered to be acceptable when the median percent recoveries for laboratory reagent spikes, laboratory surrogates, and environmental matrix spikes were between 50 and 120 percent and when the RSDs of percent recovery for laboratory reagent spikes, laboratory surrogates, and environmental matrix spikes were less than 40 percent. Individual compounds that did not meet these method-performance acceptability criteria generally were excluded from analyses and discussion related to occurrence of OWCs in drinking water, wastewater effluent, and the Big Sioux River.

For several compounds, a single method-performance acceptability criterion was relaxed to allow inclusion of the compounds in analyses and discussion. Whole-water acetophenone, whole-water indole, and whole-water phenol had RSDs for percent recoveries for laboratory reagent-spike samples that slightly exceeded the acceptance criterion (less than 40 percent), ranging from 42 to 43 percent. Dissolved tri(2-butoxyethyl)phosphate had a median percent recovery for laboratory reagent-spike samples of 130 percent, which was outside of the acceptable range of 50-120 percent. Two compounds had median environmental matrix spike recoveries that exceeded the acceptable range (50-120 percent): whole-water 5-methyl benzotriazole (140 percent) and whole-water beta-sitosterol (160 percent). Three HPCs had median environmental matrix spike recoveries that were less than the acceptable range (50-120 percent): dissolved caffeine (analytical method 1; 33 percent), dissolved cotinine (analytical method 1; 41 percent), and dissolved dehydronifedipine (46 percent). One surrogate compound (dissolved fluoranthene-d10) had a median spike recovery of 123 percent, which slightly exceeded the acceptable range (50-120 percent). All other QA/QC data for these compounds (and in the case of the surrogate fluoranthene$\mathrm{d} 10$, physically and chemically similar study target compounds) were acceptable, and the patterns of occurrence of the compounds in environmental samples were consistent with related compounds and intuitively reasonable. Although QA/QC acceptance criteria were relaxed for these constituents, the effect on the ability to make comparisons in results between sites and between sampling periods probably was small.

For compounds that had acceptable analytical method performance for laboratory reagent spikes and environmental matrix spikes, analytical results for laboratory method blanks (table 8), field equipment blanks (table 11), and field replicate samples (table 12) were evaluated to determine SRLs. SRLs were established to identify the lower levels of quantitation at which the compounds could be consistently identified by the analysts (determined by evaluating results for field replicate samples) and reasonably accurately quantified without being substantially influenced by routine contamination from either laboratory or field activities (determined by evaluating results for laboratory method blanks and field equipment blanks). For each compound meeting method performance criteria, the SRL was established such that the compound was consistently detected in both samples of primary/replicate sample pairs, and the SRL generally was substantially larger than levels of contamination detected in laboratory method blanks and field equipment blanks.

There was a single detection of a compound that was not included in analyses and discussion. Isophorone was detected in a water sample collected from the Sioux Falls finished drinking water on March 19, 2003, at a very large concentration $(36 \mu \mathrm{g} / \mathrm{L})$. At the time of sample collection, renovation activities were being conducted at the Sioux Falls drinking-water treatment plant near the tap where the sample was collected. Isophorone is a solvent commonly found in paint, and it is likely that the detection of isophorone in the drinking-water sample occurred due to contamination of the tap from cleaning of painting equipment.

Information concerning compounds excluded from data analyses due to unacceptable method performance and the established SRLs for compounds with acceptable method performance are summarized in table 7. Of the 125 different OWCs analyzed for in this study, $81 \mathrm{OWCs}$ had one or more detections in environmental water samples reported by the laboratories, and of those 81 OWCs, 63 had acceptable analytical method performance, were detected at concentrations greater than the SRLs, and were included in analyses and discussion related to occurrence of OWCs in drinking water, wastewater effluent, and the Big Sioux River.

\section{Bottom-Sediment Samples}

QA/QC data collected to assess precision and accuracy of analytical results for bottom-sediment samples were restricted to laboratory surrogates. No field QA/QC data were collected for bottom-sediment samples. Analytical results for laboratory surrogates indicated acceptable method performance for bottom-sediment analyses (table 10). Analytical results for bottom-sediment samples are presented exactly as reported by the analytical laboratories.

\section{Occurrence of Organic Wastewater Compounds}

This section of the report summarizes the occurrence of OWCs in drinking water, wastewater effluent, and the Big Sioux River in or near Sioux Falls. In addition to presenting analytical results of the OWCs, this section of the report includes results for field-measured properties and constituents. Wastewater discharges and streamflow conditions in the Big Sioux River at the time of sampling also are described.

Results for field-measured properties and constituents in water samples are given in table 14 in the Supplemental Information section. Laboratory analytical results for HPCs, HVACs, MAHs, HIACs, PAHs, and SCs in water samples are 
given in tables 15-20 in the Supplemental Information section and are reported exactly as received from the laboratory. It should be noted that for some compounds, the established SRLs were larger than some of the detected concentrations reported by the laboratories. Thus, some of the reported detected concentrations in tables 15-20 were actually censored at the SRLs for the purposes of data analysis and summary. Detected concentrations greater than SRLs for compounds with acceptable QA/QC that were used in data analysis and summary related to occurrence of OWCs are noted in tables 15-20.

Summary calculations for OWCs, including total and median concentrations for compound classes, are rounded to two significant figures in this report. However, illustrations were created using unrounded raw values. Thus, there might be very small differences between values reported in text/tables and those shown in illustrations.

\section{Streamflow Conditions and Field-Measured Properties and Constituents}

Water samples were collected during base-flow and runoff conditions during summer, winter, and spring, 2001-2004. In this report, base flow is defined as flow in the stream that is not attributable to direct runoff from recent local precipitation or snowmelt. Base-flow and runoff conditions were determined by analysis of streamflow at USGS station 06482020 prior to sampling. Above-normal or below-normal flow at the time of sampling was determined by comparison to the long-term median flow (1977-2004) at USGS station 06482020

(http://nwis.waterdata.usgs.gov).

Streamflow conditions during sampling periods are shown in figure 2. The Sioux Falls WWTP discharged continuously to the Big Sioux River during all sampling periods. During August 15-16, 2001, above-normal flow/summer base-flow conditions existed for the Big Sioux River in the Sioux Falls area. No substantial precipitation had occurred for several days prior to sampling. Streamflow at long-term USGS gaging station 06482020 was about 250 percent of the long-term (water years 1977-2004) median mid-August streamflow (about $250 \mathrm{ft}^{3} / \mathrm{s}$ ), and the Sioux Falls WWTP effluent discharge accounted for about 4 percent of the streamflow of the Big Sioux River downstream. During September 9-11, 2002, below-normal flow/late-summer base-flow conditions existed for the Big Sioux River in the Sioux Falls area; streamflow at station 06482020 was about 35 percent of the long-term median early-September streamflow (about $200 \mathrm{ft}^{3} / \mathrm{s}$ ), and the Sioux Falls WWTP effluent discharge accounted for about 35 percent of the flow of the Big Sioux River downstream. During January 22-24, 2003, below-normal flow/winter base-flow conditions existed for the Big Sioux River in the Sioux Falls area; streamflow at station 06482020 was about 45 percent of the long-term median late-January streamflow (about $70 \mathrm{ft}^{3} / \mathrm{s}$ ), and the Sioux Falls WWTP effluent discharge accounted for about 55 percent of the flow of the Big Sioux River downstream. During March 19-21, 2003, near-normal flow/latewinter storm-runoff conditions resulting from precipitation that began on March 18 existed for the Big Sioux River in the Sioux
Falls area; streamflow at station 06482020 was about 100 percent of the long-term median late-March streamflow (about $750 \mathrm{ft}^{3} / \mathrm{s}$ ), and the Sioux Falls WWTP effluent discharge accounted for about 3 percent of the flow of the Big Sioux River downstream. During June 25-27, 2003, near-normal flow/ early-summer storm-runoff conditions resulting from precipitation that began on June 24 existed for the Big Sioux River in the Sioux Falls area; streamflow at station 06482020 was about 125 percent of the long-term median late-June streamflow (about $840 \mathrm{ft}^{3} / \mathrm{s}$ ), and the Sioux Falls WWTP effluent discharge accounted for about 3 percent of the flow of the Big Sioux River downstream. During May 17-18, 2004, below-normal flow/spring storm-runoff conditions resulting from precipitation that began on May 16 existed for the Big Sioux River in the Sioux Falls area; due to an extended period of below-normal precipitation, streamflow at station 06482020 only reached a level of about 15 percent of the long-term median mid-May streamflow (about $1,000 \mathrm{ft}^{3} / \mathrm{s}$ ) during this runoff event, and the Sioux Falls WWTP effluent discharge accounted for about 15 percent of the flow of the Big Sioux River downstream. During May 30-31, 2004, above-normal flow/spring storm-runoff conditions resulting from intense precipitation that began on May 28 existed for the Big Sioux River in the Sioux Falls area; streamflow at station 06482020 was about 850 percent of the long-term median late-May streamflow (about $600 \mathrm{ft}^{3} / \mathrm{s}$ ) during this runoff event, and the Sioux Falls WWTP effluent discharge accounted for less than about 1 percent of the flow of the Big Sioux River downstream.

Results for field-measured properties and constituents in water samples are presented in table 14 and figure 3. Generally, results for field-measured properties and constituents are within typical ranges for the Big Sioux River Basin (East Dakota Water Development District, 2004).

\section{Organic Wastewater Compounds in Water Samples}

OWCs in all compound classes were detected in water samples from sampling sites in the Sioux Falls area (fig. 4, tables 21 and 22 in the Supplemental Information section). For the five sampling periods when samples were collected from the Sioux Falls finished drinking water (FDW), only one OWC was detected at a concentration greater than the SRL (metolachlor; $0.0040 \mu \mathrm{g} / \mathrm{L}$ ). Due to the consistency in results for this site, analytical results for FDW generally are omitted from discussion in following sections.

Changes in sampling objectives during the course of sampling activities complicates presentation of results. Not all sampling sites were sampled during all sampling periods; thus, a simple and consistent format for presentation of results for the different sampling periods is not possible. For this reason, results for OWCs in water samples are presented in the following four sections: (1) occurrence of organic wastewater compounds by sampling period; (2) occurrence of organic wastewater compounds by sampling site; (3) occurrence of organic wastewater compounds by compound class; and (4) occurrence of endocrine disrupting compounds. The intent of the following 

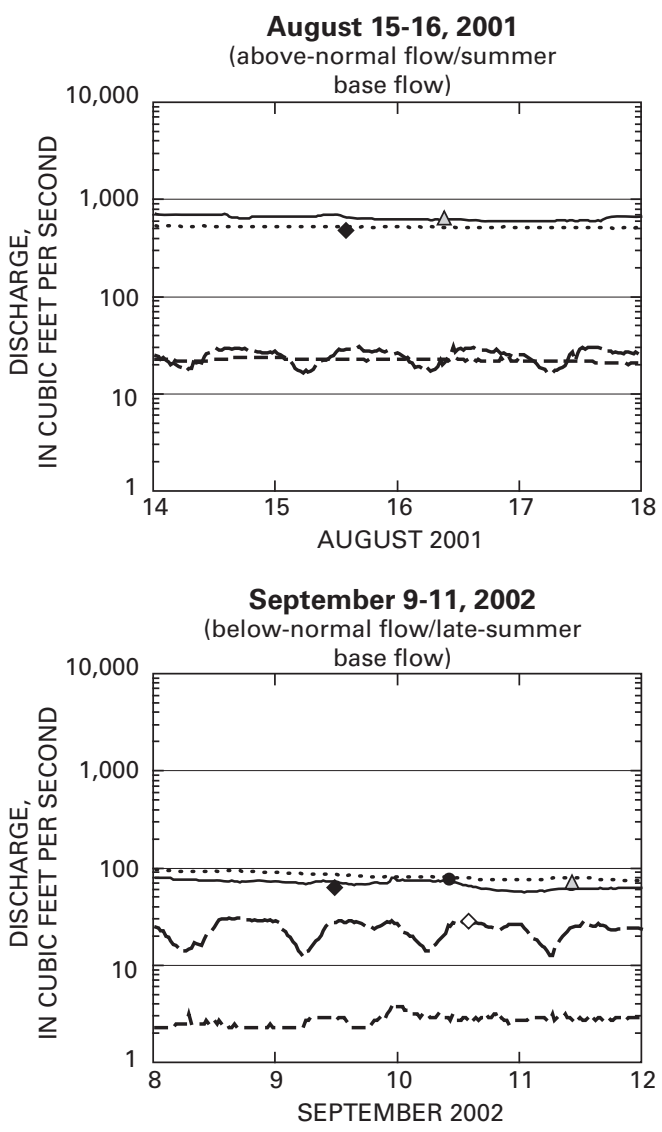

January 22-24, 2003

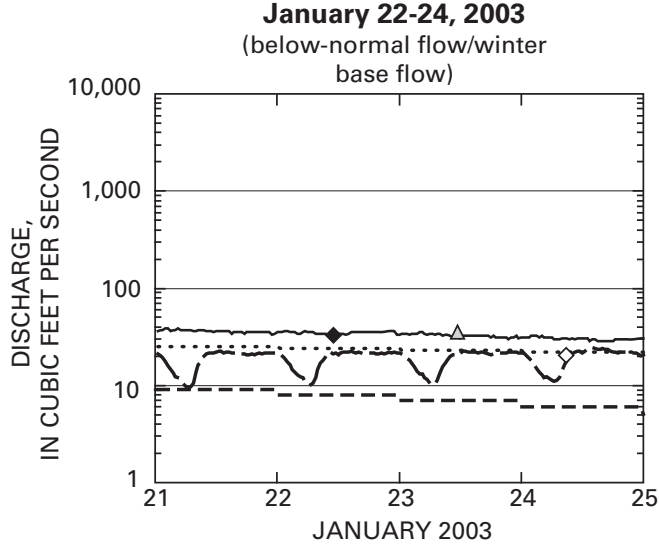

Figure 2. Flow conditions during sampling periods.
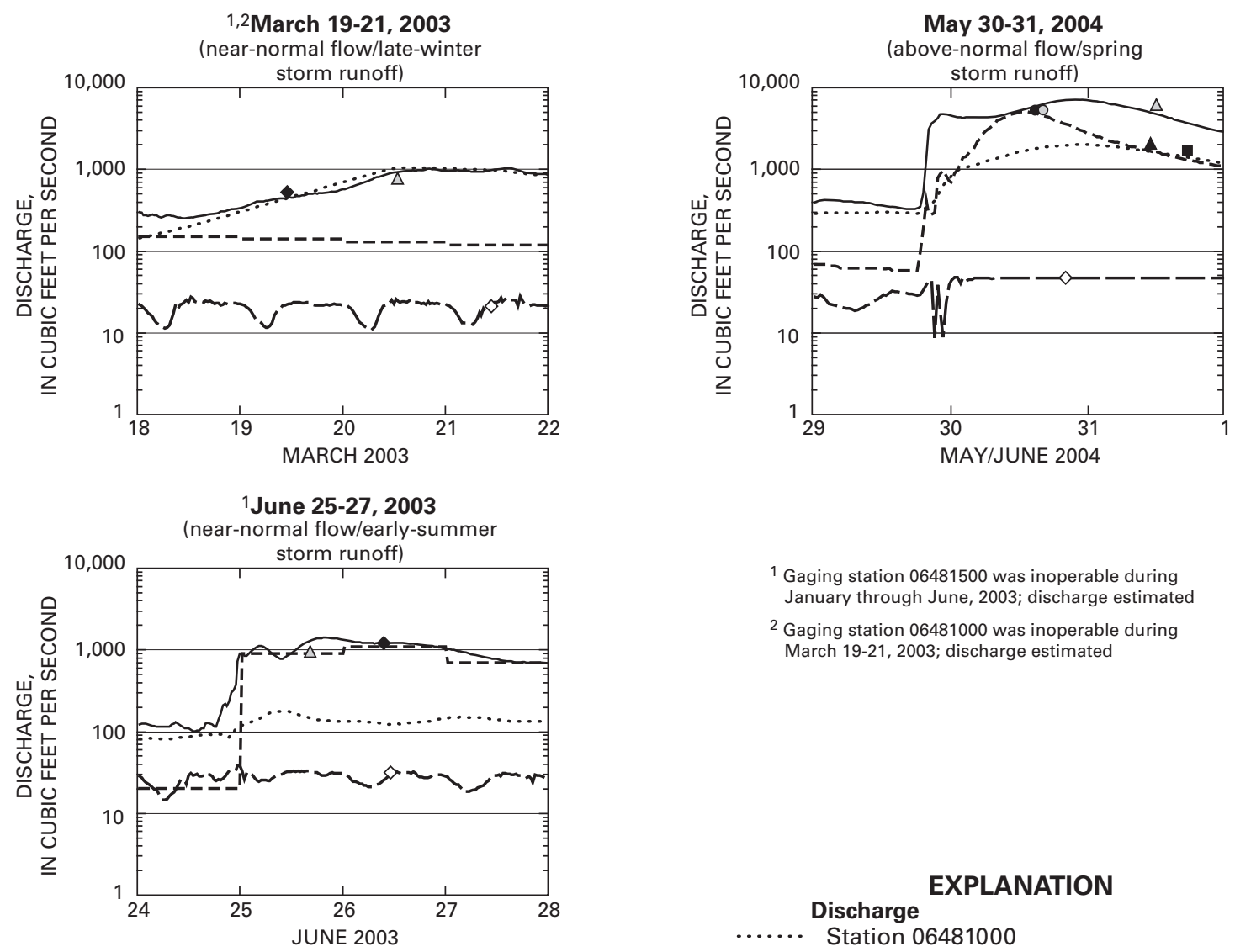

May 17-18, 2004

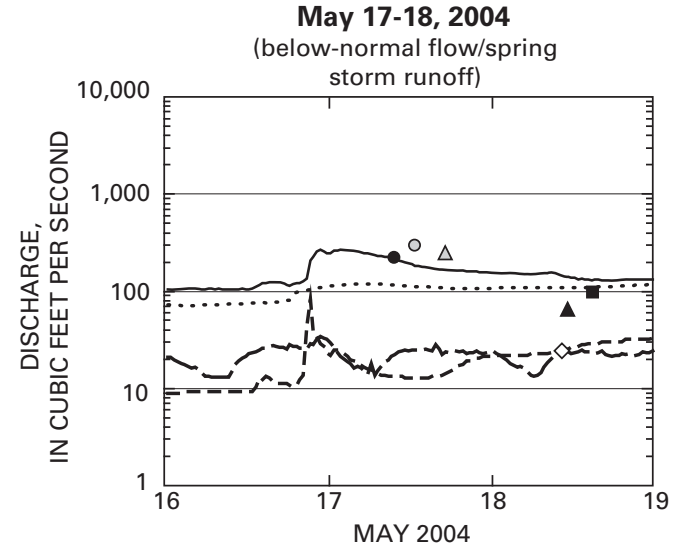

${ }^{1}$ Gaging station 06481500 was inoperable during January through June, 2003; discharge estimated

${ }^{2}$ Gaging station 06481000 was inoperable during March 19-21, 2003; discharge estimated

Discharge

EXPLANATION

Station 06481000

- . - - Station 06481500

- Station 06482020

- - Sioux Falls wastewater effluent

Sampling site discharge at time of sampling

- US1

- US2

US3

- US4 (station 06482020)

$\diamond \quad$ WWE (Sioux Falls wastewater effluent) - DS1

$\triangle \quad$ DS2
$\vec{D}$

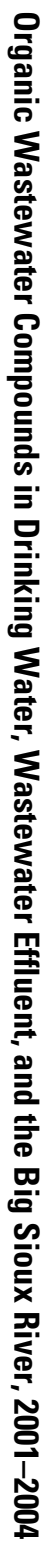



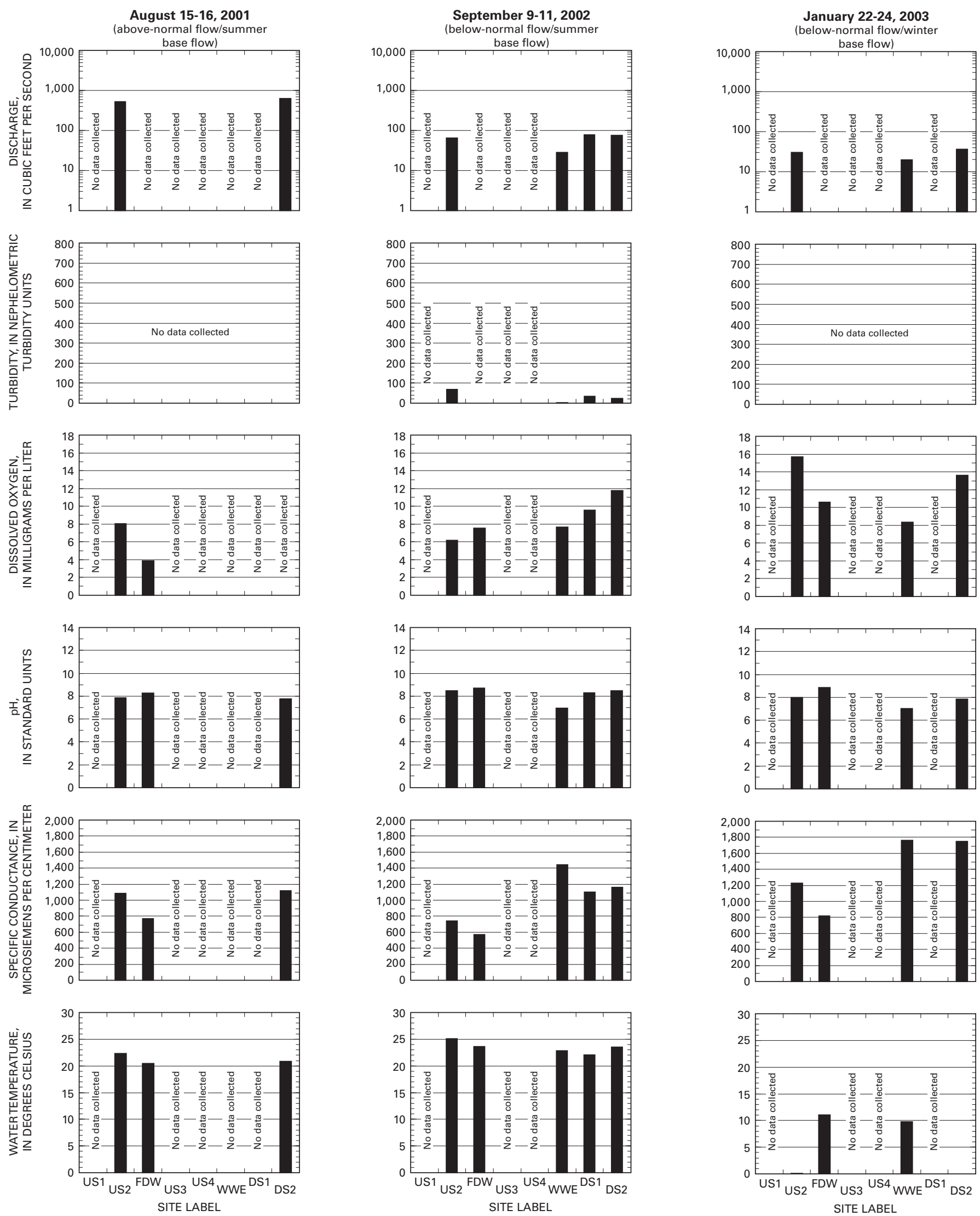

Figure 3. Results for field-measured properties and constituents. 
March 19-21, 2003

(near-normal flow/late-winter
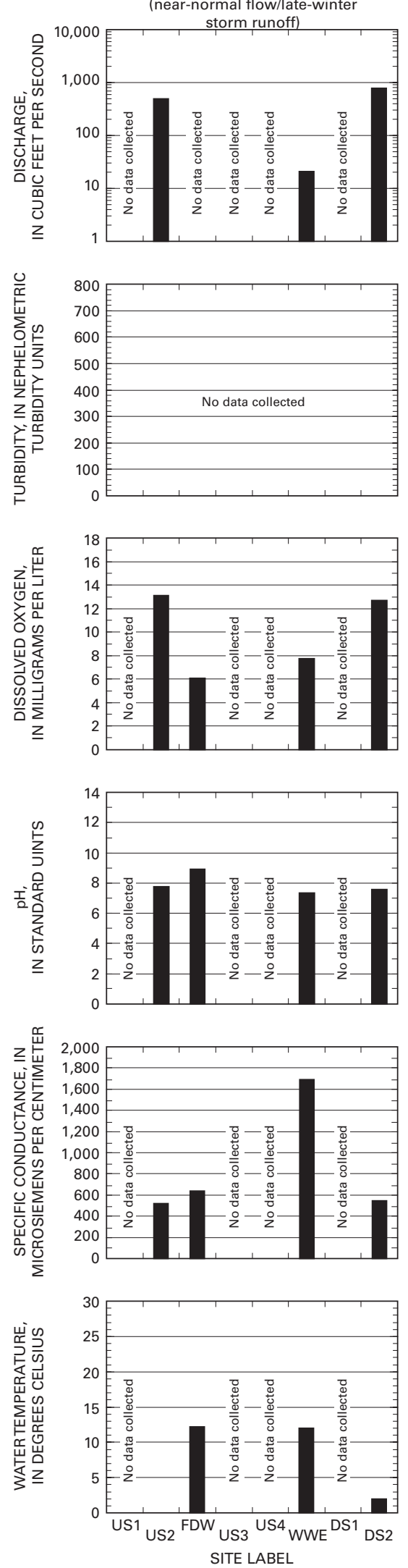

June 25-27, 2003

near-normal flow/early-summer
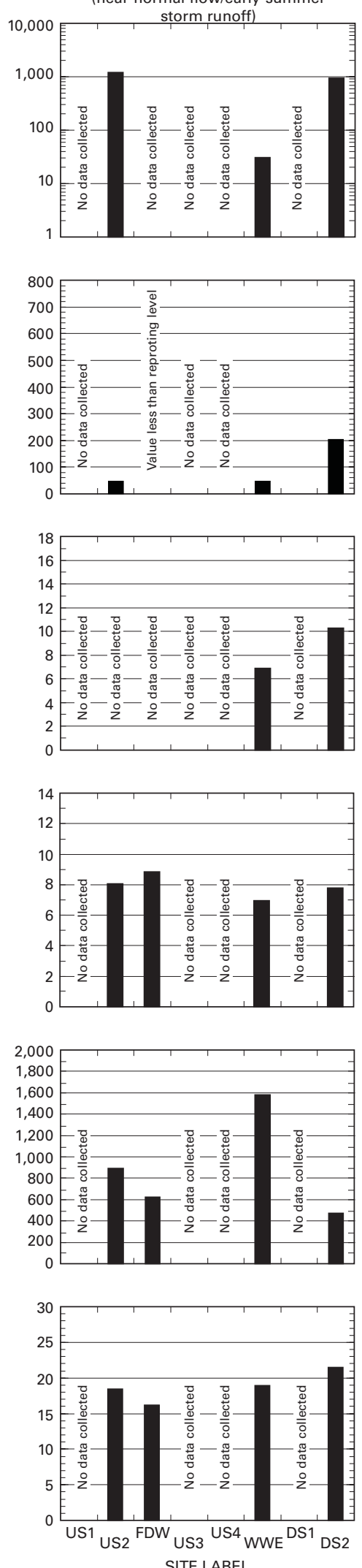

Figure 3. Results for field-measured properties and constituents. - Continued 

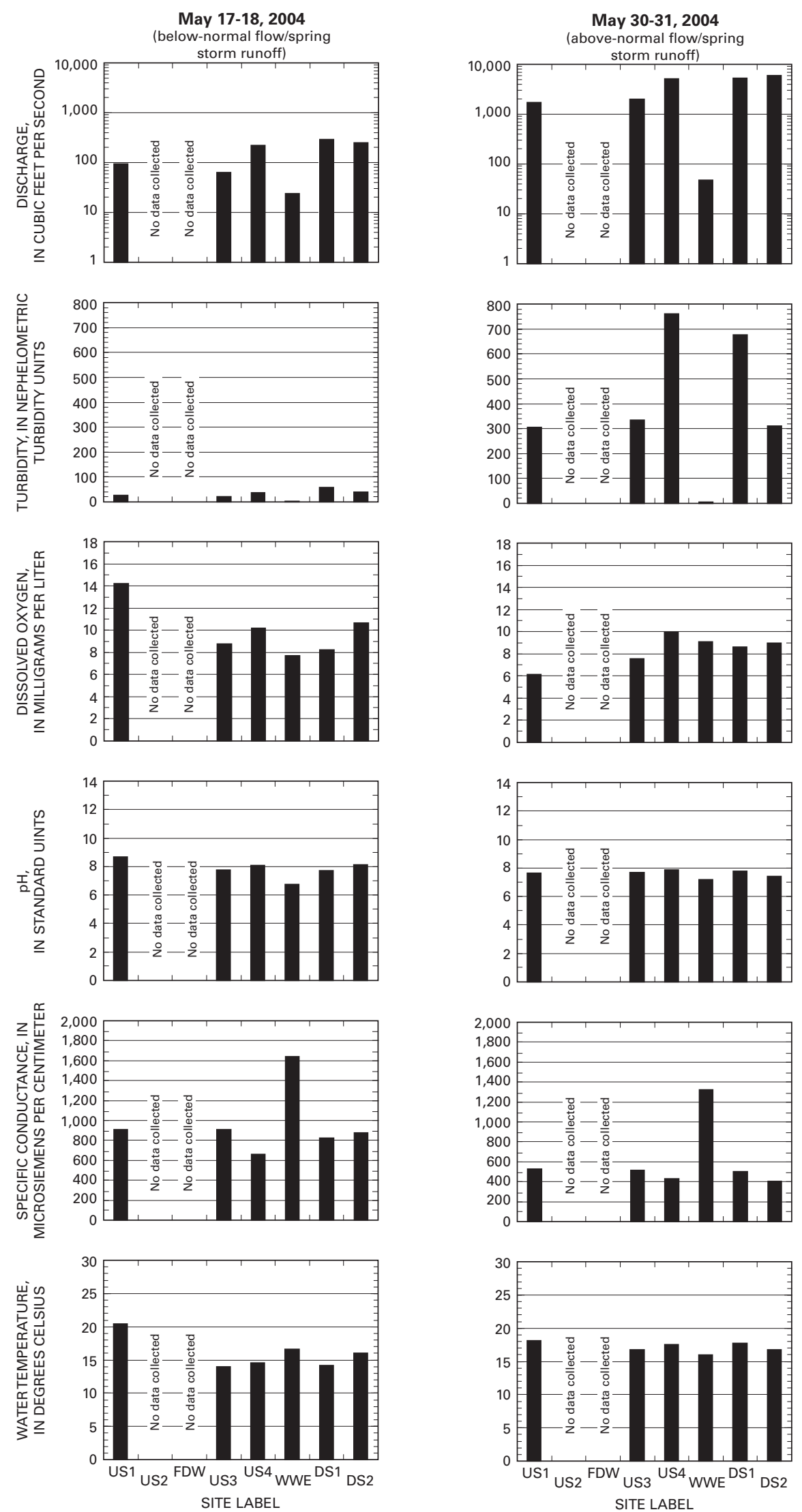

Figure 3. Results for field-measured properties and constituents.-Continued 

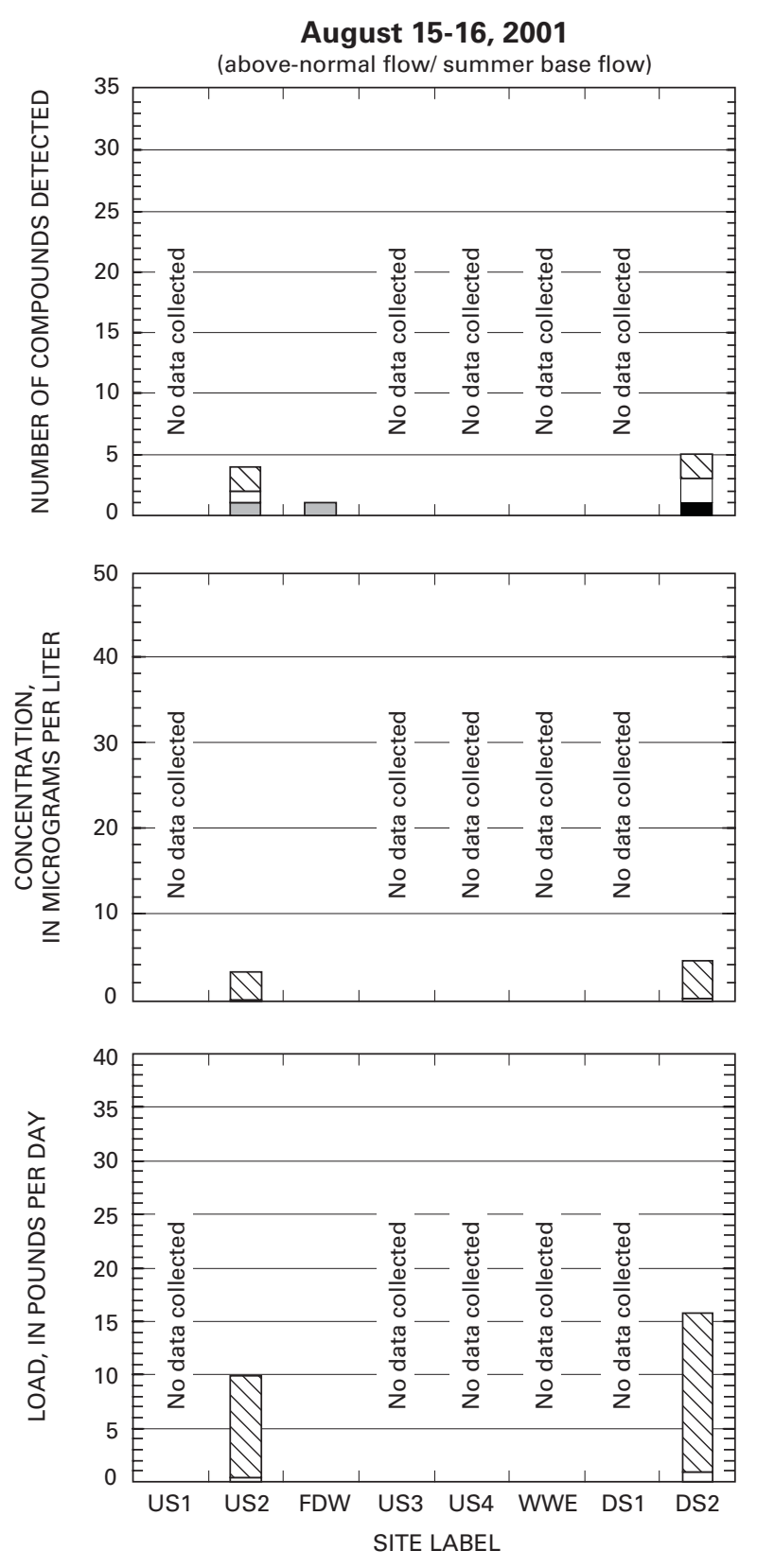

NOTE: $y$-axis variously scaled
September 9-11, 2002
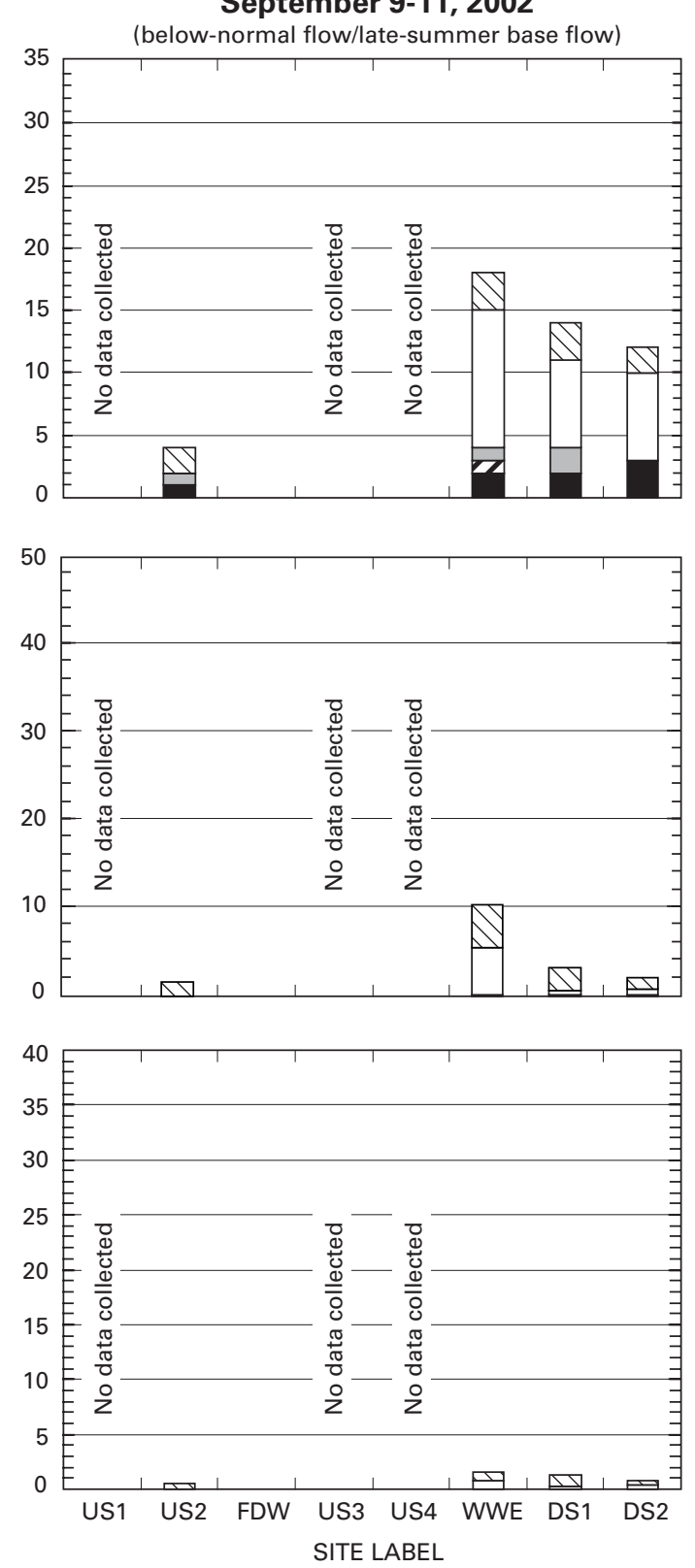

January 22-24, 2003
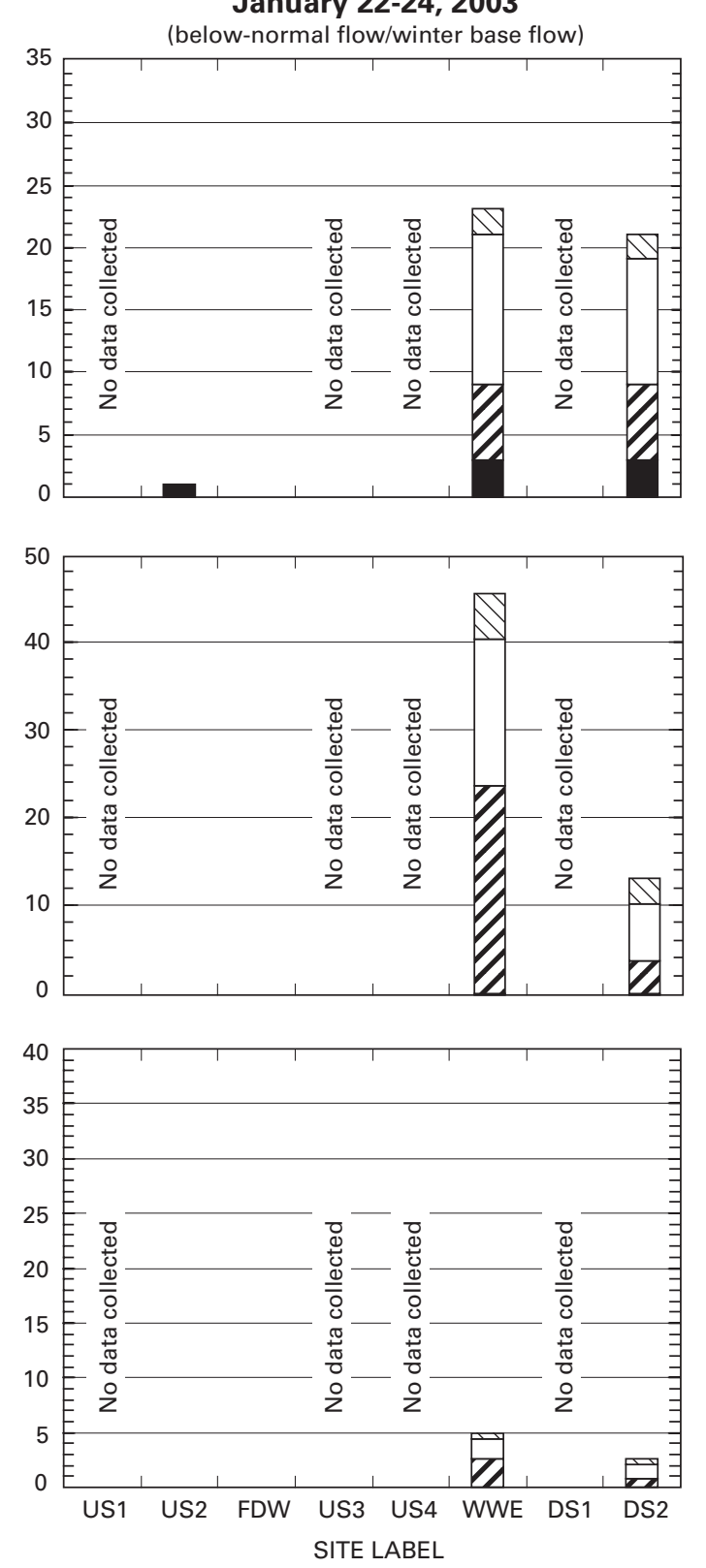

$\vec{\infty}$

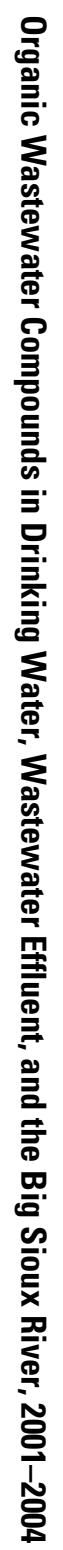

Figure 4. Results for organic wastewater compounds in water samples. 
March 19-21, 2003
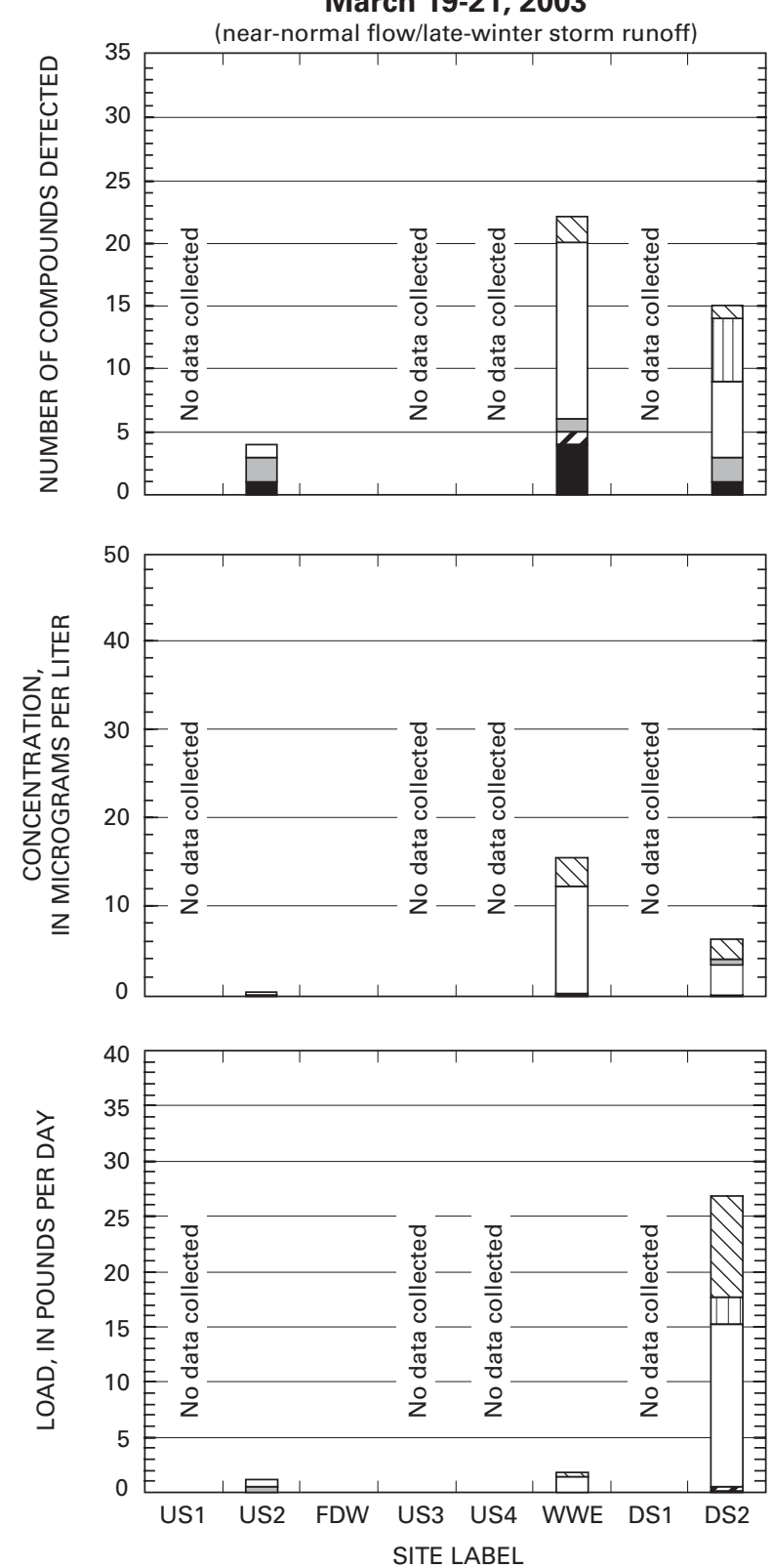

NOTE: $y$-axis variously scaled
June 25-27, 2003
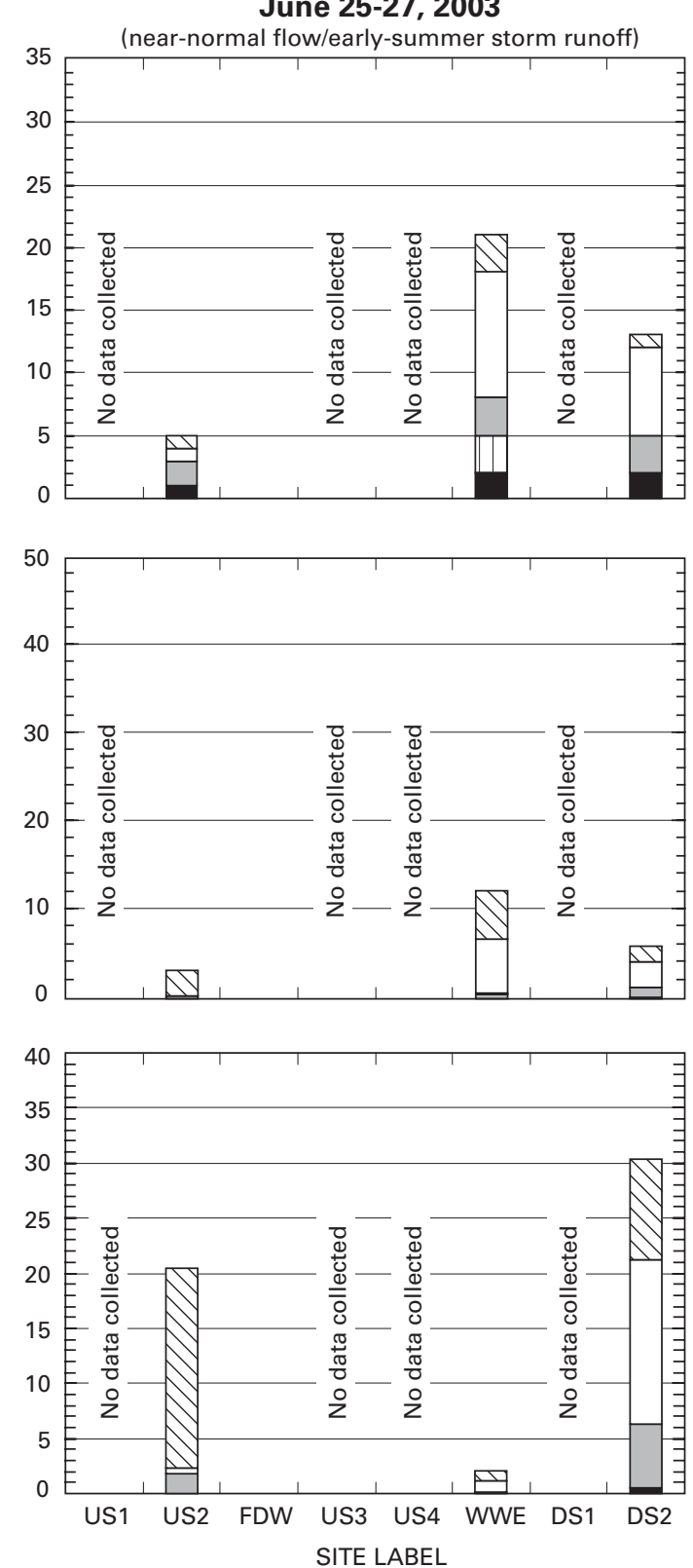

Figure 4. Results for organic wastewater compounds in water samples.-Continued 
May 17-18, 2004
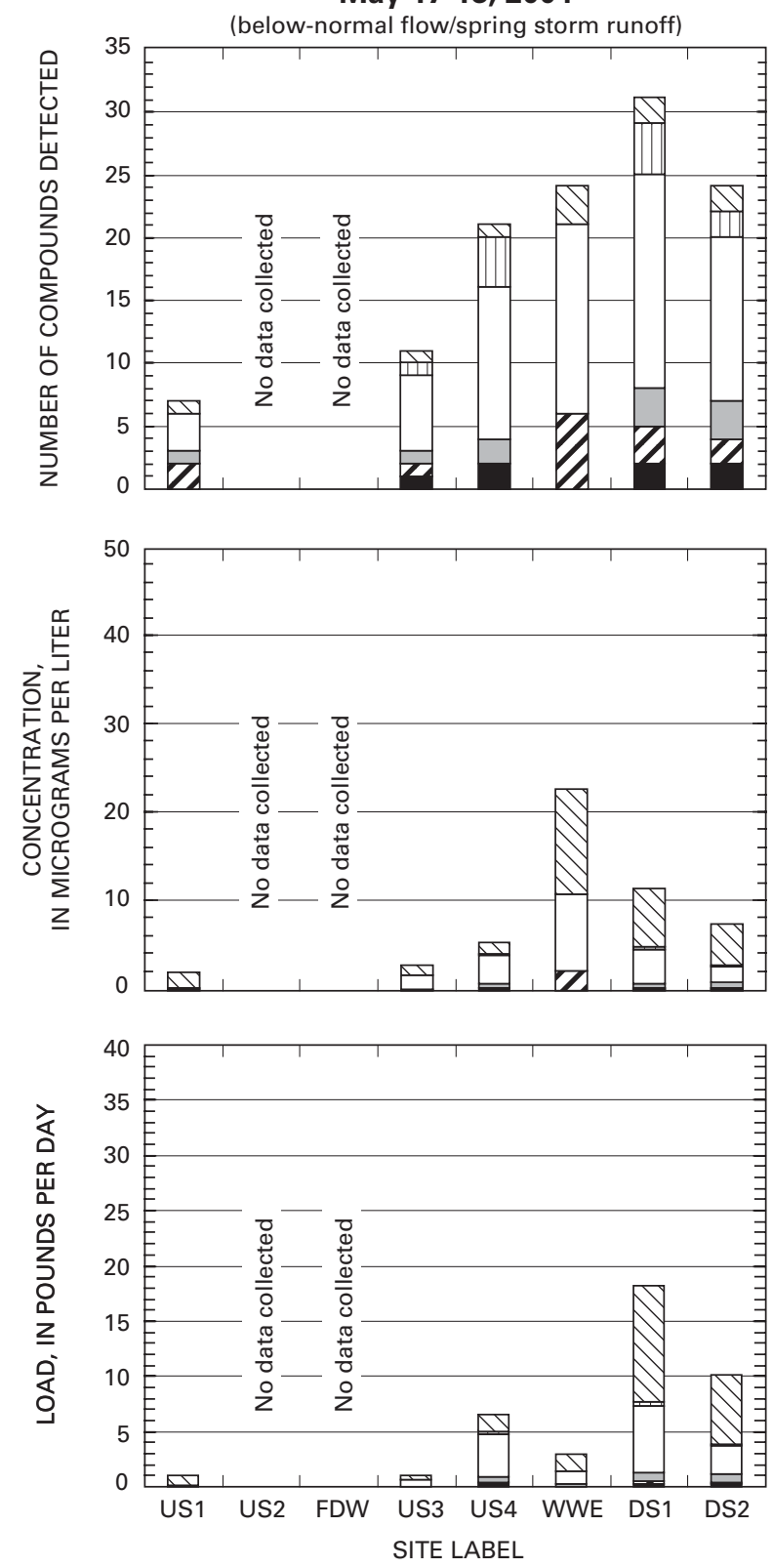

May 30-31, 2004
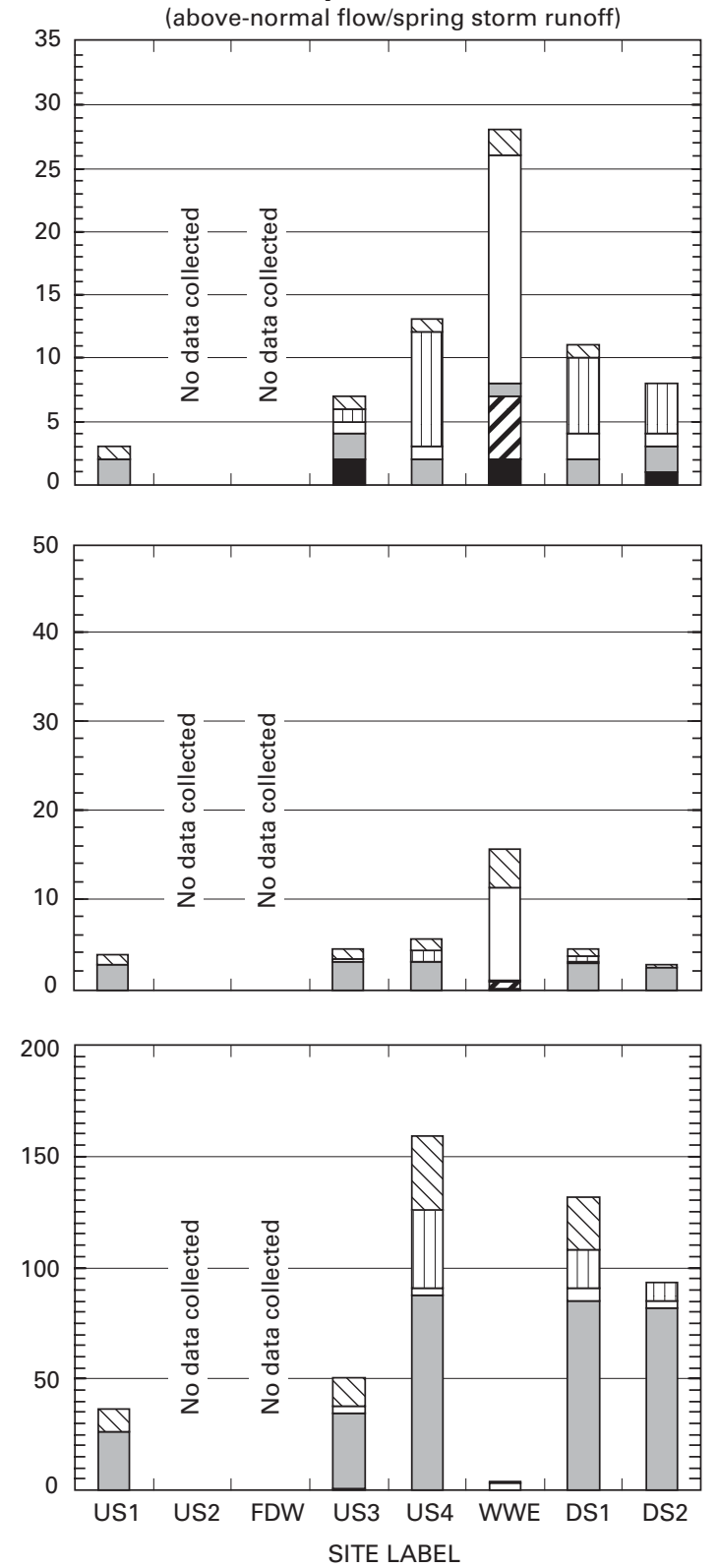

\section{EXPLANATION}

Each bar represents the total sum of all compound classes. The part of a given bar indicated for each compound class represents the amount that compound class contributes to the total

MV Sterol compounds (SCs)

$\square$ Polyaromatic hydrocarbons (PAHs) Household, industrial, and minor agricultural use compounds (HIACs)

Major agricultural herbicides (MAHs) Human and veterinary antibiotic compounds (HVACs)

Human pharmaceutical compounds (HPCs)

Figure 4. Results for organic wastewater compounds in water samples.-Continued 
sections is to present the results thoroughly so that patterns in occurrence of OWCs are apparent despite the variability in data collection among sampling periods; thus, there is some redundancy in information presented in the different sections.

\section{Occurrence of Organic Wastewater Compounds by Sampling Period}

For the August 2001 sampling period (above-normal flow/summer base-flow conditions for the Big Sioux River in the Sioux Falls area), sites US2, FDW, and DS2 were sampled. Numbers of compounds detected, concentrations, and loads were smaller for the sampling site upstream from the WWTP effluent discharge (US2) than for the sampling site downstream (DS2) (fig. 4, tables 21 and 22). SCs accounted for nearly all of the total OWC concentration for both Big Sioux River sites. Concentrations and loads of SCs were larger at the downstream site, but the increase in SC load at the downstream site probably was larger than would have been contributed by the WWTP alone (assuming typical operations of the WWTP and comparison of typical WWTP effluent discharges to Big Sioux River flow during the sampling period). HIACs accounted for a small part of the total OWC concentration for site DS2 and might have been contributed by the WWTP discharge. OWC results for the August 2001 sampling period indicate that (1) OWCs for Big Sioux River sites probably were primarily contributed by nonpoint animal agriculture activities, and (2) OWC concentrations for the downstream Big Sioux River site (DS2) probably were not strongly influenced by contributions from the Sioux Falls WWTP.

For the September 2002 sampling period (below-normal flow/late-summer base-flow conditions for the Big Sioux River in the Sioux Falls area), sites US2, FDW, WWE, DS1, and DS2 were sampled. Numbers of OWCs detected, concentrations, and loads were larger for the WWTP effluent than for Big Sioux River sites, and were smaller for the upstream Big Sioux River sampling site (US2) than for downstream sampling sites (DS1 and DS2) (fig. 4, tables 21 and 22). Total OWC concentrations were composed primarily of SCs for Big Sioux River sampling sites, and HIACs and SCs for the WWTP effluent. Possible explanations for decreases in OWC loads moving downstream include (1) degradation of OWCs in the Big Sioux River; (2) adsorption of OWCs to particulate material and sedimentation from the water column; (3) diurnal variability in wastewater effluent discharges and concentrations of OWCs in the wastewater effluent combined with effects of non-Lagrangian sampling; and/or (4) dilution effects decreasing concentrations of individual OWCs below detectable concentrations. Although total OWC concentrations and loads for the Big Sioux River sites downstream from the WWTP effluent discharge (DS1 and DS2) were not substantially larger than for the upstream site (US2), the WWTP effluent discharge influenced OWC concentrations at the downstream sites, as evidenced by the occurrence of several individual OWCs, including 7-acetyl-1,1,3,4,4,6hexamethyl tetrahydronaphthalene (AHTN) and several plasti- cizers and fire retardants, only in samples collected from the WWTP effluent and Big Sioux River downstream sites. OWC results for the September 2002 sampling period indicate that (1) OWCs for the Big Sioux River site upstream from the WWTP effluent discharge were relatively small and probably were primarily contributed by nonpoint animal agriculture activities, and (2) OWCs for the downstream Big Sioux River sites (DS1 and DS2) were influenced by contributions from the Sioux Falls WWTP, but OWC concentrations and loads for site DS2 were not substantially larger than for site US2.

For the January 2003 sampling period (below-normal flow/winter base-flow conditions for the Big Sioux River in the Sioux Falls area), sites US2, FDW, WWE, and DS2 were sampled. Numbers of OWCs detected, concentrations, and loads were larger for the WWTP effluent than for Big Sioux River sites and were substantially smaller for the upstream Big Sioux River sampling site (US2) than for the downstream site (DS2) (fig. 4, tables 21 and 22). The total OWC concentration and load for site US2 were minimal. Total OWC concentrations were composed primarily of HVACs, HIACs, and SCs for the WWTP effluent and DS2 sites. Total OWC concentrations were large for the WWTP effluent (substantially larger than for site DS2). OWC results for the January 2003 sampling period indicate that (1) OWC concentrations at the Big Sioux River site upstream from the WWTP effluent discharge were minimal, and (2) OWCs for the downstream Big Sioux River site (DS2) probably were substantially influenced by contributions from the Sioux Falls WWTP.

For the March 2003 sampling period (near-normal flow/late-winter storm-runoff conditions for the Big Sioux River in the Sioux Falls area), sites US2, FDW, WWE, and DS2 were sampled. Numbers of OWCs detected and OWC concentrations were larger for the WWTP effluent than for Big Sioux River sites and were composed primarily of HIACs and SCs (fig. 4, tables 21 and 22). However, the OWC load for the WWTP effluent was substantially smaller than for the Big Sioux River site downstream from the WWTP effluent discharge (DS2). Numbers of OWCs detected, and OWC concentrations and loads for the upstream Big Sioux River sampling site (US2) were small and composed primarily of HIACs and MAHs. Numbers of OWCs detected, and OWC concentrations and loads for the downstream Big Sioux River sampling site (DS2) were relatively large and composed primarily of HIACs, SCs, and PAHs. These patterns indicate that there were substantial contributions of OWCs to the Big Sioux River in the Sioux Falls area from sources other than the WWTP effluent discharge. Possible sources of OWCs between sites US2 and DS2 other than the WWTP effluent discharge include stormwater runoff from urban and/or agricultural areas to the Big Sioux River and/or resuspension of OWCs adsorbed to sediment deposited in the Big Sioux River between sites US2 and DS2. OWC results for the March 2003 sampling period indicate that (1) OWC concentrations at the Big Sioux River sampling site upstream from the WWTP effluent discharge were small and probably were primarily contributed by nonpoint crop agriculture sources and possibly stormwater runoff from nearby roads, 


\section{Organic Wastewater Compounds in Drinking Water, Wastewater Effluent, and the Big Sioux River, 2001-2004}

and (2) OWC concentrations at the Big Sioux River sampling site downstream from the WWTP probably were primarily contributed by OWC sources (probably a combination of urban stormwater runoff with OWCs derived from human activities and nonpoint animal agriculture sources) between sites US2 and DS2 other than the WWTP effluent discharge.

For the June 2003 sampling period (near-normal flow/early-summer storm-runoff conditions for the Big Sioux River in the Sioux Falls area), sites US2, FDW, WWE, and DS2 were sampled. Numbers of OWCs detected and OWC concentrations for the WWTP effluent were larger than for Big Sioux River sites and were composed primarily of HIACs and SCs (fig. 4, tables 21 and 22). However, the OWC load was substantially smaller for the WWTP effluent than for Big Sioux River sites both upstream (US2) and downstream (DS2) from the WWTP effluent discharge. OWCs detected for site US2 were composed primarily of SCs and MAHs. OWC load for site DS2 was relatively large and composed primarily of HIACs, SCs, and MAHs. The load of SCs decreased between sites US1 and DS2, which probably indicates deposition of SCs to sediments in the Big Sioux River between sites US1 and DS2. As is the case for the March 2003 sampling period, these patterns indicate that there were substantial contributions of OWCs to the Big Sioux River in the Sioux Falls area from sources other than the WWTP effluent discharge. OWC results for the June 2003 sampling period indicate that (1) OWC concentrations at the Big Sioux River sampling site upstream from the WWTP effluent discharge were fairly substantial and probably contributed by nonpoint animal and crop agriculture sources, and (2) OWC concentrations at the Big Sioux River sampling site downstream from the WWTP probably were contributed by OWC sources (probably a combination of urban runoff with OWCs derived from human activities and nonpoint animal agriculture sources) between sites US2 and DS2 other than the WWTP effluent discharge.

For the May 17-18, 2004, sampling period (below-normal flow/spring storm-runoff conditions for the Big Sioux River in the Sioux Falls area), sites US1, US3, US4, WWE, DS1, and DS2 were sampled. OWC concentrations for the WWTP effluent (WWE) were larger than for Big Sioux River sites and were composed primarily of HIACs and SCs (fig. 4, tables 21 and 22). However, the OWC load was substantially smaller for WWE than for the Big Sioux River sites US4, DS1, and DS2. Numbers of OWCs, and OWC concentrations and loads for sites US1 and US3 were smaller than for the other sampling sites, and were primarily composed of SCs for site US1, and HIACs and SCs for site US3. OWC concentrations and loads were substantially larger for site US4 than for sites US1 and US3, and primarily were composed of HIACs and SCs at site US4. OWC concentrations and loads for site DS1 were substantially larger than for site US4 and primarily were composed of SCs and HIACs. SCs account for most of the increase in OWC concentrations between sites US4 and DS1; HIAC loads generally were similar between sites US4 and DS1, but some individual HIACs detected for site DS1 corresponded with HIACs detected for WWE (table 22), indicating that the WWTP effluent also contributed to HIACs for site DS1. The increase in load of SCs between sites US4 and DS1 might have been contributed by nonpoint animal agriculture sources or resuspension of sediment. OWC concentrations and loads for site DS2 were substantially smaller than for site DS1, and primarily were composed of SCs and HIACs. OWC results for the May 17-18, 2004, sampling period indicate that (1) OWC loads for Big Sioux River upstream sites US1 and US3 were relatively small and probably contributed by nonpoint animal agriculture sources and possibly storm runoff from nearby roads; (2) OWC loads for the Big Sioux River upstream site US4 were larger than loads for the WWTP effluent discharge and probably were contributed by a combination of urban stormwater runoff and nonpoint animal agriculture sources contributing to the Big Sioux River between sites US3 and US4; (3) OWC loads were larger for site DS1 than for either site US4 or the WWTP effluent discharge, and the increase in OWC load between sites US4 and DS1 probably was contributed by nonpoint animal agriculture and/or resuspension of sediment, with a relatively small contribution from the WWTP effluent; and (4) OWC loads were smaller for site DS2 than for site DS1.

For the May 30-31, 2004, sampling period (above-normal flow/spring storm-runoff conditions for the Big Sioux River in the Sioux Falls area), sites US1, US3, US4, WWE, DS1, and DS2 were sampled. Numbers of OWCs detected and OWC concentrations for the WWTP effluent were larger than for Big Sioux River sites and were composed primarily of HIACs and SCs (fig. 4, tables 21 and 22). However, the OWC load was substantially smaller for the WWTP effluent than for all Big Sioux River sampling sites. Numbers of OWCs, and OWC concentrations and loads for upstream sites US1 and US3 were smaller than for the other Big Sioux River sampling sites, and were primarily composed of MAHs and SCs. OWC concentrations and loads for upstream site US4 were larger than concentrations and loads for sites US1 and US3, and primarily were composed of MAHs, SCs, and PAHs. Loads for all of these compound classes increased between sites US3 and US4. Between sites US3 and US4, the increase in load for MAHs might have been contributed by nonpoint crop sources in the Skunk Creek Basin, the increase in loads for SCs might have been contributed by nonpoint animal agriculture sources in the Skunk Creek Basin and urban stormwater runoff, and the increase in load for PAHs might have been contributed by urban stormwater runoff. OWC concentrations and loads for downstream site DS1 were smaller than for site US4 and primarily were composed of MAHs, SCs, and PAHs. Although HIACs compose a relatively small part of the total OWC concentrations for site DS1, individual HIACs detected for site DS1 (table 22) showed little correspondence with those detected for the WWTP effluent and indicate that the WWTP effluent contributed very little to concentrations and loads of OWCs for site DS1. Between sites US4 and DS1, loads of SCs and PAHs decreased, loads of MAHs were similar, and loads of HIACs increased slightly. OWC concentrations and loads for site DS2 were substantially smaller than for site DS1, and primarily were composed of MAHs and PAHs. OWC results for the May 17-18, 2004, sampling period indicate that 
(1) OWC loads for Big Sioux River upstream sites US1 and US3 were substantially smaller than for more downstream Big Sioux River sampling sites and probably were primarily contributed by nonpoint crop and animal agriculture sources;

(2) OWC loads for the Big Sioux River upstream site US4 were larger than loads for the WWTP effluent discharge and probably were contributed by a combination of urban stormwater runoff contributing to the Big Sioux River downstream from sites US1 and US3 and nonpoint crop and animal agriculture sources contributing to the Big Sioux River both upstream and downstream from sites US1 and US3; (3) OWC loads for site DS1 were smaller than for site US4 and probably were contributed by sources upstream from site US4, with very little contribution from the WWTP effluent discharge; and (4) OWC loads were smaller for site DS2 than for site DS1.

\section{Occurrence of Organic Wastewater Compounds by Sampling Site}

Site US1 is the Big Sioux River sampling site farthest upstream from the Sioux Falls WWTP discharge and is substantially upstream from any influences from the city of Sioux Falls and also is isolated from substantial road traffic. Site US1 was sampled during two sampling periods: May 17-18, 2004 (below-normal flow/spring storm-runoff conditions) and May 30-31, 2004 (above-normal flow/spring storm-runoff conditions). During both of these sampling periods, SCs and MAHs accounted for most of the total OWC concentrations (fig. 4), and probably were primarily contributed by nonpoint animal and crop agriculture sources. Total OWC concentrations for site US1 ranged from about 2 to $4 \mu \mathrm{g} / \mathrm{L}$. Total OWC loads and concentrations generally were smaller for site US1 than for more downstream Big Sioux River sites.

Site US2 is the Big Sioux River sampling site second most upstream from the Sioux Falls WWTP discharge. At site US2, Big Sioux River water is pumped from a backwater pool into the intake pipe of the Sioux Falls drinking-water treatment system, and water samples were collected directly from the intake pipe. Site US2 is located just downstream from where the Big Sioux River enters the Sioux Falls urban area. There is moderate-volume road traffic, and site US2 can be affected by local urban stormwater runoff. Site US2 was sampled during five sampling periods: August 2001 (above-normal flow/summer base-flow conditions), September 2002 (below-normal flow/late-summer base-flow conditions), January 2003 (belownormal flow/winter base-flow conditions), March 2003 (nearnormal flow/late-winter storm-runoff conditions), and June 2003 (near-normal flow/early-summer storm-runoff conditions). During the base-flow sampling periods, SCs accounted for most of the total OWC concentrations (fig. 4) and probably were primarily contributed by nonpoint animal agriculture sources. During the storm-runoff sampling periods, HIACs, MAHs, and SCs accounted for most of the total OWC concentrations and probably were primarily contributed by local urban stormwater runoff and nonpoint source agriculture sources.
Total OWC concentrations for site US2 ranged from less than 0.01 to about $3.5 \mu \mathrm{g} / \mathrm{L}$. Total OWC loads and concentrations generally were smaller for site US2 than more downstream Big Sioux River sites.

Site US3 is the Big Sioux River sampling site third most upstream from the Sioux Falls WWTP discharge. Site US3 is on the Big Sioux River diversion channel just upstream from the confluence with natural Big Sioux River channel and near the edge of the Sioux Falls urban area. Big Sioux River flow at site US3 consists primarily of flow past site US1 plus relatively small tributary inflow. There is moderate-volume road traffic, and site US3 can be affected by local urban stormwater runoff. Site US3 was sampled during two sampling periods:

May 17-18, 2004 (below-normal flow/spring storm-runoff conditions) and May 30-31, 2004 (above-normal flow/spring storm-runoff conditions). During the May 17-18, 2004, sampling period, which was a relatively small runoff event following an extended dry period, HIACs and SCs accounted for most of the total OWC concentration (fig. 4) and probably were primarily contributed by local urban stormwater runoff and nonpoint animal agriculture sources. During the May 30-31, 2004, sampling period, which was a very large runoff event, MAHs and SCs accounted for most of the total OWC concentration and probably were primarily contributed by nonpoint crop and animal agriculture sources. Total OWC concentrations for site US3 ranged from about 3 to $5 \mu \mathrm{g} / \mathrm{L}$. Total OWC loads and concentrations generally were smaller for site US3 than for more downstream Big Sioux River sites.

Site US4 is the Big Sioux River sampling site closest upstream from the Sioux Falls WWTP discharge. Site US4 is just downstream from the confluence of the natural Big Sioux River channel and the diversion channel. There is high-volume road traffic, and site US4 is downstream from nearly all potential urban stormwater runoff from Sioux Falls. Site US4 was sampled during two sampling periods: May 17-18, 2004, (below-normal flow/spring storm-runoff conditions) and May 30-31, 2004 (above-normal flow/spring storm-runoff conditions). During the May 17-18, 2004, sampling period, which was a relatively small runoff event following an extended dry period, HIACs and SCs accounted for most of the total OWC concentration (fig. 4) and probably were primarily contributed by urban stormwater runoff and nonpoint animal agriculture sources. During the May 30-31, 2004, sampling period, which was a very large runoff event, MAHs, PAHs, and SCs accounted for most of the total OWC concentration and probably were primarily contributed by nonpoint crop agriculture sources, urban stormwater runoff, and nonpoint animal agriculture sources. Total OWC concentrations for site US4 ranged from about 5 to $6 \mu \mathrm{g} / \mathrm{L}$. Total OWC loads and concentrations were smaller for site US4 than for more downstream Big Sioux River sites during the May 17-18, 2004, sampling period but were larger for site US4 than for more downstream Big Sioux River sites during the May 30-31, 2004, sampling period.

Site WWE is the Sioux Falls WWTP effluent. Site WWE was sampled during six sampling periods: September 2002 (below-normal flow/late-summer base-flow conditions), Janu- 
ary 2003 (below-normal flow/winter base-flow conditions), March 2003 (near-normal flow/late-winter storm-runoff conditions), June 2003 (near-normal flow/early-summer stormrunoff conditions), May 17-18, 2004 (below-normal flow/spring storm-runoff conditions), and May 30-31, 2004 (above-normal flow/spring storm-runoff conditions). During these sampling periods, HIACs and SCs accounted for most of the total OWC concentrations (fig. 4). Total OWC concentrations for site WWE ranged from about 10 to $45 \mu \mathrm{g} / \mathrm{L}$. Total OWC concentrations always were larger for site WWE than for Big Sioux River sites. Total OWC loads also were larger for site WWE than for all Big Sioux River sampling sites during baseflow sampling periods, but were smaller for site WWE than for Big Sioux River sites US4, DS1, and DS2 during storm-runoff sampling periods.

Site DS1 is the Big Sioux River sampling site closest downstream from the Sioux Falls WWTP discharge. Big Sioux River flow at site DS1 consists primarily of flow past site US4 plus the WWTP effluent discharge plus generally minor runoff contributed between sites US4 and DS1. Site DS1 was sampled during three sampling periods: September 2002 (below-normal flow/late-summer base-flow conditions), May 17-18, 2004 (below-normal flow/spring storm-runoff conditions), and May 30-31, 2004 (above-normal flow/spring storm-runoff conditions). During the base-flow sampling period (September 2002), SCs and HIACs accounted for most of the total OWC concentration (fig. 4) and probably were contributed by a combination of the Sioux Falls WWTP effluent discharge and nonpoint animal agriculture sources. Although the total OWC load during this sampling period was only slightly larger for site DS1 than for the upstream Big Sioux River site that was sampled (site US2), the contribution of the Sioux Falls WWTP effluent discharge to OWC concentrations at site DS1 is evidenced by occurrence of several individual OWCs, including AHTN and several plasticizers and fire retardants, only in samples collected from the WWTP effluent and Big Sioux River downstream sites (table 22). Relative proportions of OWC compound classes varied during storm-runoff conditions. During the May 17-18, 2004, sampling period (below-normal flow/spring storm-runoff conditions), SCs and HIACs accounted for most of the total OWC concentration and probably were contributed by nonpoint animal agriculture, urban stormwater runoff, and the Sioux Falls WWTP effluent discharge. Discernible contributions from the Sioux Falls WWTP effluent discharge to OWC concentrations for site DS1 are evidenced by occurrence of several individual OWCs, including AHTN, 1,3,4,6,7,8-hexahydro-4,6,6,7,8,8-hexamethyl cyclopenta-g-2-benzopyran (HHCB), and benzophenone, only in samples collected from the WWTP effluent and Big Sioux River downstream sites. The total OWC load at site DS1 was larger than the combined loads of sites US4 and WWE; in addition to the contribution from the WWTP effluent, the increase in OWC load between sites US4 and DS1 probably was contributed by nonpoint animal agriculture sources and/or resuspension of sediment. During the May 30-31, 2004, sampling period (above-normal flow/spring storm-runoff conditions), MAHs, SCs, and PAHs accounted for most of the total OWC concentration and probably were contributed by nonpoint crop and animal agriculture sources and urban stormwater runoff, with very little contribution from the WWTP effluent discharge. For all of the periods when site DS1 was sampled, total OWC concentrations ranged from about 3 to $12 \mu \mathrm{g} / \mathrm{L}$. Contributions from the WWTP effluent discharge to OWC concentrations for site DS1 were discernible during baseflow and below-normal storm-runoff conditions but were very minor during above-normal runoff conditions. Total OWC loads and concentrations were larger for site DS1 than for site DS2 during all sampling periods when both sites were sampled.

Site DS2 is the Big Sioux River sampling site farthest downstream from the Sioux Falls WWTP discharge. Big Sioux River flow at site DS2 consists primarily of flow past site DS1 plus generally minor runoff contributed between sites DS1 and DS2. Site DS2 was sampled during seven sampling periods: August 2001 (above-normal flow/summer base-flow conditions), September 2002 (below-normal flow/late-summer baseflow conditions), January 2003 (below-normal flow/winter base-flow conditions), March 2003 (near-normal flow/latewinter storm-runoff conditions), June 2003 (near-normal flow/early-summer storm-runoff conditions), May 17-18, 2004 (below-normal flow/spring storm-runoff conditions), and May 30-31, 2004 (above-normal flow/spring storm-runoff conditions). Relative proportions of OWC compound classes varied during base-flow conditions. During the August 2001 sampling period (above-normal flow/base-flow conditions), SCs accounted for most of the total OWC concentration (fig. 4) and probably were primarily contributed by nonpoint animal agriculture sources. During the September 2002 sampling period (below-normal flow/base-flow conditions), HIACs and SCs accounted for most of the total OWC concentration and probably were contributed by a combination of the Sioux Falls WWTP effluent discharge and nonpoint animal agriculture sources. Although the total OWC load during this sampling period was only slightly larger for site DS2 than for the upstream Big Sioux River site that was sampled (site US2), the contribution of the WWTP effluent discharge to OWC concentrations at site DS2 is evidenced by occurrence of several individual OWCs, including AHTN and several plasticizers and fire retardants, only in samples collected from the WWTP effluent and Big Sioux River downstream sites (table 22). During the January 2003 sampling period (below-normal flow/base-flow conditions), HIACs, HVACs, and SCs accounted for most of the total OWC concentration and probably were contributed primarily by the WWTP effluent discharge. Relative proportions of OWC compound classes varied during storm-runoff conditions. During the March 2003 sampling period (nearnormal flow/storm-runoff conditions), HIACs, SC, and PAHs accounted for most of the total OWC concentration and probably were primarily contributed by a combination of urban stormwater runoff and nonpoint animal agriculture sources. During the June 2003 sampling period (near-normal flow/storm-runoff conditions), HIACs, SCs, and MAHs accounted for most of the total OWC concentrations and probably were primarily contributed by a combination of urban 
stormwater runoff and nonpoint agriculture sources. During the May 17-18, 2004, sampling period (below-normal flow/storm runoff), SCs and HIACs accounted for most of the total OWC concentration and probably were contributed by nonpoint animal agriculture, urban stormwater runoff, and the Sioux Falls WWTP effluent discharge. Discernible contributions from the Sioux Falls WWTP effluent discharge to OWC concentrations for site DS2 are evidenced by occurrence of individual OWCs, including AHTN and HHCB, only in samples collected from sites WWE, DS1, and DS2. During the May 30-31, 2004, sampling period (above-normal flow/storm runoff), MAHs and PAHs accounted for most of the total OWC concentration and probably were contributed by nonpoint crop agriculture sources and urban stormwater runoff, with very little contribution from the WWTP effluent discharge. For all of the periods when site DS2 was sampled, total OWC concentrations ranged from about 2 to $13 \mu \mathrm{g} / \mathrm{L}$. Contributions from the WWTP effluent discharge to OWC concentrations for site DS2 were discernible during base-flow and below-normal storm-runoff conditions but were very minor during near- and above-normal runoff conditions. Total OWC loads and concentrations were smaller for site DS2 than for site DS1 during all sampling periods when both sites were sampled. Loads of all compound classes except MAHs decreased between sites DS1 and DS2 for all sampling period when both sites were sampled.

\section{Occurrence of Organic Wastewater Compounds by Compound Class}

HPCs were detected in samples collected from all sites in the Sioux Falls area except sites US1 and FDW (fig. 4, tables 21 and 22). Two different HPCs (caffeine and cotinine) were detected in samples collected from Big Sioux River sites upstream from the WWTP effluent discharge (sites US2, US3, and US4) with total detected concentrations for individual samples generally less than about $0.01 \mu \mathrm{g} / \mathrm{L}$ and generally accounting for less than about 2 percent of the total OWC concentration for any sample. Five different HPCs (1,7-dimethylxanthine, caffeine, cotinine, dehydronifedipine, and salbumatol) were detected in samples collected from the Sioux Falls WWTP effluent with total detected concentrations for individual samples ranging from about 0.031 to $0.16 \mu \mathrm{g} / \mathrm{L}$ and accounting for no more than about 1 percent of the total OWC concentration for any sample. Four different HPCs (1,7-dimethylxanthine, caffeine, cotinine, and salbumatol) were detected in samples collected from Big Sioux River sites downstream from the Sioux Falls WWTP effluent discharge with total detected concentrations for individual samples generally less than about $0.1 \mu \mathrm{g} / \mathrm{L}$ and generally accounting for less than about 2 percent of the total OWC concentrations in samples. Generally, HPCs contributed very little to OWC concentrations at any of the sampling sites in the Sioux Falls area during any streamflow conditions.

HVACs were detected in samples collected from sites US1, US3, WWE, DS1, and DS2 (fig. 4, tables 21 and 22). Two different HVACs (erythromycin- $\mathrm{H}_{2} \mathrm{O}$ and sulfamethoxazole) were detected in the May 17-18, 2004, samples collected from Big Sioux River sites upstream from the WWTP effluent discharge (sites US1 and US3) with total detected concentrations for individual samples generally less than about $0.1 \mu \mathrm{g} / \mathrm{L}$ and accounting for less than about 4 percent of the total OWC concentration. HVACs for upstream Big Sioux River sampling sites probably were contributed by nonpoint animal agriculture sources. Nine different HVACs were detected in WWE samples with total detected concentrations for individual samples ranging from about 0.050 to $24 \mu \mathrm{g} / \mathrm{L}$. HVACs were detected in all WWE samples. HVACs generally accounted for less than 10 percent of the total OWC concentrations for individual WWE samples. However, the total HVAC concentration for the January 2003 WWE sample was very large (about $24 \mu \mathrm{g} / \mathrm{L}$ ) and accounted for about 52 percent of the total OWC concentration for that sample. Seven different HVACs were detected in samples collected from downstream Big Sioux River sites (DS1 and DS2) with total detected concentrations for individual samples ranging from about 0.16 to $3.8 \mu \mathrm{g} / \mathrm{L}$ and generally accounting for less than about 2 percent of the total OWC concentrations. HVACs were only detected in the January 2003 and May 1718, 2004, samples for downstream Big Sioux River sites. The total HVAC concentration for the January 2003 sample for site DS2 was relatively large (about $3.8 \mu \mathrm{g} / \mathrm{L}$ ) and accounted for about 28 percent of the total OWC concentration for that sample. HVACs for downstream Big Sioux River sites were primarily contributed by the WWTP effluent discharge for the January 2003 sampling period and possibly a combination of nonpoint animal agriculture sources and the WWTP effluent discharge for the May 17-18, 2004, sampling period. HVACs generally accounted for a relatively small part of the total OWC concentrations in water samples collected from all sampling sites except for the January 2003 and May 17-18, 2004, samples for site WWE and downstream Big Sioux River sites.

MAHs were detected in samples collected from all sites (fig. 4, tables 21 and 22). Two different MAHs (atrazine and metolachlor) were detected in samples collected from Big Sioux River sites upstream from the WWTP effluent discharge (sites US1, US2, US3, and US4) with total detected concentrations for individual samples ranging from about 0.013 to $3.2 \mu \mathrm{g} / \mathrm{L}$. In all samples except those collected during the March 2003 and May 30-31, 2004, sampling periods, MAHs accounted for less than about 10 percent of the total OWC concentrations for upstream Big Sioux River sites. For samples collected during the March 2003 and May 30-31, 2004, sampling periods, MAHs accounted for about 41 to 72 percent of the total OWC concentrations for upstream Big Sioux River sites.

MAHs for upstream Big Sioux River sites were primarily contributed by nonpoint crop agriculture sources. One MAH (metolachlor) was detected in a single sample (August 2001 sampling period) collected from site FDW at a very small concentration $(0.0040 \mu \mathrm{g} / \mathrm{L})$. Three different MAHs (atrazine, metolachlor, and prometon) were detected in WWE samples with total detected concentrations for individual samples ranging from about 0.030 to $0.26 \mu \mathrm{g} / \mathrm{L}$ and accounting for less than about 
2 percent of the total OWC concentration in any WWE sample. Three different MAHs (atrazine, metolachlor, and prometon) were detected in Big Sioux River sites downstream from the WWTP effluent discharge (sites DS1 and DS2) with total detected concentrations for individual samples ranging from 0.038 to $3.0 \mu \mathrm{g} / \mathrm{L}$. In all samples except those collected during the June 2003 and May 30-31, 2004, sampling periods, MAHs accounted for less than about 10 percent of the total OWC concentrations for downstream Big Sioux River sites. For samples collected during the June 2003 and May 30-31, 2004, sampling periods, MAHs accounted for about 19 to 86 percent of the total OWC concentrations for downstream Big Sioux River sites. MAHs generally accounted for a relatively small part of the total OWC concentrations in samples collected from site WWE for all sampling periods and in samples collected from Big Sioux River sites during base-flow conditions. During some but not all of the storm-runoff sampling periods, MAHs accounted for a substantial part of the total OWC concentrations in samples collected from Big Sioux River sites.

HIACs were detected in samples collected from all sampling sites except FDW (fig. 4, tables 21and 22). Thirteen different HIACs were detected in samples collected from Big Sioux River sites upstream from the WWTP effluent discharge (sites US1, US2, US3, and US4) with total detected concentrations for individual samples ranging from about 0.074 to $3.2 \mu \mathrm{g} / \mathrm{L}$. HIACs generally accounted for less than 10 percent of the total OWC concentration in samples collected from upstream sites. However, HIACs accounted for 55 to 58 percent of the total OWC concentrations in samples collected from site US2 for the March 2003 sampling period, and from sites US3 and US4 for the May 17-18, 2004, sampling period. Greater proportions of HIACs for those samples probably were contributed by local stormwater runoff from roads. Individual HIACs that had the largest maximum concentrations for upstream sites include octylphenol diethoxylate (OP2EO; $0.20 \mu \mathrm{g} / \mathrm{L}$ ), octylphenol monoethoxylate (OP1EO; $0.40 \mu \mathrm{g} / \mathrm{L}$ ), para-nonylphenol (NP; $0.88 \mu \mathrm{g} / \mathrm{L})$, and tri(2-butoxyethyl)phosphate $(0.91 \mu \mathrm{g} / \mathrm{L})$. Twenty-seven different HIACs were detected in samples collected from site WWE with total detected concentrations for individual samples ranging from about 5.5 to $17 \mu \mathrm{g} / \mathrm{L}$. HIACs accounted for about 37 to 78 percent of the total OWC concentrations in WWE samples. Individual HIACs that had the largest maximum concentrations in samples collected from site WWE include AHTN $(2.1 \mu \mathrm{g} / \mathrm{L})$, nonylphenol diethoxylate (NP2EO; $6.2 \mu \mathrm{g} / \mathrm{L}$ ), nonylphenol monoethoxylate (NP1EO; $1.7 \mu \mathrm{g} / \mathrm{L}), \mathrm{NP}(1.9 \mu \mathrm{g} / \mathrm{L})$, phenol $(1.8 \mu \mathrm{g} / \mathrm{L})$, triethyl citrate $(1.1 \mu \mathrm{g} / \mathrm{L})$, tri(2-butoxyethyl)phosphate $(3.2 \mu \mathrm{g} / \mathrm{L})$, and tri(2-chloroethyl)phosphate $(2.9 \mu \mathrm{g} / \mathrm{L})$. Twenty different HIACs were detected in samples collected from sites downstream from the WWTP effluent discharge (sites DS1 and DS2) with total detected concentrations for individual samples ranging from about 0.095 to $6.6 \mu \mathrm{g} / \mathrm{L}$. HIACs generally accounted for about 20 to 55 percent of the total OWC concentrations in samples collected from downstream sites. However, HIACs accounted for less than about 5 percent of the total OWC concentrations in samples collected from down- stream sites for the August 2001 and May 30-31, 2004, samples. Individual HIACs that had the largest maximum concentrations in samples collected from downstream sites include AHTN $(0.56 \mu \mathrm{g} / \mathrm{L})$, NP2EO (3.0 $\mu \mathrm{g} / \mathrm{L})$, NP1EO $(0.82 \mu \mathrm{g} / \mathrm{L})$, NP $(1.2 \mu \mathrm{g} / \mathrm{L})$, phenol $(0.63 \mu \mathrm{g} / \mathrm{L})$, and tri(2-butoxyethyl)phosphate $(0.89 \mu \mathrm{g} / \mathrm{L})$. In samples collected from upstream Big Sioux River sites, HIACs generally accounted for a relatively small part of the total OWC concentrations during base-flow conditions and for a substantial part during some but not all of the storm-runoff sampling periods. HIACs generally accounted for a substantial part of the total OWC concentrations in samples collected from site WWE during all sampling periods. In samples collected from downstream Big Sioux River sites, HIACs generally accounted for a substantial part of the total OWC concentration during base-flow conditions and during some but not all of the storm-runoff sampling periods.

PAHs were detected in samples collected from sites US3, US4, DS1, and DS2 (fig. 4, tables 21 and 22). Ten different PAHs were detected in samples collected from Big Sioux River sites upstream from the WWTP effluent discharge (sites US3 and US4) with total detected concentrations for individual samples ranging from about 0.019 to $1.3 \mu \mathrm{g} / \mathrm{L}$. PAHs only were detected in water samples collected from upstream Big Sioux River sites for storm-runoff sampling periods, during which they accounted for about 0.7 to 17 percent of the total detected OWC concentrations. Individual PAHs that had the largest maximum concentrations for upstream sites include 1-methylnaphthalene $(0.13 \mu \mathrm{g} / \mathrm{L}), 2$-methylnaphthalene $(0.11 \mu \mathrm{g} / \mathrm{L})$, benzo[a]pyrene $(0.13 \mu \mathrm{g} / \mathrm{L})$, naphthalene $(0.19 \mu \mathrm{g} / \mathrm{L})$, and phenanthrene $(0.11 \mu \mathrm{g} / \mathrm{L})$. No PAHs were detected in samples collected from site WWE. Ten different PAHs were detected in samples collected from sites downstream from the WWTP effluent discharge (sites DS1 and DS2) with total detected concentrations for individual samples ranging from about 0.076 to $0.61 \mu \mathrm{g} / \mathrm{L}$. PAHs only were detected in water samples collected from downstream Big Sioux River sites for storm-runoff sampling periods, during which they accounted for about 1.2 to 12 percent of the total detected OWC concentrations. Individual PAHs that had the largest maximum concentrations in samples collected from downstream sites include fluoranthene $(0.17 \mu \mathrm{g} / \mathrm{L})$, naphthalene $(0.16 \mu \mathrm{g} / \mathrm{L})$, phenanthrene $(0.14 \mu \mathrm{g} / \mathrm{L})$, and pyrene $(0.12 \mu \mathrm{g} / \mathrm{L})$. PAHs only were detected at Big Sioux River sites that might be substantially affected by storm-runoff from roads. PAHs were not detected during any base-flow sampling period and were detected during some but not all storm-runoff periods. Even during runoff periods, PAHs accounted for less than 20 percent of total OWC concentrations.

SCs were detected in samples collected from all sites except FDW (fig. 4, tables 21 and 22). Two different SCs (betasitosterol and cholesterol) were detected in samples collected from Big Sioux River sites upstream from the WWTP effluent discharge (sites US1, US2, US3, and US4), with total detected concentrations for individual samples ranging from about 1.1 to $3.3 \mu \mathrm{g} / \mathrm{L}$ and accounting for about 22 to 98 percent of the total detected OWC concentrations. The SC that had the largest maximum concentrations for upstream Big Sioux River sites was 
cholesterol (2.8 $\mu \mathrm{g} / \mathrm{L})$. Three different SCs (3-beta-coprostanol, beta-sitosterol, and cholesterol) were detected in samples collected from site WWE, with total detected concentrations for individual samples ranging from about 3.1 to $12 \mu \mathrm{g} / \mathrm{L}$ and accounting for about 11 to 52 percent of the total detected OWC concentrations. The SC that had the largest maximum concentrations for site WWE was cholesterol $(5.4 \mu \mathrm{g} / \mathrm{L})$. Three different SCs (3-beta-coprostanol, beta-sitosterol, and cholesterol) were detected in samples collected at Big Sioux River sites downstream from the WWTP effluent discharge (sites DS1 and DS2), with total detected concentrations for individual samples ranging from about 0.82 to $6.7 \mu \mathrm{g} / \mathrm{L}$ and accounting for about 18 to 94 percent of the total detected OWC concentrations. The SC that had the largest maximum concentrations for downstream Big Sioux River sites was beta-sitosterol (3.7 $\mu \mathrm{g} / \mathrm{L})$. SCs generally comprised a substantial part of the total detected OWC concentrations for site WWE and Big Sioux River sites during both base-flow and storm-runoff conditions. Occurrence of the SC 3-beta-coprostanol is particularly relevant with respect to evaluating sources of OWCs because 3-beta-coprostanol is a major component of human feces, typically accounting for about 60 percent of the total fecal sterol content (Leeming and others, 1994). However, the relative amount of 3-betacoprostanol that occurs in feces of most other animals (especially herbivores; Leeming and others, 1994) generally is much lower. Several factors affect the relative composition of 3-betacoprostanol in WWTP effluents and receiving waters, including (1) variability in 3-beta-coprostanol concentrations in human feces between individuals (based largely on variable diet and composition of bacteria in the digestive tract); (2) variability in 3-beta-coprostanol removal between different WWTP processes; and (3) variability in environmental conditions that affect degradation of 3-beta-coprostanol in receiving waters (Bull and others, 2002). Because of these influencing factors, use of 3-beta-coprostanol indices to evaluate OWC sources between substantially different areas (with respect to WWTP technologies, human diet characteristics, and environmental characteristics of effluent receiving waters) should be used with caution. However, because the relative composition of 3-betacoprostanol in Sioux Falls WWTP effluents and the environmental characteristics of the Big Sioux River in the Sioux Falls area might reasonably be expected to be somewhat stable, investigation of the relative composition of 3-beta-coprostanol in water samples collected from site WWE and Big Sioux River sites provides information on the relative contribution of the Sioux Falls WWTP effluent discharge to the occurrence of OWCs in the Big Sioux River. Statistical summaries of data related to the occurrence of whole-water 3-beta-copro-stanol in water samples collected from site WWE and Big Sioux River sampling sites are presented in table 4. Whole-water 3-betacoprostanol was detected in all samples collected from site WWE. Ratios of concentrations of 3-beta-coprostanol to cholesterol (which has been used to assess the relative contribution of human sewage to total wastewater contamination; Bull and others, 2002) in water samples collected from site WWE ranged from 46 to 77 percent. Whole-water 3-beta-coprostanol was not detected in any samples collected from upstream Big Sioux River sites. Whole-water 3-beta-coprostanol was detected in two samples collected from downstream Big Sioux River sites and only during base-flow sampling periods. For the September 2002 sampling period (below-normal flow/late-summer baseflow conditions), when the Sioux Falls WWTP effluent discharge accounted for about 35 percent of the flow of the Big Sioux River, the ratio of concentrations of 3-beta-coprostanol to cholesterol was 77 percent for site WWE and 24 percent at site DS1, but 3-beta-coprostanol was not detected at site DS2. The occurrence of 3-beta-coprostanol at site DS1, but at a lower ratio to total SC concentration than for site WWE, probably indicates that human wastewater contributed to the OWC concentration at site DS1, but that 3-beta-coprostanol degraded or sedimented from the water column more quickly than cholesterol in the Big Sioux River, or was diluted relative to cholesterol by OWC sources other than the WWTP discharge. For the January 2003 sampling period (below-normal flow/winter baseflow conditions), when the Sioux Falls WWTP effluent discharge accounted for about 55 percent of the flow of the Big Sioux River, the ratio of concentrations of 3-beta-coprostanol to cholesterol was 46 percent for site WWE and 44 percent for site DS2. The similarity in ratios of concentrations of 3-betacoprostanol to cholesterol for sites WWE and DS1 indicates that the WWTP discharge substantially contributed to the occurrence of OWCs in the Big Sioux River during below-normal base-flow conditions.

\section{Occurrence of Endocrine-Disrupting Compounds}

EDCs were detected in samples collected from all sampling sites except FDW (fig. 5, tables 21 and 22). Nine different EDCs (atrazine, which is an MAH; benzophenone, OP2EO, OP1E0, and NP, which are HIACs; and anthracene, benzo[ $[a]$ pyrene, phenanthrene, and pyrene, which are PAHs) were detected in samples collected from Big Sioux River sites upstream from the WWTP effluent discharge (sites US1, US2, US3, and US4), with total detected concentrations for individual samples ranging from about 0.024 to $2.9 \mu \mathrm{g} / \mathrm{L}$. EDCs in samples collected from upstream sites generally had larger concentrations and loads for runoff sampling periods than for baseflow sampling periods and probably were primarily contributed by nonpoint crop agriculture sources and urban stormwater runoff.

Twelve different EDCs (atrazine, which is an MAH; and AHTN, benzophenone, carbaryl, chlorpyrifos, diazinon, HHCB, NP2EO, NP1E0, NP, pentachlorophenol, and triclosan, which are HIACs) were detected in samples collected from site WWE, with total detected concentrations for individual samples ranging from about 2.3 to $9.5 \mu \mathrm{g} / \mathrm{L}$. EDC concen-trations in samples collected from site WWE were largest for the January 2003 and March 2003 sampling periods, exceeding about $9 \mu \mathrm{g} / \mathrm{L}$. 
Table 4. Statistical summaries of data related to occurrence of whole-water 3-beta-coprostanol in water samples collected from wastewater effluents and the Big Sioux River.

[WWTP, wastewater treatment plant; $\mu \mathrm{g} / \mathrm{L}$, micrograms per liter; --, no data]

\begin{tabular}{|c|c|c|c|c|c|c|c|c|c|c|c|}
\hline \multirow{2}{*}{ Type of sampling sites } & \multicolumn{2}{|c|}{$\begin{array}{l}\text { Frequency of } \\
\text { detection } \\
\text { (percent) }\end{array}$} & \multirow{2}{*}{$\begin{array}{l}\text { Number } \\
\text { of } \\
\text { samples }\end{array}$} & \multirow{2}{*}{$\begin{array}{l}\text { Number } \\
\text { of } \\
\text { detec- } \\
\text { tions }\end{array}$} & \multicolumn{3}{|c|}{$\begin{array}{l}\text { Statistical summary of } 3 \text {-beta- } \\
\text { coprostanol detected } \\
\text { concentrations for all } \\
\text { sampling periods }(\mu \mathrm{g} / \mathrm{L} \text { ) }\end{array}$} & \multicolumn{4}{|c|}{$\begin{array}{l}\text { Statistical summary of the ratio of 3- } \\
\text { beta-coprostanol to cholesterol } \\
\text { concentration for samples with } \\
\text { detections (percent) }\end{array}$} \\
\hline & $\begin{array}{c}\text { Stable } \\
\text { low-flow } \\
\text { sampling } \\
\text { periods }\end{array}$ & $\begin{array}{l}\text { Stable } \\
\text { high-flow } \\
\text { and runoff } \\
\text { sampling } \\
\text { periods }\end{array}$ & & & $\begin{array}{l}\text { Mini- } \\
\text { mum }\end{array}$ & Median & $\begin{array}{c}\text { Maxi- } \\
\text { mum }\end{array}$ & $\begin{array}{l}\text { Mini- } \\
\text { mum }\end{array}$ & Median & $\begin{array}{l}\text { Max- } \\
\text { imum }\end{array}$ & $\begin{array}{l}\text { Standard } \\
\text { deviation }\end{array}$ \\
\hline $\begin{array}{l}\text { Big Sioux River sites } \\
\text { upstream from } \\
\text { WWTP effluent } \\
\text { discharge }\end{array}$ & 0 & 0 & 11 & 0 & -- & -- & -- & -- & -- & -- & -- \\
\hline WWTP effluent & 100 & 100 & 6 & 6 & 1.2 & 1.6 & 3.9 & 46 & 64 & 77 & 12 \\
\hline $\begin{array}{l}\text { Big Sioux River sites } \\
\text { downstream from } \\
\text { WWTP effluent } \\
\text { discharge }\end{array}$ & 67 & 0 & 10 & 2 & .26 & .58 & .89 & 24 & 34 & 44 & 15 \\
\hline
\end{tabular}

Fourteen different EDCs (atrazine, which is an MAH; AHTN, benzophenone, diazinon, HHCB, NP2EO, NP1E0, NP, OP2EO, and OP1EO, which are HIACs; and anthracene, benzo $[a]$ pyrene, phenanthrene, and pyrene, which are PAHs) were detected in samples collected from sites downstream from the WWTP effluent discharge (sites DS1 and DS2). Total detected EDC concentrations for individual samples ranged from about 0.048 to $4.5 \mu \mathrm{g} / \mathrm{L}$.

During base-flow periods, EDCs in water samples collected from downstream sites primarily consisted of HIACs, and concentrations varied in association with concentrations in water samples collected from site WWE and the relation between the WWTP effluent discharges and the flow in the Big Sioux River. During September 2002, when the WWTP effluent discharge accounted for about 35 percent of the flow of the Big Sioux River, EDC concentrations in water samples collected from site WWE were relatively small, and EDC concentrations in water samples collected from downstream sites were very small. During January 2003, when the WWTP effluent discharge accounted for about 55 percent of the flow of the Big Sioux River, EDC concentrations were relatively large in water samples from site WWE and the downstream sites. During storm-runoff conditions, EDCs in water samples collected from downstream sites sometimes primarily consisted of HIACs (as was the case for the March 2003 and May 17-18, 2004, sampling periods) and sometimes primarily consisted of MAHs (as was the case for the June 2003 and May 30-31, 2004, sampling periods). However, the WWTP effluent discharge did not account for a substantial part of the EDC concentrations in water samples collected from downstream sites during any storm-runoff sampling periods. During the March 2003 and
May 17-18, 2004, sampling periods, EDC concentrations in water samples from downstream sites primarily consisted of HIACs and probably were primarily contributed by urban stormwater runoff. During the June 2003 and May 30-31, 2004, sampling periods, EDC concentrations in water samples from downstream sites primarily consisted of MAHs and probably primarily were contributed by nonpoint crop agriculture sources.

\section{Organic Wastewater Compounds in Bottom Sediment}

Bottom-sediment samples were collected from three sites (US2, DS1, and DS2) during the September 2002 sampling period (below-normal flow/late-summer base flow). The bottom-sediment samples were analyzed by analytical method 5 for 3 MAHs, 44 HIACs, 10 PAHs, and 4 SCs (table 7).

OWCs in the HIAC, PAH, and SC compound classes were detected in all bottom-sediment samples (fig. 6, tables 5 and 6). No MAH compounds were detected in any bottom-sediment samples. The OWCs detected in bottom sediment have varying degrees of hydrophobic properties, which results in those compounds having a tendency to partition to particulate phase and deposit in river sediments.

Twelve different OWCs, including 4 HIACs (3-methyl1H-indole, indole, para-cresol, and phenol), 4 PAHs (2,6-dimethylnaphthalene, fluoranthene, phenanthrene, and pyrene), and 4 SCs (3-beta-coprostanol, beta-sitosterol, beta-stigmastanol, and cholesterol), were detected in bottom sediment collected from site US2. OWCs that occurred in bottom sediment collected from site US2 typically are associated with fecal 
August 15-16, 2001
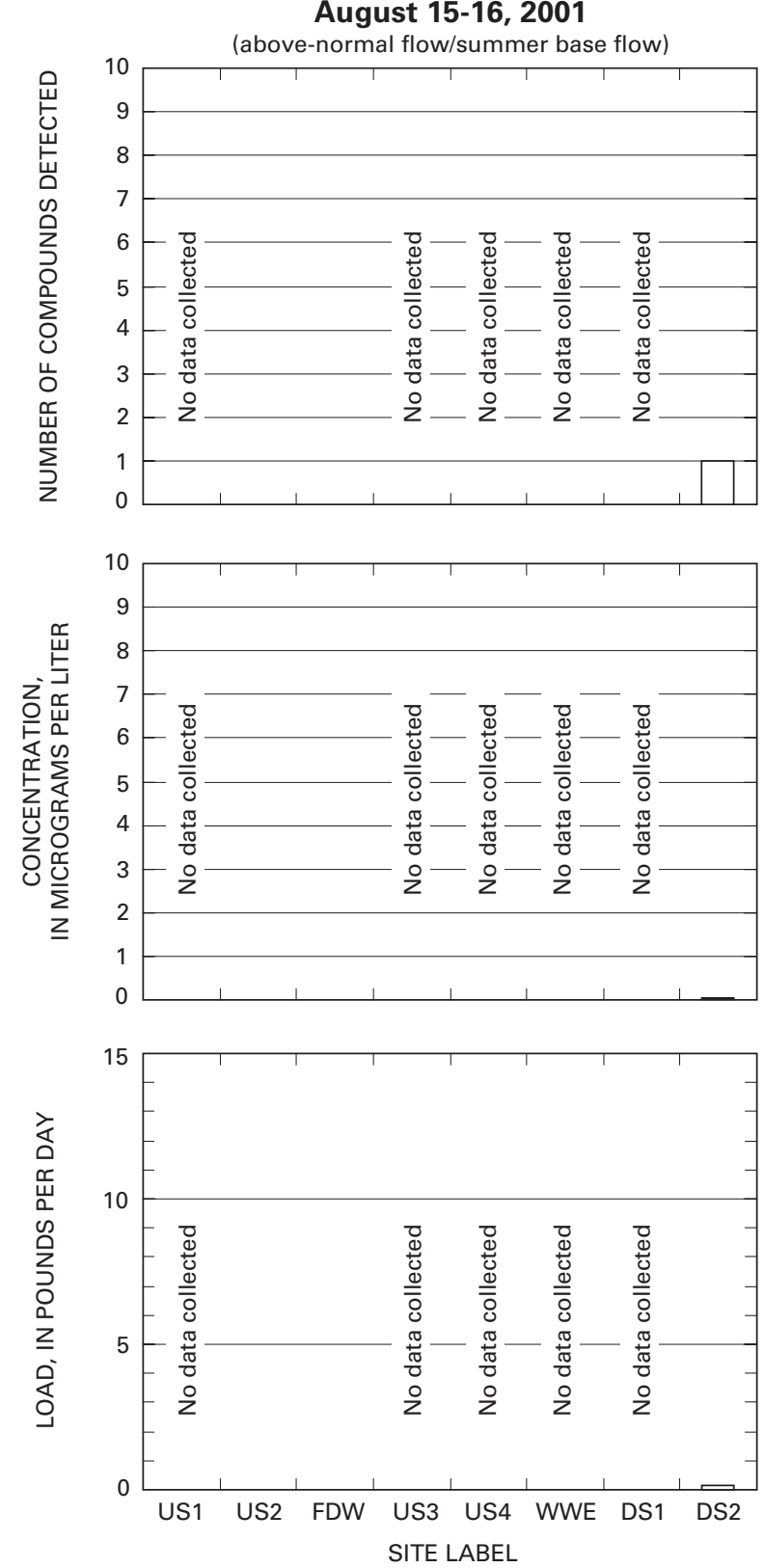

NOTE: $y$-axis variously scaled
September 9-11, 2002
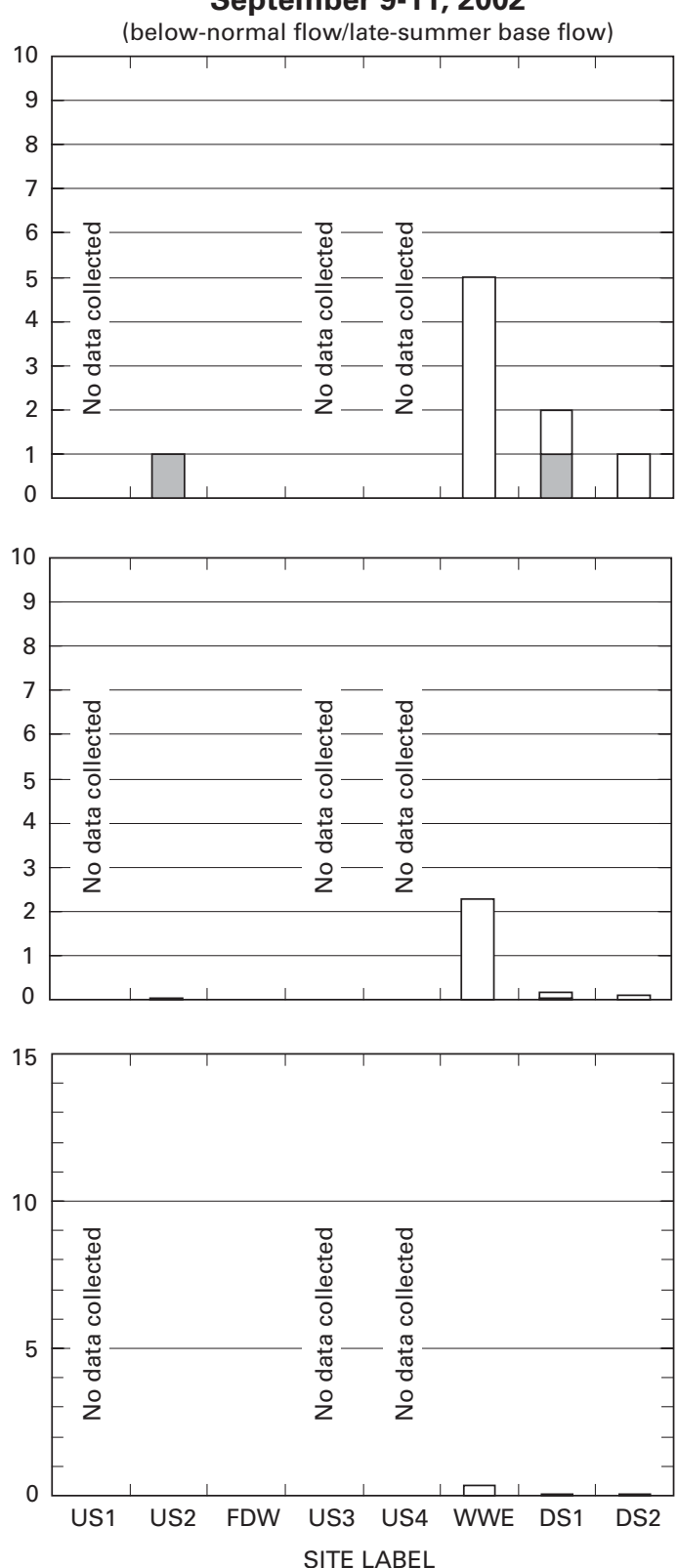

January 22-24, 2003

(below-normal flow/winter base flow)
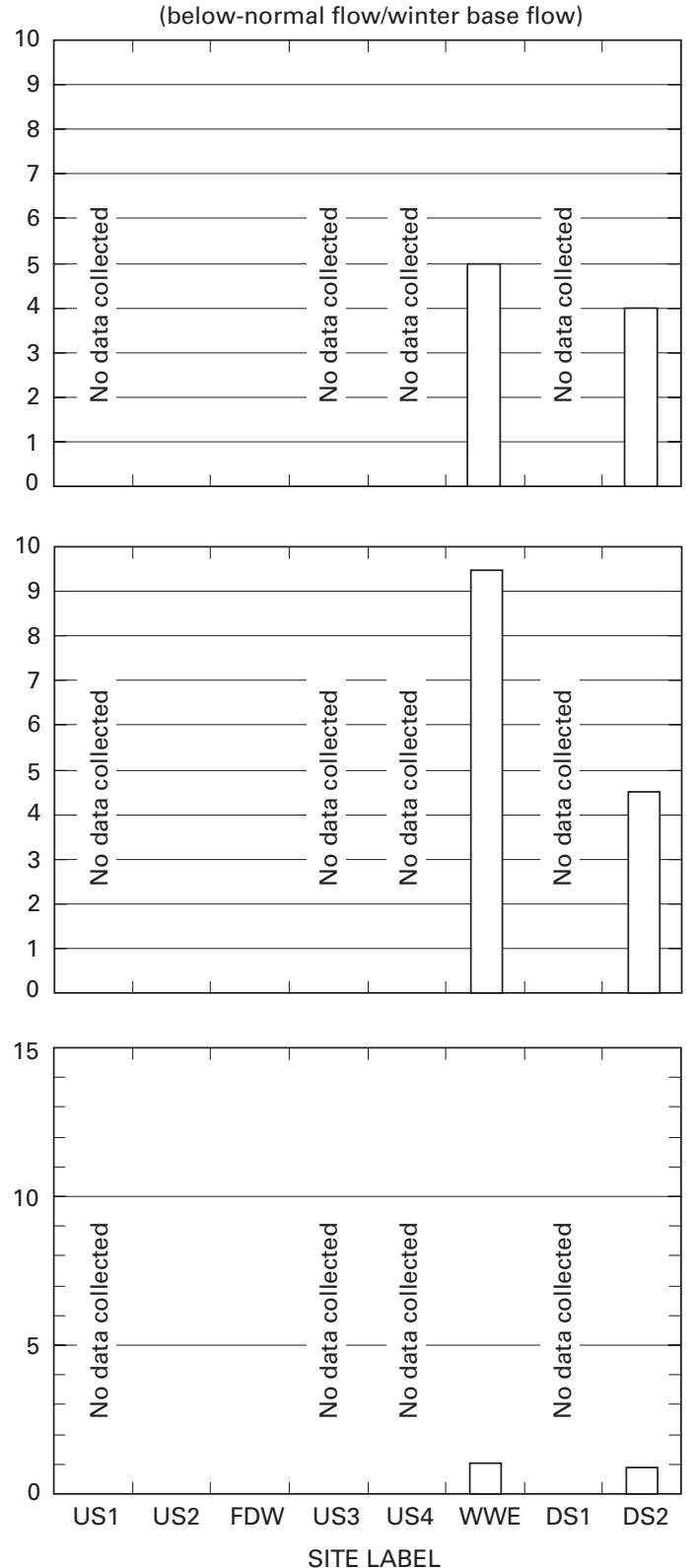

Figure 5. Results for endocrine-distrupting compounds. 
March 19-21, 2003
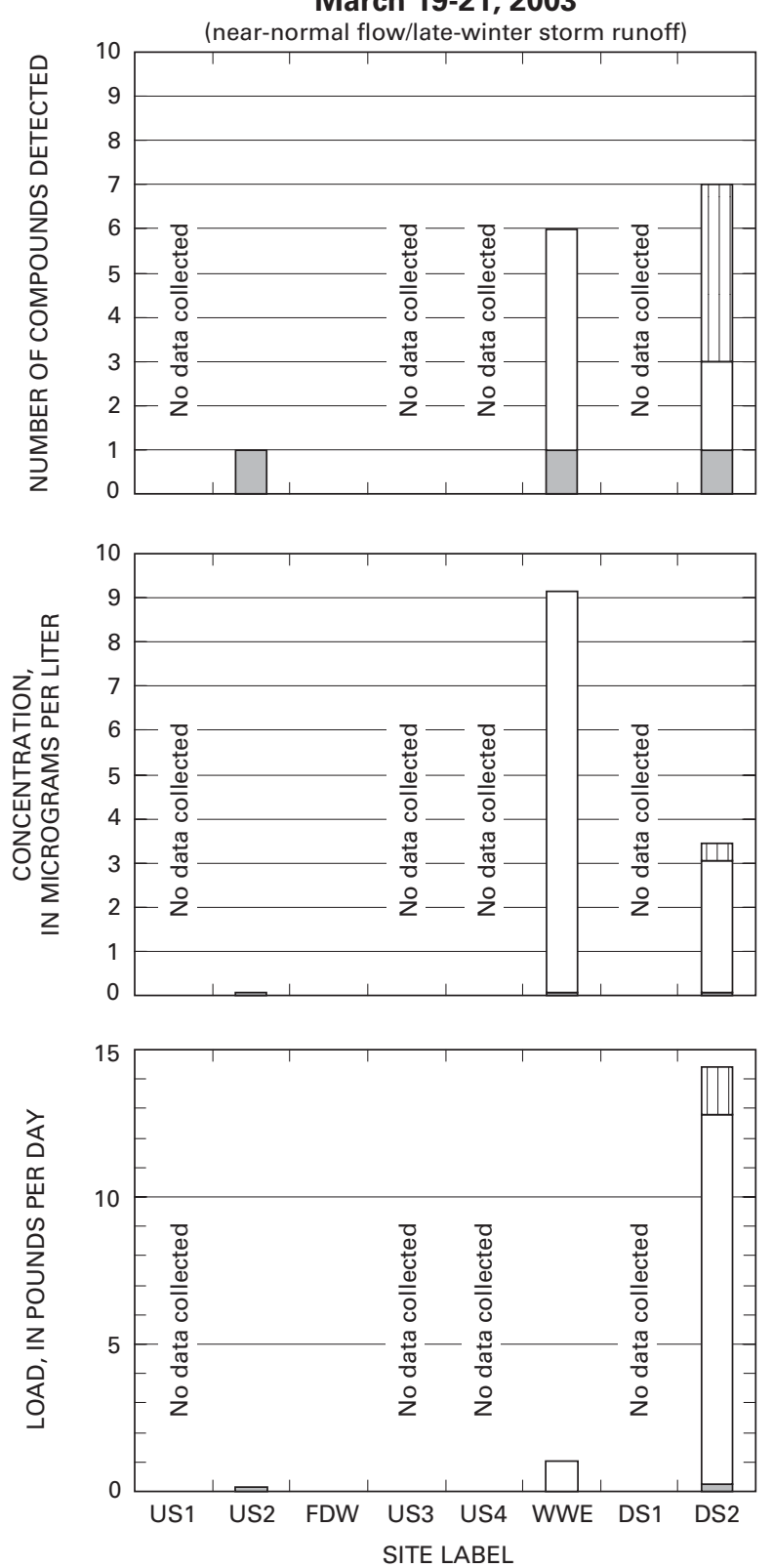

NOTE: $y$-axis variously scaled
June 25-27, 2003
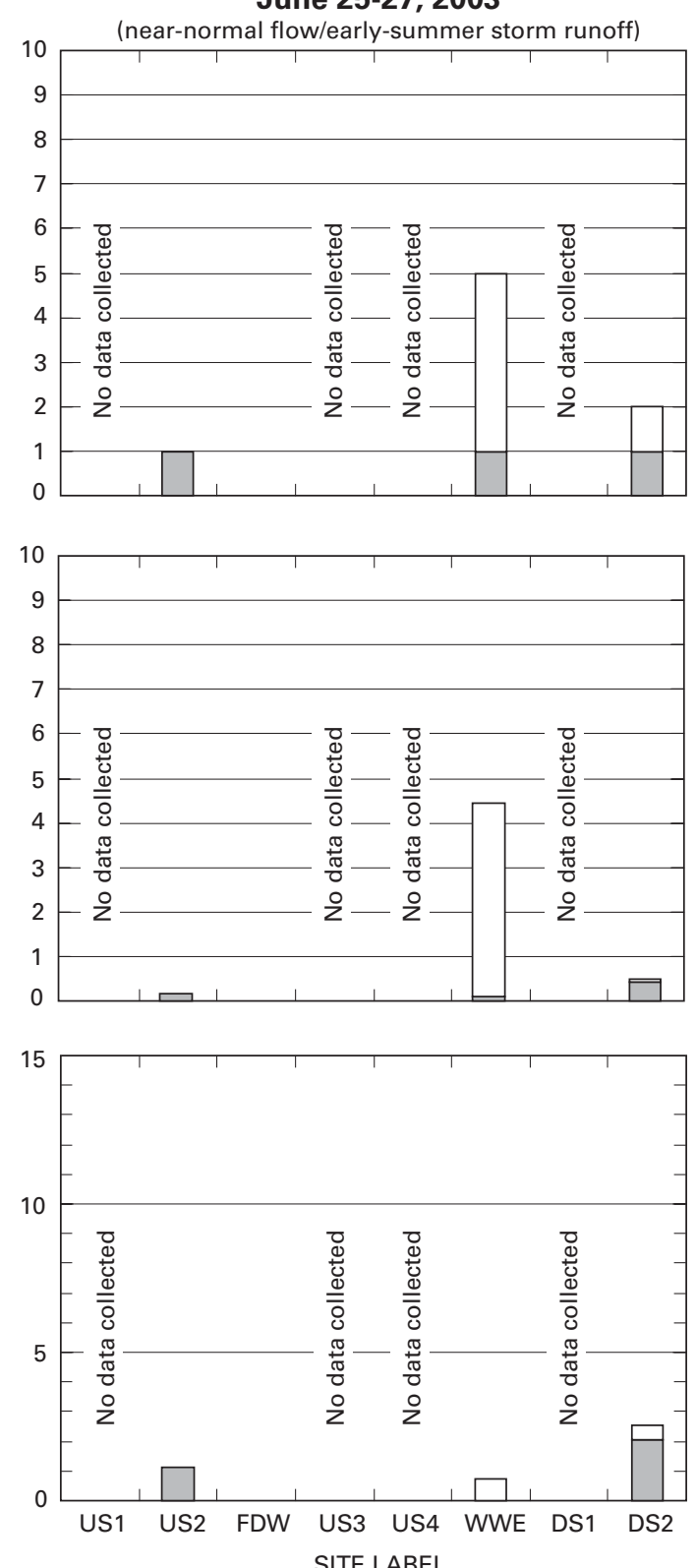

Figure 5. Results for endocrine-distrupting compounds.-Continued 
May 17-18, 2004
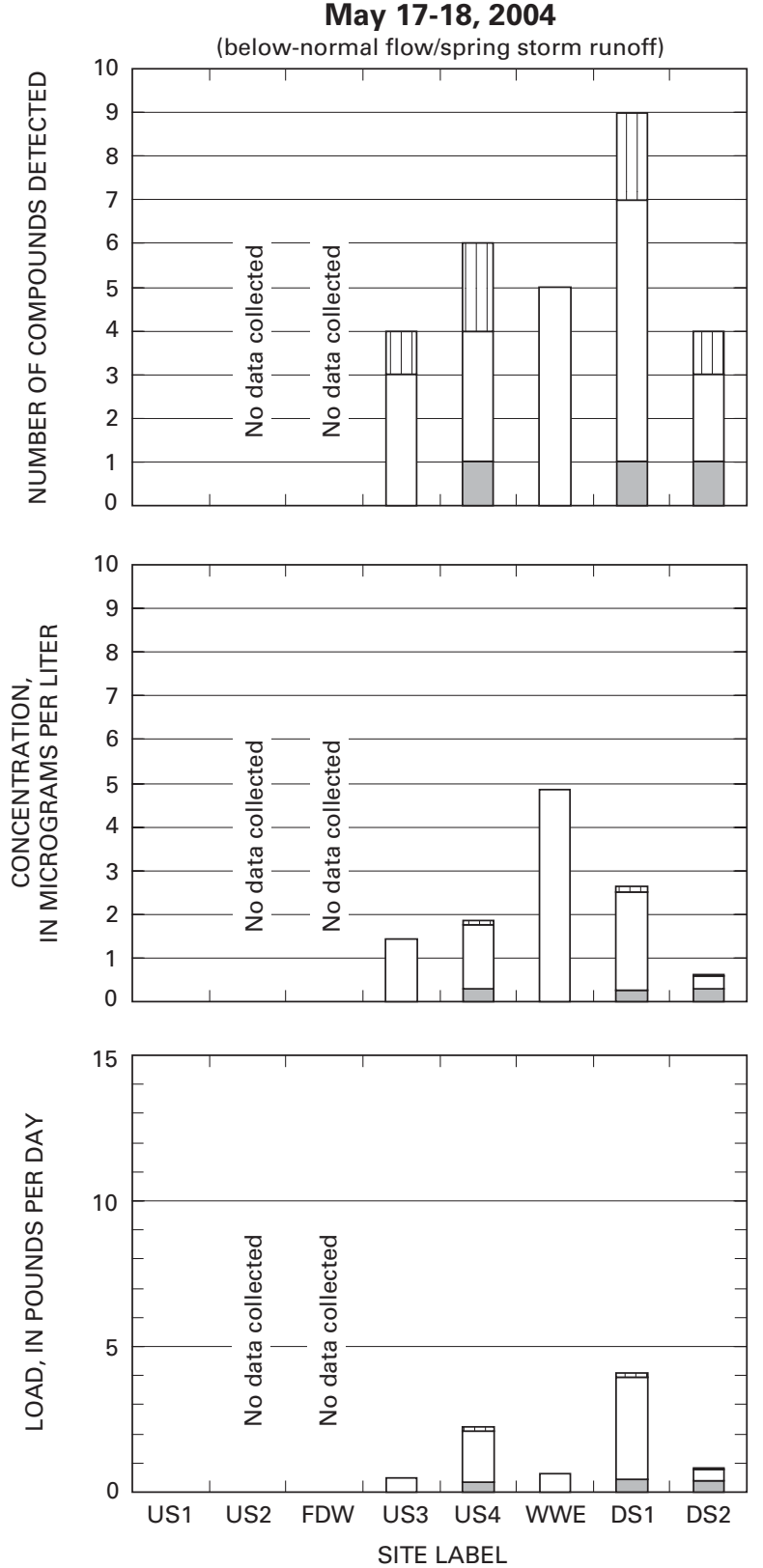

May 30-31, 2004
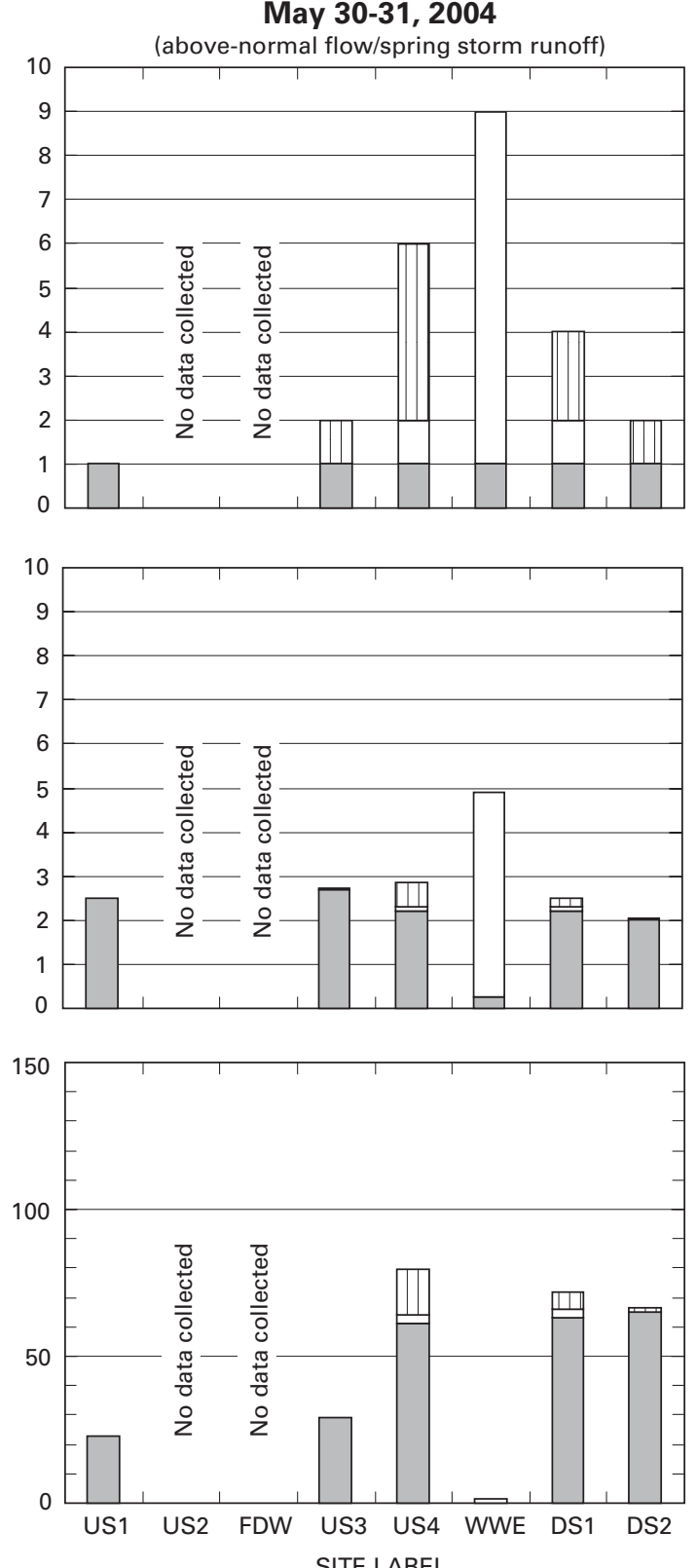

\section{EXPLANATION}

Polyaromatic hydrocarbons (PAHs) suspected of being endocrinedisrupting compounds (EDCs)

$\square$ Household, industrial, and minor agricultural use compounds (HIACs) suspected of being endocrine-disrupting compounds (EDCs)

Major agricultural herbicides (MAHs) suspected of being endocrinedisrupting compounds (EDCs)

NOTE: $y$-axis variously scaled

Figure 5. Results for endocrine-distrupting compounds.-Continued 

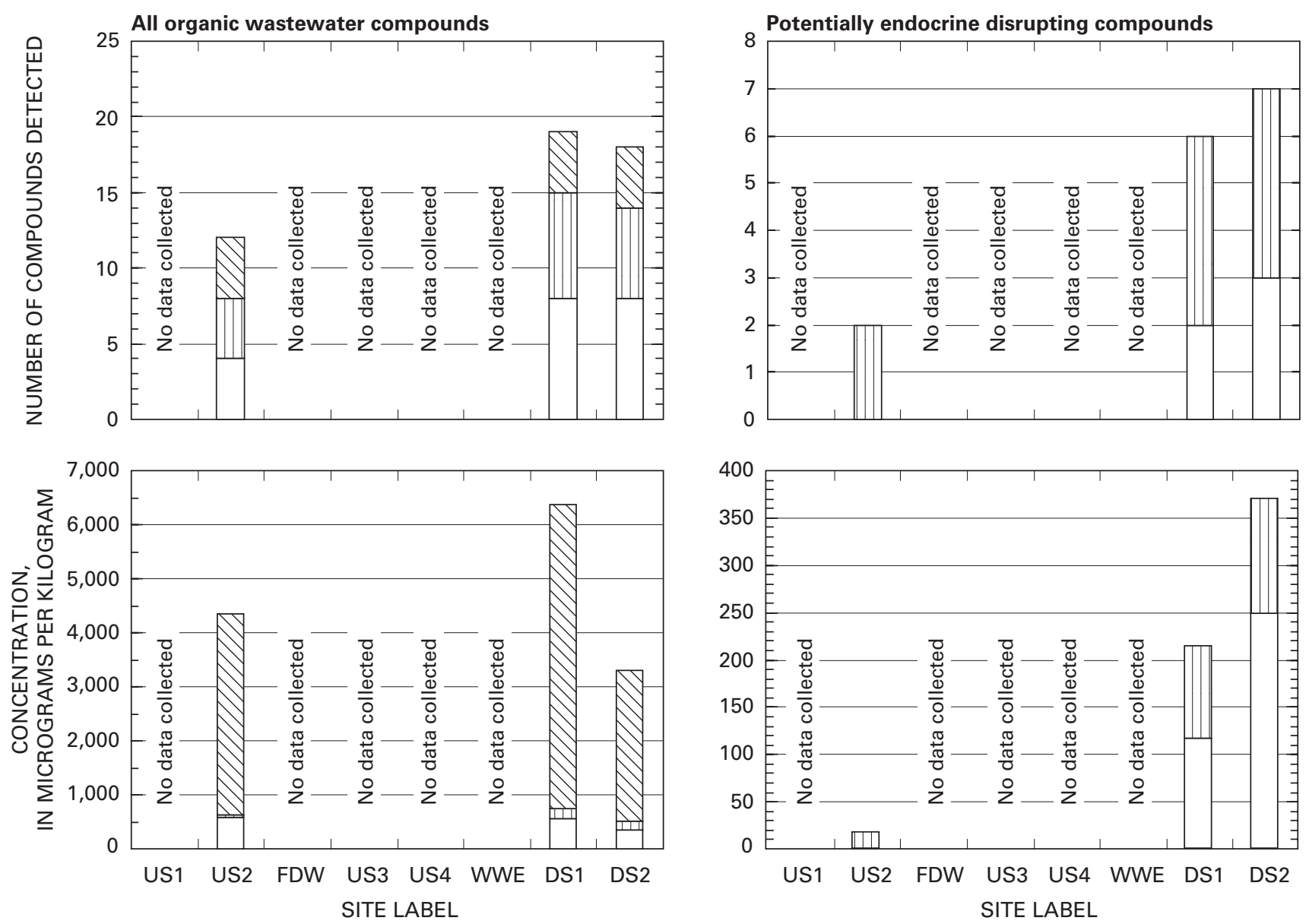

NOTE: $y$-axis variously scaled

\section{EXPLANATION}

Sterol compounds (SCs)

Polyaromatic hydrocarbons (PAHs)

Household, industrial, and minor agricultural use compounds (HIACs)

Figure 6. Results for organic wastewater compounds and suspected endocrine-disrupting compounds in bottom-sediment samples for the September 2002 sampling period.

material (3-methyl-1H-indole, indole, 3-beta-coprostanol, betasitosterol, beta-stigmastanol, and cholesterol) or with fuel combustion (2,6-dimethylnaphthalene, fluoranthene, phenanthrene, para-cresol, phenol, and pyrene). Beta-sitosterol and betastigmastanol are plant sterols and also can occur in natural waters and sediments through breakdown of native vegetation. Thus, the OWCs detected in bottom sediment collected from site US2 probably were contributed by upstream nonpoint animal agriculture sources, local runoff from roads, or (in the case of beta-sitosterol and beta-stigmastanol) breakdown of native vegetation.

Twenty different OWCs, including 9 HIACs (3-methyl1H-indole, anthraquinone, bis(2-ethylhexyl) phthalate, bisphenol-A, indole, NP2EO, para-cresol, phenol, and triclosan), 7 PAHs (2,6-dimethylnaphthalene, anthracene,

benzo $[a]$ pyrene, fluoranthene, naphthalene, phenanthrene, and pyrene), and 4 SCs (3-beta-coprostanol, beta-sitosterol, betastigmastanol, and cholesterol), were detected in bottom sediment collected from Big Sioux River sites downstream from the WWTP effluent discharge (sites DS1 and DS2). In addition to OWCs typically associated with animal fecal material (3-methyl-1H-indole, indole, 3-beta-coprostanol, beta-sitosterol, beta-stigmastanol, and cholesterol) or with fuel combustion (2,6-dimethylnaphthalene, anthracene, benzo[ $a]$ pyrene, fluoranthene, naphthalene, phenanthrene, para cresol, phenol, and pyrene), OWCs detected in bottom sediment collected from sites DS1 and DS2 also included some compounds typically associated with household or industrial wastewaters (anthraquinone, bis(2-ethylhexyl) phthalate, bisphenol-A, NP2EO, and triclosan). Thus, the OWCs detected in bottom sediment collected from sites DS1 and DS2 probably were contributed by a combination of upstream nonpoint animal agriculture sources, urban runoff, WWTP effluent discharges, or (in the case of beta-sitosterol and beta-stigmastanol) breakdown of native vegetation. 
Table 5. Statistical summaries of analytical results for organic wastewater compounds in bottom-sediment samples.

[Units are micrograms per kilogram. --, no data collected or not detected]

\begin{tabular}{|c|c|c|c|}
\hline & \multicolumn{3}{|c|}{ Station identification number and name (site label) } \\
\hline & $\begin{array}{c}433600096442400 \\
\text { Sioux Falls pump station } \\
\text { intake from Big Sioux River } \\
\text { at Sioux Falls, SD } \\
\text { (site US2, fig. 1) }\end{array}$ & $\begin{array}{c}433559096390700 \\
\text { Big Sioux River downstream } \\
\text { from Sioux Falls } \\
\text { wastewater discharge } \\
\text { (site DS1, fig. 1) }\end{array}$ & $\begin{array}{l}433541096355800 \\
\text { Big Sioux River } \\
\text { at Brandon, SD } \\
\text { (site DS2, fig. 1) }\end{array}$ \\
\hline Date of sample collection (month-day-year) & 09-09-2002 & $09-10-2002$ & $09-11-2002$ \\
\hline Time of sample collection (24-hour) & 1200 & 1030 & 1030 \\
\hline \multicolumn{4}{|c|}{ Human pharmaceutical compounds (HPCs) } \\
\hline No compounds analyzed for & -- & -- & -- \\
\hline \multicolumn{4}{|c|}{ Human and veterinary antibiotic compounds (HVACs) } \\
\hline No compounds analyzed for & -- & -- & -- \\
\hline \multicolumn{4}{|c|}{ Major agricultural herbicides (MAHs) } \\
\hline Number of compounds detected & 0 & 0 & 0 \\
\hline Minimum detected concentration & -- & -- & -- \\
\hline Median detected concentration & -- & -- & -- \\
\hline Maximum detected concentration & -- & -- & -- \\
\hline Total detected concentration & -- & -- & -- \\
\hline
\end{tabular}

Total detected concentration

Household, industrial, and minor agricultural use compounds (HIACs)

\begin{tabular}{|c|c|c|c|}
\hline Number of compounds detected & 4 & 8 & 8 \\
\hline Minimum detected concentration & 42 & 4.6 & 1.9 \\
\hline Median detected concentration & 50 & 58 & 26 \\
\hline Total detected concentration & 570 & 560 & 340 \\
\hline \multicolumn{4}{|c|}{ Polyaromatic hydrocarbons (PAHs) } \\
\hline Median detected concentration & 9.3 & 26 & 25 \\
\hline Maximum detected concentration & 21 & 38 & 58 \\
\hline Total detected concentration & 47 & 180 & 170 \\
\hline \multicolumn{4}{|c|}{ Sterol compounds (SCs) } \\
\hline Total detected concentration & 3,700 & 5,600 & 2,800 \\
\hline \multicolumn{4}{|c|}{ All organic wastewater compounds (OWCs) } \\
\hline Number of compounds detected & 12 & 19 & 18 \\
\hline Minimum detected concentration & 7.6 & 4.6 & 1.9 \\
\hline Median detected concentration & 50 & 38 & 33 \\
\hline Maximum detected concentration & 1,600 & 2,600 & 1,200 \\
\hline Total detected concentration & 4,300 & 6,400 & 3,300 \\
\hline
\end{tabular}


Table 5. Statistical summaries of analytical results for organic wastewater compounds in bottom-sediment samples.-Continued [Units are micrograms per kilogram. --, no data collected or not detected]

\begin{tabular}{|c|c|c|c|}
\hline & \multicolumn{3}{|c|}{ Station identification number and name (site label) } \\
\hline & $\begin{array}{c}433600096442400 \\
\text { Sioux Falls pump station } \\
\text { intake from Big Sioux River } \\
\text { at Sioux Falls, SD } \\
\text { (site US2, fig. 1) }\end{array}$ & $\begin{array}{c}433559096390700 \\
\text { Big Sioux River downstream } \\
\text { from Sioux Falls } \\
\text { wastewater discharge } \\
\text { (site DS1, fig. 1) }\end{array}$ & $\begin{array}{l}433541096355800 \\
\text { Big Sioux River } \\
\text { at Brandon, SD } \\
\text { (site DS2, fig. 1) }\end{array}$ \\
\hline \multicolumn{4}{|c|}{ Major agricultural herbicides (MAHs) that are suspected endocrine-disrupting compounds (EDCs) } \\
\hline Minimum detected concentration & -- & -- & -- \\
\hline Median detected concentration & -- & -- & -- \\
\hline Maximum detected concentration & -- & -- & -- \\
\hline Total detected concentration & -- & -- & -- \\
\hline \multicolumn{4}{|c|}{ Household, industrial, and minor agricultural use compounds (HIACs) that are suspected endocrine-disrupting compounds (EDCs) } \\
\hline Maximum detected concentration & -- & 110 & 180 \\
\hline Total detected concentration & -- & 120 & 250 \\
\hline
\end{tabular}

Polyaromatic hydrocarbons (PAHs) that are suspected endocrine-disrupting compounds (EDCs)

\begin{tabular}{llcr}
\hline Number of compounds detected & 2 & 4 & 4 \\
Minimum detected concentration & 7.6 & 11 & 14 \\
Median detected concentration & 8.4 & 24 & 25 \\
Maximum detected concentration & 9.3 & 38 & 58 \\
Total detected concentration & 17 & 97 & 120 \\
\hline
\end{tabular}

\begin{tabular}{lccc}
\hline & All suspected endocrine-disrupting compounds (EDCs) & & \\
\hline Number of compounds detected & 2 & 6 & 7 \\
Minimum detected concentration & 7.6 & 6.3 & 2.9 \\
Median detected concentration & 8.4 & 24 & 27 \\
Maximum detected concentration & 9.3 & 110 & 180 \\
Total detected concentration & 17 & 210 & 370
\end{tabular}

The ratios of concentrations of 3-beta-coprostanol to cholesterol in bottom sediment collected from sites US2, DS1, and DS2 were 12, 19, and 16 percent, respectively. The higher ratios for sites DS1 and DS2 probably indicate greater contributions from human sewage at those sites. The ratios in bottom sediment for sites DS1 and DS2 were smaller than ratios in water samples collected during base-flow conditions (table 4), which probably indicates degradation of 3-beta-coprostanol in bottom sediment over time and/or dilution of 3-beta-coprostanol in bottom sediment caused by deposition of organic material with smaller ratios originating from sources other than WWTP effluents.

Two EDCs (phenanthrene and pyrene, which are PAHs) were detected in bottom sediment collected from site US2. Seven EDCs (bisphenol-A, NP2EO, and triclosan, which are HIACs; and anthracene, benzo[ $a]$ pyrene, phenanthrene, and pyrene, which are PAHs) were detected in bottom sediment collected from sites DS1 and DS2.

\section{Relations Between Concentrations of Organic Wastewater Compounds in Dissolved and Whole- Water Fractions}

For the May 17-18 and May 30-31, 2004, sampling periods, water samples were collected and analyzed for both dissolved and whole-water fractions of 2 nonprescription HPCs, 2 MAHs, 43 HIACs, 10 PAHs, and 4 SCs using analytical methods 3 and 4. Evaluation of whether these compounds were occurring in dissolved or particulate phase might provide information on possible sources of the compounds that occurred in the Big Sioux River and also provide information on the types 
Table 6. Organic wastewater compounds detected in bottom-sediment samples.

[Bold text indicates suspected endocrine-disrupting compound (EDC). NP2E0, nonylphenol diethoxylate; --, no data collected]

\begin{tabular}{|c|c|c|c|}
\hline & \multicolumn{3}{|c|}{ Station identification number and name (site label) } \\
\hline & $\begin{array}{c}433600096442400 \\
\text { Sioux Falls pump station } \\
\text { intake from Big Sioux River } \\
\text { at Sioux Falls, SD } \\
\text { (site US2, fig. 1) }\end{array}$ & $\begin{array}{c}433559096390700 \\
\text { Big Sioux River downstream } \\
\text { from Sioux Falls } \\
\text { wastewater discharge } \\
\text { (site DS1, fig. 1) }\end{array}$ & $\begin{array}{l}433541096355800 \\
\text { Big Sioux River } \\
\text { at Brandon, SD } \\
\text { (site DS2, fig. 1) }\end{array}$ \\
\hline $\begin{array}{l}\text { Date of sample collection } \\
\text { (month-day-year) }\end{array}$ & 09-09-2002 & $09-10--2002$ & $09-11-2002$ \\
\hline Number of compounds detected & 12 & 19 & 18 \\
\hline \multicolumn{4}{|c|}{ Human pharmaceutical compounds (HPCs) } \\
\hline No compounds analyzed for & -- & -- & -- \\
\hline No compounds detected & -- & -- & -- \\
\hline \multicolumn{4}{|c|}{ Household, industrial, and minor agricultural-use compounds (HIACs) } \\
\hline & $\begin{array}{l}\text { 3-Methyl-1H-indole (skatol) } \\
\text { Indole } \\
\text { para-Cresol } \\
\text { Phenol }\end{array}$ & $\begin{array}{l}\text { 3-Methyl-1H-indole (skatol) } \\
\text { Anthraquinone } \\
\text { Bis(2-ethylhexyl) phthalate } \\
\text { Indole } \\
\text { NP2EO } \\
\text { para-Cresol } \\
\text { Phenol } \\
\text { Triclosan }\end{array}$ & $\begin{array}{l}\text { 3-Methyl-1H-indole (skatol) } \\
\text { Anthraquinone } \\
\text { Bisphenol-A } \\
\text { Indole } \\
\text { NP2EO } \\
\text { para-Cresol } \\
\text { Phenol } \\
\text { Triclosan }\end{array}$ \\
\hline \multicolumn{4}{|c|}{ Sterol compounds (SCs) } \\
\hline & $\begin{array}{l}\text { 3-beta-Coprostanol } \\
\text { beta-Sitosterol } \\
\text { beta-Stigmastanol } \\
\text { Cholesterol }\end{array}$ & $\begin{array}{l}\text { 3-beta-Coprostanol } \\
\text { beta-Sitosterol } \\
\text { beta-Stigmastanol } \\
\text { Cholesterol }\end{array}$ & $\begin{array}{l}\text { 3-beta-Coprostanol } \\
\text { beta-Sitosterol } \\
\text { beta-Stigmastanol } \\
\text { Cholesterol }\end{array}$ \\
\hline
\end{tabular}


of hydrologic conditions that affect the occurrence of the compounds in the river. During storm-runoff conditions, the load of OWCs in the Big Sioux River downstream from the WWTP effluent discharge was substantially larger than the load contributed by the WWTP effluent discharge. An issue of interest was the relative contributions of either direct stormwater runoff or resuspension of bottom sediment to OWC concentrations in the Big Sioux River downstream from the WWTP effluent discharge.

For many compounds, differences in method performance between analytical methods 3 and 4 complicated comparison of dissolved and whole-water fractions. For most HPCs, MAHs, HIACs, and PAHs, analytical method 4 (performed on filtered water samples) had higher percent recoveries in laboratory reagent spike samples and environmental matrix spike samples than analytical method 3 (performed on unfiltered samples). However, percent recoveries for SCs were similar between analytical methods 3 and 4 . Probably as a result of these patterns, dissolved concentrations of many HPCs, MAHs, and HIACs in environmental samples were larger than whole-water concentrations.

Analytical results for 3-beta-coprostanol and betasitosterol did not clearly indicate substantial differences between dissolved and whole-water fractions in water samples collected from Big Sioux River sites. Whole-water cholesterol concentrations generally were larger than dissolved concentrations, especially for the May 17-18, 2004, sampling period, which indicates that particulate material contributed to the whole-water concentrations.

Some PAHs (including fluoranthene, phenanthrene, and pyrene) generally had larger whole-water concentrations than dissolved concentrations, even though percent recoveries for analytical method 3 generally were lower than for analytical method 4, indicating that part of the whole-water concentration was contributed by particulate material. This general pattern was evident for samples from sites US3, US4, DS1, and DS2 during both the May 17-18 and May 30-31, 2004, sampling periods. PAHs generally are hydrophobic and tend to partition to particulate phase. The PAHs that generally had larger wholewater concentrations than dissolved concentrations also were detected in bottom sediment (collected during the September 2002 sampling period) at sites US1, DS1, and DS2 (fig. 6, tables 5 and 6). Hydrologic conditions that might result in resuspension of sediment from the river bottom also are the same types of conditions that could mobilize terrestrial particulate material and contribute it to the river in stormwater runoff, making it difficult to conclusively determine sources of the particulate fraction of OWCs in the Big Sioux River during runoff sampling periods. The data collected in this study are not adequate to conclusively determine the extent to which resuspension of bottom material might have contributed to OWC concentrations in the Big Sioux River during storm-runoff sampling periods. However, the load of OWCs for the May 17 18, 2004, sampling period (below-normal flow/spring stormrunoff conditions following extended below-normal streamflow) was substantially larger at site DS1 than at site US4. The increase in load between sites US4 and DS1 primarily was due to individual HIACs, PAHs, and SCs that also were detected in bottom-sediment samples collected during the September 2002 sampling period. These patterns might indicate that part of the increase in OWC load at site DS1 was contributed by resuspension of bottom sediment during the May 17-18, 2004, sampling period. For the May 30-31, 2004, sampling period (abovenormal flow/spring storm-runoff conditions) the load of OWCs at site DS1 was less than at site US4, and loads of PAHs and SCs decreased between sites US4 and DS1. These patterns might indicate that the load of OWCs in the Big Sioux River downstream from site US4 primarily was contributed by urban runoff and nonpoint agricultural sources upstream from site US4.

\section{Implications of Occurrence}

Several previous USGS studies have reported concentrations of OWCs in natural waters and WWTP effluents in the United States. Kolpin and others (2002) reported OWCs in water samples collected from a network of 139 streams across 30 States during 1999-2000. Glassmeyer and others (2005) reported OWCs in water samples collected from WWTP effluents and natural receiving waters for 10 municipalities across the United States. Lee and others (2004) reported OWCs in water samples collected from 65 sites (wastewater, surface water, ground water, and drinking water) in Minnesota. Kolpin and others (2004) reported OWC concentrations in water samples collected from stream sites both upstream and downstream from WWTP effluent discharges of 10 cities in Iowa. Detected concentrations of individual OWCs found in water samples collected from the Big Sioux River in or near Sioux Falls described in this report generally were within ranges of concentrations reported in these previous studies. Maximum concentrations of detected OWCs found in water samples collected from the Big Sioux River in or near Sioux Falls generally were substantially less than maxima reported by Kolpin and others (2002), Lee and others (2004), and Glassmeyer and others (2005), and generally were similar to maxima reported by Kolpin and others (2004). It should be noted that the maximum concentrations reported by Lee and others (2004) and Glassmeyer and others (2005) included results for WWTP effluents. A notable exception to these patterns is that some HVACs (including ciprofloxacin, erythromycin- $\mathrm{H}_{2} \mathrm{O}$, sulfamethoxazole, tetracycline, and trimethoprim) were detected in water samples collected from the Big Sioux River in or near Sioux Falls at concentrations generally larger than the median concentrations reported by Kolpin and others (2004) and approaching or exceeding maxima reported by Kolpin and others (2004), Lee and others (2004), and Glassmeyer and others (2005), even when concentrations in WWTP effluents were included.

There were no human-health concerns apparent in the results of this study. Only one OWC (metolachlor) was detected in the Sioux Falls finished drinking water at an extremely small concentration. Also, water-contact recreation in the Big Sioux 
River near Sioux Falls is very limited. Thus, concerns related to the occurrence of OWCs from the Big Sioux River near Sioux Falls focus primarily on effects on aquatic ecology; perhaps of primary concern would be potential endocrine-disrupting effects on aquatic organisms.

Occurrence of EDCs in aquatic systems is a very complex and sensitive issue. A complete assessment of potential effects of EDCs in the Big Sioux River in or near Sioux Falls based on the results of this study is not possible for several reasons. Sex hormones, which are the most potent EDCs, commonly are present in WWTP effluent at concentrations sufficient to cause endocrine disruption; however, sex hormones were not reported for this study. Also, a relatively small number of water-quality samples were collected from the Big Sioux River Basin during this study. WWTP effluent discharges vary with time, and concentrations of EDCs in wastewaters vary seasonally and interannually (Rodgers-Gray and others, 2000; Sheahan and others, 2002). Thus, it is very difficult to accurately quantify inputs of EDCs to the Big Sioux River Basin by determining EDC concentrations in a relatively small number of samples. Also, mixtures of individual EDCs, like those that typically were found in samples collected from the Big Sioux River, generally are believed to have the potential to act additively, but mixture effects are poorly understood (Sumpter and Johnson, 2005). Further, relatively few of the many organic compounds that might be present in WWTP effluents have been evaluated for potential endocrine-disrupting effects (Sumpter and Johnson, 2005). For the EDCs that were determined in this study, total concentrations in water samples collected from the Big Sioux River downstream from WWTP effluents rarely exceeded $2 \mu \mathrm{g} / \mathrm{L}$. It has been determined that some EDCs can have endocrine-disrupting effects at very low concentrations (near or less than $1 \mu \mathrm{g} / \mathrm{L}$ ), and some mechanisms of endocrine disruption make it very difficult to define no-effect levels (Welshons and others, 2003). However, for the EDCs determined in this study, concentrations that result in observable endocrinedisruption effects generally have been reported to be much larger than those observed in the Big Sioux River (Sumpter and Johnson, 2005).

Although this study cannot provide a definitive assessment of EDC effects in the Big Sioux River, a brief synopsis of research on the occurrence of EDCs in aquatic environments provides a context for the EDC results and illustrates the complexity of the issue of EDCs in aquatic environments. Effects of endocrine disruptors in aquatic environments often are investigated by documenting atypical sexual characteristics in individual organisms (for example, occurrence of female biomarkers in male fish), but very few studies have conclusively documented that these effects actually result in either reduced reproductive potential of the individuals or negative effects on reproductive success at the population level (Sumpter and Jobling, 1995; Gies and others, 2001). Thus, few studies of EDCs conclusively indicate negative reproductive effects in aquatic ecosystems. However, in some studies skewed sex ratios and abnormal gonadal histology indicate that individual- and population-level effects on reproductive success are possible (Desbrow and others, 1998).

Potential EDCs detected in the Big Sioux River probably were derived from three general types of sources: (1) WWTP discharges (AHTN, benzophenone, HHCB, NP2EO, NP1EO, and NP were detected in the Big Sioux River and probably were attributable to WWTP discharges); (2) urban runoff (anthracene, benzo[a]pyrene, diazinon, OP2EO, OP1EO, phenanthrene, and pyrene were detected in the Big Sioux River and probably were attributable to urban runoff); and (3) nonpoint source crop agriculture (atrazine was detected in the upper Big Sioux River Basin and primarily is attributable to nonpoint agricultural crop sources). Research has been conducted on EDCs from these types of sources. Sex hormones, alkylphenols (APs), and AP ethoxylates generally have been implicated as the primary causative agents in WWTP effluents that result in estrogenic effects in aquatic organisms (Jobling and Sumpter, 1993; Desbrow and others, 1998; Gies and others, 2001; Harris and others, 2001; and Jobling and Tyler, 2003). Sex hormones (primarily the natural and synthetic estrogens 17B estradiol and ethynyl estradiol) generally are regarded as the most potent EDCs, can produce significant atypical sexual characteristics in fish at concentrations less than $0.025 \mu \mathrm{g} / \mathrm{L}$ (Sumpter and Johnson, 2005), and in some studies have been implicated as the primary compounds contributing to feminization of male fish (Huggett and others, 2003) as a result of exposure to WWTP effluents. Sex hormones commonly are found in WWTP effluent discharges (Jobling and Tyler, 2003), so it is possible that they occur in the Big Sioux River downstream from the Sioux Falls WWTP.

AP ethoxylates and their shorter chain metabolites are complex nonionic surfactants. Of the various APs and AP ethoxylates, certain isomers of nonylphenol and octylphenol appear to have the largest endocrine-disrupting activities and have shown substantial estrogenic activity at concentrations in the range of about 8 to $10 \mu \mathrm{g} / \mathrm{L}$ (Jobling and others, 1996; Harris and others, 2001). APs and AP ethoxylates detected in the Big Sioux River at concentrations greater than the SRL include NP2EO, NP1EO, NP, OP2EO, and OP1EO. The largest combined concentration for these compounds in any water sample collected from the Big Sioux River was about $3.8 \mu \mathrm{g} / \mathrm{L}$, which is less than the reported endocrine-disruption substantial-effect level of even the most potent individual AP (Sumpter and Johnson, 2005).

Other WWTP-sourced EDCs in the Big Sioux River have shown endocrine-disrupting effects in various laboratory studies but generally are not implicated as major causative agents of endocrine disruption in aquatic organisms in field studies. The other WWTP-sourced EDCs detected in the Big Sioux River that have shown endocrine-disrupting effects include AHTN (Richard and others, 2002; Richard and others, 2004), benzophenone (Schlumpf and others, 2001), and HHCB (Richard and others, 2002; Richard and others, 2004). Generally, these compounds have much less potent endocrine-disrupting effects than either sex hormones or APs and AP ethoxylates, with substantial-effect levels based on laboratory studies 
generally exceeding $50 \mu \mathrm{g} / \mathrm{L}$ (Richard and others, 2004; Sumpter and Johnson, 2005). The maximum concentration found in any water sample collected from the Big Sioux River for any of these compounds was about $0.56 \mu \mathrm{g} / \mathrm{L}$ (AHTN was detected at this concentration in a water sample collected from site DS2).

Some researchers have concluded that EDCs are present in most, if not all, treated sewage effluents (Jobling and Tyler, 2003). In some settings, endocrine-disruption effects on aquatic organisms have occurred where WWTP effluent discharges accounted for between 25 and 50 percent of the flow of receiving waters for relatively short periods of time (about 1 month) and as little as 10 percent of the flow of receiving waters for longer periods (about 4 months) (Harries and others, 1999; Rodgers-Gray and others, 2000). Assuming an average discharge from the Sioux Falls WWTP of $22 \mathrm{ft}^{3} / \mathrm{s}$ (which was about the average discharge during the study sampling periods) and comparing this level of effluent discharge to the observed flow of the Big Sioux River during water years 1977-2004, an effluent discharge of $22 \mathrm{ft}^{3} / \mathrm{s}$ would have accounted for about 50 percent of the flow of the Big Sioux River about 8 percent of the time, about 25 percent of the flow of the Big Sioux River about 25 percent of the time, and about 10 percent of the flow of the Big Sioux River about 45 percent of the time. Based on these observations, it is possible that the Sioux Falls WWTP effluent discharges might during some periods produce endocrine-disrupting effects on aquatic organisms. However, it should be noted that concentrations and loads of EDCs decreased substantially between sites DS1 and DS2, so potential endocrine-disrupting effects of the Sioux Falls WWTP effluent discharges probably would be restricted to a relatively short reach of the Big Sioux River. Also, results of other studies demonstrating endocrine-disrupting effects of WWTP effluent discharges on aquatic organisms do not necessarily have direct application to the Big Sioux River because (1) wastewater treatment technologies of and types of raw sewage inputs to different WWTPs vary substantially and result in large variability in EDC concentrations in different WWTP effluents; and (2) EDC effects on aquatic organisms are species dependent (Sumpter and Johnson, 2005), and species present in the Big Sioux River may differ from species in other studies.

The EDCs anthracene, benzo $[a]$ pyrene, diazinon, OP2EO, OP1EO, phenanthrene, and pyrene were detected in the Big Sioux River and probably were attributable to urban runoff. Anthracene, benzo $[a]$ pyrene, phenanthrene, and pyrene are PAHs that occur as a result of incomplete combustion of fossil fuels or petroleum products that are used in road materials. Laboratory studies have implicated these compounds as EDCs (Chaloupka and others, 1993; Cooke and others, 1994; Keith, 1998) but at much higher concentrations than were detected in samples collected from the Big Sioux River. The maximum total concentration of these PAH EDCs in any individual Big Sioux River sample was about $0.55 \mu \mathrm{g} / \mathrm{L}$. OP2EO and OP1EO are alkylphenol ethoxylates with typical uses as surfactants in detergents and a large variety of other products. The maximum total concentration of OP2EO and OP1EO in any individual Big
Sioux River sample was about $0.64 \mu \mathrm{g} / \mathrm{L}$. The most potent individual APs have been reported to have substantial endocrinedisruption effects at about 8 to $10 \mu \mathrm{g} / \mathrm{L}$ (Sumpter and Johnson, 2005).

Atrazine is a herbicide contributed to the Big Sioux River primarily from nonpoint crop agriculture activities and has been implicated in both field and laboratory studies as having endocrine-disrupting effects on aquatic organisms (Hayes and others, 2003; Spano and others, 2004). Atrazine exposure has been reported to result in reproductive abnormalities in frogs at concentrations as small as $0.1 \mu \mathrm{g} / \mathrm{L}$ (Hayes and others, 2003), but reported effect levels for fish generally are substantially larger. Spano and others (2004) reported gonadal abnormalities in fish exposed to atrazine at a concentration of $100 \mu \mathrm{g} / \mathrm{L}$. Bringolf and others (2004) reported lower egg production in fathead minnows exposed to atrazine at a concentration of $0.5 \mu \mathrm{g} / \mathrm{L}$; however, the results were not found to be statistically significant. Atrazine was detected in about 67 percent of samples collected from Big Sioux River sites at concentrations ranging from 0.02 to $2.7 \mu \mathrm{g} / \mathrm{L}$ (median of $0.29 \mu \mathrm{g} / \mathrm{L}$ ). Based on the lack of definitive research establishing endocrine-disruptive effect levels for atrazine and the relatively small number of samples collected during this study, it is not possible to assess whether atrazine concentrations detected in Big Sioux River samples might have the potential for endocrine disruption of aquatic organisms. However, the relatively large frequency of detection for atrazine might indicate a cause for concern.

\section{Summary and Conclusions}

The U.S. Geological Survey (USGS) in cooperation with the city of Sioux Falls conducted several rounds of sampling to determine the occurrence of organic wastewater compounds (OWCs) in the city of Sioux Falls drinking water and wastewater effluent, and the Big Sioux River in or near Sioux Falls during August 2001 through May 2004. Water samples were collected during both base-flow and storm-runoff conditions. Water samples were collected at 8 sites, which included 4 sites upstream from the wastewater treatment plant (WWTP) discharge, 2 sites downstream from the WWTP discharge, 1 finished drinking-water site, and 1 WWTP effluent site (WWE). Not all sampling sites were sampled during every sampling round. Bottom-sediment samples were collected from three sampling sites during one of the sampling periods when water samples were collected.

A total of 125 different OWCs were analyzed for in this study using five different analytical methods. Analyses for OWCs were performed at USGS laboratories that are developing and/or refining small-concentration (less than 1 microgram per liter $(\mu \mathrm{g} / \mathrm{L}))$ analytical methods. The OWCs were classified into six compound classes: human pharmaceutical compounds (HPCs); human and veterinary antibiotic compounds (HVACs); major agricultural herbicides (MAHs); household, industrial, and minor agricultural compounds (HIACs); polyaromatic 
hydrocarbons (PAHs); and sterol compounds (SCs). Some of the compounds in the HPC, MAH, HIAC, and PAH classes are suspected of being endocrine-disrupting compounds (EDCs). Of the 125 different OWCs analyzed for in this study, 81 OWCs had one or more detections in environmental samples reported by the laboratories, and of those 81 OWCs, 63 had acceptable analytical method performance, were detected at concentrations greater than the study reporting levels, and were included in analyses and discussion related to occurrence of OWCs in drinking water, wastewater effluent, and the Big Sioux River.

OWCs in all compound classes were detected in water samples from sampling sites in the Sioux Falls area. For the five sampling periods when samples were collected from the Sioux Falls finished drinking water, only one OWC was detected at a concentration greater than the study reporting level (metolachlor; $0.0040 \mu \mathrm{g} / \mathrm{L})$.

During base-flow conditions, Big Sioux River sites upstream from the WWTP discharge had OWC contributions that primarily were from nonpoint animal or crop agriculture sources or had OWC concentrations that were minimal. The influence of the WWTP discharge on OWCs at downstream river sites during base-flow conditions ranged from small influence to substantial influence depending on the sampling period. During runoff conditions, OWCs at sites upstream from the WWTP discharge probably were primarily contributed by nonpoint animal and/or crop agriculture sources and possibly by stormwater runoff from nearby roads. OWCs at sites downstream from the WWTP discharge probably were contributed by sources other than the WWTP effluent discharge, such as stormwater runoff from urban and/or agriculture areas and/or resuspension of OWCs adsorbed to sediment deposited in the Big Sioux River. OWC loads generally were substantially smaller for upstream sites than downstream sites during both base-flow and runoff conditions.

Total OWC concentrations ranged from about 2 to $4 \mu \mathrm{g} / \mathrm{L}$ at the site farthest upstream from the WWTP discharge, from 0.01 to about $3.5 \mu \mathrm{g} / \mathrm{L}$ at the second most upstream site, from 3 to $5 \mu \mathrm{g} / \mathrm{L}$ at the third most upstream site, and from about 5 to $6 \mu \mathrm{g} / \mathrm{L}$ for the site closest upstream from the WWTP discharge. Total OWC loads and concentrations generally were smaller for the upstream sites than for the downstream sites. Total OWC concentrations for site WWE ranged from about 10 to $45 \mu \mathrm{g} / \mathrm{L}$ and always were larger than for Big Sioux River sites. Total OWC loads also were larger for site WWE than for all Big Sioux River sampling sites during base-flow sampling periods but were smaller for site WWE than for one upstream site and both downstream sites during storm-runoff sampling periods. Total OWC concentrations ranged from about 3 to $12 \mu \mathrm{g} / \mathrm{L}$ at the site closest downstream from the WWTP discharge and from about 2 to $13 \mu \mathrm{g} / \mathrm{L}$ at the farthest downstream site. Discernible concentrations from the WWTP effluent discharge to OWC concentrations at the downstream sites are evidenced by occurrence of several individual OWCs only in samples collected from site WWE and the downstream sites. Total loads and concentrations were smaller at the farthest downstream site than at the closest site downstream from the WWTP effluent.
HPCs were detected in samples collected from all Big Sioux River sites (except the site farthest upstream) and from site WWE. Generally HPCs contributed very little to OWC concentrations at any of the sampling sites during any streamflow conditions. HVACs probably were contributed by nonpoint animal agriculture sources for sites upstream from the WWTP effluent and by the WWTP effluent discharge and possibly from nonpoint animal agriculture sources for downstream sites. HVACs generally accounted for a relatively small part of the total OWC concentrations in water samples collected from all sampling sites, with the exception of two sampling periods for site WWE and the downstream sites. MAHs generally accounted for a relatively small part of the total OWC concentrations in samples collected from the WWTP effluent for all sampling periods and in samples collected from the Big Sioux River sites during base-flow conditions. During some but not all of the storm-runoff sampling periods, MAHs accounted for a substantial part of the total OWC concentrations at the river sites. In samples from the upstream sites, HIACs generally accounted for a relatively small part of the total OWC concentrations during base-flow conditions and for a substantial part during some but not all of the storm-runoff sampling periods. HIACs generally accounted for a substantial part of the total OWC concentrations in samples collected from site WWE during all sampling periods. In samples collected from downstream sites, HIACs generally accounted for a substantial part of the total OWC concentration during base-flow conditions and during some but not all of the storm-runoff sampling periods. PAHs only were detected at Big Sioux River sites that might be substantially affected by storm-runoff from roads. PAHs were not detected during any base-flow sampling period and were detected during some but not all storm-runoff periods. Even during runoff periods, PAHs accounted for less than 20 percent of total OWC concentrations. SCs generally comprised a substantial part of the total detected OWC concentrations for site WWE and Big Sioux River sites during both base-flow and storm-runoff conditions. The occurrence of the SC 3-betacoprostanol in samples from site WWE and downstream sites is particularly relevant with respect to evaluating sources of OWCs because 3-beta-coprostanol is a major component of human feces. Results indicate that the WWTP discharge substantially contributed to the occurrence of OWCs in the Big Sioux River during below-normal base-flow conditions.

EDCs were detected in samples collected from all sampling sites except the finished drinking water. EDCs in samples collected from upstream sites generally had larger concentrations and loads during runoff sampling periods than during base-flow periods and probably were primarily contributed by nonpoint crop agriculture sources. During base-flow periods, EDCs in water samples collected from downstream sites primarily consisted of HIACs, and concentrations varied in association with concentrations in water samples collected from site WWE and the relation between the WWTP effluent discharges and the flow in the Big Sioux River. During stormrunoff conditions, EDCs in water samples collected from downstream sites sometimes primarily consisted of HIACs, which 
probably were primarily contributed by urban stormwater runoff, and sometimes primarily consisted of MAHs, which probably primarily were contributed by nonpoint crop agriculture sources.

Bottom-sediment samples were collected from one upstream sampling site and two downstream sampling sites during a base-flow sampling period. The bottom-sediment samples were analyzed for $3 \mathrm{MAHs}, 44 \mathrm{HIACs}, 10 \mathrm{PAHs}$, and 4 SCs. OWCs in the HIAC, PAH, and SC compound classes were detected in all bottom-sediment samples, but no MAH compounds were detected in any bottom-sediment samples. The OWCs detected in bottom sediment collected from the upstream site probably were contributed by upstream nonpoint animal agriculture sources, local runoff from roads, or the breakdown of native vegetation. The OWCs detected in bottom sediment collected from the downstream sites probably were contributed by a combination of upstream nonpoint animal agriculture sources, urban runoff, WWTP effluent discharges, or breakdown of native vegetation.

There were no human-health concerns apparent in the results of this study. Occurrence of EDCs in aquatic systems is a very complex and sensitive issue. A complete assessment of potential effects of EDCs in the Big Sioux River in or near Sioux Falls based on the results of this study is not possible. However, EDC concentrations in the Big Sioux River generally were less than concentrations reported to have substantial endocrine-disrupting effects on aquatic organisms. The relatively large frequency of detection for atrazine might indicate a cause for concern with respect to endocrine-disruption effects for aquatic organisms.

\section{References}

Barnes, K.K., Meyer, M.T., Thurman, M.T., Furlong, E.T., Zaugg, S.D., and Barber, L.B., 2002, Water-quality data for pharmaceuticals, hormones, and other organic wastewater contaminants in U.S. streams, 1999-2000: U.S. Geological Survey Open-File Report 02-94, accessed July 7, 2006, at http://toxics.usgs.gov/pubs/OFR-02-94/

Bringolf, R.B., Belden, J.B., and Summerfelt, R.C., 2004, Effects of atrazine on fathead minnow in a short-term reproductive assay: Environmental Toxicology and Chemistry, v. 23, p. 1019-1023.

Bull, I.D., Lockheart, M.J., Elhmmali, M.M., Roberts, D.J., and Evershed, R.P., 2002, The origin of faeces by means of biomarker detection: Environment International, v. 27, p. 647654.

Burkhardt, M.R., ReVello, R.C., Smith, S.G., and Zaugg, S.D., 2005, Pressurized liquid extraction using water/isopropanol coupled with solid-phase extraction cleanup for industrial and anthropogenic waste-indicator compounds in sediment: Analytica Chemica Acta, v. 534, p. 89-100.
Cahill, J.D., Furlong, E.T., Burkhardt, M.R., Kolpin, Dana, and Anderson, L.G., 2004, Determination of pharmaceutical compounds in surface- and ground-water samples by solid-phase extraction and high-performance liquid chromatography/electrospray ionization mass spectrometry: Journal of Chromatography A, v. 1041, nos. 1-2, p. 171-180.

Chaloupka, K.L., Harper, N.R., Krishnan, V., Santostefano, M., Rodriguez, L.V., and Safe, S.H., 1993, Synergistic activity of polynuclear aromatic hydrocarbon mixtures as aryl hydrocarbon (Ah) receptor agonists: Chemico-Biological Interactions, v. 89, p. 141-158.

Cook, J.W., Dodds, E.C., Hewett, C.L., and Lawson, W., 1994, The estrogenic activity of some condensed-ring compounds in relation to their other biological activities: Proceedings of the Royal Society of London, v. 114, p. 272-286.

Desbrow, C., Routledge, E.J., Brighty, G.C., Sumpter, J.P., and Waldock, M., 1998, Identification of estrogenic chemicals in STW effluent-1. Chemical fractionation and in vitro biological screening: Environmental Science \& Technology, v. 32, p. 1549-1558.

East Dakota Water Development District, 2004, Central Big Sioux River Watershed Assessment draft final report and TMDL: Pierre, South Dakota, South Dakota Department of Environment and Natural Resources, 230 p.

Flint, R.F., 1971, Glacial and Quaternary geology: New York, John Wiley and Sons, $892 \mathrm{p}$.

Gies, Andreas; Gottschalk, Christa; Greiner, Petra; Heger, Wolfgang; Kolossa, Marike; Rechenberg, Bettina; Robkamp, Elke; Schroeter-Kermani, Christa; Steinhauser, Klaus; and Throl, Christine, 2001, Chemicals in the environment which interfere with the endocrine systems of humans and wildlife-pollution, effects, control strategies: Report by the German Federal Environmental Agency (UBA), 53 p., accessed August 5, 2005, at http://www.umweltdaten.de/ down-e/chempol2.pdf

Glassmeyer, S.T., Furlong, E.T., Kolpin, D.W., Cahill, J.D., Zaugg, S.D., Werner, S.L., Meyer, M.T., and Kryak, D.D., 2005, Transport of chemical and microbial compounds from known wastewater discharges — potential for use as indicators of human fecal contamination: Environmental Science \& Technology, v. 39, no. 14, p. 5157-5169.

Halling-Sorensen, B., Nielsen, S.N., Lanzky, P.F., Ingerslev, F., Lutzhoft, H.C.H., and Jorgensen, S.E., 1998, Occurrence, fate, and effects of pharmaceutical substances in the environment-a review: Chemosphere, v. 36, no. 2, p. 357-394.

Harries, J.E.; Janbakhsh, Afsaneh; Jobling, Susan; Matthiessen, Peter; Sumpter, J.P.; and Tyler, C.R., 1999, Estrogenic potency of effluent from two sewage treatment works in the United Kingdom: Environmental Toxicology and Chemistry, v. 18, p. 932-937.

Harris, C.A., Santos, E.M., Janbakhsh, A., Pottinger, T.G., Tyler, C.R., and Sumpter, J.P., 2001, Nonylphenol affects gonadotropin levels in the pituitary gland and plasma of female rainbow trout: Environmental Science \& Technology, v. 35, p. 2909-2916. 
Hayes, Tyrone; Haston, Kelly; Tsui, Mable; Hoang, Anhthu; Haeffele, Cathryn; and Vonk, Aaron; 2003, Atrazine-induced hermaphroditism at $0.1 \mathrm{ppb}$ in American leopard frogs (Rana pipiens)-laboratory and field evidence: Environmental Health Perspectives, v. 111, p. 568-575.

Huggett, D.B.; Foran, C.M.; Brooks, B.W.; Weston, Jim; Peterson, Bethany; Marsh, D.E.; La Point, T.W.; and Schlenk, Daniel, 2003, Comparison of in vitro and in vivo bioassays for estrogenicity in effluent from North American municipal wastewater facilities: Toxicological Sciences, v. 72, p. 77-83.

Jobling, Susan; Sheahan, David; Osborne, J.A.; Matthiessen, Peter; and Sumpter, J.P., 1996, Inhibition of testicular growth in rainbow trout (Oncorhynchus mykiss) exposed to estrogenic alkylphenolic chemicals: Environmental Toxicology and Chemistry, v. 15, no. 2, p. 194-202.

Jobling, Susan, and Sumpter, J.P., 1993, Detergent components in sewage effluent are weakly estrogenic to fish —an in vitro study using rainbow trout (Oncorhynchus mykiss) hepatocytes: Aquatic Toxicology, v. 27, p. 361-372.

Jobling, Susan, and Tyler, C.R., 2003, Endocrine disruption in wild freshwater fish: Pure and Applied Chemistry, v. 75, p. 2219-2234.

Keith, L.W., 1998, Environmental endocrine disruptors: Pure and Applied Chemistry, v. 70, p. 2319-2326.

Kolpin, D.W., Furlong, E.T., Meyer, M.T., Thurman, E.M., Zaugg, S.D., Barber, L.B., and Buxton, H.T., 2002, Pharmaceuticals, hormones, and other organic wastewater contaminants in U.S. streams, 1999-2000-a national reconnaissance: Environmental Science \& Technology, v. 36, no. 6, p. $1202-1211$.

Kolpin, D.W., Skopec, Mary, Meyer, M.T., Furlong, E.T., and Zaugg, S.D., 2004, Urban contribution of pharmaceutical and other organic wastewater contaminants to streams during differing flow conditions: Science of the Total Environment, v. 328, p. 119-130.

Lawrence, S.J., and Sando, S.K., 1989, Quality of water from surficial-outwash aquifers in the Big Sioux River Basin, eastern South Dakota: U.S. Geological Survey Water-Resources Investigations Report 89-4170, 81 p.

Leap, D.I., 1988, Geology and hydrology of Day County, South Dakota: South Dakota Geological Survey Bulletin 24, 113 p.

Lee, K.E., Barber, L.B., Furlong, E.T., Cahill, J.D., Kolpin, D.W., Meyer, M.T., and Zaugg, S.D., 2004, Presence and distribution of organic wastewater compounds in wastewater, surface, ground, and drinking waters, Minnesota, 2000-02: U.S. Geological Survey Scientific Investigations Report 2004-5138, 47 p.

Leeming, R.L., Ball, A., Ashbolt, N.J., and Nichols, P.D., 1994, Distinguishing between human and animal sources of faecal pollution: Australian Journal of Chemistry, v. 61, p. 434-435.

Rantz, S.E., and others, 1982a, Measurement and computation of streamflow-volume 1. Measurement of stage and discharge: U.S. Geological Survey Water-Supply Paper 2175, p. 1-285.
Rantz, S.E., and others, 1982b, Measurement and computation of streamflow-volume 2. Computation of discharge: U.S. Geological Survey Water-Supply Paper 2175, p. 285-631.

Richard, H.M.; Schreurs, M.; Legler, Juliette; Artola-Garicano, Elsa; Sinnige, T.L.; Lanser, P.H.; Seinen, Willem; and van der Burg, Bart, 2004, In vitro and in vivo antiestrogenic effects of polycyclic musks in zebrafish: Environmental Science \& Technology, v. 38, no. 38, p. 997-1002.

Richard, H.M., Schreurs, M., Quaedackers, M.E., Seinen, Willem, and van der Burg, Bart, 2002, Transcriptional activation of estrogen receptor $\mathrm{ER} \alpha$ and $\mathrm{ER} \beta$ by polycyclic musks is cell type dependent: Toxicology and Applied Pharmacology, v. 183, no. 1, p. 1-9.

Richardson, M.L., and Bowron, J.M., 1985, The fate of pharmaceutical chemicals in the aquatic environment: Journal of Pharmacy and Pharmacology, v. 37, p. 1-12.

Rodgers-Gray, T.P.; Jobling, Susan; Morris, Steven; Kelly, Carole; Kirby, Sonia; Janbakhsh, Afsaneh; Harries, J.E.; Waldock, M.J.; Sumpter, J.P.; and Tyler, C.R., 2000, Longterm temporal changes in the estrogenic composition of treated sewage effluent and its biological effects on fish: Environmental Science \& Technology, v. 34, no. 8, p. 1521-1528.

Schlumpf, Margret; Cotton, Beata; Conscience, Marianne; Haller, Vreni; Steinmann, Beate; and Lichtensteiger, Walter, 2001, In vitro and in vivo estrogenicity of UV screens: Environmental Health Perspectives, v. 109, p. 239-244.

Sheahan, D.A.; Brighty, G.C.; Daniel, Mic; Jobling, Susan; Harries, J.E.; Hurst, M.R.; Kennedy, Joe; Kirby, S.J.; Morris, Steven; Routledge, E.J.; Sumpter, J.P.; and Waldock, M.J., 2002, Reduction in the estrogenic activity of a treated sewage effluent discharge to an English river as a result of a decrease in the concentration of industrially derived surfactants: Environmental Toxicology and Chemistry, v. 21, no. 3, p. 515-519.

Shelton, L.R., and Capel, P.D., 1994, Guidelines for collecting and processing samples of stream bed sediment for analysis of trace elements and organic contaminants for the National Water-Quality Assessment Program: U.S. Geological Survey Open-File Report 94-458, 20 p.

South Dakota State University, 2005, South Dakota climate and weather-precipitation normals (1971-2000): Data available on Web, accessed April 7, 2005, at http://climate.sdstate.edu/data/pptnormals.shtm

Spano, Laura; Tyler, C.R.; van Aerle, Ronny; Devos, Pierre; Mandiki, S.N.M.; Silvestre, Frederic; Thome, J.P.; and Kestemont, Patrick, 2004, Effects of atrazine on sex steroid dynamics, plasma vitellogenin concentration and gonad development in adult goldfish (Carassius auratus): Aquatic Toxicology, v. 66, p. 369-379.

Sumpter, J.P., and Jobling, Susan, 1995, Vitellogenesis as a biomarker for estrogenic contamination of the aquatic environment: Environmental Health Perspectives, v. 103, p. 173-187. 
Sumpter, J.P., and Johnson, A.C., 2005, Lessons from endocrine disruption and their application to other issues concerning trace organics in the aquatic environment: Environmental Science \& Technology, v. 39, no. 12, p. 4321-4332.

Stackelberg, P.E., Furlong, E.T., Meyer, M.T., Zaugg, S.D., Henderson, A.K., and Reissman, D.B., 2004, Persistence of pharmaceutical compounds and other organic wastewater contaminants in a conventional drinking-water-treatment plant: Science of the Total Environment, v. 329, nos. 1-3, p. 99-113.

Taylor, J.K., 1987, Quality assurance of chemical measurements: Chelsea, Mich., Lewis Publishers, 328 p.

Thorpe, K.L., Hutchinson, T.H., Hetheridge, M.J., Scholze, Martin, Sumpter, J.P., and Tyler, C.R., 2001, Assessing the biological potency of binary mixtures of environmental estrogens using vitellogenin induction in juvenile rainbow trout (Oncorhynchus mykiss): Environmental Science \& Technology, v. 35, no. 35, p. 2476-2481.

U.S. Census Bureau, 2005, American factfinder: Information available on Web, accessed July 28, 2005, at http://factfinder.census.gov/home/saff/ main.html?_lang=en

U.S. Environmental Protection Agency, 1992, Guidelines establishing test procedures for the analysis of pollutants (Appendix B to part 136, Definition and procedure for the determination of the method detection limit): U.S. Code of Federal Regulations, Title 40, revised as of July 1, 1992.

U.S. Geological Survey, 1997-2004, National field manual for the collection of water-quality data: U.S. Geological Survey Techniques of Water-Resources Investigations, book 9, chaps. A1-A9, 2 v., variously paged, available on Web at http://pubs.water.usgs.gov/twri9A (chapters were originally published from 1997-1999; updates and revisions are ongoing and are summarized at http://water.usgs.gov/owq/ FieldManual/mastererrata.html).

Welshons, W.V., Thayer, K.A., Judy, B.M., Tayler, J.A., Curran, E.M., and vom Saal, F.S., 2003, Large effects from small exposures-mechanisms for endocrine disrupting chemicals with estrogenic activity: Environmental Health Perspectives, v. 111, p. 994-1006.

Zaugg, S.D., Smith, S.G., Schroeder, M.P., Barber, L.B., and Burkhardt, M.R., 2002, Methods of analysis by the U.S. Geological Survey National Water Quality Laboratory-determination of wastewater compounds by polystyrene-divinylbenzene solid-phase extraction and capillary-column gas chromatography/mass spectrometry: U.S. Geological Survey Water-Resources Investigations Report 01-4186, 37 p. 
Supplemental Information 
Table 7. Field-measured properties and constituents and analytical constituents.

[Bold text indicates suspected endocrine-disrupting compound (EDC). Units are micrograms per liter unless otherwise noted. Analytical method number: 1, Cahill and others (2004); 2, U.S. Geological Survey Organic Geochemistry Research Laboratory; 3, Lee and others (2004); 4, Zaugg and others (2002); 5, Burkhardt and others (2005). CAS RN, Chemical Abstracts Service Registry Number; $\mathrm{ft}$, feet; $\mathrm{ft}^{3} / \mathrm{s}$, cubic feet per second; $\mathrm{mm} \mathrm{Hg}$, millimeter of mercury; $\mathrm{mg} / \mathrm{L}$, milligrams per liter; $\mu \mathrm{S} / \mathrm{cm}$, microsiemens per centimeter at 25 degrees Celsius; ${ }^{\circ} \mathrm{C}$, degree Celsius; $\mu \mathrm{g} / \mathrm{kg}$, micrograms per kilogram; NTU, nephelometric turbidity unit; NA, not applicable; ND, not determined; --, no data]

\begin{tabular}{|c|c|c|c|c|c|c|}
\hline Constituent or property & $\begin{array}{l}\text { Analytical } \\
\text { method } \\
\text { number }\end{array}$ & Footnote & $\begin{array}{l}\text { Laboratory or } \\
\text { method } \\
\text { reporting level }\end{array}$ & $\begin{array}{l}\text { Study reporting } \\
\text { level for data } \\
\text { summary and } \\
\text { analysis }\end{array}$ & CAS RN & Typical use \\
\hline \multicolumn{7}{|c|}{ Field-measured properties and constituents } \\
\hline Gage height & -- & NA & $0.01 \mathrm{ft}$ & -- & -- & -- \\
\hline Discharge, instantaneous & -- & NA & $.1 \mathrm{ft}^{3} / \mathrm{s}$ & -- & -- & -- \\
\hline Turbidity & -- & NA & $1 \mathrm{NTU}$ & -- & -- & -- \\
\hline Barometric pressure & -- & NA & $1 \mathrm{~mm} \mathrm{Hg}$ & -- & -- & -- \\
\hline Dissolved oxygen & -- & NA & $.1 \mathrm{mg} / \mathrm{L}$ & -- & -- & -- \\
\hline $\mathrm{pH}$ & -- & NA & .1 standard unit & -- & -- & -- \\
\hline Specific conductance & -- & NA & $5 \mu \mathrm{S} / \mathrm{cm}$ & -- & -- & -- \\
\hline Air temperature & -- & NA & $.1^{\circ} \mathrm{C}$ & -- & -- & -- \\
\hline Water temperature & -- & NA & $.1^{\circ} \mathrm{C}$ & -- & -- & -- \\
\hline \multicolumn{7}{|c|}{ Human pharmaceutical compounds (HPCs) } \\
\hline $\begin{array}{l}\text { 1,7-Dimethylxanthine, } \\
\text { dissolved }\end{array}$ & 1 & $1,4,5$ & 0.144 & 0.030 & $611-59-6$ & caffeine metabolite \\
\hline Acetaminophen, dissolved & 1 & 3 & .036 & ND & $103-90-2$ & $\begin{array}{l}\text { antipyretic } \\
\text { (nonprescription) }\end{array}$ \\
\hline Caffeine, dissolved & 1 & $1,4,5$ & .016 & .022 & $58-08-2$ & $\begin{array}{l}\text { stimulant } \\
\text { (nonprescription) }\end{array}$ \\
\hline Caffeine, dissolved & 4 & 3 & .5 & ND & $58-08-2$ & $\begin{array}{l}\text { stimulant } \\
\text { (nonprescription) }\end{array}$ \\
\hline Caffeine, whole water & 3 & 1 & .5 & .17 & $58-08-2$ & $\begin{array}{l}\text { stimulant } \\
\text { (nonprescription) }\end{array}$ \\
\hline Carbamazepine, dissolved & 1 & 3 & .011 & ND & $298-46-4$ & $\begin{array}{l}\text { anticonvulsant, antineuralgic } \\
\text { (prescription) }\end{array}$ \\
\hline Cimetidine, dissolved & 1 & 3 & .012 & ND & $51481-61-9$ & antacid (nonprescription) \\
\hline Codeine, dissolved & 1 & 3 & .015 & ND & $76-57-3$ & analgesic (prescription) \\
\hline Cotinine, dissolved & 1 & $1,4,5$ & .014 & .0008 & $486-56-6$ & nicotine metabolite \\
\hline Cotinine, dissolved & 4 & 3 & 1 & ND & $486-56-6$ & nicotine metabolite \\
\hline Cotinine, whole water & 3 & 3 & 1 & ND & $486-56-6$ & nicotine metabolite \\
\hline Dehydronifedipine, dissolved & 1 & $1,4,5$ & .015 & .0042 & $67035-22-7$ & $\begin{array}{l}\text { nifedipine metabolite, } \\
\text { antianginal } \\
\text { (prescription) }\end{array}$ \\
\hline Diltiazem, dissolved & 1 & 3 & .016 & ND & $42399-41-7$ & $\begin{array}{l}\text { antihypertensive } \\
\text { (prescription) }\end{array}$ \\
\hline Diphenhydramine, dissolved & 1 & 3 & .015 & ND & $58-73-1$ & antihistamine (prescription) \\
\hline Fluoxetine, dissolved & 1 & 3 & .014 & ND & $54910-89-3$ & antidepressant (prescription) \\
\hline Furosemide, dissolved & 1 & 3 & .039 & ND & $54-31-9$ & diuretic (prescription) \\
\hline Gemfibrozil, dissolved & 1 & 3 & .013 & ND & $25812-30-0$ & $\begin{array}{l}\text { antihyperlipidemic } \\
\text { (prescription) }\end{array}$ \\
\hline Ibuprofen, dissolved & 1 & 3 & .042 & ND & $15687-27-1$ & $\begin{array}{l}\text { antiinflamatory } \\
\text { (nonprescription) }\end{array}$ \\
\hline Metformin, dissolved & 1 & 3 & -- & ND & $1115-70-4$ & antidiabetic (prescription) \\
\hline Miconazole, dissolved & 1 & 3 & .018 & ND & $22916-47-8$ & $\begin{array}{l}\text { antifungal } \\
\text { (nonprescription) }\end{array}$ \\
\hline Ranitidine, dissolved & 1 & 3 & .013 & ND & $66357-35-5$ & antacid (nonprescription) \\
\hline
\end{tabular}


Table 7. Field-measured properties and constituents and analytical constituents.—Continued

[Bold text indicates suspected endocrine-disrupting compound (EDC). Units are micrograms per liter unless otherwise noted. Analytical method number: 1, Cahill and others (2004); 2, U.S. Geological Survey Organic Geochemistry Research Laboratory; 3, Lee and others (2004); 4, Zaugg and others (2002); 5, Burkhardt and others (2005). CAS RN, Chemical Abstracts Service Registry Number; $\mathrm{ft}, \mathrm{feet} ; \mathrm{ft}^{3} / \mathrm{s}$, cubic feet per second; mm $\mathrm{Hg}$, millimeter of mercury; mg/L, milligrams per liter; $\mu \mathrm{S} / \mathrm{cm}$, microsiemens per centimeter at 25 degrees Celsius; ${ }^{\circ} \mathrm{C}$, degree Celsius; $\mu \mathrm{g} / \mathrm{kg}$, micrograms per kilogram; NTU, nephelometric turbidity unit; NA, not applicable; ND, not determined; --, no data]

\begin{tabular}{|c|c|c|c|c|c|c|}
\hline Constituent or property & $\begin{array}{l}\text { Analytical } \\
\text { method } \\
\text { number }\end{array}$ & Footnote & $\begin{array}{l}\text { Laboratory or } \\
\text { method } \\
\text { reporting level }\end{array}$ & $\begin{array}{l}\text { Study reporting } \\
\text { level for data } \\
\text { summary and } \\
\text { analysis }\end{array}$ & CAS RN & Typical use \\
\hline \multicolumn{7}{|c|}{ Human pharmaceutical compounds (HPCs) —Continued } \\
\hline Salbutamol, dissolved & 1 & $1,4,5$ & 0.023 & 0.023 & 18559-94-9 & $\begin{array}{l}\text { antiasthmatic } \\
\text { (prescription) }\end{array}$ \\
\hline Thiabendazole, dissolved & 1 & 3 & .011 & ND & $148-79-8$ & fungicide \\
\hline Warfarin, dissolved & 1 & 3 & .012 & ND & $81-81-2$ & $\begin{array}{l}\text { anticoagulant } \\
\text { (prescription) }\end{array}$ \\
\hline \multicolumn{7}{|c|}{ Human and veterinary antibiotic compounds (HVACs) } \\
\hline Amoxicillin, dissolved & 2 & 2 & 0.01 & 0.01 & $26787-78-0$ & $\begin{array}{l}\text { antibiotic } \\
\text { (human and veterinary; beta } \\
\text { lactam class) }\end{array}$ \\
\hline Ampicillin, dissolved & 2 & 2 & .01 & .01 & $69-53-4$ & $\begin{array}{l}\text { antibiotic } \\
\text { (human and veterinary; beta } \\
\text { lactam class) }\end{array}$ \\
\hline Anhd-Cl-tetracycline, dissolved & 2 & 2 & .01 & .3 & $4497-08-9$ & chlorotetracycline metabolite \\
\hline Anhydrotetracycline, dissolved & 2 & 2 & .01 & .15 & $13803-65-1$ & tetracycline metabolite \\
\hline Azithromycin, dissolved & 1 & 3 & .004 & ND & $83905-01-5$ & $\begin{array}{l}\text { antibiotic } \\
\text { (human and veterinary; } \\
\text { macrolide class) }\end{array}$ \\
\hline Carbadox, dissolved & 2 & 2 & $.05, .005$ & .05 & $6804-07-5$ & $\begin{array}{l}\text { antibiotic } \\
\text { (veterinary; quinolone class) }\end{array}$ \\
\hline Cefotaxime, dissolved & 2 & 2 & .01 & .01 & $63527-52-6$ & $\begin{array}{l}\text { antibiotic } \\
\text { (human and veterinary; beta } \\
\text { lactam class) }\end{array}$ \\
\hline Chlorotetracycline, dissolved & 2 & $1,4,5$ & $.02, .01$ & .056 & $57-62-5$ & $\begin{array}{l}\text { antibiotic } \\
\quad \text { (veterinary; tetracycline class) }\end{array}$ \\
\hline Ciprofloxacin, dissolved & 2 & $1,4,5$ & $.01, .005$ & .033 & $85721-33-1$ & $\begin{array}{l}\text { antibiotic } \\
\text { (human and veterinary; } \\
\text { quinolone class) }\end{array}$ \\
\hline Clinafloxacin, dissolved & 2 & 2 & .005 & .005 & $105956-97-6$ & $\begin{array}{l}\text { antibiotic } \\
\text { (human and veterinary; } \\
\text { quinolone class) }\end{array}$ \\
\hline Cloxacillin, dissolved & 2 & 2 & .01 & .01 & $61-72-3$ & $\begin{array}{l}\text { antibiotic } \\
\text { (human and veterinary; beta } \\
\text { lactam class) }\end{array}$ \\
\hline Demeclocycline, dissolved & 2 & 2 & $.02, .01$ & .02 & $127-33-3$ & $\begin{array}{l}\text { antibiotic } \\
\text { (human and veterinary; } \\
\text { tetracycline class) }\end{array}$ \\
\hline Doxycycline, dissolved & 2 & 2 & $.05, .01$ & .05 & $564-25-0$ & $\begin{array}{l}\text { antibiotic } \\
\text { (human and veterinary; } \\
\text { tetracycline class) }\end{array}$ \\
\hline Enrofloxacin, dissolved & 2 & 2 & .01 & .01 & -- & $\begin{array}{l}\text { antibiotic } \\
\text { (veterinary; quinolone class) }\end{array}$ \\
\hline
\end{tabular}


Table 7. Field-measured properties and constituents and analytical constituents.—Continued

[Bold text indicates suspected endocrine-disrupting compound (EDC). Units are micrograms per liter unless otherwise noted. Analytical method number: 1, Cahill and others (2004); 2, U.S. Geological Survey Organic Geochemistry Research Laboratory; 3, Lee and others (2004); 4, Zaugg and others (2002); 5, Burkhardt and others (2005). CAS RN, Chemical Abstracts Service Registry Number; $\mathrm{ft}$, feet; $\mathrm{ft}^{3} / \mathrm{s}$, cubic feet per second; mm Hg, millimeter of mercury; mg/L, milligrams per liter; $\mu \mathrm{S} / \mathrm{cm}$, microsiemens per centimeter at 25 degrees Celsius; ${ }^{\circ} \mathrm{C}$, degree Celsius; $\mu \mathrm{g} / \mathrm{kg}$, micrograms per kilogram; NTU, nephelometric turbidity unit; NA, not applicable; ND, not determined; --, no data]

\begin{tabular}{|c|c|c|c|c|c|c|}
\hline Constituent or property & $\begin{array}{l}\text { Analytical } \\
\text { method } \\
\text { number }\end{array}$ & Footnote & $\begin{array}{l}\text { Laboratory or } \\
\text { method } \\
\text { reporting level }\end{array}$ & $\begin{array}{l}\text { Study reporting } \\
\text { level for data } \\
\text { summary and } \\
\text { analysis }\end{array}$ & CAS RN & Typical use \\
\hline \multicolumn{7}{|c|}{ Human and veterinary antibiotic compounds (HVACs) - Continued } \\
\hline Erythromycin, dissolved & 1 & 3 & 0.009 & ND & $114-07-8$ & $\begin{array}{l}\text { antibiotic } \\
\text { (human and veterinary; } \\
\text { macrolide class) }\end{array}$ \\
\hline Erythromycin, dissolved & 2 & $1,4,5$ & $.02, .01, .005$ & 0.025 & $114-07-8$ & $\begin{array}{l}\text { antibiotic } \\
\text { (human and veterinary; } \\
\text { macrolide class) }\end{array}$ \\
\hline Erythromycin- $\mathrm{H}_{2} \mathrm{O}$, dissolved & 2 & $1,4,5$ & $.02, .01, .005$ & .046 & $114-07-8$ & erythromycin metabolite \\
\hline Flumequine, dissolved & 2 & 2 & $.05, .005$ & .05 & $42835-25-6$ & $\begin{array}{l}\text { antibiotic } \\
\text { (veterinary; quinolone class) }\end{array}$ \\
\hline Lincomycin, dissolved & 2 & $1,4,5$ & $.01, .005$ & .01 & $154-21-2$ & $\begin{array}{l}\text { antibiotic } \\
\text { (veterinary; macrolide class) }\end{array}$ \\
\hline Lomefloxacin, dissolved & 2 & 2 & .005 & .005 & $98079-51-7$ & $\begin{array}{l}\text { antibiotic } \\
\text { (veterinary; quinolone class) }\end{array}$ \\
\hline Methotrexate, dissolved & 2 & 2 & .02 & .02 & -- & $\begin{array}{l}\text { antibiotic complimentary } \\
\text { (human) }\end{array}$ \\
\hline Minocycline, dissolved & 2 & 2 & $.02, .01$ & .02 & $10118-90-8$ & $\begin{array}{l}\text { antibiotic } \\
\text { (human and veterinary; } \\
\text { tetracycline class) }\end{array}$ \\
\hline Norfloxacin, dissolved & 2 & 2 & $.01, .005$ & .01 & $70458-96-7$ & $\begin{array}{l}\text { antibiotic } \\
\text { (human and veterinary; } \\
\text { quinolone class) }\end{array}$ \\
\hline Ofloxacin, dissolved & 2 & $1,4,5$ & .005 & .15 & $83380-47-6$ & $\begin{array}{l}\text { antibiotic } \\
\text { (human and veterinary; } \\
\text { quinolone class) }\end{array}$ \\
\hline Ormetoprim, dissolved & 2 & 2 & $.01, .005$ & .01 & $6981-18-6$ & $\begin{array}{l}\text { antibiotic } \\
\quad \text { (veterinary; sulfonamide class) }\end{array}$ \\
\hline Oxacillin, dissolved & 2 & 2 & .01 & .01 & $66-79-5$ & $\begin{array}{l}\text { antibiotic } \\
\text { (human and veterinary; beta } \\
\text { lactam class) }\end{array}$ \\
\hline Oxolinic acid, dissolved & 2 & 2 & .005 & .005 & $14698-29-4$ & $\begin{array}{l}\text { antibiotic } \\
\text { (veterinary; quinolone class) }\end{array}$ \\
\hline Oxytetracycline, dissolved & 2 & 2 & $.05, .01$ & .05 & $79-57-2$ & $\begin{array}{l}\text { antibiotic } \\
\quad \text { (veterinary; tetracycline class) }\end{array}$ \\
\hline Penicillin G, dissolved & 2 & 2 & .01 & .01 & $69-57-8$ & $\begin{array}{l}\text { antibiotic } \\
\text { (human and veterinary; beta } \\
\text { lactam class) }\end{array}$ \\
\hline Penicillin V, dissolved & 2 & 2 & .01 & .01 & $87-08-1$ & $\begin{array}{l}\text { antibiotic } \\
\text { (human and veterinary; beta } \\
\text { lactam class) }\end{array}$ \\
\hline Roxarsone, dissolved & 2 & 2 & .5 & .5 & -- & $\begin{array}{l}\text { antibiotic } \\
\text { (veterinary; arsenical class) }\end{array}$ \\
\hline Roxithromycin, dissolved & 2 & 2 & $.01, .005$ & .01 & $80214-83-1$ & $\begin{array}{l}\text { antibiotic } \\
\text { (human and veterinary; } \\
\text { macrolide class) }\end{array}$ \\
\hline
\end{tabular}


Table 7. Field-measured properties and constituents and analytical constituents.-Continued

[Bold text indicates suspected endocrine-disrupting compound (EDC). Units are micrograms per liter unless otherwise noted. Analytical method number: 1, Cahill and others (2004); 2, U.S. Geological Survey Organic Geochemistry Research Laboratory; 3, Lee and others (2004); 4, Zaugg and others (2002); 5, Burkhardt and others (2005). CAS RN, Chemical Abstracts Service Registry Number; $\mathrm{ft}, \mathrm{feet} ; \mathrm{ft}^{3} / \mathrm{s}$, cubic feet per second; $\mathrm{mm} \mathrm{Hg}$, millimeter of mercury; $\mathrm{mg} / \mathrm{L}$, milligrams per liter; $\mu \mathrm{S} / \mathrm{cm}$, microsiemens per centimeter at 25 degrees Celsius; ${ }^{\circ} \mathrm{C}$, degree Celsius; $\mu \mathrm{g} / \mathrm{kg}$, micrograms per kilogram; NTU, nephelometric turbidity unit; NA, not applicable; ND, not determined; --, no data]

\begin{tabular}{|c|c|c|c|c|c|c|}
\hline Constituent or property & $\begin{array}{l}\text { Analytical } \\
\text { method } \\
\text { number }\end{array}$ & Footnote & $\begin{array}{l}\text { Laboratory or } \\
\text { method } \\
\text { reporting level }\end{array}$ & $\begin{array}{l}\text { Study reporting } \\
\text { level for data } \\
\text { summary and } \\
\text { analysis }\end{array}$ & CAS RN & Typical use \\
\hline \multicolumn{7}{|c|}{ Human and veterinary antibiotic compounds (HVACs) - Continued } \\
\hline Sarafloxacin, dissolved & 2 & 2 & $0.01,0.005$ & 0.01 & 98105-99-8 & $\begin{array}{l}\text { antibiotic } \\
\text { (veterinary; quinolone class) }\end{array}$ \\
\hline Sulfachlorpyridazine, dissolved & 2 & 2 & $.05, .005$ & .05 & $80-32-0$ & $\begin{array}{l}\text { antibiotic } \\
\text { (veterinary; sulfonamide class) }\end{array}$ \\
\hline Sulfadiazine, dissolved & 2 & 2 & .005 & .005 & $68-35-9$ & $\begin{array}{l}\text { antibiotic } \\
\text { (veterinary; sulfonamide class) }\end{array}$ \\
\hline Sulfadimethoxine, dissolved & 2 & 2 & $.01, .005$ & .01 & $122-11-2$ & $\begin{array}{l}\text { antibiotic } \\
\text { (veterinary; sulfonamide class) }\end{array}$ \\
\hline Sulfamerazine, dissolved & 2 & 2 & $.02, .005$ & .02 & $127-79-7$ & $\begin{array}{l}\text { antibiotic } \\
\text { (veterinary; sulfonamide class) }\end{array}$ \\
\hline Sulfamethazine, dissolved & 2 & 2 & $.01, .005$ & .01 & $57-68-1$ & $\begin{array}{l}\text { antibiotic } \\
\text { (veterinary; sulfonamide class) }\end{array}$ \\
\hline Sulfamethizole, dissolved & 2 & 2 & .05 & .05 & -- & $\begin{array}{l}\text { antibiotic } \\
\text { (human and veterinary; } \\
\text { sulfonamide class) }\end{array}$ \\
\hline Sulfamethoxazole, dissolved & 1 & 3 & .064 & ND & $723-46-6$ & $\begin{array}{l}\text { antibiotic } \\
\text { (human and veterinary; } \\
\text { sulfonamide class) }\end{array}$ \\
\hline Sulfamethoxazole, dissolved & 2 & $1,4,5$ & $.05, .005$ & .014 & $723-46-6$ & $\begin{array}{l}\text { antibiotic } \\
\text { (human and veterinary; } \\
\text { sulfonamide class) }\end{array}$ \\
\hline Sulfathiazole, dissolved & 2 & 2 & $.05, .005$ & .05 & $72-14-0$ & $\begin{array}{l}\text { antibiotic } \\
\text { (veterinary; sulfonamide class) }\end{array}$ \\
\hline Tetracycline, dissolved & 2 & $1,4,5$ & $.02, .01$ & 1.6 & $60-54-8$ & $\begin{array}{l}\text { antibiotic } \\
\text { (human and veterinary; } \\
\text { tetracycline class) }\end{array}$ \\
\hline Trimethoprim, dissolved & 1 & 3 & .013 & ND & $738-70-5$ & $\begin{array}{l}\text { antibiotic } \\
\text { (human and veterinary; } \\
\text { sulfonamide class) }\end{array}$ \\
\hline Trimethoprim, dissolved & 2 & $1,4,5$ & $.01, .005$ & .02 & $738-70-5$ & $\begin{array}{l}\text { antibiotic } \\
\text { (human and veterinary; } \\
\text { sulfonamide class) }\end{array}$ \\
\hline Tylosin, dissolved & 2 & $1,4,5$ & $.02, .01, .005$ & .07 & $1401-69-0$ & $\begin{array}{l}\text { antibiotic } \\
\text { (veterinary; macrolide class) }\end{array}$ \\
\hline Virginiamycin, dissolved & 2 & 2 & $.1, .01, .005$ & .1 & $21411-53-0$ & $\begin{array}{l}\text { antibiotic } \\
\text { (veterinary; macrolide class) }\end{array}$ \\
\hline \multicolumn{7}{|c|}{ Major agricultural herbicides (MAHs) } \\
\hline Atrazine, whole water & 3 & $1,4,5$ & 0.5 & 0.0002 & $1912-24-9$ & herbicide \\
\hline Atrazine, bottom sediment & 5 & 2 & $100 \mu \mathrm{g} / \mathrm{kg}$ & $100 \mu \mathrm{g} / \mathrm{kg}$ & $1912-24-9$ & herbicide \\
\hline Metolachlor, dissolved & 4 & 1,5 & .5 & .071 & $98-82-8$ & herbicide \\
\hline Metolachlor, whole water & 3 & 1,4 & .5 & .004 & $98-82-8$ & herbicide \\
\hline Metolachlor, bottom sediment & 5 & 2 & $50 \mu \mathrm{g} / \mathrm{kg}$ & $50 \mu \mathrm{g} / \mathrm{kg}$ & $98-82-8$ & herbicide \\
\hline Prometon, dissolved & 4 & 1,5 & .5 & .13 & $1610-18-0$ & herbicide \\
\hline
\end{tabular}


Table 7. Field-measured properties and constituents and analytical constituents.-Continued

[Bold text indicates suspected endocrine-disrupting compound (EDC). Units are micrograms per liter unless otherwise noted. Analytical method number: 1, Cahill and others (2004); 2, U.S. Geological Survey Organic Geochemistry Research Laboratory; 3, Lee and others (2004); 4, Zaugg and others (2002); 5, Burkhardt and others (2005). CAS RN, Chemical Abstracts Service Registry Number; $\mathrm{ft}$, feet; $\mathrm{ft}^{3} / \mathrm{s}$, cubic feet per second; $\mathrm{mm} \mathrm{Hg}$, millimeter of mercury; mg/L, milligrams per liter; $\mu \mathrm{S} / \mathrm{cm}$, microsiemens per centimeter at 25 degrees Celsius; ${ }^{\circ} \mathrm{C}$, degree Celsius; $\mu \mathrm{g} / \mathrm{kg}$, micrograms per kilogram; NTU, nephelometric turbidity unit; NA, not applicable; ND, not determined; --, no data]

\begin{tabular}{|c|c|c|c|c|c|c|}
\hline Constituent or property & $\begin{array}{l}\text { Analytical } \\
\text { method } \\
\text { number }\end{array}$ & Footnote & $\begin{array}{l}\text { Laboratory or } \\
\text { method } \\
\text { reporting level }\end{array}$ & $\begin{array}{l}\text { Study reporting } \\
\text { level for data } \\
\text { summary and } \\
\text { analysis }\end{array}$ & CAS RN & Typical use \\
\hline \multicolumn{7}{|c|}{ Major agricultural herbicides (MAHs)—Continued } \\
\hline Prometon, whole water & 3 & 1,4 & 0.5 & 0.02 & $1610-18-0$ & herbicide \\
\hline Prometon, bottom sediment & 5 & 2 & $50 \mu \mathrm{g} / \mathrm{kg}$ & $50 \mu \mathrm{g} / \mathrm{kg}$ & $1610-18-0$ & herbicide \\
\hline \multicolumn{7}{|c|}{ Household, industrial, and minor agricultural use compounds (HIACs) } \\
\hline 1,4-Dichlorobenzene, dissolved & 4 & 1,5 & 0.5 & 0.08 & $106-46-7$ & deodorizer, moth repellent \\
\hline $\begin{array}{l}\text { 1,4-Dichlorobenzene, whole } \\
\text { water }\end{array}$ & 3 & 3 & .5 & ND & $106-46-7$ & deodorizer, moth repellent \\
\hline $\begin{array}{l}\text { 1,4-Dichlorobenzene, bottom } \\
\text { sediment }\end{array}$ & 5 & 2 & $50 \mu \mathrm{g} / \mathrm{kg}$ & $50 \mu \mathrm{g} / \mathrm{kg}$ & $106-46-7$ & deodorizer, moth repellent \\
\hline $\begin{array}{l}\text { 2,2',4,4'-Tetrabromodiphenyl } \\
\text { ether, whole water }\end{array}$ & 3 & 2 & $10, .5$ & .5 & $5436-43-1$ & fire retardant \\
\hline $\begin{array}{l}\text { 2,2',4,4'-Tetrabromodiphenyl } \\
\text { ether, bottom sediment }\end{array}$ & 5 & 2 & $50 \mu \mathrm{g} / \mathrm{kg}$ & $50 \mu \mathrm{g} / \mathrm{kg}$ & $5436-43-1$ & fire retardant \\
\hline $\begin{array}{l}\text { 3,4-Dichlorophenyl } \\
\text { isocyanate, whole water }\end{array}$ & 3 & 3 & .5 & ND & $102-36-3$ & plastic additive \\
\hline $\begin{array}{l}\text { 3,4-Dichlorophenyl } \\
\text { isocyanate, bottom sediment }\end{array}$ & 5 & 2 & $100 \mu \mathrm{g} / \mathrm{kg}$ & $100 \mu \mathrm{g} / \mathrm{kg}$ & $102-36-3$ & plastic additive \\
\hline $\begin{array}{l}\text { 3-Methyl-1H-indole (skatol), } \\
\text { dissolved }\end{array}$ & 4 & 1,5 & 1 & .02 & $83-34-1$ & $\begin{array}{l}\text { bacterial metabolite, fecal } \\
\text { fragrance, dye/perfume } \\
\text { manufacturing }\end{array}$ \\
\hline $\begin{array}{l}\text { 3-Methyl-1H-indole (skatol), } \\
\text { whole water }\end{array}$ & 3 & 1,4 & 1 & .019 & $83-34-1$ & $\begin{array}{l}\text { bacterial metabolite, fecal } \\
\text { fragrance, dye/perfume } \\
\text { manufacturing }\end{array}$ \\
\hline $\begin{array}{l}\text { 3-Methyl-1H-indole (skatol), } \\
\text { bottom sediment }\end{array}$ & 5 & 1,4 & $50 \mu \mathrm{g} / \mathrm{kg}$ & $30 \mu \mathrm{g} / \mathrm{kg}$ & $83-34-1$ & $\begin{array}{l}\text { bacterial metabolite, fecal } \\
\text { fragrance, dye/perfume } \\
\text { manufacturing }\end{array}$ \\
\hline $\begin{array}{l}\text { 3-tert-Butyl-4-hydroxy anisole } \\
\text { (BHA), dissolved }\end{array}$ & 4 & 2 & 5 & 5 & $121-00-6$ & antioxidant \\
\hline $\begin{array}{l}\text { 3-tert-Butyl-4-hydroxy anisole } \\
\text { (BHA), whole water }\end{array}$ & 3 & 3 & 5 & ND & $121-00-6$ & antioxidant \\
\hline 4-Cumylphenol, dissolved & 4 & 2 & 1 & 1 & $599-64-4$ & detergent metabolite \\
\hline 4-Cumylphenol, whole water & 3 & 2 & 1 & 1 & $599-64-4$ & detergent metabolite \\
\hline $\begin{array}{l}\text { 4-Cumylphenol, bottom } \\
\text { sediment }\end{array}$ & 5 & 2 & $50 \mu \mathrm{g} / \mathrm{kg}$ & $50 \mu \mathrm{g} / \mathrm{kg}$ & 599-64-4 & detergent metabolite \\
\hline $\begin{array}{l}\text { 4-normal-Octylphenol, } \\
\text { dissolved }\end{array}$ & 4 & 2 & 1 & 1 & $1806-26-4$ & detergent metabolite \\
\hline $\begin{array}{l}\text { 4-normal-Octylphenol, whole } \\
\text { water }\end{array}$ & 3 & 2 & 1 & 1 & $1806-26-4$ & detergent metabolite \\
\hline $\begin{array}{l}\text { 4-normal-Octylphenol, bottom } \\
\text { sediment }\end{array}$ & 5 & 2 & $50 \mu \mathrm{g} / \mathrm{kg}$ & $50 \mu \mathrm{g} / \mathrm{kg}$ & $1806-26-4$ & detergent metabolite \\
\hline 4-tert-Octylphenol, dissolved & 4 & 2 & 1 & 1 & $140-66-9$ & detergent metabolite \\
\hline 4-tert-Octylphenol, whole water & 3 & 2 & 1 & .26 & $140-66-9$ & detergent metabolite \\
\hline
\end{tabular}


Table 7. Field-measured properties and constituents and analytical constituents.-Continued

[Bold text indicates suspected endocrine-disrupting compound (EDC). Units are micrograms per liter unless otherwise noted. Analytical method number: 1, Cahill and others (2004); 2, U.S. Geological Survey Organic Geochemistry Research Laboratory; 3, Lee and others (2004); 4, Zaugg and others (2002); 5, Burkhardt and others (2005). CAS RN, Chemical Abstracts Service Registry Number; $\mathrm{ft}$, feet; $\mathrm{ft}^{3} / \mathrm{s}$, cubic feet per second; $\mathrm{mm} \mathrm{Hg}$, millimeter of mercury; $\mathrm{mg} / \mathrm{L}$, milligrams per liter; $\mu \mathrm{S} / \mathrm{cm}$, microsiemens per centimeter at 25 degrees Celsius; ${ }^{\circ} \mathrm{C}$, degree Celsius; $\mu \mathrm{g} / \mathrm{kg}$, micrograms per kilogram; NTU, nephelometric turbidity unit; NA, not applicable; ND, not determined; --, no data]

\begin{tabular}{|c|c|c|c|c|c|c|}
\hline Constituent or property & $\begin{array}{l}\text { Analytical } \\
\text { method } \\
\text { number }\end{array}$ & Footnote & $\begin{array}{l}\text { Laboratory or } \\
\text { method } \\
\text { reporting level }\end{array}$ & $\begin{array}{l}\text { Study reporting } \\
\text { level for data } \\
\text { summary and } \\
\text { analysis }\end{array}$ & CAS RN & Typical use \\
\hline \multicolumn{7}{|c|}{ Household, industrial, and minor agricultural use compounds (HIACs)—Continued } \\
\hline $\begin{array}{l}\text { 4-tert-Octylphenol, bottom } \\
\text { sediment }\end{array}$ & 5 & 2 & $50 \mu \mathrm{g} / \mathrm{kg}$ & $50 \mu \mathrm{g} / \mathrm{kg}$ & $140-66-9$ & detergent metabolite \\
\hline $\begin{array}{l}\text { 5-Methyl-1H-benzotriazole, } \\
\text { dissolved }\end{array}$ & 4 & 3 & 2 & ND & $136-85-6$ & anticorrosive \\
\hline $\begin{array}{l}\text { 5-Methyl-1H-benzotriazole, } \\
\text { whole water }\end{array}$ & 3 & $1,4,5$ & 2 & .33 & $136-85-6$ & anticorrosive \\
\hline $\begin{array}{l}\text { 7-Acetyl-1,1,3,4,4,6- } \\
\text { hexamethyl } \\
\text { tetrahydronaphthalene } \\
\text { (AHTN), dissolved }\end{array}$ & 4 & 1,5 & .5 & .23 & $21145-77-7$ & fragrance \\
\hline $\begin{array}{l}\text { 7-Acetyl-1,1,3,4,4,6- } \\
\text { hexamethyl } \\
\text { tetrahydronaphthalene } \\
\text { (AHTN), whole water }\end{array}$ & 3 & 1,4 & .5 & .048 & $21145-77-7$ & fragrance \\
\hline $\begin{array}{l}\text { 7-Acetyl-1,1,3,4,4,6- } \\
\text { hexamethyl } \\
\text { tetrahydronaphthalene } \\
\text { (AHTN), bottom sediment }\end{array}$ & 5 & 2 & $50 \mu \mathrm{g} / \mathrm{kg}$ & $50 \mu \mathrm{g} / \mathrm{kg}$ & $21145-77-7$ & fragrance \\
\hline Acetophenone, dissolved & 4 & 2 & .5 & .5 & $98-86-2$ & fragrance \\
\hline Acetophenone, whole water & 3 & 1,4 & .5 & .08 & $98-86-2$ & fragrance \\
\hline Acetophenone, bottom sediment & 5 & 2 & $50 \mu \mathrm{g} / \mathrm{kg}$ & $50 \mu \mathrm{g} / \mathrm{kg}$ & $98-86-2$ & fragrance \\
\hline Anthraquinone, dissolved & 4 & 1,5 & .5 & .12 & $84-65-1$ & dye manufacturing, pesticide \\
\hline Anthraquinone, whole water & 3 & 1,4 & .5 & .098 & $84-65-1$ & dye manufacturing, pesticide \\
\hline $\begin{array}{l}\text { Anthraquinone, bottom } \\
\text { sediment }\end{array}$ & 5 & 1,4 & $50 \mu \mathrm{g} / \mathrm{kg}$ & $4 \mu \mathrm{g} / \mathrm{kg}$ & $84-65-1$ & dye manufacturing, pesticide \\
\hline Benzophenone, dissolved & 4 & 1,5 & .5 & .066 & $119-61-9$ & photoinitiator, fixative \\
\hline Benzophenone, whole water & 3 & 3 & .5 & ND & $119-61-9$ & photoinitiator, fixative \\
\hline $\begin{array}{l}\text { Benzophenone, bottom } \\
\text { sediment }\end{array}$ & 5 & 2 & $50 \mu \mathrm{g} / \mathrm{kg}$ & $50 \mu \mathrm{g} / \mathrm{kg}$ & $119-61-9$ & photoinitiator, fixative \\
\hline $\begin{array}{l}\text { Bis(2-ethylhexyl) phthalate, } \\
\text { whole water }\end{array}$ & 3 & 3 & 2 & ND & $117-81-7$ & plasticizer \\
\hline $\begin{array}{l}\text { Bis(2-ethylhexyl) phthalate, } \\
\text { bottom sediment }\end{array}$ & 5 & 1,4 & $100 \mu \mathrm{g} / \mathrm{kg}$ & $100 \mu \mathrm{g} / \mathrm{kg}$ & $117-81-7$ & plasticizer \\
\hline Bisphenol-A, dissolved & 4 & 3 & 1 & ND & $80-05-7$ & plasticizer \\
\hline Bisphenol-A, whole water & 3 & 3 & 1 & ND & $80-05-7$ & plasticizer \\
\hline Bisphenol-A, bottom sediment & 5 & 1,4 & $100 \mu \mathrm{g} / \mathrm{kg}$ & $100 \mu \mathrm{g} / \mathrm{kg}$ & $80-05-7$ & plasticizer \\
\hline Bromacil, dissolved & 4 & 3 & .5 & ND & $314-40-9$ & herbicide \\
\hline Bromacil, whole water & 3 & $1,4,5$ & .5 & .068 & $314-40-9$ & herbicide \\
\hline Bromacil, bottom sediment & 5 & 2 & $100 \mu \mathrm{g} / \mathrm{kg}$ & $100 \mu \mathrm{g} / \mathrm{kg}$ & $314-40-9$ & herbicide \\
\hline Camphor, dissolved & 4 & 1,5 & .5 & .029 & $76-22-2$ & fumigant and flavorant \\
\hline Camphor, whole water & 3 & 2 & .5 & .5 & $76-22-2$ & fumigant and flavorant \\
\hline Camphor, bottom sediment & 5 & 2 & $50 \mu \mathrm{g} / \mathrm{kg}$ & $50 \mu \mathrm{g} / \mathrm{kg}$ & $76-22-2$ & fumigant and flavorant \\
\hline
\end{tabular}


Table 7. Field-measured properties and constituents and analytical constituents.—Continued

[Bold text indicates suspected endocrine-disrupting compound (EDC). Units are micrograms per liter unless otherwise noted. Analytical method number: 1, Cahill and others (2004); 2, U.S. Geological Survey Organic Geochemistry Research Laboratory; 3, Lee and others (2004); 4, Zaugg and others (2002); 5, Burkhardt and others (2005). CAS RN, Chemical Abstracts Service Registry Number; $\mathrm{ft}$, feet; $\mathrm{ft}^{3} / \mathrm{s}$, cubic feet per second; $\mathrm{mm} \mathrm{Hg}$, millimeter of mercury; mg/L, milligrams per liter; $\mu \mathrm{S} / \mathrm{cm}$, microsiemens per centimeter at 25 degrees Celsius; ${ }^{\circ} \mathrm{C}$, degree Celsius; $\mu \mathrm{g} / \mathrm{kg}$, micrograms per kilogram; NTU, nephelometric turbidity unit; NA, not applicable; ND, not determined; --, no data]

\begin{tabular}{|c|c|c|c|c|c|c|}
\hline Constituent or property & $\begin{array}{l}\text { Analytical } \\
\text { method } \\
\text { number }\end{array}$ & Footnote & $\begin{array}{l}\text { Laboratory or } \\
\text { method } \\
\text { reporting level }\end{array}$ & $\begin{array}{l}\text { Study reporting } \\
\text { level for data } \\
\text { summary and } \\
\text { analysis }\end{array}$ & CAS RN & Typical use \\
\hline
\end{tabular}

Household, industrial, and minor agricultural use compounds (HIACs)—Continued

\begin{tabular}{|c|c|c|c|c|c|c|}
\hline Carbaryl, dissolved & 4 & 1,5 & 1 & 0.14 & $63-25-2$ & insecticide \\
\hline Carbaryl, whole water & 3 & 3 & 1 & ND & $63-25-2$ & insecticide \\
\hline Chlorpyrifos, dissolved & 4 & 2 & .5 & .5 & $2921-88-2$ & insecticide \\
\hline Chlorpyrifos, whole water & 3 & $1,4,5$ & .5 & .014 & $2921-88-2$ & insecticide \\
\hline Chlorpyrifos, bottom sediment & 5 & 2 & $50 \mu \mathrm{g} / \mathrm{kg}$ & $50 \mu \mathrm{g} / \mathrm{kg}$ & $2921-88-2$ & insecticide \\
\hline $\begin{array}{l}\text { N,N-Diethyl-meta-toluamide } \\
\text { (DEET), dissolved }\end{array}$ & 4 & 1,5 & .5 & .034 & $134-62-3$ & insect repellent \\
\hline $\begin{array}{l}\text { N,N-Diethyl-meta-toluamide } \\
\text { (DEET), whole water }\end{array}$ & 3 & 1,4 & .5 & .042 & $134-62-3$ & insect repellent \\
\hline $\begin{array}{l}\text { N,N-Diethyl-meta-toluamide } \\
\text { (DEET), bottom sediment }\end{array}$ & 5 & 2 & $100 \mu \mathrm{g} / \mathrm{kg}$ & $100 \mu \mathrm{g} / \mathrm{kg}$ & $134-62-3$ & insect repellent \\
\hline Diazinon, dissolved & 4 & 2 & .5 & .5 & $333-41-5$ & insecticide \\
\hline Diazinon, whole water & 3 & $1,4,5$ & .5 & .027 & $333-41-5$ & insecticide \\
\hline Diazinon, bottom sediment & 5 & 2 & $50 \mu \mathrm{g} / \mathrm{kg}$ & $50 \mu \mathrm{g} / \mathrm{kg}$ & $333-41-5$ & insecticide \\
\hline Dichlorvos, dissolved & 4 & 3 & 1 & ND & $62-73-7$ & insecticide \\
\hline Dichlorvos, whole water & 3 & 3 & 1 & ND & $62-73-7$ & insecticide \\
\hline Diethyl phthalate, whole water & 3 & 3 & .5 & ND & $84-66-2$ & plasticizer \\
\hline $\begin{array}{l}\text { Diethyl phthalate, bottom } \\
\text { sediment }\end{array}$ & 5 & 2 & $50 \mu \mathrm{g} / \mathrm{kg}$ & $50 \mu \mathrm{g} / \mathrm{kg}$ & $84-66-2$ & plasticizer \\
\hline D-Limonene, dissolved & 4 & 3 & .5 & ND & $5989-27-5$ & solvent, fragrance \\
\hline D-Limonene, whole water & 3 & 3 & .5 & ND & $5989-27-5$ & solvent, fragrance \\
\hline D-Limonene, bottom sediment & 5 & 2 & $50 \mu \mathrm{g} / \mathrm{kg}$ & $50 \mu \mathrm{g} / \mathrm{kg}$ & $5989-27-5$ & solvent, fragrance \\
\hline $\begin{array}{l}\text { 1,3,4,6,7,8-Hexahydro- } \\
\text { 4,6,6,7,8,8-hexamethyl } \\
\text { cyclopenta-g-2-benzopyran } \\
\text { (HHCB), dissolved }\end{array}$ & 4 & 1,5 & .5 & .061 & $1222-05-5$ & fragrance \\
\hline $\begin{array}{l}\text { 1,3,4,6,7,8-Hexahydro- } \\
\text { 4,6,6,7,8,8-hexamethyl } \\
\text { cyclopenta-g-2-benzopyran } \\
\text { (HHCB), whole water }\end{array}$ & 3 & 1,4 & .5 & .045 & $1222-05-5$ & fragrance \\
\hline $\begin{array}{l}\text { 1,3,4,6,7,8-Hexahydro- } \\
\text { 4,6,6,7,8,8-hexamethyl } \\
\text { cyclopenta-g-2-benzopyran } \\
\text { (HHCB), bottom sediment }\end{array}$ & 5 & 2 & $50 \mu \mathrm{g} / \mathrm{kg}$ & $50 \mu \mathrm{g} / \mathrm{kg}$ & $1222-05-5$ & fragrance \\
\hline Indole, dissolved & 4 & 1,5 & .5 & .042 & $120-72-9$ & $\begin{array}{l}\text { amino-acid metabolite, fragrance, } \\
\text { pesticide inert ingredient }\end{array}$ \\
\hline Indole, whole water & 3 & 1,4 & .5 & .015 & $120-72-9$ & $\begin{array}{l}\text { amino-acid metabolite, fragrance, } \\
\text { pesticide inert ingredient }\end{array}$ \\
\hline Indole, bottom sediment & 5 & 1,4 & $50 \mu \mathrm{g} / \mathrm{kg}$ & $1.9 \mu \mathrm{g} / \mathrm{kg}$ & $120-72-9$ & $\begin{array}{l}\text { amino-acid metabolite, fragrance, } \\
\text { pesticide inert ingredient }\end{array}$ \\
\hline Isoborneol, dissolved & 4 & 2 & .5 & .5 & $124-76-5$ & fragrance, flavorant \\
\hline Isoborneol, whole water & 3 & 2 & .5 & .5 & $124-76-5$ & fragrance, flavorant \\
\hline Isoborneol, bottom sediment & 5 & 2 & $50 \mu \mathrm{g} / \mathrm{kg}$ & $50 \mu \mathrm{g} / \mathrm{kg}$ & $124-76-5$ & fragrance, flavorant \\
\hline
\end{tabular}


Table 7. Field-measured properties and constituents and analytical constituents.-Continued

[Bold text indicates suspected endocrine-disrupting compound (EDC). Units are micrograms per liter unless otherwise noted. Analytical method number: 1, Cahill and others (2004); 2, U.S. Geological Survey Organic Geochemistry Research Laboratory; 3, Lee and others (2004); 4, Zaugg and others (2002); 5, Burkhardt and others (2005). CAS RN, Chemical Abstracts Service Registry Number; $\mathrm{ft}$, feet; $\mathrm{ft}^{3} / \mathrm{s}$, cubic feet per second; $\mathrm{mm} \mathrm{Hg}$, millimeter of mercury; $\mathrm{mg} / \mathrm{L}$, milligrams per liter; $\mu \mathrm{S} / \mathrm{cm}$, microsiemens per centimeter at 25 degrees Celsius; ${ }^{\circ} \mathrm{C}$, degree Celsius; $\mu \mathrm{g} / \mathrm{kg}$, micrograms per kilogram; NTU, nephelometric turbidity unit; NA, not applicable; ND, not determined; --, no data]

\begin{tabular}{|c|c|c|c|c|c|c|}
\hline Constituent or property & $\begin{array}{c}\text { Analytical } \\
\text { method } \\
\text { number }\end{array}$ & Footnote & $\begin{array}{l}\text { Laboratory or } \\
\text { method } \\
\text { reporting level }\end{array}$ & $\begin{array}{l}\text { Study reporting } \\
\text { level for data } \\
\text { summary and } \\
\text { analysis }\end{array}$ & CAS RN & Typical use \\
\hline \multicolumn{7}{|c|}{ Household, industrial, and minor agricultural use compounds (HIACs)—Continued } \\
\hline Isophorone, dissolved & 4 & 1,5 & 0.5 & 0.047 & $78-59-1$ & solvent \\
\hline Isophorone, whole water & 3 & 3 & .5 & ND & $78-59-1$ & solvent \\
\hline Isophorone, bottom sediment & 5 & 2 & $50 \mu \mathrm{g} / \mathrm{kg}$ & $50 \mu \mathrm{g} / \mathrm{kg}$ & $78-59-1$ & solvent \\
\hline $\begin{array}{l}\text { Isopropylbenzene (cumene), } \\
\text { dissolved }\end{array}$ & 4 & 3 & .5 & ND & $98-82-8$ & solvent \\
\hline $\begin{array}{l}\text { Isopropylbenzene (cumene), } \\
\text { whole water }\end{array}$ & 3 & 3 & .5 & ND & $98-82-8$ & solvent \\
\hline $\begin{array}{l}\text { Isopropylbenzene (cumene), } \\
\text { bottom sediment }\end{array}$ & 5 & 2 & $50 \mu \mathrm{g} / \mathrm{kg}$ & $50 \mu \mathrm{g} / \mathrm{kg}$ & $98-82-8$ & solvent \\
\hline Isoquinoline, dissolved & 4 & 2 & .5 & .5 & $119-65-3$ & $\begin{array}{l}\text { chemical and pharmaceutical } \\
\text { manufacturing }\end{array}$ \\
\hline Isoquinoline, whole water & 3 & 3 & .5 & ND & $119-65-3$ & $\begin{array}{l}\text { chemical and pharmaceutical } \\
\text { manufacturing }\end{array}$ \\
\hline Isoquinoline, bottom sediment & 5 & 2 & $50 \mu \mathrm{g} / \mathrm{kg}$ & $50 \mu \mathrm{g} / \mathrm{kg}$ & $119-65-3$ & $\begin{array}{l}\text { chemical and pharmaceutical } \\
\text { manufacturing }\end{array}$ \\
\hline Menthol, dissolved & 4 & 2 & .5 & .5 & $89-78-1$ & $\begin{array}{l}\text { pharmaceutical additive, } \\
\text { fragrance, flavorant }\end{array}$ \\
\hline Menthol, whole water & 3 & 3 & .5 & ND & $89-78-1$ & $\begin{array}{l}\text { pharmaceutical additive, } \\
\text { fragrance, flavorant }\end{array}$ \\
\hline Menthol, bottom sediment & 5 & 2 & $50 \mu \mathrm{g} / \mathrm{kg}$ & $50 \mu \mathrm{g} / \mathrm{kg}$ & $89-78-1$ & $\begin{array}{l}\text { pharmaceutical additive, } \\
\text { fragrance, flavorant }\end{array}$ \\
\hline Metalaxyl, dissolved & 4 & 2 & .5 & .5 & 57837-19-1 & agricultural fungicide \\
\hline Metalaxyl, whole water & 3 & 2 & .5 & .5 & 57837-19-1 & agricultural fungicide \\
\hline Metalaxyl, bottom sediment & 5 & 2 & $100 \mu \mathrm{g} / \mathrm{kg}$ & $100 \mu \mathrm{g} / \mathrm{kg}$ & 57837-19-1 & agricultural fungicide \\
\hline Methyl salicylate, dissolved & 4 & 2 & .5 & .5 & $119-36-8$ & flavoring agent, liniment \\
\hline Methyl salicylate, whole water & 3 & 2 & .5 & .017 & $119-36-8$ & flavoring agent, liniment \\
\hline $\begin{array}{l}\text { Methyl salicylate, bottom } \\
\text { sediment }\end{array}$ & 5 & 2 & $100 \mu \mathrm{g} / \mathrm{kg}$ & $100 \mu \mathrm{g} / \mathrm{kg}$ & $119-36-8$ & flavoring agent, liniment \\
\hline $\begin{array}{l}\text { Nonylphenol diethoxylate } \\
\text { (NP2EO), dissolved }\end{array}$ & 4 & 1 & 5 & 3.5 & $26027-38-2$ & detergent metabolite \\
\hline $\begin{array}{l}\text { Nonylphenol diethoxylate } \\
\text { (NP2EO), whole water }\end{array}$ & 3 & $1,4,5$ & 5 & .66 & $26027-38-2$ & detergent metabolite \\
\hline $\begin{array}{l}\text { Nonylphenol diethoxylate } \\
\text { (NP2EO), bottom sediment }\end{array}$ & 5 & 1,4 & $500 \mu \mathrm{g} / \mathrm{kg}$ & $65 \mu \mathrm{g} / \mathrm{kg}$ & $26027-38-2$ & detergent metabolite \\
\hline $\begin{array}{l}\text { Nonylphenol monoethoxylate } \\
\text { (NP1EO), whole water }\end{array}$ & 3 & 1,4 & 2 & .55 & $27986-36-3$ & detergent metabolite \\
\hline $\begin{array}{l}\text { Nonylphenol monoethoxylate } \\
\text { (NP1EO), bottom sediment }\end{array}$ & 5 & 2 & $500 \mu \mathrm{g} / \mathrm{kg}$ & $500 \mu \mathrm{g} / \mathrm{kg}$ & $27986-36-3$ & detergent metabolite \\
\hline $\begin{array}{l}\text { Octylphenol diethoxylate } \\
\text { (OP2EO), dissolved }\end{array}$ & 4 & 1,5 & 1 & .19 & $26636-32-8$ & detergent metabolite \\
\hline $\begin{array}{l}\text { Octylphenol diethoxylate } \\
\text { (OP2EO), whole water }\end{array}$ & 3 & 2 & 1 & .14 & $26636-32-8$ & detergent metabolite \\
\hline $\begin{array}{l}\text { Octylphenol diethoxylate } \\
\text { (OP2EO), bottom sediment }\end{array}$ & 5 & 2 & $100 \mu \mathrm{g} / \mathrm{kg}$ & $100 \mu \mathrm{g} / \mathrm{kg}$ & $26636-32-8$ & detergent metabolite \\
\hline
\end{tabular}


Table 7. Field-measured properties and constituents and analytical constituents.—Continued

[Bold text indicates suspected endocrine-disrupting compound (EDC). Units are micrograms per liter unless otherwise noted. Analytical method number: 1, Cahill and others (2004); 2, U.S. Geological Survey Organic Geochemistry Research Laboratory; 3, Lee and others (2004); 4, Zaugg and others (2002); 5, Burkhardt and others (2005). CAS RN, Chemical Abstracts Service Registry Number; $\mathrm{ft}$, feet; $\mathrm{ft}^{3} / \mathrm{s}$, cubic feet per second; $\mathrm{mm} \mathrm{Hg}$, millimeter of mercury; $\mathrm{mg} / \mathrm{L}$, milligrams per liter; $\mu \mathrm{S} / \mathrm{cm}$, microsiemens per centimeter at 25 degrees Celsius; ${ }^{\circ} \mathrm{C}$, degree Celsius; $\mu \mathrm{g} / \mathrm{kg}$, micrograms per kilogram; NTU, nephelometric turbidity unit; NA, not applicable; ND, not determined; --, no data]

\begin{tabular}{|c|c|c|c|c|c|c|}
\hline Constituent or property & $\begin{array}{l}\text { Analytical } \\
\text { method } \\
\text { number }\end{array}$ & Footnote & $\begin{array}{l}\text { Laboratory or } \\
\text { method } \\
\text { reporting level }\end{array}$ & $\begin{array}{l}\text { Study reporting } \\
\text { level for data } \\
\text { summary and } \\
\text { analysis }\end{array}$ & CAS RN & Typical use \\
\hline \multicolumn{7}{|c|}{ Household, industrial, and minor agricultural use compounds (HIACs)—Continued } \\
\hline $\begin{array}{l}\text { Octylphenol monoethoxylate } \\
\text { (OP1EO), dissolved }\end{array}$ & 3 & 1,5 & 1 & 0.39 & $26636-32-8$ & detergent metabolite \\
\hline $\begin{array}{l}\text { Octylphenol monoethoxylate } \\
\text { (OP1EO), whole water }\end{array}$ & 3 & 2 & 1 & 5.2 & $26636-32-8$ & detergent metabolite \\
\hline $\begin{array}{l}\text { Octylphenol monoethoxylate } \\
\text { (OP1EO), bottom sediment }\end{array}$ & 5 & 2 & $100 \mu \mathrm{g} / \mathrm{kg}$ & $100 \mu \mathrm{g} / \mathrm{kg}$ & $26636-32-8$ & detergent metabolite \\
\hline para-Cresol, dissolved & 4 & 1,5 & 1 & .079 & $106-44-5$ & $\begin{array}{l}\text { antioxidant, manufacturing, fuel } \\
\text { combustion byproduct }\end{array}$ \\
\hline para-Cresol, whole water & 3 & 2 & 1 & 1 & $106-44-5$ & $\begin{array}{l}\text { antioxidant, manufacturing, fuel } \\
\text { combustion byproduct }\end{array}$ \\
\hline para-Cresol, bottom sediment & 5 & 1,4 & $100 \mu \mathrm{g} / \mathrm{kg}$ & $21 \mu \mathrm{g} / \mathrm{kg}$ & $106-44-5$ & $\begin{array}{l}\text { antioxidant, manufacturing, fuel } \\
\text { combustion byproduct }\end{array}$ \\
\hline $\begin{array}{l}\text { para-Nonylphenol (NP), } \\
\text { dissolved }\end{array}$ & 4 & 1,5 & 5 & .83 & $84852-15-3$ & detergent metabolite \\
\hline $\begin{array}{l}\text { para-Nonylphenol (NP), whole } \\
\text { water }\end{array}$ & 3 & 1 & 5 & .64 & $84852-15-3$ & detergent metabolite \\
\hline $\begin{array}{l}\text { para-Nonylphenol (NP), } \\
\text { bottom sediment }\end{array}$ & 5 & 2 & $500 \mu \mathrm{g} / \mathrm{kg}$ & $500 \mu \mathrm{g} / \mathrm{kg}$ & $84852-15-3$ & detergent metabolite \\
\hline Pentachlorophenol, dissolved & 4 & 1,5 & 2 & .42 & $87-86-5$ & pesticide, wood preservative \\
\hline $\begin{array}{l}\text { Pentachlorophenol, whole } \\
\text { water }\end{array}$ & 3 & 3 & 2 & ND & $87-86-5$ & pesticide, wood preservative \\
\hline $\begin{array}{l}\text { Pentachlorophenol, bottom } \\
\text { sediment }\end{array}$ & 5 & 2 & $200 \mu \mathrm{g} / \mathrm{kg}$ & $200 \mu \mathrm{g} / \mathrm{kg}$ & $87-86-5$ & pesticide, wood preservative \\
\hline Phenol, dissolved & 4 & 1,5 & .5 & .34 & $108-95-2$ & $\begin{array}{l}\text { resin and pharmaceutical } \\
\text { manufacturing, disinfectant }\end{array}$ \\
\hline Phenol, whole water & 3 & 1,4 & .5 & .94 & $108-95-2$ & $\begin{array}{l}\text { resin and pharmaceutical } \\
\text { manufacturing, disinfectant }\end{array}$ \\
\hline Phenol, bottom sediment & 5 & 1,4 & $50 \mu \mathrm{g} / \mathrm{kg}$ & $19 \mu \mathrm{g} / \mathrm{kg}$ & $108-95-2$ & $\begin{array}{l}\text { resin and pharmaceutical } \\
\text { manufacturing, disinfectant }\end{array}$ \\
\hline Tetrachloroethylene, dissolved & 4 & 3 & .5 & ND & $127-18-4$ & solvent, degreaser \\
\hline $\begin{array}{l}\text { Tetrachloroethylene, whole } \\
\text { water }\end{array}$ & 3 & 3 & .5 & ND & $127-18-4$ & solvent, degreaser \\
\hline $\begin{array}{l}\text { Tetrachloroethylene, bottom } \\
\text { sediment }\end{array}$ & 5 & 2 & $50 \mu \mathrm{g} / \mathrm{kg}$ & $50 \mu \mathrm{g} / \mathrm{kg}$ & $127-18-4$ & solvent, degreaser \\
\hline Tributyl phosphate, dissolved & 4 & 1,5 & .5 & .18 & $126-73-8$ & plasticizer \\
\hline Tributyl phosphate, whole water & 3 & 1,4 & .5 & .059 & $126-73-8$ & plasticizer \\
\hline $\begin{array}{l}\text { Tributyl phosphate, bottom } \\
\text { sediment }\end{array}$ & 5 & 2 & $50 \mu \mathrm{g} / \mathrm{kg}$ & $50 \mu \mathrm{g} / \mathrm{kg}$ & $126-73-8$ & plasticizer \\
\hline Triclosan, dissolved & 4 & 1,5 & 1 & .16 & $3380-34-5$ & antimicrobial disinfectant \\
\hline Triclosan, whole water & 3 & 1,4 & 1 & .15 & $3380-34-5$ & antimicrobial disinfectant \\
\hline Triclosan, bottom sediment & 5 & 1,4 & $50 \mu \mathrm{g} / \mathrm{kg}$ & $2.9 \mu \mathrm{g} / \mathrm{kg}$ & $3380-34-5$ & antimicrobial disinfectant \\
\hline
\end{tabular}


Table 7. Field-measured properties and constituents and analytical constituents.-Continued

[Bold text indicates suspected endocrine-disrupting compound (EDC). Units are micrograms per liter unless otherwise noted. Analytical method number: 1, Cahill and others (2004); 2, U.S. Geological Survey Organic Geochemistry Research Laboratory; 3, Lee and others (2004); 4, Zaugg and others (2002); 5, Burkhardt and others (2005). CAS RN, Chemical Abstracts Service Registry Number; $\mathrm{ft}, \mathrm{feet} ; \mathrm{ft}^{3} / \mathrm{s}$, cubic feet per second; $\mathrm{mm} \mathrm{Hg}$, millimeter of mercury; $\mathrm{mg} / \mathrm{L}$, milligrams per liter; $\mu \mathrm{S} / \mathrm{cm}$, microsiemens per centimeter at 25 degrees Celsius; ${ }^{\circ} \mathrm{C}$, degree Celsius; $\mu \mathrm{g} / \mathrm{kg}$, micrograms per kilogram; NTU, nephelometric turbidity unit; NA, not applicable; ND, not determined; --, no data]

\begin{tabular}{|c|c|c|c|c|c|c|}
\hline Constituent or property & $\begin{array}{l}\text { Analytical } \\
\text { method } \\
\text { number }\end{array}$ & Footnote & $\begin{array}{l}\text { Laboratory or } \\
\text { method } \\
\text { reporting level }\end{array}$ & $\begin{array}{l}\text { Study reporting } \\
\text { level for data } \\
\text { summary and } \\
\text { analysis }\end{array}$ & CAS RN & Typical use \\
\hline \multicolumn{7}{|c|}{ Household, industrial, and minor agricultural use compounds (HIACs)—Continued } \\
\hline $\begin{array}{l}\text { Triethyl citrate (ethyl citrate), } \\
\text { dissolved }\end{array}$ & 4 & 1,5 & 0.5 & 0.21 & $77-93-0$ & plasticizer \\
\hline $\begin{array}{l}\text { Triethyl citrate (ethyl citrate), } \\
\text { whole water }\end{array}$ & 3 & 1,4 & .5 & .051 & $77-93-0$ & plasticizer \\
\hline Triphenyl phosphate, dissolved & 4 & 1,5 & .5 & .066 & $115-86-6$ & plasticizer \\
\hline $\begin{array}{l}\text { Triphenyl phosphate, whole } \\
\text { water }\end{array}$ & 3 & 1,4 & .5 & .033 & $115-86-6$ & plasticizer \\
\hline $\begin{array}{l}\text { Triphenyl phosphate, bottom } \\
\text { sediment }\end{array}$ & 5 & 2 & $100 \mu \mathrm{g} / \mathrm{kg}$ & $100 \mu \mathrm{g} / \mathrm{kg}$ & $115-86-6$ & plasticizer \\
\hline $\begin{array}{l}\text { Tri(2-butoxyethyl)phosphate, } \\
\text { dissolved }\end{array}$ & 4 & 1,5 & .5 & .4 & $78-51-3$ & fire retardant \\
\hline $\begin{array}{l}\text { Tri(2-butoxyethyl)phosphate, } \\
\text { whole water }\end{array}$ & 3 & 1,4 & .5 & .13 & $78-51-3$ & fire retardant \\
\hline $\begin{array}{l}\text { Tri(2-butoxyethyl)phosphate, } \\
\text { bottom sediment }\end{array}$ & 5 & 2 & $100 \mu \mathrm{g} / \mathrm{kg}$ & $100 \mu \mathrm{g} / \mathrm{kg}$ & $78-51-3$ & fire retardant \\
\hline $\begin{array}{l}\text { Tri(2-chloroethyl)phosphate, } \\
\text { dissolved }\end{array}$ & 4 & 1,5 & .5 & .074 & $115-96-8$ & fire retardant \\
\hline $\begin{array}{l}\text { Tri(2-chloroethyl)phosphate, } \\
\text { whole water }\end{array}$ & 3 & 1,4 & .5 & .1 & $115-96-8$ & fire retardant \\
\hline $\begin{array}{l}\text { Tri(2-chloroethyl)phosphate, } \\
\text { bottom sediment }\end{array}$ & 5 & 2 & $100 \mu \mathrm{g} / \mathrm{kg}$ & $100 \mu \mathrm{g} / \mathrm{kg}$ & $115-96-8$ & fire retardant \\
\hline $\begin{array}{l}\text { Tri(dichloroisopropyl) } \\
\text { phosphate, dissolved }\end{array}$ & 4 & 1,5 & .5 & .13 & $13674-87-8$ & fire retardant \\
\hline $\begin{array}{l}\text { Tri(dichloroisopropyl) } \\
\text { phosphate, whole water }\end{array}$ & 3 & 1,4 & .5 & .071 & $13674-87-8$ & fire retardant \\
\hline $\begin{array}{l}\text { Tri(dichloroisopropyl) } \\
\text { phosphate, bottom sediment }\end{array}$ & 5 & 2 & $100 \mu \mathrm{g} / \mathrm{kg}$ & $100 \mu \mathrm{g} / \mathrm{kg}$ & $13674-87-8$ & fire retardant \\
\hline \multicolumn{7}{|c|}{ Polyaromatic hydrocarbons (PAHs) } \\
\hline 1-Methylnaphthalene, dissolved & 4 & 1,5 & 0.5 & 0.04 & $90-12-0$ & PAH \\
\hline $\begin{array}{l}\text { 1-Methylnaphthalene, whole } \\
\text { water }\end{array}$ & 3 & 3 & .5 & ND & $90-12-0$ & PAH \\
\hline $\begin{array}{l}\text { 1-Methylnaphthalene, bottom } \\
\text { sediment }\end{array}$ & 5 & 2 & $50 \mu \mathrm{g} / \mathrm{kg}$ & $50 \mu \mathrm{g} / \mathrm{kg}$ & $90-12-0$ & PAH \\
\hline $\begin{array}{l}\text { 2,6-Dimethylnaphthalene, } \\
\text { dissolved }\end{array}$ & 4 & 1,5 & .5 & .053 & $581-42-0$ & PAH \\
\hline $\begin{array}{l}\text { 2,6-Dimethylnaphthalene, whole } \\
\text { water }\end{array}$ & 3 & 3 & .5 & ND & $581-42-0$ & PAH \\
\hline $\begin{array}{l}\text { 2,6-Dimethylnaphthalene, } \\
\text { bottom sediment }\end{array}$ & 5 & 1,4 & $50 \mu \mathrm{g} / \mathrm{kg}$ & $20 \mu \mathrm{g} / \mathrm{kg}$ & $581-42-0$ & PAH \\
\hline 2-Methylnaphthalene, dissolved & 4 & 1,5 & .5 & .06 & $91-57-6$ & PAH \\
\hline
\end{tabular}


Table 7. Field-measured properties and constituents and analytical constituents.—Continued

[Bold text indicates suspected endocrine-disrupting compound (EDC). Units are micrograms per liter unless otherwise noted. Analytical method number: 1, Cahill and others (2004); 2, U.S. Geological Survey Organic Geochemistry Research Laboratory; 3, Lee and others (2004); 4, Zaugg and others (2002); 5, Burkhardt and others (2005). CAS RN, Chemical Abstracts Service Registry Number; $\mathrm{ft}$, feet; $\mathrm{ft}^{3} / \mathrm{s}$, cubic feet per second; mm Hg, millimeter of mercury; mg/L, milligrams per liter; $\mu \mathrm{S} / \mathrm{cm}$, microsiemens per centimeter at 25 degrees Celsius; ${ }^{\circ} \mathrm{C}$, degree Celsius; $\mu \mathrm{g} / \mathrm{kg}$, micrograms per kilogram; NTU, nephelometric turbidity unit; NA, not applicable; ND, not determined; --, no data]

\begin{tabular}{|c|c|c|c|c|c|c|}
\hline Constituent or property & $\begin{array}{c}\text { Analytical } \\
\text { method } \\
\text { number }\end{array}$ & Footnote & $\begin{array}{l}\text { Laboratory or } \\
\text { method } \\
\text { reporting level }\end{array}$ & $\begin{array}{l}\text { Study reporting } \\
\text { level for data } \\
\text { summary and } \\
\text { analysis }\end{array}$ & CAS RN & Typical use \\
\hline \multicolumn{7}{|c|}{ Polyaromatic hydrocarbons (PAHs) —Continued } \\
\hline $\begin{array}{l}\text { 2-Methylnaphthalene, whole } \\
\text { water }\end{array}$ & 3 & 3 & 0.5 & ND & $91-57-6$ & PAH \\
\hline $\begin{array}{l}\text { 2-Methylnaphthalene, bottom } \\
\text { sediment }\end{array}$ & 5 & 2 & $50 \mu \mathrm{g} / \mathrm{kg}$ & $50 \mu \mathrm{g} / \mathrm{kg}$ & $91-57-6$ & PAH \\
\hline Anthracene, dissolved & 4 & 1 & .5 & .082 & $120-12-7$ & PAH \\
\hline Anthracene, whole water & 3 & $1,4,5$ & .5 & .06 & $120-12-7$ & PAH \\
\hline Anthracene, bottom sediment & 5 & 1,4 & $50 \mu \mathrm{g} / \mathrm{kg}$ & $10 \mu \mathrm{g} / \mathrm{kg}$ & $120-12-7$ & PAH \\
\hline Benzo $[a]$ pyrene, dissolved & 4 & 2 & .5 & .5 & $50-32-8$ & PAH \\
\hline Benzo $[a]$ pyrene, whole water & 3 & $1,4,5$ & .5 & .03 & $50-32-8$ & PAH \\
\hline $\begin{array}{l}\text { Benzo }[a] \text { pyrene, bottom } \\
\text { sediment }\end{array}$ & 5 & 1,4 & $50 \mu \mathrm{g} / \mathrm{kg}$ & $25 \mu \mathrm{g} / \mathrm{kg}$ & $50-32-8$ & PAH \\
\hline Carbazole, dissolved & 4 & 1,5 & .5 & .036 & $86-74-8$ & chemical manufacturing, $\mathrm{PAH}$ \\
\hline Carbazole, whole water & 3 & 2 & .5 & .22 & $86-74-8$ & chemical manufacturing, $\mathrm{PAH}$ \\
\hline Carbazole, bottom sediment & 5 & 2 & $50 \mu \mathrm{g} / \mathrm{kg}$ & $50 \mu \mathrm{g} / \mathrm{kg}$ & $86-74-8$ & chemical manufacturing, $\mathrm{PAH}$ \\
\hline Fluoranthene, dissolved & 4 & 1 & .5 & .017 & $206-44-0$ & PAH \\
\hline Fluoranthene, whole water & 3 & $1,4,5$ & .5 & .15 & $206-44-0$ & PAH \\
\hline Fluoranthene, bottom sediment & 5 & 1,4 & $50 \mu \mathrm{g} / \mathrm{kg}$ & $9.3 \mu \mathrm{g} / \mathrm{kg}$ & $206-44-0$ & PAH \\
\hline Naphthalene, dissolved & 4 & 1,5 & .5 & .049 & $91-20-3$ & PAH \\
\hline Naphthalene, whole water & 3 & 3 & .5 & ND & $91-20-3$ & PAH \\
\hline Naphthalene, bottom sediment & 5 & 1,4 & $50 \mu \mathrm{g} / \mathrm{kg}$ & $8.2 \mu \mathrm{g} / \mathrm{kg}$ & $91-20-3$ & PAH \\
\hline Phenanthrene, dissolved & 4 & 1 & .5 & .02 & $85-01-8$ & PAH \\
\hline Phenanthrene, whole water & 3 & $1,4,5$ & .5 & .019 & $85-01-8$ & PAH \\
\hline $\begin{array}{l}\text { Phenanthrene, bottom } \\
\text { sediment }\end{array}$ & 5 & 1,4 & $50 \mu \mathrm{g} / \mathrm{kg}$ & $7.6 \mu \mathrm{g} / \mathrm{kg}$ & $85-01-8$ & PAH \\
\hline Pyrene, dissolved & 4 & 1 & .5 & .012 & $129-00-0$ & PAH \\
\hline Pyrene, whole water & 3 & $1,4,5$ & .5 & .04 & $129-00-0$ & PAH \\
\hline Pyrene, bottom sediment & 5 & 1,4 & $50 \mu \mathrm{g} / \mathrm{kg}$ & $9.3 \mu \mathrm{g} / \mathrm{kg}$ & $129-00-0$ & PAH \\
\hline \multicolumn{7}{|c|}{ Sterol compounds (SCs) } \\
\hline 3-beta-Coprostanol, dissolved & 4 & 1 & 2 & 0.77 & $360-68-9$ & fecal sterol \\
\hline 3-beta-Coprostanol, whole water & 3 & $1,4,5$ & 2 & .26 & $360-68-9$ & fecal sterol \\
\hline $\begin{array}{l}\text { 3-beta-Coprostanol, bottom } \\
\text { sediment }\end{array}$ & 5 & 1,4 & $250 \mu \mathrm{g} / \mathrm{kg}$ & $190 \mu \mathrm{g} / \mathrm{kg}$ & $360-68-9$ & fecal sterol \\
\hline beta-Sitosterol, dissolved & 4 & 1 & 2 & 1.2 & $83-46-5$ & plant sterol \\
\hline beta-Sitosterol, whole water & 3 & $1,4,5$ & 2 & .57 & $83-46-5$ & plant sterol \\
\hline $\begin{array}{l}\text { beta-Sitosterol, bottom } \\
\text { sediment }\end{array}$ & 5 & 1,4 & $250 \mu \mathrm{g} / \mathrm{kg}$ & $250 \mu \mathrm{g} / \mathrm{kg}$ & $83-46-5$ & plant sterol \\
\hline beta-Stigmastanol, dissolved & 4 & 2 & 2 & 1.8 & $19466-47-8$ & plant sterol \\
\hline beta-Stigmastanol, whole water & 3 & 3 & 2 & ND & $19466-47-8$ & plant sterol \\
\hline $\begin{array}{l}\text { beta-Stigmastanol, bottom } \\
\text { sediment }\end{array}$ & 5 & 1,4 & $500 \mu \mathrm{g} / \mathrm{kg}$ & $500 \mu \mathrm{g} / \mathrm{kg}$ & $19466-47-8$ & plant sterol \\
\hline
\end{tabular}


Table 7. Field-measured properties and constituents and analytical constituents.-Continued

[Bold text indicates suspected endocrine-disrupting compound (EDC). Units are micrograms per liter unless otherwise noted. Analytical method number: 1, Cahill and others (2004); 2, U.S. Geological Survey Organic Geochemistry Research Laboratory; 3, Lee and others (2004); 4, Zaugg and others (2002); 5, Burkhardt and others (2005). CAS RN, Chemical Abstracts Service Registry Number; $\mathrm{ft}, \mathrm{feet} ; \mathrm{ft}^{3} / \mathrm{s}$, cubic feet per second; $\mathrm{mm} \mathrm{Hg}$, millimeter of mercury; $\mathrm{mg} / \mathrm{L}$, milligrams per liter; $\mu \mathrm{S} / \mathrm{cm}$, microsiemens per centimeter at 25 degrees Celsius; ${ }^{\circ} \mathrm{C}$, degree Celsius; $\mu \mathrm{g} / \mathrm{kg}$, micrograms per kilogram; NTU, nephelometric turbidity unit; NA, not applicable; ND, not determined; --, no data]

\begin{tabular}{|c|c|c|c|c|c|c|}
\hline Constituent or property & $\begin{array}{c}\text { Analytical } \\
\text { method } \\
\text { number }\end{array}$ & Footnote & $\begin{array}{l}\text { Laboratory or } \\
\text { method } \\
\text { reporting level }\end{array}$ & $\begin{array}{l}\text { Study reporting } \\
\text { level for data } \\
\text { summary and } \\
\text { analysis }\end{array}$ & CAS RN & Typical use \\
\hline \multicolumn{7}{|c|}{ Sterol compounds (SCs)_-Continued } \\
\hline Cholesterol, dissolved & 4 & 1 & 2 & 0.94 & $57-88-5$ & plant/animal sterol \\
\hline Cholesterol, whole water & 3 & $1,4,5$ & 2 & .64 & $57-88-5$ & plant/animal sterol \\
\hline Cholesterol, bottom sediment & 5 & 1,4 & $500 \mu \mathrm{g} / \mathrm{kg}$ & $500 \mu \mathrm{g} / \mathrm{kg}$ & $57-88-5$ & plant/animal sterol \\
\hline \multicolumn{7}{|c|}{ Laboratory quality-assurance/quality-control surrogate compounds } \\
\hline $\begin{array}{l}\text { Bisphenol-A-d3 (surrogate), } \\
\text { dissolved }\end{array}$ & 4 & NA & $\begin{array}{l}0.1 \text { percent } \\
\text { recovery }\end{array}$ & $\begin{array}{l}0.1 \text { percent } \\
\text { recovery }\end{array}$ & -- & laboratory analytical surrogate \\
\hline $\begin{array}{l}\text { Bisphenol-A-d3 (surrogate), } \\
\text { whole water }\end{array}$ & 3 & NA & $\begin{array}{l}.1 \text { percent } \\
\text { recovery }\end{array}$ & $\begin{array}{l}.1 \text { percent } \\
\text { recovery }\end{array}$ & -- & laboratory analytical surrogate \\
\hline $\begin{array}{l}\text { Bisphenol-A-d3 (surrogate), } \\
\text { whole water (b) }\end{array}$ & 3 & NA & $\begin{array}{l}.1 \text { percent } \\
\text { recovery }\end{array}$ & $\begin{array}{l}.1 \text { percent } \\
\text { recovery }\end{array}$ & -- & laboratory analytical surrogate \\
\hline $\begin{array}{l}\text { Bisphenol-A-d8 (surrogate), } \\
\text { whole water }\end{array}$ & 3 & NA & $\begin{array}{l}.1 \text { percent } \\
\text { recovery }\end{array}$ & $\begin{array}{l}.1 \text { percent } \\
\text { recovery }\end{array}$ & -- & laboratory analytical surrogate \\
\hline $\begin{array}{l}\text { Bisphenol-A-d8 (surrogate), } \\
\text { bottom sediment }\end{array}$ & 5 & NA & $\begin{array}{l}.1 \text { percent } \\
\text { recovery }\end{array}$ & $\begin{array}{l}.1 \text { percent } \\
\text { recovery }\end{array}$ & -- & laboratory analytical surrogate \\
\hline $\begin{array}{l}\text { Caffeine-c13 (surrogate), } \\
\text { dissolved }\end{array}$ & 4 & NA & $\begin{array}{l}.1 \text { percent } \\
\text { recovery }\end{array}$ & $\begin{array}{l}.1 \text { percent } \\
\text { recovery }\end{array}$ & -- & laboratory analytical surrogate \\
\hline $\begin{array}{l}\text { Caffeine-c13 (surrogate), whole } \\
\text { water }\end{array}$ & 3 & NA & $\begin{array}{l}.1 \text { percent } \\
\text { recovery }\end{array}$ & $\begin{array}{l}.1 \text { percent } \\
\text { recovery }\end{array}$ & -- & laboratory analytical surrogate \\
\hline $\begin{array}{l}\text { Caffeine-d8 (surrogate), whole } \\
\text { water }\end{array}$ & 3 & NA & $\begin{array}{l}.1 \text { percent } \\
\text { recovery }\end{array}$ & $\begin{array}{l}.1 \text { percent } \\
\text { recovery }\end{array}$ & -- & laboratory analytical surrogate \\
\hline $\begin{array}{l}\text { Decafluorobiphenyl } \\
\text { (surrogate), dissolved }\end{array}$ & 4 & NA & $\begin{array}{l}.1 \text { percent } \\
\text { recovery }\end{array}$ & $\begin{array}{l}.1 \text { percent } \\
\text { recovery }\end{array}$ & $434-90-2$ & laboratory analytical surrogate \\
\hline $\begin{array}{l}\text { Decafluorobiphenyl } \\
\text { (surrogate), whole water }\end{array}$ & 3 & NA & $\begin{array}{c}.1 \\
\text { percent recovery }\end{array}$ & $\begin{array}{l}.1 \text { percent } \\
\text { recovery }\end{array}$ & $434-90-2$ & laboratory analytical surrogate \\
\hline $\begin{array}{l}\text { Decafluorobiphenyl } \\
\text { (surrogate), bottom sediment }\end{array}$ & 5 & NA & $\begin{array}{l}.1 \text { percent } \\
\text { recovery }\end{array}$ & $\begin{array}{l}.1 \text { percent } \\
\text { recovery }\end{array}$ & $434-90-2$ & laboratory analytical surrogate \\
\hline $\begin{array}{l}\text { Ethyl-nicontinate-d4 } \\
\text { (surrogate), dissolved }\end{array}$ & 1 & NA & $\begin{array}{l}.1 \text { percent } \\
\text { recovery }\end{array}$ & $\begin{array}{l}.1 \text { percent } \\
\text { recovery }\end{array}$ & -- & laboratory analytical surrogate \\
\hline $\begin{array}{l}\text { Fluoranthene-d10 (surrogate), } \\
\text { dissolved }\end{array}$ & 4 & NA & $\begin{array}{l}.1 \text { percent } \\
\text { recovery }\end{array}$ & $\begin{array}{l}.1 \text { percent } \\
\text { recovery }\end{array}$ & $93951-69-0$ & laboratory analytical surrogate \\
\hline $\begin{array}{l}\text { Fluoranthene-d10 (surrogate), } \\
\text { whole water }\end{array}$ & 3 & NA & $\begin{array}{l}.1 \text { percent } \\
\text { recovery }\end{array}$ & $\begin{array}{l}.1 \text { percent } \\
\text { recovery }\end{array}$ & $93951-69-0$ & laboratory analytical surrogate \\
\hline $\begin{array}{l}\text { Fluoranthene-d10 (surrogate), } \\
\text { bottom sediment }\end{array}$ & 5 & NA & $\begin{array}{l}.1 \text { percent } \\
\text { recovery }\end{array}$ & $\begin{array}{l}.1 \text { percent } \\
\text { recovery }\end{array}$ & $93951-69-0$ & laboratory analytical surrogate \\
\hline \multicolumn{7}{|c|}{${ }^{1}$ Constituent detected in one or more environmental samples at concentration(s) greater than study reporting level. } \\
\hline \multicolumn{7}{|c|}{${ }^{2}$ Constituent not detected in any environmental sample at concentration(s) greater than study reporting level. } \\
\hline \multicolumn{7}{|c|}{$\begin{array}{l}{ }^{3} \text { Results for laboratory reagent-spike samples, laboratory surrogate samples, and/or matrix-spike samples unacceptable; constituent excluded from analyses } \\
\text { ind discussion related to occurrence of organic wastewater compounds in drinking water, wastewater effluent, and the Big Sioux River. }\end{array}$} \\
\hline \multicolumn{7}{|c|}{$\begin{array}{l}{ }^{4} \text { Constituent included in summary analyses and discussion related to occurrence of organic wastewater compounds in drinking water, wastewater effluent, and } \\
\text { he Big Sioux River for samples collected on or before June } 27,2003 \text {. }\end{array}$} \\
\hline
\end{tabular}


Table 8. Statistical summaries of analytical results for detected compounds in laboratory method-blank samples.

[Bold text indicates suspected endocrine-disrupting compound (EDC). Analytical method number: 1, Cahill and others (2004); 2, U.S. Geological Survey Organic Geochemistry Research Laboratory; 3, Lee and others (2004); 4, Zaugg and others (2002). $\mu \mathrm{g} / \mathrm{L}$, micrograms per liter; ND, not determined; e, estimated; --, not applicable]

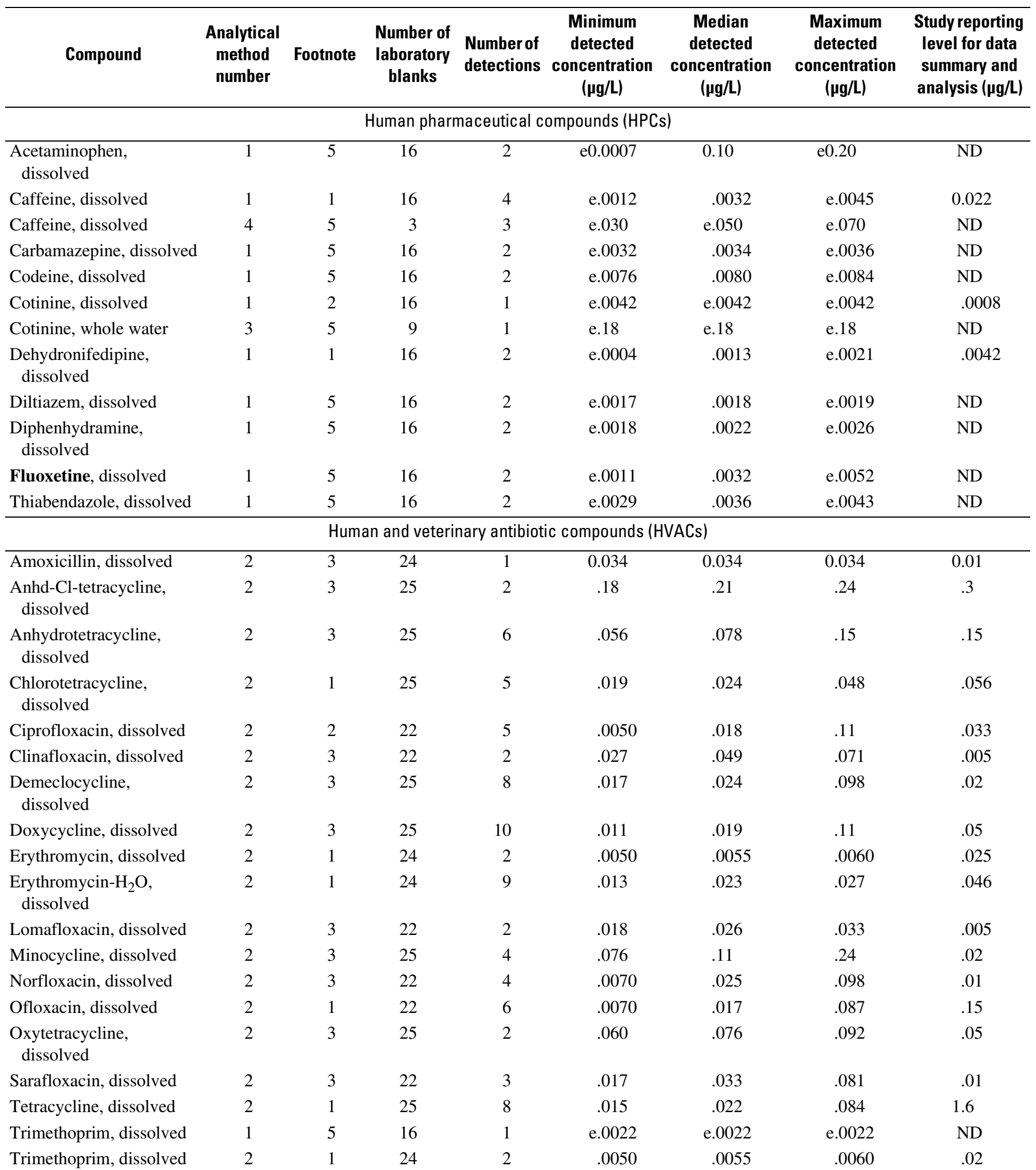


Table 8. Statistical summaries of analytical results for detected compounds in laboratory method-blank samples.—Continued

[Bold text indicates suspected endocrine-disrupting compound (EDC). Analytical method number: 1, Cahill and others (2004); 2, U.S. Geological Survey Organic Geochemistry Research Laboratory; 3, Lee and others (2004); 4, Zaugg and others (2002). $\mu \mathrm{g} / \mathrm{L}$, micrograms per liter; ND, not determined; e, estimated; --, not applicable]

\begin{tabular}{|c|c|c|c|c|c|c|c|c|}
\hline Compound & $\begin{array}{l}\text { Analytical } \\
\text { method } \\
\text { number }\end{array}$ & Footnote & $\begin{array}{l}\text { Number of } \\
\text { laboratory } \\
\text { blanks }\end{array}$ & $\begin{array}{l}\text { Number of } \\
\text { detections }\end{array}$ & $\begin{array}{c}\text { Minimum } \\
\text { detected } \\
\text { concentration } \\
(\mu \mathrm{g} / \mathrm{L})\end{array}$ & $\begin{array}{c}\text { Median } \\
\text { detected } \\
\text { concentration } \\
(\mu \mathrm{g} / \mathrm{L})\end{array}$ & $\begin{array}{c}\text { Maximum } \\
\text { detected } \\
\text { concentration } \\
(\mu \mathrm{g} / \mathrm{L})\end{array}$ & $\begin{array}{l}\text { Study reporting } \\
\text { level for data } \\
\text { summary and } \\
\text { analysis ( } \mu \mathrm{g} / \mathrm{L})\end{array}$ \\
\hline \multicolumn{9}{|c|}{ Major agricultural herbicides (MAHs) } \\
\hline Atrazine, whole water & 3 & 1 & 7 & 1 & $\mathrm{e} 0.0001$ & $\mathrm{e} 0.0001$ & $\mathrm{e} 0.0001$ & 0.0002 \\
\hline Metolachlor, whole water & 3 & 2 & 9 & 1 & e. 012 & e. 012 & e. 012 & .004 \\
\hline \multicolumn{9}{|c|}{ Household, industrial, and minor agricultural use compounds (HIACs) } \\
\hline $\begin{array}{l}\text { 1,4-Dichlorobenzene, } \\
\text { dissolved }\end{array}$ & 4 & 1 & 3 & 3 & $\mathrm{e} 0.010$ & 0.020 & 0.040 & 0.08 \\
\hline $\begin{array}{l}\text { 4-tert-Octylphenol, } \\
\text { dissolved }\end{array}$ & 4 & 3 & 3 & 2 & e.020 & .060 & e. 10 & 1 \\
\hline $\begin{array}{l}\text { Acetophenone, whole } \\
\text { water }\end{array}$ & 3 & 1 & 9 & 2 & e.038 & .039 & e. 040 & .08 \\
\hline $\begin{array}{l}\text { Benzophenone, whole } \\
\text { water }\end{array}$ & 3 & 5 & 9 & 2 & e. 072 & .19 & e. 31 & ND \\
\hline $\begin{array}{l}\text { Bis(2-ethylhexyl) } \\
\text { phthalate, whole water }\end{array}$ & 3 & 5 & 7 & 5 & e. 11 & e.71 & e3.4 & ND \\
\hline Bisphenol-A, dissolved & 4 & 5 & 3 & 1 & e. 20 & e. 20 & e. 20 & ND \\
\hline Camphor, whole water & 3 & 3 & 9 & 2 & e. 0047 & .0056 & e.0064 & .5 \\
\hline $\begin{array}{l}\text { Diethyl phthalate, whole } \\
\text { water }\end{array}$ & 3 & 5 & 9 & 2 & e. 018 & .025 & e.031 & ND \\
\hline $\begin{array}{l}\text { Nonylphenol } \\
\text { diethoxylate (NP2EO), } \\
\text { whole water }\end{array}$ & 3 & 2 & 9 & 1 & e2.7 & $\mathrm{e} 2.7$ & e2.7 & .66 \\
\hline $\begin{array}{l}\text { Octylphenol } \\
\text { diethoxylate (OP2EO), } \\
\text { dissolved }\end{array}$ & 4 & 1 & 3 & 2 & e. 080 & .090 & e. 10 & .19 \\
\hline $\begin{array}{l}\text { Octylphenol } \\
\text { monoethoxylate } \\
\text { (OP1EO), dissolved }\end{array}$ & 4 & 1 & 3 & 2 & e. 20 & .25 & e. 30 & .39 \\
\hline $\begin{array}{l}\text { Octylphenol } \\
\text { monoethoxylate } \\
\text { (OP1EO), whole water }\end{array}$ & 3 & 3 & 9 & 6 & e. 14 & .16 & e2.6 & 5.2 \\
\hline $\begin{array}{l}\text { para-Nonylphenol (NP), } \\
\text { dissolved }\end{array}$ & 4 & 4 & 3 & 3 & e. 40 & e. 70 & e1.5 & .83 \\
\hline
\end{tabular}


Table 8. Statistical summaries of analytical results for detected compounds in laboratory method-blank samples.—Continued

[Bold text indicates suspected endocrine-disrupting compound (EDC). Analytical method number: 1, Cahill and others (2004); 2, U.S. Geological Survey Organic Geochemistry Research Laboratory; 3, Lee and others (2004); 4, Zaugg and others (2002). $\mu \mathrm{g} / \mathrm{L}$, micrograms per liter; ND, not determined; e, estimated; --, not applicable]

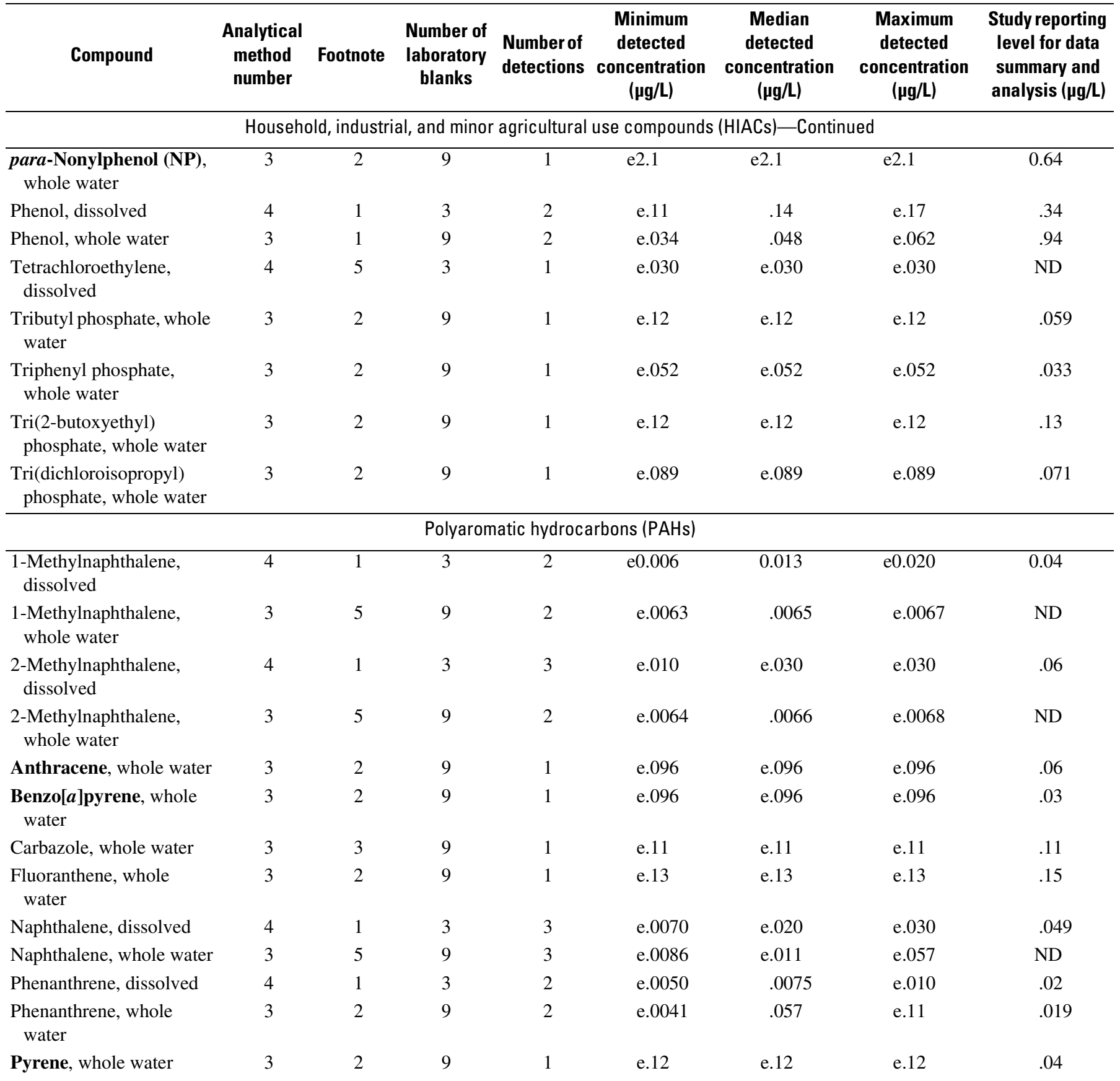


Table 8. Statistical summaries of analytical results for detected compounds in laboratory method-blank samples. - Continued

[Bold text indicates suspected endocrine-disrupting compound (EDC). Analytical method number: 1, Cahill and others (2004); 2, U.S. Geological Survey Organic Geochemistry Research Laboratory; 3, Lee and others (2004); 4, Zaugg and others (2002). $\mu \mathrm{g} / \mathrm{L}$, micrograms per liter; ND, not determined; e, estimated; --, not applicable]

\begin{tabular}{|c|c|c|c|c|c|c|c|c|}
\hline Compound & $\begin{array}{c}\text { Analytical } \\
\text { method } \\
\text { number }\end{array}$ & Footnote & $\begin{array}{c}\text { Number of } \\
\text { laboratory } \\
\text { blanks }\end{array}$ & $\begin{array}{l}\text { Number of } \\
\text { detections }\end{array}$ & $\begin{array}{c}\text { Minimum } \\
\text { detected } \\
\text { concentration } \\
(\mu \mathrm{g} / \mathrm{L})\end{array}$ & $\begin{array}{c}\text { Median } \\
\text { detected } \\
\text { concentration } \\
(\mu \mathrm{g} / \mathrm{L})\end{array}$ & $\begin{array}{c}\text { Maximum } \\
\text { detected } \\
\text { concentration } \\
(\mu \mathrm{g} / \mathrm{L})\end{array}$ & $\begin{array}{l}\text { Study reporting } \\
\text { level for data } \\
\text { summary and } \\
\text { analysis ( } \mu \mathrm{g} / \mathrm{L})\end{array}$ \\
\hline \multicolumn{9}{|c|}{ Sterol compounds (SCs) } \\
\hline $\begin{array}{l}\text { 3-beta-Coprostanol, } \\
\text { dissolved }\end{array}$ & 4 & 1 & 3 & 2 & $\mathrm{e} 0.50$ & 0.55 & $\mathrm{e} 0.60$ & 0.77 \\
\hline $\begin{array}{l}\text { beta-Stigmastanol, } \\
\text { dissolved }\end{array}$ & 4 & 1 & 3 & 2 & e. 70 & .80 & e. 90 & 1.8 \\
\hline Cholesterol, dissolved & 4 & 1 & 3 & 3 & e. 50 & e. 60 & e. 80 & .94 \\
\hline
\end{tabular}

${ }^{1}$ Compound detected in one or more method-blank samples but at concentrations generally substantially less than study reporting level; for environmental samples associated with method-blank samples with detections, a screening level of five times the detected concentration in the method-blank sample was used.

${ }^{2}$ Compound generally detected infrequently in method-blank samples (generally less than about 10 percent of method-blank samples); compound was not detected in environmental samples associated with method-blank samples with detections, or compound was detected in method-blank samples at concentrations substantially less than detected concentrations in environmental samples associated with the method-blank samples with detections.

${ }^{3}$ Compound detected in method-blank samples but not detected in any environmental samples at concentrations greater than study reporting level.

${ }^{4}$ Compound detected in method-blank samples but at concentrations substantially less than detected concentrations in environmental samples associated with the method-blank samples with detections.

${ }^{5}$ Compound detected in method-blank samples; however, compound was excluded from analyses and discussion related to occurrence of organic wastewater compounds in drinking water, wastewater effluents based on results for laboratory reagen-spike or environmental matrix-spike samples. 
Table 9. Statistical summaries of analytical results for laboratory reagent-spike samples.

[Bold text indicates suspected endocrine-disrupting compound (EDC). Analytical method number: 1, Cahill and others (2004); 2, U.S. Geological Survey Organic Geochemistry Research Laboratory; 3, Lee and others (2004); 4, Zaugg and others (2002). RSD, relative standard deviation; --, not applicable]

\begin{tabular}{|c|c|c|c|c|c|c|c|}
\hline Compound & $\begin{array}{c}\text { Analytical } \\
\text { method } \\
\text { number }\end{array}$ & Footnote & $\begin{array}{c}\text { Number of } \\
\text { laboratory } \\
\text { spikes }\end{array}$ & $\begin{array}{c}\text { Minimum } \\
\text { percent } \\
\text { recovery }\end{array}$ & $\begin{array}{l}\text { Median } \\
\text { percent } \\
\text { recovery }\end{array}$ & $\begin{array}{c}\text { Maximum } \\
\text { percent } \\
\text { recovery }\end{array}$ & $\begin{array}{c}\text { Percent } \\
\text { recovery } \\
\text { RSD }\end{array}$ \\
\hline \multicolumn{8}{|c|}{ Human pharmaceutical compounds (HPCs) } \\
\hline 1,7-Dimethylxanthine, dissolved & 1 & 1 & 16 & 62 & 81 & 119 & 19 \\
\hline Acetaminophen, dissolved & 1 & 1 & 16 & 50 & 67 & 106 & 23 \\
\hline Caffeine, dissolved & 1 & 1 & 16 & 68 & 75 & 101 & 10 \\
\hline Carbamazepine, dissolved & 1 & 1 & 16 & 56 & 69 & 90 & 13 \\
\hline Cimetidine, dissolved & 1 & 2 & 16 & 6 & 27 & 41 & 41 \\
\hline Codeine, dissolved & 1 & 1 & 16 & 61 & 71 & 167 & 34 \\
\hline Cotinine, dissolved & 1 & 1 & 16 & 56 & 74 & 92 & 15 \\
\hline Cotinine, dissolved & 4 & 2 & 3 & 43 & 44 & 45 & 3 \\
\hline Diphenhydramine, dissolved & 1 & 2 & 16 & 41 & 45 & 64 & 14 \\
\hline Fluoxetine, dissolved & 1 & 2 & 16 & 20 & 29 & 55 & 33 \\
\hline Furosemide, dissolved & 1 & 2 & 16 & 0 & 15 & 35 & 253 \\
\hline Gemfibrozil, dissolved & 1 & 2 & 16 & 9 & 26 & 160 & 102 \\
\hline Ibuprofen, dissolved & 1 & 2 & 16 & 32 & 44 & 100 & 38 \\
\hline Metformin, dissolved & 1 & 2 & 16 & 0 & 0 & 4 & 118 \\
\hline Miconazole, dissolved & 1 & 2 & 16 & 2 & 5 & 43 & 105 \\
\hline Ranitidine, dissolved & 1 & 2 & 16 & 24 & 34 & 59 & 25 \\
\hline Salbutamol, dissolved & 1 & 1 & 16 & 64 & 73 & 97 & 11 \\
\hline Thiabendazole, dissolved & 1 & 1 & 16 & 67 & 70 & 90 & 11 \\
\hline \multicolumn{8}{|c|}{ Major agricultural herbicides (MAHs) } \\
\hline Atrazine, whole water & 3 & 1 & 1 & 60 & 60 & 60 & -- \\
\hline Metolachlor, dissolved & 4 & 1 & 3 & 90 & 95 & 100 & 5 \\
\hline Metolachlor, whole water & 3 & 1 & 4 & 34 & 78 & 92 & 36 \\
\hline Prometon, dissolved & 4 & 1 & 3 & 90 & 110 & 115 & 13 \\
\hline Prometon, whole water & 3 & 1 & 4 & 49 & 73 & 89 & 23 \\
\hline \multicolumn{8}{|c|}{ Household, industrial, and minor agricultural use compounds (HIACs) } \\
\hline 1,4-Dichlorobenzene, dissolved & 4 & 1 & 3 & 60 & 65 & 85 & 19 \\
\hline 1,4-Dichlorobenzene, whole water & 3 & 2 & 4 & 20 & 24 & 89 & 86 \\
\hline $\begin{array}{l}2,2^{\prime}, \mathbf{4}, \mathbf{4}^{\prime} \text {-Tetrabromodiphenyl ether, whole } \\
\text { water }\end{array}$ & 3 & 1 & 1 & 47 & 47 & 47 & -- \\
\hline 3,4-Dichlorophenyl isocyanate, whole water & 3 & 2 & 1 & 175 & 175 & 175 & -- \\
\hline 3-Methyl-1H-indole (skatol), dissolved & 4 & 1 & 3 & 90 & 90 & 100 & 6 \\
\hline 3-Methyl-1H-indole (skatol), whole water & 3 & 1 & 4 & 38 & 69 & 107 & 40 \\
\hline
\end{tabular}


Table 9. Statistical summaries of analytical results for laboratory reagent-spike samples.—Continued

[Bold text indicates suspected endocrine-disrupting compound (EDC). Analytical method number: 1, Cahill and others (2004); 2, U.S. Geological Survey Organic Geochemistry Research Laboratory; 3, Lee and others (2004); 4, Zaugg and others (2002). RSD, relative standard deviation; --, not applicable]

\begin{tabular}{|c|c|c|c|c|c|c|c|}
\hline Compound & $\begin{array}{l}\text { Analytical } \\
\text { method } \\
\text { number }\end{array}$ & Footnote & $\begin{array}{c}\text { Number of } \\
\text { laboratory } \\
\text { spikes }\end{array}$ & $\begin{array}{l}\text { Minimum } \\
\text { percent } \\
\text { recovery }\end{array}$ & $\begin{array}{l}\text { Median } \\
\text { percent } \\
\text { recovery }\end{array}$ & $\begin{array}{l}\text { Maximum } \\
\text { percent } \\
\text { recovery }\end{array}$ & $\begin{array}{l}\text { Percent } \\
\text { recovery } \\
\text { RSD }\end{array}$ \\
\hline $\begin{array}{l}\text { 3-tert-Butyl-4-hydroxy anisole (BHA), } \\
\text { dissolved }\end{array}$ & 4 & 1 & 3 & 70 & 75 & 75 & 4 \\
\hline $\begin{array}{l}\text { 3-tert-Butyl-4-hydroxy anisole (BHA), } \\
\text { whole water }\end{array}$ & 3 & 2 & 4 & 2 & 35 & 75 & 82 \\
\hline 4-Cumylphenol, dissolved & 4 & 1 & 3 & 85 & 105 & 115 & 15 \\
\hline 4-Cumylphenol, whole water & 3 & 1 & 4 & 50 & 76 & 116 & 34 \\
\hline 4-normal-Octylphenol, dissolved & 4 & 1 & 3 & 80 & 85 & 85 & 3 \\
\hline 4-normal-Octylphenol, whole water & 3 & 1 & 4 & 60 & 72 & 97 & 21 \\
\hline 4-tert-Octylphenol, dissolved & 4 & 1 & 3 & 80 & 85 & 90 & 6 \\
\hline $\begin{array}{l}\text { 7-Acetyl-1,1,3,4,4,6-hexamethyl } \\
\text { tetrahydronaphthalene (AHTN), } \\
\text { dissolved }\end{array}$ & 4 & 1 & 3 & 85 & 90 & 100 & 8 \\
\hline $\begin{array}{l}\text { 7-Acetyl-1,1,3,4,4,6-hexamethyl } \\
\text { tetrahydronaphthalene (AHTN), whole } \\
\text { water }\end{array}$ & 3 & 1 & 4 & 50 & 71 & 114 & 35 \\
\hline Acetophenone, dissolved & 4 & 1 & 3 & 85 & 100 & 110 & 13 \\
\hline Acetophenone, whole water & 3 & 3 & 4 & 41 & 71 & 116 & 43 \\
\hline Anthraquinone, dissolved & 4 & 1 & 3 & 75 & 85 & 90 & 9 \\
\hline Anthraquinone, whole water & 3 & 1 & 4 & 39 & 72 & 89 & 31 \\
\hline Camphor, dissolved & 4 & 1 & 3 & 90 & 95 & 95 & 3 \\
\hline Camphor, whole water & 3 & 1 & 4 & 40 & 69 & 109 & 40 \\
\hline Carbaryl, dissolved & 4 & 1 & 3 & 50 & 55 & 55 & 5 \\
\hline Carbaryl, whole water & 3 & 2 & 4 & 14 & 65 & 121 & 66 \\
\hline Chlorpyrifos, dissolved & 4 & 1 & 3 & 80 & 80 & 85 & 4 \\
\hline Chlorpyrifos, whole water & 3 & 1 & 4 & 48 & 74 & 112 & 35 \\
\hline $\begin{array}{l}\text { N,N-Diethyl-meta-toluamide (DEET), } \\
\text { dissolved }\end{array}$ & 4 & 1 & 3 & 75 & 95 & 100 & 15 \\
\hline $\begin{array}{l}\text { N,N-Diethyl-meta-toluamide (DEET), whole } \\
\text { water }\end{array}$ & 3 & 1 & 4 & 47 & 79 & 100 & 29 \\
\hline Diazinon, dissolved & 4 & 1 & 3 & 85 & 95 & 100 & 8 \\
\hline Diazinon, whole water & 3 & 1 & 4 & 46 & 71 & 108 & 35 \\
\hline Dichlorvos, dissolved & 4 & 2 & 3 & 4 & 6 & 7 & 19 \\
\hline Dichlorvos, whole water & 3 & 2 & 4 & 33 & 74 & 105 & 44 \\
\hline Diethyl phthalate, whole water & 3 & 2 & 1 & 44 & 44 & 44 & -- \\
\hline D-Limonene, dissolved & 4 & 2 & 3 & 37 & 47 & 65 & 29 \\
\hline
\end{tabular}


Table 9. Statistical summaries of analytical results for laboratory reagent-spike samples.-Continued

[Bold text indicates suspected endocrine-disrupting compound (EDC). Analytical method number: 1, Cahill and others (2004); 2, U.S. Geological Survey Organic Geochemistry Research Laboratory; 3, Lee and others (2004); 4, Zaugg and others (2002). RSD, relative standard deviation; --, not applicable]

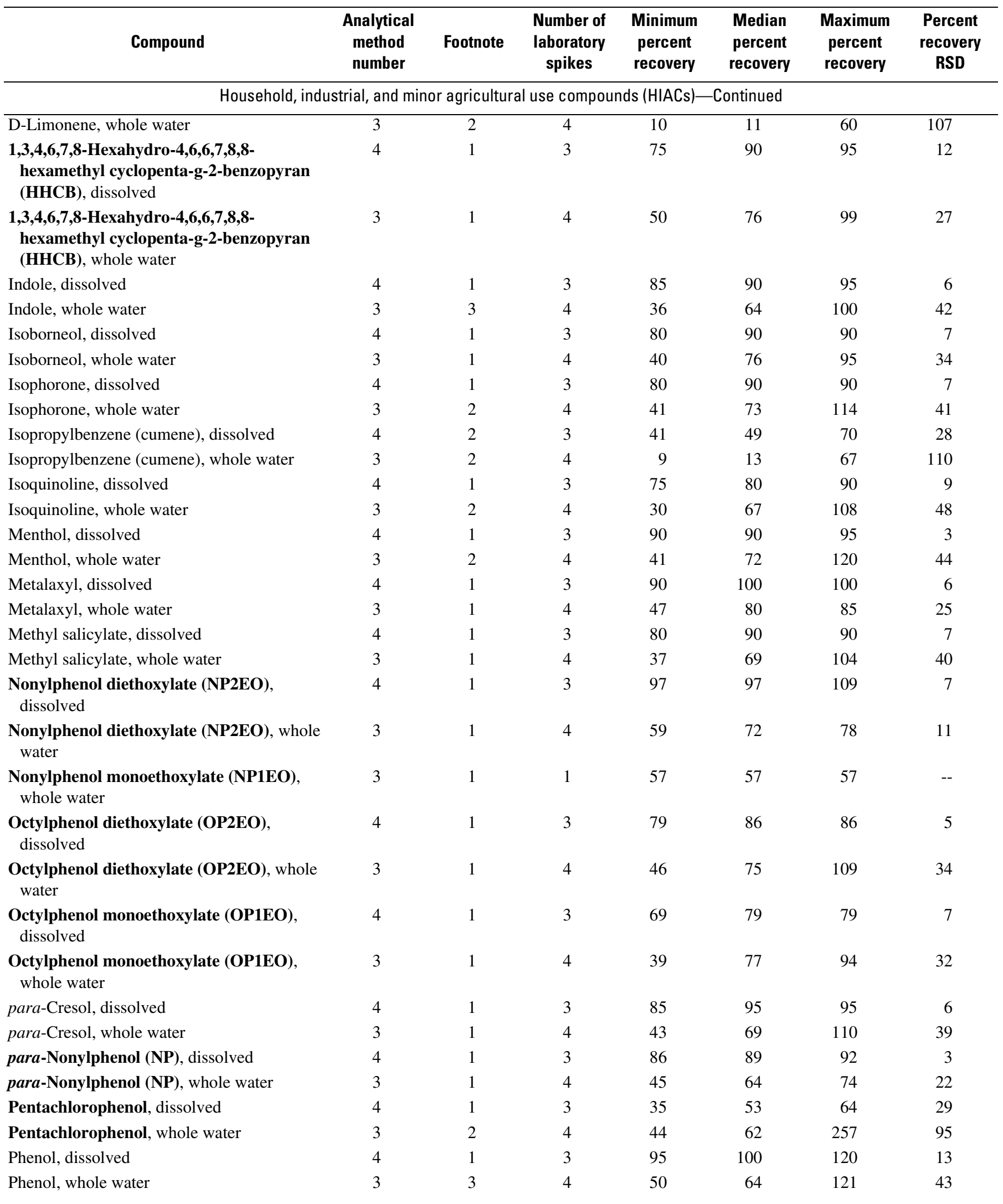


Table 9. Statistical summaries of analytical results for laboratory reagent-spike samples.-Continued

[Bold text indicates suspected endocrine-disrupting compound (EDC). Analytical method number: 1, Cahill and others (2004); 2, U.S. Geological Survey Organic Geochemistry Research Laboratory; 3, Lee and others (2004); 4, Zaugg and others (2002). RSD, relative standard deviation; --, not applicable]

\begin{tabular}{|c|c|c|c|c|c|c|c|}
\hline Compound & $\begin{array}{c}\text { Analytical } \\
\text { method } \\
\text { number }\end{array}$ & Footnote & $\begin{array}{c}\text { Number of } \\
\text { laboratory } \\
\text { spikes }\end{array}$ & $\begin{array}{c}\text { Minimum } \\
\text { percent } \\
\text { recovery }\end{array}$ & $\begin{array}{l}\text { Median } \\
\text { percent } \\
\text { recovery }\end{array}$ & $\begin{array}{c}\text { Maximum } \\
\text { percent } \\
\text { recovery }\end{array}$ & $\begin{array}{c}\text { Percent } \\
\text { recovery } \\
\text { RSD }\end{array}$ \\
\hline \multicolumn{8}{|c|}{ Household, industrial, and minor agricultural use compounds (HIACs) - Continued } \\
\hline Tetrachloroethylene, dissolved & 4 & 2 & 3 & 29 & 34 & 60 & 41 \\
\hline Tetrachloroethylene, whole water & 3 & 2 & 4 & 5 & 8 & 38 & 104 \\
\hline Triclosan, dissolved & 4 & 1 & 3 & 75 & 85 & 85 & 7 \\
\hline Triclosan, whole water & 3 & 1 & 4 & 60 & 73 & 90 & 17 \\
\hline Triethyl citrate (ethyl citrate), dissolved & 4 & 1 & 3 & 90 & 105 & 110 & 10 \\
\hline Triethyl citrate (ethyl citrate), whole water & 3 & 1 & 4 & 46 & 69 & 75 & 20 \\
\hline Triphenyl phosphate, dissolved & 4 & 1 & 3 & 90 & 105 & 110 & 10 \\
\hline Tri(2-chloroethyl)phosphate, dissolved & 4 & 1 & 3 & 90 & 110 & 115 & 13 \\
\hline Tri(2-chloroethyl)phosphate, whole water & 3 & 1 & 4 & 42 & 71 & 93 & 30 \\
\hline Tri(dichloroisopropyl)phosphate, dissolved & 4 & 1 & 3 & 90 & 115 & 130 & 18 \\
\hline Tri(dichloroisopropyl)phosphate, whole water & 3 & 1 & 4 & 50 & 75 & 108 & 31 \\
\hline \multicolumn{8}{|c|}{ Polyaromatic hydrocarbons (PAHs) } \\
\hline 1-Methylnaphthalene, dissolved & 4 & 1 & 3 & 80 & 80 & 90 & 7 \\
\hline 1-Methylnaphthalene, whole water & 3 & 2 & 4 & 35 & 46 & 103 & 55 \\
\hline 2,6-Dimethylnaphthalene, dissolved & 4 & 1 & 3 & 80 & 80 & 90 & 7 \\
\hline 2,6-Dimethylnaphthalene, whole water & 3 & 2 & 4 & 34 & 46 & 99 & 54 \\
\hline Carbazole, whole water & 3 & 1 & 4 & 55 & 80 & 117 & 32 \\
\hline Fluoranthene, dissolved & 4 & 1 & 3 & 90 & 100 & 110 & 10 \\
\hline Fluoranthene, whole water & 3 & 1 & 4 & 60 & 72 & 112 & 29 \\
\hline Naphthalene, dissolved & 4 & 1 & 3 & 70 & 75 & 80 & 7 \\
\hline Naphthalene, whole water & 3 & 2 & 4 & 27 & 50 & 102 & 55 \\
\hline Phenanthrene, dissolved & 4 & 1 & 3 & 90 & 90 & 100 & 6 \\
\hline Phenanthrene, whole water & 3 & 1 & 4 & 45 & 67 & 111 & 38 \\
\hline Pyrene, dissolved & 4 & 1 & 3 & 80 & 85 & 90 & 6 \\
\hline Pyrene, whole water & 3 & 1 & 4 & 50 & 72 & 113 & 34 \\
\hline \multicolumn{8}{|c|}{ Sterol compounds (SCs) } \\
\hline 3-beta-Coprostanol, dissolved & 4 & 1 & 3 & 79 & 80 & 81 & 2 \\
\hline 3-beta-Coprostanol, whole water & 3 & 1 & 4 & 64 & 71 & 76 & 8 \\
\hline beta-Sitosterol, dissolved & 4 & 1 & 3 & 51 & 54 & 83 & 28 \\
\hline beta-Sitosterol, whole water & 3 & 1 & 4 & 65 & 76 & 86 & 12 \\
\hline beta-Stigmastanol, dissolved & 4 & 1 & 3 & 53 & 59 & 91 & 31 \\
\hline
\end{tabular}




\section{Organic Wastewater Compounds in Drinking Water, Wastewater Effluent, and the Big Sioux River, 2001-2004}

Table 9. Statistical summaries of analytical results for laboratory reagent-spike samples.-Continued

[Bold text indicates suspected endocrine-disrupting compound (EDC). Analytical method number: 1, Cahill and others (2004); 2, U.S. Geological Survey Organic Geochemistry Research Laboratory; 3, Lee and others (2004); 4, Zaugg and others (2002). RSD, relative standard deviation; --, not applicable]

\begin{tabular}{|c|c|c|c|c|c|c|c|}
\hline Compound & $\begin{array}{c}\text { Analytical } \\
\text { method } \\
\text { number }\end{array}$ & Footnote & $\begin{array}{c}\text { Number of } \\
\text { laboratory } \\
\text { spikes }\end{array}$ & $\begin{array}{c}\text { Minimum } \\
\text { percent } \\
\text { recovery }\end{array}$ & $\begin{array}{l}\text { Median } \\
\text { percent } \\
\text { recovery }\end{array}$ & $\begin{array}{c}\text { Maximum } \\
\text { percent } \\
\text { recovery }\end{array}$ & $\begin{array}{c}\text { Percent } \\
\text { recovery } \\
\text { RSD }\end{array}$ \\
\hline beta-Stigmastanol, whole water & 3 & 1 & 4 & 60 & 74 & 87 & 18 \\
\hline Cholesterol, dissolved & 4 & 1 & 3 & 68 & 83 & 88 & 13 \\
\hline
\end{tabular}

\footnotetext{
${ }^{1}$ Median percent recovery for reagent-spike samples near or within acceptable range (50-120 percent), and percent recovery RSD acceptable (less than 40 percent); laboratory-reagent spike results judged to be acceptable.

${ }^{2}$ Median percent recovery for reagent-spike samples outside of acceptable range (50-120 percent), or percent recovery RSD unacceptable (greater than 40 percent); compound excluded from analyses and discussion related to occurrence of organic wastewater compounds in drinking water, wastewater effluents, and the Big Sioux River.

${ }^{3}$ Median percent recovery for reagent-spike samples within acceptable range (50-120 percent), but percent recovery RSD slightly exceeded acceptable range (less than 40 percent); all other quality-assurance/quality-control results for compound were acceptable; laboratory-reagent spike results judged to be acceptable.

${ }^{4}$ Median percent recovery for reagent-spike samples exceeded acceptable range (50-120 percent), but percent recovery RSD within acceptable range (less than 40 percent); all other quality-assurance/quality-control results for compound were acceptable; laboratory-reagent spike results judged to be acceptable.
} 
Table 10. Statistical summaries of analytical results for laboratory surrogate-spike compounds.

[Analytical method number: 1, Cahill and others (2004); 3, Lee and others (2004); 4, Zaugg and others (2002); 5, Burkhardt and others (2005). RSD, relative standard deviation]

\begin{tabular}{|c|c|c|c|c|c|c|c|c|}
\hline Compound & $\begin{array}{c}\text { Analytical } \\
\text { method } \\
\text { number }\end{array}$ & Footnote & $\begin{array}{l}\text { Number of } \\
\text { samples } \\
\text { spiked with } \\
\text { surrogate } \\
\text { compounds }\end{array}$ & $\begin{array}{c}\text { Minimum } \\
\text { surrogate } \\
\text { percent } \\
\text { recovery }\end{array}$ & $\begin{array}{l}\text { Median } \\
\text { surrogate } \\
\text { percent } \\
\text { recovery }\end{array}$ & $\begin{array}{c}\text { Maximum } \\
\text { surrogate } \\
\text { percent } \\
\text { recovery }\end{array}$ & $\begin{array}{l}\text { Acceptable } \\
\text { range for } \\
\text { median } \\
\text { surrogate } \\
\text { percent } \\
\text { recovery }\end{array}$ & $\begin{array}{c}\text { Surrogate } \\
\text { percent } \\
\text { recovery } \\
\text { RSD }\end{array}$ \\
\hline Bisphenol-A-d3 (surrogate), dissolved & 4 & 2 & 12 & 118 & 148 & 164 & $50-120$ & 9 \\
\hline Bisphenol-A-d3 (surrogate), whole water (b) & 3 & 2 & 15 & 3 & 173 & 218 & $50-120$ & 43 \\
\hline Bisphenol-A-d8 (surrogate), whole water & 3 & 1 & 13 & 51 & 81 & 111 & $50-120$ & 24 \\
\hline Bisphenol-A-d8 (surrogate), bottom sediment & 5 & 1 & 3 & 21 & 27 & 27 & $18-44$ & 14 \\
\hline Caffeine-c13 (surrogate), dissolved & 1 & 1 & 4 & 62 & 72 & 82 & $50-120$ & 12 \\
\hline Caffeine-c13 (surrogate), dissolved & 4 & 2 & 12 & 114 & 125 & 136 & $50-120$ & 5 \\
\hline Caffeine-c13 (surrogate), whole water & 3 & 1 & 15 & 58 & 82 & 141 & $50-120$ & 27 \\
\hline Caffeine-d8 (surrogate), whole water & 3 & 1 & 12 & 50 & 72 & 89 & $50-120$ & 16 \\
\hline Decafluorobiphenyl (surrogate), dissolved & 4 & 1 & 12 & 73 & 89 & 96 & $50-120$ & 9 \\
\hline Decafluorobiphenyl (surrogate), whole water & 3 & 1 & 27 & 22 & 55 & 73 & $50-120$ & 24 \\
\hline $\begin{array}{l}\text { Decafluorobiphenyl (surrogate), bottom } \\
\text { sediment }\end{array}$ & 5 & 3 & 3 & 19 & 31 & 48 & $30-60$ & 45 \\
\hline Ethyl-nicontinate-d4 (surrogate), dissolved & 1 & 1 & 27 & 42 & 85 & 117 & $50-120$ & 20 \\
\hline Fluoranthene-d10 (surrogate), dissolved & 4 & 4 & 12 & 114 & 123 & 132 & $50-120$ & 4 \\
\hline Fluoranthene-d10 (surrogate), whole water & 3 & 1 & 27 & 41 & 59 & 118 & $50-120$ & 33 \\
\hline $\begin{array}{l}\text { Fluoranthene-d10 (surrogate), bottom } \\
\text { sediment }\end{array}$ & 5 & 1 & 3 & 50 & 79 & 80 & $70-85$ & 24 \\
\hline
\end{tabular}

\footnotetext{
${ }^{1}$ Median percent recovery for surrogate-spike compounds near or within acceptable range, and percent recovery RSD acceptable (less than 40 percent).

${ }^{2}$ Median percent recovery for surrogate-spike compounds outside of acceptable range and/or percent recovery RSD unacceptable (greater than 40 percent); compound excluded from analyses and discussion related to occurrence of organic wastewater compounds in drinking water, wastewater effluents, and the Big Sioux
} River.

${ }^{3}$ Median percent recovery for surrogate-spike compounds within acceptable range, but percent recovery RSD higher than acceptable range; discussions with ana-

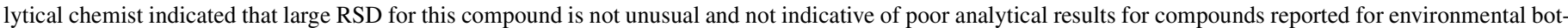

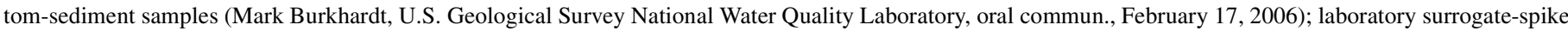
results for bottom-sediment samples judged to be acceptable.

${ }^{4}$ Median percent recovery for the fluoranthene-d10 surrogate slightly exceeded the acceptable range. Other quality-assurance/quality-control results for study tar-

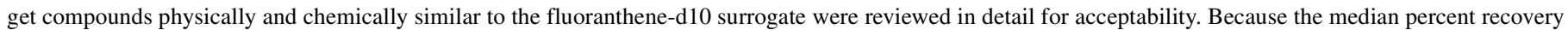

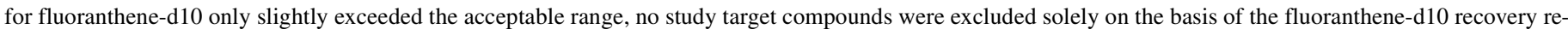
sults. 
Table 11. Statistical summaries of analytical results for detected compounds in field equipment-blank samples.

[Bold text indicates suspected endocrine-disrupting compound (EDC). Analytical method number: 1, Cahill and others (2004); 2, U.S. Geological Survey Organic Geochemistry Research Laboratory; 3, Lee and others (2004); 4, Zaugg and others (2002). $\mu \mathrm{g} / \mathrm{L}$, micrograms per liter; e, estimated]

\begin{tabular}{|c|c|c|c|c|c|c|c|c|}
\hline Compound & $\begin{array}{c}\text { Analytical } \\
\text { method } \\
\text { number }\end{array}$ & Footnote & $\begin{array}{c}\text { Number of } \\
\text { blank } \\
\text { samples }\end{array}$ & $\begin{array}{l}\text { Number of } \\
\text { detections }\end{array}$ & $\begin{array}{c}\text { Minimum } \\
\text { detected } \\
\text { concentration } \\
(\mu \mathrm{g} / \mathrm{L})\end{array}$ & $\begin{array}{c}\text { Median } \\
\text { detected } \\
\text { concentration } \\
(\mu \mathrm{g} / \mathrm{L})\end{array}$ & $\begin{array}{c}\text { Maximum } \\
\text { detected } \\
\text { concentration } \\
(\mu \mathrm{g} / \mathrm{L})\end{array}$ & $\begin{array}{l}\text { Study reporting } \\
\text { level for data } \\
\text { summary and } \\
\text { analysis ( } \mu \mathrm{g} / \mathrm{L} \text { ) }\end{array}$ \\
\hline \multicolumn{9}{|c|}{ Human pharmaceutical compounds (HPCs) } \\
\hline Acetaminophen, dissolved & 1 & 2 & 6 & 2 & $\mathrm{e} 0.0058$ & $\mathrm{e} 0.0074$ & $\mathrm{e} 0.0091$ & -- \\
\hline Caffeine, dissolved & 1 & 1 & 6 & 1 & e.0108 & e.0108 & e.0108 & 0.022 \\
\hline Diphenhydramine, dissolved & 1 & 2 & 6 & 1 & e.0004 & e.0004 & e.0004 & -- \\
\hline Fluoxetine, dissolved & 1 & 2 & 6 & 1 & e. 018 & e. 018 & e. 018 & -- \\
\hline \multicolumn{9}{|c|}{ Human and veterinary antibiotic compounds (HVACs) } \\
\hline Ciprofloxacin, dissolved & 2 & 1 & 6 & 1 & $\mathrm{e} 0.011$ & $\mathrm{e} 0.011$ & $\mathrm{e} 0.011$ & 0.033 \\
\hline Clinafloxacin, dissolved & 2 & 1 & 6 & 1 & e.0060 & e.0060 & e.0060 & .005 \\
\hline Erythromycin- $\mathrm{H}_{2} \mathrm{O}$, dissolved & 2 & 1 & 6 & 1 & e.019 & e.019 & e.019 & .046 \\
\hline Sulfamethoxazole, dissolved & 2 & 1 & 6 & 1 & e.017 & e.017 & e.017 & .014 \\
\hline \multicolumn{9}{|c|}{ Household, industrial, and minor agricultural use compounds (HIACs) } \\
\hline 4-tert-Octylphenol, whole water & 3 & 1 & 5 & 1 & $\mathrm{e} 0.13$ & $\mathrm{e} 0.13$ & $\mathrm{e} 0.13$ & 0.26 \\
\hline Phenol, whole water & 3 & 1 & 5 & 2 & e. 45 & e. 46 & e. 47 & .94 \\
\hline \multicolumn{9}{|c|}{ Sterol compounds (SCs) } \\
\hline beta-Stigmastanol, dissolved & 4 & 1 & 4 & 1 & $\mathrm{e} 1.0$ & $\mathrm{e} 1.0$ & $\mathrm{e} 1.0$ & 1.8 \\
\hline
\end{tabular}

${ }^{1}$ Compound detected infrequently in field equipment-blank samples at concentrations generally substantially less than study reporting level; compound not detected at concentration greater than study reporting level in environmental sample associated with field equipment-blank sample with detection.

${ }^{2}$ Compound detected in field equipment-blank samples; however, compound was excluded from analyses and discussion related to occurrence of organic wastewater compounds in Big Sioux River and wastewater effluents based on results for laboratory reagent-spike or environmental matrix-spike samples. 
Table 12. Statistical summaries for field replicate samples for organic wastewater compounds (OWCs) detected in any sample for any primary/replicate sample pair.

[Bold text indicates suspected endocrine-disrupting compound (EDC)]

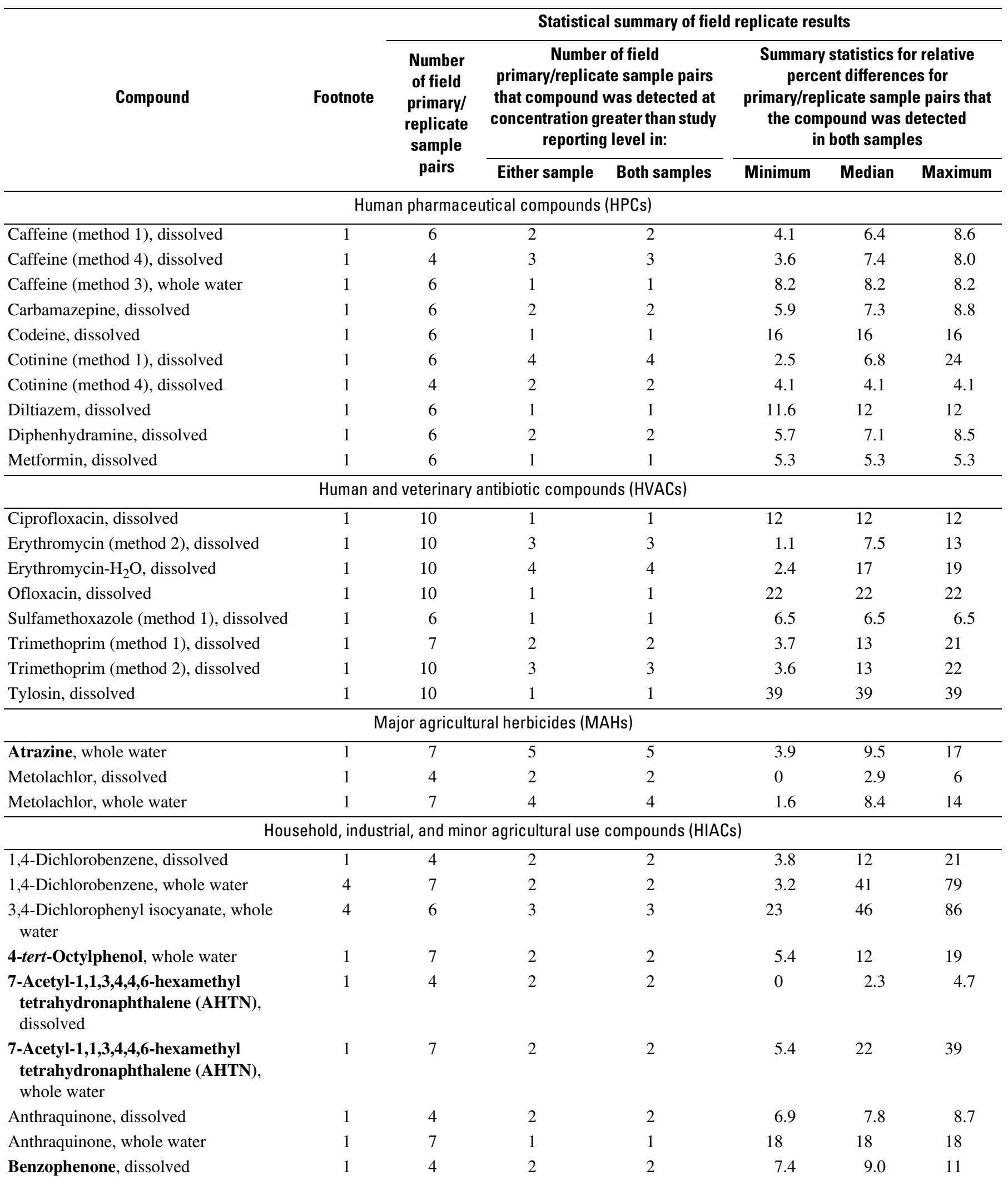


Table 12. Statistical summaries for field replicate samples for organic wastewater compounds (OWCs) detected in any sample for any primary/replicate sample pair.-Continued

[Bold text indicates suspected endocrine-disrupting compound (EDC)]

\begin{tabular}{|c|c|c|c|c|c|c|c|}
\hline \multirow{3}{*}{ Compound } & \multirow{3}{*}{ Footnote } & \multicolumn{6}{|c|}{ Statistical summary of field replicate results } \\
\hline & & \multirow{2}{*}{$\begin{array}{l}\text { Number } \\
\text { of field } \\
\text { primary/ } \\
\text { replicate } \\
\text { sample } \\
\text { pairs }\end{array}$} & \multicolumn{2}{|c|}{$\begin{array}{l}\text { Number of field } \\
\text { primary/replicate sample pairs } \\
\text { that compound was detected at } \\
\text { concentration greater than study } \\
\text { reporting level in: }\end{array}$} & \multicolumn{3}{|c|}{$\begin{array}{l}\text { Summary statistics for relative } \\
\text { percent differences for } \\
\text { primary/replicate sample pairs that } \\
\text { the compound was detected } \\
\text { in both samples }\end{array}$} \\
\hline & & & Either sample & Both samples & Minimum & Median & Maximum \\
\hline Bromoform, dissolved & 1 & 4 & 2 & 2 & 4.7 & 6.0 & 7.4 \\
\hline Camphor, dissolved & 1 & 4 & 1 & 1 & 9.8 & 9.8 & 9.8 \\
\hline Carbaryl, dissolved & 1 & 4 & 1 & 1 & 7.4 & 7.4 & 7.4 \\
\hline $\begin{array}{l}\mathrm{N}, \mathrm{N} \text {-Diethyl-meta-toluamide (DEET), } \\
\text { dissolved }\end{array}$ & 1 & 4 & 3 & 3 & 0 & 0 & 1.2 \\
\hline $\begin{array}{l}\text { 1,3,4,6,7,8-Hexahydro-4,6,6,7,8,8- } \\
\text { hexamethyl cyclopenta-g-2- } \\
\text { benzopyran (HHCB), whole water }\end{array}$ & 1 & 7 & 2 & 2 & 15 & 33 & 50 \\
\hline Indole, dissolved & 1 & 4 & 2 & 2 & 12 & 13 & 15 \\
\hline Isophorone, dissolved & 1 & 4 & 1 & 1 & 5.6 & 5.6 & 5.6 \\
\hline $\begin{array}{l}\text { Nonylphenol diethoxylate (NP2EO), } \\
\text { dissolved }\end{array}$ & 1 & 4 & 2 & 2 & 4.5 & 28 & 52 \\
\hline $\begin{array}{l}\text { Nonylphenol diethoxylate (NP2EO), } \\
\text { whole water }\end{array}$ & 1 & 7 & 1 & 1 & 11 & 11 & 11 \\
\hline para-Nonylphenol (NP), whole water & 1 & 7 & 1 & 1 & 12 & 12 & 12 \\
\hline Pentachlorophenol, dissolved & 1 & 4 & 1 & 1 & 10 & 10 & 10 \\
\hline Phenol, dissolved & 3 & 4 & 1 & 1 & 55 & 55 & 55 \\
\hline Tetrachloroethylene, dissolved & 1 & 4 & 1 & 1 & 20 & 20 & 20 \\
\hline Tributyl phosphate, dissolved & 1 & 4 & 3 & 3 & 0 & 5.4 & 7.7 \\
\hline Tributyl phosphate, whole water & 1 & 7 & 3 & 3 & 0 & 5.2 & 8.0 \\
\hline Triclosan, dissolved & 1 & 4 & 2 & 2 & 0 & 9.1 & 18 \\
\hline Triethyl citrate (ethyl citrate), dissolved & 1 & 4 & 2 & 2 & 0 & 3.2 & 6.5 \\
\hline $\begin{array}{l}\text { Triethyl citrate (ethyl citrate), whole } \\
\text { water }\end{array}$ & 1 & 7 & 2 & 2 & 1.2 & 13 & 26 \\
\hline Triphenyl phosphate, dissolved & 1 & 4 & 3 & 3 & 0 & 3.4 & 4.1 \\
\hline Triphenyl phosphate, whole water & 1 & 7 & 1 & 1 & 5.9 & 5.9 & 5.9 \\
\hline Tri(2-butoxyethyl)phosphate, dissolved & 1 & 4 & 1 & 1 & 5.3 & 5.3 & 5.3 \\
\hline
\end{tabular}


Table 12. Statistical summaries for field replicate samples for organic wastewater compounds (OWCs) detected in any sample for any primary/replicate sample pair.-Continued

[Bold text indicates suspected endocrine-disrupting compound (EDC)]

\begin{tabular}{|c|c|c|c|c|c|c|c|}
\hline \multirow{3}{*}{ Compound } & \multirow{3}{*}{ Footnote } & \multicolumn{6}{|c|}{ Statistical summary of field replicate results } \\
\hline & & \multirow{2}{*}{$\begin{array}{c}\text { Number } \\
\text { of field } \\
\text { primary/ } \\
\text { replicate } \\
\text { sample } \\
\text { pairs }\end{array}$} & \multicolumn{2}{|c|}{$\begin{array}{c}\text { Number of field } \\
\text { primary/replicate sample pairs } \\
\text { that compound was detected at } \\
\text { concentration greater than study } \\
\text { reporting level in: }\end{array}$} & \multicolumn{3}{|c|}{$\begin{array}{l}\text { Summary statistics for relative } \\
\text { percent differences for } \\
\text { primary/replicate sample pairs that } \\
\text { the compound was detected } \\
\text { in both samples }\end{array}$} \\
\hline & & & Either sample & Both samples & Minimum & Median & Maximum \\
\hline $\begin{array}{l}\text { Tri(2-butoxyethyl)phosphate, whole } \\
\text { water }\end{array}$ & 2 & 7 & 2 & 1 & 4.5 & 4.5 & 4.5 \\
\hline Tri(2-chloroethyl)phosphate, dissolved & 1 & 4 & 3 & 3 & 2.9 & 3.5 & 7.1 \\
\hline $\begin{array}{l}\text { Tri(2-chloroethyl)phosphate, whole } \\
\text { water }\end{array}$ & 2 & 7 & 3 & 2 & 1.7 & 16 & 30 \\
\hline \multicolumn{8}{|c|}{ Polyaromatic hydrocarbons (PAHs) } \\
\hline 1-Methylnaphthalene, whole water & 1 & 7 & 1 & 1 & 9.5 & 9.5 & 9.5 \\
\hline 2-Methylnaphthalene, whole water & 1 & 7 & 1 & 1 & 23 & 23 & 23 \\
\hline Carbazole, dissolved & 1 & 4 & 1 & 1 & 2.0 & 2.0 & 2.0 \\
\hline Fluoranthene, dissolved & 1 & 4 & 1 & 1 & 5.6 & 5.6 & 5.6 \\
\hline Naphthalene, dissolved & 1 & 4 & 1 & 1 & 4.0 & 4.0 & 4.0 \\
\hline Phenanthrene, dissolved & 1 & 4 & 1 & 1 & 6.5 & 6.5 & 6.5 \\
\hline Phenanthrene, whole water & 1 & 7 & 2 & 2 & 4.3 & 31 & 58 \\
\hline Pyrene, dissolved & 1 & 4 & 1 & 1 & 0 & 0 & 0 \\
\hline Cholesterol, dissolved & 1 & 4 & 2 & 2 & 0 & 16 & 32 \\
\hline Cholesterol, whole water & 2 & 7 & 6 & 5 & 1.9 & 29 & 49 \\
\hline
\end{tabular}

${ }^{1}$ When compound was detected at concentrations greater than the study reporting level in either sample of a primary/replicate sample pair, compound was always detected in both samples; median relative percent difference acceptable (less than 40 percent); field replicate results judged to be acceptable.

${ }^{2}$ For one primary/replicate sample pair, compound was detected at a concentration greater than the study reporting level in either the primary or replicate sample, but not both; median relative percent difference acceptable (less than 40 percent); all other quality-assurance/quality-control results for compound were acceptable; field replicate results judged to be acceptable.

${ }^{3}$ Compound was detected at a concentration greater than the study reporting level in both samples of a single primary/replicate sample pair; relative percent difference exceeded 40 percent; all other quality-assurance/quality-control results for compound were acceptable; field replicate results judged to be acceptable.

${ }^{4}$ Compound was detected at a concentration greater than the study reporting level in multiple primary/replicate sample pairs; median relative percent difference exceeded 40 percent; compound excluded from analyses and discussion related to occurrence of emerging contaminants in drinking water, wastewater effluents, and the Big Sioux River. 
Table 13. Statistical summaries for environmental matrix-spike samples.

[Bold text indicates suspected endocrine-disrupting compound (EDC). Analytical method number: 1, Cahill and others (2004); 3, Lee and others (2004); 4, Zaugg and others (2002). RSD, relative standard deviation]

\begin{tabular}{|c|c|c|c|c|c|c|c|}
\hline Compound & $\begin{array}{l}\text { Analytical } \\
\text { method } \\
\text { number }\end{array}$ & Footnote & $\begin{array}{l}\text { Number of } \\
\text { matrix spike } \\
\text { samples }\end{array}$ & $\begin{array}{l}\text { Minimum } \\
\text { percent } \\
\text { recovery }\end{array}$ & $\begin{array}{l}\text { Median } \\
\text { percent } \\
\text { recovery }\end{array}$ & $\begin{array}{c}\text { Maximum } \\
\text { percent } \\
\text { recovery }\end{array}$ & $\begin{array}{c}\text { Percent } \\
\text { recovery } \\
\text { RSD }\end{array}$ \\
\hline \multicolumn{8}{|c|}{ Human pharmaceutical compounds (HPCs) } \\
\hline 1,7-Dimethylxanthine, dissolved & 1 & 1 & 10 & 42 & 60 & 71 & 16 \\
\hline Acetaminophen, dissolved & 1 & 3 & 10 & -9.3 & 40 & 52 & 46 \\
\hline Caffeine, dissolved & 1 & 2 & 10 & 29 & 33 & 45 & 15 \\
\hline Caffeine, whole water & 3 & 1 & 3 & 89 & 94 & 100 & 7.7 \\
\hline Carbamazepine, dissolved & 1 & 3 & 10 & 4.9 & 19 & 33 & 48 \\
\hline Cimetidine, dissolved & 1 & 3 & 10 & 8.3 & 23 & 32 & 44 \\
\hline Codeine, dissolved & 1 & 3 & 10 & 38 & 70 & 140 & 49 \\
\hline Cotinine, dissolved & 1 & 2 & 10 & 31 & 41 & 56 & 23 \\
\hline Diltiazem, dissolved & 1 & 3 & 10 & 5.9 & 12 & 30 & 60 \\
\hline Diphenhydramine, dissolved & 1 & 3 & 10 & 8.2 & 11 & 29 & 55 \\
\hline Fluoxetine, dissolved & 1 & 3 & 10 & 0 & .22 & 20 & 250 \\
\hline Furosemide, dissolved & 1 & 3 & 10 & 0 & 8.0 & 49 & 120 \\
\hline Gemfibrozil, dissolved & 1 & 3 & 10 & 0 & 0 & 17 & 210 \\
\hline Ibuprofen, dissolved & 1 & 3 & 10 & 0 & 0 & 35 & 320 \\
\hline Metformin, dissolved & 1 & 3 & 10 & 0 & 1.5 & 9.3 & 120 \\
\hline Miconazole, dissolved & 1 & 3 & 10 & 0 & 0 & 30 & 320 \\
\hline Ranitidine, dissolved & 1 & 3 & 10 & 0 & 11 & 42 & 78 \\
\hline Salbutamol, dissolved & 1 & 1 & 10 & 33 & 51 & 64 & 24 \\
\hline Trimethoprim, dissolved & 1 & 3 & 9 & 10 & 18 & 32 & 40 \\
\hline \multicolumn{8}{|c|}{ Major agricultural herbicides (MAHs) } \\
\hline Atrazine, whole water & 3 & 1 & 3 & 110 & 120 & 160 & 19 \\
\hline Metolachlor, dissolved & 4 & 1 & 3 & 88 & 96 & 110 & 9.9 \\
\hline Metolachlor, whole water & 3 & 1 & 3 & 53 & 69 & 82 & 21 \\
\hline Prometon, dissolved & 4 & 1 & 3 & 100 & 110 & 120 & 7.2 \\
\hline Prometon, whole water & 3 & 1 & 3 & 80 & 100 & 110 & 15 \\
\hline \multicolumn{8}{|c|}{ Household, industrial, and minor agricultural use compounds (HIACs) } \\
\hline 1,4-Dichlorobenzene, dissolved & 4 & 1 & 3 & 69 & 69 & 84 & 12 \\
\hline 1,4-Dichlorobenzene, whole water & 3 & 3 & 3 & 23 & 23 & 45 & 42 \\
\hline $\begin{array}{l}\mathbf{2 , 2}, \mathbf{4}, \mathbf{4}^{\prime} \text {-Tetrabromodiphenyl ether, } \\
\text { whole water }\end{array}$ & 3 & 1 & 3 & 58 & 72 & 72 & 12 \\
\hline 3,4-Dichlorophenyl isocyanate, whole & 3 & 3 & 3 & 39 & 110 & 230 & 78 \\
\hline
\end{tabular}


Table 13. Statistical summaries for environmental matrix-spike samples. - Continued

[Bold text indicates suspected endocrine-disrupting compound (EDC). Analytical method number: 1, Cahill and others (2004); 3, Lee and others (2004); 4, Zaugg and others (2002). RSD, relative standard deviation]

\begin{tabular}{|c|c|c|c|c|c|c|c|}
\hline Compound & $\begin{array}{l}\text { Analytical } \\
\text { method } \\
\text { number }\end{array}$ & Footnote & $\begin{array}{l}\text { Number of } \\
\text { matrix spike } \\
\text { samples }\end{array}$ & $\begin{array}{l}\text { Minimum } \\
\text { percent } \\
\text { recovery }\end{array}$ & $\begin{array}{l}\text { Median } \\
\text { percent } \\
\text { recovery }\end{array}$ & $\begin{array}{l}\text { Maximum } \\
\text { percent } \\
\text { recovery }\end{array}$ & $\begin{array}{l}\text { Percent } \\
\text { recovery } \\
\text { RSD }\end{array}$ \\
\hline 3-Methyl-1H-indole (skatol), dissolved & 4 & 1 & 3 & 95 & 97 & 100 & 5.2 \\
\hline 3-Methyl-1H-indole (skatol), whole water & 3 & 1 & 3 & 62 & 81 & 85 & 16 \\
\hline $\begin{array}{l}\text { 3-tert-Butyl-4-hydroxy anisole (BHA), } \\
\text { dissolved }\end{array}$ & 4 & 1 & 3 & 84 & 87 & 92 & 4.9 \\
\hline $\begin{array}{l}\text { 3-tert-Butyl-4-hydroxy anisole (BHA), } \\
\text { whole water }\end{array}$ & 3 & 3 & 3 & 3.0 & 7.2 & 63 & 140 \\
\hline 4-Cumylphenol, dissolved & 4 & 1 & 3 & 100 & 110 & 120 & 11 \\
\hline 4-Cumylphenol, whole water & 3 & 1 & 3 & 71 & 98 & 100 & 19 \\
\hline 4-normal-Octylphenol, dissolved & 4 & 1 & 3 & 71 & 100 & 110 & 21 \\
\hline 5-Methyl-1H-benzotriazole, dissolved & 4 & 3 & 3 & 180 & 210 & 220 & 10 \\
\hline 5-Methyl-1H-benzotriazole, whole water & 3 & 2 & 3 & 130 & 140 & 200 & 23 \\
\hline $\begin{array}{l}\text { 7-Acetyl-1,1,3,4,4,6-hexamethyl } \\
\text { tetrahydronaphthalene (AHTN), } \\
\text { dissolved }\end{array}$ & 4 & 1 & 3 & 84 & 88 & 100 & 10 \\
\hline $\begin{array}{l}\text { 7-Acetyl-1,1,3,4,4,6-hexamethyl } \\
\text { tetrahydronaphthalene (AHTN), whole } \\
\text { water }\end{array}$ & 3 & 1 & 3 & 58 & 71 & 72 & 12 \\
\hline Acetophenone, dissolved & 4 & 1 & 3 & 100 & 100 & 110 & 3.1 \\
\hline Acetophenone, whole water & 3 & 1 & 3 & 67 & 81 & 98 & 20 \\
\hline Bromacil, dissolved & 4 & 3 & 3 & 100 & 130 & 130 & 11 \\
\hline Bromacil, whole water & 3 & 1 & 3 & 78 & 110 & 110 & 17 \\
\hline Camphor, dissolved & 4 & 1 & 3 & 94 & 96 & 100 & 3.7 \\
\hline Camphor, whole water & 3 & 1 & 3 & 62 & 81 & 94 & 20 \\
\hline Carbaryl, dissolved & 4 & 1 & 3 & 78 & 83 & 96 & 11 \\
\hline Carbaryl, whole water & 3 & 3 & 3 & 140 & 150 & 170 & 10 \\
\hline Chlorpyrifos, dissolved & 4 & 1 & 3 & 63 & 87 & 97 & 21 \\
\hline Chlorpyrifos, whole water & 3 & 1 & 3 & 44 & 63 & 72 & 23 \\
\hline $\begin{array}{l}\text { N,N-Diethyl-meta-toluamide (DEET), } \\
\text { dissolved }\end{array}$ & 4 & 1 & 3 & 96 & 100 & 110 & 8.4 \\
\hline $\begin{array}{l}\text { N,N-Diethyl-meta-toluamide (DEET), } \\
\text { whole water }\end{array}$ & 3 & 1 & 3 & 67 & 92 & 99 & 20 \\
\hline Diazinon, dissolved & 4 & 1 & 3 & 96 & 96 & 100 & 3.1 \\
\hline Diazinon, whole water & 3 & 1 & 3 & 62 & 81 & 90 & 18 \\
\hline Dichlorvos, dissolved & 4 & 3 & 3 & 13 & 16 & 21 & 23 \\
\hline Dichlorvos, whole water & 3 & 1 & 3 & 75 & 94 & 94 & 12 \\
\hline Diethyl phthalate, whole water & 3 & 1 & 3 & 71 & 90 & 94 & 15 \\
\hline
\end{tabular}


Table 13. Statistical summaries for environmental matrix-spike samples. - Continued

[Bold text indicates suspected endocrine-disrupting compound (EDC). Analytical method number: 1, Cahill and others (2004); 3, Lee and others (2004); 4, Zaugg and others (2002). RSD, relative standard deviation]

\begin{tabular}{|c|c|c|c|c|c|c|c|}
\hline Compound & $\begin{array}{l}\text { Analytical } \\
\text { method } \\
\text { number }\end{array}$ & Footnote & $\begin{array}{c}\text { Number of } \\
\text { matrix spike } \\
\text { samples }\end{array}$ & $\begin{array}{l}\text { Minimum } \\
\text { percent } \\
\text { recovery }\end{array}$ & $\begin{array}{l}\text { Median } \\
\text { percent } \\
\text { recovery }\end{array}$ & $\begin{array}{l}\text { Maximum } \\
\text { percent } \\
\text { recovery }\end{array}$ & $\begin{array}{l}\text { Percent } \\
\text { recovery } \\
\text { RSD }\end{array}$ \\
\hline D-Limonene, dissolved & 4 & 3 & 3 & 42 & 43 & 46 & 4.8 \\
\hline D-Limonene, whole water & 3 & 3 & 3 & 7.1 & 7.6 & 24 & 75 \\
\hline $\begin{array}{l}\text { 1,3,4,6,7,8-Hexahydro-4,6,6,7,8,8- } \\
\text { hexamethyl cyclopenta-g-2- } \\
\text { benzopyran (HHCB), whole water }\end{array}$ & 3 & 1 & 3 & 53 & 79 & 81 & 22 \\
\hline Indole, dissolved & 4 & 1 & 3 & 84 & 87 & 97 & 7.7 \\
\hline Isophorone, whole water & 3 & 1 & 3 & 67 & 90 & 94 & 18 \\
\hline Isopropylbenzene (cumene), dissolved & 4 & 3 & 3 & 46 & 46 & 59 & 15 \\
\hline Isopropylbenzene (cumene), whole water & 3 & 3 & 3 & 10 & 10 & 26 & 57 \\
\hline Isoquinoline, dissolved & 4 & 1 & 3 & 88 & 91 & 100 & 7.5 \\
\hline Isoquinoline, whole water & 3 & 1 & 3 & 62 & 76 & 81 & 13 \\
\hline Menthol, dissolved & 4 & 1 & 3 & 88 & 110 & 120 & 15 \\
\hline Menthol, whole water & 3 & 1 & 3 & 67 & 81 & 85 & 13 \\
\hline Metalaxyl, dissolved & 4 & 1 & 3 & 96 & 100 & 110 & 7.0 \\
\hline Metalaxyl, whole water & 3 & 1 & 3 & 62 & 94 & 100 & 25 \\
\hline $\begin{array}{l}\text { Octylphenol diethoxylate (OP2EO), } \\
\text { dissolved }\end{array}$ & 4 & 1 & 3 & 78 & 100 & 110 & 17 \\
\hline $\begin{array}{l}\text { Octylphenol diethoxylate (OP2EO), } \\
\text { whole water }\end{array}$ & 3 & 1 & 3 & 72 & 84 & 91 & 12 \\
\hline $\begin{array}{l}\text { Octylphenol monoethoxylate (OP1EO), } \\
\text { dissolved }\end{array}$ & 4 & 1 & 3 & 60 & 95 & 100 & 27 \\
\hline $\begin{array}{l}\text { Octylphenol monoethoxylate (OP1EO), } \\
\text { whole water }\end{array}$ & 3 & 1 & 3 & 54 & 69 & 77 & 18 \\
\hline para-Cresol, dissolved & 4 & 1 & 3 & 91 & 100 & 110 & 7.4 \\
\hline para-Cresol, whole water & 3 & 1 & 3 & 75 & 85 & 85 & 6.9 \\
\hline para-Nonylphenol (NP), dissolved & 4 & 1 & 3 & 77 & 96 & 100 & 16 \\
\hline para-Nonylphenol (NP), whole water & 3 & 1 & 3 & 76 & 85 & 92 & 9.3 \\
\hline Pentachlorophenol, dissolved & 4 & 1 & 3 & 83 & 88 & 93 & 5.6 \\
\hline Pentachlorophenol, whole water & 3 & 1 & 3 & 83 & 85 & 85 & 1.7 \\
\hline Phenol, dissolved & 4 & 1 & 3 & 93 & 100 & 110 & 8.6 \\
\hline
\end{tabular}


Table 13. Statistical summaries for environmental matrix-spike samples. - Continued

[Bold text indicates suspected endocrine-disrupting compound (EDC). Analytical method number: 1, Cahill and others (2004); 3, Lee and others (2004); 4, Zaugg and others (2002). RSD, relative standard deviation]

\begin{tabular}{|c|c|c|c|c|c|c|c|}
\hline Compound & $\begin{array}{l}\text { Analytical } \\
\text { method } \\
\text { number }\end{array}$ & Footnote & $\begin{array}{c}\text { Number of } \\
\text { matrix spike } \\
\text { samples }\end{array}$ & $\begin{array}{c}\text { Minimum } \\
\text { percent } \\
\text { recovery }\end{array}$ & $\begin{array}{l}\text { Median } \\
\text { percent } \\
\text { recovery }\end{array}$ & $\begin{array}{l}\text { Maximum } \\
\text { percent } \\
\text { recovery }\end{array}$ & $\begin{array}{c}\text { Percent } \\
\text { recovery } \\
\text { RSD }\end{array}$ \\
\hline Phenol, whole water & 3 & 1 & 3 & 58 & 72 & 90 & 22 \\
\hline Tetrachloroethylene, dissolved & 4 & 3 & 3 & 27 & 37 & 46 & 26 \\
\hline Tributyl phosphate, whole water & 3 & 1 & 3 & 62 & 81 & 94 & 20 \\
\hline Triclosan, dissolved & 4 & 1 & 3 & 92 & 110 & 110 & 11 \\
\hline Triclosan, whole water & 3 & 1 & 3 & 110 & 110 & 120 & 4.9 \\
\hline Triethyl citrate (ethyl citrate), dissolved & 4 & 1 & 3 & 110 & 110 & 130 & 7.9 \\
\hline Triethyl citrate (ethyl citrate), whole water & 3 & 1 & 3 & 80 & 93 & 99 & 11 \\
\hline Tri(2-butoxyethyl)phosphate, whole water & 3 & 1 & 3 & 80 & 88 & 90 & 6.1 \\
\hline Tri(2-chloroethyl)phosphate, dissolved & 4 & 1 & 3 & 100 & 110 & 120 & 5.2 \\
\hline Tri(2-chloroethyl)phosphate, whole water & 3 & 1 & 3 & 80 & 100 & 100 & 14 \\
\hline Tri(dichloroisopropyl)phosphate, dissolved & 4 & 1 & 3 & 110 & 120 & 120 & 4.9 \\
\hline $\begin{array}{l}\text { Tri(dichloroisopropyl)phosphate, whole } \\
\text { water }\end{array}$ & 3 & 1 & 3 & 98 & 110 & 110 & 7.0 \\
\hline \multicolumn{8}{|c|}{ Polyaromatic hydrocarbons (PAHs) } \\
\hline 1-Methylnaphthalene, dissolved & 4 & 1 & 3 & 86 & 89 & 92 & 3.6 \\
\hline 1-Methylnaphthalene, whole water & 3 & 3 & 3 & 44 & 49 & 72 & 26 \\
\hline Benzo $[a]$ pyrene, whole water & 3 & 1 & 3 & 53 & 63 & 67 & 12 \\
\hline Carbazole, dissolved & 4 & 1 & 3 & 120 & 120 & 130 & 5.7 \\
\hline Carbazole, whole water & 3 & 1 & 3 & 84 & 99 & 110 & 14 \\
\hline Fluoranthene, dissolved & 4 & 1 & 3 & 82 & 99 & 110 & 13 \\
\hline Fluoranthene, whole water & 3 & 1 & 3 & 71 & 75 & 95 & 16 \\
\hline Naphthalene, dissolved & 4 & 1 & 3 & 75 & 77 & 80 & 3.4 \\
\hline Naphthalene, whole water & 3 & 3 & 3 & 40 & 44 & 67 & 29 \\
\hline Phenanthrene, dissolved & 4 & 1 & 3 & 90 & 95 & 100 & 5.5 \\
\hline Phenanthrene, whole water & 3 & 1 & 3 & 70 & 71 & 87 & 13 \\
\hline Pyrene, dissolved & 4 & 1 & 3 & 66 & 86 & 88 & 15 \\
\hline Pyrene, whole water & 3 & 1 & 3 & 58 & 62 & 82 & 19 \\
\hline \multicolumn{8}{|c|}{ Sterol compounds (SCs) } \\
\hline 3-beta-Coprostanol, dissolved & 4 & 1 & 3 & 70 & 92 & 95 & 16 \\
\hline 3-beta-Coprostanol, whole water & 3 & 1 & 3 & 73 & 100 & 100 & 20 \\
\hline beta-Sitosterol, dissolved & 4 & 1 & 3 & 58 & 93 & 95 & 26 \\
\hline
\end{tabular}




\section{Organic Wastewater Compounds in Drinking Water, Wastewater Effluent, and the Big Sioux River, 2001-2004}

Table 13. Statistical summaries for environmental matrix-spike samples.-Continued

[Bold text indicates suspected endocrine-disrupting compound (EDC). Analytical method number: 1, Cahill and others (2004); 3, Lee and others (2004); 4, Zaugg and others (2002). RSD, relative standard deviation]

\begin{tabular}{|c|c|c|c|c|c|c|c|}
\hline Compound & $\begin{array}{c}\text { Analytical } \\
\text { method } \\
\text { number }\end{array}$ & Footnote & $\begin{array}{c}\text { Number of } \\
\text { matrix spike } \\
\text { samples }\end{array}$ & $\begin{array}{l}\text { Minimum } \\
\text { percent } \\
\text { recovery }\end{array}$ & $\begin{array}{l}\text { Median } \\
\text { percent } \\
\text { recovery }\end{array}$ & $\begin{array}{c}\text { Maximum } \\
\text { percent } \\
\text { recovery }\end{array}$ & $\begin{array}{c}\text { Percent } \\
\text { recovery } \\
\text { RSD }\end{array}$ \\
\hline \multicolumn{8}{|c|}{ Sterol compounds (SCs)_-Continued } \\
\hline beta-Sitosterol, whole water & 3 & 2 & 3 & 140 & 160 & 210 & 21 \\
\hline beta-Stigmastanol, dissolved & 4 & 1 & 3 & 53 & 78 & 91 & 26 \\
\hline Cholesterol, whole water & 3 & 1 & 3 & 82 & 90 & 120 & 21 \\
\hline
\end{tabular}

${ }^{1}$ Median spike recovery within acceptable range (50-120 percent), and median spike recovery RSD acceptable (less than 40 percent); matrix-spike results judged to be acceptable.

${ }^{2}$ Median spike recovery outside acceptable range (50-120 percent), but median spike recovery RSD acceptable (less than 40 percent) and all other qualityassurance/quality-control results acceptable; matrix-spike results judged to be acceptable.

${ }^{3}$ Median spike recovery outside of acceptable range ( 50-120 percent), and/or median spike recovery RSD unacceptable (greater than 40 percent); compound excluded from analyses and discussion related to occurrence of organic wastewater compounds in Big Sioux River and wastewater effluents. 
Table 14. Results for field-measured properties and constituents in water samples.

$\left[\mathrm{ft}^{3} / \mathrm{s}\right.$, cubic feet per second; NTU, nephelometric turbidity units; mm Hg, millimeter of mercury; $\mathrm{mg} / \mathrm{L}$, milligrams per liter; $\mu \mathrm{S} / \mathrm{cm}$, microsiemens per centimeter at 25 degrees Celsius; ${ }^{\circ} \mathrm{C}$, degrees Celsius; e, estimated; $<$, less than; --, no data collected]

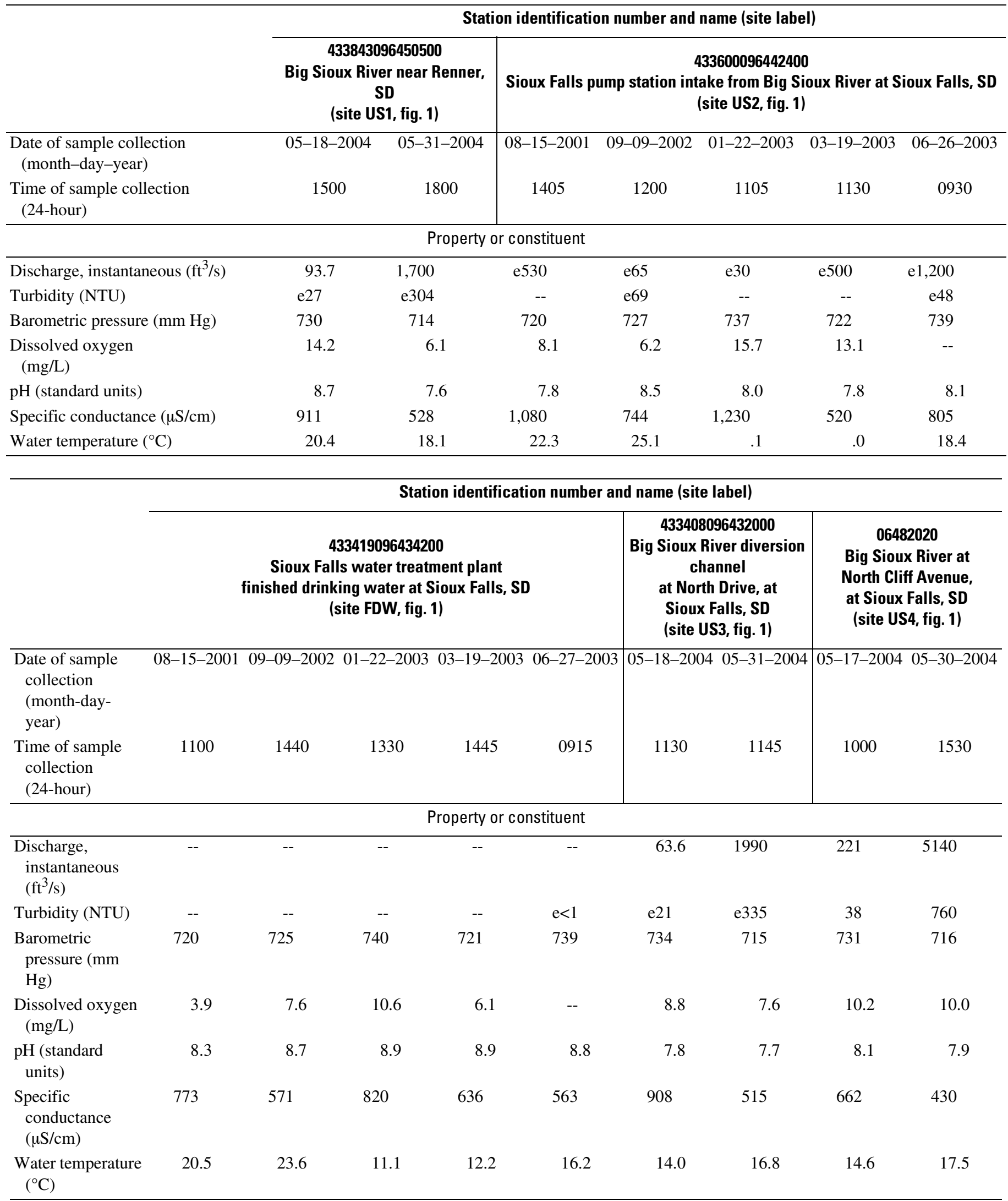




\section{Organic Wastewater Compounds in Drinking Water, Wastewater Effluent, and the Big Sioux River, 2001-2004}

Table 14. Results for field-measured properties and constituents in water samples.-Continued

$\left[\mathrm{ft}^{3} / \mathrm{s}\right.$, cubic feet per second; NTU, nephelometric turbidity units; mm Hg, millimeter of mercury; $\mathrm{mg} / \mathrm{L}$, milligrams per liter; $\mu \mathrm{S} / \mathrm{cm}$, microsiemens per centimeter at 25 degrees Celsius; ${ }^{\circ} \mathrm{C}$, degrees Celsius; e, estimated; <, less than; --, no data collected]

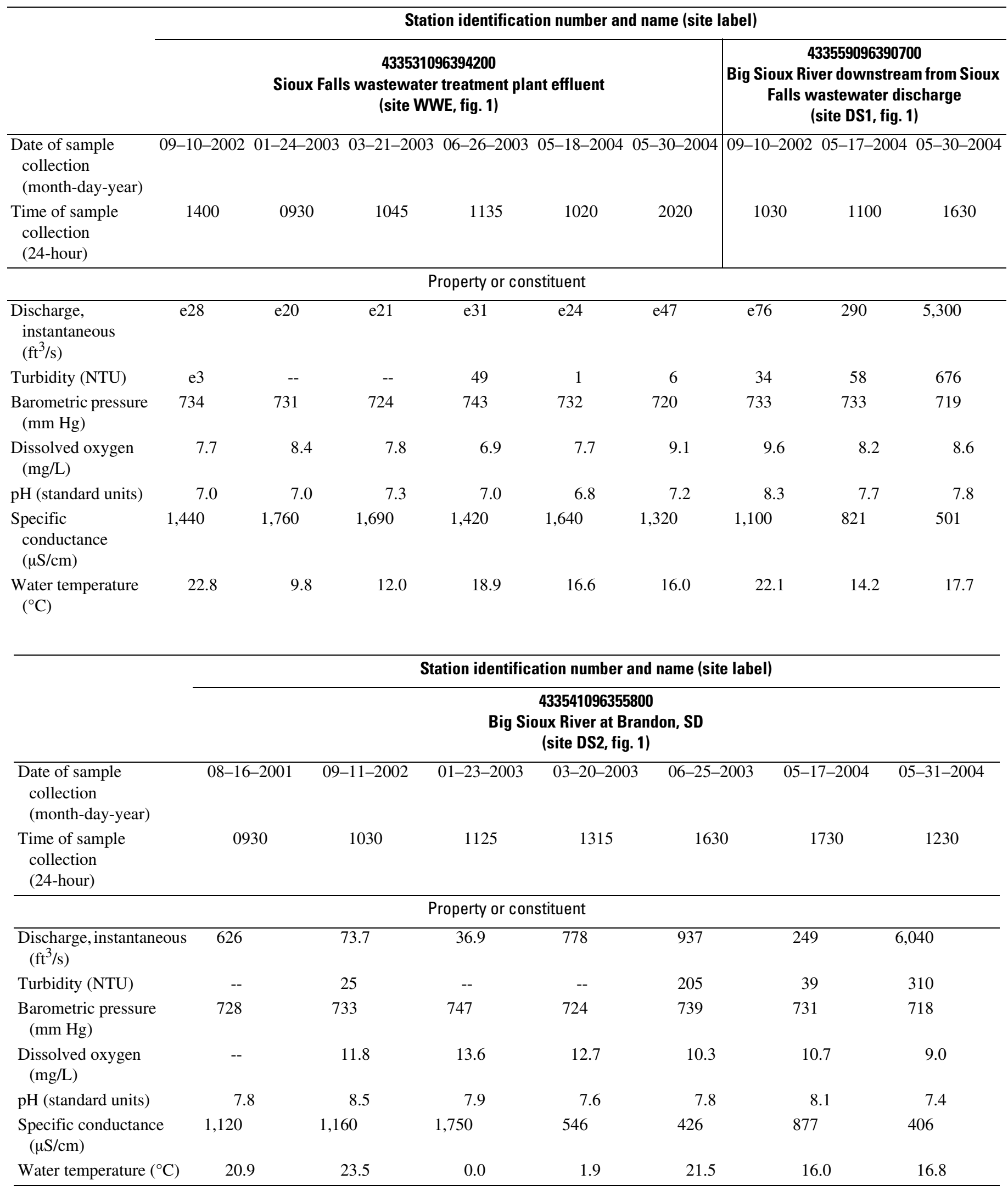


Table 15. Analytical results for human pharmaceutical compounds (HPCs) in water samples.

[Bold text indicates suspected endocrine-disrupting compound (EDC). Shaded cells indicate concentrations greater than study reporting levels for compounds with acceptable quality assurance/quality control, and concentrations were used in analyses related to occurrence of organic wastewater compounds. Units are micrograms per liter. Analytical method number: 1, Cahill and others (2004); 3, Lee and others (2004); 4, Zaugg and others (2002). ND, not determined; UD, undetected, laboratory reporting level not determined; e, estimated; <, less than; --, no data collected]

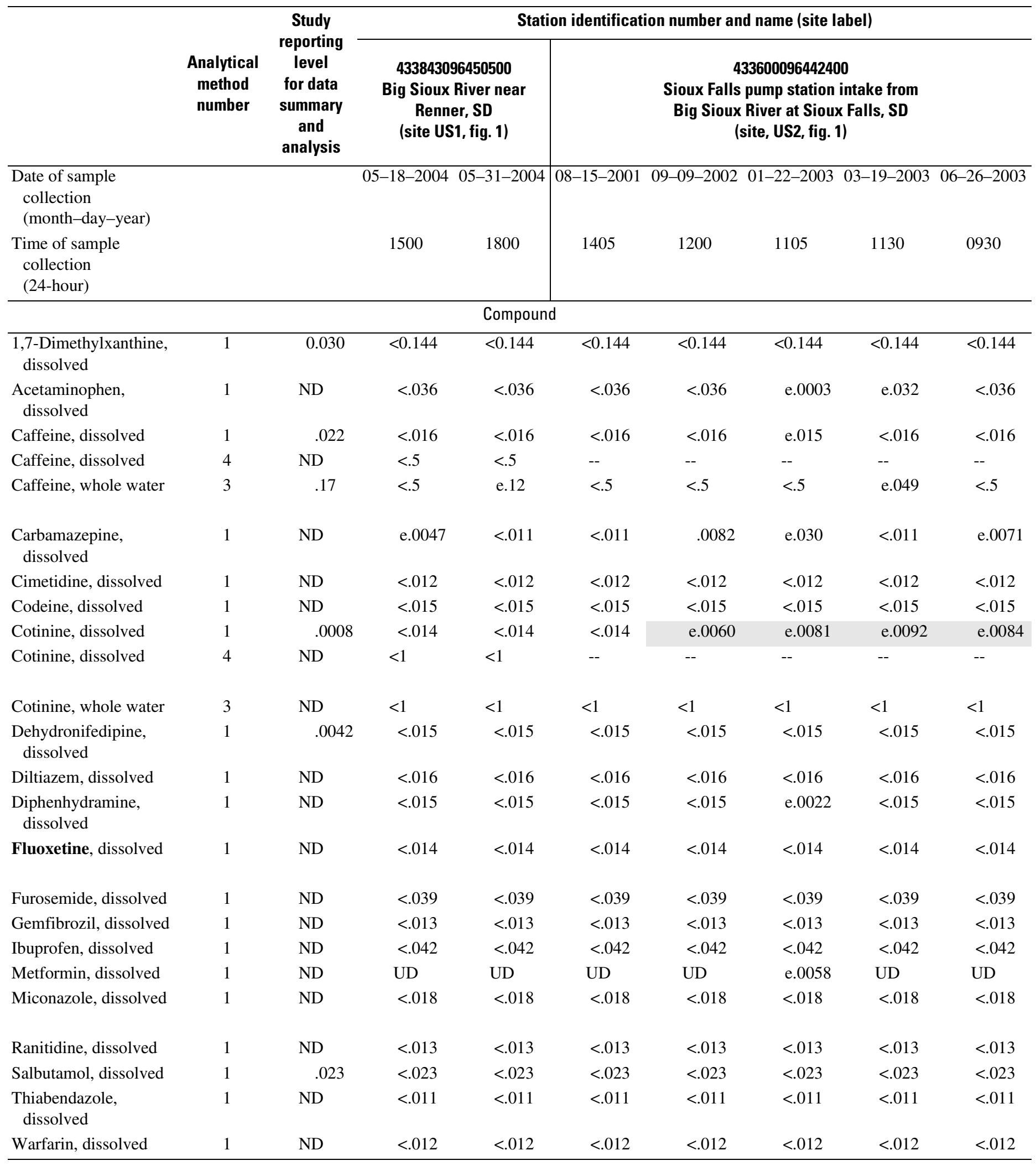




\section{Organic Wastewater Compounds in Drinking Water, Wastewater Effluent, and the Big Sioux River, 2001-2004}

Table 15. Analytical results for human pharmaceutical compounds (HPCs) in water samples.-Continued

[Bold text indicates suspected endocrine-disrupting compound (EDC). Shaded cells indicate concentrations greater than study reporting levels for compounds with acceptable quality assurance/quality control, and concentrations were used in analyses related to occurrence of organic wastewater compounds. Units are micrograms per liter. Analytical method number: 1, Cahill and others (2004); 3, Lee and others (2004); 4, Zaugg and others (2002). ND, not determined; UD, undetected, laboratory reporting level not determined; e, estimated; <, less than; --, no data collected]

\begin{tabular}{|c|c|c|c|c|c|c|c|}
\hline \multirow[b]{3}{*}{$\begin{array}{l}\text { Date of sample collection } \\
\text { (month-day-year) }\end{array}$} & \multirow{3}{*}{$\begin{array}{c}\text { Analytical } \\
\text { method } \\
\text { number }\end{array}$} & \multirow{3}{*}{$\begin{array}{c}\text { Study } \\
\text { reporting } \\
\text { level } \\
\text { for data } \\
\text { summary } \\
\text { and } \\
\text { analysis }\end{array}$} & \multicolumn{5}{|c|}{ Station identification number and name (site label) } \\
\hline & & & \multicolumn{5}{|c|}{$\begin{array}{c}433419096434200 \\
\text { Sioux Falls water treatment plant } \\
\text { finished drinking water at Sioux Falls, SD } \\
\text { (site FDW, fig. 1) }\end{array}$} \\
\hline & & & $08-15-2001$ & 09-09-2002 & $01-22-2003$ & $03-19-2003$ & $06-27-2003$ \\
\hline $\begin{array}{l}\text { Time of sample collection } \\
\text { (24-hour) }\end{array}$ & & & 1100 & 1440 & 1330 & 1445 & 0915 \\
\hline \multicolumn{8}{|c|}{ Compound } \\
\hline 1,7-Dimethylxanthine, dissolved & 1 & 0.030 & $<0.144$ & $<0.144$ & $<0.144$ & $<0.144$ & $<0.144$ \\
\hline Acetaminophen, dissolved & 1 & ND & $<.036$ & $<.036$ & $<.036$ & $<.036$ & $<.036$ \\
\hline Caffeine, dissolved & 1 & .022 & $<.016$ & $<.016$ & $<.016$ & $<.016$ & $<.016$ \\
\hline Caffeine, dissolved & 4 & ND & -- & -- & -- & -- & -- \\
\hline Caffeine, whole water & 3 & .17 & $<.5$ & $<.5$ & $<.5$ & $<.5$ & $<.5$ \\
\hline Carbamazepine, dissolved & 1 & ND & $<.011$ & $<.011$ & $<.011$ & $<.011$ & $<.011$ \\
\hline Cimetidine, dissolved & 1 & ND & $<.012$ & $<.012$ & $<.012$ & $<.012$ & $<.012$ \\
\hline Codeine, dissolved & 1 & ND & $<.015$ & $<.015$ & e.0058 & $<.015$ & $<.015$ \\
\hline Cotinine, dissolved & 1 & .0008 & $<.014$ & $<.014$ & $<.014$ & $<.014$ & $<.014$ \\
\hline Cotinine, dissolved & 4 & ND & -- & -- & -- & -- & -- \\
\hline Cotinine, whole water & 3 & ND & $<1$ & $<1$ & $<1$ & $<1$ & $<1$ \\
\hline Dehydronifedipine, dissolved & 1 & .0042 & $<.015$ & $<.015$ & e. 0020 & $<.015$ & $<.015$ \\
\hline Diltiazem, dissolved & 1 & ND & $<.016$ & $<.016$ & e.0017 & $<.016$ & $<.016$ \\
\hline Diphenhydramine, dissolved & 1 & ND & $<.015$ & $<.015$ & e. 0024 & $<.015$ & $<.015$ \\
\hline Fluoxetine, dissolved & 1 & ND & $<.014$ & $<.014$ & $<.014$ & $<.014$ & $<.014$ \\
\hline Furosemide, dissolved & 1 & ND & $<.039$ & $<.039$ & $<.039$ & $<.039$ & $<.039$ \\
\hline Gemfibrozil, dissolved & 1 & ND & $<.013$ & $<.013$ & $<.013$ & $<.013$ & $<.013$ \\
\hline Ibuprofen, dissolved & 1 & ND & $<.042$ & $<.042$ & $<.042$ & $<.042$ & $<.042$ \\
\hline Metformin, dissolved & 1 & ND & UD & UD & UD & UD & UD \\
\hline Miconazole, dissolved & 1 & ND & $<.018$ & $<.018$ & $<.018$ & $<.018$ & $<.018$ \\
\hline Ranitidine, dissolved & 1 & ND & $<.013$ & $<.013$ & $<.013$ & $<.013$ & $<.013$ \\
\hline Salbutamol, dissolved & 1 & .023 & $<.023$ & $<.023$ & $<.023$ & $<.023$ & $<.023$ \\
\hline Thiabendazole, dissolved & 1 & ND & $<.011$ & $<.011$ & $<.011$ & $<.011$ & $<.011$ \\
\hline Warfarin, dissolved & 1 & ND & $<.012$ & $<.012$ & $<.012$ & $<.012$ & $<.012$ \\
\hline
\end{tabular}


Table 15. Analytical results for human pharmaceutical compounds (HPCs) in water samples. - Continued

[Bold text indicates suspected endocrine-disrupting compound (EDC). Shaded cells indicate concentrations greater than study reporting levels for compounds with acceptable quality assurance/quality control, and concentrations were used in analyses related to occurrence of organic wastewater compounds. Units are micrograms per liter. Analytical method number: 1, Cahill and others (2004); 3, Lee and others (2004); 4, Zaugg and others (2002). ND, not determined; UD, undetected, laboratory reporting level not determined; e, estimated; <, less than; --, no data collected]

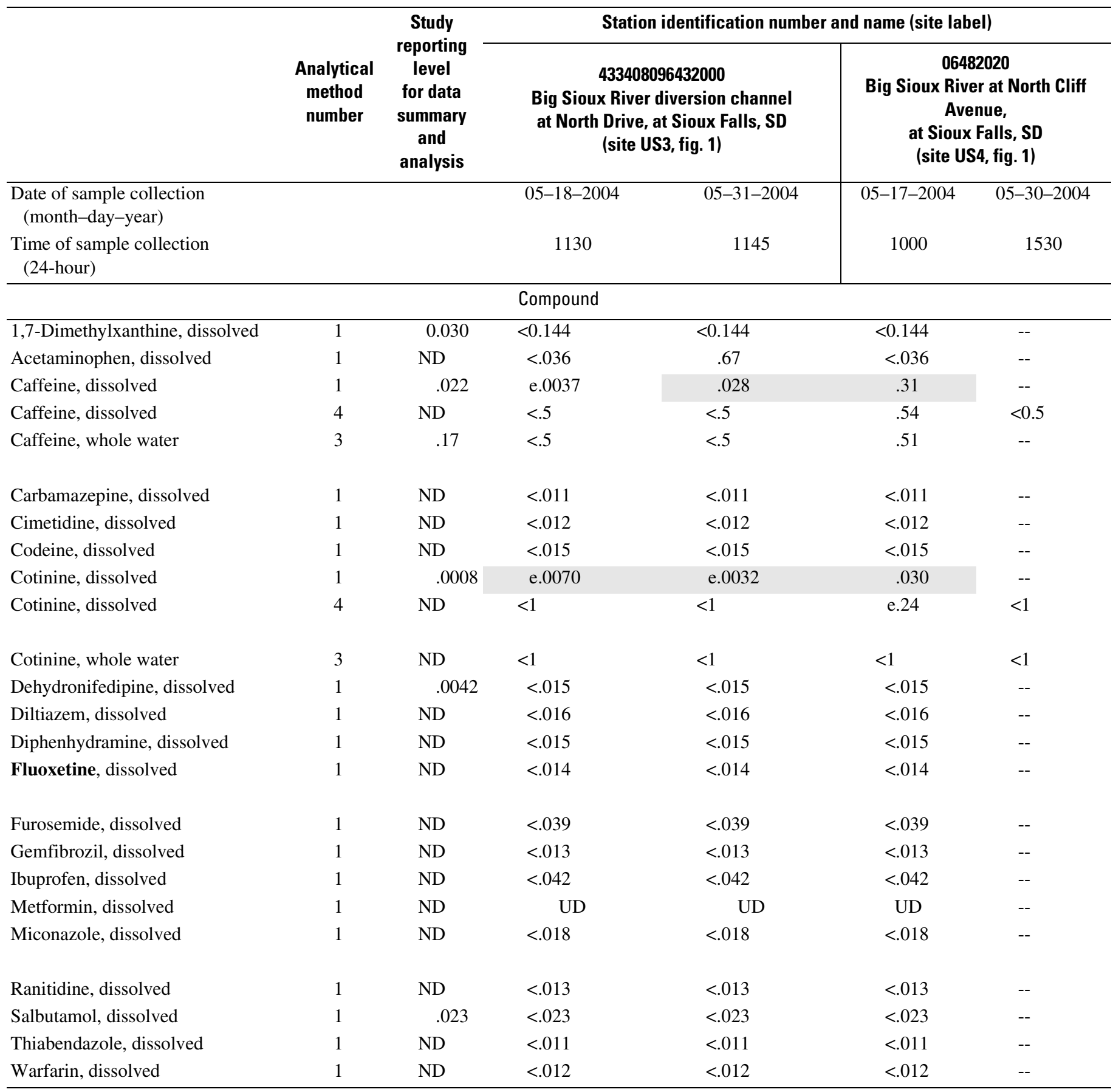


Table 15. Analytical results for human pharmaceutical compounds (HPCs) in water samples._-Continued

[Bold text indicates suspected endocrine-disrupting compound (EDC). Shaded cells indicate concentrations greater than study reporting levels for compounds with acceptable quality assurance/quality control, and concentrations were used in analyses related to occurrence of organic wastewater compounds. Units are micrograms per liter. Analytical method number: 1, Cahill and others (2004); 3, Lee and others (2004); 4, Zaugg and others (2002). ND, not determined; UD, undetected, laboratory reporting level not determined; e, estimated; <, less than; --, no data collected]

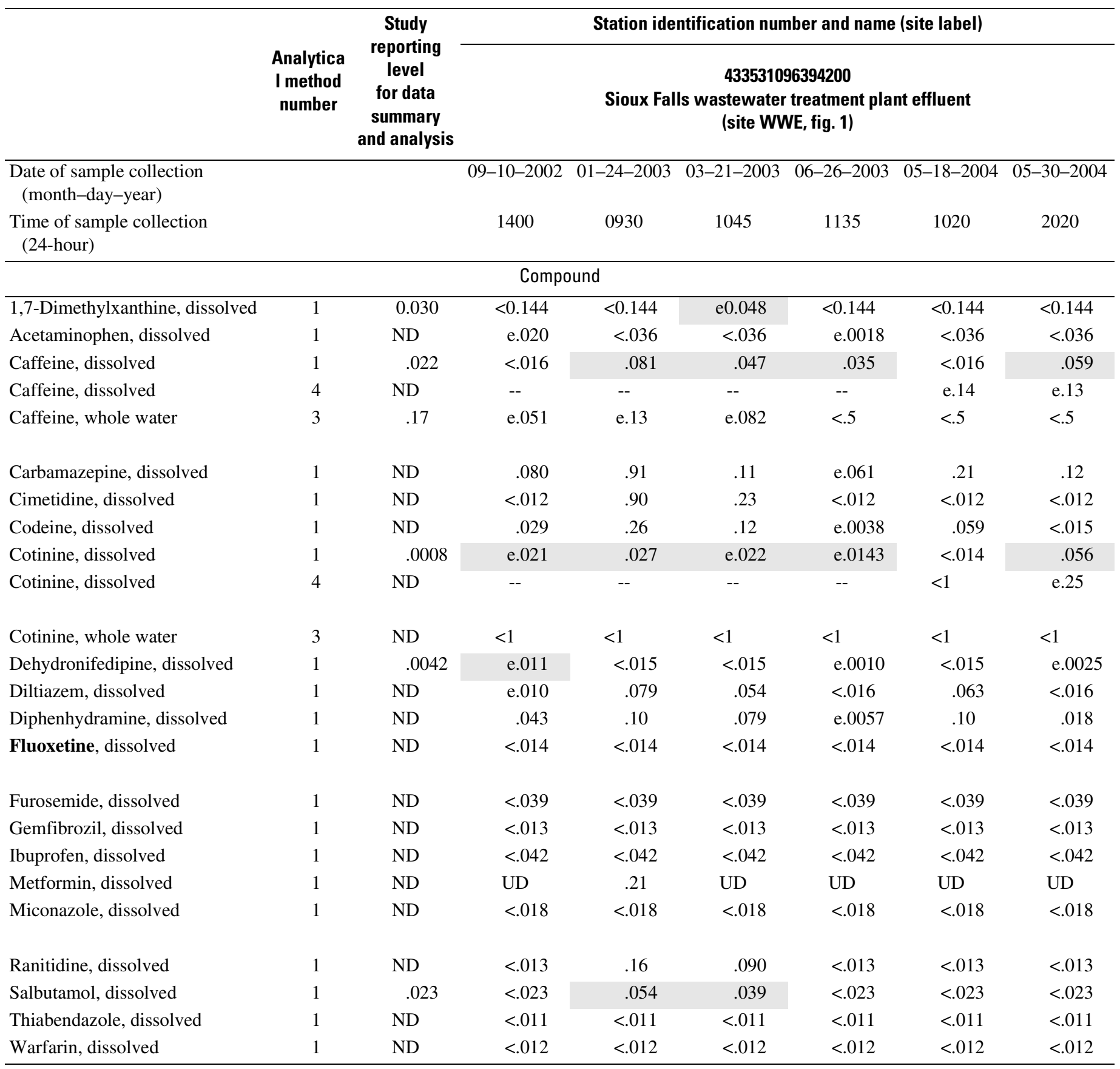


Table 15. Analytical results for human pharmaceutical compounds (HPCs) in water samples.-Continued

[Bold text indicates suspected endocrine-disrupting compound (EDC). Shaded cells indicate concentrations greater than study reporting levels for compounds with acceptable quality assurance/quality control, and concentrations were used in analyses related to occurrence of organic wastewater compounds. Units are micrograms per liter. Analytical method number: 1, Cahill and others (2004); 3, Lee and others (2004); 4, Zaugg and others (2002). ND, not determined; UD, undetected, laboratory reporting level not determined; e, estimated; <, less than; --, no data collected]

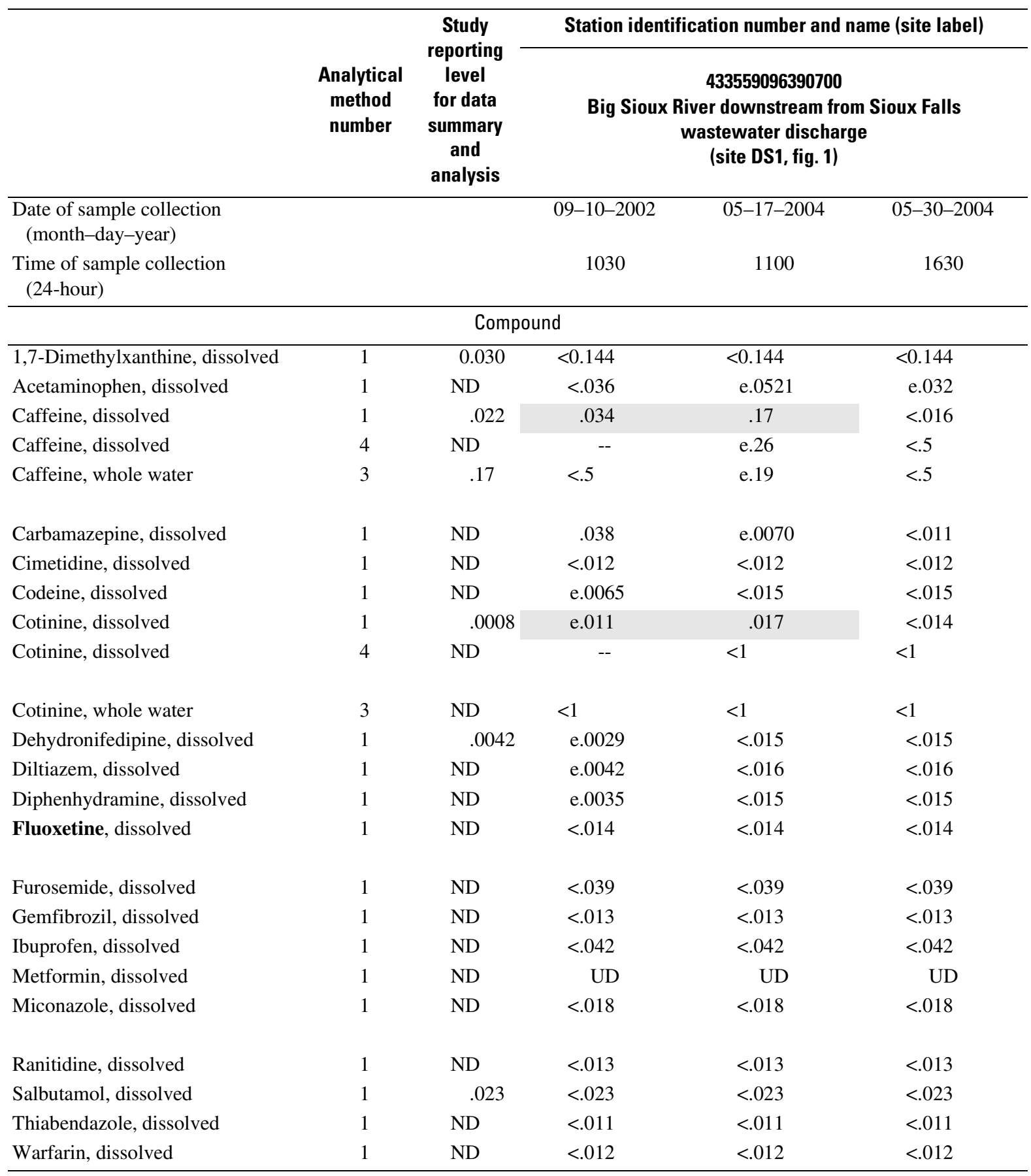


Table 15. Analytical results for human pharmaceutical compounds (HPCs) in water samples._- Continued

[Bold text indicates suspected endocrine-disrupting compound (EDC). Shaded cells indicate concentrations greater than study reporting levels for compounds with acceptable quality assurance/quality control, and concentrations were used in analyses related to occurrence of organic wastewater compounds. Units are micrograms per liter. Analytical method number: 1, Cahill and others (2004); 3, Lee and others (2004); 4, Zaugg and others (2002). ND, not determined; UD, undetected, laboratory reporting level not determined; e, estimated; <, less than; --, no data collected]

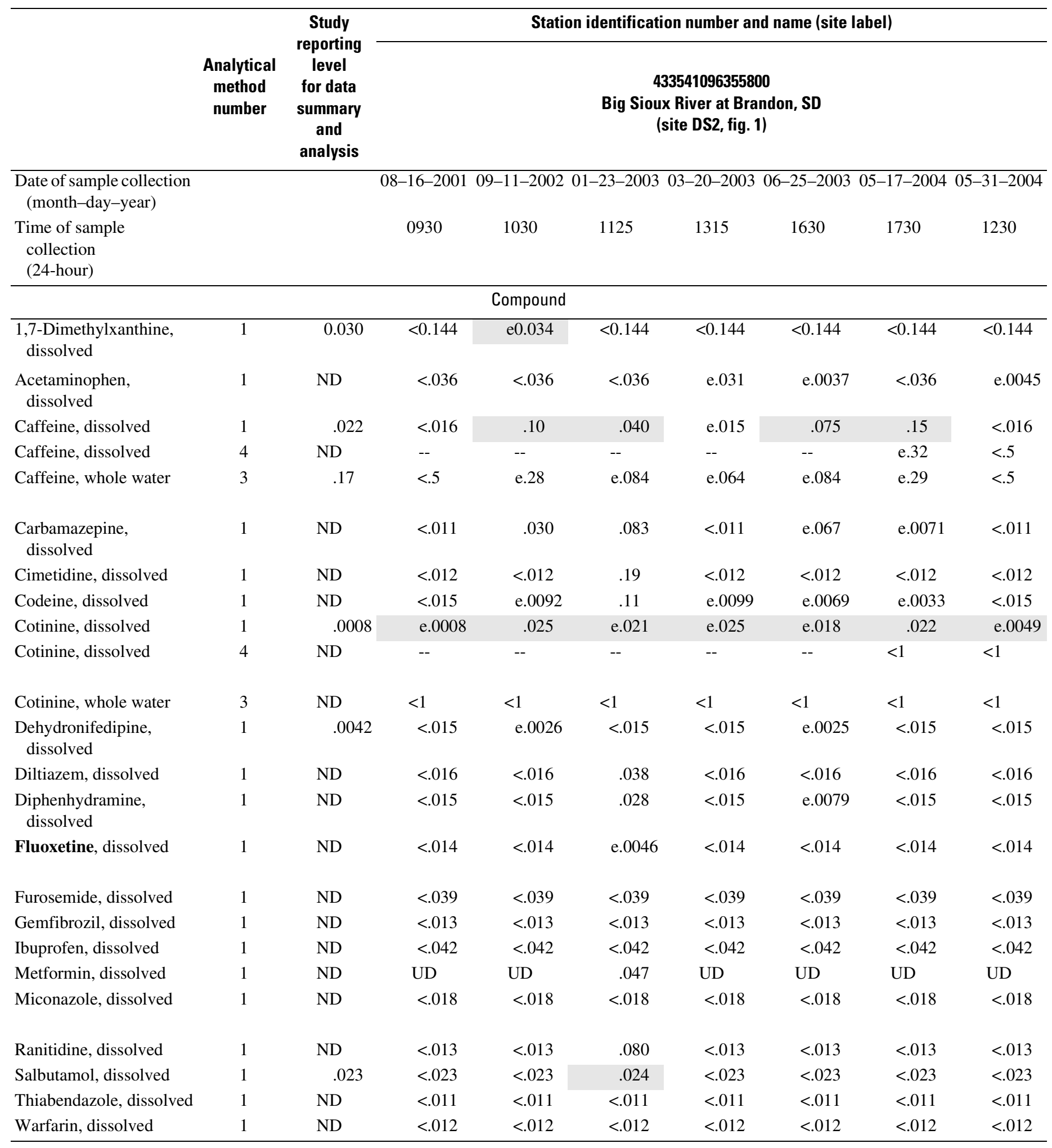


Table 16. Analytical results for human and veterinary antibiotic compounds (HVACs) in water samples.

[Shaded cells indicate concentrations greater than study reporting levels for compounds with acceptable quality assurance/quality control, and concentrations were used in analyses related to occurrence of organic wastewater compounds. Units are micrograms per liter. Analytical method number: 1, Cahill and others (2004); 2, U.S. Geological Survey Organic Geochemistry Research Laboratory. ND, not determined; e, estimated; <, less than; --, no data collected]

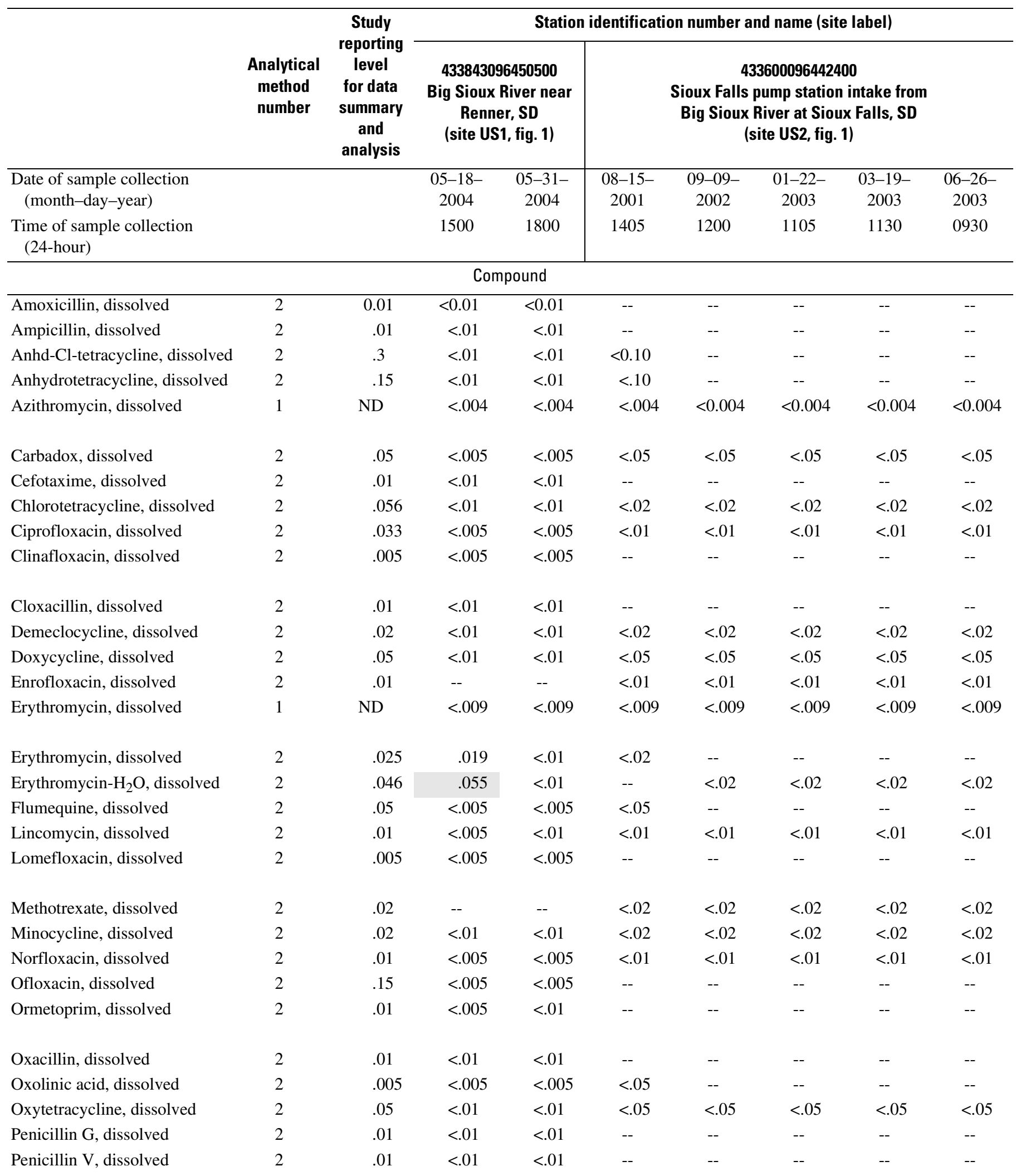


Table 16. Analytical results for human and veterinary antibiotic compounds (HVACs) in water samples.-Continued

[Shaded cells indicate concentrations greater than study reporting levels for compounds with acceptable quality assurance/quality control, and concentrations were used in analyses related to occurrence of organic wastewater compounds. Units are micrograms per liter. Analytical method number: 1, Cahill and others (2004); U.S. Geological Survey Organic Geochemistry Research Laboratory. ND, not determined; e, estimated; <, less than; --, no data collected]

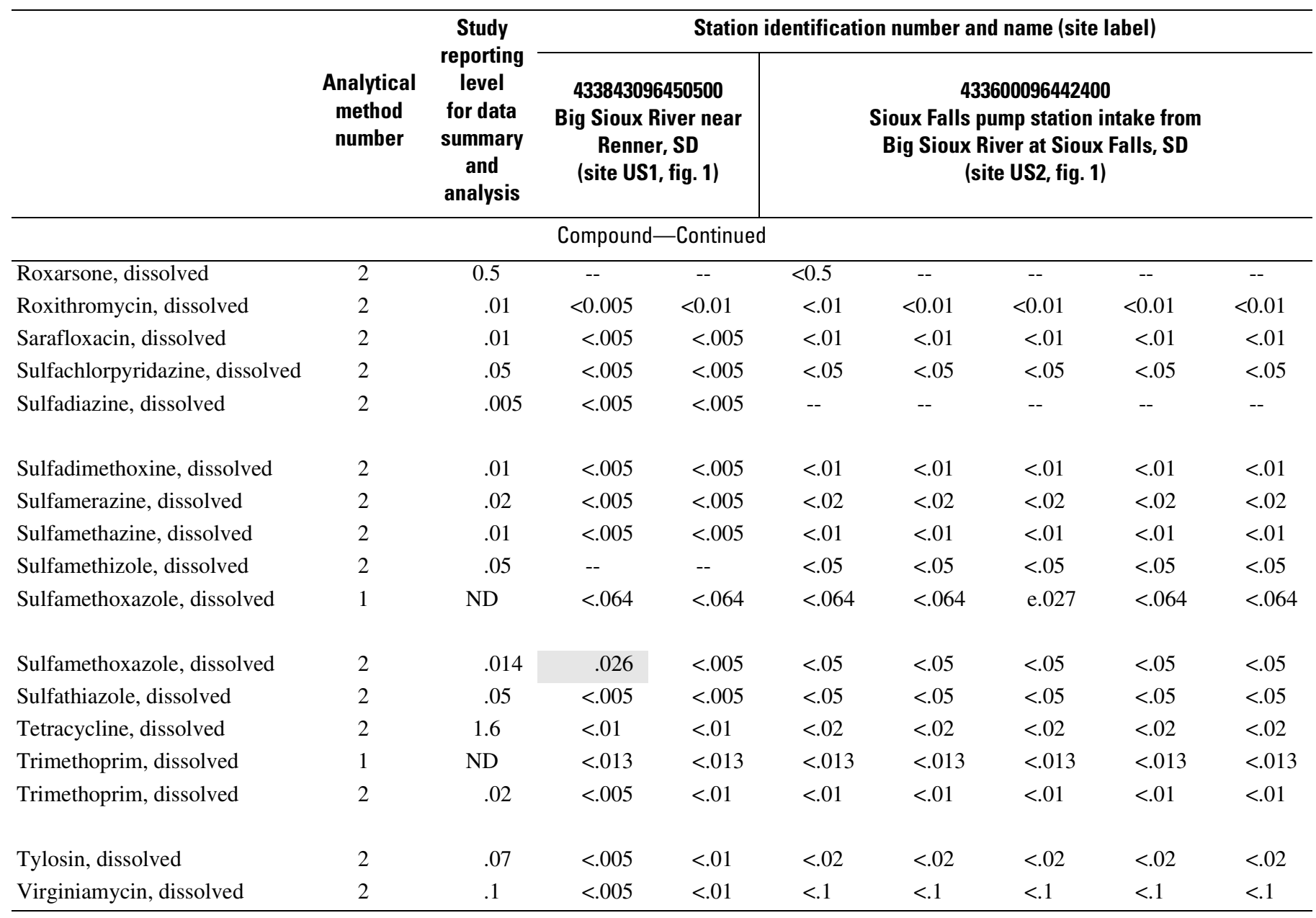


Table 16. Analytical results for human and veterinary antibiotic compounds (HVACs) in water samples.-Continued

[Shaded cells indicate concentrations greater than study reporting levels for compounds with acceptable quality assurance/quality control, and concentrations were used in analyses related to occurrence of organic wastewater compounds. Units are micrograms per liter. Analytical method number: 1, Cahill and others (2004); 2, U.S. Geological Survey Organic Geochemistry Research Laboratory. ND, not determined; e, estimated; <, less than; --, no data collected]

\begin{tabular}{|c|c|c|c|c|c|c|c|}
\hline & & & & ation identific & ion number an & name (site labe & \\
\hline & $\begin{array}{c}\text { Analytical } \\
\text { method } \\
\text { number }\end{array}$ & $\begin{array}{l}\text { level } \\
\text { for data } \\
\text { summary } \\
\text { and }\end{array}$ & & $\begin{array}{r}\text { Sioux F } \\
\text { finished dri }\end{array}$ & $\begin{array}{l}3341909643420 \\
\text { Is water treatn } \\
\text { ing water at S } \\
\text { site FDW, fig. }\end{array}$ & $\begin{array}{l}\text { uxt plant } \\
\text { ux Falls, SD }\end{array}$ & \\
\hline $\begin{array}{l}\text { Time of sample collection } \\
\text { (24-hour) }\end{array}$ & & & 1100 & 1440 & 1330 & 1445 & 0915 \\
\hline & & & Compound & & & & \\
\hline Amoxicillin, dissolved & 2 & 0.01 & -- & -- & -- & -- & -- \\
\hline Ampicillin, dissolved & 2 & .01 & -- & -- & -- & -- & -- \\
\hline Carbadox, dissolved & 2 & .05 & $<.05$ & $<.05$ & $<.05$ & $<.05$ & $<.05$ \\
\hline Cefotaxime, dissolved & 2 & .01 & -- & -- & -- & -- & -- \\
\hline Chlorotetracycline, dissolved & 2 & .056 & $<.02$ & $<.02$ & $<.02$ & $<.02$ & $<.02$ \\
\hline Ciprofloxacin, dissolved & 2 & .033 & $<.01$ & $<.01$ & $<.01$ & $<.01$ & $<.01$ \\
\hline Clinafloxacin, dissolved & 2 & .005 & -- & -- & -- & -- & -- \\
\hline Cloxacillin, dissolved & 2 & .01 & -- & -- & -- & -- & -- \\
\hline Demeclocycline, dissolved & 2 & .02 & $<.02$ & $<.02$ & $<.02$ & $<.02$ & $<.02$ \\
\hline Lincomycin, dissolved & 2 & .01 & $<.01$ & $<.01$ & $<.01$ & $<.01$ & $<.01$ \\
\hline Lomefloxacin, dissolved & 2 & .005 & -- & -- & -- & -- & -- \\
\hline Methotrexate, dissolved & 2 & .02 & $<.02$ & $<.02$ & $<.02$ & $<.02$ & $<.02$ \\
\hline Minocycline, dissolved & 2 & .02 & $<.02$ & $<.02$ & $<.02$ & $<.02$ & $<.02$ \\
\hline Norfloxacin, dissolved & 2 & .01 & $<.01$ & $<.01$ & $<.01$ & $<.01$ & $<.01$ \\
\hline Ofloxacin, dissolved & 2 & .15 & -- & -- & -- & -- & -- \\
\hline Ormetoprim, dissolved & 2 & .01 & -- & -- & -- & -- & -- \\
\hline Oxacillin, dissolved & 2 & .01 & -- & -- & -- & -- & -- \\
\hline Oxolinic acid, dissolved & 2 & .005 & $<.05$ & -- & -- & -- & -- \\
\hline Oxytetracycline, dissolved & 2 & .05 & $<.05$ & $<.05$ & $<.05$ & $<.05$ & $<.05$ \\
\hline Penicillin G, dissolved & 2 & .01 & -- & -- & -- & -- & -- \\
\hline Penicillin V, dissolved & 2 & .01 & -- & -- & -- & -- & -- \\
\hline
\end{tabular}


Table 16. Analytical results for human and veterinary antibiotic compounds (HVACs) in water samples.—Continued

[Shaded cells indicate concentrations greater than study reporting levels for compounds with acceptable quality assurance/quality control, and concentrations were used in analyses related to occurrence of organic wastewater compounds. Units are micrograms per liter. Analytical method number: 1 , Cahill and others (2004); 2, U.S. Geological Survey Organic Geochemistry Research Laboratory. ND, not determined; e, estimated; <, less than; --, no data collected]

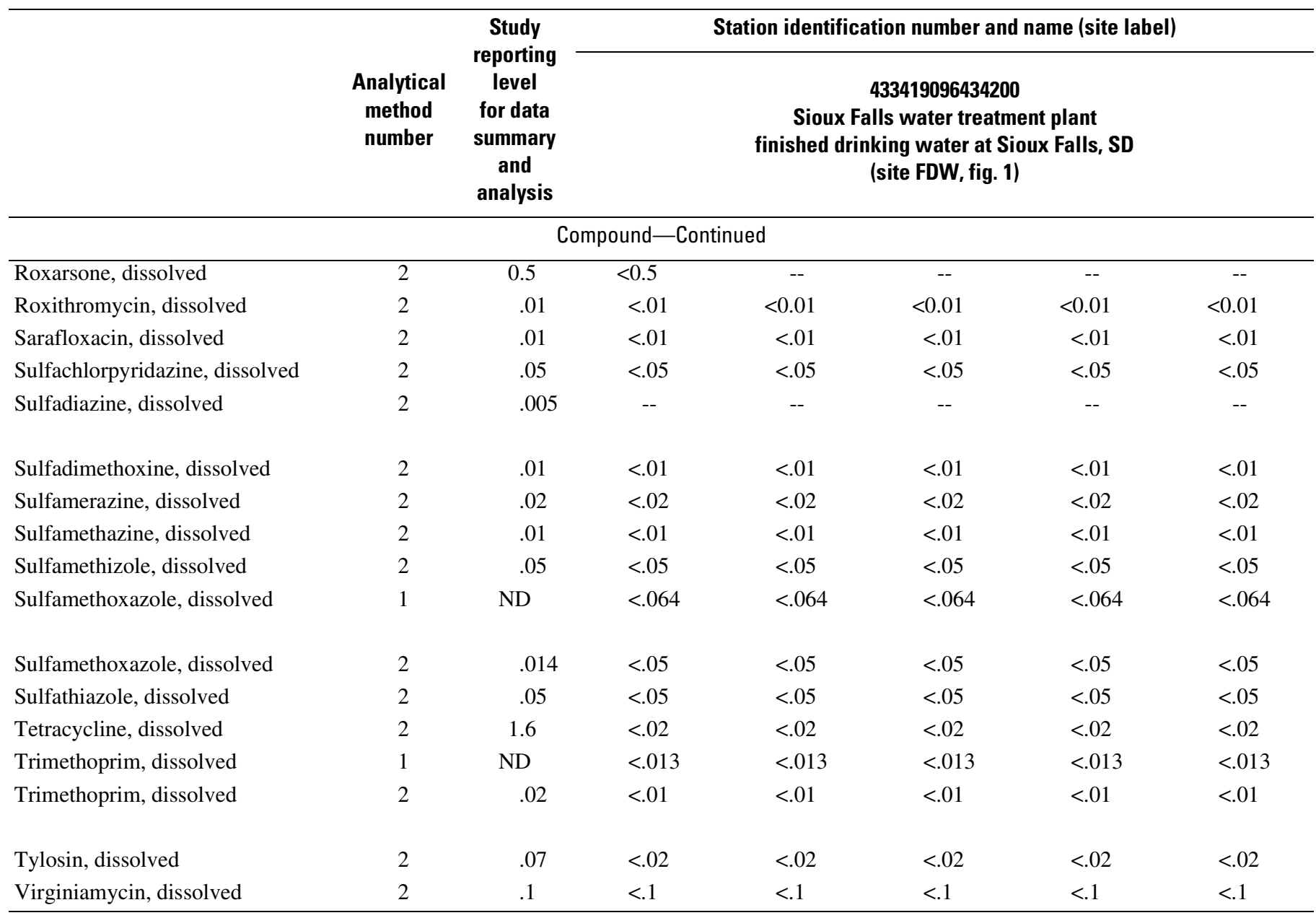


Table 16. Analytical results for human and veterinary antibiotic compounds (HVACs) in water samples.-Continued

[Shaded cells indicate concentrations greater than study reporting levels for compounds with acceptable quality assurance/quality control, and concentrations were used in analyses related to occurrence of organic wastewater compounds. Units are micrograms per liter. Analytical method number: 1 , Cahill and others (2004); 2, U.S. Geological Survey Organic Geochemistry Research Laboratory. ND, not determined; e, estimated; <, less than; --, no data collected]

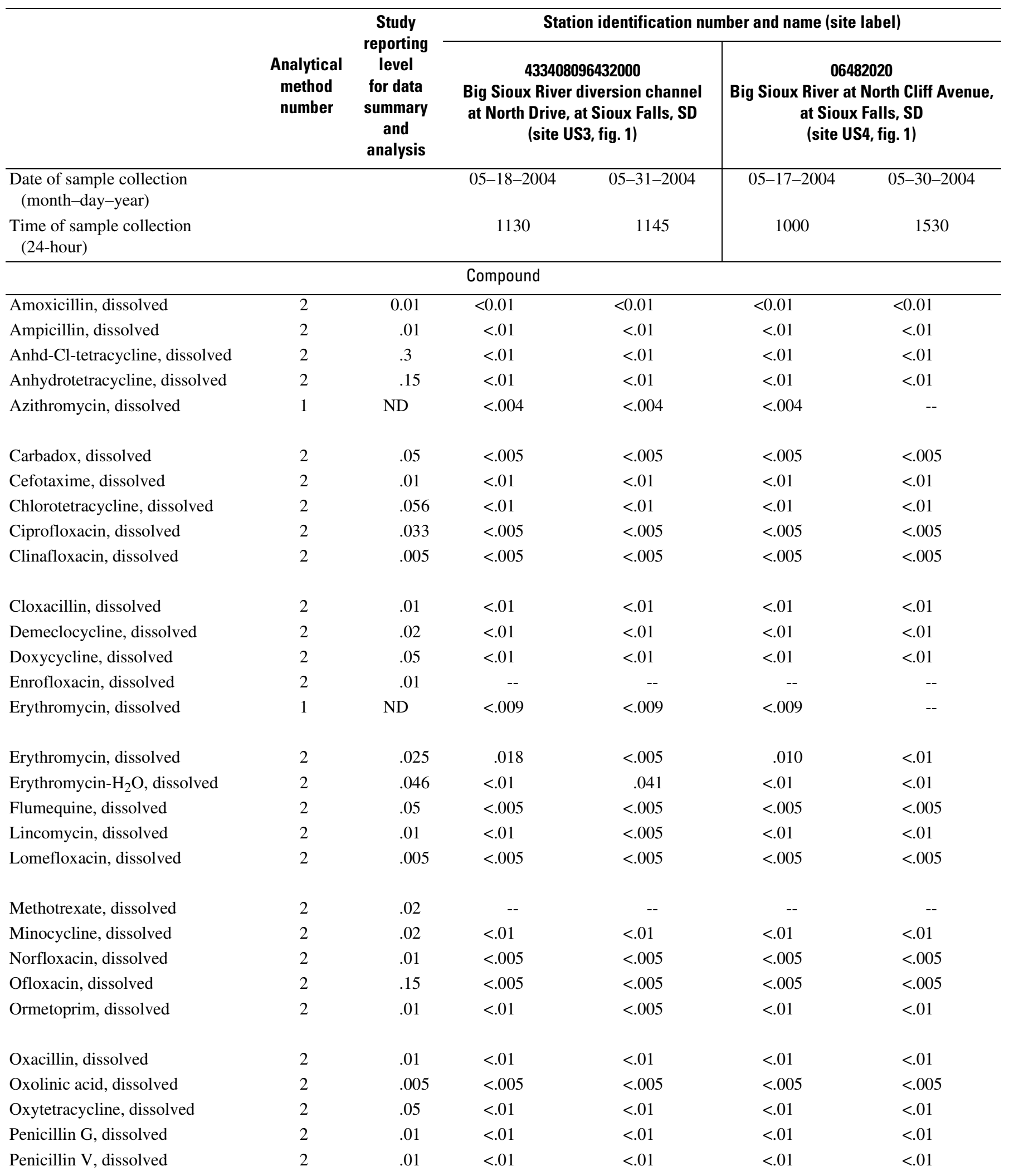


Table 16. Analytical results for human and veterinary antibiotic compounds (HVACs) in water samples.-Continued

[Shaded cells indicate concentrations greater than study reporting levels for compounds with acceptable quality assurance/quality control, and concentrations were used in analyses related to occurrence of organic wastewater compounds. Units are micrograms per liter. Analytical method number: 1 , Cahill and others (2004); 2, U.S. Geological Survey Organic Geochemistry Research Laboratory. ND, not determined; e, estimated; <, less than; --, no data collected]

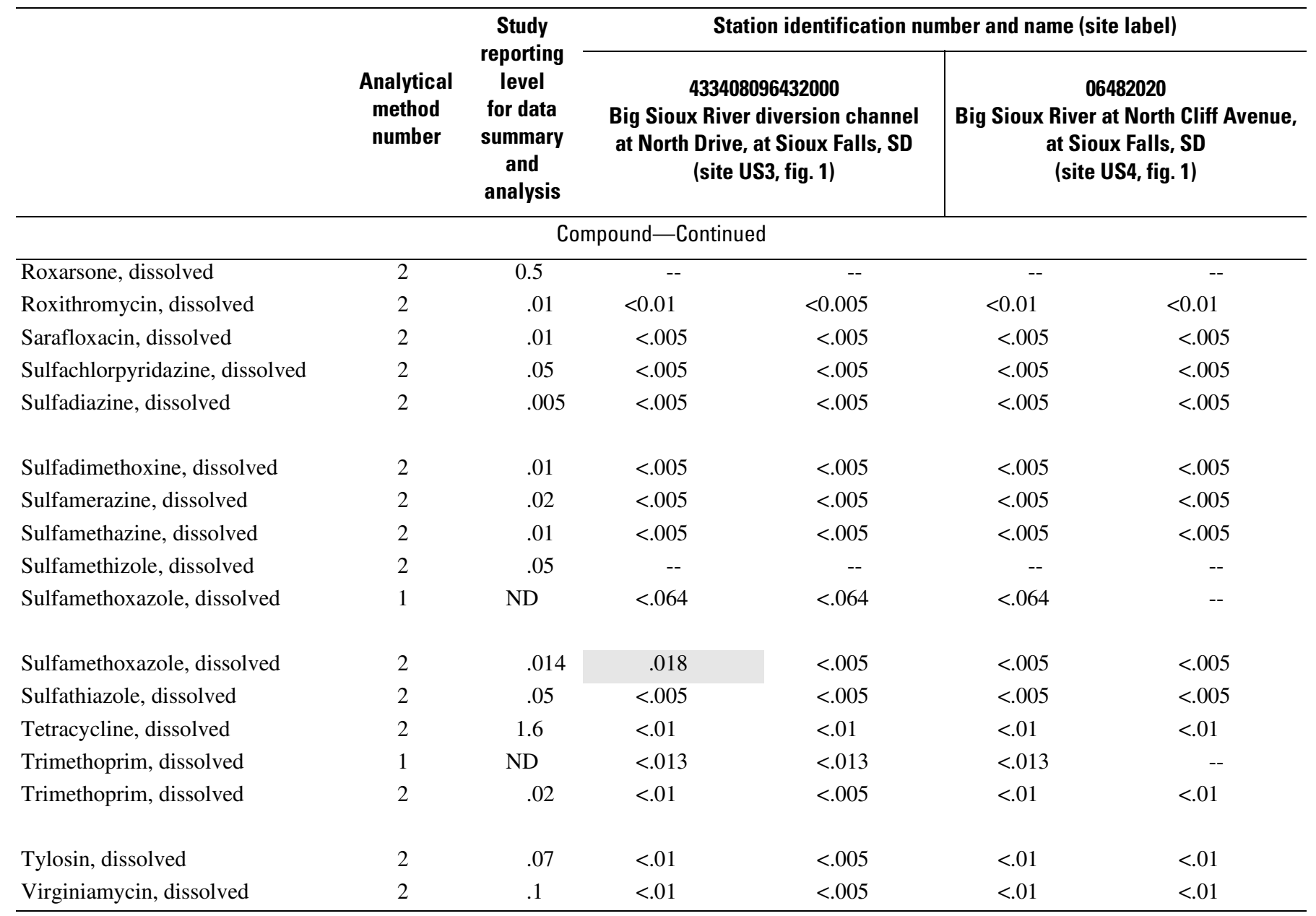


Table 16. Analytical results for human and veterinary antibiotic compounds (HVACs) in water samples.—Continued

[Shaded cells indicate concentrations greater than study reporting levels for compounds with acceptable quality assurance/quality control, and concentrations were used in analyses related to occurrence of organic wastewater compounds. Units are micrograms per liter. Analytical method number: 1, Cahill and others (2004); U.S. Geological Survey Organic Geochemistry Research Laboratory. ND, not determined; e, estimated; <, less than; --, no data collected]

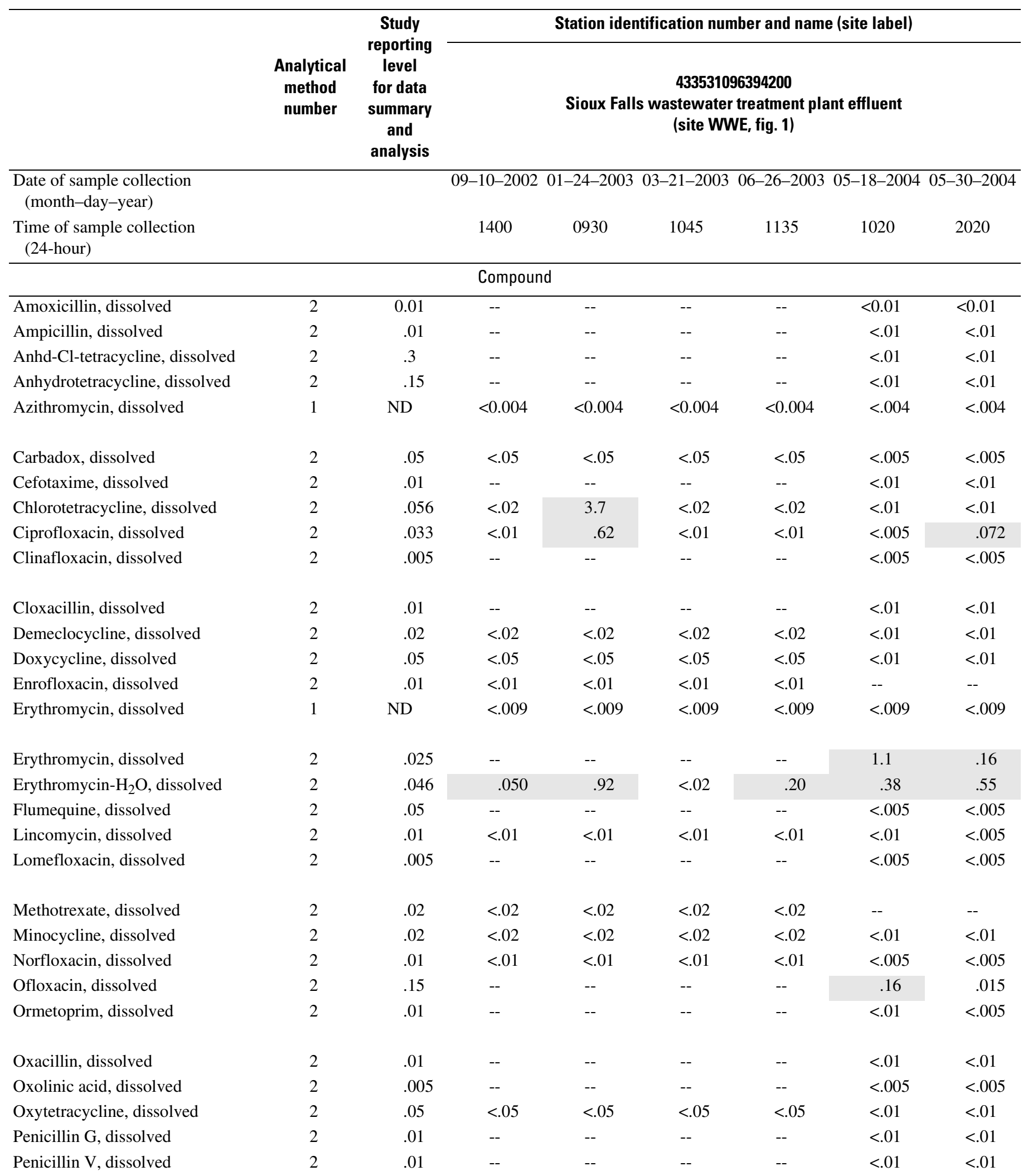


Table 16. Analytical results for human and veterinary antibiotic compounds (HVACs) in water samples. - Continued

[Shaded cells indicate concentrations greater than study reporting levels for compounds with acceptable quality assurance/quality control, and concentrations were used in analyses related to occurrence of organic wastewater compounds. Units are micrograms per liter. Analytical method number: 1, Cahill and others (2004); 2, U.S. Geological Survey Organic Geochemistry Research Laboratory. ND, not determined; e, estimated; <, less than; --, no data collected]

\begin{tabular}{|c|c|c|c|c|c|c|c|c|}
\hline & \multirow[b]{2}{*}{$\begin{array}{l}\text { Analytical } \\
\text { method } \\
\text { number }\end{array}$} & \multirow{2}{*}{$\begin{array}{l}\text { Study } \\
\text { reporting } \\
\text { level } \\
\text { for data } \\
\text { summary } \\
\text { and } \\
\text { analysis }\end{array}$} & \multicolumn{6}{|c|}{ Station identification number and name (site label) } \\
\hline & & & \multicolumn{6}{|c|}{$\begin{array}{c}433531096394200 \\
\text { Sioux Falls wastewater treatment plant effluent } \\
\text { (site WWE, fig. 1) }\end{array}$} \\
\hline Roxithromycin, dissolved & 2 & .01 & $<0.01$ & $<0.01$ & $<0.01$ & $<0.01$ & $<0.01$ & $<0.005$ \\
\hline Sarafloxacin, dissolved & 2 & .01 & $<.01$ & $<.01$ & $<.01$ & $<.01$ & $<.005$ & $<.005$ \\
\hline Sulfachlorpyridazine, dissolved & 2 & .05 & $<.05$ & $<.05$ & $<.05$ & $<.05$ & $<.005$ & $<.005$ \\
\hline Sulfadiazine, dissolved & 2 & .005 & -- & -- & -- & -- & $<.005$ & $<.005$ \\
\hline Sulfamethizole, dissolved & 2 & .05 & $<.05$ & $<.05$ & $<.05$ & $<.05$ & -- & -- \\
\hline Sulfamethoxazole, dissolved & 1 & ND & .15 & $<.064$ & $<.064$ & e. 042 & .34 & $<.064$ \\
\hline Sulfamethoxazole, dissolved & 2 & .014 & $<.05$ & 1.1 & $<.05$ & .15 & .099 & .016 \\
\hline Sulfathiazole, dissolved & 2 & .05 & $<.05$ & $<.05$ & $<.05$ & $<.05$ & $<.005$ & $<.005$ \\
\hline Tetracycline, dissolved & 2 & 1.6 & $<.02$ & 17 & $<.02$ & $<.02$ & $<.01$ & $<.01$ \\
\hline Trimethoprim, dissolved & 1 & ND & $<.013$ & .21 & .13 & e. 018 & .11 & .021 \\
\hline Trimethoprim, dissolved & 2 & .02 & $<.01$ & .39 & .090 & .050 & .10 & .028 \\
\hline
\end{tabular}


Table 16. Analytical results for human and veterinary antibiotic compounds (HVACs) in water samples. - Continued

[Shaded cells indicate concentrations greater than study reporting levels for compounds with acceptable quality assurance/quality control, and concentrations were used in analyses related to occurrence of organic wastewater compounds. Units are micrograms per liter. Analytical method number: 1, Cahill and others (2004); 2, U.S. Geological Survey Organic Geochemistry Research Laboratory. ND, not determined; e, estimated; $<$, less than; --, no data collected]

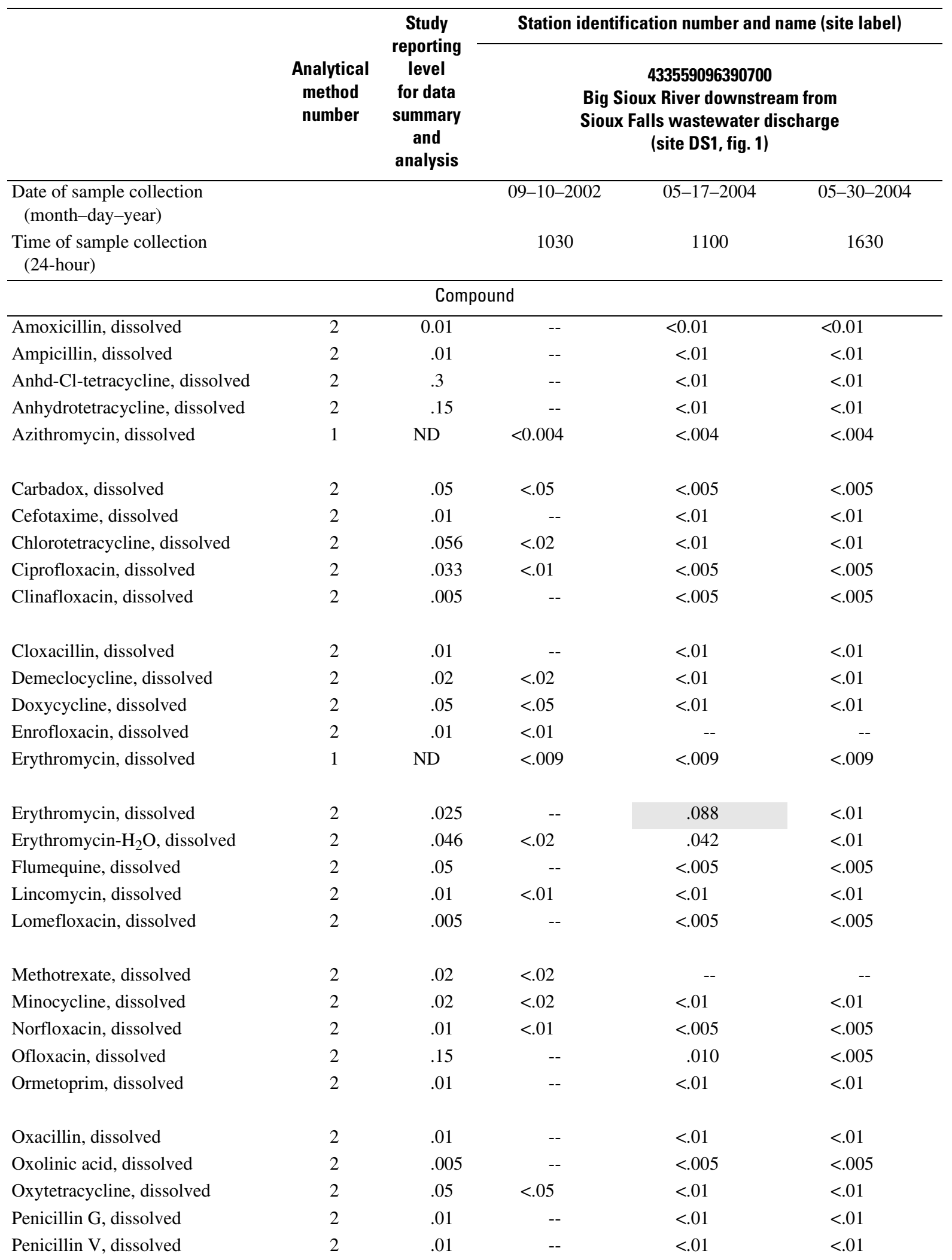


Table 16. Analytical results for human and veterinary antibiotic compounds (HVACs) in water samples. - Continued

[Shaded cells indicate concentrations greater than study reporting levels for compounds with acceptable quality assurance/quality control, and concentrations were used in analyses related to occurrence of organic wastewater compounds. Units are micrograms per liter. Analytical method number: 1, Cahill and others (2004); 2, U.S. Geological Survey Organic Geochemistry Research Laboratory. ND, not determined; e, estimated; $<$, less than; --, no data collected]

\begin{tabular}{|c|c|c|c|c|c|}
\hline & \multirow[b]{2}{*}{$\begin{array}{l}\text { Analytical } \\
\text { method } \\
\text { number }\end{array}$} & \multirow{2}{*}{$\begin{array}{c}\text { Study } \\
\text { reporting } \\
\text { level } \\
\text { for data } \\
\text { summary } \\
\text { and } \\
\text { analysis }\end{array}$} & \multicolumn{3}{|c|}{ Station identification number and name (site label) } \\
\hline & & & \multicolumn{3}{|c|}{$\begin{array}{l}433559096390700 \\
\text { Big Sioux River downstream from } \\
\text { Sioux Falls wastewater discharge } \\
\text { (site DS1, fig. 1) }\end{array}$} \\
\hline \multicolumn{6}{|c|}{ Compound-Continued } \\
\hline Roxarsone, dissolved & 2 & 0.05 & -- & -- & -- \\
\hline Roxithromycin, dissolved & 2 & .01 & $<0.01$ & $<0.01$ & $<0.01$ \\
\hline Sarafloxacin, dissolved & 2 & .01 & $<.01$ & $<.005$ & $<.005$ \\
\hline Sulfachlorpyridazine, dissolved & 2 & .05 & $<.05$ & $<.005$ & $<.005$ \\
\hline Sulfadiazine, dissolved & 2 & .005 & -- & $<.005$ & $<.005$ \\
\hline Sulfadimethoxine, dissolved & 2 & .01 & $<.01$ & $<.005$ & $<.005$ \\
\hline Sulfamerazine, dissolved & 2 & .02 & $<.02$ & $<.005$ & $<.005$ \\
\hline Sulfamethazine, dissolved & 2 & .01 & $<.01$ & $<.005$ & $<.005$ \\
\hline Sulfamethizole, dissolved & 2 & .05 & $<.05$ & -- & -- \\
\hline Sulfamethoxazole, dissolved & 1 & ND & e.036 & $<.064$ & $<.064$ \\
\hline Sulfamethoxazole, dissolved & 2 & .014 & $<.05$ & .047 & $<.005$ \\
\hline Sulfathiazole, dissolved & 2 & .05 & $<.05$ & $<.005$ & $<.005$ \\
\hline Tetracycline, dissolved & 2 & 1.6 & $<.02$ & $<.01$ & $<.01$ \\
\hline Trimethoprim, dissolved & 1 & ND & $<.013$ & e.0062 & $<.013$ \\
\hline Trimethoprim, dissolved & 2 & .02 & $<.01$ & .020 & $<.01$ \\
\hline Tylosin, dissolved & 2 & .07 & $<.02$ & $<.01$ & $<.01$ \\
\hline Virginiamycin, dissolved & 2 & .1 & $<.1$ & $<.01$ & $<.01$ \\
\hline
\end{tabular}


Table 16. Analytical results for human and veterinary antibiotic compounds (HVACs) in water samples.-Continued

[Shaded cells indicate concentrations greater than study reporting levels for compounds with acceptable quality assurance/quality control, and concentrations were used in analyses related to occurrence of organic wastewater compounds. Units are micrograms per liter. Analytical method number: 1, Cahill and others (2004); 2 , U.S. Geological Survey Organic Geochemistry Research Laboratory. ND, not determined; e, estimated; <, less than; --, no data collected]

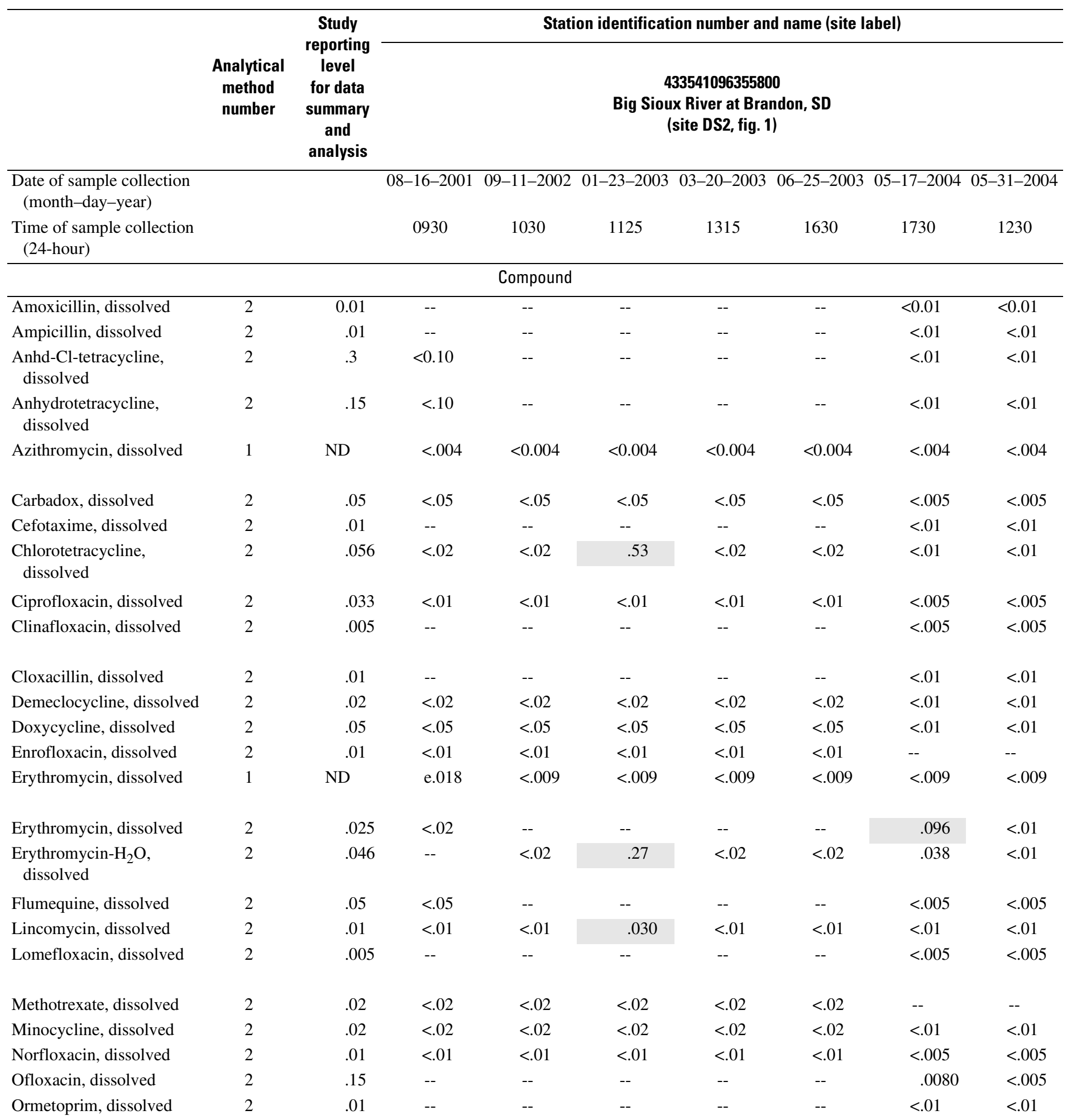


Table 16. Analytical results for human and veterinary antibiotic compounds (HVACs) in water samples. - Continued

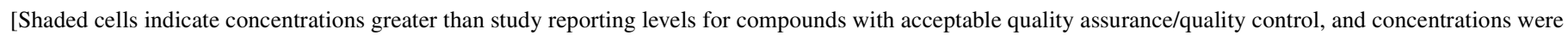

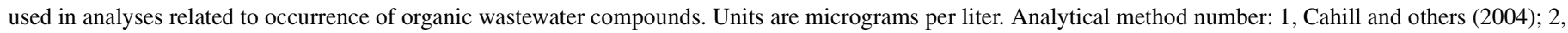
U.S. Geological Survey Organic Geochemistry Research Laboratory. ND, not determined; e, estimated; <, less than; --, no data collected]

\begin{tabular}{|c|c|c|c|c|c|c|c|c|c|}
\hline \multirow{2}{*}{\multicolumn{3}{|c|}{$\begin{array}{c}\text { level } \\
\text { for data } \\
\text { summary } \\
\text { and } \\
\text { analysis }\end{array}$}} & \multicolumn{7}{|c|}{ Station identification number and name (site label) } \\
\hline & & & \multicolumn{7}{|c|}{$\begin{array}{c}433541096355800 \\
\text { Big Sioux River at Brandon, SD } \\
\text { (site DS2, fig. 1) }\end{array}$} \\
\hline \multicolumn{10}{|c|}{ Compound-Continued } \\
\hline Oxacillin, dissolved & 2 & 0.01 & -- & -- & -- & -- & -- & $<0.01$ & $<0.01$ \\
\hline Oxolinic acid, dissolved & 2 & .005 & $<0.05$ & -- & -- & -- & -- & $<.005$ & $<.005$ \\
\hline Oxytetracycline, dissolved & 2 & .05 & $<.05$ & $<0.05$ & $<0.05$ & $<0.05$ & $<0.05$ & $<.01$ & $<.01$ \\
\hline Penicillin G, dissolved & 2 & .01 & -- & -- & -- & -- & -- & $<.01$ & $<.01$ \\
\hline Penicillin V, dissolved & 2 & .01 & -- & -- & -- & -- & -- & $<.01$ & $<.01$ \\
\hline Roxarsone, dissolved & 2 & .5 & $<.5$ & -- & -- & -- & -- & -- & -- \\
\hline Roxithromycin, dissolved & 2 & .01 & $<.01$ & $<.01$ & $<.01$ & $<.01$ & $<.01$ & $<.01$ & $<.01$ \\
\hline Sarafloxacin, dissolved & 2 & .01 & $<.01$ & $<.01$ & $<.01$ & $<.01$ & $<.01$ & $<.005$ & $<.005$ \\
\hline $\begin{array}{l}\text { Sulfachlorpyridazine, } \\
\text { dissolved }\end{array}$ & 2 & .05 & $<.05$ & $<.05$ & $<.05$ & $<.05$ & $<.05$ & $<.005$ & $<.005$ \\
\hline Sulfadiazine, dissolved & 2 & .005 & -- & -- & -- & -- & -- & $<.005$ & $<.005$ \\
\hline $\begin{array}{l}\text { Sulfadimethoxine, } \\
\text { dissolved }\end{array}$ & 2 & .01 & $<.01$ & $<.01$ & $<.01$ & $<.01$ & $<.01$ & $<.005$ & $<.005$ \\
\hline Sulfamerazine, dissolved & 2 & .02 & $<.02$ & $<.02$ & $<.02$ & $<.02$ & $<.02$ & $<.005$ & $<.005$ \\
\hline Sulfamethazine, dissolved & 2 & .01 & $<.01$ & $<.01$ & $<.01$ & $<.01$ & $<.01$ & $<.005$ & $<.005$ \\
\hline Sulfamethizole, dissolved & 2 & .05 & $<.05$ & $<.05$ & $<.05$ & $<.05$ & $<.05$ & -- & -- \\
\hline $\begin{array}{l}\text { Sulfamethoxazole, } \\
\text { dissolved }\end{array}$ & 1 & ND & $<.064$ & e. 023 & .20 & $<.064$ & .064 & $<.064$ & $<.064$ \\
\hline $\begin{array}{l}\text { Sulfamethoxazole, } \\
\text { dissolved }\end{array}$ & 2 & .014 & $<.05$ & $<.05$ & .31 & $<.05$ & $<.05$ & .061 & $<.005$ \\
\hline Sulfathiazole, dissolved & 2 & .05 & $<.05$ & $<.05$ & $<.05$ & $<.05$ & $<.05$ & $<.005$ & $<.005$ \\
\hline Tetracycline, dissolved & 2 & 1.6 & $<.02$ & $<.02$ & 2.50 & $<.02$ & $<.02$ & $<.01$ & $<.01$ \\
\hline Trimethoprim, dissolved & 1 & ND & $<.013$ & $<.013$ & .11 & $<.013$ & .029 & e.0042 & $<.013$ \\
\hline Trimethoprim, dissolved & 2 & .02 & $<.01$ & $<.01$ & .12 & $<.01$ & $<.01$ & $<.01$ & $<.01$ \\
\hline Tylosin, dissolved & 2 & .07 & $<.02$ & $<.02$ & $<.02$ & $<.02$ & $<.02$ & $<.01$ & $<.01$ \\
\hline Virginiamycin, dissolved & 2 & .1 & $<.1$ & $<.1$ & $<.1$ & $<.1$ & $<.1$ & $<.01$ & $<.01$ \\
\hline
\end{tabular}


Table 17. Analytical results for major agricultural herbicides (MAHs) in water and bottom-sediment samples.

[Bold text indicates suspected endocrine-disrupting compound (EDC). Shaded cells indicate concentrations greater than study reporting levels for compounds with acceptable quality assurance/quality control, and concentrations were used in analyses related to occurrence of organic wastewater compounds. Units are micrograms per liter unless otherwise noted. Analytical method number: 3, Lee and others (2004); 4, Zaugg and others (2002); 5, Burkhardt and others (2005). $\mu \mathrm{g} / \mathrm{kg}$, micrograms per kilogram; e, estimated; <, less than; --, no data collected]

\begin{tabular}{|c|c|c|c|c|c|c|c|c|c|}
\hline & \multirow[b]{2}{*}{$\begin{array}{c}\text { Analytical } \\
\text { method } \\
\text { number }\end{array}$} & \multirow{2}{*}{$\begin{array}{c}\text { Study } \\
\text { reporting } \\
\text { level } \\
\text { for data } \\
\text { summary and } \\
\text { analysis }\end{array}$} & \multicolumn{7}{|c|}{ Station identification number and name (site label) } \\
\hline & & & \multicolumn{2}{|c|}{$\begin{array}{l}433843096450500 \\
\text { Big Sioux River near } \\
\text { Renner, SD } \\
\text { (site US1, fig. 1) }\end{array}$} & \multicolumn{5}{|c|}{$\begin{array}{l}433600096442400 \\
\text { Sioux Falls pump station intake from } \\
\text { Big Sioux River at Sioux Falls, SD } \\
\text { (site US2, fig. 1) }\end{array}$} \\
\hline $\begin{array}{l}\text { Date of sample collection } \\
\text { (month-day-year) }\end{array}$ & & & $\begin{array}{c}05-18- \\
2004\end{array}$ & $\begin{array}{c}05-31- \\
2004\end{array}$ & $\begin{array}{c}08-15- \\
2001\end{array}$ & $\begin{array}{c}09-09- \\
2002\end{array}$ & $\begin{array}{l}01-22- \\
2003\end{array}$ & $\begin{array}{c}03-19- \\
2003\end{array}$ & $\begin{array}{c}06-26- \\
2003\end{array}$ \\
\hline $\begin{array}{l}\text { Time of sample collection } \\
\text { (24-hour) }\end{array}$ & & & 1500 & 1800 & 1405 & 1200 & 1105 & 1130 & 0930 \\
\hline \multicolumn{10}{|c|}{ Compound } \\
\hline Atrazine, whole water & 3 & 0.0002 & $<0.5$ & 2.5 & -- & $\mathrm{e} 0.024$ & $<0.5$ & $\mathrm{e} 0.051$ & 0.17 \\
\hline Atrazine, bottom sediment & 5 & $100 \mu \mathrm{g} / \mathrm{kg}$ & -- & -- & -- & $<100 \mu \mathrm{g} / \mathrm{kg}$ & -- & -- & -- \\
\hline Metolachlor, dissolved & 4 & .071 & e.071 & e.35 & -- & -- & -- & -- & -- \\
\hline Metolachlor, whole water & 3 & .004 & $<.5$ & e.30 & $\mathrm{e} 0.013$ & $<.5$ & $<.5$ & e. 12 & e. 10 \\
\hline Metolachlor, bottom sediment & 5 & $50 \mu \mathrm{g} / \mathrm{kg}$ & -- & -- & -- & $<50 \mu \mathrm{g} / \mathrm{kg}$ & -- & -- & -- \\
\hline Prometon, dissolved & 4 & .13 & $<.5$ & $<.5$ & -- & -- & -- & -- & -- \\
\hline Prometon, whole water & 3 & .02 & $<.5$ & $<.5$ & $<.5$ & $<.5$ & $<.5$ & $<.5$ & $<.5$ \\
\hline Prometon, bottom sediment & 5 & $50 \mu \mathrm{g} / \mathrm{kg}$ & -- & -- & -- & $<50 \mu \mathrm{g} / \mathrm{kg}$ & -- & -- & -- \\
\hline
\end{tabular}

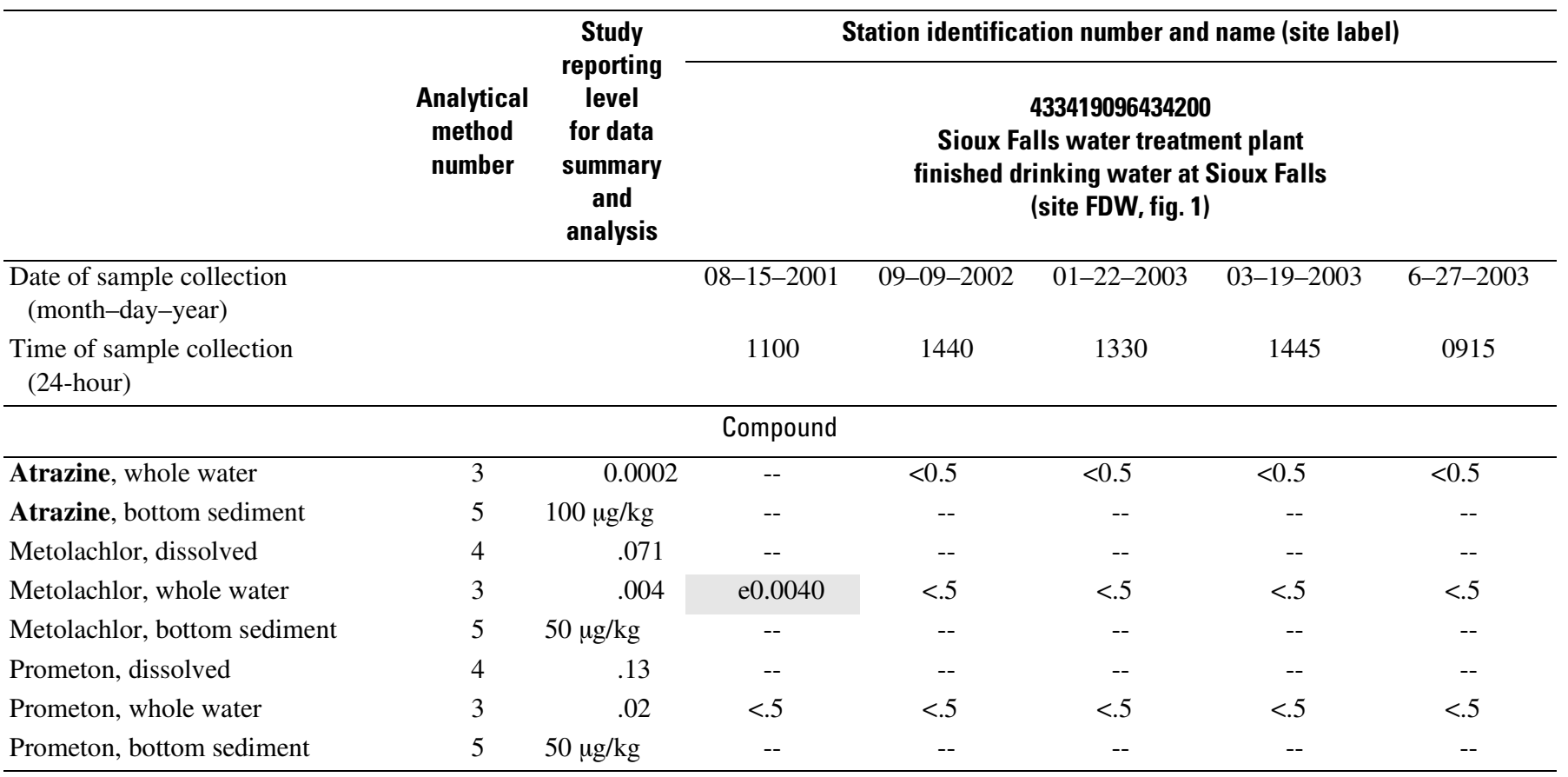


Table 17. Analytical results for major agricultural herbicides (MAHs) in water and bottom-sediment samples.-Continued

[Bold text indicates suspected endocrine-disrupting compound (EDC). Shaded cells indicate concentrations greater than study reporting levels for compounds with acceptable quality assurance/quality control, and concentrations were used in analyses related to occurrence of organic wastewater compounds. Units are micrograms per liter unless otherwise noted. Analytical method number: 3, Lee and others (2004); 4, Zaugg and others (2002); 5, Burkhardt and others (2005). $\mu \mathrm{g} / \mathrm{kg}$, micrograms per kilogram; e, estimated; <, less than; --, no data collected]

\begin{tabular}{|c|c|c|c|c|c|c|}
\hline \multirow{2}{*}{$\begin{array}{c}\text { Date of sample collection } \\
\text { (month-day-year) }\end{array}$} & \multirow[b]{2}{*}{$\begin{array}{l}\text { Analytical } \\
\text { method } \\
\text { number }\end{array}$} & \multirow[b]{2}{*}{$\begin{array}{c}\text { Study } \\
\text { reporting } \\
\text { level } \\
\text { for data } \\
\text { summary and } \\
\text { analysis }\end{array}$} & \multicolumn{4}{|c|}{ Station identification number and name (site label) } \\
\hline & & & \multicolumn{2}{|c|}{$\begin{array}{c}433408096432000 \\
\text { Big Sioux River diversion channel } \\
\text { at North Drive, at Sioux Falls, SD } \\
\text { (site US3, fig. 1) }\end{array}$} & \multicolumn{2}{|c|}{$\begin{array}{c}06482020 \\
\text { Big Sioux River at North Cliff Avenue, } \\
\text { at Sioux Falls, SD } \\
\text { (site US4, fig. 1) }\end{array}$} \\
\hline $\begin{array}{l}\text { Time of sample collection } \\
\text { (24-hour) }\end{array}$ & & & 1130 & 1145 & 1000 & 1530 \\
\hline \multicolumn{7}{|c|}{ Compound } \\
\hline Atrazine, whole water & 3 & 0.0002 & $<0.5$ & 2.7 & $\mathrm{e} 0.30$ & 2.2 \\
\hline Metolachlor, bottom sediment & 5 & $50 \mu \mathrm{g} / \mathrm{kg}$ & -- & -- & -- & -- \\
\hline Prometon, dissolved & 4 & .13 & $<.5$ & $<.5$ & $<.5$ & $<.5$ \\
\hline Prometon, whole water & 3 & .02 & $<.5$ & $<.5$ & $<.5$ & $<.5$ \\
\hline Prometon, bottom sediment & 5 & $50 \mu \mathrm{g} / \mathrm{kg}$ & -- & -- & -- & -- \\
\hline
\end{tabular}

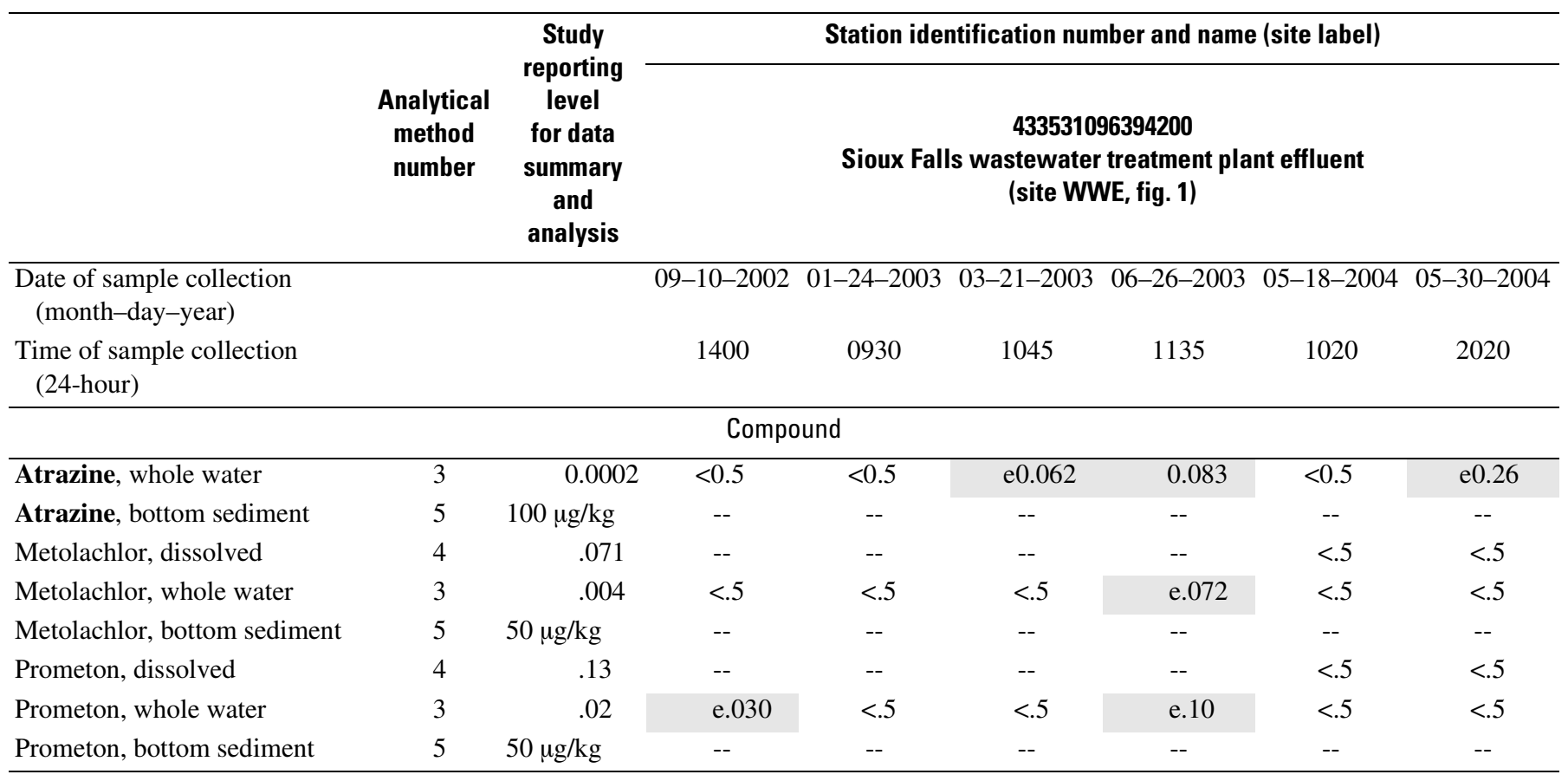


Table 17. Analytical results for major agricultural herbicides (MAHs) in water and bottom-sediment samples.-Continued

[Bold text indicates suspected endocrine-disrupting compound (EDC). Shaded cells indicate concentrations greater than study reporting levels for compounds with acceptable quality assurance/quality control, and concentrations were used in analyses related to occurrence of organic wastewater compounds. Units are micrograms per liter unless otherwise noted. Analytical method number: 3, Lee and others (2004); 4, Zaugg and others (2002); 5, Burkhardt and others (2005). $\mu \mathrm{g} / \mathrm{kg}$, micrograms per kilogram; e, estimated; <, less than; --, no data collected]

\section{Analytical Study reporting level number for data summary and analysis}

\section{Station identification number and name (site label)}

433559096390700

Big Sioux River downstream from Sioux Falls wastewater discharge (site DS1, fig. 1)

\begin{tabular}{lcc}
\hline $\begin{array}{l}\text { Date of sample collection } \\
\text { (month-day-year) }\end{array}$ & $09-10-2002$ & $05-17-2004$ \\
$\begin{array}{l}\text { Time of sample collection } \\
\text { (24-hour) }\end{array}$ & 1030 & 1100 \\
\hline
\end{tabular}

\begin{tabular}{|c|c|c|c|c|c|}
\hline \multicolumn{6}{|c|}{ Compound } \\
\hline Atrazine, whole water & 3 & 0.0002 & $\mathrm{e} 0.018$ & $\mathrm{e} 0.27$ & 2.2 \\
\hline Atrazine, bottom sediment & 5 & $100 \mu \mathrm{g} / \mathrm{kg}$ & $<100 \mu \mathrm{g} / \mathrm{kg}$ & -- & -- \\
\hline Metolachlor, dissolved & 4 & .071 & -- & e. 11 & .78 \\
\hline Metolachlor, whole water & 3 & .004 & $<.5$ & e.048 & .65 \\
\hline Metolachlor, bottom sediment & 5 & $50 \mu \mathrm{g} / \mathrm{kg}$ & $<50 \mu \mathrm{g} / \mathrm{kg}$ & -- & -- \\
\hline Prometon, dissolved & 4 & .13 & -- & e.13 & $<.5$ \\
\hline Prometon, whole water & 3 & .02 & e.020 & $<.5$ & $<.5$ \\
\hline Prometon, bottom sediment & 5 & $50 \mu \mathrm{g} / \mathrm{kg}$ & $<50 \mu \mathrm{g} / \mathrm{kg}$ & -- & -- \\
\hline
\end{tabular}

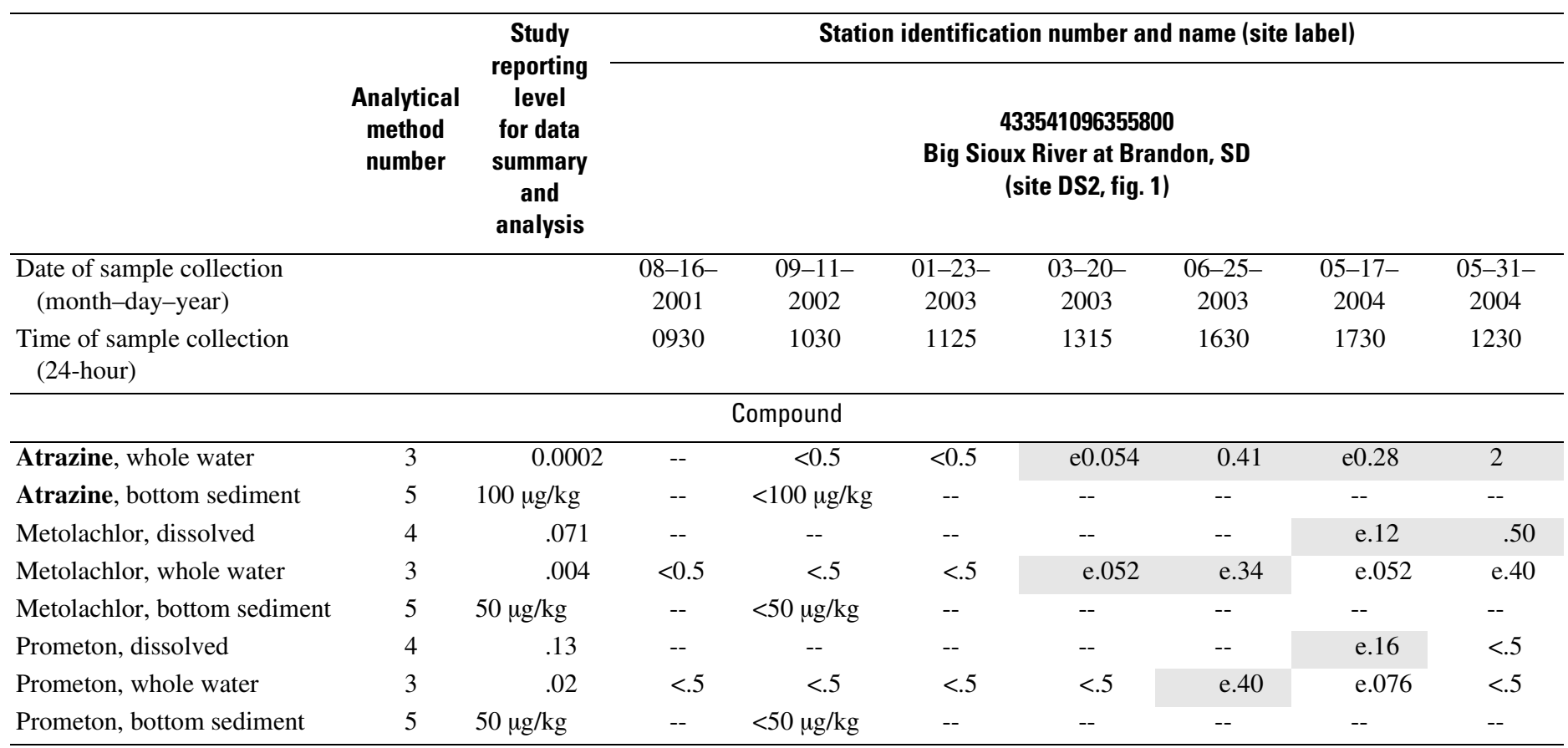


Table 18. Analytical results for household, industrial, and minor agricultural use compounds (HIACs) in water and bottom-sediment samples.

[Bold text indicates suspected endocrine-disrupting compound (EDC). Shaded cells indicate concentrations greater than study reporting levels for compounds with acceptable quality assurance/quality control, and concentrations were used in analyses related to occurrence of organic wastewater compounds.

Units are micrograms per liter unless otherwise noted. Analytical method number: 3, Lee and others (2004); 4, Zaugg and others (2002); 5,

Burkhardt and others (2005). $\mu \mathrm{g} / \mathrm{kg}$, micrograms per kilogram; ND, not determined; e, estimated; <, less than; --, no data collected]

\begin{tabular}{|c|c|c|c|c|c|c|c|c|c|}
\hline \multirow{2}{*}{+2} & \multirow{3}{*}{$\begin{array}{l}\text { Analytical } \\
\text { method } \\
\text { number }\end{array}$} & \multirow{3}{*}{$\begin{array}{c}\text { Study } \\
\text { reporting } \\
\text { level } \\
\text { for data } \\
\text { summary and } \\
\text { analysis }\end{array}$} & \multicolumn{7}{|c|}{ Station identification number and name (site label) } \\
\hline & & & \multicolumn{2}{|c|}{$\begin{array}{c}433843096450500 \\
\text { Big Sioux River near } \\
\text { Renner, SD } \\
\text { (site US1, fig. 1) }\end{array}$} & \multicolumn{5}{|c|}{$\begin{array}{c}433600096442400 \\
\text { Sioux Falls pump station intake from } \\
\text { Big Sioux River at Sioux Falls, SD } \\
\text { (site US2, fig. 1) }\end{array}$} \\
\hline $\begin{array}{l}\text { Date of sample } \\
\text { collection } \\
\text { (month-day-year) }\end{array}$ & & & $\begin{array}{c}05-18- \\
2004\end{array}$ & $\begin{array}{c}05-31- \\
2004\end{array}$ & $\begin{array}{c}08-15- \\
2001\end{array}$ & $\begin{array}{c}09-09- \\
2002\end{array}$ & $\begin{array}{c}01-22- \\
2003\end{array}$ & $\begin{array}{c}03-19- \\
2003\end{array}$ & $\begin{array}{c}06-26- \\
2003\end{array}$ \\
\hline $\begin{array}{l}\text { Time of sample } \\
\text { collection } \\
\text { (24-hour) }\end{array}$ & & & 1500 & 1800 & 1405 & 1200 & 1105 & 1130 & 0930 \\
\hline \multicolumn{10}{|c|}{ Compound } \\
\hline $\begin{array}{l}\text { 1,4-Dichlorobenzene, } \\
\text { dissolved }\end{array}$ & 4 & 0.08 & $<0.5$ & $<0.5$ & -- & -- & -- & -- & -- \\
\hline $\begin{array}{l}\text { 1,4-Dichlorobenzene, } \\
\text { whole water }\end{array}$ & 3 & ND & $<.5$ & $<.5$ & $<0.5$ & $<0.5$ & $<0.5$ & $<0.5$ & $<0.5$ \\
\hline $\begin{array}{l}\text { 1,4-Dichlorobenzene, } \\
\text { bottom sediment }\end{array}$ & 5 & $50 \mu \mathrm{g} / \mathrm{kg}$ & -- & -- & -- & $<50 \mu \mathrm{g} / \mathrm{kg}$ & -- & -- & -- \\
\hline $\begin{array}{l}\mathbf{2 , 2}, \mathbf{4}, \mathbf{4}^{\prime} \text {-Tetrabromo- } \\
\text { diphenyl ether, whole } \\
\text { water }\end{array}$ & 3 & .5 & $<.5$ & $<.5$ & -- & $<10$ & $<10$ & $<10$ & -- \\
\hline $\begin{array}{l}\text { 2,2',4,4'-Tetrabromo- } \\
\text { diphenyl ether, } \\
\text { bottom sediment }\end{array}$ & 5 & $50 \mu \mathrm{g} / \mathrm{kg}$ & -- & -- & -- & $<50 \mu \mathrm{g} / \mathrm{kg}$ & -- & -- & -- \\
\hline $\begin{array}{l}\text { 3,4-Dichlorophenyl } \\
\text { isocyanate, whole } \\
\text { water }\end{array}$ & 4 & ND & $<.5$ & $<.5$ & -- & $<.5$ & $<.5$ & $<.5$ & -- \\
\hline $\begin{array}{l}\text { 3,4-Dichlorophenyl } \\
\text { isocyanate, bottom } \\
\text { sediment }\end{array}$ & 3 & $100 \mu \mathrm{g} / \mathrm{kg}$ & -- & -- & -- & $<100 \mu \mathrm{g} / \mathrm{kg}$ & -- & -- & -- \\
\hline $\begin{array}{l}\text { 3-Methyl-1H-indole } \\
\text { (skatol), dissolved }\end{array}$ & 5 & .02 & $<1$ & $<1$ & -- & -- & -- & -- & -- \\
\hline $\begin{array}{l}\text { 3-Methyl-1H-indole } \\
\text { (skatol), whole water }\end{array}$ & 3 & .019 & $<1$ & $<1$ & $<1$ & $<1$ & $<1$ & $<1$ & $<1$ \\
\hline $\begin{array}{l}\text { 3-Methyl-1H-indole } \\
\text { (skatol), bottom } \\
\text { sediment }\end{array}$ & 5 & $30 \mu \mathrm{g} / \mathrm{kg}$ & -- & -- & -- & $51 \mu \mathrm{g} / \mathrm{kg}$ & -- & -- & -- \\
\hline $\begin{array}{l}\text { 3-tert-Butyl-4-hydroxy } \\
\text { anisole (BHA), } \\
\text { dissolved }\end{array}$ & 4 & 5 & $<5$ & $<5$ & -- & -- & -- & -- & -- \\
\hline $\begin{array}{l}\text { 3-tert-Butyl-4-hydroxy } \\
\text { anisole (BHA), whole } \\
\text { water }\end{array}$ & 3 & ND & $<5$ & $<5$ & $<5$ & $<5$ & $<5$ & $<5$ & $<5$ \\
\hline $\begin{array}{l}\text { 4-Cumylphenol, } \\
\text { dissolved }\end{array}$ & 5 & 1 & $<1$ & $<1$ & -- & -- & -- & -- & -- \\
\hline
\end{tabular}


Table 18. Analytical results for household, industrial, and minor agricultural use compounds (HIACs) in water and bottom-sediment samples.-Continued

[Bold text indicates suspected endocrine-disrupting compound (EDC). Shaded cells indicate concentrations greater than study reporting levels for compounds with acceptable quality assurance/quality control, and concentrations were used in analyses related to occurrence of organic wastewater compounds.

Units are micrograms per liter unless otherwise noted. Analytical method number: 3, Lee and others (2004); 4, Zaugg and others (2002); 5,

Burkhardt and others (2005). $\mu \mathrm{g} / \mathrm{kg}$, micrograms per kilogram; ND, not determined; e, estimated; <, less than; --, no data collected]

\begin{tabular}{|c|c|c|c|c|c|c|c|c|c|}
\hline & \multirow[b]{2}{*}{$\begin{array}{l}\text { Analytical } \\
\text { method } \\
\text { number }\end{array}$} & \multirow{2}{*}{$\begin{array}{c}\text { Study } \\
\text { reporting } \\
\text { level } \\
\text { for data } \\
\text { summary and } \\
\text { analysis }\end{array}$} & \multicolumn{7}{|c|}{ Station identification number and name (site label) } \\
\hline & & & \multicolumn{2}{|c|}{$\begin{array}{c}433843096450500 \\
\text { Big Sioux River near } \\
\text { Renner, SD } \\
\text { (site US1, fig. 1) }\end{array}$} & \multicolumn{5}{|c|}{$\begin{array}{c}433600096442400 \\
\text { Sioux Falls pump station intake from } \\
\text { Big Sioux River at Sioux Falls, SD } \\
\text { (site US2, fig. 1) }\end{array}$} \\
\hline \multicolumn{10}{|c|}{ Compound-Continued } \\
\hline $\begin{array}{l}\text { 4-Cumylphenol, whole } \\
\text { water }\end{array}$ & 3 & 1 & $<1$ & $<1$ & $<1$ & $<1$ & $<1$ & $<1$ & $<1$ \\
\hline $\begin{array}{l}\text { 4-Cumylphenol, bottom } \\
\text { sediment }\end{array}$ & 5 & $50 \mu \mathrm{g} / \mathrm{kg}$ & -- & -- & -- & $<50 \mu \mathrm{g} / \mathrm{kg}$ & -- & -- & -- \\
\hline $\begin{array}{l}\text { 4-normal-Octylphenol, } \\
\text { dissolved }\end{array}$ & 4 & 1 & $<1$ & $<1$ & -- & -- & -- & -- & -- \\
\hline $\begin{array}{l}\text { 4-normal-Octylphenol, } \\
\text { whole water }\end{array}$ & 3 & 1 & $<1$ & $<1$ & $<1$ & $<1$ & $<1$ & $<1$ & $<1$ \\
\hline $\begin{array}{l}\text { 4-normal-Octylphenol, } \\
\text { bottom sediment }\end{array}$ & 5 & $50 \mu \mathrm{g} / \mathrm{kg}$ & -- & -- & -- & $<50 \mu \mathrm{g} / \mathrm{kg}$ & -- & -- & -- \\
\hline $\begin{array}{l}\text { 4-tert-Octylphenol, } \\
\text { dissolved }\end{array}$ & 4 & 1 & $<1$ & $<1$ & -- & -- & -- & -- & -- \\
\hline $\begin{array}{l}\text { 4-tert-Octylphenol, } \\
\text { whole water }\end{array}$ & 3 & .26 & $<1$ & $<1$ & e. 17 & $<1$ & $<1$ & $<1$ & $<1$ \\
\hline $\begin{array}{l}\text { 4-tert-Octylphenol, } \\
\text { bottom sediment }\end{array}$ & 5 & $50 \mu \mathrm{g} / \mathrm{kg}$ & -- & -- & -- & $<50 \mu \mathrm{g} / \mathrm{kg}$ & -- & -- & -- \\
\hline $\begin{array}{l}\text { 5-Methyl-1H- } \\
\text { benzotriazole, } \\
\text { dissolved }\end{array}$ & 4 & ND & $<2$ & $<2$ & -- & -- & -- & -- & -- \\
\hline $\begin{array}{l}\text { 5-Methyl-1H- } \\
\text { benzotriazole, whole } \\
\text { water }\end{array}$ & 3 & .33 & $<2$ & $<2$ & $<2$ & $<2$ & $<2$ & $<2$ & $<2$ \\
\hline $\begin{array}{l}\text { 7-Acetyl-1,1,3,4,4,6- } \\
\text { hexamethyl } \\
\text { tetrahydronaphthale } \\
\text { ne (AHTN), dissolved }\end{array}$ & 4 & .23 & $<.5$ & $<.5$ & -- & -- & -- & -- & -- \\
\hline $\begin{array}{l}\text { 7-Acetyl-1,1,3,4,4,6- } \\
\text { hexamethyl } \\
\text { tetrahydronaphthale } \\
\text { ne (AHTN), whole } \\
\text { water }\end{array}$ & 3 & .048 & $<.5$ & $<.5$ & $<.5$ & $<.5$ & $<.5$ & $<.5$ & $<.5$ \\
\hline $\begin{array}{l}\text { 7-Acetyl-1,1,3,4,4,6- } \\
\text { hexamethyl } \\
\text { tetrahydronaphthale } \\
\text { ne (AHTN), bottom } \\
\text { sediment }\end{array}$ & 5 & $50 \mu \mathrm{g} / \mathrm{kg}$ & -- & -- & -- & $<50 \mu \mathrm{g} / \mathrm{kg}$ & -- & -- & -- \\
\hline $\begin{array}{l}\text { Acetophenone, } \\
\text { dissolved }\end{array}$ & 4 & .5 & $<.5$ & $<.5$ & -- & -- & -- & -- & -- \\
\hline $\begin{array}{l}\text { Acetophenone, whole } \\
\text { water }\end{array}$ & 3 & .08 & $<.5$ & $<.5$ & $<.5$ & $<.5$ & $<.5$ & $<.5$ & $<.5$ \\
\hline
\end{tabular}


Table 18. Analytical results for household, industrial, and minor agricultural use compounds (HIACs) in water and bottom-sediment samples.-Continued

[Bold text indicates suspected endocrine-disrupting compound (EDC). Shaded cells indicate concentrations greater than study reporting levels for compounds with acceptable quality assurance/quality control, and concentrations were used in analyses related to occurrence of organic wastewater compounds. Units are micrograms per liter unless otherwise noted. Analytical method number: 3, Lee and others (2004); 4, Zaugg and others (2002); 5 , Burkhardt and others (2005). $\mu \mathrm{g} / \mathrm{kg}$, micrograms per kilogram; ND, not determined; e, estimated; <, less than; --, no data collected]

\begin{tabular}{|c|c|c|c|c|c|c|c|c|c|}
\hline & \multirow[b]{2}{*}{$\begin{array}{l}\text { Analytical } \\
\text { method } \\
\text { number }\end{array}$} & \multirow{2}{*}{$\begin{array}{c}\text { Study } \\
\text { reporting } \\
\text { level } \\
\text { for data } \\
\text { summary and } \\
\text { analysis }\end{array}$} & \multicolumn{7}{|c|}{ Station identification number and name (site label) } \\
\hline & & & \multicolumn{2}{|c|}{$\begin{array}{c}433843096450500 \\
\text { Big Sioux River near } \\
\text { Renner, SD } \\
\text { (site US1, fig. 1) }\end{array}$} & \multicolumn{5}{|c|}{$\begin{array}{c}433600096442400 \\
\text { Sioux Falls pump station intake from } \\
\text { Big Sioux River at Sioux Falls, SD } \\
\text { (site US2, fig. 1) }\end{array}$} \\
\hline \multicolumn{10}{|c|}{ Compound-Continued } \\
\hline $\begin{array}{l}\text { Acetophenone, bottom } \\
\text { sediment }\end{array}$ & 5 & $50 \mu \mathrm{g} / \mathrm{kg}$ & -- & -- & -- & $<50 \mu \mathrm{g} / \mathrm{kg}$ & -- & -- & -- \\
\hline $\begin{array}{l}\text { Anthraquinone, } \\
\text { dissolved }\end{array}$ & 4 & 0.12 & $<0.5$ & $<0.5$ & -- & -- & -- & -- & -- \\
\hline $\begin{array}{l}\text { Anthraquinone, whole } \\
\text { water }\end{array}$ & 3 & .098 & $<.5$ & $<.5$ & $<0.5$ & $<5$ & $<0.5$ & $<0.5$ & $<0.5$ \\
\hline $\begin{array}{l}\text { Anthraquinone, bottom } \\
\text { sediment }\end{array}$ & 5 & $4 \mu \mathrm{g} / \mathrm{kg}$ & -- & -- & -- & $<50 \mu \mathrm{g} / \mathrm{kg}$ & -- & -- & -- \\
\hline $\begin{array}{l}\text { Benzophenone, } \\
\text { dissolved }\end{array}$ & 4 & .066 & $<.5$ & $<.5$ & -- & -- & -- & -- & -- \\
\hline $\begin{array}{l}\text { Benzophenone, whole } \\
\text { water }\end{array}$ & 3 & ND & $<.5$ & $<.5$ & $<.5$ & $<.5$ & $<.5$ & $<.5$ & e. 12 \\
\hline $\begin{array}{l}\text { Benzophenone, bottom } \\
\text { sediment }\end{array}$ & 5 & $50 \mu \mathrm{g} / \mathrm{kg}$ & -- & -- & -- & $<50 \mu \mathrm{g} / \mathrm{kg}$ & -- & -- & -- \\
\hline $\begin{array}{l}\text { Bis(2-ethylhexyl) } \\
\text { phthalate, whole water }\end{array}$ & 3 & ND & $<2$ & $<2$ & -- & $<.5$ & $\mathrm{e} 2.1$ & $<.5$ & $<.5$ \\
\hline $\begin{array}{l}\text { Bis(2-ethylhexyl) } \\
\text { phthalate, bottom } \\
\text { sediment }\end{array}$ & 5 & $100 \mu \mathrm{g} / \mathrm{kg}$ & -- & -- & -- & $<100 \mu \mathrm{g} / \mathrm{kg}$ & -- & -- & -- \\
\hline Bisphenol-A, dissolved & 4 & ND & $<1$ & $<1$ & -- & -- & -- & -- & -- \\
\hline $\begin{array}{l}\text { Bisphenol-A, whole } \\
\text { water }\end{array}$ & 3 & ND & $<1$ & $<1$ & $<1$ & $<1$ & $<1$ & $<1$ & $<1$ \\
\hline $\begin{array}{l}\text { Bisphenol-A, bottom } \\
\text { sediment }\end{array}$ & 5 & $100 \mu \mathrm{g} / \mathrm{kg}$ & -- & -- & -- & $<100 \mu \mathrm{g} / \mathrm{kg}$ & -- & -- & -- \\
\hline Bromacil, dissolved & 4 & ND & $<.5$ & $<.5$ & -- & -- & -- & -- & -- \\
\hline Bromacil, whole water & 3 & .068 & $<.5$ & $<.5$ & $<.5$ & $<.5$ & $<.5$ & $<.5$ & $<.5$ \\
\hline $\begin{array}{l}\text { Bromacil, bottom } \\
\text { sediment }\end{array}$ & 5 & $100 \mu \mathrm{g} / \mathrm{kg}$ & -- & -- & -- & $<100 \mu \mathrm{g} / \mathrm{kg}$ & -- & -- & -- \\
\hline Camphor, dissolved & 4 & .029 & $<.5$ & $<.5$ & -- & -- & -- & -- & -- \\
\hline Camphor, whole water & 3 & .5 & $<.5$ & $<.5$ & $<.5$ & $<.5$ & $<.5$ & $<.5$ & $<.5$ \\
\hline $\begin{array}{l}\text { Camphor, bottom } \\
\text { sediment }\end{array}$ & 5 & $50 \mu \mathrm{g} / \mathrm{kg}$ & -- & -- & -- & $<50 \mu \mathrm{g} / \mathrm{kg}$ & -- & -- & -- \\
\hline Carbaryl, dissolved & 4 & .14 & $<1$ & $<1$ & -- & -- & -- & -- & -- \\
\hline Carbaryl, whole water & 3 & ND & $<1$ & $<1$ & $<1$ & $<1$ & $<1$ & $<1$ & $<1$ \\
\hline Chlorpyrifos, dissolved & 4 & .5 & $<.5$ & $<.5$ & -- & -- & -- & -- & -- \\
\hline $\begin{array}{l}\text { Chlorpyrifos, whole } \\
\text { water }\end{array}$ & 3 & .014 & $<.5$ & $<.5$ & $<.5$ & $<.5$ & $<.5$ & $<.5$ & $<.5$ \\
\hline
\end{tabular}


Table 18. Analytical results for household, industrial, and minor agricultural use compounds (HIACs) in water and bottom-sediment samples.-Continued

[Bold text indicates suspected endocrine-disrupting compound (EDC). Shaded cells indicate concentrations greater than study reporting levels for compounds with acceptable quality assurance/quality control, and concentrations were used in analyses related to occurrence of organic wastewater compounds. Units are micrograms per liter unless otherwise noted. Analytical method number: 3, Lee and others (2004); 4, Zaugg and others (2002); 5 , Burkhardt and others (2005). $\mu \mathrm{g} / \mathrm{kg}$, micrograms per kilogram; ND, not determined; e, estimated; <, less than; --, no data collected]

\begin{tabular}{|c|c|c|c|c|c|c|c|c|c|}
\hline & \multirow[b]{2}{*}{$\begin{array}{l}\text { Analytical } \\
\text { method } \\
\text { number }\end{array}$} & \multirow{2}{*}{$\begin{array}{c}\text { Study } \\
\text { reporting } \\
\text { level } \\
\text { for data } \\
\text { summary and } \\
\text { analysis }\end{array}$} & \multicolumn{7}{|c|}{ Station identification number and name (site label) } \\
\hline & & & \multicolumn{2}{|c|}{$\begin{array}{c}433843096450500 \\
\text { Big Sioux River near } \\
\text { Renner, SD } \\
\text { (site US1, fig. 1) }\end{array}$} & \multicolumn{5}{|c|}{$\begin{array}{c}433600096442400 \\
\text { Sioux Falls pump station intake from } \\
\text { Big Sioux River at Sioux Falls, SD } \\
\text { (site US2, fig. 1) }\end{array}$} \\
\hline \multicolumn{10}{|c|}{ Compound-Continued } \\
\hline $\begin{array}{l}\text { Chlorpyrifos, bottom } \\
\text { sediment }\end{array}$ & 5 & $50 \mu \mathrm{g} / \mathrm{kg}$ & -- & -- & -- & $<50 \mu \mathrm{g} / \mathrm{kg}$ & -- & -- & -- \\
\hline $\begin{array}{l}\text { N,N-Diethyl-meta- } \\
\text { toluamide (DEET), } \\
\text { dissolved }\end{array}$ & 4 & 0.034 & $\mathrm{e} 0.034$ & $<0.5$ & -- & -- & -- & -- & -- \\
\hline $\begin{array}{l}\text { N,N-Diethyl-meta- } \\
\text { toluamide (DEET), } \\
\text { whole water }\end{array}$ & 3 & .042 & $<.5$ & $<.5$ & $<0.5$ & $<0.5$ & $<0.5$ & $<0.5$ & $\mathrm{e} 0.074$ \\
\hline $\begin{array}{l}\text { N,N-Diethyl-meta- } \\
\text { toluamide (DEET), } \\
\text { bottom sediment }\end{array}$ & 5 & $100 \mu \mathrm{g} / \mathrm{kg}$ & -- & -- & -- & $<100 \mu \mathrm{g} / \mathrm{kg}$ & -- & -- & -- \\
\hline Diazinon, dissolved & 4 & .5 & $<5$ & $<.5$ & -- & -- & -- & -- & -- \\
\hline Diazinon, whole water & 3 & .027 & $<.5$ & $<.5$ & $<.5$ & $<.5$ & $<.5$ & $<.5$ & $<.5$ \\
\hline $\begin{array}{l}\text { Diazinon, bottom } \\
\text { sediment }\end{array}$ & 5 & $50 \mu \mathrm{g} / \mathrm{kg}$ & -- & -- & -- & $<50 \mu \mathrm{g} / \mathrm{kg}$ & -- & -- & -- \\
\hline Dichlorvos, dissolved & 4 & ND & $<1$ & $<1$ & -- & -- & -- & -- & -- \\
\hline Dichlorvos, whole water & 3 & ND & $<1$ & $<1$ & $<1$ & $<1$ & $<1$ & $<1$ & $<1$ \\
\hline $\begin{array}{l}\text { Diethyl phthalate, } \\
\text { whole water }\end{array}$ & 3 & ND & $<.5$ & $<.5$ & -- & $<.5$ & $<.5$ & $<.5$ & -- \\
\hline $\begin{array}{c}\text { Diethyl phthalate, } \\
\text { bottom sediment }\end{array}$ & 5 & $50 \mu \mathrm{g} / \mathrm{kg}$ & -- & -- & -- & $<50 \mu \mathrm{g} / \mathrm{kg}$ & -- & -- & -- \\
\hline D-Limonene, dissolved & 4 & ND & $<.5$ & $<.5$ & -- & -- & -- & -- & -- \\
\hline $\begin{array}{l}\text { D-Limonene, whole } \\
\text { water }\end{array}$ & 3 & ND & $<.5$ & $<.5$ & $<.5$ & $<.5$ & $<.5$ & $<.5$ & $<.5$ \\
\hline $\begin{array}{l}\text { D-Limonene, bottom } \\
\text { sediment }\end{array}$ & 5 & $50 \mu \mathrm{g} / \mathrm{kg}$ & -- & -- & -- & $<50 \mu \mathrm{g} / \mathrm{kg}$ & -- & -- & -- \\
\hline $\begin{array}{l}\text { 1,3,4,6,7,8-Hexahydro- } \\
\text { 4,6,6,7,8,8- } \\
\text { hexamethyl } \\
\text { cyclopenta-g-2- } \\
\text { benzopyran (HHCB), } \\
\text { dissolved }\end{array}$ & 4 & .061 & $<.5$ & $<.5$ & -- & -- & -- & -- & -- \\
\hline $\begin{array}{l}\text { 1,3,4,6,7,8-Hexahydro- } \\
\text { 4,6,6,7,8,8- } \\
\text { hexamethyl } \\
\text { cyclopenta-g-2- } \\
\text { benzopyran (HHCB), } \\
\text { whole water }\end{array}$ & 3 & .045 & $<.5$ & $<.5$ & $<.5$ & $<.5$ & $<.5$ & $<.5$ & $<.5$ \\
\hline
\end{tabular}


Table 18. Analytical results for household, industrial, and minor agricultural use compounds (HIACs) in water and bottom-sediment samples.-Continued

[Bold text indicates suspected endocrine-disrupting compound (EDC). Shaded cells indicate concentrations greater than study reporting levels for compounds with acceptable quality assurance/quality control, and concentrations were used in analyses related to occurrence of organic wastewater compounds. Units are micrograms per liter unless otherwise noted. Analytical method number: 3, Lee and others (2004); 4, Zaugg and others (2002); 5 , Burkhardt and others (2005). $\mu \mathrm{g} / \mathrm{kg}$, micrograms per kilogram; ND, not determined; e, estimated; <, less than; --, no data collected]

\begin{tabular}{|c|c|c|c|c|c|c|c|c|c|}
\hline & \multirow[b]{2}{*}{$\begin{array}{l}\text { Analytical } \\
\text { method } \\
\text { number }\end{array}$} & \multirow{2}{*}{$\begin{array}{l}\text { Study } \\
\text { reporting } \\
\text { level } \\
\text { for data } \\
\text { summary and } \\
\text { analysis }\end{array}$} & \multicolumn{7}{|c|}{ Station identification number and name (site label) } \\
\hline & & & \multicolumn{2}{|c|}{$\begin{array}{c}433843096450500 \\
\text { Big Sioux River near } \\
\text { Renner, SD } \\
\text { (site US1, fig. 1) }\end{array}$} & \multicolumn{5}{|c|}{$\begin{array}{c}433600096442400 \\
\text { Sioux Falls pump station intake from } \\
\text { Big Sioux River at Sioux Falls, SD } \\
\text { (site US2, fig. 1) }\end{array}$} \\
\hline \multicolumn{10}{|c|}{ Compound-Continued } \\
\hline $\begin{array}{l}\text { 1,3,4,6,7,8-Hexahydro- } \\
\text { 4,6,6,7,8,8- } \\
\text { hexamethyl } \\
\text { cyclopenta-g-2- } \\
\text { benzopyran (HHCB), } \\
\text { bottom sediment }\end{array}$ & 5 & $50 \mu \mathrm{g} / \mathrm{kg}$ & -- & -- & -- & $<50 \mu \mathrm{g} / \mathrm{kg}$ & -- & -- & -- \\
\hline Indole, dissolved & 4 & 0.042 & $<0.5$ & $<0.5$ & -- & -- & -- & -- & -- \\
\hline Indole, whole water & 3 & .015 & $<.5$ & $<.5$ & $<0.5$ & $<0.5$ & $<0.5$ & $<0.5$ & $<0.5$ \\
\hline Indole, bottom sediment & 5 & $1.9 \mu \mathrm{g} / \mathrm{kg}$ & -- & -- & -- & e $42 \mu \mathrm{g} / \mathrm{kg}$ & -- & -- & -- \\
\hline Isoborneol, dissolved & 4 & .5 & $<.5$ & $<.5$ & -- & -- & -- & -- & -- \\
\hline Isoborneol, whole water & 3 & .5 & $<.5$ & $<.5$ & $<.5$ & $<.5$ & $<.5$ & $<.5$ & $<.5$ \\
\hline $\begin{array}{l}\text { Isoborneol, bottom } \\
\text { sediment }\end{array}$ & 5 & $50 \mu \mathrm{g} / \mathrm{kg}$ & -- & -- & -- & $<50 \mu \mathrm{g} / \mathrm{kg}$ & -- & -- & -- \\
\hline Isophorone, dissolved & 4 & .047 & e. 054 & $<.5$ & -- & -- & -- & -- & -- \\
\hline Isophorone, whole water & 3 & ND & $<.5$ & $<.5$ & $<.5$ & $<.5$ & $<.5$ & $<.5$ & $<.5$ \\
\hline $\begin{array}{l}\text { Isophorone, bottom } \\
\text { sediment }\end{array}$ & 5 & $50 \mu \mathrm{g} / \mathrm{kg}$ & -- & -- & -- & $<50 \mu \mathrm{g} / \mathrm{kg}$ & -- & -- & -- \\
\hline $\begin{array}{l}\text { Isopropylbenzene } \\
\text { (cumene), dissolved }\end{array}$ & 4 & ND & $<.5$ & $<.5$ & -- & -- & -- & -- & -- \\
\hline $\begin{array}{l}\text { Isopropylbenzene } \\
\text { (cumene), whole water }\end{array}$ & 3 & ND & $<.5$ & $<.5$ & $<.5$ & $<.5$ & $<.5$ & $<.5$ & $<.5$ \\
\hline $\begin{array}{l}\text { Isopropylbenzene } \\
\text { (cumene), bottom } \\
\text { sediment }\end{array}$ & 5 & $50 \mu \mathrm{g} / \mathrm{kg}$ & -- & -- & -- & $<50 \mu \mathrm{g} / \mathrm{kg}$ & -- & -- & -- \\
\hline Isoquinoline, dissolved & 4 & .5 & $<.5$ & $<.5$ & -- & -- & -- & -- & -- \\
\hline $\begin{array}{l}\text { Isoquinoline, whole } \\
\text { water }\end{array}$ & 3 & ND & $<.5$ & $<.5$ & $<.5$ & $<.5$ & $<.5$ & $<.5$ & $<.5$ \\
\hline $\begin{array}{l}\text { Isoquinoline, bottom } \\
\text { sediment }\end{array}$ & 5 & $50 \mu \mathrm{g} / \mathrm{kg}$ & -- & -- & -- & $<50 \mu \mathrm{g} / \mathrm{kg}$ & -- & -- & -- \\
\hline Menthol, dissolved & 4 & .5 & $<.5$ & $<.5$ & -- & -- & -- & -- & -- \\
\hline Menthol, whole water & 3 & ND & $<.5$ & $<.5$ & $<.5$ & $<.5$ & $<.5$ & $<.5$ & $<.5$ \\
\hline $\begin{array}{l}\text { Menthol, bottom } \\
\text { sediment }\end{array}$ & 5 & $50 \mu \mathrm{g} / \mathrm{kg}$ & -- & -- & -- & $<50 \mu \mathrm{g} / \mathrm{kg}$ & -- & -- & -- \\
\hline Metalaxyl, dissolved & 4 & .5 & $<.5$ & $<.5$ & -- & -- & -- & -- & -- \\
\hline Metalaxyl, whole water & 3 & .5 & $<.5$ & $<.5$ & $<.5$ & $<.5$ & $<.5$ & $<.5$ & $<.5$ \\
\hline $\begin{array}{l}\text { Metalaxyl, bottom } \\
\text { sediment }\end{array}$ & 5 & $100 \mu \mathrm{g} / \mathrm{kg}$ & -- & -- & -- & $<100 \mu \mathrm{g} / \mathrm{kg}$ & -- & -- & -- \\
\hline
\end{tabular}


Table 18. Analytical results for household, industrial, and minor agricultural use compounds (HIACs) in water and bottom-sediment samples.-Continued

[Bold text indicates suspected endocrine-disrupting compound (EDC). Shaded cells indicate concentrations greater than study reporting levels for compounds with acceptable quality assurance/quality control, and concentrations were used in analyses related to occurrence of organic wastewater compounds.

Units are micrograms per liter unless otherwise noted. Analytical method number: 3, Lee and others (2004); 4, Zaugg and others (2002); 5 ,

Burkhardt and others (2005). $\mu \mathrm{g} / \mathrm{kg}$, micrograms per kilogram; ND, not determined; e, estimated; <, less than; --, no data collected]

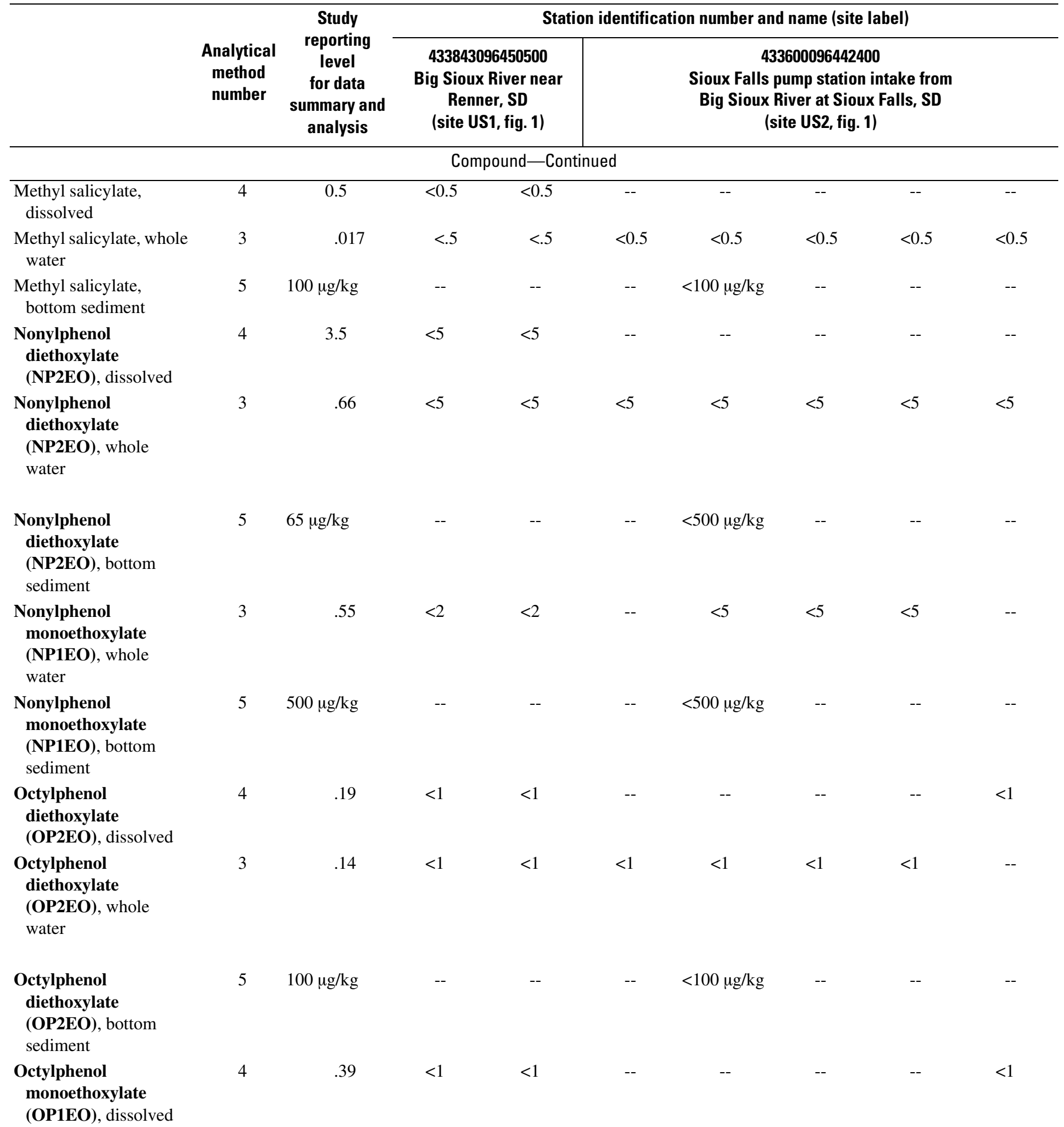


Table 18. Analytical results for household, industrial, and minor agricultural use compounds (HIACs) in water and bottom-sediment samples.-Continued

[Bold text indicates suspected endocrine-disrupting compound (EDC). Shaded cells indicate concentrations greater than study reporting levels for compounds with acceptable quality assurance/quality control, and concentrations were used in analyses related to occurrence of organic wastewater compounds. Units are micrograms per liter unless otherwise noted. Analytical method number: 3, Lee and others (2004); 4, Zaugg and others (2002); 5 , Burkhardt and others (2005). $\mu \mathrm{g} / \mathrm{kg}$, micrograms per kilogram; ND, not determined; e, estimated; <, less than; --, no data collected]

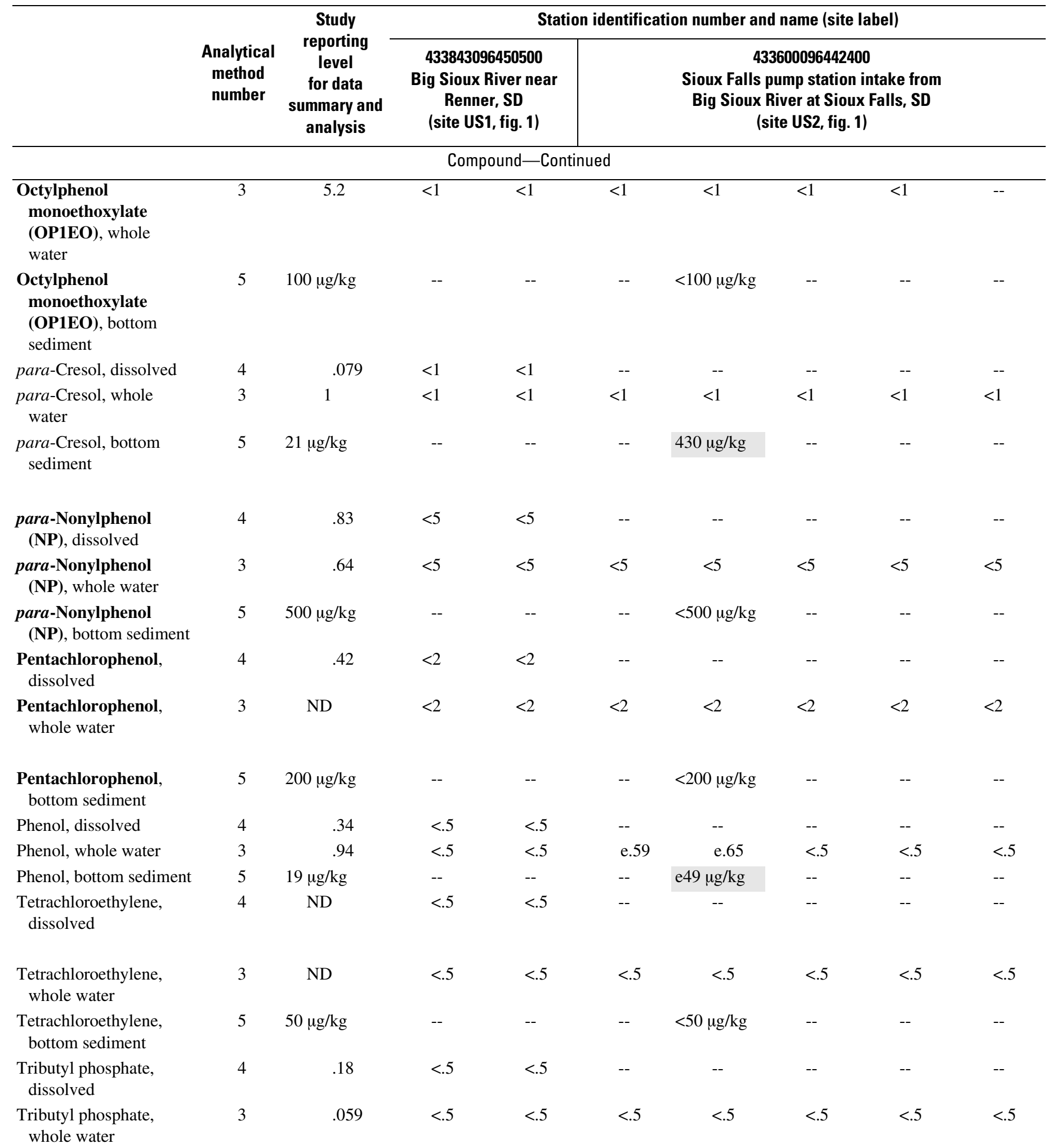


Table 18. Analytical results for household, industrial, and minor agricultural use compounds (HIACs) in water and bottom-sediment samples.-Continued

[Bold text indicates suspected endocrine-disrupting compound (EDC). Shaded cells indicate concentrations greater than study reporting levels for compounds with acceptable quality assurance/quality control, and concentrations were used in analyses related to occurrence of organic wastewater compounds.

Units are micrograms per liter unless otherwise noted. Analytical method number: 3, Lee and others (2004); 4, Zaugg and others (2002); 5 ,

Burkhardt and others (2005). $\mu \mathrm{g} / \mathrm{kg}$, micrograms per kilogram; ND, not determined; e, estimated; <, less than; --, no data collected]

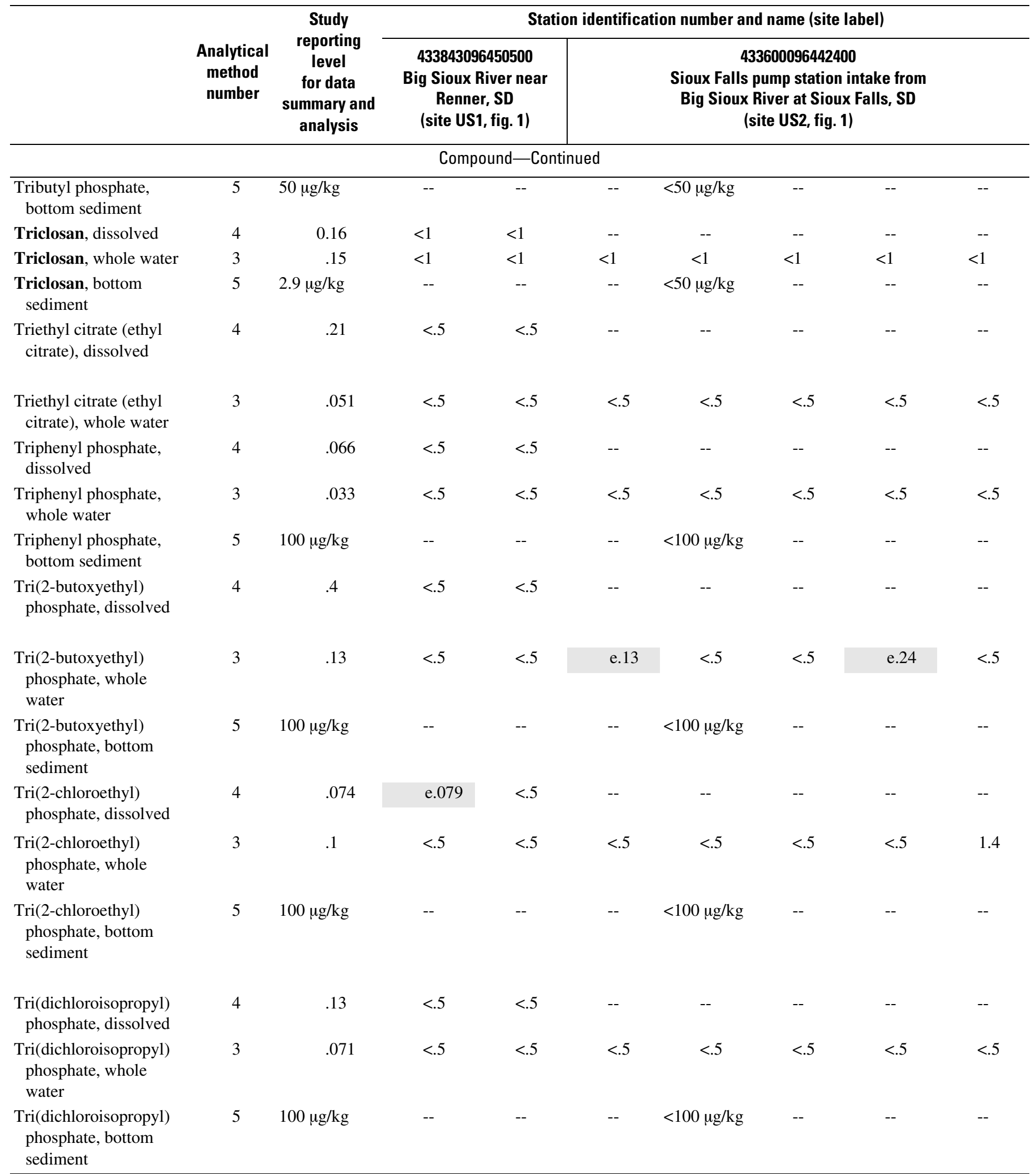


Table 18. Analytical results for household, industrial, and minor agricultural use compounds (HIACs) in water and bottom-sediment samples.-Continued

[Bold text indicates suspected endocrine-disrupting compound (EDC). Shaded cells indicate concentrations greater than study reporting levels for compounds with acceptable quality assurance/quality control, and concentrations were used in analyses related to occurrence of organic wastewater compounds.

Units are micrograms per liter unless otherwise noted. Analytical method number: 3, Lee and others (2004); 4, Zaugg and others (2002); 5,

Burkhardt and others (2005). $\mu \mathrm{g} / \mathrm{kg}$, micrograms per kilogram; ND, not determined; e, estimated; <, less than; --, no data collected]

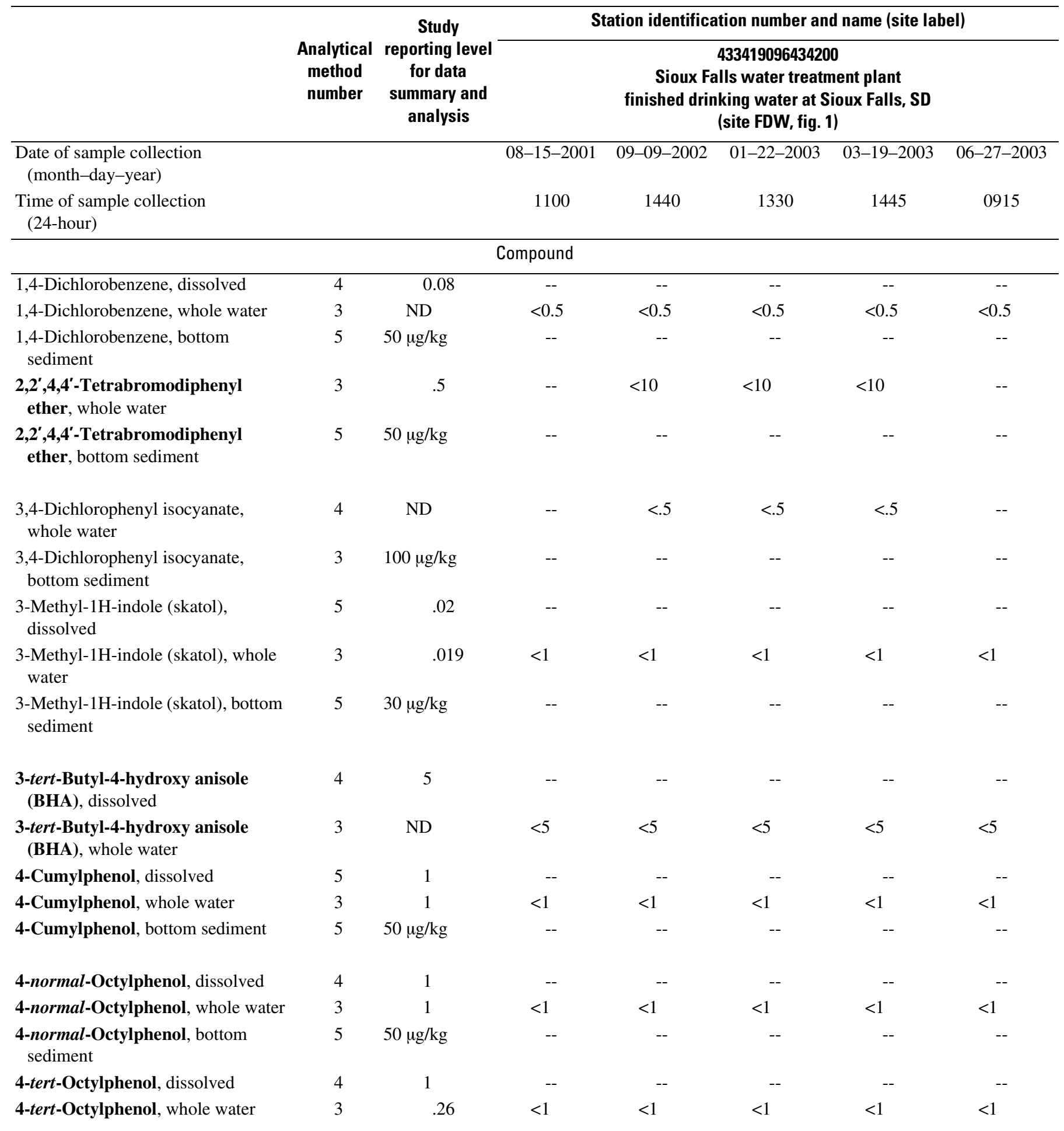


Table 18. Analytical results for household, industrial, and minor agricultural use compounds (HIACs) in water and bottom-sediment samples.-Continued

[Bold text indicates suspected endocrine-disrupting compound (EDC). Shaded cells indicate concentrations greater than study reporting levels for compounds with acceptable quality assurance/quality control, and concentrations were used in analyses related to occurrence of organic wastewater compounds.

Units are micrograms per liter unless otherwise noted. Analytical method number: 3, Lee and others (2004); 4, Zaugg and others (2002); 5 ,

Burkhardt and others (2005). $\mu \mathrm{g} / \mathrm{kg}$, micrograms per kilogram; ND, not determined; e, estimated; <, less than; --, no data collected]

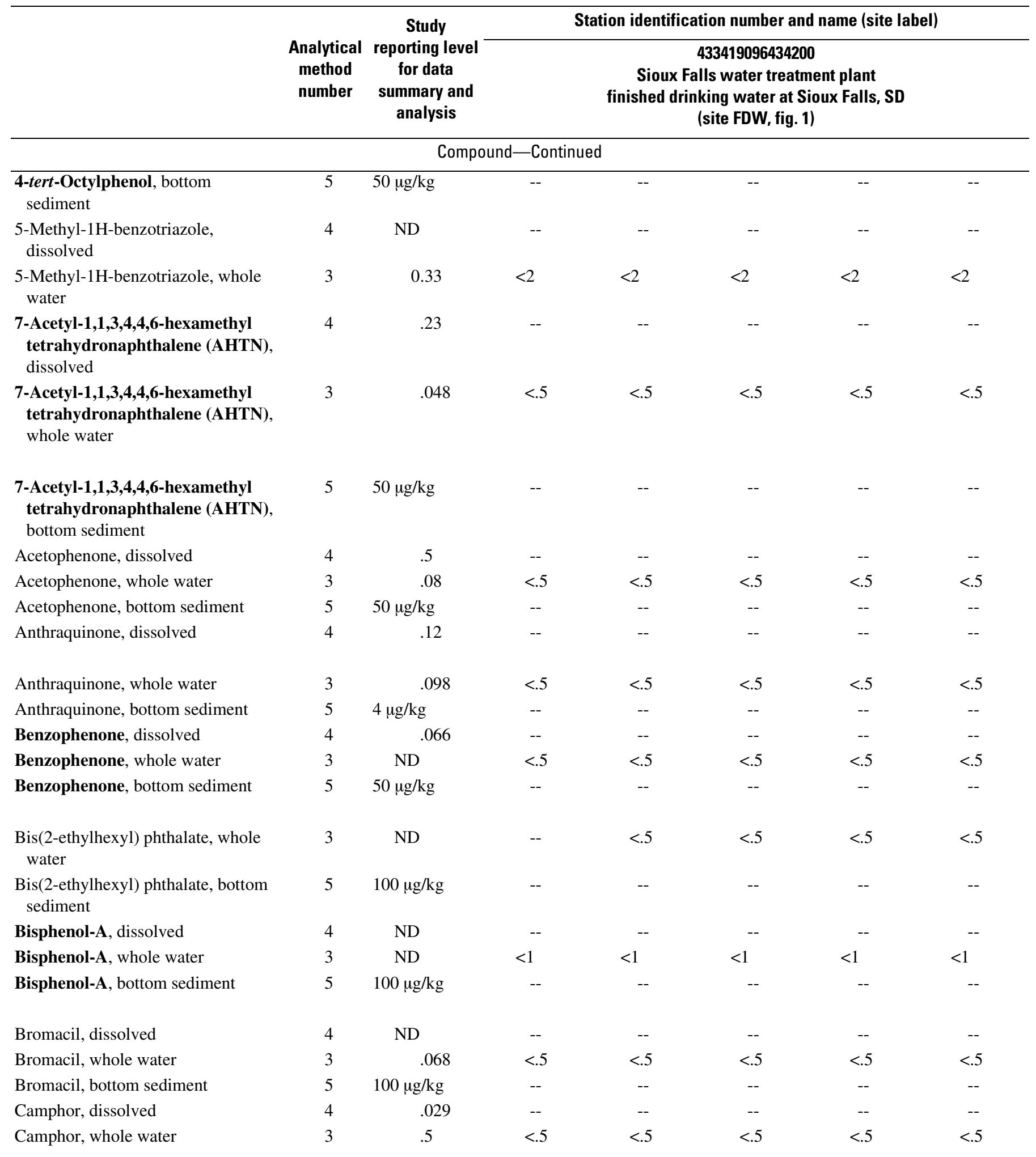


Table 18. Analytical results for household, industrial, and minor agricultural use compounds (HIACs) in water and bottom-sediment samples.-Continued

[Bold text indicates suspected endocrine-disrupting compound (EDC). Shaded cells indicate concentrations greater than study reporting levels for compounds with acceptable quality assurance/quality control, and concentrations were used in analyses related to occurrence of organic wastewater compounds. Units are micrograms per liter unless otherwise noted. Analytical method number: 3, Lee and others (2004); 4, Zaugg and others (2002); 5, Burkhardt and others (2005). $\mu \mathrm{g} / \mathrm{kg}$, micrograms per kilogram; ND, not determined; e, estimated; <, less than; --, no data collected]

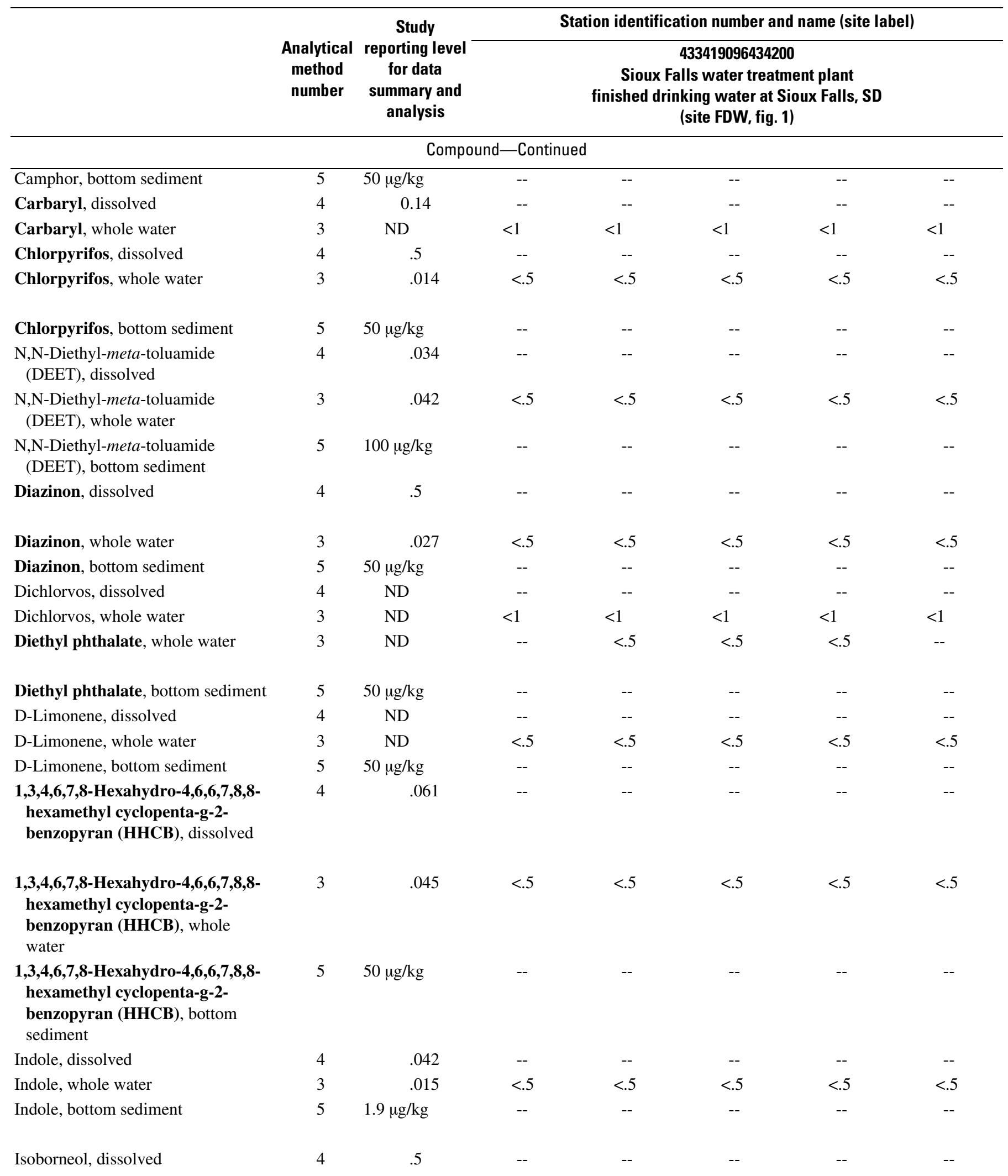


Table 18. Analytical results for household, industrial, and minor agricultural use compounds (HIACs) in water and bottom-sediment samples.-Continued

[Bold text indicates suspected endocrine-disrupting compound (EDC). Shaded cells indicate concentrations greater than study reporting levels for compounds with acceptable quality assurance/quality control, and concentrations were used in analyses related to occurrence of organic wastewater compounds.

Units are micrograms per liter unless otherwise noted. Analytical method number: 3, Lee and others (2004); 4, Zaugg and others (2002); 5 ,

Burkhardt and others (2005). $\mu \mathrm{g} / \mathrm{kg}$, micrograms per kilogram; ND, not determined; e, estimated; <, less than; --, no data collected]

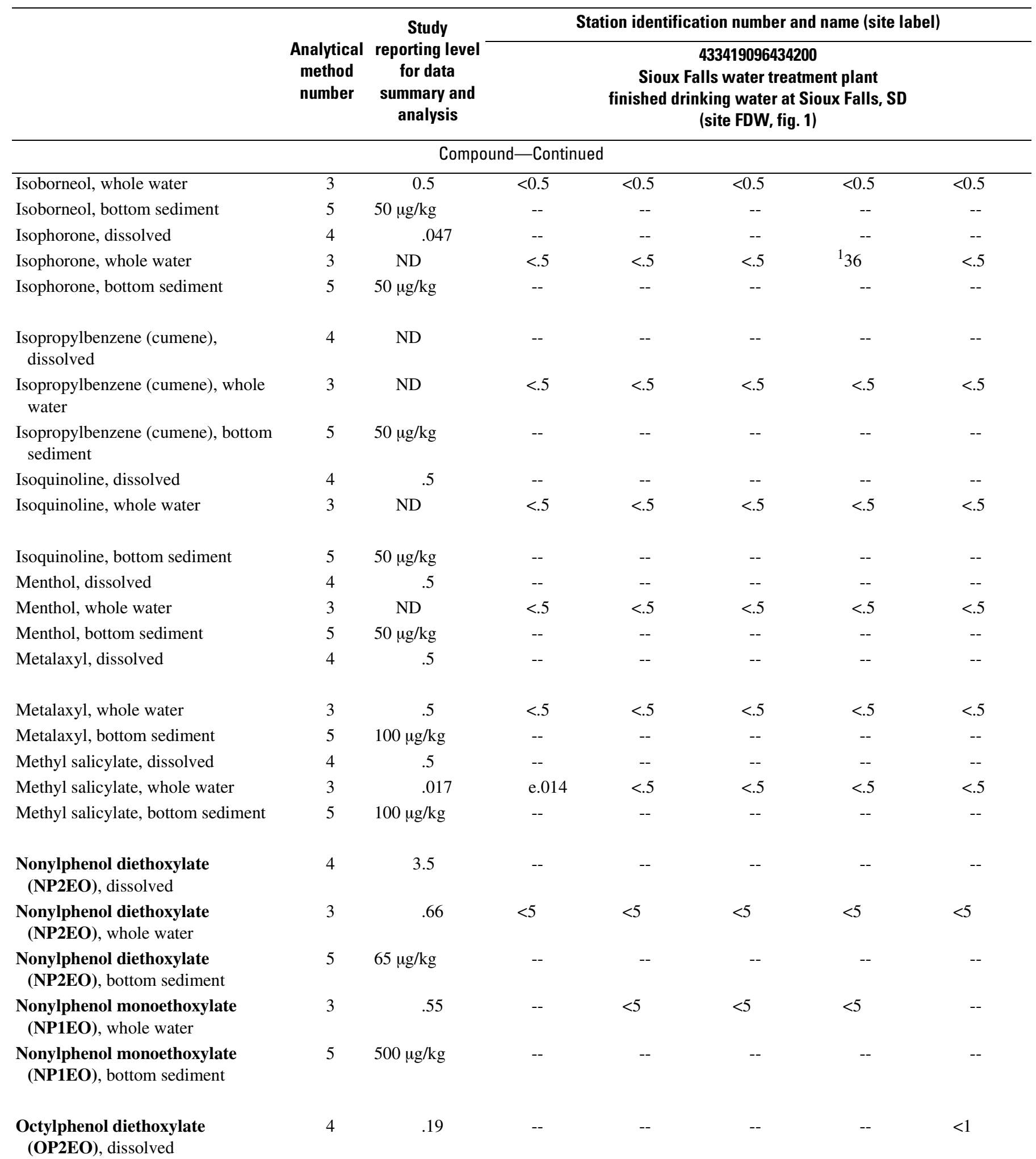


Table 18. Analytical results for household, industrial, and minor agricultural use compounds (HIACs) in water and bottom-sediment samples.-Continued

[Bold text indicates suspected endocrine-disrupting compound (EDC). Shaded cells indicate concentrations greater than study reporting levels for compounds with acceptable quality assurance/quality control, and concentrations were used in analyses related to occurrence of organic wastewater compounds. Units are micrograms per liter unless otherwise noted. Analytical method number: 3, Lee and others (2004); 4, Zaugg and others (2002); 5, Burkhardt and others (2005). $\mu \mathrm{g} / \mathrm{kg}$, micrograms per kilogram; ND, not determined; e, estimated; <, less than; --, no data collected]

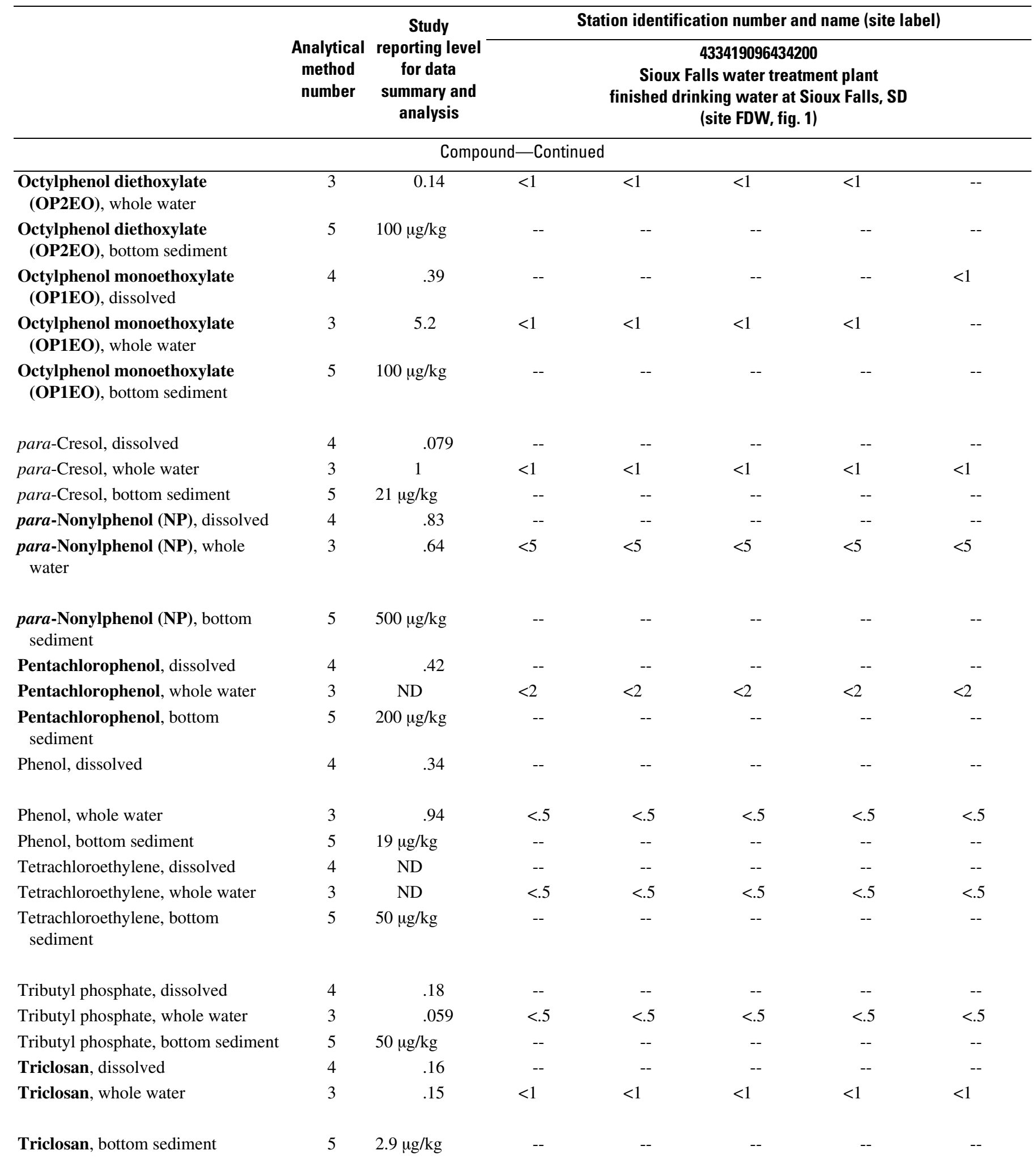


Table 18. Analytical results for household, industrial, and minor agricultural use compounds (HIACs) in water and bottom-sediment samples.-Continued

[Bold text indicates suspected endocrine-disrupting compound (EDC). Shaded cells indicate concentrations greater than study reporting levels for compounds with acceptable quality assurance/quality control, and concentrations were used in analyses related to occurrence of organic wastewater compounds.

Units are micrograms per liter unless otherwise noted. Analytical method number: 3, Lee and others (2004); 4, Zaugg and others (2002); 5,

Burkhardt and others (2005). $\mu \mathrm{g} / \mathrm{kg}$, micrograms per kilogram; ND, not determined; e, estimated; <, less than; --, no data collected]

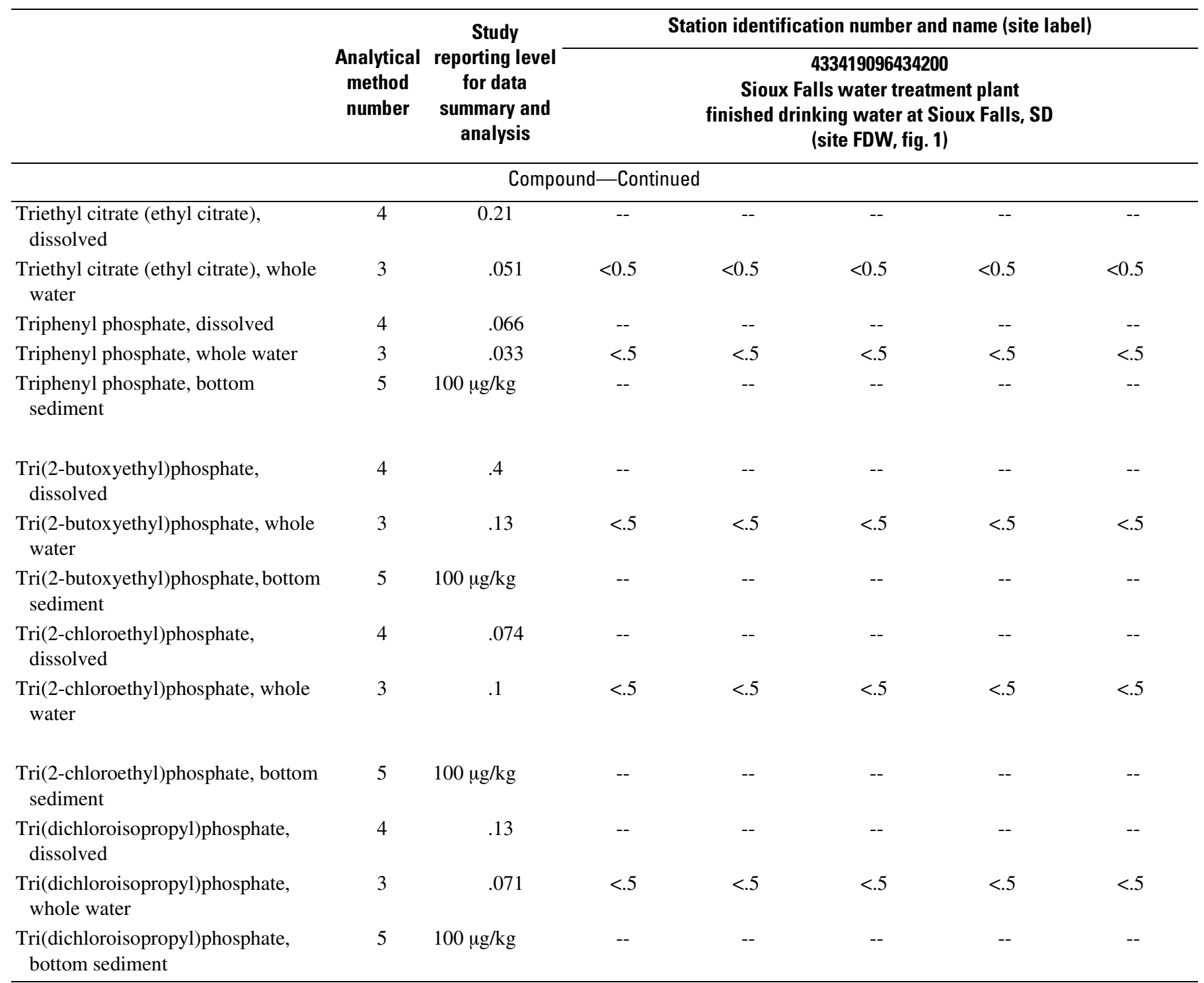


Table 18. Analytical results for household, industrial, and minor agricultural use compounds (HIACs) in water and bottom-sediment samples.-Continued

[Bold text indicates suspected endocrine-disrupting compound (EDC). Shaded cells indicate concentrations greater than study reporting levels for compounds with acceptable quality assurance/quality control, and concentrations were used in analyses related to occurrence of organic wastewater compounds.

Units are micrograms per liter unless otherwise noted. Analytical method number: 3, Lee and others (2004); 4, Zaugg and others (2002); 5,

Burkhardt and others (2005). $\mu \mathrm{g} / \mathrm{kg}$, micrograms per kilogram; ND, not determined; e, estimated; <, less than; --, no data collected]

\begin{tabular}{|c|c|c|c|c|c|c|}
\hline \multirow{3}{*}{$\begin{array}{c} \\
\text { Date of sample collection } \\
\text { (month-day-year) }\end{array}$} & \multirow{3}{*}{$\begin{array}{c}\text { Analytical } \\
\text { method } \\
\text { number }\end{array}$} & \multirow{4}{*}{$\begin{array}{l}\text { Study } \\
\text { reporting level } \\
\text { for data } \\
\text { summary and } \\
\text { analysis }\end{array}$} & \multicolumn{4}{|c|}{ Station identification number and name (site label) } \\
\hline & & & \multicolumn{2}{|c|}{$\begin{array}{c}433408096432000 \\
\text { Big Sioux River diversion channel } \\
\text { at North Drive, at Sioux Falls, SD } \\
\text { (site US3, fig. 1) }\end{array}$} & \multicolumn{2}{|c|}{$\begin{array}{c}06482020 \\
\text { Big Sioux River at North Cliff Avenue, } \\
\text { at Sioux Falls, SD } \\
\text { (site US4, fig. 1) }\end{array}$} \\
\hline & & & $05-18-2004$ & $05-31-2004$ & $05-17-2004$ & 05-30-2004 \\
\hline $\begin{array}{l}\text { Time of sample collection } \\
\text { (24-hour) }\end{array}$ & & & 1130 & 1145 & 1000 & 1530 \\
\hline \multicolumn{7}{|c|}{ Compound } \\
\hline 1,4-Dichlorobenzene, dissolved & 4 & 0.08 & $<0.5$ & $<0.5$ & $<0.5$ & $<0.5$ \\
\hline 1,4-Dichlorobenzene, whole water & 3 & ND & $<.5$ & $<.5$ & $<.5$ & $<.5$ \\
\hline $\begin{array}{l}\text { 1,4-Dichlorobenzene, bottom } \\
\text { sediment }\end{array}$ & 5 & $50 \mu \mathrm{g} / \mathrm{kg}$ & -- & -- & -- & -- \\
\hline $\begin{array}{l}2,2^{\prime}, 4,4^{\prime} \text {-Tetrabromodiphenyl } \\
\text { ether, whole water }\end{array}$ & 3 & .5 & $<.5$ & $<.5$ & $<.5$ & $<.5$ \\
\hline $\begin{array}{l}\text { 2,2',4,4'-Tetrabromodiphenyl } \\
\text { ether, bottom sediment }\end{array}$ & 5 & $50 \mu \mathrm{g} / \mathrm{kg}$ & -- & -- & -- & -- \\
\hline $\begin{array}{l}\text { 3,4-Dichlorophenyl isocyanate, } \\
\text { whole water }\end{array}$ & 4 & ND & $<.5$ & e.053 & e.35 & $<.5$ \\
\hline $\begin{array}{l}\text { 3,4-Dichlorophenyl isocyanate, } \\
\text { bottom sediment }\end{array}$ & 3 & $100 \mu \mathrm{g} / \mathrm{kg}$ & -- & -- & -- & -- \\
\hline $\begin{array}{l}\text { 3-Methyl-1H-indole (skatol), } \\
\text { dissolved }\end{array}$ & 5 & .02 & $<1$ & $<1$ & $<1$ & $<1$ \\
\hline $\begin{array}{l}\text { 3-Methyl-1H-indole (skatol), whole } \\
\text { water }\end{array}$ & 3 & .019 & $<1$ & $<1$ & $<1$ & $<1$ \\
\hline $\begin{array}{l}\text { 3-Methyl-1H-indole (skatol), bottom } \\
\text { sediment }\end{array}$ & 5 & $30 \mu \mathrm{g} / \mathrm{kg}$ & -- & -- & -- & -- \\
\hline $\begin{array}{l}\text { 3-tert-Butyl-4-hydroxy anisole } \\
\text { (BHA), dissolved }\end{array}$ & 4 & 5 & $<5$ & $<5$ & $<5$ & $<5$ \\
\hline $\begin{array}{l}\text { 3-tert-Butyl-4-hydroxy anisole } \\
\text { (BHA), whole water }\end{array}$ & 3 & ND & $<5$ & $<5$ & $<5$ & $<5$ \\
\hline 4-Cumylphenol, dissolved & 5 & 1 & $<1$ & $<1$ & $<1$ & $<1$ \\
\hline 4-Cumylphenol, whole water & 3 & 1 & $<1$ & $<1$ & $<1$ & $<1$ \\
\hline 4-Cumylphenol, bottom sediment & 5 & $50 \mu \mathrm{g} / \mathrm{kg}$ & -- & -- & -- & -- \\
\hline 4-normal-Octylphenol, dissolved & 4 & 1 & $<1$ & $<1$ & $<1$ & $<1$ \\
\hline 4-normal-Octylphenol, whole water & 3 & 1 & $<1$ & $<1$ & $<1$ & $<1$ \\
\hline $\begin{array}{l}\text { 4-normal-Octylphenol, bottom } \\
\text { sediment }\end{array}$ & 5 & $50 \mu \mathrm{g} / \mathrm{kg}$ & -- & -- & -- & -- \\
\hline 4-tert-Octylphenol, dissolved & 4 & 1 & $<1$ & $<1$ & $<1$ & $<1$ \\
\hline 4-tert-Octylphenol, whole water & 3 & .26 & $<1$ & $<1$ & e. 23 & $<1$ \\
\hline $\begin{array}{l}\text { 4-tert-Octylphenol, bottom } \\
\text { sediment }\end{array}$ & 5 & $50 \mu \mathrm{g} / \mathrm{kg}$ & -- & -- & -- & -- \\
\hline
\end{tabular}


Table 18. Analytical results for household, industrial, and minor agricultural use compounds (HIACs) in water and bottom-sediment samples.-Continued

[Bold text indicates suspected endocrine-disrupting compound (EDC). Shaded cells indicate concentrations greater than study reporting levels for compounds with acceptable quality assurance/quality control, and concentrations were used in analyses related to occurrence of organic wastewater compounds.

Units are micrograms per liter unless otherwise noted. Analytical method number: 3, Lee and others (2004); 4, Zaugg and others (2002); 5 ,

Burkhardt and others (2005). $\mu \mathrm{g} / \mathrm{kg}$, micrograms per kilogram; ND, not determined; e, estimated; <, less than; --, no data collected]

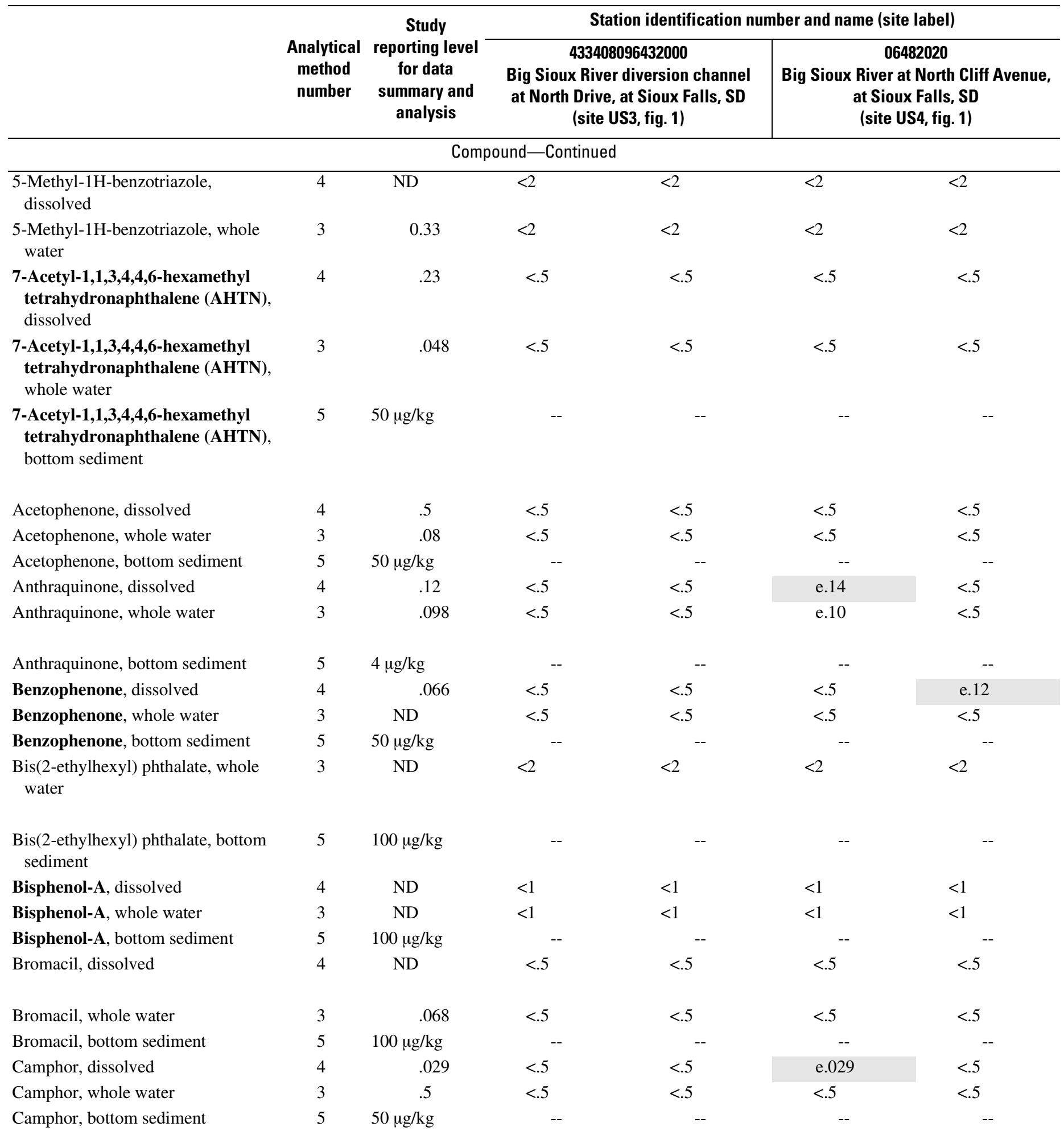


Table 18. Analytical results for household, industrial, and minor agricultural use compounds (HIACs) in water and bottom-sediment samples.-Continued

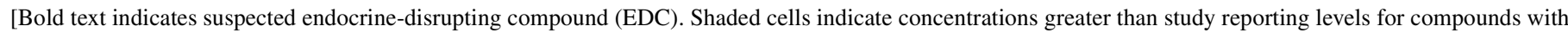
acceptable quality assurance/quality control, and concentrations were used in analyses related to occurrence of organic wastewater compounds.

Units are micrograms per liter unless otherwise noted. Analytical method number: 3, Lee and others (2004); 4, Zaugg and others (2002); 5,

Burkhardt and others (2005). $\mu \mathrm{g} / \mathrm{kg}$, micrograms per kilogram; ND, not determined; e, estimated; <, less than; --, no data collected]

\begin{tabular}{|c|c|c|c|c|c|c|}
\hline & \multirow[b]{2}{*}{$\begin{array}{l}\text { Analytical } \\
\text { method } \\
\text { number }\end{array}$} & \multirow{2}{*}{$\begin{array}{l}\text { Study } \\
\text { reporting level } \\
\text { for data } \\
\text { summary and } \\
\text { analysis }\end{array}$} & \multicolumn{4}{|c|}{ Station identification number and name (site label) } \\
\hline & & & \multicolumn{2}{|c|}{$\begin{array}{c}433408096432000 \\
\text { Big Sioux River diversion channel } \\
\text { at North Drive, at Sioux Falls, SD } \\
\text { (site US3, fig. 1) }\end{array}$} & \multicolumn{2}{|c|}{$\begin{array}{c}06482020 \\
\text { Big Sioux River at North Cliff Avenue, } \\
\text { at Sioux Falls, SD } \\
\text { (site US4, fig. 1) }\end{array}$} \\
\hline \multicolumn{7}{|c|}{ Compound-Continued } \\
\hline Carbaryl, dissolved & 4 & 0.14 & $<1$ & $<1$ & $<1$ & $<1$ \\
\hline Carbaryl, whole water & 3 & ND & $<1$ & $<1$ & $<1$ & $<1$ \\
\hline Chlorpyrifos, dissolved & 4 & .5 & $<.5$ & $<.5$ & $<.5$ & $<.5$ \\
\hline Chlorpyrifos, whole water & 3 & .014 & $<.5$ & $<.5$ & $<.5$ & $<.5$ \\
\hline Chlorpyrifos, bottom sediment & 5 & $50 \mu \mathrm{g} / \mathrm{kg}$ & -- & -- & -- & -- \\
\hline $\begin{array}{l}\text { N,N-Diethyl-meta-toluamide } \\
\text { (DEET), dissolved }\end{array}$ & 4 & .034 & e.051 & $<.5$ & e.085 & $<.5$ \\
\hline $\begin{array}{l}\text { N,N-Diethyl-meta-toluamide } \\
\text { (DEET), whole water }\end{array}$ & 3 & .042 & $<.5$ & $<.5$ & $<.5$ & $<.5$ \\
\hline $\begin{array}{l}\text { N,N-Diethyl-meta-toluamide } \\
\text { (DEET), bottom sediment }\end{array}$ & 5 & $100 \mu \mathrm{g} / \mathrm{kg}$ & -- & -- & -- & -- \\
\hline Diazinon, dissolved & 4 & .5 & $<.5$ & $<.5$ & $<.5$ & $<.5$ \\
\hline Diazinon, whole water & 3 & .027 & $<.5$ & $<.5$ & $<.5$ & $<.5$ \\
\hline Diazinon, bottom sediment & 5 & $50 \mu \mathrm{g} / \mathrm{kg}$ & -- & -- & -- & -- \\
\hline Dichlorvos, dissolved & 4 & ND & $<1$ & $<1$ & $<1$ & $<1$ \\
\hline Dichlorvos, whole water & 3 & ND & $<1$ & $<1$ & $<1$ & $<1$ \\
\hline Diethyl phthalate, whole water & 3 & ND & $<.5$ & $<.5$ & $<.5$ & $<.5$ \\
\hline Diethyl phthalate, bottom sediment & 5 & $50 \mu \mathrm{g} / \mathrm{kg}$ & -- & -- & -- & -- \\
\hline D-Limonene, dissolved & 4 & ND & e.068 & $<.5$ & $<.5$ & $<.5$ \\
\hline D-Limonene, whole water & 3 & ND & $<.5$ & $<.5$ & $<.5$ & $\mathrm{e} 1.8$ \\
\hline D-Limonene, bottom sediment & 5 & $50 \mu \mathrm{g} / \mathrm{kg}$ & -- & -- & -- & -- \\
\hline $\begin{array}{l}\text { 1,3,4,6,7,8-Hexahydro-4,6,6,7,8,8- } \\
\text { hexamethyl cyclopenta-g-2- } \\
\text { benzopyran (HHCB), dissolved }\end{array}$ & 4 & .061 & $<.5$ & $<.5$ & $<.5$ & $<.5$ \\
\hline $\begin{array}{l}\text { 1,3,4,6,7,8-Hexahydro-4,6,6,7,8,8- } \\
\text { hexamethyl cyclopenta-g-2- } \\
\text { benzopyran (HHCB), whole } \\
\text { water }\end{array}$ & 3 & .045 & $<.5$ & $<.5$ & $<.5$ & $<.5$ \\
\hline $\begin{array}{l}\text { 1,3,4,6,7,8-Hexahydro-4,6,6,7,8,8- } \\
\text { hexamethyl cyclopenta-g-2- } \\
\text { benzopyran (HHCB), bottom } \\
\text { sediment }\end{array}$ & 5 & $50 \mu \mathrm{g} / \mathrm{kg}$ & -- & -- & -- & -- \\
\hline Indole, dissolved & 4 & .042 & $<.5$ & $<.5$ & e. 080 & $<.5$ \\
\hline Indole, whole water & 3 & .015 & $<.5$ & $<.5$ & $<.5$ & $<.5$ \\
\hline Indole, bottom sediment & 5 & $1.9 \mu \mathrm{g} / \mathrm{kg}$ & -- & -- & -- & -- \\
\hline Isoborneol, dissolved & 4 & .5 & $<.5$ & $<.5$ & $<.5$ & $<.5$ \\
\hline
\end{tabular}


Table 18. Analytical results for household, industrial, and minor agricultural use compounds (HIACs) in water and bottom-sediment samples.-Continued

[Bold text indicates suspected endocrine-disrupting compound (EDC). Shaded cells indicate concentrations greater than study reporting levels for compounds with acceptable quality assurance/quality control, and concentrations were used in analyses related to occurrence of organic wastewater compounds.

Units are micrograms per liter unless otherwise noted. Analytical method number: 3, Lee and others (2004); 4, Zaugg and others (2002); 5 ,

Burkhardt and others (2005). $\mu \mathrm{g} / \mathrm{kg}$, micrograms per kilogram; ND, not determined; e, estimated; <, less than; --, no data collected]

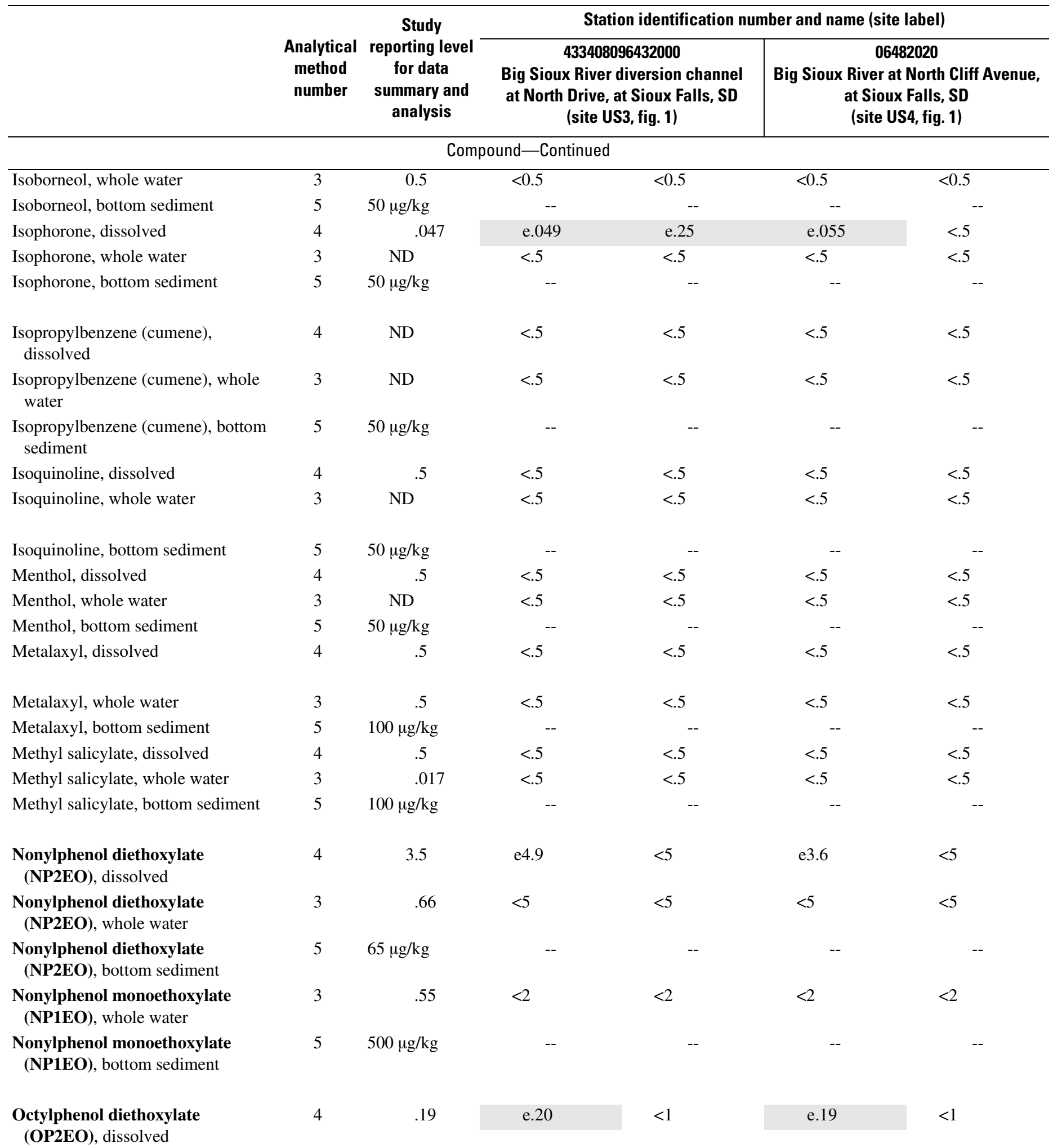


Table 18. Analytical results for household, industrial, and minor agricultural use compounds (HIACs) in water and bottom-sediment samples.-Continued

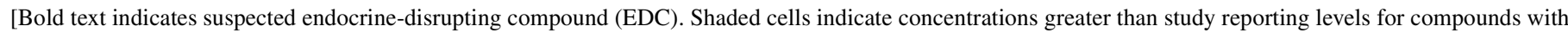
acceptable quality assurance/quality control, and concentrations were used in analyses related to occurrence of organic wastewater compounds.

Units are micrograms per liter unless otherwise noted. Analytical method number: 3, Lee and others (2004); 4, Zaugg and others (2002); 5,

Burkhardt and others (2005). $\mu \mathrm{g} / \mathrm{kg}$, micrograms per kilogram; ND, not determined; e, estimated; <, less than; --, no data collected]

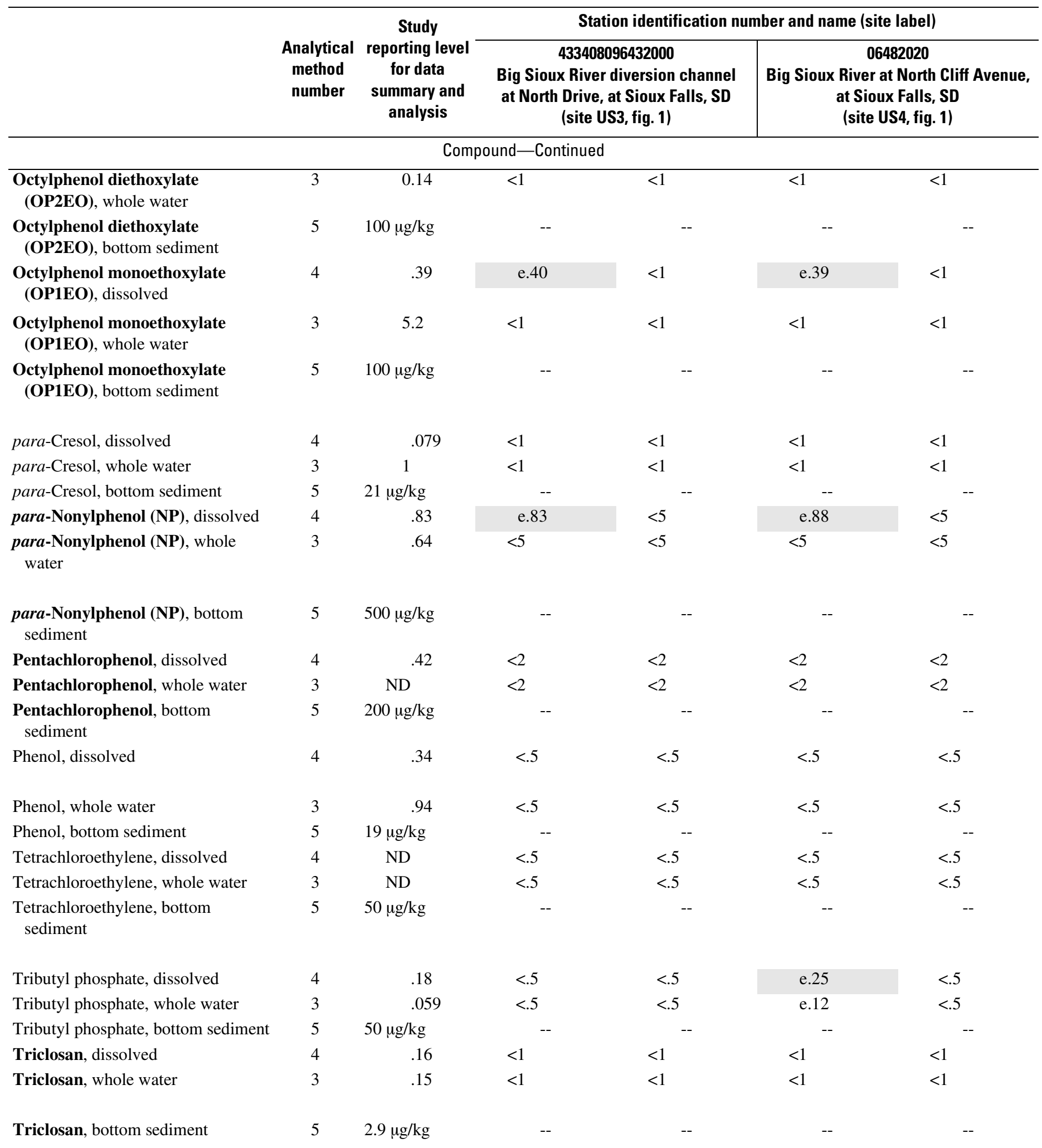


Table 18. Analytical results for household, industrial, and minor agricultural use compounds (HIACs) in water and bottom-sediment samples.-Continued

[Bold text indicates suspected endocrine-disrupting compound (EDC). Shaded cells indicate concentrations greater than study reporting levels for compounds with acceptable quality assurance/quality control, and concentrations were used in analyses related to occurrence of organic wastewater compounds.

Units are micrograms per liter unless otherwise noted. Analytical method number: 3, Lee and others (2004); 4, Zaugg and others (2002); 5 ,

Burkhardt and others (2005). $\mu \mathrm{g} / \mathrm{kg}$, micrograms per kilogram; ND, not determined; e, estimated; <, less than; --, no data collected]

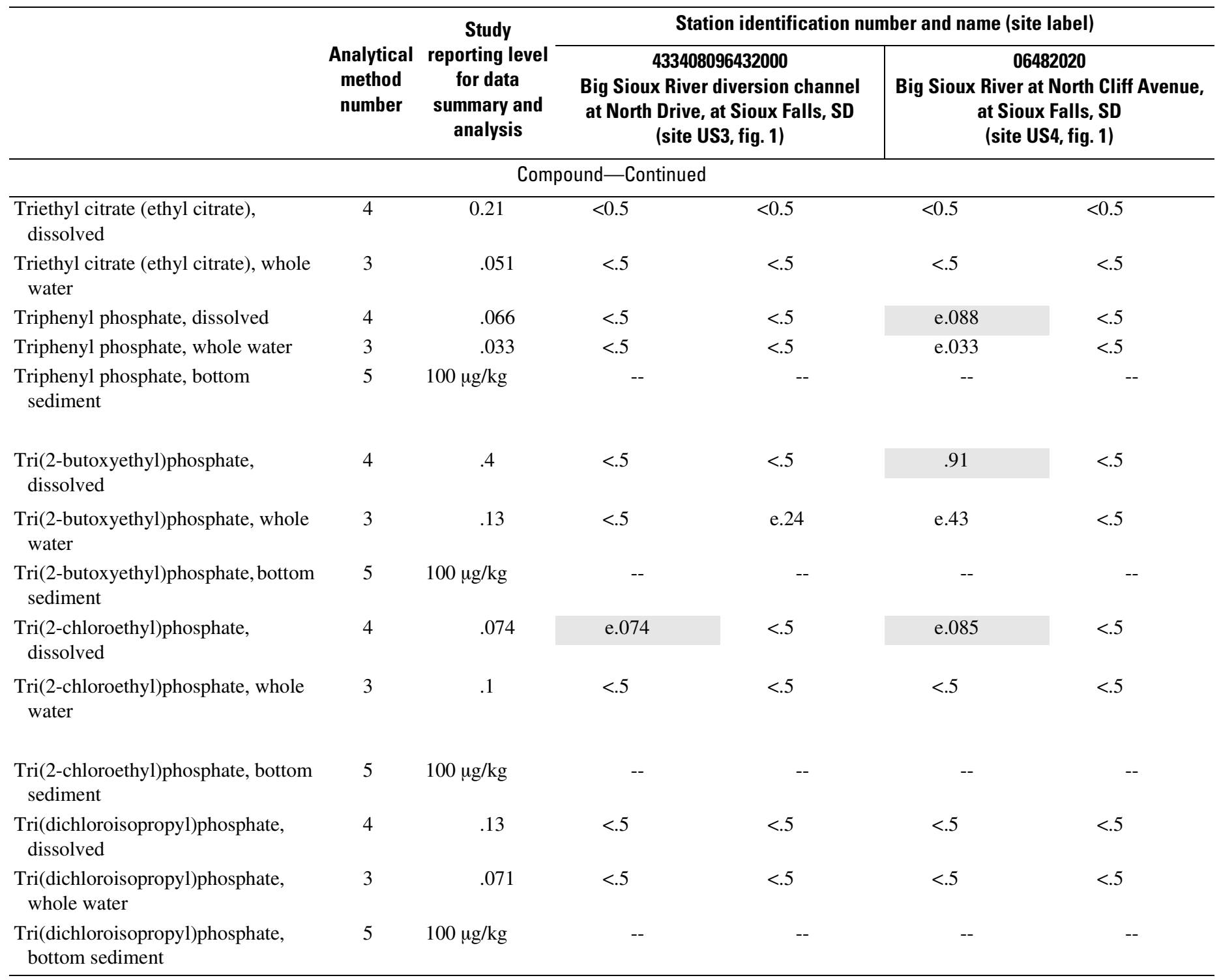


Table 18. Analytical results for household, industrial, and minor agricultural use compounds (HIACs) in water and bottom-sediment samples.-Continued

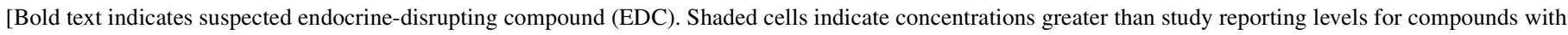
acceptable quality assurance/quality control, and concentrations were used in analyses related to occurrence of organic wastewater compounds.

Units are micrograms per liter unless otherwise noted. Analytical method number: 3, Lee and others (2004); 4, Zaugg and others (2002); 5,

Burkhardt and others (2005). $\mu \mathrm{g} / \mathrm{kg}$, micrograms per kilogram; ND, not determined; e, estimated; <, less than; --, no data collected]

\begin{tabular}{|c|c|c|c|c|c|c|c|c|}
\hline & \multirow[b]{2}{*}{$\begin{array}{l}\text { Analytical } \\
\text { method } \\
\text { number }\end{array}$} & \multirow{2}{*}{$\begin{array}{c}\text { Study } \\
\text { reporting } \\
\text { level } \\
\text { for data } \\
\text { summary and } \\
\text { analysis }\end{array}$} & \multicolumn{6}{|c|}{ Station identification number and name (site label) } \\
\hline & & & \multicolumn{6}{|c|}{$\begin{array}{c}433531096394200 \\
\text { Sioux Falls wastewater treatment plant effluent } \\
\text { (site WWE, fig. 1) }\end{array}$} \\
\hline $\begin{array}{l}\text { Date of sample collection } \\
\text { (month-day-year) }\end{array}$ & & & $09-10-200$ & $1-24-20$ & $3-21-200$ & $-26-200$ & $\overline{-18-200}$ & $-30-2004$ \\
\hline $\begin{array}{l}\text { Time of sample collection } \\
\text { (24-hour) }\end{array}$ & & & 1400 & 0930 & 1045 & 1135 & 1020 & 2020 \\
\hline \multicolumn{9}{|c|}{ Compound } \\
\hline 1,4-Dichlorobenzene, dissolved & 4 & 0.08 & -- & -- & -- & -- & $\mathrm{e} 0.16$ & $\mathrm{e} 0.53$ \\
\hline 1,4-Dichlorobenzene, whole water & 3 & ND & $<0.5$ & $<0.5$ & $\mathrm{e} 0.084$ & $\mathrm{e} 0.11$ & e.094 & e. 20 \\
\hline $\begin{array}{l}\text { 1,4-Dichlorobenzene, bottom } \\
\text { sediment }\end{array}$ & 5 & $50 \mu \mathrm{g} / \mathrm{kg}$ & -- & -- & -- & -- & -- & -- \\
\hline $\begin{array}{l}\text { 2,2',4,4'-Tetrabromodiphenyl } \\
\text { ether, whole water }\end{array}$ & 3 & .5 & $<10$ & $<10$ & $<10$ & -- & $<.5$ & $<.5$ \\
\hline $\begin{array}{l}\text { 2,2',4,4'-Tetrabromodiphenyl } \\
\text { ether, bottom sediment }\end{array}$ & 5 & $50 \mu \mathrm{g} / \mathrm{kg}$ & -- & -- & -- & -- & -- & -- \\
\hline $\begin{array}{l}\text { 3,4-Dichlorophenyl isocyanate, } \\
\text { whole water }\end{array}$ & 4 & ND & e.32 & e. 21 & e. 23 & -- & e3.9 & $\mathrm{e} 2.7$ \\
\hline $\begin{array}{l}\text { 3,4-Dichlorophenyl isocyanate, } \\
\text { bottom sediment }\end{array}$ & 3 & $100 \mu \mathrm{g} / \mathrm{kg}$ & -- & -- & -- & -- & -- & -- \\
\hline $\begin{array}{l}\text { 3-Methyl-1H-indole (skatol), } \\
\text { dissolved }\end{array}$ & 5 & .02 & -- & -- & -- & -- & $<1$ & $<1$ \\
\hline $\begin{array}{l}\text { 3-Methyl-1H-indole (skatol), whole } \\
\text { water }\end{array}$ & 3 & .019 & $<1$ & $<1$ & e. 019 & $<1$ & $<1$ & $<1$ \\
\hline $\begin{array}{l}\text { 3-Methyl-1H-indole (skatol), bottom } \\
\text { sediment }\end{array}$ & 5 & $30 \mu \mathrm{g} / \mathrm{kg}$ & -- & -- & -- & -- & -- & -- \\
\hline $\begin{array}{l}\text { 3-tert-Butyl-4-hydroxy anisole } \\
\text { (BHA), dissolved }\end{array}$ & 4 & 5 & -- & -- & -- & -- & $<5$ & $<5$ \\
\hline $\begin{array}{l}\text { 3-tert-Butyl-4-hydroxy anisole } \\
\text { (BHA), whole water }\end{array}$ & 3 & ND & $<5$ & $<5$ & $<5$ & $<5$ & $<5$ & $<5$ \\
\hline 4-Cumylphenol, dissolved & 5 & 1 & -- & -- & -- & -- & $<1$ & $<1$ \\
\hline 4-Cumylphenol, whole water & 3 & 1 & $<1$ & $<1$ & $<1$ & $<1$ & $<1$ & $<1$ \\
\hline 4-Cumylphenol, bottom sediment & 5 & $50 \mu \mathrm{g} / \mathrm{kg}$ & -- & -- & -- & -- & -- & -- \\
\hline 4-normal-Octylphenol, dissolved & 4 & 1 & -- & -- & -- & -- & $<1$ & $<1$ \\
\hline 4-normal-Octylphenol, whole water & 3 & 1 & $<1$ & $<1$ & $<1$ & $<1$ & $<1$ & $<1$ \\
\hline $\begin{array}{l}\text { 4-normal-Octylphenol, bottom } \\
\text { sediment }\end{array}$ & 5 & $50 \mu \mathrm{g} / \mathrm{kg}$ & -- & -- & -- & -- & -- & -- \\
\hline 4-tert-Octylphenol, dissolved & 4 & 1 & -- & -- & -- & -- & $<1$ & $<1$ \\
\hline 4-tert-Octylphenol, whole water & 3 & .26 & $<1$ & $<1$ & $<1$ & $<1$ & e.19 & $<1$ \\
\hline $\begin{array}{l}\text { 4-tert-Octylphenol, bottom } \\
\text { sediment }\end{array}$ & 5 & $50 \mu \mathrm{g} / \mathrm{kg}$ & -- & -- & -- & -- & -- & -- \\
\hline
\end{tabular}


Table 18. Analytical results for household, industrial, and minor agricultural use compounds (HIACs) in water and bottom-sediment samples.-Continued

[Bold text indicates suspected endocrine-disrupting compound (EDC). Shaded cells indicate concentrations greater than study reporting levels for compounds with acceptable quality assurance/quality control, and concentrations were used in analyses related to occurrence of organic wastewater compounds.

Units are micrograms per liter unless otherwise noted. Analytical method number: 3, Lee and others (2004); 4, Zaugg and others (2002); 5,

Burkhardt and others (2005). $\mu \mathrm{g} / \mathrm{kg}$, micrograms per kilogram; ND, not determined; e, estimated; <, less than; --, no data collected]

\begin{tabular}{|c|c|c|c|c|c|c|c|c|}
\hline & \multirow[b]{2}{*}{$\begin{array}{l}\text { Analytical } \\
\text { method } \\
\text { number }\end{array}$} & \multirow{2}{*}{$\begin{array}{c}\text { Study } \\
\text { reporting } \\
\text { level } \\
\text { for data } \\
\text { summary and } \\
\text { analysis }\end{array}$} & \multicolumn{6}{|c|}{ Station identification number and name (site label) } \\
\hline & & & \multicolumn{6}{|c|}{$\begin{array}{c}433531096394200 \\
\text { Sioux Falls wastewater treatment plant effluent } \\
\text { (site WWE, fig. 1) }\end{array}$} \\
\hline \multicolumn{9}{|c|}{ Compound-Continued } \\
\hline $\begin{array}{l}\text { 5-Methyl-1H-benzotriazole, } \\
\text { dissolved }\end{array}$ & 4 & ND & -- & -- & -- & -- & -- & -- \\
\hline $\begin{array}{l}\text { 5-Methyl-1H-benzotriazole, whole } \\
\text { water }\end{array}$ & 3 & 0.33 & 0.33 & 1.9 & $\mathrm{e} 0.52$ & $<2$ & $\mathrm{e} 0.72$ & $<2$ \\
\hline $\begin{array}{l}\text { 7-Acetyl-1,1,3,4,4,6-hexamethyl } \\
\text { tetrahydronaphthalene (AHTN), } \\
\text { dissolved }\end{array}$ & 4 & .23 & -- & -- & -- & -- & 2.1 & 1.7 \\
\hline $\begin{array}{l}\text { 7-Acetyl-1,1,3,4,4,6-hexamethyl } \\
\text { tetrahydronaphthalene (AHTN), } \\
\text { whole water }\end{array}$ & 3 & .048 & .66 & 1.3 & .84 & 1.1 & 1.9 & .88 \\
\hline $\begin{array}{l}\text { 7-Acetyl-1,1,3,4,4,6-hexamethyl } \\
\text { tetrahydronaphthalene (AHTN), } \\
\text { bottom sediment }\end{array}$ & 5 & $50 \mu \mathrm{g} / \mathrm{kg}$ & -- & -- & -- & -- & -- & -- \\
\hline Acetophenone, dissolved & 4 & .5 & -- & -- & -- & -- & $<.5$ & $<.5$ \\
\hline Acetophenone, whole water & 3 & .08 & $<.5$ & $<.5$ & $<.5$ & e. 12 & $<.5$ & $<.5$ \\
\hline Acetophenone, bottom sediment & 5 & $50 \mu \mathrm{g} / \mathrm{kg}$ & -- & -- & -- & -- & -- & -- \\
\hline Anthraquinone, dissolved & 4 & .12 & -- & -- & -- & -- & $<.5$ & e. 12 \\
\hline Anthraquinone, whole water & 3 & .098 & $<.5$ & $<.5$ & $<.5$ & $<.5$ & $<.5$ & $<.5$ \\
\hline Anthraquinone, bottom sediment & 5 & $4 \mu \mathrm{g} / \mathrm{kg}$ & -- & -- & -- & -- & -- & -- \\
\hline Benzophenone, dissolved & 4 & .066 & -- & -- & -- & -- & e. 20 & e. 14 \\
\hline Benzophenone, whole water & 3 & ND & e. 12 & e. 23 & e. 077 & e. 15 & e. 14 & e.064 \\
\hline Benzophenone, bottom sediment & 5 & $50 \mu \mathrm{g} / \mathrm{kg}$ & -- & -- & -- & -- & -- & -- \\
\hline $\begin{array}{l}\text { Bis(2-ethylhexyl) phthalate, whole } \\
\text { water }\end{array}$ & 3 & ND & $\mathrm{e} 27$ & $<.5$ & $<.5$ & $<.5$ & $<2$ & 5.5 \\
\hline $\begin{array}{l}\text { Bis(2-ethylhexyl) phthalate, bottom } \\
\text { sediment }\end{array}$ & 5 & $100 \mu \mathrm{g} / \mathrm{kg}$ & -- & -- & -- & -- & -- & -- \\
\hline Bisphenol-A, dissolved & 4 & ND & -- & -- & -- & -- & $<1$ & $<1$ \\
\hline Bisphenol-A, whole water & 3 & ND & $<1$ & $<1$ & $<1$ & $<1$ & $<1$ & $<1$ \\
\hline Bisphenol-A, bottom sediment & 5 & $100 \mu \mathrm{g} / \mathrm{kg}$ & -- & -- & -- & -- & -- & -- \\
\hline Bromacil, dissolved & 4 & ND & -- & -- & -- & -- & $<.5$ & $<.5$ \\
\hline Bromacil, whole water & 3 & .068 & $<.5$ & $<.5$ & $<.5$ & $<.5$ & $<.5$ & $<.5$ \\
\hline Bromacil, bottom sediment & 5 & $100 \mu \mathrm{g} / \mathrm{kg}$ & -- & -- & -- & -- & -- & -- \\
\hline Camphor, dissolved & 4 & .029 & -- & -- & -- & -- & $<.5$ & $<.5$ \\
\hline Camphor, whole water & 3 & .5 & $<.5$ & $<.5$ & $<.5$ & $<.5$ & $<.5$ & $<.5$ \\
\hline Camphor, bottom sediment & 5 & $50 \mu \mathrm{g} / \mathrm{kg}$ & -- & -- & -- & -- & -- & -- \\
\hline Carbaryl, dissolved & 4 & .14 & -- & -- & -- & -- & $<1$ & e. 14 \\
\hline
\end{tabular}


Table 18. Analytical results for household, industrial, and minor agricultural use compounds (HIACs) in water and bottom-sediment samples.-Continued

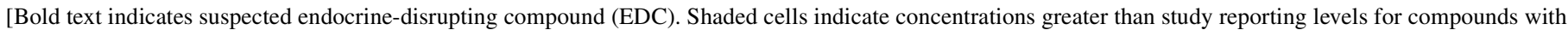
acceptable quality assurance/quality control, and concentrations were used in analyses related to occurrence of organic wastewater compounds.

Units are micrograms per liter unless otherwise noted. Analytical method number: 3, Lee and others (2004); 4, Zaugg and others (2002); 5,

Burkhardt and others (2005). $\mu \mathrm{g} / \mathrm{kg}$, micrograms per kilogram; ND, not determined; e, estimated; <, less than; --, no data collected]

\begin{tabular}{|c|c|c|c|c|c|c|c|c|}
\hline & \multirow{3}{*}{$\begin{array}{l}\text { Analytical } \\
\text { method } \\
\text { number }\end{array}$} & \multirow{2}{*}{$\begin{array}{c}\text { Study } \\
\text { reporting } \\
\text { level } \\
\text { for data } \\
\text { summary and } \\
\text { analysis }\end{array}$} & \multicolumn{6}{|c|}{ Station identification number and name (site label) } \\
\hline & & & \multicolumn{6}{|c|}{$\begin{array}{c}433531096394200 \\
\text { Sioux Falls wastewater treatment plant effluent } \\
\text { (site WWE, fig. 1) }\end{array}$} \\
\hline \multicolumn{8}{|c|}{ Compound-Continued } & \\
\hline Carbaryl, whole water & 3 & ND & $<1$ & $<1$ & $<1$ & $<1$ & $<1$ & $<1$ \\
\hline Chlorpyrifos, dissolved & 4 & 0.5 & -- & -- & -- & -- & $<.5$ & $<.5$ \\
\hline Chlorpyrifos, whole water & 3 & .014 & e.014 & $<.5$ & $<.5$ & $<.5$ & $<.5$ & $<.5$ \\
\hline Chlorpyrifos, bottom sediment & 5 & $50 \mu \mathrm{g} / \mathrm{kg}$ & -- & -- & -- & -- & -- & -- \\
\hline $\begin{array}{l}\text { N,N-Diethyl-meta-toluamide } \\
\text { (DEET), dissolved }\end{array}$ & 4 & .034 & -- & -- & -- & -- & e. 2 & e.14 \\
\hline $\begin{array}{l}\text { N,N-Diethyl-meta-toluamide } \\
\text { (DEET), whole water }\end{array}$ & 3 & .042 & $<.5$ & e.012 & e. 22 & $<.5$ & e. 21 & e. 070 \\
\hline $\begin{array}{l}\text { N,N-Diethyl-meta-toluamide } \\
\text { (DEET), bottom sediment }\end{array}$ & 5 & $100 \mu \mathrm{g} / \mathrm{kg}$ & -- & -- & -- & -- & -- & -- \\
\hline Diazinon, dissolved & 4 & .5 & -- & -- & -- & -- & $<.5$ & $<.5$ \\
\hline Diazinon, whole water & 3 & .027 & e.027 & $<.5$ & $<.5$ & $<.5$ & $<.5$ & $<.5$ \\
\hline Diazinon, bottom sediment & 5 & $50 \mu \mathrm{g} / \mathrm{kg}$ & -- & -- & -- & -- & -- & -- \\
\hline Dichlorvos, dissolved & 4 & ND & -- & -- & -- & -- & $<1$ & $<1$ \\
\hline Dichlorvos, whole water & 3 & ND & $<1$ & $<1$ & $<1$ & $<1$ & $<1$ & $<1$ \\
\hline Diethyl phthalate, whole water & 3 & ND & $<.5$ & $<.5$ & $<.5$ & -- & $<.5$ & $<.5$ \\
\hline Diethyl phthalate, bottom sediment & 5 & $50 \mu \mathrm{g} / \mathrm{kg}$ & -- & -- & -- & -- & -- & -- \\
\hline D-Limonene, dissolved & 4 & ND & -- & -- & -- & -- & $<.5$ & $<.5$ \\
\hline D-Limonene, whole water & 3 & ND & $<.5$ & $<.5$ & $<.5$ & $<.5$ & $<.5$ & $<.5$ \\
\hline D-Limonene, bottom sediment & 5 & $50 \mu \mathrm{g} / \mathrm{kg}$ & -- & -- & -- & -- & -- & -- \\
\hline $\begin{array}{l}\text { 1,3,4,6,7,8-Hexahydro-4,6,6,7,8,8- } \\
\text { hexamethyl cyclopenta-g-2- } \\
\text { benzopyran (HHCB), dissolved }\end{array}$ & 4 & .061 & -- & -- & -- & -- & e. 40 & e.32 \\
\hline $\begin{array}{l}\text { 1,3,4,6,7,8-Hexahydro-4,6,6,7,8,8- } \\
\text { hexamethyl cyclopenta-g-2- } \\
\text { benzopyran (HHCB), whole } \\
\text { water }\end{array}$ & 3 & .045 & e. 16 & e.29 & e. 18 & e. 21 & e. 28 & e. 12 \\
\hline $\begin{array}{l}\text { 1,3,4,6,7,8-Hexahydro-4,6,6,7,8,8- } \\
\text { hexamethyl cyclopenta-g-2- } \\
\text { benzopyran (HHCB), bottom } \\
\text { sediment }\end{array}$ & 5 & $50 \mu \mathrm{g} / \mathrm{kg}$ & -- & -- & -- & -- & -- & -- \\
\hline Indole, dissolved & 4 & .042 & -- & -- & -- & -- & e. 080 & $<.5$ \\
\hline Indole, whole water & 3 & .015 & $<.5$ & $<.5$ & e. 017 & $<.5$ & $<.5$ & $<.5$ \\
\hline Indole, bottom sediment & 5 & $1.9 \mu \mathrm{g} / \mathrm{kg}$ & -- & -- & -- & -- & -- & -- \\
\hline Isoborneol, dissolved & 4 & .5 & -- & -- & -- & -- & $<.5$ & $<.5$ \\
\hline Isoborneol, whole water & 3 & .5 & $<.5$ & $<.5$ & $<.5$ & $<.5$ & $<.5$ & $<.5$ \\
\hline
\end{tabular}


Table 18. Analytical results for household, industrial, and minor agricultural use compounds (HIACs) in water and bottom-sediment samples.-Continued

[Bold text indicates suspected endocrine-disrupting compound (EDC). Shaded cells indicate concentrations greater than study reporting levels for compounds with acceptable quality assurance/quality control, and concentrations were used in analyses related to occurrence of organic wastewater compounds.

Units are micrograms per liter unless otherwise noted. Analytical method number: 3, Lee and others (2004); 4, Zaugg and others (2002); 5,

Burkhardt and others (2005). $\mu \mathrm{g} / \mathrm{kg}$, micrograms per kilogram; ND, not determined; e, estimated; <, less than; --, no data collected]

\begin{tabular}{|c|c|c|c|c|c|c|c|c|}
\hline & \multirow[b]{2}{*}{$\begin{array}{l}\text { Analytical } \\
\text { method } \\
\text { number }\end{array}$} & \multirow{2}{*}{$\begin{array}{c}\text { Study } \\
\text { reporting } \\
\text { level } \\
\text { for data } \\
\text { summary and } \\
\text { analysis }\end{array}$} & \multicolumn{6}{|c|}{ Station identification number and name (site label) } \\
\hline & & & \multicolumn{6}{|c|}{$\begin{array}{c}433531096394200 \\
\text { Sioux Falls wastewater treatment plant effluent } \\
\text { (site WWE, fig. 1) }\end{array}$} \\
\hline \multicolumn{9}{|c|}{ Compound-Continued } \\
\hline Isoborneol, bottom sediment & 5 & $50 \mu \mathrm{g} / \mathrm{kg}$ & -- & -- & -- & -- & -- & -- \\
\hline Isophorone, dissolved & 4 & .047 & -- & -- & -- & -- & $<0.5$ & $<0.5$ \\
\hline Isophorone, whole water & 3 & ND & $<0.5$ & $<0.5$ & $<0.5$ & $<0.5$ & $<.5$ & $<.5$ \\
\hline Isophorone, bottom sediment & 5 & $50 \mu \mathrm{g} / \mathrm{kg}$ & -- & -- & -- & -- & -- & -- \\
\hline $\begin{array}{l}\text { Isopropylbenzene (cumene), } \\
\text { dissolved }\end{array}$ & 4 & ND & -- & -- & -- & -- & $<.5$ & $<.5$ \\
\hline $\begin{array}{l}\text { Isopropylbenzene (cumene), whole } \\
\text { water }\end{array}$ & 3 & ND & $<.5$ & $<.5$ & $<.5$ & $<.5$ & $<.5$ & $<.5$ \\
\hline $\begin{array}{l}\text { Isopropylbenzene (cumene), bottom } \\
\text { sediment }\end{array}$ & 5 & $50 \mu \mathrm{g} / \mathrm{kg}$ & -- & -- & -- & -- & -- & -- \\
\hline Isoquinoline, dissolved & 4 & .5 & -- & -- & -- & -- & $<.5$ & $<.5$ \\
\hline Isoquinoline, whole water & 3 & ND & $<.5$ & $<.5$ & $<.5$ & $<.5$ & $<.5$ & $<.5$ \\
\hline Isoquinoline, bottom sediment & 5 & $50 \mu \mathrm{g} / \mathrm{kg}$ & -- & -- & -- & -- & -- & -- \\
\hline Menthol, dissolved & 4 & .5 & -- & -- & -- & -- & $<.5$ & $<.5$ \\
\hline Menthol, whole water & 3 & ND & $<.5$ & $<.5$ & $<.5$ & $<.5$ & $<.5$ & $<.5$ \\
\hline Menthol, bottom sediment & 5 & $50 \mu \mathrm{g} / \mathrm{kg}$ & -- & -- & -- & -- & -- & -- \\
\hline Metalaxyl, dissolved & 4 & .5 & -- & -- & -- & -- & $<.5$ & $<.5$ \\
\hline Metalaxyl, whole water & 3 & .5 & $<.5$ & $<.5$ & $<.5$ & $<.5$ & $<.5$ & $<.5$ \\
\hline Metalaxyl, bottom sediment & 5 & $100 \mu \mathrm{g} / \mathrm{kg}$ & -- & -- & -- & -- & -- & -- \\
\hline Methyl salicylate, dissolved & 4 & .5 & -- & -- & -- & -- & $<.5$ & $<.5$ \\
\hline Methyl salicylate, whole water & 3 & .017 & $<.5$ & $<.5$ & $<.5$ & $<.5$ & $<.5$ & $<.5$ \\
\hline Methyl salicylate, bottom sediment & 5 & $100 \mu \mathrm{g} / \mathrm{kg}$ & -- & -- & -- & -- & -- & -- \\
\hline $\begin{array}{l}\text { Nonylphenol diethoxylate } \\
\text { (NP2EO), dissolved }\end{array}$ & 4 & 3.5 & -- & -- & -- & -- & e4.3 & e1.6 \\
\hline $\begin{array}{l}\text { Nonylphenol diethoxylate } \\
\text { (NP2EO), whole water }\end{array}$ & 3 & .66 & e1.4 & $\mathrm{e} 6.2$ & e6.2 & $\mathrm{e} 2.1$ & $<5$ & e. 66 \\
\hline $\begin{array}{l}\text { Nonylphenol diethoxylate } \\
\text { (NP2EO), bottom sediment }\end{array}$ & 5 & $65 \mu \mathrm{g} / \mathrm{kg}$ & -- & -- & -- & -- & -- & -- \\
\hline $\begin{array}{l}\text { Nonylphenol monoethoxylate } \\
\text { (NP1EO), whole water }\end{array}$ & 3 & .55 & e. 43 & $\mathrm{e} 1.5$ & e 1.7 & e. 94 & $<2$ & e. 50 \\
\hline $\begin{array}{l}\text { Nonylphenol monoethoxylate } \\
\text { (NP1EO), bottom sediment }\end{array}$ & 5 & $500 \mu \mathrm{g} / \mathrm{kg}$ & -- & -- & -- & -- & -- & -- \\
\hline $\begin{array}{l}\text { Octylphenol diethoxylate } \\
\text { (OP2EO), dissolved }\end{array}$ & 4 & .19 & -- & -- & -- & -- & $<1$ & $<1$ \\
\hline $\begin{array}{l}\text { Octylphenol diethoxylate } \\
\text { (OP2EO), whole water }\end{array}$ & 3 & .14 & $<1$ & $<1$ & $<1$ & e. 13 & e. 067 & $<1$ \\
\hline
\end{tabular}


Table 18. Analytical results for household, industrial, and minor agricultural use compounds (HIACs) in water and bottom-sediment samples.-Continued

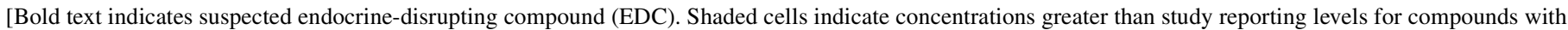
acceptable quality assurance/quality control, and concentrations were used in analyses related to occurrence of organic wastewater compounds.

Units are micrograms per liter unless otherwise noted. Analytical method number: 3, Lee and others (2004); 4, Zaugg and others (2002); 5,

Burkhardt and others (2005). $\mu \mathrm{g} / \mathrm{kg}$, micrograms per kilogram; ND, not determined; e, estimated; <, less than; --, no data collected]

\begin{tabular}{|c|c|c|c|c|c|c|c|c|}
\hline & \multirow[b]{2}{*}{$\begin{array}{l}\text { Analytical } \\
\text { method } \\
\text { number }\end{array}$} & \multirow{2}{*}{$\begin{array}{c}\text { Study } \\
\text { reporting } \\
\text { level } \\
\text { for data } \\
\text { summary and } \\
\text { analysis }\end{array}$} & \multicolumn{6}{|c|}{ Station identification number and name (site label) } \\
\hline & & & \multicolumn{6}{|c|}{$\begin{array}{c}433531096394200 \\
\text { Sioux Falls wastewater treatment plant effluent } \\
\text { (site WWE, fig. 1) }\end{array}$} \\
\hline \multicolumn{9}{|c|}{ Compound-Continued } \\
\hline $\begin{array}{l}\text { Octylphenol diethoxylate } \\
\text { (OP2EO), bottom sediment }\end{array}$ & 5 & $100 \mu \mathrm{g} / \mathrm{kg}$ & -- & -- & -- & -- & -- & -- \\
\hline $\begin{array}{l}\text { Octylphenol monoethoxylate } \\
\text { (OP1EO), dissolved }\end{array}$ & 4 & .39 & -- & -- & -- & -- & $<1$ & $<1$ \\
\hline $\begin{array}{l}\text { Octylphenol monoethoxylate } \\
\text { (OP1EO), whole water }\end{array}$ & 3 & 5.2 & $<1$ & $<1$ & $<1$ & $<1$ & $<1$ & -- \\
\hline $\begin{array}{l}\text { Octylphenol monoethoxylate } \\
\text { (OP1EO), bottom sediment }\end{array}$ & 5 & $100 \mu \mathrm{g} / \mathrm{kg}$ & -- & -- & -- & -- & -- & -- \\
\hline para-Cresol, dissolved & 4 & .079 & -- & -- & -- & -- & e.11 & e.079 \\
\hline para-Cresol, whole water & 3 & 1 & $<1$ & $<1$ & $<1$ & $<1$ & $<1$ & $<1$ \\
\hline para-Cresol, bottom sediment & 5 & $21 \mu \mathrm{g} / \mathrm{kg}$ & -- & -- & -- & -- & -- & -- \\
\hline para-Nonylphenol (NP), dissolved & 4 & .83 & -- & -- & -- & -- & e1.9 & $\mathrm{e} 1.1$ \\
\hline $\begin{array}{l}\text { para-Nonylphenol (NP), whole } \\
\text { water }\end{array}$ & 3 & .64 & $<5$ & $<5$ & $<5$ & $<5$ & $<5$ & e.64 \\
\hline $\begin{array}{l}\text { para-Nonylphenol (NP), bottom } \\
\text { sediment }\end{array}$ & 5 & $500 \mu \mathrm{g} / \mathrm{kg}$ & -- & -- & -- & -- & -- & -- \\
\hline Pentachlorophenol, dissolved & 4 & .42 & -- & -- & -- & -- & $<2$ & $\mathrm{e} .42$ \\
\hline Pentachlorophenol, whole water & 3 & ND & e. 040 & $<2$ & $<2$ & $<2$ & $<2$ & $<2$ \\
\hline $\begin{array}{l}\text { Pentachlorophenol, bottom } \\
\text { sediment }\end{array}$ & 5 & $200 \mu \mathrm{g} / \mathrm{kg}$ & -- & -- & -- & -- & -- & -- \\
\hline Phenol, dissolved & 4 & .34 & -- & -- & -- & -- & e. 30 & .72 \\
\hline Phenol, whole water & 3 & .94 & e1.8 & $<.5$ & $<.5$ & e. 38 & $<.5$ & e. 15 \\
\hline Phenol, bottom sediment & 5 & $19 \mu \mathrm{g} / \mathrm{kg}$ & -- & -- & -- & -- & -- & -- \\
\hline Tetrachloroethylene, dissolved & 4 & $\mathrm{ND}$ & -- & -- & -- & -- & $<.5$ & e.087 \\
\hline Tetrachloroethylene, whole water & 3 & ND & $<.5$ & $<.5$ & $<.5$ & $<.5$ & $<.5$ & $<.5$ \\
\hline $\begin{array}{l}\text { Tetrachloroethylene, bottom } \\
\text { sediment }\end{array}$ & 5 & $50 \mu \mathrm{g} / \mathrm{kg}$ & -- & -- & -- & -- & -- & -- \\
\hline Tributyl phosphate, dissolved & 4 & .18 & -- & -- & -- & -- & e. 25 & e. 19 \\
\hline Tributyl phosphate, whole water & 3 & .059 & e. 21 & e.46 & e. 25 & e. 28 & e.11 & e.059 \\
\hline Tributyl phosphate, bottom sediment & 5 & $50 \mu \mathrm{g} / \mathrm{kg}$ & -- & -- & -- & -- & -- & -- \\
\hline Triclosan, dissolved & 4 & .16 & -- & -- & -- & -- & e. 24 & e. 16 \\
\hline Triclosan, whole water & 3 & .15 & e.097 & e. 18 & e. 17 & e. 14 & e. 14 & $<1$ \\
\hline Triclosan, bottom sediment & 5 & $2.9 \mu \mathrm{g} / \mathrm{kg}$ & -- & -- & -- & -- & -- & -- \\
\hline $\begin{array}{l}\text { Triethyl citrate (ethyl citrate), } \\
\text { dissolved }\end{array}$ & 4 & .21 & -- & -- & -- & -- & 1.1 & e. 32 \\
\hline
\end{tabular}


Table 18. Analytical results for household, industrial, and minor agricultural use compounds (HIACs) in water and bottom-sediment samples.-Continued

[Bold text indicates suspected endocrine-disrupting compound (EDC). Shaded cells indicate concentrations greater than study reporting levels for compounds with acceptable quality assurance/quality control, and concentrations were used in analyses related to occurrence of organic wastewater compounds.

Units are micrograms per liter unless otherwise noted. Analytical method number: 3, Lee and others (2004); 4, Zaugg and others (2002); 5,

Burkhardt and others (2005). $\mu \mathrm{g} / \mathrm{kg}$, micrograms per kilogram; ND, not determined; e, estimated; <, less than; --, no data collected]

\begin{tabular}{|c|c|c|c|c|c|c|c|c|}
\hline & \multirow[b]{2}{*}{$\begin{array}{l}\text { Analytical } \\
\text { method } \\
\text { number }\end{array}$} & \multirow{2}{*}{$\begin{array}{c}\text { Study } \\
\text { reporting } \\
\text { level } \\
\text { for data } \\
\text { summary and } \\
\text { analysis }\end{array}$} & \multicolumn{6}{|c|}{ Station identification number and name (site label) } \\
\hline & & & \multicolumn{6}{|c|}{$\begin{array}{c}433531096394200 \\
\text { Sioux Falls wastewater treatment plant effluent } \\
\text { (site WWE, fig. 1) }\end{array}$} \\
\hline \multicolumn{9}{|c|}{ Compound-Continued } \\
\hline $\begin{array}{l}\text { Triethyl citrate (ethyl citrate), whole } \\
\text { water }\end{array}$ & 3 & 0.051 & $\mathrm{e} 0.27$ & 0.86 & 0.77 & 0.61 & 0.86 & $\mathrm{e} 0.17$ \\
\hline Triphenyl phosphate, dissolved & 4 & .066 & -- & -- & -- & -- & e.12 & e. 074 \\
\hline Triphenyl phosphate, whole water & 3 & .033 & $<.5$ & $<.5$ & $<.5$ & e. 079 & $<.5$ & $<.5$ \\
\hline $\begin{array}{l}\text { Triphenyl phosphate, bottom } \\
\text { sediment }\end{array}$ & 5 & $100 \mu \mathrm{g} / \mathrm{kg}$ & -- & -- & -- & -- & -- & -- \\
\hline $\begin{array}{l}\text { Tri(2-butoxyethyl)phosphate, } \\
\text { dissolved }\end{array}$ & 4 & .4 & -- & -- & -- & -- & $<.5$ & $<.5$ \\
\hline $\begin{array}{l}\text { Tri(2-butoxyethyl)phosphate, whole } \\
\text { water }\end{array}$ & 3 & .13 & $<.5$ & e 3.2 & .85 & $<.5$ & $<.5$ & $<.5$ \\
\hline $\begin{array}{l}\text { Tri(2-butoxyethyl)phosphate, bottom } \\
\text { sediment }\end{array}$ & 5 & $100 \mu \mathrm{g} / \mathrm{kg}$ & -- & -- & -- & -- & -- & -- \\
\hline $\begin{array}{l}\text { Tri(2-chloroethyl)phosphate, } \\
\text { dissolved }\end{array}$ & 4 & .074 & -- & -- & -- & -- & .69 & 2.9 \\
\hline $\begin{array}{l}\text { Tri(2-chloroethyl)phosphate, whole } \\
\text { water }\end{array}$ & 3 & .1 & e. 34 & e.36 & e. 32 & e. 34 & .58 & 1.7 \\
\hline $\begin{array}{l}\text { Tri(2-chloroethyl)phosphate, bottom } \\
\text { sediment }\end{array}$ & 5 & $100 \mu \mathrm{g} / \mathrm{kg}$ & -- & -- & -- & -- & -- & -- \\
\hline $\begin{array}{l}\text { Tri(dichloroisopropyl)phosphate, } \\
\text { dissolved }\end{array}$ & 4 & .13 & -- & -- & -- & -- & e. 42 & e. 47 \\
\hline $\begin{array}{l}\text { Tri(dichloroisopropyl)phosphate, } \\
\text { whole water }\end{array}$ & 3 & .071 & e. 25 & e.39 & e. 16 & e. 24 & e. 24 & e. 32 \\
\hline $\begin{array}{l}\text { Tri(dichloroisopropyl)phosphate, } \\
\text { bottom sediment }\end{array}$ & 5 & $100 \mu \mathrm{g} / \mathrm{kg}$ & -- & -- & -- & -- & -- & -- \\
\hline
\end{tabular}


Table 18. Analytical results for household, industrial, and minor agricultural use compounds (HIACs) in water and bottomsediment samples.-Continued

[Bold text indicates suspected endocrine-disrupting compound (EDC). Shaded cells indicate concentrations greater than study reporting levels for compounds with acceptable quality assurance/quality control, and concentrations were used in analyses related to occurrence of organic wastewater compounds. Units are micrograms per liter unless otherwise noted. Analytical method number: 3, Lee and others (2004); 4, Zaugg and others (2002); 5, Burkhardt and others (2005). $\mu \mathrm{g} / \mathrm{kg}$, micrograms per kilogram; ND, not determined; e, estimated; <, less than; --, no data collected]

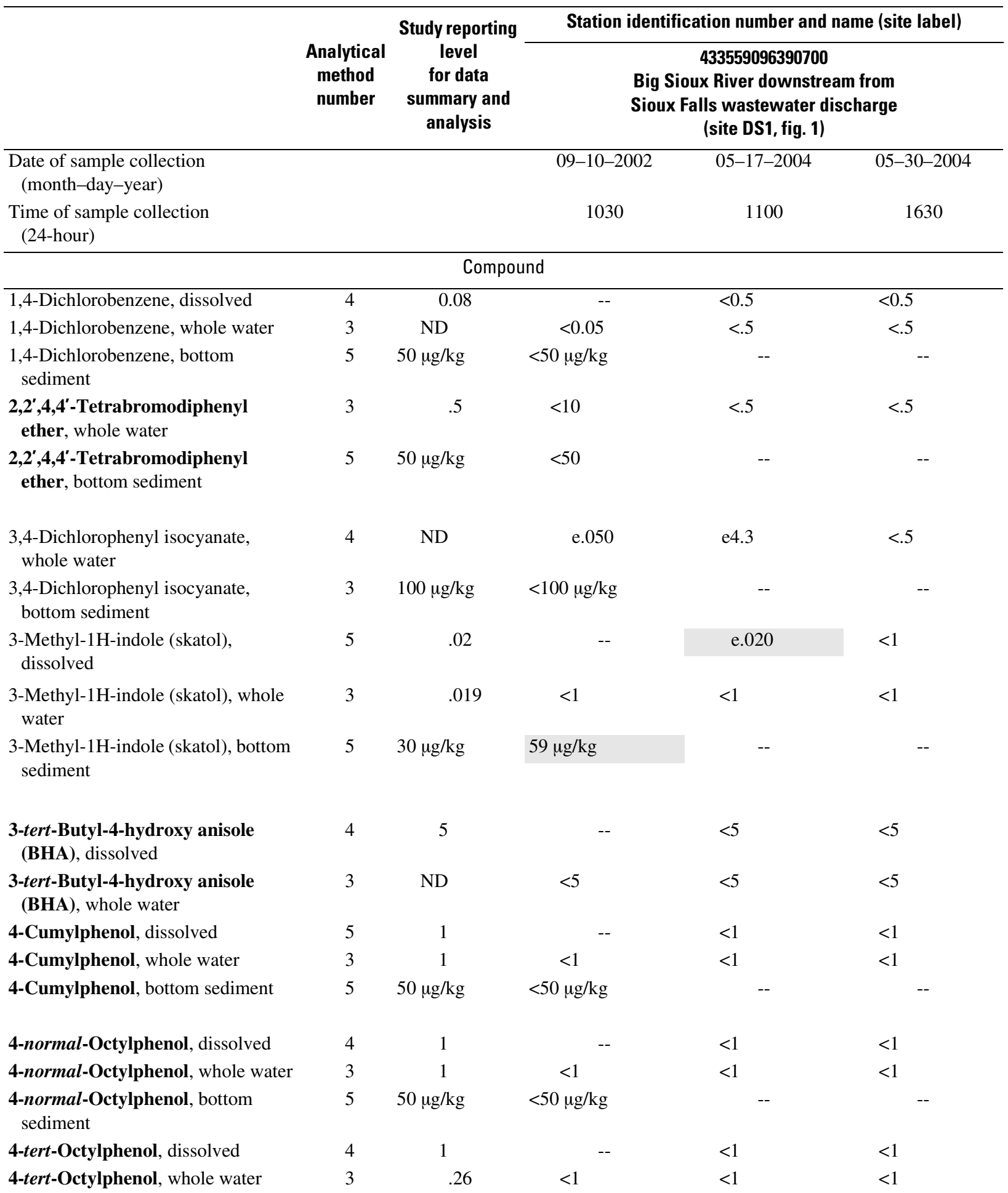


Table 18. Analytical results for household, industrial, and minor agricultural use compounds (HIACs) in water and bottomsediment samples.-Continued

[Bold text indicates suspected endocrine-disrupting compound (EDC). Shaded cells indicate concentrations greater than study reporting levels for compounds with acceptable quality assurance/quality control, and concentrations were used in analyses related to occurrence of organic wastewater compounds. Units are micrograms per liter unless otherwise noted. Analytical method number: 3, Lee and others (2004); 4, Zaugg and others (2002); 5, Burkhardt and others (2005). $\mu \mathrm{g} / \mathrm{kg}$, micrograms per kilogram; ND, not determined; e, estimated; <, less than; --, no data collected]

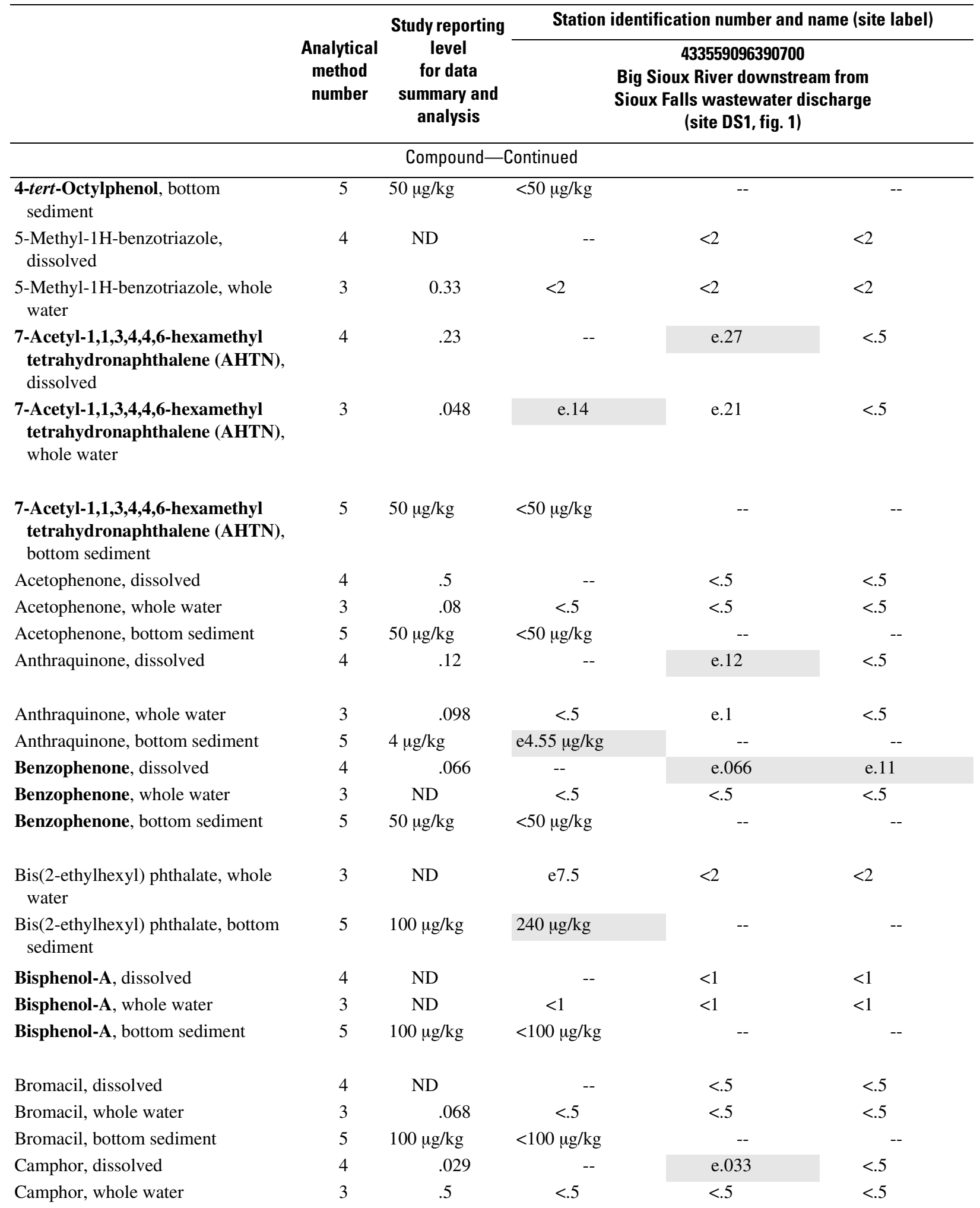


Table 18. Analytical results for household, industrial, and minor agricultural use compounds (HIACs) in water and bottomsediment samples.-Continued

[Bold text indicates suspected endocrine-disrupting compound (EDC). Shaded cells indicate concentrations greater than study reporting levels for compounds with acceptable quality assurance/quality control, and concentrations were used in analyses related to occurrence of organic wastewater compounds. Units are micrograms per liter unless otherwise noted. Analytical method number: 3, Lee and others (2004); 4, Zaugg and others (2002); 5, Burkhardt and others (2005). $\mu \mathrm{g} / \mathrm{kg}$, micrograms per kilogram; ND, not determined; e, estimated; <, less than; --, no data collected]

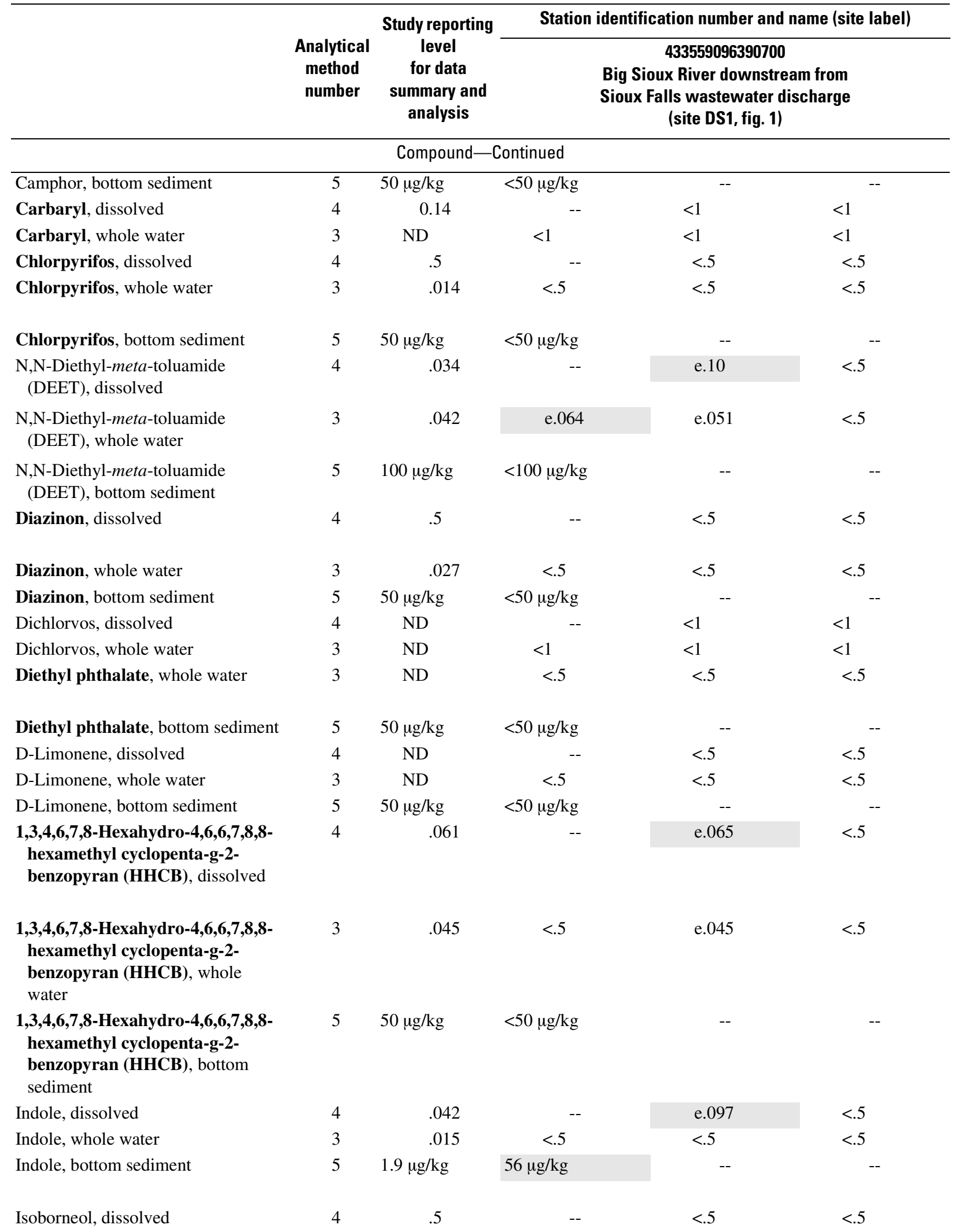


Table 18. Analytical results for household, industrial, and minor agricultural use compounds (HIACs) in water and bottomsediment samples.-Continued

[Bold text indicates suspected endocrine-disrupting compound (EDC). Shaded cells indicate concentrations greater than study reporting levels for compounds with acceptable quality assurance/quality control, and concentrations were used in analyses related to occurrence of organic wastewater compounds. Units are micrograms per liter unless otherwise noted. Analytical method number: 3, Lee and others (2004); 4, Zaugg and others (2002); 5, Burkhardt and others (2005). $\mu \mathrm{g} / \mathrm{kg}$, micrograms per kilogram; ND, not determined; e, estimated; <, less than; --, no data collected]

\begin{tabular}{|c|c|c|c|c|c|}
\hline & \multirow{3}{*}{$\begin{array}{l}\text { Analytical } \\
\text { method } \\
\text { number }\end{array}$} & \multirow{2}{*}{$\begin{array}{c}\text { Study reporting } \\
\text { level } \\
\text { for data } \\
\text { summary and } \\
\text { analysis }\end{array}$} & \multicolumn{3}{|c|}{ Station identification number and name (site label) } \\
\hline & & & \multicolumn{3}{|c|}{$\begin{array}{c}433559096390700 \\
\text { Big Sioux River downstream from } \\
\text { Sioux Falls wastewater discharge } \\
\text { (site DS1, fig. 1) }\end{array}$} \\
\hline \multicolumn{5}{|c|}{ Compound-Continued } & \\
\hline Isoborneol, whole water & 3 & 0.5 & $<0.5$ & $<0.5$ & $<0.5$ \\
\hline Isoborneol, bottom sediment & 5 & $50 \mu \mathrm{g} / \mathrm{kg}$ & $<50 \mu \mathrm{g} / \mathrm{kg}$ & -- & -- \\
\hline Isophorone, dissolved & 4 & .047 & -- & $<.5$ & $<.5$ \\
\hline Isophorone, whole water & 3 & ND & $<.5$ & $<.5$ & $<.5$ \\
\hline Isophorone, bottom sediment & 5 & $50 \mu \mathrm{g} / \mathrm{kg}$ & $<50 \mu \mathrm{g} / \mathrm{kg}$ & -- & -- \\
\hline $\begin{array}{l}\text { Isopropylbenzene (cumene), } \\
\text { dissolved }\end{array}$ & 4 & ND & -- & $<.5$ & $<.5$ \\
\hline $\begin{array}{l}\text { Isopropylbenzene (cumene), whole } \\
\text { water }\end{array}$ & 3 & ND & $<.5$ & $<.5$ & $<.5$ \\
\hline $\begin{array}{l}\text { Isopropylbenzene (cumene), bottom } \\
\text { sediment }\end{array}$ & 5 & $50 \mu \mathrm{g} / \mathrm{kg}$ & $<50 \mu \mathrm{g} / \mathrm{kg}$ & -- & -- \\
\hline Isoquinoline, dissolved & 4 & .5 & -- & $<.5$ & $<.5$ \\
\hline Isoquinoline, whole water & 3 & ND & $<.5$ & $<.5$ & $<.5$ \\
\hline Isoquinoline, bottom sediment & 5 & $50 \mu \mathrm{g} / \mathrm{kg}$ & $<50 \mu \mathrm{g} / \mathrm{kg}$ & -- & -- \\
\hline Menthol, dissolved & 4 & .5 & -- & $<.5$ & $<.5$ \\
\hline Menthol, whole water & 3 & ND & $<.5$ & $<.5$ & $<.5$ \\
\hline Menthol, bottom sediment & 5 & $50 \mu \mathrm{g} / \mathrm{kg}$ & $<50 \mu \mathrm{g} / \mathrm{kg}$ & -- & -- \\
\hline Metalaxyl, dissolved & 4 & .5 & -- & $<.5$ & $<.5$ \\
\hline Metalaxyl, whole water & 3 & .5 & $<.5$ & $<.5$ & $<.5$ \\
\hline Metalaxyl, bottom sediment & 5 & $100 \mu \mathrm{g} / \mathrm{kg}$ & $<100 \mu \mathrm{g} / \mathrm{kg}$ & -- & -- \\
\hline Methyl salicylate, dissolved & 4 & .5 & -- & $<.5$ & $<.5$ \\
\hline Methyl salicylate, whole water & 3 & .017 & $<.5$ & $<.5$ & $<.5$ \\
\hline Methyl salicylate, bottom sediment & 5 & $100 \mu \mathrm{g} / \mathrm{kg}$ & $<100 \mu \mathrm{g} / \mathrm{kg}$ & -- & -- \\
\hline $\begin{array}{l}\text { Nonylphenol diethoxylate } \\
\text { (NP2EO), dissolved }\end{array}$ & 4 & 3.5 & -- & $\mathrm{e} 5.0$ & $<5$ \\
\hline $\begin{array}{l}\text { Nonylphenol diethoxylate } \\
\text { (NP2EO), whole water }\end{array}$ & 3 & .66 & $<5$ & $<5$ & $<5$ \\
\hline $\begin{array}{l}\text { Nonylphenol diethoxylate } \\
\text { (NP2EO), bottom sediment }\end{array}$ & 5 & $65 \mu \mathrm{g} / \mathrm{kg}$ & $\mathrm{e} 110 \mu \mathrm{g} / \mathrm{kg}$ & -- & -- \\
\hline $\begin{array}{l}\text { Nonylphenol monoethoxylate } \\
\text { (NP1EO), whole water }\end{array}$ & 3 & .55 & $<5$ & $<2$ & $<2$ \\
\hline $\begin{array}{l}\text { Nonylphenol monoethoxylate } \\
\text { (NP1EO), bottom sediment }\end{array}$ & 5 & $500 \mu \mathrm{g} / \mathrm{kg}$ & $<500 \mu \mathrm{g} / \mathrm{kg}$ & -- & -- \\
\hline $\begin{array}{l}\text { Octylphenol diethoxylate } \\
\text { (OP2EO), dissolved }\end{array}$ & 4 & .19 & -- & e. 24 & $<1$ \\
\hline $\begin{array}{l}\text { Octylphenol diethoxylate } \\
\text { (OP2EO), whole water }\end{array}$ & 3 & .14 & $<1$ & $<1$ & $<1$ \\
\hline
\end{tabular}


Table 18. Analytical results for household, industrial, and minor agricultural use compounds (HIACs) in water and bottomsediment samples.-Continued

[Bold text indicates suspected endocrine-disrupting compound (EDC). Shaded cells indicate concentrations greater than study reporting levels for compounds with acceptable quality assurance/quality control, and concentrations were used in analyses related to occurrence of organic wastewater compounds. Units are micrograms per liter unless otherwise noted. Analytical method number: 3, Lee and others (2004); 4, Zaugg and others (2002); 5, Burkhardt and others (2005). $\mu \mathrm{g} / \mathrm{kg}$, micrograms per kilogram; ND, not determined; e, estimated; <, less than; --, no data collected]

\begin{tabular}{|c|c|c|c|c|c|}
\hline & \multirow{3}{*}{$\begin{array}{c}\text { Analytical } \\
\text { method } \\
\text { number }\end{array}$} & \multirow{2}{*}{$\begin{array}{l}\text { Study reporting } \\
\text { level } \\
\text { for data } \\
\text { summary and } \\
\text { analysis }\end{array}$} & \multicolumn{3}{|c|}{ Station identification number and name (site label) } \\
\hline & & & \multicolumn{3}{|c|}{$\begin{array}{l}433559096390700 \\
\text { Big Sioux River downstream from } \\
\text { Sioux Falls wastewater discharge } \\
\text { (site DS1, fig. 1) }\end{array}$} \\
\hline \multicolumn{5}{|c|}{ Compound-Continued } & \\
\hline $\begin{array}{l}\text { Octylphenol diethoxylate } \\
\text { (OP2EO), bottom sediment }\end{array}$ & 5 & $100 \mu \mathrm{g} / \mathrm{kg}$ & $<100 \mu \mathrm{g} / \mathrm{kg}$ & -- & -- \\
\hline $\begin{array}{l}\text { Octylphenol monoethoxylate } \\
\text { (OP1EO), dissolved }\end{array}$ & 4 & .39 & -- & $\mathrm{e} 0.4$ & $<1$ \\
\hline $\begin{array}{l}\text { Octylphenol monoethoxylate } \\
\text { (OP1EO), whole water }\end{array}$ & 3 & 5.2 & $<1$ & e.43 & $<1$ \\
\hline $\begin{array}{l}\text { Octylphenol monoethoxylate } \\
\text { (OP1EO), bottom sediment }\end{array}$ & 5 & $100 \mu \mathrm{g} / \mathrm{kg}$ & $<100 \mu \mathrm{g} / \mathrm{kg}$ & -- & -- \\
\hline para-Cresol, dissolved & 4 & .079 & -- & $<1$ & $<1$ \\
\hline para-Cresol, whole water & 3 & 1 & $<1$ & $<1$ & $<1$ \\
\hline para-Cresol, bottom sediment & 5 & $21 \mu \mathrm{g} / \mathrm{kg}$ & $\mathrm{e} 65 \mu \mathrm{g} / \mathrm{kg}$ & -- & -- \\
\hline para-Nonylphenol (NP), dissolved & 4 & .83 & -- & $\mathrm{e} 1.2$ & $<5$ \\
\hline $\begin{array}{l}\text { para-Nonylphenol (NP), whole } \\
\text { water }\end{array}$ & 3 & .64 & $<5$ & $<5$ & $<5$ \\
\hline $\begin{array}{l}\text { para-Nonylphenol (NP), bottom } \\
\text { sediment }\end{array}$ & 5 & $500 \mu \mathrm{g} / \mathrm{kg}$ & $<500 \mu \mathrm{g} / \mathrm{kg}$ & -- & -- \\
\hline Pentachlorophenol, dissolved & 4 & .42 & -- & $<2$ & $<2$ \\
\hline Pentachlorophenol, whole water & 3 & ND & $<2$ & $<2$ & $<2$ \\
\hline $\begin{array}{l}\text { Pentachlorophenol, bottom } \\
\text { sediment }\end{array}$ & 5 & $200 \mu \mathrm{g} / \mathrm{kg}$ & $<200 \mu \mathrm{g} / \mathrm{kg}$ & -- & -- \\
\hline Phenol, dissolved & 4 & .34 & -- & e.26 & $<.5$ \\
\hline Phenol, whole water & 3 & .94 & $<.5$ & $<.5$ & $<.5$ \\
\hline Phenol, bottom sediment & 5 & $19 \mu \mathrm{g} / \mathrm{kg}$ & $\mathrm{e} 19 \mu \mathrm{g} / \mathrm{kg}$ & -- & -- \\
\hline Tetrachloroethylene, dissolved & 4 & ND & -- & $<.5$ & $<.5$ \\
\hline Tetrachloroethylene, whole water & 3 & ND & $<.5$ & $<.5$ & $<.5$ \\
\hline $\begin{array}{l}\text { Tetrachloroethylene, bottom } \\
\text { sediment }\end{array}$ & 5 & $50 \mu \mathrm{g} / \mathrm{kg}$ & $<50 \mu \mathrm{g} / \mathrm{kg}$ & -- & -- \\
\hline Tributyl phosphate, dissolved & 4 & .18 & -- & e. 20 & $<.5$ \\
\hline Tributyl phosphate, whole water & 3 & .059 & e.082 & e.094 & $<.5$ \\
\hline Tributyl phosphate, bottom sediment & 5 & $50 \mu \mathrm{g} / \mathrm{kg}$ & $<50 \mu \mathrm{g} / \mathrm{kg}$ & -- & -- \\
\hline Triclosan, dissolved & 4 & .16 & -- & $<1$ & $<1$ \\
\hline Triclosan, whole water & 3 & .15 & $<1$ & $<1$ & $<1$ \\
\hline Triclosan, bottom sediment & 5 & $2.9 \mu \mathrm{g} / \mathrm{kg}$ & $\mathrm{e} 6.27 \mu \mathrm{g} / \mathrm{kg}$ & -- & -- \\
\hline $\begin{array}{l}\text { Triethyl citrate (ethyl citrate), } \\
\text { dissolved }\end{array}$ & 4 & .21 & -- & e. 23 & $<.5$ \\
\hline
\end{tabular}


Table 18. Analytical results for household, industrial, and minor agricultural use compounds (HIACs) in water and bottomsediment samples. - Continued

[Bold text indicates suspected endocrine-disrupting compound (EDC). Shaded cells indicate concentrations greater than study reporting levels for compounds with acceptable quality assurance/quality control, and concentrations were used in analyses related to occurrence of organic wastewater compounds. Units are micrograms per liter unless otherwise noted. Analytical method number: 3, Lee and others (2004); 4, Zaugg and others (2002); 5, Burkhardt and others (2005). $\mu \mathrm{g} / \mathrm{kg}$, micrograms per kilogram; ND, not determined; e, estimated; <, less than; --, no data collected]

\begin{tabular}{|c|c|c|c|c|c|}
\hline & \multirow{3}{*}{$\begin{array}{c}\text { Analytical } \\
\text { method } \\
\text { number }\end{array}$} & \multirow[b]{2}{*}{$\begin{array}{l}\text { Study reporting } \\
\text { level } \\
\text { for data } \\
\text { summary and } \\
\text { analysis }\end{array}$} & \multicolumn{3}{|c|}{ Station identification number and name (site label) } \\
\hline & & & \multicolumn{3}{|c|}{$\begin{array}{c}433559096390700 \\
\text { Big Sioux River downstream from } \\
\text { Sioux Falls wastewater discharge } \\
\text { (site DS1, fig. 1) }\end{array}$} \\
\hline \multicolumn{5}{|c|}{ Compound-Continued } & \\
\hline $\begin{array}{l}\text { Triethyl citrate (ethyl citrate), whole } \\
\text { water }\end{array}$ & 3 & 0.051 & $\mathrm{e} 0.051$ & $\mathrm{e} 0.12$ & $<0.5$ \\
\hline Triphenyl phosphate, dissolved & 4 & .066 & -- & e.069 & $<.5$ \\
\hline Triphenyl phosphate, whole water & 3 & .033 & $<.5$ & $<.5$ & $<.5$ \\
\hline $\begin{array}{l}\text { Triphenyl phosphate, bottom } \\
\text { sediment }\end{array}$ & 5 & $100 \mu \mathrm{g} / \mathrm{kg}$ & $<100 \mu \mathrm{g} / \mathrm{kg}$ & -- & -- \\
\hline $\begin{array}{l}\text { Tri(2-butoxyethyl)phosphate, } \\
\text { dissolved }\end{array}$ & 4 & .4 & -- & e. 41 & $<.5$ \\
\hline $\begin{array}{l}\text { Tri(2-butoxyethyl)phosphate, whole } \\
\text { water }\end{array}$ & 3 & .13 & e. 13 & $<.5$ & $<.5$ \\
\hline $\begin{array}{l}\text { Tri(2-butoxyethyl)phosphate, bottom } \\
\text { sediment }\end{array}$ & 5 & $100 \mu \mathrm{g} / \mathrm{kg}$ & $<100 \mu \mathrm{g} / \mathrm{kg}$ & -- & -- \\
\hline $\begin{array}{l}\text { Tri(2-chloroethyl)phosphate, } \\
\text { dissolved }\end{array}$ & 4 & .074 & -- & e. 20 & e.089 \\
\hline $\begin{array}{l}\text { Tri(2-chloroethyl)phosphate, whole } \\
\text { water }\end{array}$ & 3 & .1 & e. 10 & e. 15 & $<.5$ \\
\hline $\begin{array}{l}\text { Tri(2-chloroethyl)phosphate, bottom } \\
\text { sediment }\end{array}$ & 5 & $100 \mu \mathrm{g} / \mathrm{kg}$ & $<100 \mu \mathrm{g} / \mathrm{kg}$ & -- & -- \\
\hline $\begin{array}{l}\text { Tri(dichloroisopropyl)phosphate, } \\
\text { dissolved }\end{array}$ & 4 & .13 & -- & e. 13 & $<.5$ \\
\hline $\begin{array}{l}\text { Tri(dichloroisopropyl)phosphate, } \\
\text { whole water }\end{array}$ & 3 & .071 & e.071 & $<.5$ & $<.5$ \\
\hline $\begin{array}{l}\text { Tri(dichloroisopropyl)phosphate, } \\
\text { bottom sediment }\end{array}$ & 5 & $100 \mu \mathrm{g} / \mathrm{kg}$ & $<100 \mu \mathrm{g} / \mathrm{kg}$ & -- & -- \\
\hline
\end{tabular}


Table 18. Analytical results for household, industrial, and minor agricultural use compounds (HIACs) in water and bottom-sediment samples.-Continued

[Bold text indicates suspected endocrine-disrupting compound (EDC). Shaded cells indicate concentrations greater than study reporting levels for compounds with acceptable quality assurance/quality control, and concentrations were used in analyses related to occurrence of organic wastewater compounds. Units are micrograms per liter unless otherwise noted. Analytical method number: 3, Lee and others (2004); 4, Zaugg and others (2002); 5, Burkhardt and others (2005). $\mu \mathrm{g} / \mathrm{kg}$, micrograms per kilogram; ND, not determined; e, estimated; <, less than; --, no data collected]

\begin{tabular}{|c|c|c|c|c|c|c|c|c|c|}
\hline \multirow{3}{*}{$\begin{array}{l} \\
\\
\text { Date of sample } \\
\text { collection } \\
\text { (month-day-year) }\end{array}$} & \multirow{3}{*}{$\begin{array}{l}\text { Analytical } \\
\text { method } \\
\text { number }\end{array}$} & \multirow{3}{*}{$\begin{array}{c}\text { Study reporting } \\
\text { level } \\
\text { for data } \\
\text { summary and } \\
\text { analysis }\end{array}$} & \multicolumn{7}{|c|}{ Station identification number and name (site label) } \\
\hline & & & \multicolumn{7}{|c|}{$\begin{array}{c}433541096355800 \\
\text { Big Sioux River at Brandon, SD } \\
\text { (site DS2, fig. 1) }\end{array}$} \\
\hline & & & $\begin{array}{c}08-16- \\
2001\end{array}$ & 09-11-2002 & $\begin{array}{c}01-23- \\
2003\end{array}$ & $\begin{array}{c}03-20- \\
2003\end{array}$ & $\begin{array}{c}06-25- \\
2003\end{array}$ & $\begin{array}{c}05-17- \\
2004\end{array}$ & $\begin{array}{c}05-31- \\
2004\end{array}$ \\
\hline $\begin{array}{l}\text { Time of sample } \\
\text { collection } \\
\text { (24-hour) }\end{array}$ & & & 0930 & 1030 & 1125 & 1315 & 1630 & 1730 & 1230 \\
\hline \multicolumn{10}{|c|}{ Compound } \\
\hline $\begin{array}{l}\text { 1,4-Dichlorobenzene, } \\
\text { dissolved }\end{array}$ & 4 & 0.08 & -- & -- & -- & -- & -- & $<0.5$ & $<0.5$ \\
\hline $\begin{array}{l}\text { 1,4-Dichlorobenzene, } \\
\text { whole water }\end{array}$ & 3 & ND & $<0.5$ & $<0.5$ & $<0.5$ & $<0.5$ & $<0.5$ & $<.5$ & $<.5$ \\
\hline $\begin{array}{l}\text { 1,4-Dichlorobenzene, } \\
\text { bottom sediment }\end{array}$ & 5 & $50 \mu \mathrm{g} / \mathrm{kg}$ & -- & $<50 \mu \mathrm{g} / \mathrm{kg}$ & -- & -- & -- & -- & -- \\
\hline $\begin{array}{l}2,2^{\prime}, 4,4^{\prime}- \\
\text { Tetrabromodiphenyl } \\
\text { ether, whole water }\end{array}$ & 3 & .5 & -- & $<10$ & $<10$ & $<10$ & -- & $<.5$ & $<.5$ \\
\hline $\begin{array}{l}2,2^{\prime}, 4,4^{\prime} \text { - } \\
\text { Tetrabromodiphenyl } \\
\text { ether, bottom } \\
\text { sediment }\end{array}$ & 5 & $50 \mu \mathrm{g} / \mathrm{kg}$ & -- & $<50 \mu \mathrm{g} / \mathrm{kg}$ & -- & -- & -- & -- & -- \\
\hline $\begin{array}{l}\text { 3,4-Dichlorophenyl } \\
\text { isocyanate, whole } \\
\text { water }\end{array}$ & 4 & ND & -- & e. 052 & $<.5$ & e. 053 & -- & $\mathrm{e} 2.0$ & $<.5$ \\
\hline $\begin{array}{l}\text { 3,4-Dichlorophenyl } \\
\text { isocyanate, bottom } \\
\text { sediment }\end{array}$ & 3 & $100 \mu \mathrm{g} / \mathrm{kg}$ & -- & $<100 \mu \mathrm{g} / \mathrm{kg}$ & -- & -- & -- & -- & -- \\
\hline $\begin{array}{l}\text { 3-Methyl-1H-indole } \\
\text { (skatol), dissolved }\end{array}$ & 5 & .02 & -- & -- & -- & -- & -- & $<1$ & $<1$ \\
\hline $\begin{array}{l}\text { 3-Methyl-1H-indole } \\
\text { (skatol), whole water }\end{array}$ & 3 & .019 & $<1$ & $<1$ & $<1$ & $<1$ & $<1$ & $<1$ & $<1$ \\
\hline $\begin{array}{l}\text { 3-Methyl-1H-indole } \\
\text { (skatol), bottom } \\
\text { sediment }\end{array}$ & 5 & $30 \mu \mathrm{g} / \mathrm{kg}$ & -- & $\mathrm{e} 34 \mu \mathrm{g} / \mathrm{kg}$ & -- & -- & -- & -- & -- \\
\hline $\begin{array}{l}\text { 3-tert-Butyl-4-hydroxy } \\
\text { anisole (BHA), } \\
\text { dissolved }\end{array}$ & 4 & 5 & -- & -- & -- & -- & -- & $<5$ & $<5$ \\
\hline $\begin{array}{l}\text { 3-tert-Butyl-4-hydroxy } \\
\text { anisole (BHA), whole } \\
\text { water }\end{array}$ & 3 & ND & $<5$ & $<5$ & $<5$ & $<5$ & $<5$ & $<5$ & $<5$ \\
\hline $\begin{array}{l}\text { 4-Cumylphenol, } \\
\text { dissolved }\end{array}$ & 5 & 1 & -- & -- & -- & -- & -- & $<1$ & $<1$ \\
\hline
\end{tabular}


Table 18. Analytical results for household, industrial, and minor agricultural use compounds (HIACs) in water and bottom-sediment samples.-Continued

[Bold text indicates suspected endocrine-disrupting compound (EDC). Shaded cells indicate concentrations greater than study reporting levels for compounds with acceptable quality assurance/quality control, and concentrations were used in analyses related to occurrence of organic wastewater compounds. Units are micrograms per liter unless otherwise noted. Analytical method number: 3, Lee and others (2004); 4, Zaugg and others (2002); 5, Burkhardt and others (2005). $\mu \mathrm{g} / \mathrm{kg}$, micrograms per kilogram; ND, not determined; e, estimated; <, less than; --, no data collected]

\begin{tabular}{|c|c|c|c|c|c|c|c|c|c|}
\hline & \multirow[b]{2}{*}{$\begin{array}{l}\text { Analytical } \\
\text { method } \\
\text { number }\end{array}$} & \multirow{2}{*}{$\begin{array}{c}\text { Study reporting } \\
\text { level } \\
\text { for data } \\
\text { summary and } \\
\text { analysis }\end{array}$} & \multicolumn{7}{|c|}{ Station identification number and name (site label) } \\
\hline & & & \multicolumn{7}{|c|}{$\begin{array}{c}433541096355800 \\
\text { Big Sioux River at Brandon, SD } \\
\text { (site DS2, fig. 1) }\end{array}$} \\
\hline \multicolumn{10}{|c|}{ Compound-Continued } \\
\hline $\begin{array}{l}\text { 4-Cumylphenol, whole } \\
\text { water }\end{array}$ & 3 & 1 & $<1$ & $<1$ & $<1$ & $<1$ & $<1$ & $<1$ & $<1$ \\
\hline $\begin{array}{l}\text { 4-Cumylphenol, } \\
\text { bottom sediment }\end{array}$ & 5 & $50 \mu \mathrm{g} / \mathrm{kg}$ & -- & $<50 \mu \mathrm{g} / \mathrm{kg}$ & -- & -- & -- & -- & -- \\
\hline $\begin{array}{l}\text { 4-normal-Octylphenol, } \\
\text { dissolved }\end{array}$ & 4 & 1 & -- & -- & -- & -- & -- & $<1$ & $<1$ \\
\hline $\begin{array}{l}\text { 4-normal-Octylphenol, } \\
\text { whole water }\end{array}$ & 3 & 1 & $<1$ & $<1$ & $<1$ & $<1$ & $<1$ & $<1$ & $<1$ \\
\hline $\begin{array}{l}\text { 4-normal-Octylphenol, } \\
\text { bottom sediment }\end{array}$ & 5 & $50 \mu \mathrm{g} / \mathrm{kg}$ & -- & $<50 \mu \mathrm{g} / \mathrm{kg}$ & -- & -- & -- & -- & -- \\
\hline $\begin{array}{l}\text { 4-tert-Octylphenol, } \\
\text { dissolved }\end{array}$ & 4 & 1 & -- & -- & -- & -- & -- & $<1$ & $<1$ \\
\hline $\begin{array}{l}\text { 4-tert-Octylphenol, } \\
\text { whole water }\end{array}$ & 3 & .26 & $<1$ & $<1$ & $<1$ & $<1$ & $<1$ & e. 16 & $<1$ \\
\hline $\begin{array}{l}\text { 4-tert-Octylphenol, } \\
\text { bottom sediment }\end{array}$ & 5 & $50 \mu \mathrm{g} / \mathrm{kg}$ & -- & $<50 \mu \mathrm{g} / \mathrm{kg}$ & -- & -- & -- & -- & -- \\
\hline $\begin{array}{l}\text { 5-Methyl-1H- } \\
\text { benzotriazole, } \\
\text { dissolved }\end{array}$ & 4 & ND & -- & -- & -- & -- & -- & $<2$ & $<2$ \\
\hline $\begin{array}{l}\text { 5-Methyl-1H- } \\
\text { benzotriazole, whole } \\
\text { water }\end{array}$ & 3 & .33 & $<2$ & $<2$ & $<2$ & $<2$ & $<2$ & $<2$ & $<2$ \\
\hline $\begin{array}{l}\text { 7-Acetyl-1,1,3,4,4,6- } \\
\text { hexamethyl } \\
\text { tetrahydronaphthale } \\
\text { ne (AHTN), dissolved }\end{array}$ & 4 & .23 & -- & -- & -- & -- & -- & e. 23 & $<.5$ \\
\hline $\begin{array}{l}\text { 7-Acetyl-1,1,3,4,4,6- } \\
\text { hexamethyl } \\
\text { tetrahydronaphthale } \\
\text { ne (AHTN), whole } \\
\text { water }\end{array}$ & 3 & .048 & e. 048 & e. 11 & .56 & e.096 & $<.5$ & e. 20 & $<.5$ \\
\hline $\begin{array}{l}\text { 7-Acetyl-1,1,3,4,4,6- } \\
\text { hexamethyl } \\
\text { tetrahydronaphthale } \\
\text { ne (AHTN), bottom } \\
\text { sediment }\end{array}$ & 5 & $50 \mu \mathrm{g} / \mathrm{kg}$ & -- & $<50 \mu \mathrm{g} / \mathrm{kg}$ & -- & -- & -- & -- & -- \\
\hline $\begin{array}{l}\text { Acetophenone, } \\
\text { dissolved }\end{array}$ & 4 & .5 & -- & -- & -- & -- & -- & $<.5$ & $<.5$ \\
\hline $\begin{array}{l}\text { Acetophenone, whole } \\
\text { water }\end{array}$ & 3 & .08 & $<.5$ & $<.5$ & $<.5$ & $<.5$ & $<.5$ & $<.5$ & $<.5$ \\
\hline
\end{tabular}


Table 18. Analytical results for household, industrial, and minor agricultural use compounds (HIACs) in water and bottom-sediment samples.-Continued

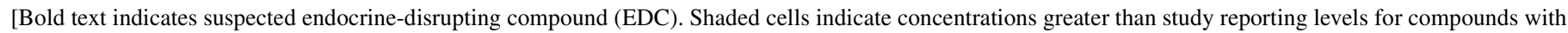

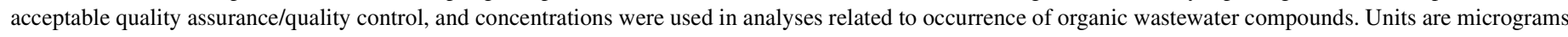

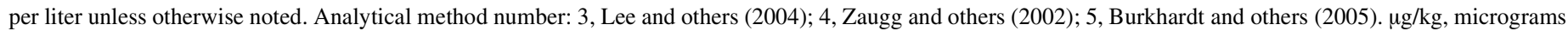
per kilogram; ND, not determined; e, estimated; <, less than; --, no data collected]

\begin{tabular}{|c|c|c|c|c|c|c|c|c|c|}
\hline & \multirow{3}{*}{$\begin{array}{l}\text { Analytical } \\
\text { method } \\
\text { number }\end{array}$} & \multirow{3}{*}{$\begin{array}{c}\text { Study reporting } \\
\text { level } \\
\text { for data } \\
\text { summary and } \\
\text { analysis }\end{array}$} & \multicolumn{7}{|c|}{ Station identification number and name (site label) } \\
\hline & & & \multicolumn{7}{|c|}{$\begin{array}{c}433541096355800 \\
\text { Big Sioux River at Brandon, SD } \\
\text { (site DS2, fig. 1) }\end{array}$} \\
\hline \multicolumn{8}{|c|}{ Compound-Continued } & & \\
\hline $\begin{array}{l}\text { Acetophenone, bottom } \\
\text { sediment }\end{array}$ & 5 & $50 \mu \mathrm{g} / \mathrm{kg}$ & -- & $<50 \mu \mathrm{g} / \mathrm{kg}$ & -- & -- & -- & -- & -- \\
\hline $\begin{array}{l}\text { Anthraquinone, } \\
\text { dissolved }\end{array}$ & 4 & .12 & -- & -- & -- & -- & -- & $\mathrm{e} 0.12$ & $<0.5$ \\
\hline $\begin{array}{l}\text { Anthraquinone, whole } \\
\text { water }\end{array}$ & 3 & .098 & $<0.5$ & $<.5$ & $<0.5$ & $\mathrm{e} 0.098$ & $\mathrm{e} 0.42$ & $<.5$ & $<.5$ \\
\hline $\begin{array}{l}\text { Anthraquinone, bottom } \\
\text { sediment }\end{array}$ & 5 & $4 \mu \mathrm{g} / \mathrm{kg}$ & -- & $\mathrm{e} 8.0 \mu \mathrm{g} / \mathrm{kg}$ & -- & -- & -- & -- & -- \\
\hline $\begin{array}{l}\text { Benzophenone, } \\
\text { dissolved }\end{array}$ & 4 & .066 & -- & -- & -- & -- & -- & $<.5$ & $<.5$ \\
\hline $\begin{array}{l}\text { Benzophenone, whole } \\
\text { water }\end{array}$ & 3 & ND & $<.5$ & $<.5$ & e.098 & $<.5$ & $<.5$ & $<.5$ & $<.5$ \\
\hline $\begin{array}{l}\text { Benzophenone, bottom } \\
\text { sediment }\end{array}$ & 5 & $50 \mu \mathrm{g} / \mathrm{kg}$ & -- & $<50 \mu \mathrm{g} / \mathrm{kg}$ & -- & -- & -- & -- & -- \\
\hline $\begin{array}{l}\text { Bis(2-ethylhexyl) } \\
\text { phthalate, whole water }\end{array}$ & 3 & ND & -- & $<.5$ & $\mathrm{e} 2.6$ & $\mathrm{e} 1.4$ & $<.5$ & e. 41 & $<2$ \\
\hline $\begin{array}{l}\text { Bis(2-ethylhexyl) } \\
\text { phthalate, bottom } \\
\text { sediment }\end{array}$ & 5 & $100 \mu \mathrm{g} / \mathrm{kg}$ & -- & $<100 \mu \mathrm{g} / \mathrm{kg}$ & -- & -- & -- & -- & -- \\
\hline Bisphenol-A, dissolved & 4 & ND & -- & -- & -- & -- & -- & $<1$ & $<1$ \\
\hline $\begin{array}{l}\text { Bisphenol-A, whole } \\
\text { water }\end{array}$ & 3 & ND & $<1$ & $<1$ & $<1$ & $<1$ & $<1$ & $<1$ & $<1$ \\
\hline $\begin{array}{l}\text { Bisphenol-A, bottom } \\
\text { sediment }\end{array}$ & 5 & $100 \mu \mathrm{g} / \mathrm{kg}$ & -- & $\mathrm{e} 180 \mu \mathrm{g} / \mathrm{kg}$ & -- & -- & -- & -- & -- \\
\hline Bromacil, dissolved & 4 & ND & -- & -- & -- & -- & -- & $<.5$ & $<.5$ \\
\hline Bromacil, whole water & 3 & .068 & $<.5$ & e.068 & $<.5$ & $<.5$ & $<.5$ & $<.5$ & $<.5$ \\
\hline $\begin{array}{l}\text { Bromacil, bottom } \\
\text { sediment }\end{array}$ & 5 & $100 \mu \mathrm{g} / \mathrm{kg}$ & -- & $<100 \mu \mathrm{g} / \mathrm{kg}$ & -- & -- & -- & -- & -- \\
\hline Camphor, dissolved & 4 & .029 & -- & -- & -- & -- & -- & e.030 & $<.5$ \\
\hline Camphor, whole water & 3 & .5 & $<.5$ & $<.5$ & $<.5$ & $<.5$ & $<.5$ & $<.5$ & $<.5$ \\
\hline $\begin{array}{l}\text { Camphor, bottom } \\
\text { sediment }\end{array}$ & 5 & $50 \mu \mathrm{g} / \mathrm{kg}$ & -- & $<50 \mu \mathrm{g} / \mathrm{kg}$ & -- & -- & -- & -- & -- \\
\hline Carbaryl, dissolved & 4 & .14 & -- & -- & -- & -- & -- & $<1$ & $<1$ \\
\hline Carbaryl, whole water & 3 & ND & $<1$ & $<1$ & $<1$ & $<1$ & e.79 & $<1$ & $<1$ \\
\hline $\begin{array}{l}\text { Chlorpyrifos, } \\
\text { dissolved }\end{array}$ & 4 & .5 & -- & -- & -- & -- & -- & $<.5$ & $<.5$ \\
\hline $\begin{array}{l}\text { Chlorpyrifos, whole } \\
\text { water }\end{array}$ & 3 & .014 & $<.5$ & $<.5$ & $<.5$ & $<.5$ & $<.5$ & $<.5$ & $<.5$ \\
\hline
\end{tabular}


Table 18. Analytical results for household, industrial, and minor agricultural use compounds (HIACs) in water and bottom-sediment samples.-Continued

[Bold text indicates suspected endocrine-disrupting compound (EDC). Shaded cells indicate concentrations greater than study reporting levels for compounds with acceptable quality assurance/quality control, and concentrations were used in analyses related to occurrence of organic wastewater compounds. Units are micrograms per liter unless otherwise noted. Analytical method number: 3, Lee and others (2004); 4, Zaugg and others (2002); 5, Burkhardt and others (2005). $\mu \mathrm{g} / \mathrm{kg}$, micrograms per kilogram; ND, not determined; e, estimated; <, less than; --, no data collected]

\begin{tabular}{|c|c|c|c|c|c|c|c|c|c|}
\hline & \multirow[b]{2}{*}{$\begin{array}{l}\text { Analytical } \\
\text { method } \\
\text { number }\end{array}$} & \multirow{2}{*}{$\begin{array}{c}\text { Study reporting } \\
\text { level } \\
\text { for data } \\
\text { summary and } \\
\text { analysis }\end{array}$} & \multicolumn{7}{|c|}{ Station identification number and name (site label) } \\
\hline & & & \multicolumn{7}{|c|}{$\begin{array}{c}433541096355800 \\
\text { Big Sioux River at Brandon, SD } \\
\text { (site DS2, fig. 1) }\end{array}$} \\
\hline \multicolumn{10}{|c|}{ Compound-Continued } \\
\hline $\begin{array}{l}\text { Chlorpyrifos, bottom } \\
\text { sediment }\end{array}$ & 5 & $50 \mu \mathrm{g} / \mathrm{kg}$ & -- & $<50 \mu \mathrm{g} / \mathrm{kg}$ & -- & -- & -- & -- & -- \\
\hline $\begin{array}{l}\text { N,N-Diethyl-meta- } \\
\text { toluamide (DEET), } \\
\text { dissolved }\end{array}$ & 4 & 0.034 & -- & -- & -- & -- & -- & $\mathrm{e} 0.10$ & $<0.5$ \\
\hline $\begin{array}{l}\text { N,N-Diethyl-meta- } \\
\text { toluamide (DEET), } \\
\text { whole water }\end{array}$ & 3 & .042 & $<0.5$ & e0.094 & $\mathrm{e} 0.076$ & $<0.5$ & $\mathrm{e} 0.34$ & e. 042 & $<.5$ \\
\hline $\begin{array}{l}\text { N,N-Diethyl-meta- } \\
\text { toluamide (DEET), } \\
\text { bottom sediment }\end{array}$ & 5 & $100 \mu \mathrm{g} / \mathrm{kg}$ & -- & $<100 \mu \mathrm{g} / \mathrm{kg}$ & -- & -- & -- & -- & -- \\
\hline Diazinon, dissolved & 4 & .5 & -- & -- & -- & -- & -- & $<.5$ & $<.5$ \\
\hline Diazinon, whole water & 3 & .027 & $<.5$ & $<.5$ & $<.5$ & $<.5$ & e. 089 & $<.5$ & $<.5$ \\
\hline $\begin{array}{l}\text { Diazinon, bottom } \\
\text { sediment }\end{array}$ & 5 & $50 \mu \mathrm{g} / \mathrm{kg}$ & -- & $<50 \mu \mathrm{g} / \mathrm{kg}$ & -- & -- & -- & -- & -- \\
\hline Dichlorvos, dissolved & 4 & ND & -- & -- & -- & -- & -- & $<1$ & $<1$ \\
\hline $\begin{array}{l}\text { Dichlorvos, whole } \\
\text { water }\end{array}$ & 3 & ND & $<1$ & $<1$ & $<1$ & $<1$ & $<1$ & $<1$ & $<1$ \\
\hline $\begin{array}{l}\text { Diethyl phthalate, } \\
\text { whole water }\end{array}$ & 3 & ND & -- & $<.5$ & $<.5$ & $<.5$ & -- & $<.5$ & $<.5$ \\
\hline $\begin{array}{l}\text { Diethyl phthalate, } \\
\text { bottom sediment }\end{array}$ & 5 & $50 \mu \mathrm{g} / \mathrm{kg}$ & -- & $<50 \mu \mathrm{g} / \mathrm{kg}$ & -- & -- & -- & -- & -- \\
\hline D-Limonene, dissolved & 4 & ND & -- & -- & -- & -- & -- & $<.5$ & $<.5$ \\
\hline $\begin{array}{l}\text { D-Limonene, whole } \\
\text { water }\end{array}$ & 3 & ND & $<.5$ & $<.5$ & $<.5$ & $<.5$ & $<.5$ & $<.5$ & $<.5$ \\
\hline $\begin{array}{l}\text { D-Limonene, bottom } \\
\text { sediment }\end{array}$ & 5 & $50 \mu \mathrm{g} / \mathrm{kg}$ & -- & $<50 \mu \mathrm{g} / \mathrm{kg}$ & -- & -- & -- & -- & -- \\
\hline $\begin{array}{l}\text { 1,3,4,6,7,8-Hexahydro- } \\
4,6,6,7,8,8- \\
\text { hexamethyl } \\
\text { cyclopenta-g-2- } \\
\text { benzopyran } \\
\text { (HHCB), dissolved }\end{array}$ & 4 & .061 & -- & -- & -- & -- & -- & e.061 & $<.5$ \\
\hline $\begin{array}{l}\text { 1,3,4,6,7,8-Hexahydro- } \\
4,6,6,7,8,8- \\
\text { hexamethyl } \\
\text { cyclopenta-g-2- } \\
\text { benzopyran } \\
\text { (HHCB), whole water }\end{array}$ & 3 & .045 & $<.5$ & $<.5$ & e. 13 & $<.5$ & $<.5$ & $<.5$ & $<.5$ \\
\hline
\end{tabular}


Table 18. Analytical results for household, industrial, and minor agricultural use compounds (HIACs) in water and bottom-sediment samples.-Continued

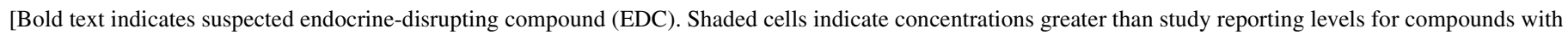

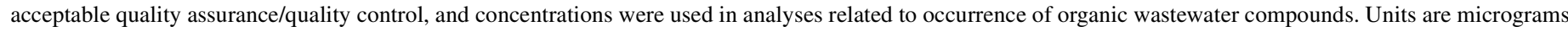

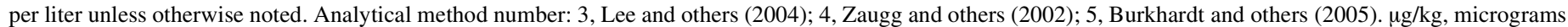
per kilogram; ND, not determined; e, estimated; <, less than; --, no data collected]

\begin{tabular}{|c|c|c|c|c|c|c|c|c|c|}
\hline & \multirow{2}{*}{$\begin{array}{l}\text { Analytical } \\
\text { method } \\
\text { number }\end{array}$} & \multirow{2}{*}{$\begin{array}{l}\text { Study reporting } \\
\text { level } \\
\text { for data } \\
\text { summary and } \\
\text { analysis }\end{array}$} & \multicolumn{7}{|c|}{ Station identification number and name (site label) } \\
\hline & & & \multicolumn{7}{|c|}{$\begin{array}{c}433541096355800 \\
\text { Big Sioux River at Brandon, SD } \\
\text { (site DS2, fig. 1) }\end{array}$} \\
\hline \multicolumn{10}{|c|}{ Compound-Continued } \\
\hline $\begin{array}{l}\text { 1,3,4,6,7,8-Hexahydro- } \\
\text { 4,6,6,7,8,8- } \\
\text { hexamethyl } \\
\text { cyclopenta-g-2- } \\
\text { benzopyran } \\
\text { (HHCB), bottom } \\
\text { sediment }\end{array}$ & 5 & $50 \mu \mathrm{g} / \mathrm{kg}$ & -- & $<50 \mu \mathrm{g} / \mathrm{kg}$ & -- & -- & -- & -- & -- \\
\hline Indole, dissolved & 4 & 0.042 & -- & -- & -- & -- & -- & $\mathrm{e} 0.042$ & $<0.5$ \\
\hline Indole, whole water & 3 & .015 & $<0.5$ & $<0.5$ & $<0.5$ & $\mathrm{e} 0.015$ & $<0.5$ & $<.5$ & $<.5$ \\
\hline Indole, bottom sediment & 5 & $1.9 \mu \mathrm{g} / \mathrm{kg}$ & -- & $\mathrm{e} 1.9 \mu \mathrm{g} / \mathrm{kg}$ & -- & -- & -- & -- & -- \\
\hline Isoborneol, dissolved & 4 & .5 & -- & -- & -- & -- & -- & $<.5$ & $<.5$ \\
\hline Isoborneol, whole water & 3 & .5 & $<.5$ & $<.5$ & $<.5$ & $<.5$ & $<.5$ & $<.5$ & $<.5$ \\
\hline $\begin{array}{l}\text { Isoborneol, bottom } \\
\text { sediment }\end{array}$ & 5 & $50 \mu \mathrm{g} / \mathrm{kg}$ & -- & $<50 \mu \mathrm{g} / \mathrm{kg}$ & -- & -- & -- & -- & -- \\
\hline Isophorone, dissolved & 4 & .047 & -- & -- & -- & -- & -- & e. 047 & $<.5$ \\
\hline $\begin{array}{l}\text { Isophorone, whole } \\
\text { water }\end{array}$ & 3 & ND & $<.5$ & $<.5$ & $<.5$ & $<.5$ & $<.5$ & $<.5$ & $<.5$ \\
\hline $\begin{array}{l}\text { Isophorone, bottom } \\
\text { sediment }\end{array}$ & 5 & $50 \mu \mathrm{g} / \mathrm{kg}$ & -- & $<50 \mu \mathrm{g} / \mathrm{kg}$ & -- & -- & -- & -- & -- \\
\hline $\begin{array}{l}\text { Isopropylbenzene } \\
\text { (cumene), dissolved }\end{array}$ & 4 & ND & -- & -- & -- & -- & -- & $<.5$ & $<.5$ \\
\hline $\begin{array}{l}\text { Isopropylbenzene } \\
\text { (cumene), whole } \\
\text { water }\end{array}$ & 3 & ND & $<.5$ & $<.5$ & $<.5$ & $<.5$ & $<.5$ & $<.5$ & $<.5$ \\
\hline $\begin{array}{l}\text { Isopropylbenzene } \\
\text { (cumene), bottom } \\
\text { sediment }\end{array}$ & 5 & $50 \mu \mathrm{g} / \mathrm{kg}$ & -- & $<50 \mu \mathrm{g} / \mathrm{kg}$ & -- & -- & -- & -- & -- \\
\hline Isoquinoline, dissolved & 4 & .5 & -- & -- & -- & -- & -- & $<.5$ & $<.5$ \\
\hline $\begin{array}{l}\text { Isoquinoline, whole } \\
\text { water }\end{array}$ & 3 & ND & $<.5$ & $<.5$ & $<.5$ & $<.5$ & $<.5$ & $<.5$ & $<.5$ \\
\hline $\begin{array}{l}\text { Isoquinoline, bottom } \\
\text { sediment }\end{array}$ & 5 & $50 \mu \mathrm{g} / \mathrm{kg}$ & -- & $<50 \mu \mathrm{g} / \mathrm{kg}$ & -- & -- & -- & -- & -- \\
\hline Menthol, dissolved & 4 & .5 & -- & -- & -- & -- & -- & $<.5$ & $<.5$ \\
\hline Menthol, whole water & 3 & ND & $<.5$ & $<.5$ & $<.5$ & $<.5$ & $<.5$ & $<.5$ & $<.5$ \\
\hline $\begin{array}{l}\text { Menthol, bottom } \\
\text { sediment }\end{array}$ & 5 & $50 \mu \mathrm{g} / \mathrm{kg}$ & -- & $<50 \mu \mathrm{g} / \mathrm{kg}$ & -- & -- & -- & -- & -- \\
\hline Metalaxyl, dissolved & 4 & .5 & -- & -- & -- & -- & -- & $<.5$ & $<.5$ \\
\hline Metalaxyl, whole water & 3 & .5 & $<.5$ & $<.5$ & $<.5$ & $<.5$ & $<.5$ & $<.5$ & $<.5$ \\
\hline
\end{tabular}


Table 18. Analytical results for household, industrial, and minor agricultural use compounds (HIACs) in water and bottom-sediment samples.-Continued

[Bold text indicates suspected endocrine-disrupting compound (EDC). Shaded cells indicate concentrations greater than study reporting levels for compounds with acceptable quality assurance/quality control, and concentrations were used in analyses related to occurrence of organic wastewater compounds. Units are micrograms per liter unless otherwise noted. Analytical method number: 3, Lee and others (2004); 4, Zaugg and others (2002); 5, Burkhardt and others (2005). $\mu \mathrm{g} / \mathrm{kg}$, micrograms per kilogram; ND, not determined; e, estimated; <, less than; --, no data collected]

\begin{tabular}{|c|c|c|c|c|c|c|c|c|c|}
\hline & \multirow[b]{2}{*}{$\begin{array}{l}\text { Analytical } \\
\text { method } \\
\text { number }\end{array}$} & \multirow{2}{*}{$\begin{array}{l}\text { Study reporting } \\
\text { level } \\
\text { for data } \\
\text { summary and } \\
\text { analysis }\end{array}$} & \multicolumn{7}{|c|}{ Station identification number and name (site label) } \\
\hline & & & \multicolumn{7}{|c|}{$\begin{array}{c}433541096355800 \\
\text { Big Sioux River at Brandon, SD } \\
\text { (site DS2, fig. 1) }\end{array}$} \\
\hline \multicolumn{10}{|c|}{ Compound-Continued } \\
\hline $\begin{array}{l}\text { Metalaxyl, bottom } \\
\text { sediment }\end{array}$ & 5 & $100 \mu \mathrm{g} / \mathrm{kg}$ & -- & $<100 \mu \mathrm{g} / \mathrm{kg}$ & -- & -- & -- & -- & -- \\
\hline $\begin{array}{l}\text { Methyl salicylate, } \\
\text { dissolved }\end{array}$ & 4 & 0.5 & -- & -- & -- & -- & -- & $<0.5$ & $<0.5$ \\
\hline $\begin{array}{l}\text { Methyl salicylate, } \\
\text { whole water }\end{array}$ & 3 & .017 & $<0.5$ & $<0.5$ & $<0.5$ & $<0.5$ & $<0.5$ & $<.5$ & $<.5$ \\
\hline $\begin{array}{l}\text { Methyl salicylate, } \\
\text { bottom sediment }\end{array}$ & 5 & $100 \mu \mathrm{g} / \mathrm{kg}$ & -- & $<100 \mu \mathrm{g} / \mathrm{kg}$ & -- & -- & -- & -- & -- \\
\hline $\begin{array}{l}\text { Nonylphenol } \\
\text { diethoxylate } \\
\text { (NP2EO), dissolved }\end{array}$ & 4 & 3.5 & -- & -- & -- & -- & -- & $<5$ & $<5$ \\
\hline $\begin{array}{l}\text { Nonylphenol } \\
\text { diethoxylate } \\
\text { (NP2EO), whole } \\
\text { water }\end{array}$ & 3 & .66 & $<5$ & $<5$ & $\mathrm{e} 3.0$ & e2.9 & $<5$ & $<5$ & $<5$ \\
\hline $\begin{array}{l}\text { Nonylphenol } \\
\text { diethoxylate } \\
\text { (NP2EO), bottom } \\
\text { sediment }\end{array}$ & 5 & $65 \mu \mathrm{g} / \mathrm{kg}$ & -- & $\mathrm{e} 65 \mu \mathrm{g} / \mathrm{kg}$ & -- & -- & -- & -- & -- \\
\hline $\begin{array}{l}\text { Nonylphenol } \\
\text { monoethoxylate } \\
\text { (NP1EO), whole } \\
\text { water }\end{array}$ & 3 & .55 & -- & $<5$ & e. 82 & $<5$ & $<5$ & $<2$ & $<2$ \\
\hline $\begin{array}{l}\text { Nonylphenol } \\
\text { monoethoxylate } \\
\text { (NP1EO), bottom } \\
\text { sediment }\end{array}$ & 5 & $500 \mu \mathrm{g} / \mathrm{kg}$ & -- & $<500 \mu \mathrm{g} / \mathrm{kg}$ & -- & -- & -- & -- & -- \\
\hline $\begin{array}{l}\text { Octylphenol } \\
\text { diethoxylate } \\
\text { (OP2EO), dissolved }\end{array}$ & 4 & .19 & -- & -- & -- & -- & -- & $<1$ & $<1$ \\
\hline $\begin{array}{l}\text { Octylphenol } \\
\text { diethoxylate } \\
\text { (OP2EO), whole } \\
\text { water }\end{array}$ & 3 & .14 & $<1$ & $<1$ & $<1$ & $<1$ & $<1$ & $<1$ & $<1$ \\
\hline $\begin{array}{l}\text { Octylphenol } \\
\text { diethoxylate } \\
\text { (OP2EO), bottom } \\
\text { sediment }\end{array}$ & 5 & $100 \mu \mathrm{g} / \mathrm{kg}$ & -- & $<100 \mu \mathrm{g} / \mathrm{kg}$ & -- & -- & -- & -- & -- \\
\hline $\begin{array}{l}\text { Octylphenol } \\
\text { monoethoxylate } \\
\text { (OP1EO), dissolved }\end{array}$ & 4 & .39 & -- & -- & -- & -- & -- & $<1$ & $<1$ \\
\hline
\end{tabular}


Table 18. Analytical results for household, industrial, and minor agricultural use compounds (HIACs) in water and bottom-sediment samples.-Continued

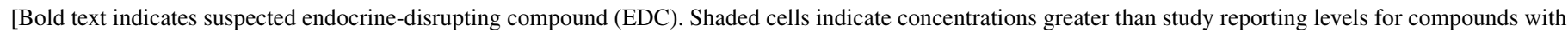

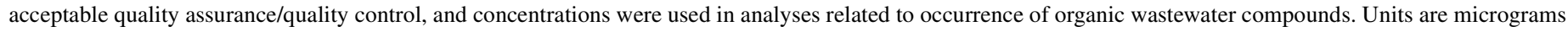

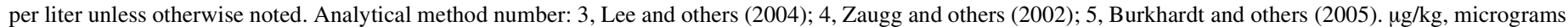
per kilogram; ND, not determined; e, estimated; <, less than; --, no data collected]

\begin{tabular}{|c|c|c|c|c|c|c|c|c|c|}
\hline & \multirow{2}{*}{$\begin{array}{l}\text { Analytical } \\
\text { method } \\
\text { number }\end{array}$} & \multirow{2}{*}{$\begin{array}{c}\text { Study reporting } \\
\text { level } \\
\text { for data } \\
\text { summary and } \\
\text { analysis }\end{array}$} & \multicolumn{7}{|c|}{ Station identification number and name (site label) } \\
\hline & & & \multicolumn{7}{|c|}{$\begin{array}{c}433541096355800 \\
\text { Big Sioux River at Brandon, SD } \\
\text { (site DS2, fig. 1) }\end{array}$} \\
\hline \multicolumn{10}{|c|}{ Compound-Continued } \\
\hline $\begin{array}{l}\text { Octylphenol } \\
\text { monoethoxylate } \\
\text { (OP1EO), whole } \\
\text { water }\end{array}$ & 3 & 5.2 & $<1$ & $<1$ & $<1$ & $\mathrm{e} 0.42$ & $<1$ & $<1$ & $<1$ \\
\hline $\begin{array}{l}\text { Octylphenol } \\
\text { monoethoxylate } \\
\text { (OP1EO), bottom } \\
\text { sediment }\end{array}$ & 5 & $100 \mu \mathrm{g} / \mathrm{kg}$ & -- & $<100 \mu \mathrm{g} / \mathrm{kg}$ & -- & -- & -- & -- & -- \\
\hline para-Cresol, dissolved & 4 & .079 & -- & -- & -- & -- & -- & $<1$ & $<1$ \\
\hline $\begin{array}{l}\text { para-Cresol, whole } \\
\text { water }\end{array}$ & 3 & 1 & $<1$ & $<1$ & $<1$ & $<1$ & $<1$ & $<1$ & $<1$ \\
\hline $\begin{array}{l}\text { para-Cresol, bottom } \\
\text { sediment }\end{array}$ & 5 & $21 \mu \mathrm{g} / \mathrm{kg}$ & -- & e $21 \mu \mathrm{g} / \mathrm{kg}$ & -- & -- & -- & -- & -- \\
\hline $\begin{array}{l}\text { para-Nonylphenol } \\
\text { (NP), dissolved }\end{array}$ & 4 & .83 & -- & -- & -- & -- & -- & $<5$ & $<5$ \\
\hline $\begin{array}{l}\text { para-Nonylphenol } \\
\text { (NP), whole water }\end{array}$ & 3 & .64 & $<5$ & $<5$ & $<5$ & $<5$ & $<5$ & $<5$ & $<5$ \\
\hline $\begin{array}{l}\text { para- Nonylphenol } \\
\text { (NP), bottom } \\
\text { sediment }\end{array}$ & 5 & $500 \mu \mathrm{g} / \mathrm{kg}$ & -- & $<500 \mu \mathrm{g} / \mathrm{kg}$ & -- & -- & -- & -- & -- \\
\hline $\begin{array}{l}\text { Pentachlorophenol, } \\
\text { dissolved }\end{array}$ & 4 & .42 & -- & -- & -- & -- & -- & $<2$ & $<2$ \\
\hline $\begin{array}{l}\text { Pentachlorophenol, } \\
\text { whole water }\end{array}$ & 3 & ND & $<2$ & $<2$ & $<2$ & $<2$ & e3.6 & $<2$ & $<2$ \\
\hline $\begin{array}{l}\text { Pentachlorophenol, } \\
\text { bottom sediment }\end{array}$ & 5 & $200 \mu \mathrm{g} / \mathrm{kg}$ & -- & $<200 \mu \mathrm{g} / \mathrm{kg}$ & -- & -- & -- & -- & -- \\
\hline Phenol, dissolved & 4 & .34 & -- & -- & -- & -- & -- & e. 24 & $<.5$ \\
\hline Phenol, whole water & 3 & .94 & e.63 & e.61 & e. 56 & $<.5$ & e. 28 & $<.5$ & e. 22 \\
\hline $\begin{array}{l}\text { Phenol, bottom } \\
\text { sediment }\end{array}$ & 5 & $19 \mu \mathrm{g} / \mathrm{kg}$ & -- & e $32 \mu \mathrm{g} / \mathrm{kg}$ & -- & -- & -- & -- & -- \\
\hline $\begin{array}{l}\text { Tetrachloroethylene, } \\
\text { dissolved }\end{array}$ & 4 & ND & -- & -- & -- & -- & -- & $<.5$ & $<.5$ \\
\hline $\begin{array}{l}\text { Tetrachloroethylene, } \\
\text { whole water }\end{array}$ & 3 & ND & $<.5$ & $<.5$ & e.069 & $<.5$ & $<.5$ & $<.5$ & $<.5$ \\
\hline $\begin{array}{l}\text { Tetrachloroethylene, } \\
\text { bottom sediment }\end{array}$ & 5 & $50 \mu \mathrm{g} / \mathrm{kg}$ & -- & $<50 \mu \mathrm{g} / \mathrm{kg}$ & -- & -- & -- & -- & -- \\
\hline $\begin{array}{l}\text { Tributyl phosphate, } \\
\text { dissolved }\end{array}$ & 4 & .18 & -- & -- & -- & -- & -- & e. 24 & $<.5$ \\
\hline $\begin{array}{l}\text { Tributyl phosphate, } \\
\text { whole water }\end{array}$ & 3 & .059 & $<.5$ & e. 092 & e. 25 & $<.5$ & e. 63 & e. 12 & $<.5$ \\
\hline
\end{tabular}


Table 18. Analytical results for household, industrial, and minor agricultural use compounds (HIACs) in water and bottom-sediment samples.-Continued

[Bold text indicates suspected endocrine-disrupting compound (EDC). Shaded cells indicate concentrations greater than study reporting levels for compounds with acceptable quality assurance/quality control, and concentrations were used in analyses related to occurrence of organic wastewater compounds. Units are micrograms per liter unless otherwise noted. Analytical method number: 3, Lee and others (2004); 4, Zaugg and others (2002); 5, Burkhardt and others (2005). $\mu \mathrm{g} / \mathrm{kg}$, micrograms per kilogram; ND, not determined; e, estimated; <, less than; --, no data collected]

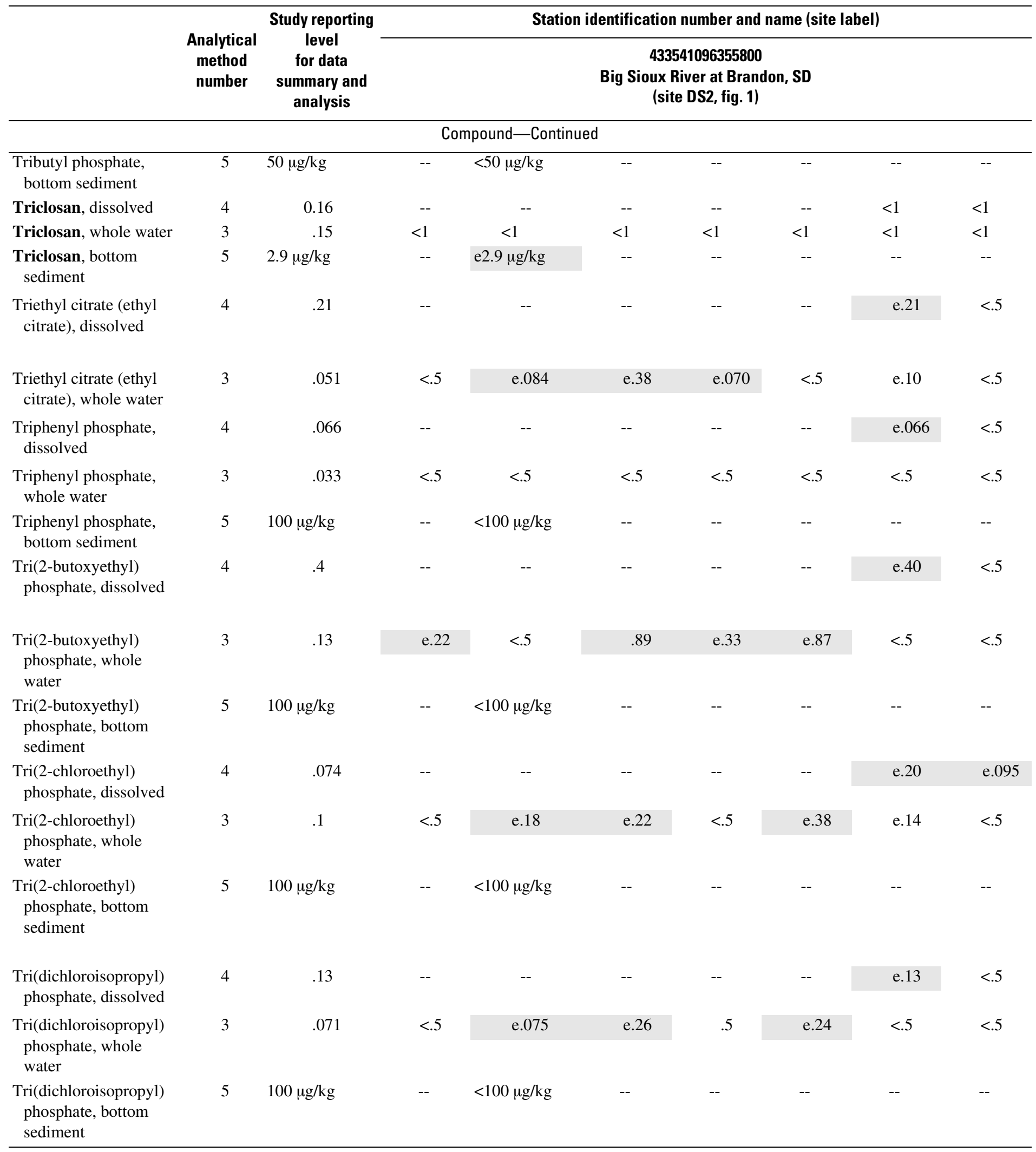

${ }^{1}$ Very high likelihood that detection of compound was due to contamination; value was ignored in analyses and discussion. 
Table 19. Analytical results for polyaromatic hydrocarbons (PAHs) in water and bottom-sediment samples.

[Bold text indicates suspected endocrine-disrupting compound (EDC). Shaded cells indicate concentrations greater than study reporting levels for compounds with acceptable quality assurance/quality control, and concentrations were used in analyses related to occurrence of organic wastewater compounds. Units are micrograms per liter unless otherwise noted. Analytical method number: 3, Lee and others (2004); 4, Zaugg and others (2002); 5, Burkhardt and others (2005). $\mu \mathrm{g} / \mathrm{kg}$, micrograms per kilogram; ND, not determined; e, estimated; <, less than; --, no data collected]

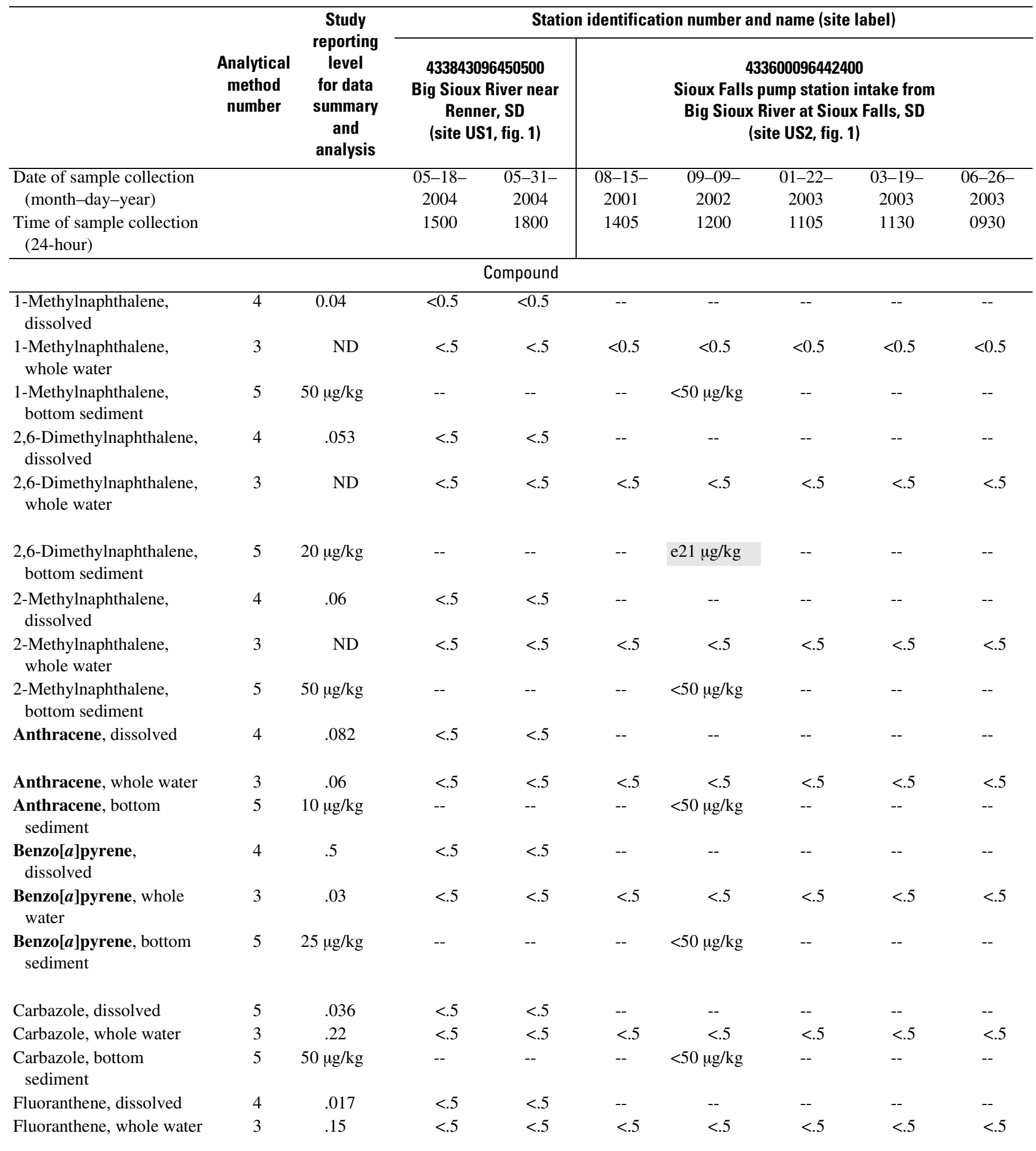


Table 19. Analytical results for polyaromatic hydrocarbons (PAHs) in water and bottom-sediment samples.-Continued

[Bold text indicates suspected endocrine-disrupting compound (EDC). Shaded cells indicate concentrations greater than study reporting levels for compounds with acceptable quality assurance/quality control, and concentrations were used in analyses related to occurrence of organic wastewater compounds. Units are micrograms per liter unless otherwise noted. Analytical method number: 3, Lee and others (2004); 4, Zaugg and others (2002); 5, Burkhardt and others (2005). $\mu \mathrm{g} / \mathrm{kg}$, micrograms per kilogram;; ND, not determined; e, estimated; <, less than; --, no data collected]

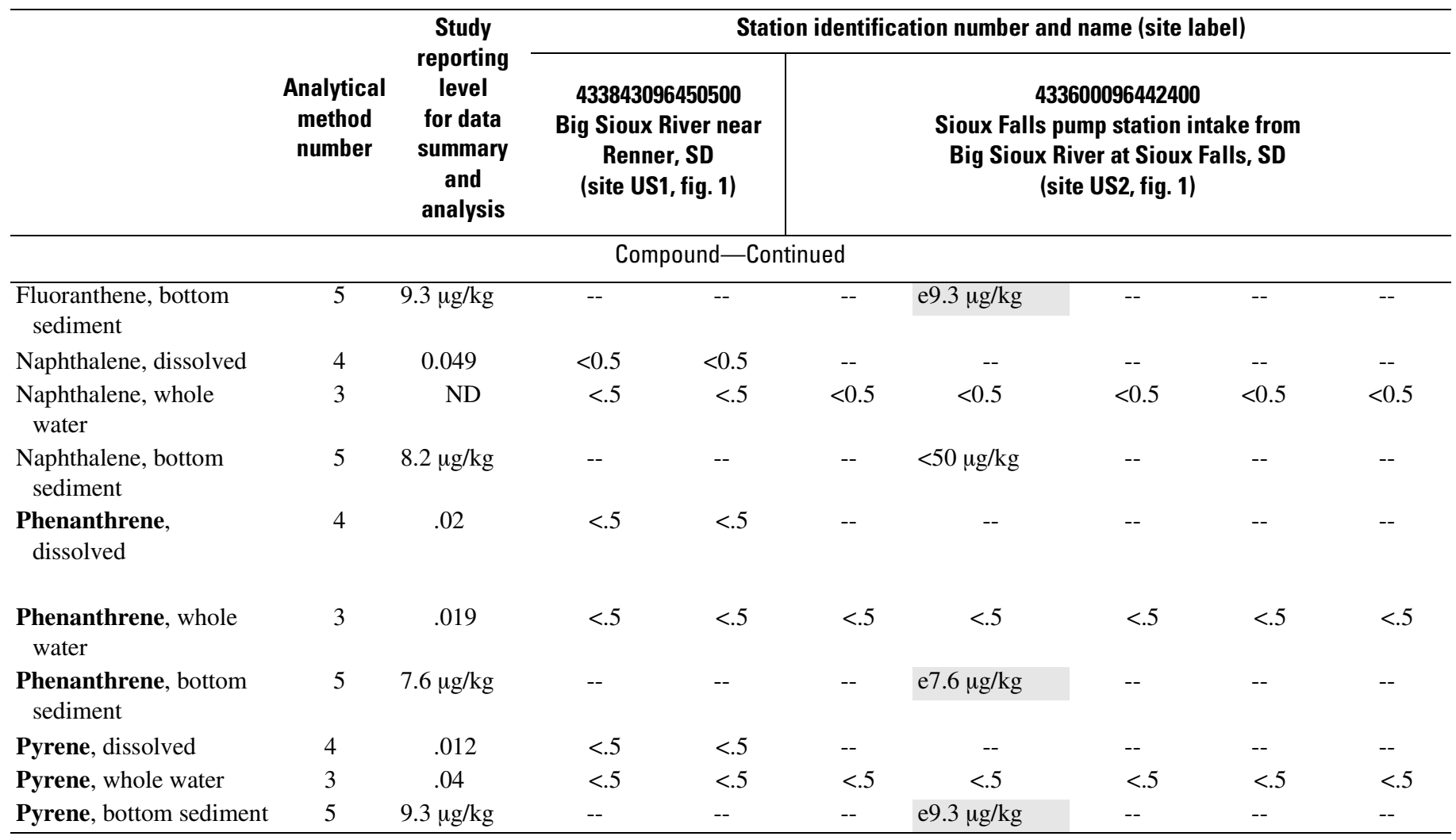


Table 19. Analytical results for polyaromatic hydrocarbons (PAHs) in water and bottom-sediment samples.-Continued

[Bold text indicates suspected endocrine-disrupting compound (EDC). Shaded cells indicate concentrations greater than study reporting levels for compounds with acceptable quality assurance/quality control, and concentrations were used in analyses related to occurrence of organic wastewater compounds. Units are micrograms per liter unless otherwise noted. Analytical method number: 3, Lee and others (2004); 4, Zaugg and others (2002); 5, Burkhardt and others (2005). $\mu \mathrm{g} / \mathrm{kg}$, micrograms per kilogram; ND, not determined; e, estimated; <, less than; --, no data collected]

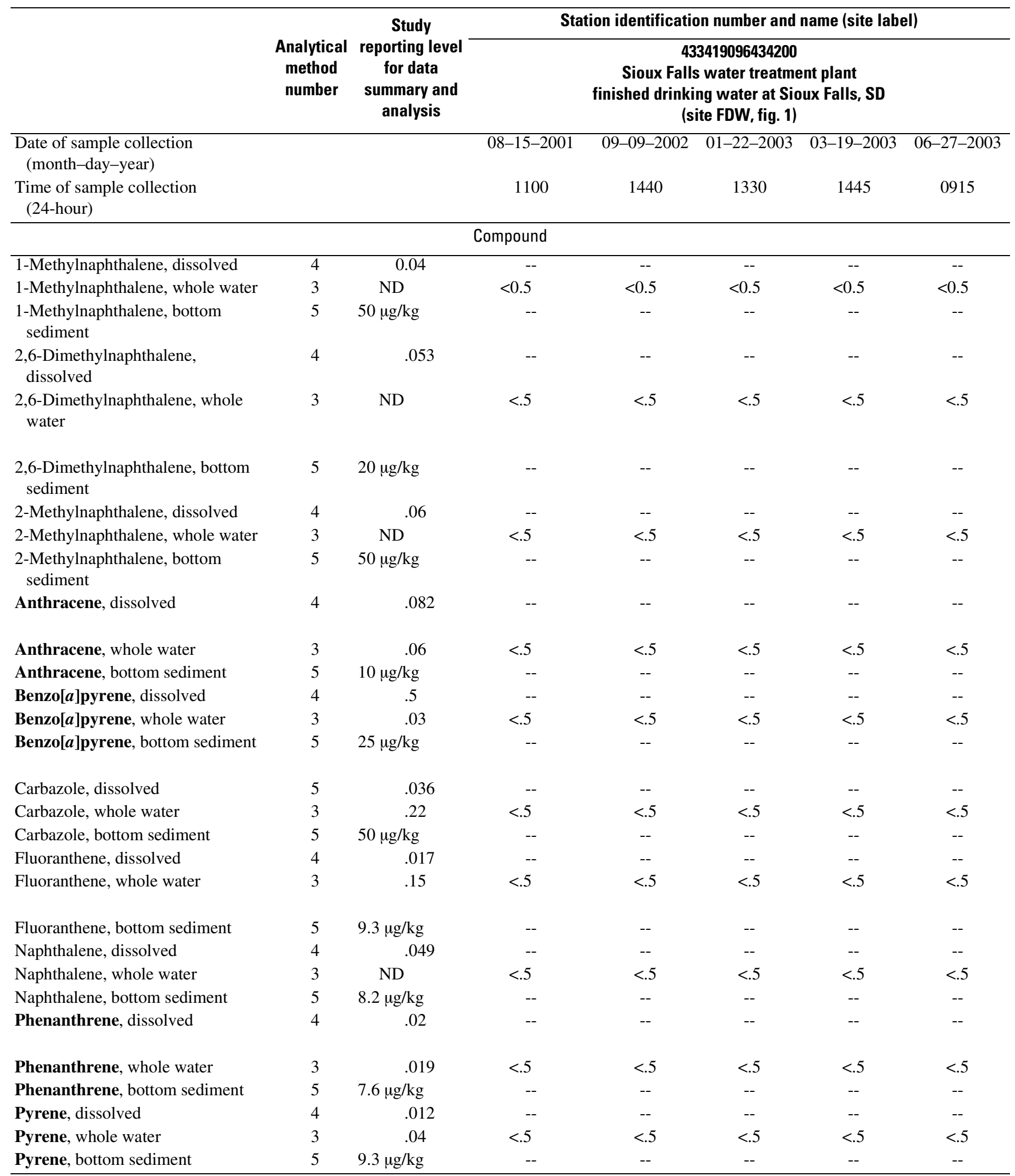


Table 19. Analytical results for polyaromatic hydrocarbons (PAHs) in water and bottom-sediment samples.—Continued

[Bold text indicates suspected endocrine-disrupting compound (EDC). Shaded cells indicate concentrations greater than study reporting levels for compounds with acceptable quality assurance/quality control, and concentrations were used in analyses related to occurrence of organic wastewater compounds. Units are micrograms per liter. unless otherwise noted. Analytical method number: 3, Lee and others (2004); 4, Zaugg and others (2002); 5, Burkhardt and others (2005). $\mu \mathrm{g} / \mathrm{kg}$, micrograms per kilogram; ND, not determined; e, estimated; <, less than; --, no data collected]

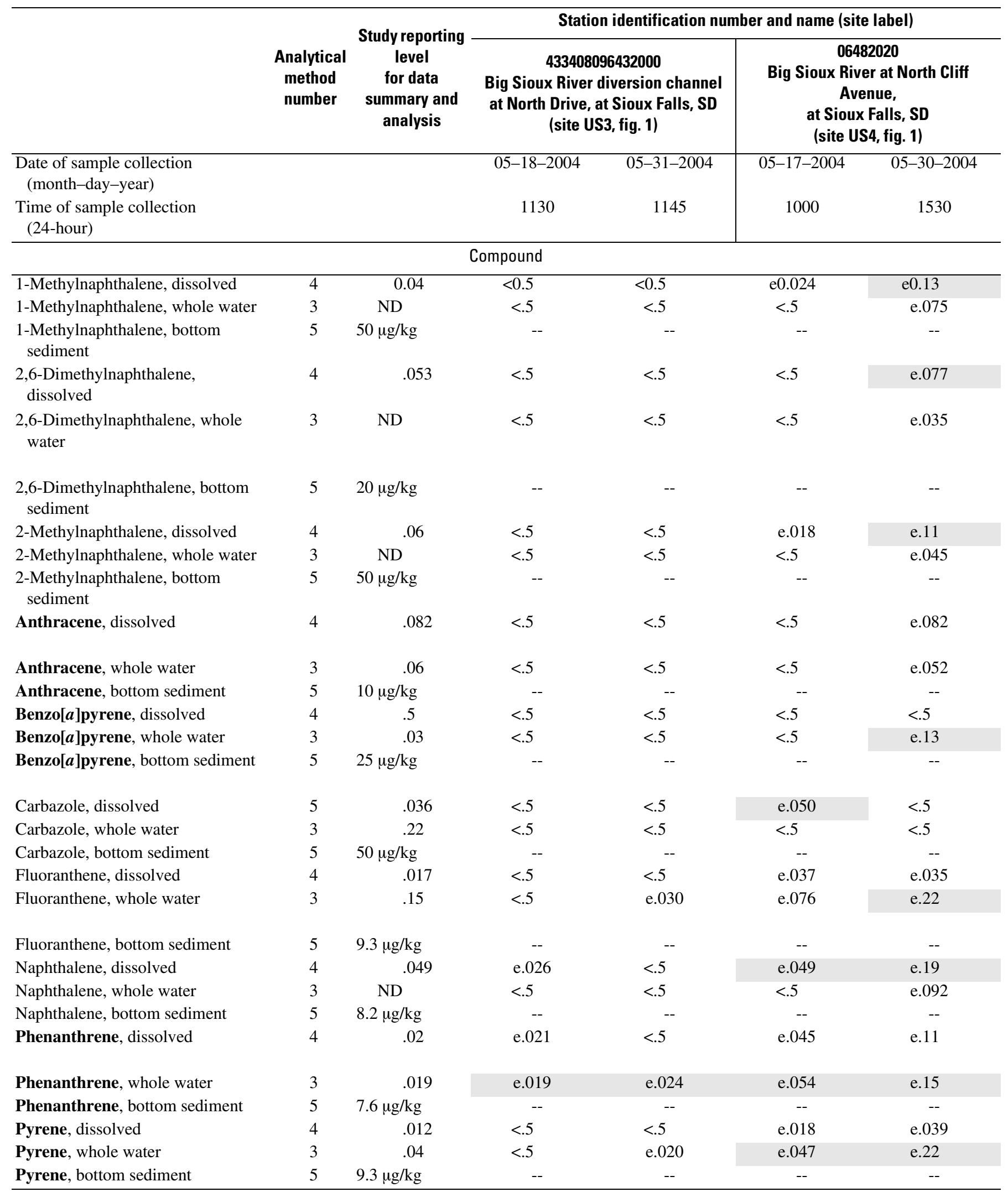


Table 19. Analytical results for polyaromatic hydrocarbons (PAHs) in water and bottom-sediment samples.-Continued

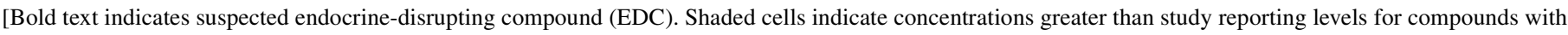
acceptable quality assurance/quality control, and concentrations were used in analyses related to occurrence of organic wastewater compounds. Units are micrograms per liter. unless otherwise noted. Analytical method number: 3, Lee and others (2004); 4, Zaugg and others (2002); 5, Burkhardt and others (2005). $\mu \mathrm{g} / \mathrm{kg}$, micrograms per kilogram; ND, not determined; e, estimated; <, less than; --, no data collected]

\begin{tabular}{|c|c|c|c|c|c|c|c|c|}
\hline & \multirow[b]{2}{*}{$\begin{array}{c}\text { Analytical } \\
\text { method } \\
\text { number }\end{array}$} & \multirow{2}{*}{$\begin{array}{c}\text { Study reporting } \\
\text { level } \\
\text { for data } \\
\text { summary and } \\
\text { analysis }\end{array}$} & \multicolumn{6}{|c|}{ Station identification number and name (site label) } \\
\hline & & & \multicolumn{6}{|c|}{$\begin{array}{c}433531096394200 \\
\text { Sioux Falls wastewater treatment plant effluent } \\
\text { (site WWE, fig. 1) }\end{array}$} \\
\hline $\begin{array}{l}\text { Date of sample collection } \\
\text { (month-day-year) }\end{array}$ & & & $\begin{array}{c}09-10- \\
2002\end{array}$ & $\begin{array}{c}01-24- \\
2003\end{array}$ & $\begin{array}{c}03-21- \\
2003\end{array}$ & $\begin{array}{c}06-26- \\
2003\end{array}$ & $\begin{array}{c}05-18- \\
2004\end{array}$ & $\begin{array}{c}05-30- \\
2004\end{array}$ \\
\hline Time of sample collection (24-hour) & & & 1400 & 0930 & 1045 & 1135 & 1020 & 2020 \\
\hline \multicolumn{9}{|c|}{ Compound } \\
\hline 1-Methylnaphthalene, dissolved & 4 & 0.04 & -- & -- & -- & -- & $<0.5$ & $<0.5$ \\
\hline 1-Methylnaphthalene, whole water & 3 & ND & $<0.5$ & $<0.5$ & $<0.5$ & $<0.5$ & $<.5$ & $<.5$ \\
\hline $\begin{array}{l}\text { 1-Methylnaphthalene, bottom } \\
\text { sediment }\end{array}$ & 5 & $50 \mu \mathrm{g} / \mathrm{kg}$ & -- & -- & -- & -- & -- & -- \\
\hline 2,6-Dimethylnaphthalene, dissolved & 4 & .053 & -- & -- & -- & -- & $<.5$ & $<.5$ \\
\hline $\begin{array}{l}\text { 2,6-Dimethylnaphthalene, whole } \\
\text { water }\end{array}$ & 3 & ND & $<.5$ & $<.5$ & $<.5$ & $<.5$ & $<.5$ & $<.5$ \\
\hline $\begin{array}{l}\text { 2,6-Dimethylnaphthalene, bottom } \\
\text { sediment }\end{array}$ & 5 & $20 \mu \mathrm{g} / \mathrm{kg}$ & -- & -- & -- & -- & -- & -- \\
\hline 2-Methylnaphthalene, dissolved & 4 & .06 & -- & -- & -- & -- & $<.5$ & $<.5$ \\
\hline 2-Methylnaphthalene, whole water & 3 & ND & $<.5$ & $<.5$ & $<.5$ & $<.5$ & $<.5$ & $<.5$ \\
\hline $\begin{array}{l}\text { 2-Methylnaphthalene, bottom } \\
\text { sediment }\end{array}$ & 5 & $50 \mu \mathrm{g} / \mathrm{kg}$ & -- & -- & -- & -- & -- & -- \\
\hline Anthracene, dissolved & 4 & .082 & -- & -- & -- & -- & $<.5$ & $<.5$ \\
\hline Anthracene, whole water & 3 & .06 & $<.5$ & $<.5$ & $<.5$ & $<.5$ & $<.5$ & $<.5$ \\
\hline Anthracene, bottom sediment & 5 & $10 \mu \mathrm{g} / \mathrm{kg}$ & -- & -- & -- & -- & -- & -- \\
\hline Benzo $[a]$ pyrene, dissolved & 4 & .5 & -- & -- & -- & -- & $<.5$ & $<.5$ \\
\hline Benzo $[a]$ pyrene, whole water & 3 & .03 & $<.5$ & $<.5$ & $<.5$ & $<.5$ & $<.5$ & $<.5$ \\
\hline Benzo $[a]$ pyrene, bottom sediment & 5 & $25 \mu \mathrm{g} / \mathrm{kg}$ & -- & -- & -- & -- & -- & -- \\
\hline Carbazole, dissolved & 5 & .036 & -- & -- & -- & -- & $<.5$ & $<.5$ \\
\hline Carbazole, whole water & 3 & .22 & $<.5$ & $<.5$ & $<.5$ & $<.5$ & $<.5$ & $<.5$ \\
\hline Carbazole, bottom sediment & 5 & $50 \mu \mathrm{g} / \mathrm{kg}$ & -- & -- & -- & -- & -- & -- \\
\hline Fluoranthene, dissolved & 4 & .017 & -- & -- & -- & -- & $<.5$ & $<.5$ \\
\hline Fluoranthene, whole water & 3 & .15 & $<.5$ & $<.5$ & $<.5$ & $<.5$ & $<.5$ & e. 14 \\
\hline Fluoranthene, bottom sediment & 5 & $9.3 \mu \mathrm{g} / \mathrm{kg}$ & -- & -- & -- & -- & -- & -- \\
\hline Naphthalene, dissolved & 4 & .049 & -- & -- & -- & -- & $<.5$ & $<.5$ \\
\hline Naphthalene, whole water & 3 & ND & $<.5$ & $<.5$ & $<.5$ & $<.5$ & $<.5$ & $<.5$ \\
\hline Naphthalene, bottom sediment & 5 & $8.2 \mu \mathrm{g} / \mathrm{kg}$ & -- & -- & -- & -- & -- & -- \\
\hline Phenanthrene, dissolved & 4 & .02 & -- & -- & -- & -- & $<.5$ & $<.5$ \\
\hline Phenanthrene, whole water & 3 & .019 & $<.5$ & $<.5$ & $<.5$ & $<.5$ & $<.5$ & $<.5$ \\
\hline Phenanthrene, bottom sediment & 5 & $7.6 \mu \mathrm{g} / \mathrm{kg}$ & -- & -- & -- & -- & -- & -- \\
\hline Pyrene, dissolved & 4 & .012 & -- & -- & -- & -- & $<.5$ & $<.5$ \\
\hline Pyrene, whole water & 3 & .04 & $<.5$ & $<.5$ & $<.5$ & $<.5$ & e.018 & $<.5$ \\
\hline Pyrene, bottom sediment & 5 & $9.3 \mu \mathrm{g} / \mathrm{kg}$ & -- & -- & -- & -- & -- & -- \\
\hline
\end{tabular}


Table 19. Analytical results for polyaromatic hydrocarbons (PAHs) in water and bottom-sediment samples. - Continued

[Bold text indicates suspected endocrine-disrupting compound (EDC). Shaded cells indicate concentrations greater than study reporting levels for compounds with acceptable quality assurance/quality control, and concentrations were used in analyses related to occurrence of organic wastewater compounds. Units are micrograms per liter unless otherwise noted. Analytical method number: 3, Lee and others (2004); 4, Zaugg and others (2002); 5, Burkhardt and others (2005). $\mu \mathrm{g} / \mathrm{kg}$, micrograms per kilogram; ND, not determined; e, estimated; <, less than; --, no data collected]

\section{Analytical Study reporting level method number}

Station identification number and name (site label)

433559096390700

Big Sioux River downstream from

Sioux Falls wastewater discharge (site DS1, fig. 1)

\begin{tabular}{|c|c|c|c|}
\hline $\begin{array}{l}\text { Date of sample collection } \\
\text { (month-day-year) }\end{array}$ & 09-10-2002 & $05-17-2004$ & $05-30-2004$ \\
\hline $\begin{array}{l}\text { Time of sample collection } \\
\text { (24-hour) }\end{array}$ & 1030 & 1100 & 1630 \\
\hline
\end{tabular}

\begin{tabular}{|c|c|c|c|c|c|}
\hline \multicolumn{6}{|c|}{ Compound } \\
\hline 1-Methylnaphthalene, dissolved & 4 & 0.04 & -- & $\mathrm{e} 0.024$ & $\mathrm{e} 0.11$ \\
\hline 1-Methylnaphthalene, whole water & 3 & ND & $<0.5$ & $<.5$ & e.072 \\
\hline $\begin{array}{l}\text { 1-Methylnaphthalene, bottom } \\
\text { sediment }\end{array}$ & 5 & $50 \mu \mathrm{g} / \mathrm{kg}$ & $<50 \mu \mathrm{g} / \mathrm{kg}$ & -- & -- \\
\hline $\begin{array}{l}\text { 2,6-Dimethylnaphthalene, } \\
\text { dissolved }\end{array}$ & 4 & .053 & -- & $<.5$ & e. 053 \\
\hline $\begin{array}{l}\text { 2,6-Dimethylnaphthalene, whole } \\
\text { water }\end{array}$ & 3 & ND & $<.5$ & $<.5$ & $<.5$ \\
\hline $\begin{array}{l}\text { 2,6-Dimethylnaphthalene, bottom } \\
\text { sediment }\end{array}$ & 5 & $20 \mu \mathrm{g} / \mathrm{kg}$ & $\mathrm{e} 36 \mu \mathrm{g} / \mathrm{kg}$ & -- & -- \\
\hline 2-Methylnaphthalene, dissolved & 4 & .06 & -- & e.029 & e.077 \\
\hline 2-Methylnaphthalene, whole water & 3 & ND & $<.5$ & $<.5$ & e.041 \\
\hline $\begin{array}{l}\text { 2-Methylnaphthalene, bottom } \\
\text { sediment }\end{array}$ & 5 & $50 \mu \mathrm{g} / \mathrm{kg}$ & $<50 \mu \mathrm{g} / \mathrm{kg}$ & -- & -- \\
\hline Anthracene, dissolved & 4 & .082 & -- & $<.5$ & $<.5$ \\
\hline Anthracene, whole water & 3 & .06 & $<.5$ & $<.5$ & $<.5$ \\
\hline Anthracene, bottom sediment & 5 & $10 \mu \mathrm{g} / \mathrm{kg}$ & e11 $\mu \mathrm{g} / \mathrm{kg}$ & -- & -- \\
\hline Benzo $[a]$ pyrene, dissolved & 4 & .5 & -- & $<.5$ & $<.5$ \\
\hline $\operatorname{Benzo}[a]$ pyrene, whole water & 3 & .03 & $<.5$ & $<.5$ & $<.5$ \\
\hline Benzo $[a]$ pyrene, bottom sediment & 5 & $25 \mu \mathrm{g} / \mathrm{kg}$ & e26 $\mu \mathrm{g} / \mathrm{kg}$ & -- & -- \\
\hline Carbazole, dissolved & 5 & .036 & -- & e.037 & $<.5$ \\
\hline Carbazole, whole water & 3 & .22 & $<.5$ & $<.5$ & $<.5$ \\
\hline Carbazole, bottom sediment & 5 & $50 \mu \mathrm{g} / \mathrm{kg}$ & $<50 \mu \mathrm{g} / \mathrm{kg}$ & -- & -- \\
\hline Fluoranthene, dissolved & 4 & .017 & -- & e.026 & e.030 \\
\hline Fluoranthene, whole water & 3 & .15 & $<.5$ & e. 087 & e. 10 \\
\hline Fluoranthene, bottom sediment & 5 & $9.3 \mu \mathrm{g} / \mathrm{kg}$ & e31 $\mu \mathrm{g} / \mathrm{kg}$ & -- & -- \\
\hline Naphthalene, dissolved & 4 & .049 & -- & e. 060 & e.16 \\
\hline Naphthalene, whole water & 3 & ND & $<.5$ & $<.5$ & e.093 \\
\hline Naphthalene, bottom sediment & 5 & $8.2 \mu \mathrm{g} / \mathrm{kg}$ & e $12 \mu \mathrm{g} / \mathrm{kg}$ & -- & -- \\
\hline Phenanthrene, dissolved & 4 & .02 & -- & e. 032 & e. 076 \\
\hline Phenanthrene, whole water & 3 & .019 & $<.5$ & e. 052 & e. 12 \\
\hline Phenanthrene, bottom sediment & 5 & $7.6 \mu \mathrm{g} / \mathrm{kg}$ & $\mathrm{e} 38 \mu \mathrm{g} / \mathrm{kg}$ & -- & -- \\
\hline Pyrene, dissolved & 4 & .012 & -- & e.020 & e.027 \\
\hline Pyrene, whole water & 3 & .04 & $<.5$ & e. 067 & e. 086 \\
\hline Pyrene, bottom sediment & 5 & $9.3 \mu \mathrm{g} / \mathrm{kg}$ & e $22 \mu \mathrm{g} / \mathrm{kg}$ & -- & -- \\
\hline
\end{tabular}


Table 19. Analytical results for polyaromatic hydrocarbons (PAHs) in water and bottom-sediment samples.-Continued

[Bold text indicates suspected endocrine-disrupting compound (EDC). Shaded cells indicate concentrations greater than study reporting levels for compounds with acceptable quality assurance/quality control, and concentrations were used in analyses related to occurrence of organic wastewater compounds. Units are micrograms per liter unless otherwise noted. Analytical method number: 3, Lee and others (2004); 4, Zaugg and others (2002); 5, Burkhardt and others (2005). $\mu \mathrm{g} / \mathrm{kg}$, micrograms per kilogram; ND, not determined; e, estimated; <, less than; --, no data collected]

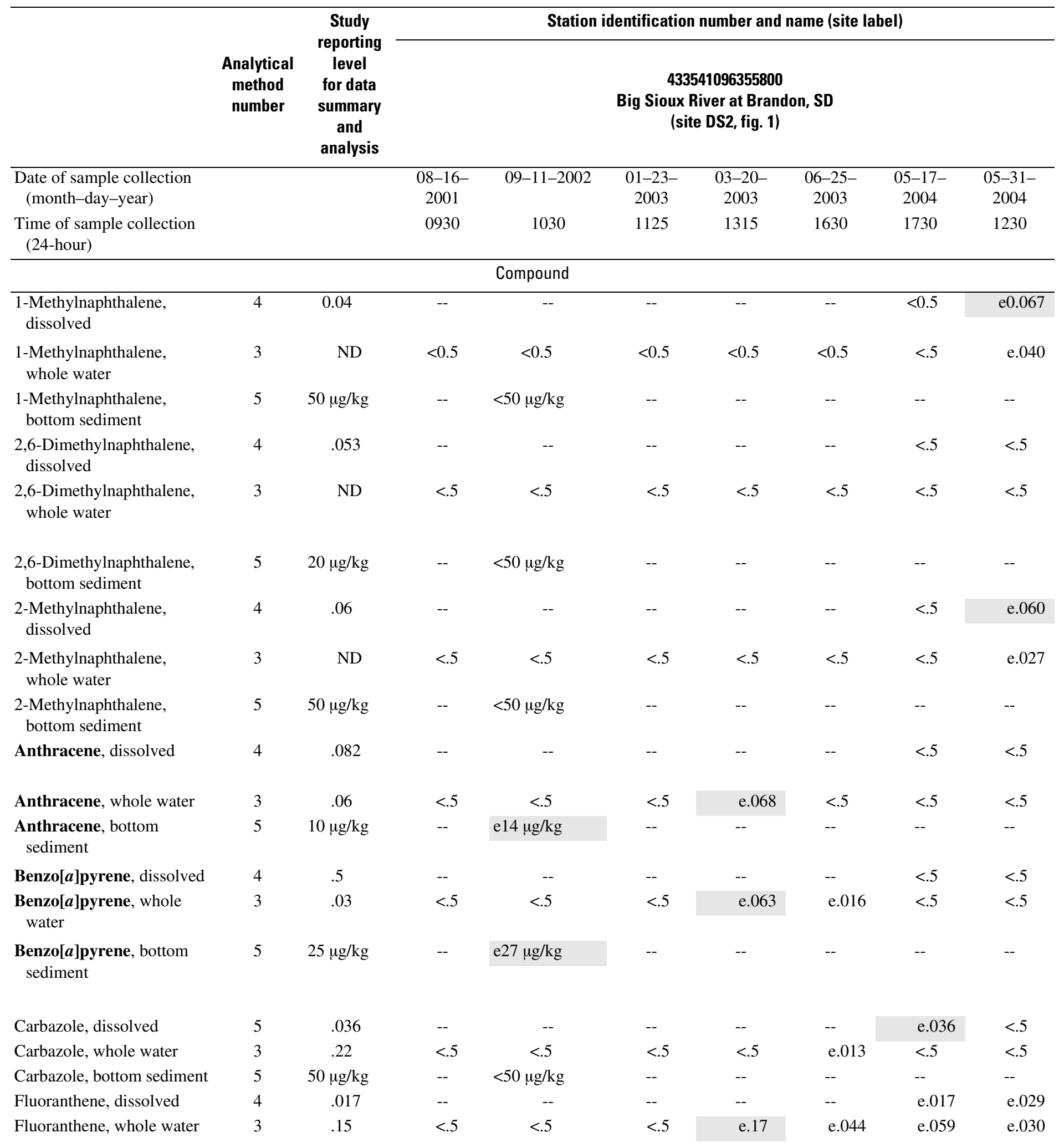


Table 19. Analytical results for polyaromatic hydrocarbons (PAHs) in water and bottom-sediment samples. - Continued

[Bold text indicates suspected endocrine-disrupting compound (EDC). Shaded cells indicate concentrations greater than study reporting levels for compounds with acceptable quality assurance/quality control, and concentrations were used in analyses related to occurrence of organic wastewater compounds. Units are micrograms per liter unless otherwise noted. Analytical method number: 3, Lee and others (2004); 4, Zaugg and others (2002); 5, Burkhardt and others (2005). $\mu \mathrm{g} / \mathrm{kg}$, micrograms per kilogram; ND, not determined; e, estimated; <, less than; --, no data collected]

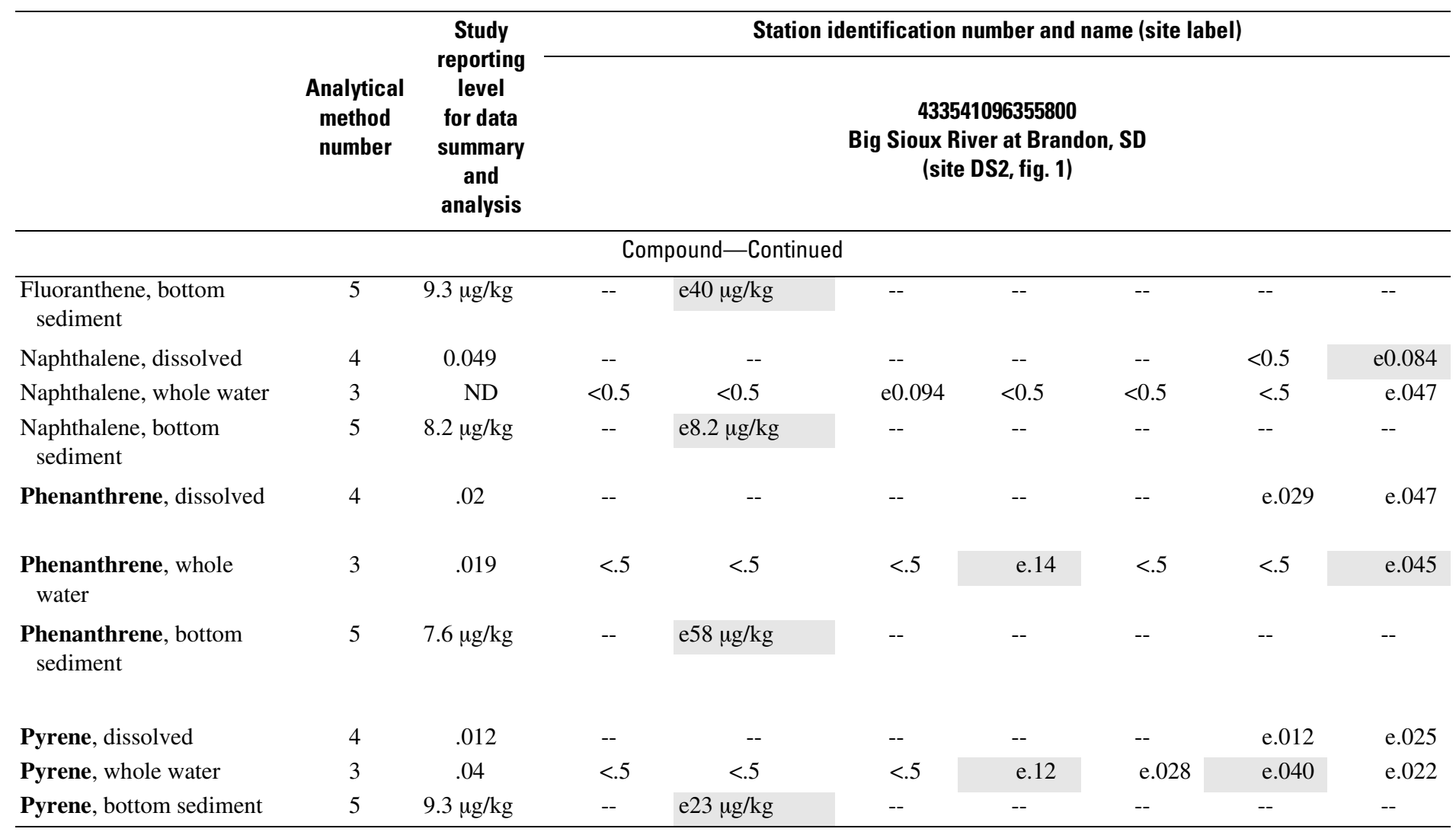


Table 20. Analytical results for sterol compounds (SCs) in water and bottom-sediment samples.

[Shaded cells indicate concentrations greater than study reporting levels for compounds with acceptable quality assurance/quality control, and concentrations were used in analyses related to occurrence of organic wastewater compounds. Units are micrograms per liter unless otherwise noted. Analytical method number: 3 , Lee and others (2004); 4, Zaugg and others (2002); 5, Burkhardt and others (2005). $\mu \mathrm{g} / \mathrm{kg}$, micrograms per kilogram; ND, not determined; e, estimated; <, less than; ,-- no data collected]

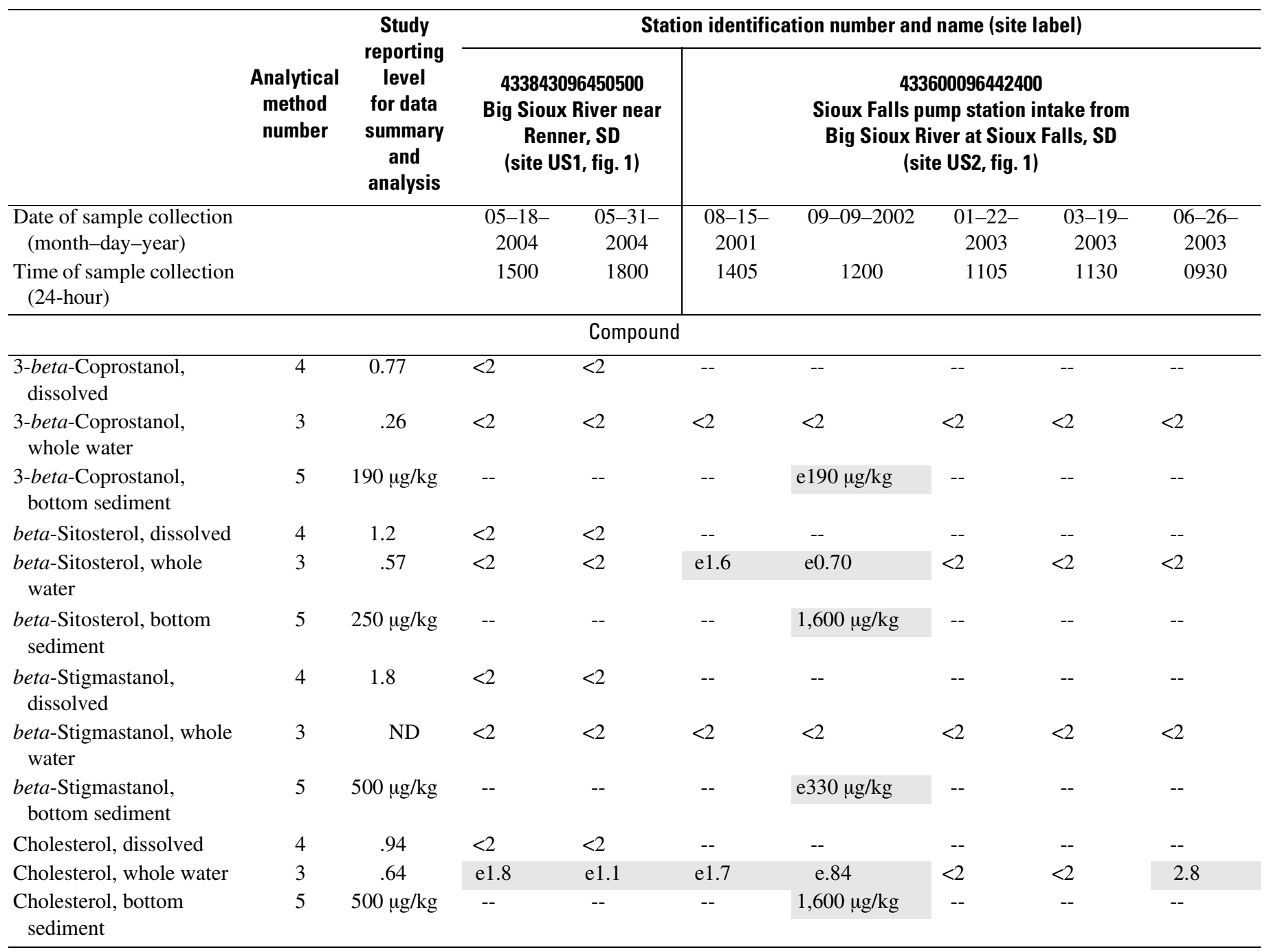


Table 20. Analytical results for sterol compounds (SCs) in water and bottom-sediment samples._- Continued

[Shaded cells indicate concentrations greater than study reporting levels for compounds with acceptable quality assurance/quality control, and concentrations were used in analyses related to occurrence of organic wastewater compounds. Units are micrograms per liter unless otherwise noted. Analytical method number: 3 , Lee and others (2004); 4, Zaugg and others (2002); 5, Burkhardt and others (2005). $\mu \mathrm{g} / \mathrm{kg}$, micrograms per kilogram; ND, not determined; e, estimated; <, less than; -- , no data collected]

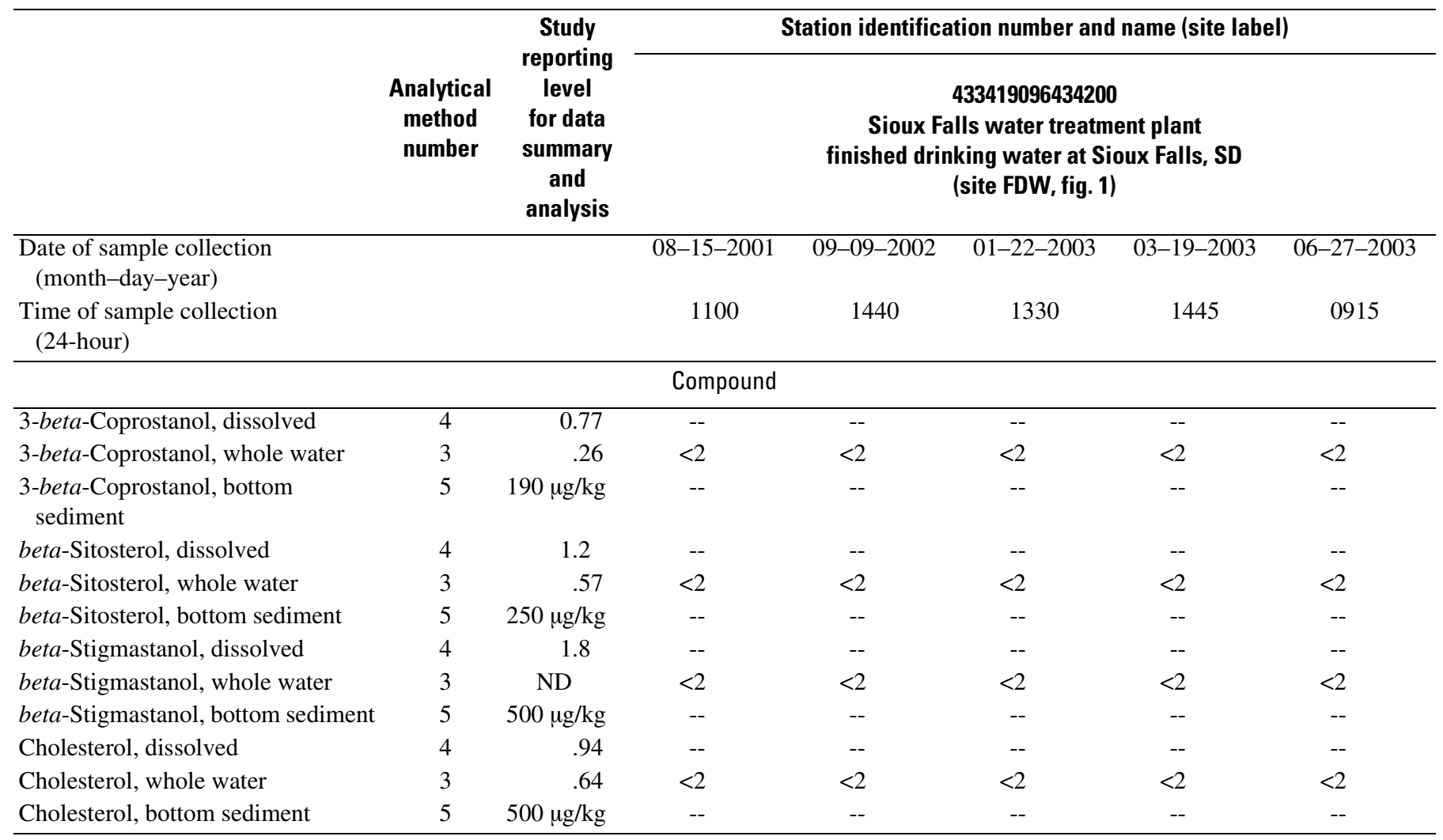

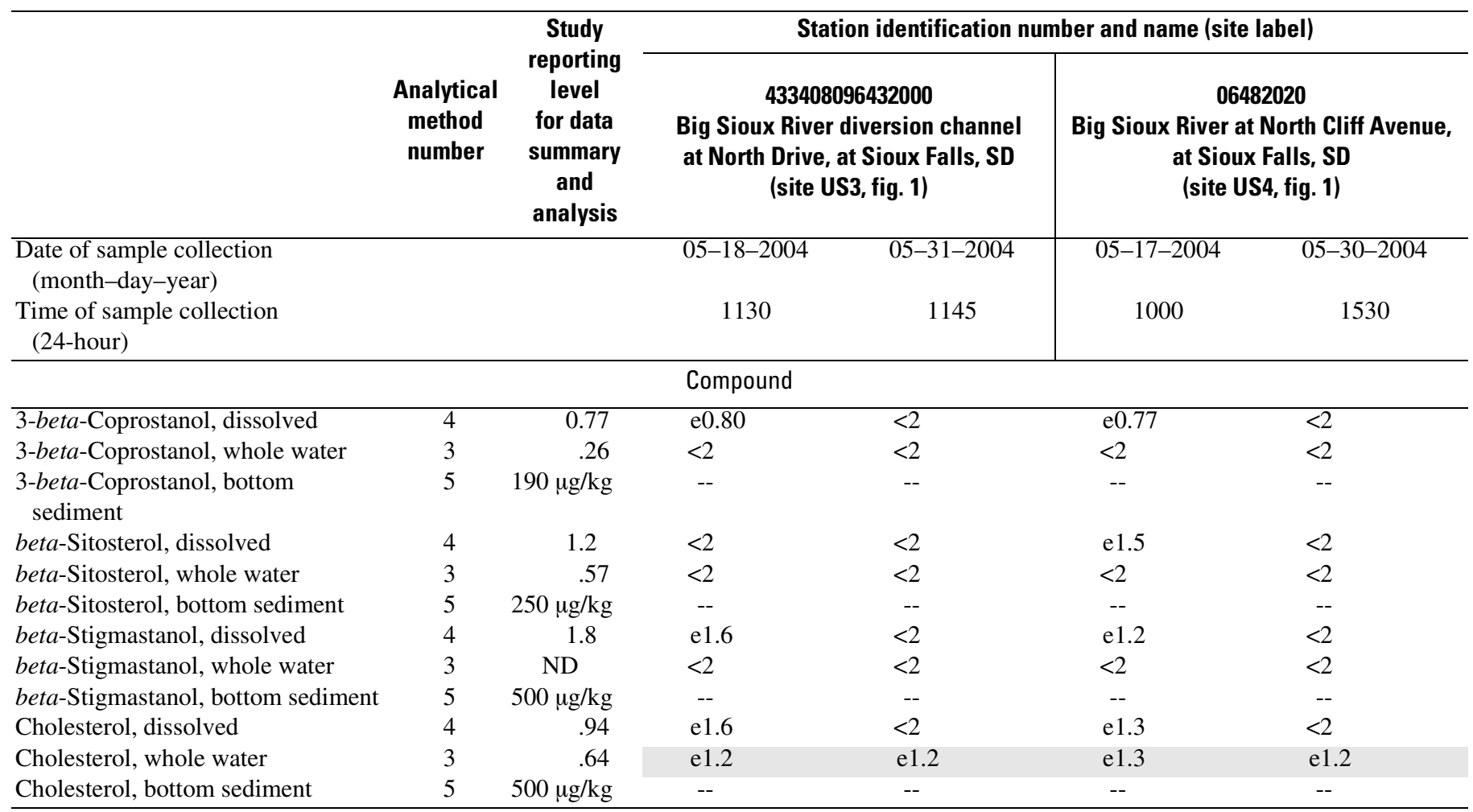


Table 20. Analytical results for sterol compounds (SCs) in water and bottom-sediment samples.—Continued

[Shaded cells indicate concentrations greater than study reporting levels for compounds with acceptable quality assurance/quality control, and concentrations were used in analyses related to occurrence of organic wastewater compounds. Units are micrograms per liter unless otherwise noted. Analytical method number: 3 , Lee and others (2004); 4, Zaugg and others (2002); 5, Burkhardt and others (2005). $\mu \mathrm{g} / \mathrm{kg}$, micrograms per kilogram; ND, not determined; e, estimated; <, less than;

,-- no data collected]

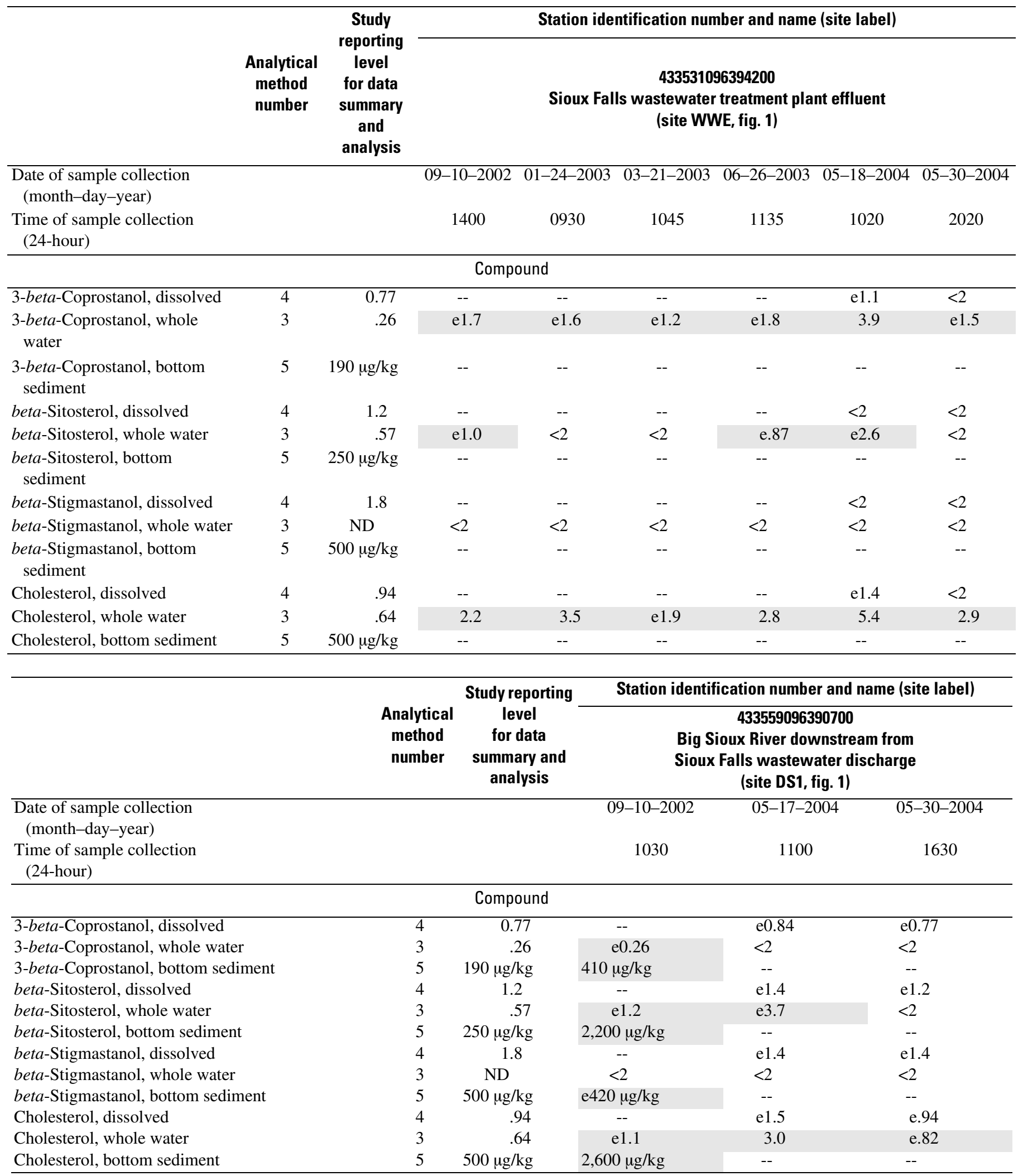


Table 20. Analytical results for sterol compounds (SCs) in water and bottom-sediment samples.-Continued

[Shaded cells indicate concentrations greater than study reporting levels for compounds with acceptable quality assurance/quality control, and concentrations were used in analyses related to occurrence of organic wastewater compounds. Units are micrograms per liter unless otherwise noted. Analytical method number: 3 , Lee and others (2004); 4, Zaugg and others (2002); 5, Burkhardt and others (2005). $\mu \mathrm{g} / \mathrm{kg}$, micrograms per kilogram; ND, not determined; e, estimated; <, less than; -- , no data collected]

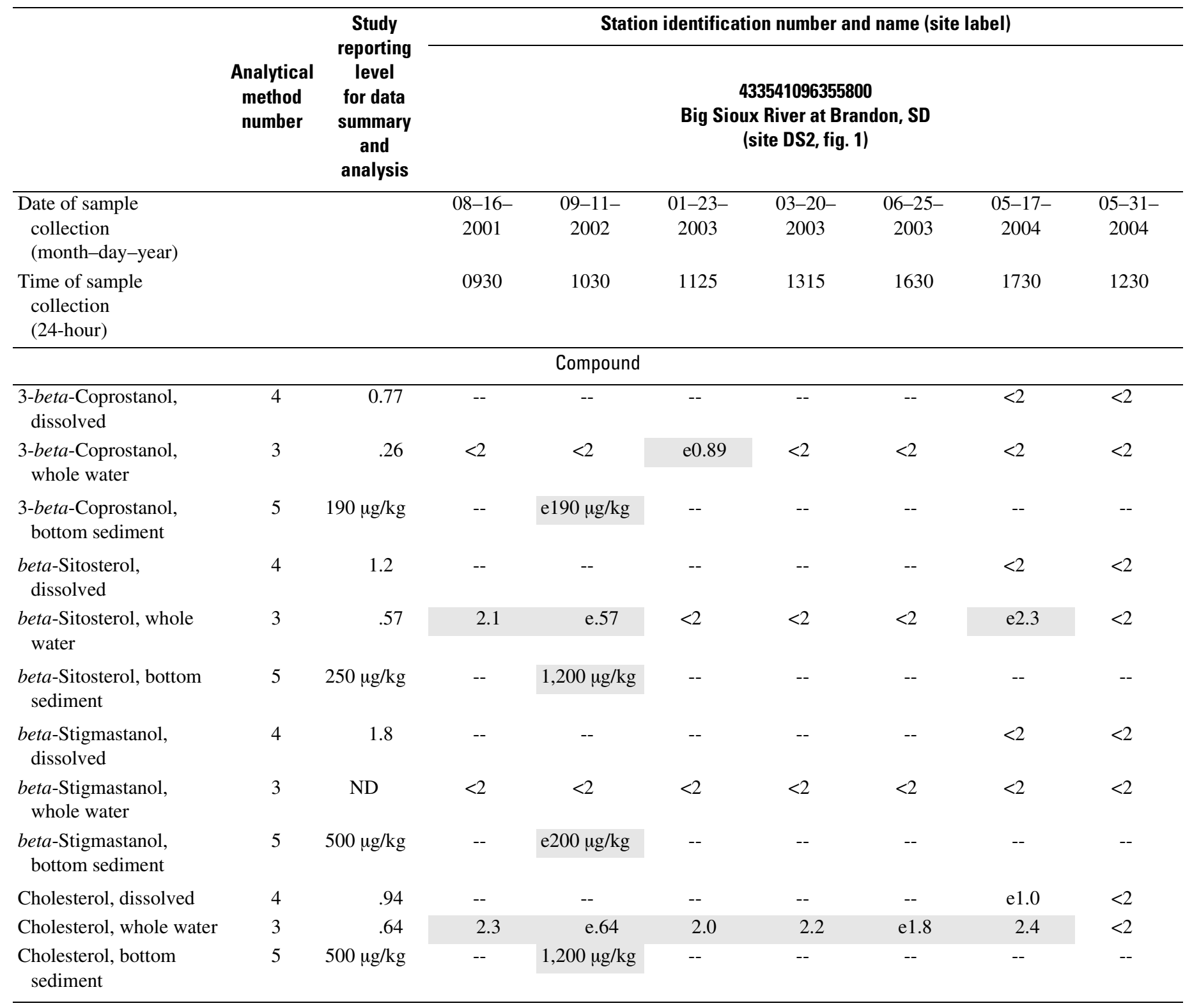


Table 21. Statistical summaries of analytical results and load results for organic wastewater compounds in water samples.

[Units are micrograms per liter unless otherwise noted. --, not detected or not applicable]

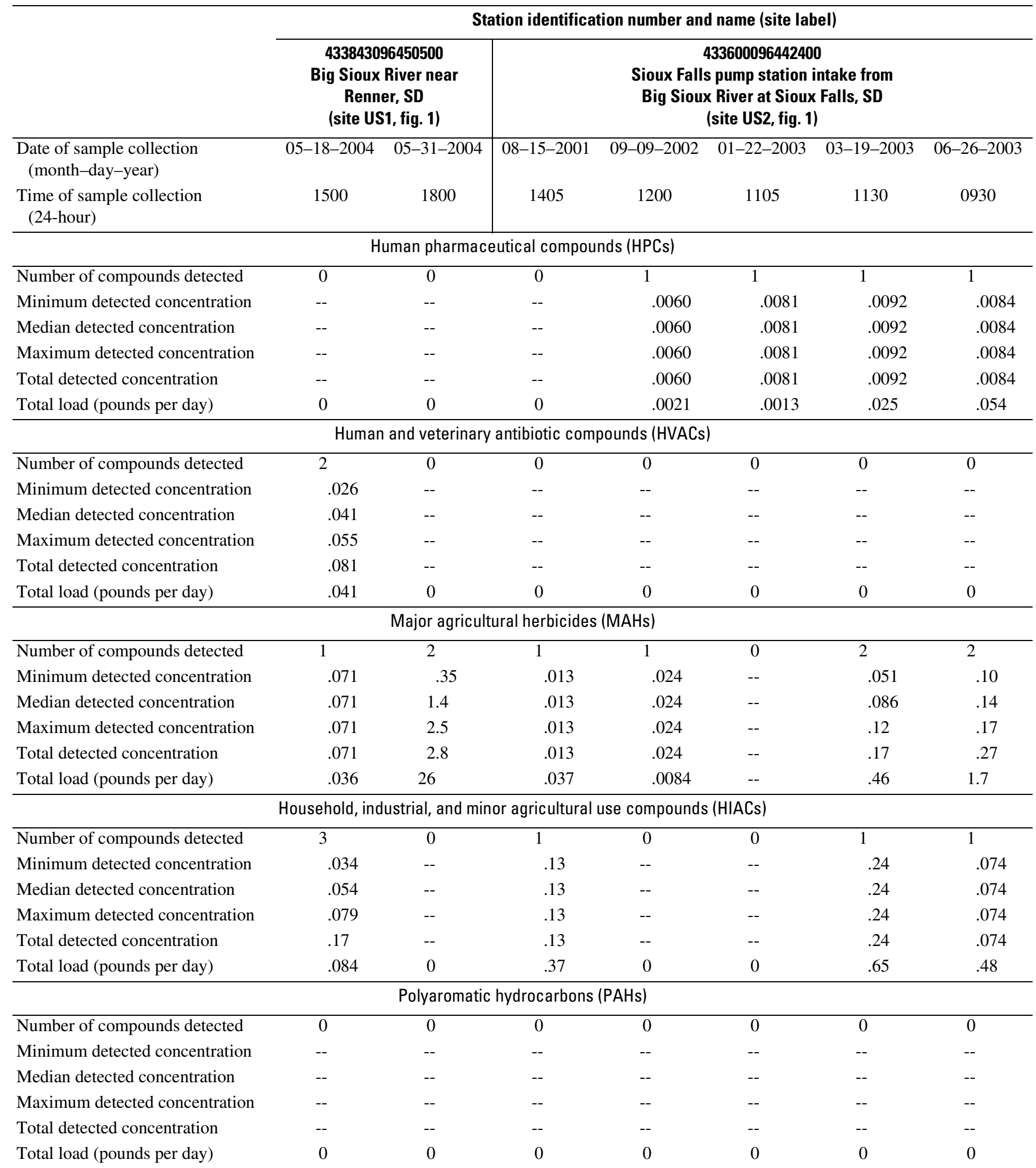


Table 21. Statistical summaries of analytical results and load results for organic wastewater compounds in water samples.-Continued [Units are micrograms per liter unless otherwise noted. --, not detected or not applicable]

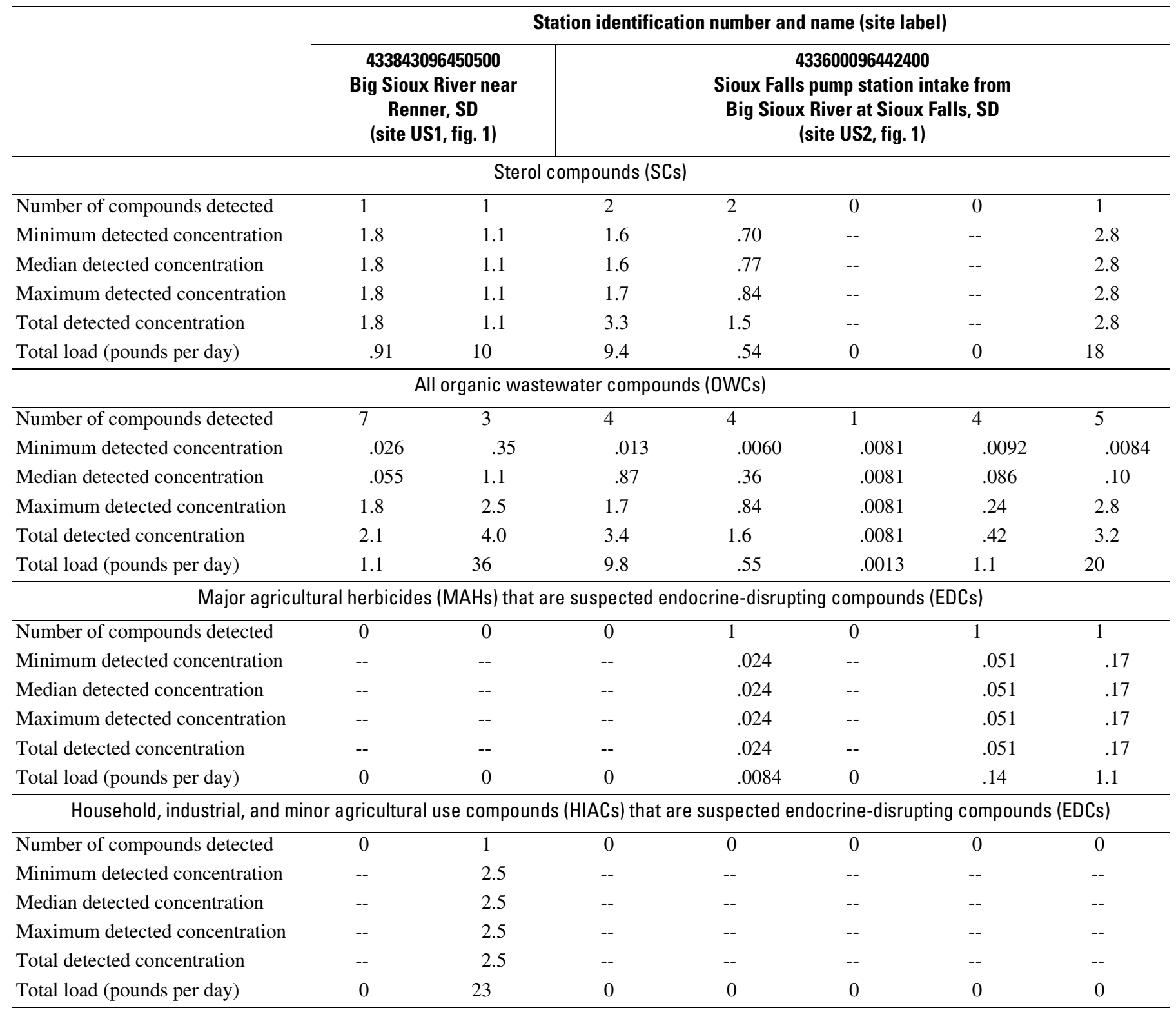

Polyaromatic hydrocarbons (PAHs) that are suspected endocrine-disrupting compounds (EDCs)

\begin{tabular}{|c|c|c|c|c|c|c|c|}
\hline Number of compounds detected & 0 & 0 & 0 & 0 & 0 & 0 & 0 \\
\hline Minimum detected concentration & -- & -- & -- & -- & -- & -- & -- \\
\hline Median detected concentration & -- & -- & -- & -- & -- & -- & -- \\
\hline Maximum detected concentration & -- & -- & -- & -- & -- & -- & -- \\
\hline Total detected concentration & -- & -- & -- & -- & -- & -- & -- \\
\hline Total load (pounds per day) & 0 & 0 & 0 & 0 & 0 & 0 & 0 \\
\hline \multicolumn{8}{|c|}{ All suspected endocrine-disrupting compounds (EDCs) } \\
\hline Minimum detected concentration & -- & 2.5 & -- & .024 & -- & .051 & .17 \\
\hline Median detected concentration & -- & 2.5 & -- & .024 & -- & .051 & .17 \\
\hline Maximum detected concentration & -- & 2.5 & -- & .024 & -- & .051 & .17 \\
\hline Total detected concentration & -- & 2.5 & -- & .024 & -- & .051 & .17 \\
\hline Total load (pounds per day) & 0 & 23 & 0 & .0084 & 0 & .14 & 1.1 \\
\hline
\end{tabular}


Table 21. Statistical summaries of analytical results and load results for organic wastewater compounds in water samples.-Continued [Units are micrograms per liter unless otherwise noted. --, not detected or not applicable]

\begin{tabular}{|c|c|c|c|c|c|}
\hline \multirow[b]{3}{*}{$\begin{array}{l}\text { Date of sample collection } \\
\text { (month-day-year) }\end{array}$} & \multicolumn{5}{|c|}{ Station identification number and name (site label) } \\
\hline & \multicolumn{5}{|c|}{$\begin{array}{c}433419096434200 \\
\text { Sioux Falls water treatment plant finished drinking water at Sioux Falls, SD } \\
\text { (site FDW, fig. 1) }\end{array}$} \\
\hline & $08-15-2001$ & 09-09-2002 & $01-22-2003$ & $03-19-2003$ & $06-27-2003$ \\
\hline $\begin{array}{l}\text { Time of sample collection } \\
\text { (24-hour) }\end{array}$ & 1100 & 1440 & 1330 & 1445 & 0915 \\
\hline \multicolumn{6}{|c|}{ Human pharmaceutical compounds (HPCs) } \\
\hline Number of compounds detected & 0 & 0 & 0 & 0 & 0 \\
\hline Minimum detected concentration & -- & -- & -- & -- & -- \\
\hline Median detected concentration & -- & -- & -- & -- & -- \\
\hline Maximum detected concentration & -- & -- & -- & -- & -- \\
\hline Number of compounds detected & 0 & 0 & 0 & 0 & 0 \\
\hline Minimum detected concentration & -- & -- & -- & -- & -- \\
\hline Median detected concentration & -- & -- & -- & -- & -- \\
\hline Maximum detected concentration & -- & -- & -- & -- & -- \\
\hline Total detected concentration & -- & -- & -- & -- & -- \\
\hline Total load (pounds per day) & 0 & 0 & 0 & 0 & 0 \\
\hline \multicolumn{6}{|c|}{ Major agricultural herbicides (MAHs) } \\
\hline Number of compounds detected & 1 & 0 & 0 & 0 & 0 \\
\hline Minimum detected concentration & .0040 & -- & -- & -- & -- \\
\hline
\end{tabular}

Total load (pounds per day)

Household, industrial, and minor agricultural use compounds (HIACs)

\begin{tabular}{|c|c|c|c|c|c|}
\hline Number of compounds detected & 0 & 0 & 0 & 0 & 0 \\
\hline Minimum detected concentration & -- & -- & -- & -- & -- \\
\hline Median detected concentration & -- & -- & -- & -- & -- \\
\hline Total detected concentration & -- & -- & -- & -- & -- \\
\hline Total load (pounds per day) & 0 & 0 & 0 & 0 & 0 \\
\hline \multicolumn{6}{|c|}{ Polyaromatic hydrocarbons (PAHs) } \\
\hline Minimum detected concentration & -- & -- & -- & -- & -- \\
\hline Median detected concentration & -- & -- & -- & -- & -- \\
\hline Maximum detected concentration & -- & -- & -- & -- & -- \\
\hline Total detected concentration & -- & -- & -- & -- & -- \\
\hline Total load (pounds per day) & 0 & 0 & 0 & 0 & 0 \\
\hline
\end{tabular}


Table 21. Statistical summaries of analytical results and load results for organic wastewater compounds in water samples.-Continued

[Units are micrograms per liter unless otherwise noted. --, not detected or not applicable]

\begin{tabular}{|c|c|c|c|c|c|}
\hline & \multicolumn{5}{|c|}{ Station identification number and name (site label) } \\
\hline & \multicolumn{5}{|c|}{$\begin{array}{c}433419096434200 \\
\text { Sioux Falls water treatment plant finished drinking water at Sioux Falls, SD } \\
\text { (site FDW, fig. 1) }\end{array}$} \\
\hline \multicolumn{6}{|c|}{ Sterol compounds (SCs) } \\
\hline Number of compounds detected & 0 & 0 & 0 & 0 & 0 \\
\hline Minimum detected concentration & -- & -- & -- & -- & -- \\
\hline Median detected concentration & -- & -- & -- & -- & -- \\
\hline Maximum detected concentration & -- & -- & -- & -- & -- \\
\hline Total detected concentration & -- & -- & -- & -- & -- \\
\hline Total load (pounds per day) & 0 & 0 & 0 & 0 & 0 \\
\hline \multicolumn{6}{|c|}{ All organic wastewater compounds (OWCs) } \\
\hline Number of compounds detected & 1 & 0 & 0 & 0 & 0 \\
\hline Minimum detected concentration & .0040 & -- & -- & -- & -- \\
\hline Median detected concentration & .0040 & -- & -- & -- & -- \\
\hline Maximum detected concentration & .0040 & -- & -- & -- & -- \\
\hline Total detected concentration & .0040 & -- & -- & -- & -- \\
\hline Total load (pounds per day) & -- & 0 & 0 & 0 & 0 \\
\hline
\end{tabular}

Major agricultural herbicides (MAHs) that are suspected endocrine-disrupting compounds (EDCs)

\begin{tabular}{llllll}
\hline Number of compounds detected & 0 & 0 & 0 & 0 & 0 \\
Minimum detected concentration & -- & - & -- & -- & - \\
Median detected concentration & - & -- & -- & -- & -- \\
Maximum detected concentration & -- & - & -- & -- & - \\
Total detected concentration & -- & - & -- & -- & - \\
Total load (pounds per day) & 0 & 0 & 0 & 0 & 0 \\
\hline
\end{tabular}

Household, industrial, and minor agricultural use compounds (HIACs) that are suspected endocrine-disrupting compounds (EDCs)

\begin{tabular}{|c|c|c|c|c|c|}
\hline Number of compounds detected & 0 & 0 & 0 & 0 & 0 \\
\hline Minimum detected concentration & -- & -- & -- & -- & -- \\
\hline Median detected concentration & -- & -- & -- & -- & -- \\
\hline Total detected concentration & -- & -- & -- & -- & -- \\
\hline Total load (pounds per day) & 0 & 0 & 0 & 0 & 0 \\
\hline
\end{tabular}

Polyaromatic hydrocarbons (PAHs) that are suspected endocrine-disrupting compounds (EDCs)

\begin{tabular}{|c|c|c|c|c|c|}
\hline Number of compounds detected & 0 & 0 & 0 & 0 & 0 \\
\hline Minimum detected concentration & -- & -- & -- & -- & -- \\
\hline Median detected concentration & -- & -- & -- & -- & -- \\
\hline Total detected concentration & -- & -- & -- & -- & -- \\
\hline Total load (pounds per day) & 0 & 0 & 0 & 0 & 0 \\
\hline \multicolumn{6}{|c|}{ All suspected endocrine-disrupting compounds (EDCs) } \\
\hline Minimum detected concentration & -- & -- & -- & -- & -- \\
\hline Median detected concentration & -- & -- & -- & -- & -- \\
\hline Maximum detected concentration & -- & -- & -- & -- & -- \\
\hline Total detected concentration & -- & -- & -- & -- & -- \\
\hline Total load (pounds per day) & 0 & 0 & 0 & 0 & 0 \\
\hline
\end{tabular}


Table 21. Statistical summaries of analytical results and load results for organic wastewater compounds in water samples.—Continued [Units are micrograms per liter unless otherwise noted. --, not detected or not applicable]

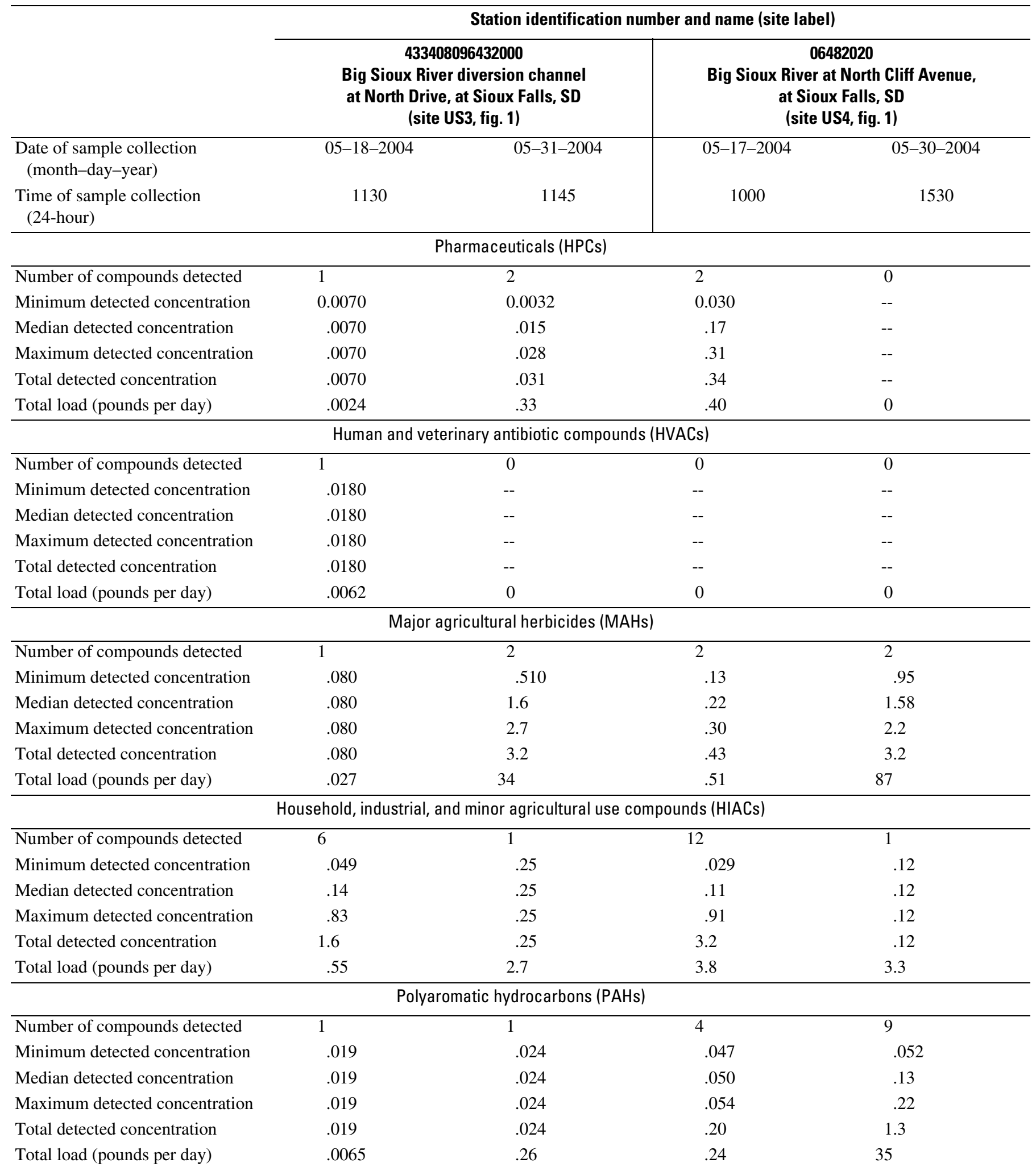


Table 21. Statistical summaries of analytical results and load results for organic wastewater compounds in water samples. - Continued

[Units are micrograms per liter unless otherwise noted. --, not detected or not applicable]

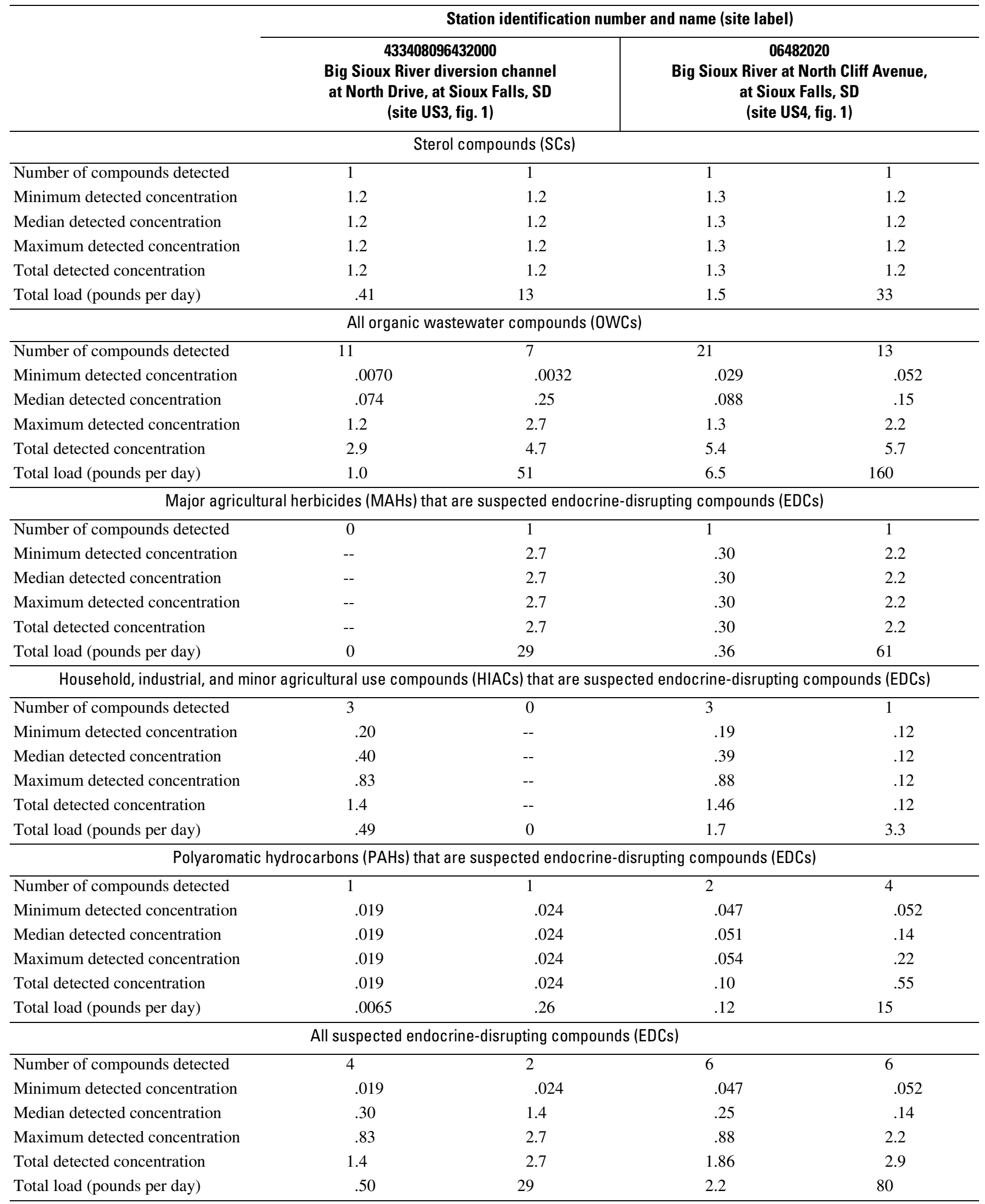


Table 21. Statistical summaries of analytical results and load results for organic wastewater compounds in water samples.-Continued [Units are micrograms per liter unless otherwise noted. --, not detected or not applicable]

\begin{tabular}{|c|c|c|c|c|c|c|}
\hline \multirow[b]{3}{*}{$\begin{array}{l}\text { Date of sample collection } \\
\text { (month-day-year) }\end{array}$} & \multicolumn{6}{|c|}{ Station identification number and name (site label) } \\
\hline & \multicolumn{6}{|c|}{$\begin{array}{c}433531096394200 \\
\text { Sioux Falls wastewater treatment plant effluent } \\
\text { (site WWE, fig. 1) }\end{array}$} \\
\hline & 09-10-2002 & $01-24-2003$ & $03-21-2003$ & 06-26-2003 & $05-18-2004$ & 05-30-2004 \\
\hline $\begin{array}{l}\text { Time of sample collection } \\
\text { (24-hour) }\end{array}$ & 1400 & 930 & 1045 & 1135 & 1020 & 2020 \\
\hline \multicolumn{7}{|c|}{ Pharmaceuticals (HPCs) } \\
\hline Number of compounds detected & 2 & 3 & 4 & 2 & 0 & 2 \\
\hline Minimum detected concentration & .011 & .027 & .022 & .014 & -- & .056 \\
\hline Median detected concentration & .016 & .054 & .043 & .025 & -- & .057 \\
\hline Maximum detected concentration & .021 & .081 & .048 & .035 & -- & .059 \\
\hline Number of compounds detected & 1 & 6 & 1 & 3 & 6 & 5 \\
\hline Minimum detected concentration & .050 & .39 & .090 & .050 & .070 & .016 \\
\hline Median detected concentration & .050 & 1.0 & .090 & .15 & .27 & .072 \\
\hline Maximum detected concentration & .050 & 17 & .090 & .20 & 1.1 & .55 \\
\hline Total detected concentration & .050 & 24 & .090 & .40 & 2.2 & .82 \\
\hline Total load (pounds per day) & .0075 & 2.6 & .010 & .067 & .29 & .21 \\
\hline \multicolumn{7}{|c|}{ Major agricultural herbicides (MAHs) } \\
\hline Number of compounds detected & 1 & 0 & 1 & 3 & 0 & 1 \\
\hline Minimum detected concentration & .030 & -- & .062 & .072 & -- & .26 \\
\hline Minimum detected concentration & .014 & .12 & .017 & .079 & .080 & .074 \\
\hline Median detected concentration & .27 & .66 & .29 & .31 & .25 & .32 \\
\hline Maximum detected concentration & 1.8 & 6.2 & 6.2 & 2.1 & 2.1 & 2.9 \\
\hline Total detected concentration & 5.5 & 17 & 12 & 6.0 & 8.7 & 10 \\
\hline Total load (pounds per day) & .82 & 1.8 & 1.4 & 1.0 & 1.1 & 2.6 \\
\hline \multicolumn{7}{|c|}{ Polyaromatic hydrocarbons (PAHs) } \\
\hline Number of compounds detected & 0 & 0 & 0 & 0 & 0 & 0 \\
\hline Minimum detected concentration & -- & -- & -- & -- & -- & -- \\
\hline Median detected concentration & -- & -- & -- & -- & -- & -- \\
\hline Maximum detected concentration & -- & -- & -- & -- & -- & -- \\
\hline Total detected concentration & -- & -- & -- & -- & -- & -- \\
\hline Total load (pounds per day) & 0 & 0 & 0 & 0 & 0 & 0 \\
\hline
\end{tabular}


Table 21. Statistical summaries of analytical results and load results for organic wastewater compounds in water samples. - Continued

[Units are micrograms per liter unless otherwise noted. --, not detected or not applicable]

\begin{tabular}{|c|c|c|c|c|c|c|}
\hline & \multicolumn{6}{|c|}{ Station identification number and name (site label) } \\
\hline & \multicolumn{6}{|c|}{$\begin{array}{c}433531096394200 \\
\text { Sioux Falls wastewater treatment plant effluent } \\
\text { (site WWE, fig. 1) }\end{array}$} \\
\hline \multicolumn{7}{|c|}{ Sterol compounds (SCs) } \\
\hline Number of compounds detected & 3 & 2 & 2 & 3 & 3 & 2 \\
\hline Maximum detected concentration & 2.2 & 3.5 & 1.9 & 2.8 & 5.4 & 2.9 \\
\hline Total detected concentration & 4.9 & 5.1 & 3.1 & 5.5 & 12 & 4.4 \\
\hline Total load (pounds per day) & .74 & .55 & .35 & .91 & 1.5 & 1.1 \\
\hline \multicolumn{7}{|c|}{ All organic wastewater compounds (OWCs) } \\
\hline Maximum detected concentration & 2.2 & 17.0 & 6.2 & 2.8 & 5.4 & 2.9 \\
\hline Total detected concentration & 10 & 46 & 16 & 12 & 23 & 16 \\
\hline Total load (pounds per day) & 1.6 & 4.9 & 1.8 & 2.0 & 3.0 & 4.0 \\
\hline \multicolumn{7}{|c|}{ Major agricultural herbicides (MAHs) that are suspected endocrine-disrupting compounds (EDCs) } \\
\hline Number of compounds detected & 0 & 0 & 1 & 1 & 0 & 1 \\
\hline Minimum detected concentration & -- & -- & .062 & .083 & -- & .26 \\
\hline Median detected concentration & -- & -- & .062 & .083 & -- & .26 \\
\hline Maximum detected concentration & -- & -- & .062 & .083 & -- & .26 \\
\hline Total detected concentration & -- & -- & .062 & .083 & -- & .26 \\
\hline Total load (pounds per day) & 0 & 0 & .0070 & .014 & 0 & .066 \\
\hline Total load (pounds per day) & .34 & 1.0 & 1.0 & .73 & .63 & 1.2 \\
\hline
\end{tabular}

Polyaromatic hydrocarbons (PAHs) that are suspected endocrine-disrupting compounds (EDCs)

\begin{tabular}{|c|c|c|c|c|c|c|}
\hline Number of compounds detected & 0 & 0 & 0 & 0 & 0 & 0 \\
\hline Minimum detected concentration & -- & -- & -- & -- & -- & -- \\
\hline Median detected concentration & -- & -- & -- & -- & -- & -- \\
\hline Maximum detected concentration & -- & -- & -- & -- & -- & -- \\
\hline Total detected concentration & -- & -- & -- & -- & -- & -- \\
\hline Total load (pounds per day) & 0 & 0 & 0 & 0 & 0 & 0 \\
\hline \multicolumn{7}{|c|}{ All suspected endocrine-disrupting compounds (EDCs) } \\
\hline Number of compounds detected & 5 & 5 & 6 & 5 & 5 & 9 \\
\hline Minimum detected concentration & .014 & .18 & .062 & .083 & .20 & .14 \\
\hline Median detected concentration & .16 & 1.3 & .51 & .94 & .40 & .32 \\
\hline Maximum detected concentration & 1.4 & 6.2 & 6.2 & 2.1 & 2.1 & 1.7 \\
\hline Total detected concentration & 2.3 & 9.5 & 9.2 & 4.4 & 4.8 & 4.9 \\
\hline Total load (pounds per day) & .34 & 1.02 & 1.0 & .74 & .63 & 1.2 \\
\hline
\end{tabular}


Table 21. Statistical summaries of analytical results and load results for organic wastewater compounds in water samples.—Continued [Units are micrograms per liter unless otherwise noted. --, not detected or not applicable]

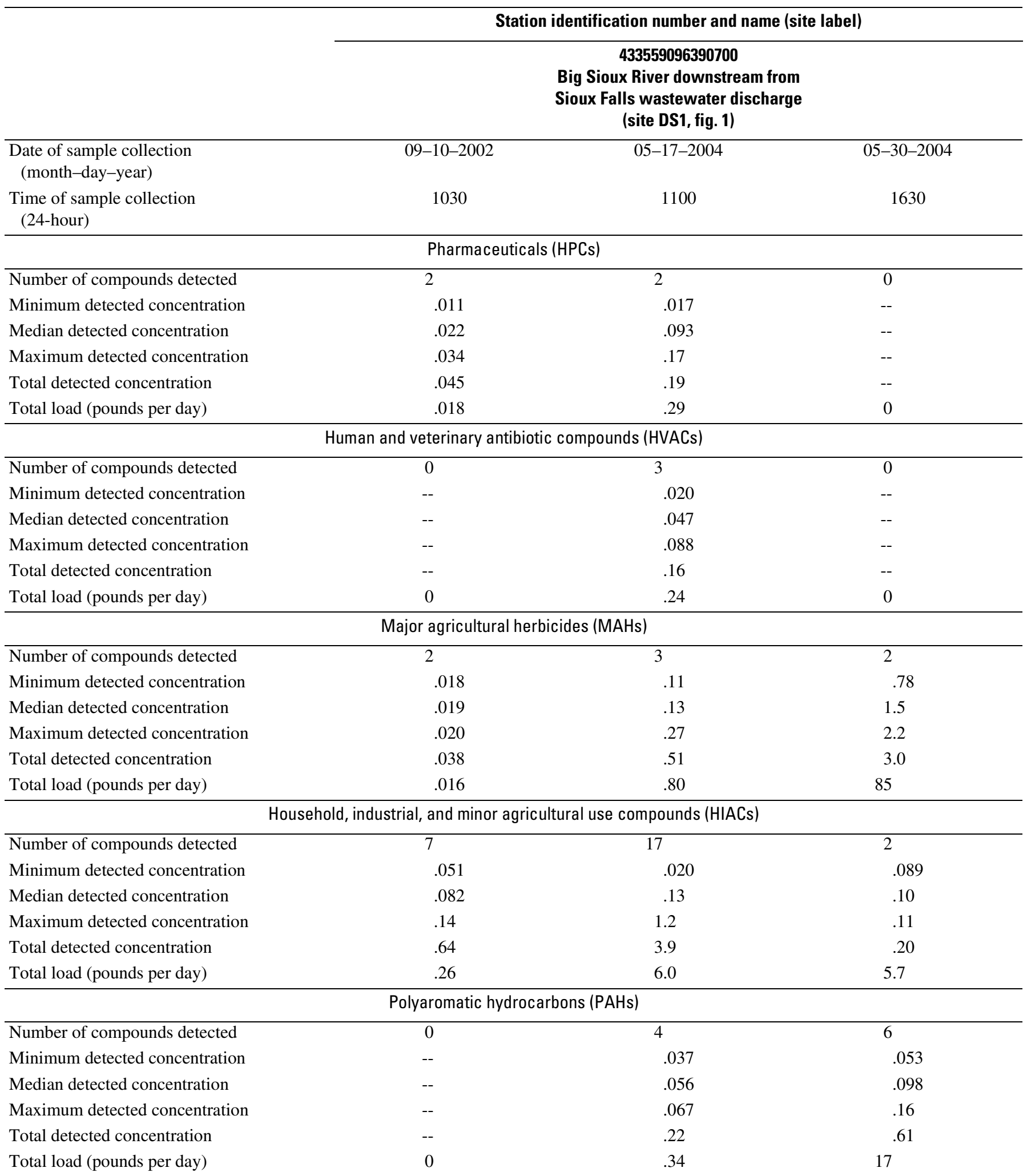


Table 21. Statistical summaries of analytical results and load results for organic wastewater compounds in water samples. -Continued

[Units are micrograms per liter unless otherwise noted. --, not detected or not applicable]

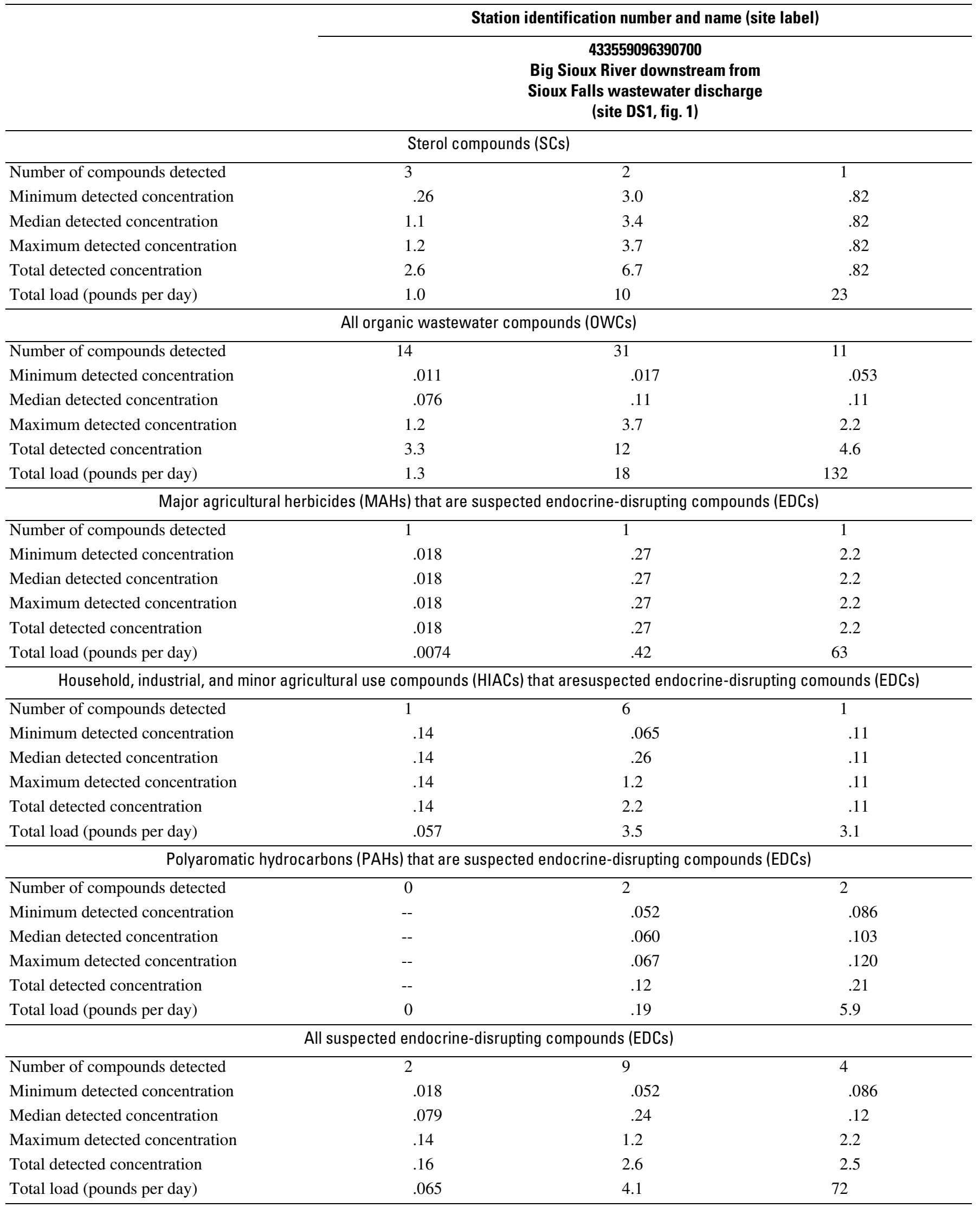


Table 21. Statistical summaries of analytical results and load results for organic wastewater compounds in water samples.-Continued [Units are micrograms per liter unless otherwise noted. --, not detected or not applicable]

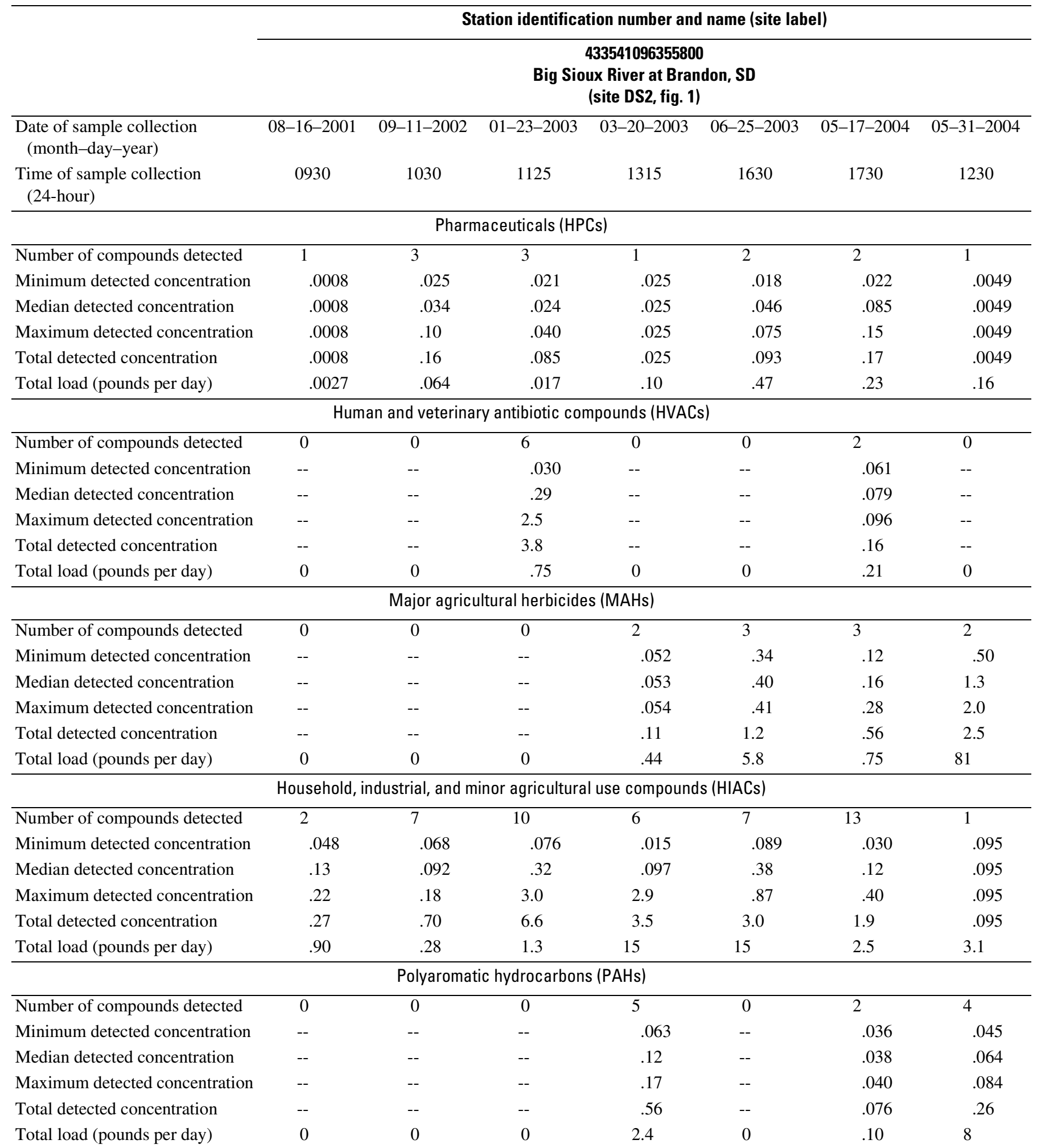


Table 21. Statistical summaries of analytical results and load results for organic wastewater compounds in water samples. - Continued

[Units are micrograms per liter unless otherwise noted. --, not detected or not applicable]

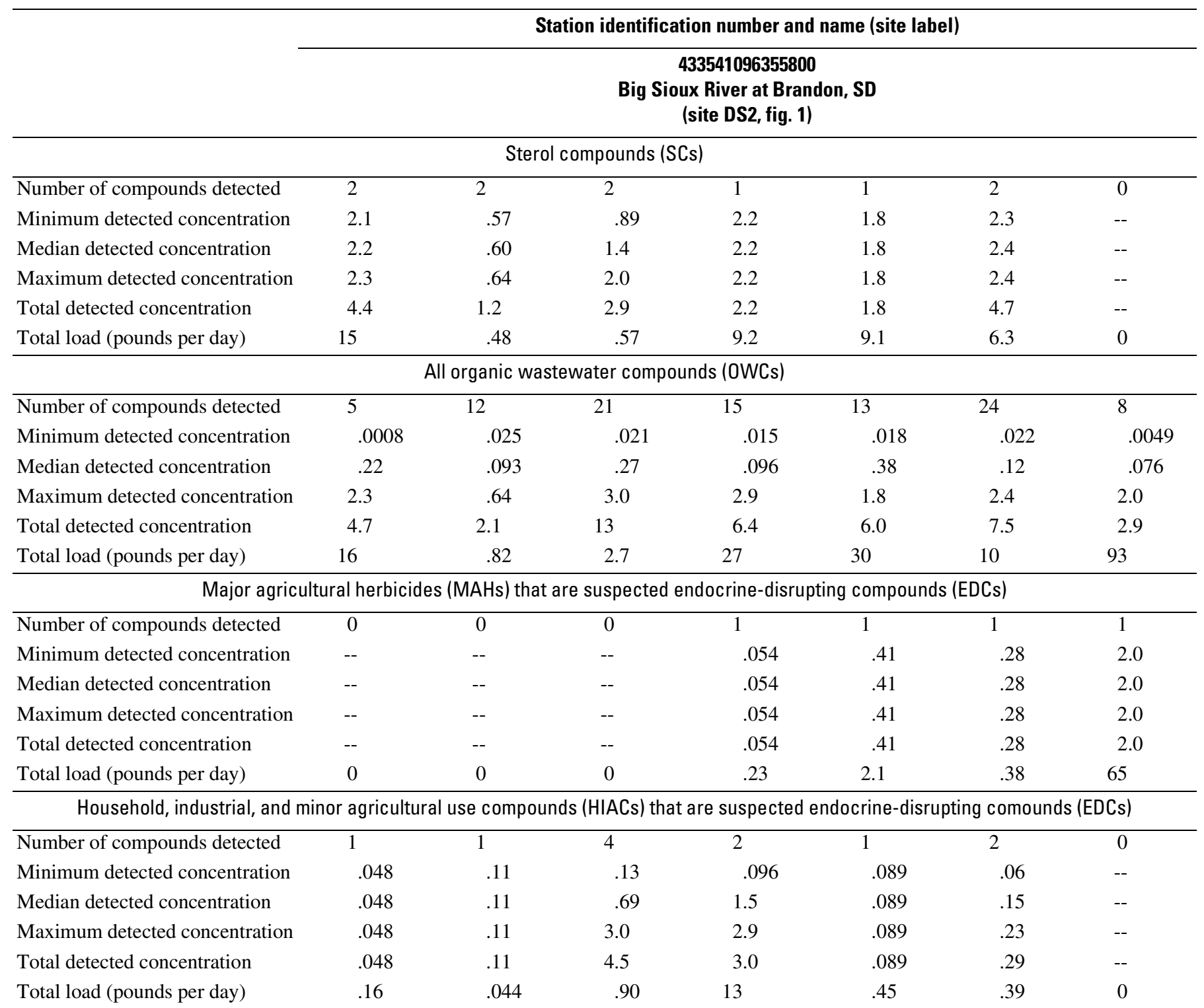

Polyaromatic hydrocarbons (PAHs) that are suspected endocrine-disrupting compounds (EDCs)

\begin{tabular}{|c|c|c|c|c|c|c|c|}
\hline Number of compounds detected & 0 & 0 & 0 & 4 & 0 & 1 & 1 \\
\hline Minimum detected concentration & -- & -- & -- & .063 & -- & .040 & .045 \\
\hline Median detected concentration & -- & -- & -- & .094 & -- & .040 & .045 \\
\hline Total detected concentration & -- & -- & -- & .39 & -- & .040 & .045 \\
\hline Total load (pounds per day) & 0 & 0 & 0 & 1.6 & 0 & .054 & 1.5 \\
\hline & & ted end & isrupti & ounds (E & & & \\
\hline Minimum detected concentration & .048 & .11 & .13 & .054 & .089 & .040 & .045 \\
\hline Median detected concentration & .048 & .11 & .69 & .096 & .25 & .15 & 1.0 \\
\hline Maximum detected concentration & .048 & .11 & 3.0 & 2.9 & .41 & .28 & 2.0 \\
\hline Total detected concentration & .048 & .11 & 4.5 & 3.4 & .50 & .61 & 2.0 \\
\hline Total load (pounds per day) & .16 & .044 & .90 & 14 & 2.5 & .82 & 67 \\
\hline
\end{tabular}


Table 22. Organic wastewater compounds detected at concentrations greater than study reporting levels in water samples.

[Bold text indicates suspected endocrine-disrupting compound (EDC). DEET, N,N-diethyl-meta-toluamide; NP, para-nonylphenol; NP1EO, nonylphenol monoethoxylate; NP2EO, nonylphenol diethoxylate; OP1EO, octylphenol monoethoxylate; OP2EO, octylphenol diethoxylate; --, none detected]

\begin{tabular}{|c|c|c|c|c|c|c|c|c|c|c|c|c|}
\hline \multirow[b]{3}{*}{$\begin{array}{l}\text { Date of sample } \\
\text { collection } \\
\text { (month-day-year) }\end{array}$} & \multicolumn{12}{|c|}{ Station identification number and name (site label) } \\
\hline & \multicolumn{2}{|c|}{$\begin{array}{c}433843096450500 \\
\text { Big Sioux River near } \\
\text { Renner, SD } \\
\text { (site US1, fig. 1) }\end{array}$} & \multicolumn{5}{|c|}{$\begin{array}{c}433600096442400 \\
\text { Sioux Falls pump station intake from } \\
\text { Big Sioux River at Sioux Falls, SD } \\
\text { (site US2, fig. 1) }\end{array}$} & \multicolumn{5}{|c|}{$\begin{array}{c}433419096434200 \\
\text { Sioux Falls water treatment plant } \\
\text { finished drinking water at Sioux Falls, SD } \\
\text { (site FDW, fig. 1) }\end{array}$} \\
\hline & $\begin{array}{c}05-18- \\
2004\end{array}$ & $\begin{array}{c}05-31- \\
2004\end{array}$ & $\begin{array}{c}08-15- \\
2001\end{array}$ & $\begin{array}{c}09-09- \\
2002\end{array}$ & $\begin{array}{c}01-22- \\
2003\end{array}$ & $\begin{array}{c}03-19- \\
2003\end{array}$ & $\begin{array}{c}06-26- \\
2003\end{array}$ & $\begin{array}{c}08-15- \\
2001\end{array}$ & $\begin{array}{c}09-09- \\
2002\end{array}$ & $\begin{array}{c}01-22- \\
2003\end{array}$ & $\begin{array}{c}03-19- \\
2003\end{array}$ & $\begin{array}{c}06-27- \\
2003\end{array}$ \\
\hline $\begin{array}{l}\text { Time of sample } \\
\text { collection } \\
\text { (24-hour) }\end{array}$ & 1500 & 1800 & 1405 & 1200 & 1105 & 1130 & 0930 & 1100 & 1440 & 1330 & 1445 & 0915 \\
\hline $\begin{array}{l}\text { Number of compounds } \\
\text { detected }\end{array}$ & 7 & 3 & 4 & 4 & 1 & 4 & 5 & 1 & 0 & 0 & 0 & 0 \\
\hline $\begin{array}{l}\text { Human pharmaceutical } \\
\text { compounds (HPCs) }\end{array}$ & -- & -- & -- & Cotinine & Cotinine & Cotinine & Cotinine & -- & -- & -- & -- & -- \\
\hline $\begin{array}{l}\text { Human and veterinary } \\
\text { antibiotic compounds } \\
\text { (HVACs) }\end{array}$ & $\begin{array}{l}\text { Erythromy- } \\
\text { cin- } \mathrm{H}_{2} \mathrm{O} \\
\text { Sulfameth- } \\
\text { oxazole }\end{array}$ & -- & -- & -- & -- & -- & -- & -- & -- & -- & -- & -- \\
\hline $\begin{array}{l}\text { Major agricultural } \\
\text { herbicides (MAHs) }\end{array}$ & Metolachlor & $\begin{array}{l}\text { Atrazine } \\
\text { Metolachlor }\end{array}$ & Metolachlor & Atrazine & -- & $\begin{array}{l}\text { Atrazine } \\
\text { Metolachlor }\end{array}$ & $\begin{array}{l}\text { Atrazine } \\
\text { Metolachlor }\end{array}$ & Metolachlor & -- & -- & -- & -- \\
\hline $\begin{array}{l}\text { Household, industrial, } \\
\text { and minor agricultural- } \\
\text { use compounds } \\
\text { (HIACs) }\end{array}$ & $\begin{array}{l}\text { DEET } \\
\text { Isophorone } \\
\text { Tri(2-chlor- } \\
\text { oethyl) } \\
\text { phosphate }\end{array}$ & -- & $\begin{array}{l}\text { Tri( } 2- \\
\text { butoxy- } \\
\text { ethyl) } \\
\text { phosphate }\end{array}$ & -- & -- & $\begin{array}{l}\text { Tri }(2- \\
\text { butoxy- } \\
\text { ethyl) } \\
\text { phosphate }\end{array}$ & DEET & -- & -- & -- & -- & -- \\
\hline $\begin{array}{l}\text { Polyaromatic } \\
\text { hydrocarbons (PAHs) }\end{array}$ & -- & -- & -- & -- & -- & -- & -- & -- & -- & -- & -- & -- \\
\hline Sterol compounds (SCs) & Cholesterol & Cholesterol & $\begin{array}{l}\text { beta- } \\
\text { Sitosterol } \\
\text { Cholesterol }\end{array}$ & $\begin{array}{l}\text { beta- } \\
\text { Sitosterol } \\
\text { Cholesterol }\end{array}$ & -- & -- & Cholesterol & -- & -- & -- & -- & -- \\
\hline
\end{tabular}


Table 22. Organic wastewater compounds detected at concentrations greater than study reporting levels in water samples.-Continued

[Bold text indicates suspected endocrine-disrupting compound (EDC). DEET, N,N-diethyl-meta-toluamide; NP, para-nonylphenol; NP1EO, nonylphenol monoethoxylate; NP2EO, nonylphenol diethoxylate; OP1EO, octylphenol monoethoxylate; OP2EO, octylphenol diethoxylate; --, none detected]

\begin{tabular}{|c|c|c|c|c|c|c|c|c|c|c|}
\hline \multirow[b]{3}{*}{$\begin{array}{l}\text { Date of sample } \\
\text { collection } \\
\text { (month-day-year) }\end{array}$} & \multicolumn{10}{|c|}{ Station identification number and name (site label) } \\
\hline & \multicolumn{2}{|c|}{$\begin{array}{l}433408096432000 \\
\text { Big Sioux River diversion } \\
\text { channel at North Drive, at } \\
\text { Sioux Falls, SD } \\
\text { (site US3, fig. 1) }\end{array}$} & \multicolumn{2}{|c|}{$\begin{array}{c}06482020 \\
\text { Big Sioux River at North Cliff } \\
\text { Avenue, at Sioux Falls, SD } \\
\text { (site US4, fig. 1) }\end{array}$} & \multicolumn{6}{|c|}{$\begin{array}{c}433531096394200 \\
\text { Sioux Falls wastewater treatment plant effluent } \\
\text { (site WWE, fig. 1) }\end{array}$} \\
\hline & $05-18-2004$ & 05-31-2004 & 05-17-2004 & 05-30-2004 & 09-10-2002 & $01-24-2003$ & $03-21-2003$ & $06-26-2003$ & 05-18-2004 & 05-30-2004 \\
\hline $\begin{array}{l}\text { Time of sample } \\
\text { collection } \\
\text { (24-hour) }\end{array}$ & 1130 & 1145 & 1000 & 1530 & 1400 & 0930 & 1045 & 1135 & 1020 & 2020 \\
\hline $\begin{array}{l}\text { Number of compounds } \\
\text { detected }\end{array}$ & 11 & 7 & 21 & 13 & 18 & 23 & 22 & 21 & 24 & 28 \\
\hline $\begin{array}{l}\text { Human pharmaceutical } \\
\text { compounds (HPCs) }\end{array}$ & Cotinine & $\begin{array}{l}\text { Caffeine } \\
\text { Cotinine }\end{array}$ & $\begin{array}{l}\text { Caffeine } \\
\text { Cotinine }\end{array}$ & -- & $\begin{array}{l}\text { Dehydronif- } \\
\text { edipine } \\
\text { Cotinine }\end{array}$ & $\begin{array}{l}\text { Caffeine } \\
\text { Cotinine } \\
\text { Salbutamol }\end{array}$ & $\begin{array}{l}\text { 1,7-Dimethyl- } \\
\text { xanthine } \\
\text { Caffeine } \\
\text { Cotinine } \\
\text { Salbutamol }\end{array}$ & $\begin{array}{l}\text { Caffeine } \\
\text { Cotinine }\end{array}$ & -- & $\begin{array}{l}\text { Caffeine } \\
\text { Cotinine }\end{array}$ \\
\hline $\begin{array}{l}\text { Human and veterinary } \\
\text { antibiotic compounds } \\
\text { (HVACs) }\end{array}$ & $\begin{array}{l}\text { Sulfameth- } \\
\text { oxazole }\end{array}$ & -- & -- & -- & $\begin{array}{l}\text { Erythromycin- } \\
\mathrm{H}_{2} \mathrm{O}\end{array}$ & $\begin{array}{l}\text { Chloro- } \\
\text { tetracycline } \\
\text { Ciprofloxacin } \\
\text { Erythromycin- } \\
\mathrm{H}_{2} \mathrm{O} \\
\text { Sulfameth- } \\
\text { oxazole } \\
\text { Tetracycline } \\
\text { Trimethoprim }\end{array}$ & Trimethoprim & $\begin{array}{l}\text { Erythromycin- } \\
\mathrm{H}_{2} \mathrm{O} \\
\text { Sulfameth- } \\
\text { oxazole } \\
\text { Trimethoprim }\end{array}$ & $\begin{array}{l}\text { Erythromycin } \\
\text { Erythromycin- } \\
\mathrm{H}_{2} \mathrm{O} \\
\text { Ofloxacin } \\
\text { Sulfameth- } \\
\text { oxazole } \\
\text { Trimethoprim } \\
\text { Tylosin }\end{array}$ & $\begin{array}{l}\text { Ciprofloxacin } \\
\text { Erythromycin } \\
\text { Erythromycin- } \\
\mathrm{H}_{2} \mathrm{O} \\
\text { Trimethoprim }\end{array}$ \\
\hline $\begin{array}{l}\text { Major agricultural } \\
\text { herbicides (MAHs) }\end{array}$ & Metolachlor & $\begin{array}{l}\text { Atrazine } \\
\text { Metolachlor }\end{array}$ & $\begin{array}{l}\text { Atrazine } \\
\text { Metolachlor }\end{array}$ & $\begin{array}{l}\text { Atrazine } \\
\text { Metolachlor }\end{array}$ & Prometon & -- & Atrazine & $\begin{array}{l}\text { Atrazine } \\
\text { Metolachlor } \\
\text { Prometon }\end{array}$ & -- & Atrazine \\
\hline
\end{tabular}


[Bold text indicates suspected endocrine-disrupting compound (EDC). DEET, N,N-diethyl-meta-toluamide; NP, para-nonylphenol; NP1EO, nonylphenol monoethoxylate; NP2EO, nonylphenol diethoxylate; OP1EO, octylphenol monoethoxylate; OP2EO, octylphenol diethoxylate; --, none detected]

\begin{tabular}{|c|c|c|c|c|c|c|c|c|c|}
\hline & \multicolumn{9}{|c|}{ Station identification number and name (site label) } \\
\hline & $\begin{array}{c}433408096432000 \\
\text { Big Sioux River diversion } \\
\text { channel at North Drive, at } \\
\text { Sioux Falls, SD } \\
\text { (site US3, fig. 1) }\end{array}$ & $\begin{array}{r}064 \\
\text { Big Sioux Riv } \\
\text { Avenue, at S } \\
\text { (site US }\end{array}$ & $\begin{array}{l}2020 \\
\text { ioux Falls, SD } \\
4, \text { fig. 1) }\end{array}$ & & Sioux Fa & $\begin{array}{r}43353109 \\
\text { alls wastewater } \\
\text { (site WW }\end{array}$ & $\begin{array}{l}36394200 \\
\text { treatment plant } \\
\text { VE, fig. 1) }\end{array}$ & effluent & \\
\hline $\begin{array}{l}\text { Household, industrial, } \\
\text { and minor agricultural- } \\
\text { use compounds } \\
\text { (HIACs) }\end{array}$ & $\begin{array}{l}\text { DEET } \\
\text { Isophorone } \\
\text { OP2EO } \\
\text { OP1EO } \\
\text { NP } \\
\text { Tri(2-chloro- } \\
\text { ethyl) } \\
\text { phosphate }\end{array}$ & $\begin{array}{l}\text { Anthraqui- } \\
\text { none } \\
\text { Camphor } \\
\text { DEET } \\
\text { Indole } \\
\text { Isophorone } \\
\text { OP2EO } \\
\text { OP1EO } \\
\text { NP } \\
\text { Tributyl } \\
\text { phosphate } \\
\text { Triphenyl } \\
\text { phosphate } \\
\text { Tri(2- } \\
\text { butoxyethyl) } \\
\text { phosphate } \\
\text { Tri(2- } \\
\text { chloroethyl) } \\
\text { phosphate }\end{array}$ & $\begin{array}{l}\text { Benzophe- } \\
\text { none }\end{array}$ & $\begin{array}{l}\text { 5-Methyl-1H- } \\
\text { benzotria- } \\
\text { zole } \\
\text { AHTN } \\
\text { Chlorpyrifos } \\
\text { Diazinon } \\
\text { HHCB } \\
\text { NP2EO } \\
\text { Phenol } \\
\text { Tributyl } \\
\text { phosphate } \\
\text { Triethyl citrate } \\
\text { (ethyl } \\
\text { citrate) } \\
\text { Tri(2- } \\
\text { chloroethyl) } \\
\text { phosphate } \\
\text { Tri(dichlorois } \\
\text { opropyl)pho } \\
\text { sphate }\end{array}$ & $\begin{array}{l}\text { 5-Methyl-1H- } \\
\text { benzotria- } \\
\text { zole } \\
\text { AHTN } \\
\text { DEET } \\
\text { HHCB } \\
\text { NP2EO } \\
\text { NP1EO } \\
\text { Tributyl } \\
\text { phosphate } \\
\text { Triclosan } \\
\text { Triethyl citrate } \\
\text { (ethyl } \\
\text { citrate) } \\
\text { Tri(2- } \\
\text { butoxyethyl) } \\
\text { phosphate } \\
\text { Tri(2- } \\
\text { chloroethyl) } \\
\text { phosphate } \\
\text { Tri(dichlorois } \\
\text { opropyl)pho } \\
\text { sphate }\end{array}$ & $\begin{array}{l}\text { 3-Methyl-1H- } \\
\text { indole } \\
\text { (skatol) } \\
\text { 5-Methyl-1H- } \\
\text { benzotria- } \\
\text { zole } \\
\text { AHTN } \\
\text { DEET } \\
\text { HHCB } \\
\text { Indole } \\
\text { NP2EO } \\
\text { NP1EO } \\
\text { Tributyl } \\
\text { phosphate } \\
\text { Triclosan } \\
\text { Triethyl citrate } \\
\text { (ethyl } \\
\text { citrate) } \\
\text { Tri(2- } \\
\text { butoxyethyl) } \\
\text { phosphate } \\
\text { Tri(2- } \\
\text { chloroethyl) } \\
\text { phosphate } \\
\text { Tri(dichloro- } \\
\text { isopropyl) } \\
\text { phosphate }\end{array}$ & $\begin{array}{l}\text { AHTN } \\
\text { Acetophenone } \\
\text { HHCB } \\
\text { NP2EO } \\
\text { NP1EO } \\
\text { Tributyl } \\
\text { phosphate } \\
\text { Triethyl citrate } \\
\text { (ethyl } \\
\text { citrate) } \\
\text { Triphenyl } \\
\text { phosphate } \\
\text { Tri(2- } \\
\text { chloroethyl) } \\
\text { phosphate } \\
\text { Tri(dichloro- } \\
\text { isopropyl) } \\
\text { phosphate }\end{array}$ & $\begin{array}{l}1,4- \\
\text { Dichloroben } \\
\text { zene } \\
\text { 5-Methyl-1H- } \\
\text { benzotria- } \\
\text { zole } \\
\text { AHTN } \\
\text { Benzophe- } \\
\text { none } \\
\text { DEET } \\
\text { HHCB } \\
\text { Indole } \\
\text { para-Cresol } \\
\text { NP } \\
\text { Tributyl } \\
\text { phosphate } \\
\text { Triclosan } \\
\text { Triethyl citrate } \\
\text { (ethyl } \\
\text { citrate) } \\
\text { Triphenyl } \\
\text { phosphate } \\
\text { Tri(2- } \\
\text { chloroethyl) } \\
\text { phosphate } \\
\text { Tri(dichloro- } \\
\text { isopropyl) } \\
\text { phosphate }\end{array}$ & $\begin{array}{l}\text { 1,4-dichloro- } \\
\text { benzene } \\
\text { AHTN } \\
\text { Anthraqui- } \\
\text { none } \\
\text { Benzophe- } \\
\text { none } \\
\text { Carbaryl } \\
\text { DEET } \\
\text { HHCB } \\
\text { NP2EO } \\
\text { para-Cresol } \\
\text { NP } \\
\text { Pentachloro- } \\
\text { phenol } \\
\text { Phenol } \\
\text { Tetrachloro- } \\
\text { ethylene } \\
\text { Tributyl } \\
\text { phosphate } \\
\text { Triclosan } \\
\text { Triethyl citrate } \\
\text { (ethyl } \\
\text { citrate) } \\
\text { Triphenyl } \\
\text { phosphate } \\
\text { Tri(2- } \\
\text { chloroethyl) } \\
\text { phosphate } \\
\text { Tri(dichloro- } \\
\text { isopropyl) } \\
\text { phosphate }\end{array}$ \\
\hline
\end{tabular}


Table 22. Organic wastewater compounds detected at concentrations greater than study reporting levels in water samples.-Continued

[Bold text indicates suspected endocrine-disrupting compound (EDC). DEET, N,N-diethyl-meta-toluamide; NP, para-nonylphenol; NP1EO, nonylphenol monoethoxylate; NP2EO, nonylphenol diethoxylate; OP1EO, octylphenol monoethoxylate; OP2EO, octylphenol diethoxylate; --, none detected]

\begin{tabular}{|c|c|c|c|c|c|c|c|c|c|c|}
\hline \multirow[b]{3}{*}{$\begin{array}{l}\text { Polyaromatic } \\
\text { hydrocarbons (PAHs) }\end{array}$} & \multicolumn{10}{|c|}{ Station identification number and name (site label) } \\
\hline & \multicolumn{2}{|c|}{$\begin{array}{l}433408096432000 \\
\text { Big Sioux River diversion } \\
\text { channel at North Drive, at } \\
\text { Sioux Falls, SD } \\
\text { (site US3, fig. 1) }\end{array}$} & \multicolumn{2}{|c|}{$\begin{array}{c}06482020 \\
\text { Big Sioux River at North Cliff } \\
\text { Avenue, at Sioux Falls, SD } \\
\text { (site US4, fig. 1) }\end{array}$} & \multicolumn{6}{|c|}{$\begin{array}{c}433531096394200 \\
\text { Sioux Falls wastewater treatment plant effluent } \\
\text { (site WWE, fig. 1) }\end{array}$} \\
\hline & Phenanthrene & Phenanthrene & $\begin{array}{l}\text { Carbazole } \\
\text { Naphthalene } \\
\text { Phenanth- } \\
\text { rene } \\
\text { Pyrene }\end{array}$ & $\begin{array}{l}\text { 1-Methyl- } \\
\text { naphthalene } \\
\text { 2,6-Dimethyl- } \\
\text { naphthalene } \\
\text { 2-Methyl- } \\
\text { naphthalene } \\
\text { Anthracene } \\
\text { Benzo[a] } \\
\text { pyrene } \\
\text { Fluoranthene } \\
\text { Naphthalene } \\
\text { Phenanth- } \\
\text { rene } \\
\text { Pyrene }\end{array}$ & -- & -- & -- & -- & -- & -- \\
\hline Sterol compounds (SCs) & Cholesterol & Cholesterol & Cholesterol & Cholesterol & $\begin{array}{l}\text { 3-beta- } \\
\text { Coprostanol } \\
\text { beta-Sitosterol } \\
\text { Cholesterol }\end{array}$ & $\begin{array}{l}\text { 3-beta- } \\
\text { Coprostanol } \\
\text { Cholesterol }\end{array}$ & $\begin{array}{l}\text { 3-beta- } \\
\text { Coprostanol } \\
\text { Cholesterol }\end{array}$ & $\begin{array}{l}\text { 3-beta- } \\
\text { Coprostanol } \\
\text { beta-Sitosterol } \\
\text { Cholesterol }\end{array}$ & $\begin{array}{l}\text { 3-beta- } \\
\text { Coprostanol } \\
\text { beta-Sitosterol } \\
\text { Cholesterol }\end{array}$ & $\begin{array}{l}\text { 3-beta- } \\
\text { Coprostanol } \\
\text { Cholesterol }\end{array}$ \\
\hline
\end{tabular}


[Bold text indicates suspected endocrine-disrupting compound (EDC). DEET, N,N-diethyl-meta-toluamide; NP, para-nonylphenol; NP1EO, nonylphenol monoethoxylate; NP2EO, nonylphenol diethoxylate; OP1EO, octylphenol monoethoxylate; OP2EO, octylphenol diethoxylate; --, none detected]

\begin{tabular}{|c|c|c|c|c|c|c|c|c|c|c|}
\hline \multirow[b]{3}{*}{$\begin{array}{l}\text { Date of sample } \\
\text { collection } \\
\text { (month-day-year) }\end{array}$} & \multicolumn{10}{|c|}{ Station identification number and name (site label) } \\
\hline & \multicolumn{3}{|c|}{$\begin{array}{c}433559096390700 \\
\text { Big Sioux River downstream from } \\
\text { Sioux Falls wastewater discharge } \\
\text { (site DS1, fig. 1) }\end{array}$} & \multicolumn{7}{|c|}{$\begin{array}{c}433541096355800 \\
\text { Big Sioux River at Brandon, SD } \\
\text { (site DS2, fig. 1) }\end{array}$} \\
\hline & 09-10-2002 & $05-17-2004$ & 05-30-2004 & 08-16-2001 & 09-11-2002 & $01-23-2003$ & 03-20-2003 & $06-25-2003$ & $05-17-2004$ & 05-31-2004 \\
\hline $\begin{array}{l}\text { Time of sample } \\
\text { collection } \\
\text { (24-hour) }\end{array}$ & 1030 & 1100 & 1630 & 0930 & 1030 & 1125 & 1315 & 1630 & 1730 & 1230 \\
\hline $\begin{array}{l}\text { Number of compounds } \\
\text { detected }\end{array}$ & 14 & 31 & 11 & 5 & 12 & 21 & 15 & 13 & 27 & 8 \\
\hline $\begin{array}{l}\text { Human pharmaceutical } \\
\text { compounds (HPCs) }\end{array}$ & $\begin{array}{l}\text { Cotinine } \\
\text { Caffeine }\end{array}$ & $\begin{array}{l}\text { Caffeine } \\
\text { Cotinine }\end{array}$ & & Cotinine & $\begin{array}{l}\text { 1,7-Dimethyl- } \\
\text { xanthine } \\
\text { Caffeine } \\
\text { Cotinine }\end{array}$ & $\begin{array}{l}\text { Cotinine } \\
\text { Caffeine } \\
\text { Salbutamol }\end{array}$ & Cotinine & $\begin{array}{l}\text { Caffeine } \\
\text { Cotinine }\end{array}$ & $\begin{array}{l}\text { Caffeine } \\
\text { Cotinine }\end{array}$ & Cotinine \\
\hline $\begin{array}{l}\text { Human and veterinary } \\
\text { antibiotic compounds } \\
\text { (HVACs) }\end{array}$ & -- & $\begin{array}{l}\text { Erythromycin } \\
\text { Sulfamethox- } \\
\text { azole } \\
\text { Trimethoprim }\end{array}$ & -- & -- & -- & $\begin{array}{l}\text { Chlorotetra- } \\
\text { cycline } \\
\text { Erythromycin- } \\
\mathrm{H}_{2} \mathrm{O} \\
\text { Lincomycin } \\
\text { Sulfameth- } \\
\text { oxazole } \\
\text { Tetracycline } \\
\text { Trimethoprim }\end{array}$ & -- & -- & $\begin{array}{l}\text { Erythromycin } \\
\text { Sulfameth- } \\
\text { oxazole }\end{array}$ & -- \\
\hline $\begin{array}{l}\text { Major agricultural } \\
\text { herbicides (MAHs) }\end{array}$ & $\begin{array}{l}\text { Atrazine } \\
\text { Prometon }\end{array}$ & $\begin{array}{l}\text { Atrazine } \\
\text { Metolachlor } \\
\text { Prometon }\end{array}$ & $\begin{array}{l}\text { Atrazine } \\
\text { Metolachlor }\end{array}$ & -- & -- & -- & $\begin{array}{l}\text { Atrazine } \\
\text { Metolachlor }\end{array}$ & $\begin{array}{l}\text { Atrazine } \\
\text { Metolachlor } \\
\text { Prometon }\end{array}$ & $\begin{array}{l}\text { Atrazine } \\
\text { Metolachlor } \\
\text { Prometon }\end{array}$ & $\begin{array}{l}\text { Atrazine } \\
\text { Metolachlor }\end{array}$ \\
\hline
\end{tabular}


Table 22. Organic wastewater compounds detected at concentrations greater than study reporting levels in water samples.-Continued

[Bold text indicates suspected endocrine-disrupting compound (EDC). DEET, N,N-diethyl-meta-toluamide; NP, para-nonylphenol; NP1EO, nonylphenol monoethoxylate; NP2EO, nonylphenol diethoxylate; OP1EO, octylphenol monoethoxylate; OP2EO, octylphenol diethoxylate; --, none detected]

\begin{tabular}{|c|c|c|c|c|c|c|c|c|c|c|}
\hline & \multicolumn{10}{|c|}{ Station identification number and name (site label) } \\
\hline & \multicolumn{3}{|c|}{$\begin{array}{c}433559096390700 \\
\text { Big Sioux River downstream from } \\
\text { Sioux Falls wastewater discharge } \\
\text { (site DS1, fig. 1) }\end{array}$} & \multicolumn{7}{|c|}{$\begin{array}{c}433541096355800 \\
\text { Big Sioux River at Brandon, SD } \\
\text { (site DS2, fig. 1) }\end{array}$} \\
\hline $\begin{array}{l}\text { Household, industrial, } \\
\text { and minor agricultural- } \\
\text { use compounds } \\
\text { (HIACs) }\end{array}$ & $\begin{array}{l}\text { AHTN } \\
\text { DEET } \\
\text { Tributyl } \\
\text { phosphate } \\
\text { Triethyl citrate } \\
\text { (ethyl } \\
\text { citrate) } \\
\text { Tri(2- } \\
\text { butoxyethyl) } \\
\text { phosphate } \\
\text { Tri(2- } \\
\text { chloroethyl) } \\
\text { phosphate } \\
\text { Tri(dichloro- } \\
\text { isopropyl) } \\
\text { phosphate }\end{array}$ & $\begin{array}{l}\text { 3-Methyl-1H- } \\
\text { indole } \\
\text { (skatol) } \\
\text { AHTN } \\
\text { Anthraqui- } \\
\text { none } \\
\text { Benzophe- } \\
\text { none } \\
\text { Camphor } \\
\text { DEET } \\
\text { HHCB } \\
\text { Indole } \\
\text { OP2EO } \\
\text { OP1EO } \\
\text { NP } \\
\text { Tributyl } \\
\text { phosphate } \\
\text { Triethyl citrate } \\
\text { (ethyl } \\
\text { citrate) } \\
\text { Triphenyl } \\
\text { phosphate } \\
\text { Tri(2- } \\
\text { butoxyethyl) } \\
\text { phosphate } \\
\text { Tri(2- } \\
\text { chloroethyl) } \\
\text { phosphate } \\
\text { Tri(dichloro- } \\
\text { isopropyl) } \\
\text { phosphate }\end{array}$ & $\begin{array}{l}\text { Benzophe- } \\
\text { none } \\
\text { Tri(2- } \\
\text { chloroethyl) } \\
\text { phosphate }\end{array}$ & $\begin{array}{l}\text { AHTN } \\
\text { Tri(2- } \\
\text { butoxyethyl) } \\
\text { phosphate }\end{array}$ & $\begin{array}{l}\text { AHTN } \\
\text { Bromacil } \\
\text { DEET } \\
\text { Tributyl } \\
\text { phosphate } \\
\text { Triethyl citrate } \\
\text { (ethyl } \\
\text { citrate) } \\
\text { Tri(2- } \\
\text { chloroethyl) } \\
\text { phosphate } \\
\text { Tri(dichloro- } \\
\text { isopropyl) } \\
\text { phosphate }\end{array}$ & $\begin{array}{l}\text { AHTN } \\
\text { DEET } \\
\text { HHCB } \\
\text { NP2EO } \\
\text { NP1EO } \\
\text { Tributyl } \\
\text { phosphate } \\
\text { Triethyl citrate } \\
\text { (ethyl } \\
\text { citrate) } \\
\text { Tri(2- } \\
\text { butoxyethyl) } \\
\text { phosphate } \\
\text { Tri(2- } \\
\text { chloroethyl) } \\
\text { phosphate } \\
\text { Tri(dichloro- } \\
\text { isopropyl) } \\
\text { phosphate }\end{array}$ & $\begin{array}{l}\text { AHTN } \\
\text { Anthraqui- } \\
\text { none } \\
\text { Indole } \\
\text { NP2EO } \\
\text { Triethyl citrate } \\
\text { (ethyl } \\
\text { citrate) } \\
\text { Tri(2- } \\
\text { butoxyethyl) } \\
\text { phosphate }\end{array}$ & $\begin{array}{l}\text { Anthraqui- } \\
\text { none } \\
\text { DEET } \\
\text { Diazinon } \\
\text { Tributyl } \\
\text { phosphate } \\
\text { Tri(2- } \\
\text { butoxyethyl) } \\
\text { phosphate } \\
\text { Tri(2- } \\
\text { chloroethyl) } \\
\text { phosphate } \\
\text { Tri(dichloro- } \\
\text { isopropyl) } \\
\text { phosphate }\end{array}$ & $\begin{array}{l}\text { AHTN } \\
\text { Anthraqui- } \\
\text { none } \\
\text { Camphor } \\
\text { DEET } \\
\text { HHCB } \\
\text { Indole } \\
\text { Isophorone } \\
\text { Isophorone } \\
\text { Tributyl } \\
\text { phosphate } \\
\text { Triethyl citrate } \\
\text { (ethyl } \\
\text { citrate) } \\
\text { Triphenyl } \\
\text { phosphate } \\
\text { Tri(2- } \\
\text { butoxyethyl) } \\
\text { phosphate } \\
\text { Tri(2- } \\
\text { chloroethyl) } \\
\text { phosphate } \\
\text { Tri(dichloro- } \\
\text { isopropyl) } \\
\text { phosphate } \\
\text { Tri(2- } \\
\text { chloroethyl) } \\
\text { phosphate } \\
\text { Tri(dichloro- } \\
\text { isopropyl) } \\
\text { phosphate }\end{array}$ & $\begin{array}{l}\text { Tri(2- } \\
\text { chloroethyl) } \\
\text { phosphate }\end{array}$ \\
\hline
\end{tabular}


[Bold text indicates suspected endocrine-disrupting compound (EDC). DEET, N,N-diethyl-meta-toluamide; NP, para-nonylphenol; NP1EO, nonylphenol monoethoxylate; NP2EO, nonylphenol diethoxylate; OP1EO, octylphenol monoethoxylate; OP2EO, octylphenol diethoxylate; --, none detected]

\begin{tabular}{|c|c|c|c|c|c|c|c|c|c|c|}
\hline \multirow[b]{3}{*}{$\begin{array}{l}\text { Polyaromatic } \\
\text { hydrocarbons (PAHs) }\end{array}$} & \multicolumn{10}{|c|}{ Station identification number and name (site label) } \\
\hline & \multicolumn{3}{|c|}{$\begin{array}{c}433559096390700 \\
\text { Big Sioux River downstream from } \\
\text { Sioux Falls wastewater discharge } \\
\text { (site DS1, fig. 1) }\end{array}$} & \multicolumn{7}{|c|}{$\begin{array}{c}433541096355800 \\
\text { Big Sioux River at Brandon, SD } \\
\text { (site DS2, fig. 1) }\end{array}$} \\
\hline & -- & $\begin{array}{l}\text { Carbazole } \\
\text { Naphthalene } \\
\text { Phenan- } \\
\text { threne } \\
\text { Pyrene }\end{array}$ & $\begin{array}{l}\text { 1-Methyl- } \\
\text { naphthalene } \\
\text { 2,6-Dimethyl- } \\
\text { naphthalene } \\
\text { 2-Methyl- } \\
\text { naphthalene } \\
\text { Naphthalene } \\
\text { Phenan- } \\
\text { threne } \\
\text { Pyrene }\end{array}$ & -- & -- & -- & $\begin{array}{l}\text { Anthracene } \\
\text { Benzo }[a] \\
\text { pyrene } \\
\text { Fluoranthene } \\
\text { Phenan- } \\
\text { threne } \\
\text { Pyrene }\end{array}$ & -- & $\begin{array}{l}\text { Carbazole } \\
\text { Pyrene }\end{array}$ & $\begin{array}{l}\text { 1-Methyl- } \\
\text { naphthalene } \\
\text { 2-Methyl- } \\
\text { naphthalene } \\
\text { Naphthalene } \\
\text { Pyrene }\end{array}$ \\
\hline Sterol compounds (SCs) & $\begin{array}{l}\text { 3-beta- } \\
\text { Coprostanol } \\
\text { beta-Sitosterol } \\
\text { Cholesterol }\end{array}$ & $\begin{array}{l}\text { beta-Sitosterol } \\
\text { Cholesterol }\end{array}$ & Cholesterol & $\begin{array}{l}\text { beta-Sitosterol } \\
\text { Cholesterol }\end{array}$ & $\begin{array}{l}\text { beta-Sitosterol } \\
\text { Cholesterol }\end{array}$ & $\begin{array}{l}\text { 3-beta- } \\
\text { Coprostanol } \\
\text { Cholesterol }\end{array}$ & Cholesterol & Cholesterol & $\begin{array}{l}\text { beta-Sitosterol } \\
\text { Cholesterol }\end{array}$ & -- \\
\hline
\end{tabular}


For more information concerning the research in this report, contact: U.S. Geological Survey

South Dakota Water Science Center

1608 Mt. View Road

Rapid City, SD 57702

This publication is available online at URL http://pubs.water.usgs.gov/sir2006-5118

Information regarding the water resources in South Dakota is available at: http://sd.water.usgs.gov/ 
옹 